UNIVERSIDADE DE SÃO PAULO

FACULDADE DE FILOSOFIA, LETRAS E CIÊNCIAS HUMANAS

DEPARTAMENTO DE HISTÓRIA

PROGRAMA DE PÓS-GRADUAÇÃO EM HISTÓRIA SOCIAL

\title{
Lasar Segall e a perseguição ao Modernismo: Arte Degenerada na Alemanha e no Brasil
}

Daniel Rincon Caires

\begin{abstract}
Dissertação apresentada ao Programa de Pós-Graduação (Mestrado) em História Social, do Departamento de História da Faculdade de Filosofia, Letras e Ciências Humanas da Universidade de São Paulo.
\end{abstract}

Orientador: Prof. Dr. Francisco Cabral Alambert Junior 

Autorizo a reprodução e divulgação total ou parcial deste trabalho, por qualquer meio convencional ou eletrônico, para fins de estudo e pesquisa, desde que citada a fonte.

Catalogação na Publicação Serviço

de Biblioteca e Documentação

Faculdade de Filosofia, Letras e Ciências Humanas da Universidade de São Paulo

Cl Caires, Daniel Rincon

Lasar Segall e a perseguição ao Modernismo: Arte Degenerada na Alemanha e no Brasil / Daniel Rincon

Caires ; orientador Francisco Cabral Alambert Junior. -

São Paulo, 2019.

$279 \mathrm{f}$.

Dissertação (Mestrado) - Faculdade de Filosofia, Letras e Ciências Humanas da Universidade de São Paulo. Departamento de História. Área de concentração: História Social.

1. Modernismo. 2. Degeneração. 3. Lasar Segall. 4.

Crítica de Arte. 5. Nazismo. I. Alambert Junior, Francisco Cabral, orient. II. Título. 



\section{ENTREGA DO EXEMPLAR CORRIGIDO DA DISSERTACCÃO/TESE \\ Termo de Ciência e Concordância do (a) orientador (a)}

Nome do (a) aluno (a): DANIEL RINCON CAIRES
Data da defesa: $\frac{4}{6 / / 19}$
Nome do Prof. (a) orientador (a): FnANCisco C. ALAMBERT JR.

Nos termos da legislação vigente, declaro ESTAR CIENTE do conteúdo deste EXEMPLAR CORRIGIDO elaborado em atenção às sugestões dos membros da comissão Julgadora na sessão de defesa do trabalho, manifestando-me plenamente favorável ao seu encaminhamento e publicação no Portal Digital de Teses da USP.

São Paulo, $1,8 / 19$ 
Aos meus pais, Regina e José 



\section{Agradecimentos}

Ao meu orientador, Francisco Alambert, pela confiança depositada em meu projeto e pela supervisão de minha pesquisa. A Helouise Costa, com quem tive o privilégio de conviver e trabalhar, pelos generosos ensinamentos e pela leitura atenta de meu relatório de qualificação e sugestões que me ofereceu tanto na ocasião do exame quanto em outros momentos da trajetória da pesquisa. A Vera d'Horta, que me acolheu no Museu Lasar Segall e me apresentou não só o universo do artista russo, mas me guiou nos primeiros passos no campo da História da Arte. À Vera devo agradecer também pelas sugestões e críticas que recebi em meu exame de qualificação bem como durante o ato de defesa. Gostaria de agradecer ainda os professores que completaram minha banca de defesa, Annateresa Fabris e Marcos Napolitano. Ao amigo professor Nachmann Falbel, pelos ensinamentos eruditos que tive o privilégio de colher de sua pessoa. Agradeço a indicação e empréstimo de fontes raras e as sugestões que me ofereceu ao longo do processo. A Pierina Camargo, museóloga do Museu Lasar Segall, pela generosidade com que compartilhou seus conhecimentos a respeito da obra e da vida de Lasar Segall. À Associação Cultural de Amigos do Museu Lasar Segall e ao Instituto Brasileiro de Museus (IBRAM), que custearam parte de minha formação na língua alemã.

Este trabalho foi realizado ao longo de minha atividade profissional como pesquisador junto ao Museu Lasar Segall, onde colaboro principalmente na gestão do Arquivo Lasar Segall. Por isso, devo agradecer a Jorge Schwartz e Marcelo Monzanni, diretores do Museu Lasar Segall durante o desenvolvimento desta pesquisa, que proporcionaram tempo e espaço para a aquisição das ferramentas fundamentais necessárias ao trabalho de pesquisa. É importante ressaltar o esclarecimento destes gestores, já que raramente encontrei, no ambiente museal, reconhecimento ao valor das atividades de pesquisa.

Gostaria de agradecer a pessoas que se dispuseram a enviar materiais bibliográficos e fontes indisponíveis no Brasil: Susanne Knuth (Kulturhistorisches Museum Rostock); Jürgen Nitsche, historiador autônomo em Chemnitz, que compartilhou suas pesquisas inéditas; Neil Levi (Drew University); Joseph Masheck (Hofstra University); Grit Reinhold (Sächsische Landesbibliothek - Staats- und Universitätsbibliothek Dresden); a Melanie Vietmaier (Kunstsammlung Nordheim-Westfalen) devo não só o envio de materiais, mas ideias e reflexões importantes advindas de nossos diálogos; Mathis Ingenhaag (Bundesarchiv - Koblenz), Elisabeth Angermair (Stadtarchiv München).

Finalmente, gostaria de agradecer aos meus filhos -Marina, Luiza e José - pelo fundamental apoio ao longo deste projeto. 

Esta dissertação analisa o discurso de repúdio à arte moderna, conforme este se manifestou em relação à obra do artista russo-brasileiro Lasar Segall (1889-1957). A singular trajetória deste artista, que viveu e produziu na Europa e no Brasil, permite que se observe e compare as retóricas dos refratários ao modernismo em diferentes lugares e épocas. Na busca pelas matrizes conceituais dessa mentalidade, recuou-se a observação para as décadas finais do século XIX, momento em que se consolidaram algumas formas novas de se compreender o fenômeno estético, amparadas na ótica positivo-cientificista, assim como categorias pejorativas de qualificação do modernismo, como a de “degeneração". Atenção especial foi conferida à análise da política cultural do regime nacional-socialista, que empreendeu a partir de 1937 uma "ação contra a arte degenerada", responsável por expurgar dos museus públicos alemães uma grande quantidade de obras de arte moderna, e por exibir em exposições difamatórias um conjunto delas, entre as quais, algumas de Lasar Segall. No Brasil, observou-se as relações entre o Estado Novo e a arte moderna, em especial no monitoramento de seus artífices pelos órgãos de repressão política.

Palavras-chave: 1. Modernismo, 2. Degeneração, 3. Lasar Segall, 4. Crítica de Arte, 5. Nazismo 

This dissertation analyzes the discourse of repudiation of modern art, as manifested about the work of Russian-Brazilian artist Lasar Segall (1889-1957). The unique trajectory of this artist, who lived and produced in Europe and Brazil, allows comparisons of refractory discourses about modernism in different places and times. In the search for the conceptual matrices of this rhetoric, the observation returned to the final decades of the nineteenth century, when some new forms of understanding the aesthetic phenomenon consolidated, supported by the positive-scientificist view, as well as pejorative categories of qualification of the modernism, such as "degeneration." Special attention was given to the analysis of the cultural policy of the National Socialist regime, which from 1937 on undertook an "action against degenerate art", responsible for purging a large number of modern works of art from the German public museums, and for exhibiting in defamatory exhibitions a group of them, including some of Lasar Segall. In regards to the Brazilian case, the research dedicated attention to the relations between the Estado Novo and modern art, especially in the monitoring of its artificers by the organs of political repression.
\end{abstract}

Key-words: 1. Modernism; 2. Degeneration; 3. Lasar Segall, 4. Art Criticism, 5. Nazism. 



\section{ÍNDICE}

Introdução.

1

Capítulo 1 - e seu ódio será perfeito: um olhar sobre a gênese da sensibilidade antimodernana Alemanha.

Capítulo 2 - Uma arte que clama por camisa-de-força: arte moderna como sintoma de degeneração.

Capítulo 3 - Estética Positiva, nacionalismo naturalista: recepções ao modernismo no Brasil

Capítulo 4 - Rotas alteradas: trajetórias das obras de Lasar Segall confiscadas na "Ação contra a Arte Degenerada".

Capítulo 5 - “O russo naturalizado brasileiro": Lasar Segall e o antimodernismo no Brasil.....

Considerações finais.

Bibliografia e Fontes

Anexos

Caderno de Imagens. 



\section{Introdução}

O objeto central desta dissertação é o pensamento estético antimoderno - e as ações dele decorrentes - conforme se manifestou ao redor da obra do artista Lasar Segall. Acompanhando de perto a linha sinuosa das vivências múltiplas deste "eterno caminhante", foi possível observar as formas e nuances da recepção ao modernismo, em diversos lugares, em diversos momentos.

A perseguição ao objeto levou ao século XIX, na busca pelas raízes do repúdio à modernidade estética. Parecia impossível compreender adequadamente as ideias da crítica antimoderna das décadas iniciais do século XX sem buscar seus fundamentos num passado um pouco mais distante. Somente assim se poderia observar suas transformações, reapropriações e reaparições.

A dissertação estrutura-se em cinco capítulos. No primeiro, procura-se observar a formação da sensibilidade antimoderna na Alemanha, tratando de remetê-la aos fatores sociais, políticos e econômicos que circundam essa gênese. Identificam-se alguns indivíduos responsáveis pelo desenvolvimento da retórica antimoderna, cujos discursos são analisados.

O capítulo 2 é dedicado ao estudo do conceito de degeneração e de seu emprego no campo da crítica de arte. Neste segmento, os trabalhos de Cesare Lombroso e Max Nordau mereceram leituras mais detalhadas, já que estes autores foram identificados como maiores responsáveis pela aplicação do pensamento médico-cientificista no estudo dos produtos culturais e artísticos.

O capítulo 3 é voltado ao escrutínio do panorama da estética e da crítica de arte brasileiras nos momentos dos primeiros contatos com as propostas modernas, remetendose, tanto quanto possível, ao contexto social e político. Destaca-se neste capítulo o estudo do pensamento de algumas figuras que se tornariam célebres por sua resistência às propostas modernistas.

O capítulo 4 acompanha a proveniência das obras de Lasar Segall que foram confiscadas na Ação Contra a Arte Degenerada empreendida pelo regime Nazista. Para tanto, procurou-se perseguir sua trajetória desde o momento em que entraram nas coleções de museus públicos germânicos, passando pelo confisco e exibição nas mostras de Arte Degenerada, até o destino final de cada obra: troca de mãos, restituição, destruição, desaparecimento. O caso Segall serviu como guia para uma análise do contexto, facultando a observação de tendências mais gerais. 
O capítulo final dedica-se à exposição do caso brasileiro, destacando-se com ênfase os episódios de atritos entre as propostas estéticas de Lasar Segall e a crítica antimodernista. Há espaço também para a observação da atuação dos órgãos estatais de monitoramento político sobre as atividades dos artistas e intelectuais ligados ao modernismo. 
$[\ldots]$

cuidado com aqueles que censuram com facilidade eles temem aquilo que não conhecem

cuidado com aqueles que procuram sempre as multidões pois eles não são nada sozinhos cuidado com o homem medíocre, a mulher medíocre cuidado com seu amor, seu amor é medíocre, procura o medíocre

mas há gênio em seu ódio

há gênio suficiente em seu ódio para matá-lo para matar qualquer um por desprezarem a solidão por desconhecerem a solidão eles irão tentar destruir qualquer coisa que seja diferente deles mesmos incapazes de criar arte eles não entenderão arte e irão considerar seu próprio fracasso como criadores como um fracasso do mundo incapazes de amar completamente eles se convencerão de que seu amor é incompleto e então eles vão odiá-lo e seu ódio será perfeito

como um diamante reluzente

como uma faca

como uma montanha

como um tigre

como cicuta

sua mais perfeita arte

Charles Bukowski ${ }^{1}$

\footnotetext{
1 Tradução livre de excerto de The Genius of the Crowd. In: BUKOWSKI, Charles. The Roominghouse Madrigals - Early Selected Poems - 1946-1966. Los Angeles: Black Sparrow Press, 1988, p. 31-33.
} 



\section{Capítulo 1 \\ e seu ódio será perfeito: um olhar sobre a gênese da sensibilidade antimoderna na Alemanha}

Os nazistas afirmavam que a "nova era" inaugurada por eles iria trazer consigo uma nova arte. Rejeitavam a arte moderna que florescera nas décadas finais do século XIX, o impressionismo, realismo e simbolismo de franceses e alemães. Detestavam - ao menos parte importante do grupo - a arte de vanguarda produzida por correntes de experimentadores - expressionistas, futuristas, cubistas, dadaístas - que se elevara ao estatuto de tendência estética principal ao longo do período republicano. Ao mesmo tempo, os nazistas evitavam associar-se à arte "tradicional", feita por aqueles que se haviam mantido irredutivelmente ligados a formas e temas anteriores às ondas de renovações da segunda metade do século XIX.

A promessa dos nazistas não foi cumprida. Eles não foram capazes de fomentar uma "nova" pintura, escultura, literatura. A faceta propositiva de seu regime, ao menos no que se refere à arte, não se concretizou. Tornaram-se especialistas em condenar, perseguir e destruir, mas pouco criaram. Sua maior realização foi a bem azeitada máquina de odiar. A “ação contra a arte degenerada", empreendimento pelo qual expurgaram dos museus públicos a arte moderna considerada daninha, reuniu mais de 20 mil itens, que foram meticulosamente catalogados, classificados, empregados para fins de propaganda, vendidos para o exterior ou trocados por obras consideradas desejáveis. Finalmente, uma parte expressiva foi destruída. No final, o ódio foi sua melhor arte.

Compreender as estruturas retóricas que ampararam esses atos de ódio é um dos objetivos desta pesquisa. Observando os estudos já realizados sobre o tema, percebe-se a tendência de retornar ao século XIX em busca de uma explicação para o surgimento do fenômeno nazista, bem como para detectar a gênese do repúdio à arte moderna ${ }^{2}$. Durante a pesquisa, procurou-se compreender as circunstâncias que permitiram a formação de um pensamento antimoderno.

\footnotetext{
2 Olaf Peters, em artigo publicado recentemente, oferece uma espécie de inventário do que se deve observar para compreender o surgimento do pensamento nazista e as raízes da ação contra a arte degenerada; cfe. PETERS, Olaf. From Nordau to Hitler: "Degeneration" and anti-modernism between the fin-de-siècle and the national socialist takeover of power. In: PETERS, Olaf (Ed.) Degenerate Art: the attack on modern art in Nazi Germany, 1937. New York: Neue Galerie New York, 2014. pp. 16-35.
} 
Um estudo influente sobre a formação da sensibilidade germânica moderna é o de Norbert Elias ${ }^{3}$. Nesse trabalho, Elias observou algumas etapas da longa e ainda não resolvida tensão entre o par conceitual Kultur/Zivilisation (Cultura e Civilização), analisando com vagar sua peculiar utilização entre os alemães. Elias principia oferecendo definições dos conceitos a partir dos seus usos. Civilização, na visão dos que a tem como coisa positiva, é movimento que aprimora uma situação original, vista como imperfeita e incompleta: equivale a progresso. Por outro lado, na visão dos que preferem o valor da Cultura como algo essencial, acabado, respeitável, venerável e já próximo do perfeito, civilização é movimento que degrada uma situação ideal: equivale a decadência, degeneração ${ }^{4}$. Civilização é humanista e universalista, não se preocupa com a determinação de essências ou com a delimitação de diferenças entre as pessoas e povos, mas procura aquilo que é característica universal. Cultura procura a particularidade que acentua a diferença.

A preferência por um ou outro significado pode depender de situações específicas de cada povo usuário: entre aqueles em que o Estado está consolidado, as fronteiras estabelecidas e a unidade garantida, tende-se a preferir a visão universalista. Entre os que ainda lutam por definir-se enquanto povo, lidando com fronteiras políticas e espirituais incertas, ameaçados pela fragmentação, o empuxo contrário, de aglutinação nuclear, parece mais fortuito ${ }^{5}$.

Para Elias, o processo social responsável pela gênese do par conceitual antitético Cultura/Civilização tem seu "ponto de partida concreto nas experiências e situações de fins do século XVIII”' . Deve-se às categorizações instituídas pela intelligentsia da classe média alemã - composta majoritariamente por servidores públicos, um grupo sem expressão política cuja legitimação repousava em suas supostas "realizações intelectuais,

\footnotetext{
${ }^{3}$ ELIAS, Norbert. O Processo Civilizador - Vol. I - Uma História dos Costumes. Rio de Janeiro: Jorge Zahar Editor, 1994.

${ }^{4}$ ELIAS, 1994, p. 24.

${ }^{5}$ ELIAS, 1994, p. 25. No caso dos povos germânicos, que atravessaram o século XIX lutando por encontrar um eixo que lastreasse sua unidade política, alcançando apenas tardiamente a unificação, haveria uma necessidade premente em delimitar um núcleo identitário capaz de superar as forças dissuasórias e, portanto, uma supervalorização do conceito de Cultura, na acepção de Elias. A interpretação que Adolf Hitler deu a esse embate é significativa: "Um dos mais visíveis sintomas da decadência do antigo Império [Austro-Húngaro] era, incontestavelmente, a lenta diminuição da cultura geral. Sob essa denominação não se deve incluir o que hoje se chama 'civilização'. Ao contrário, a civilização atual parece significar uma inimiga da verdadeira noção do que seja a elevação moral do espírito de um povo"; cfe. HITLER, Adolf. Minha Luta - Edição Histórica. Trad. Klaus von Punchen. São Paulo: Centauro, 2016; p. 194.

${ }^{6}$ ELIAS, 1994, p. 27.
} 
científicas ou artísticas"7. Tais realizações espirituais não apenas a singularizariam, mas demarcariam um afastamento em relação ao outro que, de início, é a classe cortesã, que governava e lhe era hierarquicamente superior. No discurso da intelligentsia, a classe cortesã é descrita como afastada de sua essência, ocupada apenas com aspectos superficiais e aparentes: voltada à Civilização ${ }^{8}$.

Essa antítese que surge como forma de demarcar limites sociais passa, com a hegemonia burguesa, a servir para demarcar limites nacionais: após 1789, é à França e às potências "ocidentais" que se relega o rótulo de "civilizadas" na acepção pejorativa, ou seja, materialistas e superficiais 9 .

"Com a lenta ascensão da burguesia alemã, de classe de segunda categoria para depositária da consciência nacional e, finalmente - muito tarde e com reservas - para classe governante, de uma classe que, no início, foi obrigada a se ver ou legitimar principalmente se contrastando com a classe superior aristocrática de corte e, em seguida, definindo-se contra nações concorrentes, a antítese entre Kultur e Zivilisation, com todos seus significados correlatos, muda em significação e função: de antítese primariamente social torna-se primariamente nacional' ${ }^{\prime 10}$.

Essa noção passa a fazer parte, portanto, do próprio núcleo identitário dos germânicos. Há a tendência de se considerar que o que define o alemão é um elemento de sua essência, algo herdado dos ancestrais, parte de sua constituição mais elementar. Essa suposta essência, com a ascensão do discurso cientificista na segunda metade do século XIX, iria cada vez mais se identificar em termos biológicos como "raça". Nessa forma de pensar, tudo aquilo que viesse de fora, especialmente quando resultasse em alterações, seria lido como atentado à essência germânica. Elemento potencialmente daninho e desarticulador do que havia de mais valioso, era compreendido como infiltração a ser combatida.

A interpretação da trajetória alemã feita por Peter Viereck complementa e oferece novas nuances para a antítese Kultur/Zivilisation desenvolvida por Elias ${ }^{11}$. Viereck situa

\footnotetext{
${ }^{7}$ ELIAS, 1994, p. 28.

${ }^{8}$ Essa descrição pejorativa da corte trazia, em germe, uma prevenção nacionalista, já que a suposta preferência cortesã pelo superficial e pelo aparente, no discurso das classes médias, seria algo adquirido dos modos da corte francesa, representando um afastamento, por parte da corte alemã, da essência germânica. Elias notava também que o discurso dessa intelligentsia, ao distribuir valor positivo exclusivamente à esfera espiritual, tendia a desprezar atividades "concretas" - como a política partidária, por exemplo - o que teria um papel importante, mais tarde, na vida alemã. Não seriam poucos os que acusariam os alemães de serem "idealistas", desligados dos aspectos pragmáticos da vida. Residiria aí, segundo muitos historiadores, o motivo do fracasso do liberalismo na Alemanha do século XIX.

${ }^{9}$ ELIAS, 1994, p. 46.

${ }^{10}$ ELIAS, 1994, p. 47; itálico no original.

11 VIERECK, Peter. Metapolitics: from Wagner and the German Romantics to Hitler. New Jersey: Transaction Publishers, 2004. As circunstâncias em que Viereck produziu e publicou seu estudo devem ser
} 
num passado ainda mais remoto a busca pela delimitação de uma diferença essencial, que resulta na eleição da Kultur como elemento identitário central e supremo. Em sua interpretação, a história dos povos germânicos era atravessada, desde pelo menos o período da dominação romana, por um duradouro complexo de inferioridade diante do "Ocidente", que resultava num ressentimento agressivo, manifestado em revoltas periódicas - culturais, políticas, religiosas e "raciais", "em nome de um barbarismo nãoromanizado, irracional, elementar, poderoso e genuinamente bravo". Viereck argumenta que o apego a esse suposto substrato essencial - a Kultur - exterioriza um dispositivo de demarcação identitária destinado a afirmar a superioridade diante da Zivilisation estrangeira. $\mathrm{O}$ autor reencontrava traços intermitentes desse dispositivo ao longo da trajetória germânica, tanto em Lutero, que teria guiado seus esforços pelo repúdio à civilização ocidental, então representada pelo renascimento e pelo humanismo, quanto entre os luminares da primeira geração romântica, no final do século XVIII, que reagia contra o pensamento iluminista francês ${ }^{12}$. A última dessas revoltas, segundo Viereck, era aquela que afligia a Europa na altura da publicação de sua obra, o nazismo, "a ruptura mais radical de todos os tempos com a cultura ocidental"13.

Para Viereck, a ideologia romântica - comprometida com a devoção à Kultur instituiria uma visão política própria, cujos desdobramentos se mostrariam desastrosos. No lugar do pacto social iluminista, baseado na existência de direitos essenciais e inalienáveis que, na prática, limitavam o poder do Estado, os românticos teriam desenvolvido a ideia de um estado orgânico, superior às individualidades que o compunham. Formularam uma noção política alternativa àquela oferecida pelo pensamento iluminista: no lugar do estado liberal fiador dos direitos e servidor dos indivíduos, idealizaram um estado fundamentado na Kultur - na essência da "raça". Tal Estado só admite indivíduos que se submetam a ele e que devotem sua existência a servilo. Adam Müller, segundo Viereck, foi responsável por codificar essa noção política

consideradas quando se analisa seu conteúdo. Como ele mesmo ressalta no prefácio à edição de 2002 , o livro registra o ponto de vista de um norte-americano submetido a uma forte angústia diante da aparente invencibilidade da máquina de guerra nazista. Publicado em 1941, antes de Pearl Harbor e das primeiras derrotas de Hitler diante do Exército Vermelho, a obra apresenta uma espécie de argumentação propiciatória, procurando convencer os leitores americanos da necessidade de sustentar total resistência ao avanço do nazismo após uma inevitável queda da Europa. Mesmo produzida sob tais circunstâncias, a obra consegue fugir ao tom propagandístico e traz análises que ainda parecem válidas quanto à formação da mentalidade germânica.

12 "O romantismo é a versão oitocentista da perene revolta germânica contra o patrimônio ocidental" (VIERECK, 2004, p. 19).

13 Idem, p. 15. 
romântica. Para ele, o estado não deveria ser um instrumento nas mãos de uma pessoa ou grupo particular. A soma dos indivíduos formaria um todo maior que suas partes, tornando-se ela mesma um organismo que deveria evoluir livremente, e para cujo progresso todos os cidadãos deveriam sacrificar suas liberdades individuais ${ }^{14}$. Esse organismo superior seria definido, ao longo do século XIX, como o Volk (povo).

Deriva dessa tensão entre Cultura e Civilização a ideia do Sonderweg, que permearia muitos discursos sobre a Alemanha ao longo de todo o século XIX e parte do seguinte. Repetidamente acionado por sucessivas gerações, a teoria do Sonderweg literalmente, "caminho singular" - sustenta que a história da Alemanha teria tomado um desvio, seguindo uma rota especial no interior da modernidade, sem paralelos no restante da Europa. Conforme demonstraram Blackbourne e Eley ${ }^{15}$, a crença na existência de um padrão singular de desenvolvimento na Alemanha se manteve inalterada, variando apenas o juízo de valor sobre ela ao longo do tempo. A geração de nacionalistas alemães da primeira metade do século XIX acreditava que a Alemanha seguia uma rota particular em relação ao restante da Europa, e entendia como positiva essa diferença. Para eles, o seu ideal era superior ao da Revolução Francesa. Após a unificação (1871), as classes educadas continuaram entendendo a Alemanha como um modelo de desenvolvimento moderno diferente e superior ao das democracias parlamentares ocidentais. Nas palavras de Edgar Feuchtwanger, ele mesmo um historiador até certo ponto comprometido com a noção de Sonderweg,

“[...] a cultura política alemã era muito diferente daquela que prevalecia em sistemas parlamentares plenos, como a Grã-Bretanha e a França. De fato, a maior parte dos alemães educados desejava que ela fosse assim, tinha orgulho do seu sistema e sentia desprezo pelas tradições mais democráticas do Ocidente. Eles acreditavam num Sonderweg positivo, o caminho da Europa Central, que era distinto daquele do Ocidente licencioso, da mesma forma que diferia do bárbaro Oriente. A Kultur germânica iria sanar os males do mundo. Ela era mais profunda, mais voltada para si mesma que a civilização superficial do Ocidente, que, do ponto de vista da Alemanha, estava corrompida pela ganância individualista e pelo egoísmo"16.

Essa concepção de uma diferença positiva ganharia força com a Primeira Guerra ${ }^{17}$ e estaria sempre presente ao longo do período de Weimar. Após a Segunda Guerra, os

\footnotetext{
14 Idem, p. 33.

${ }^{15}$ BLACKBOURN, David; ELEY, Geoff. The Peculiarities of German History - Bourgeois Society and Politics in Nineteenth-Century Germany. Oxford: Oxford University Press, 1984.

${ }^{16}$ FEUCHTWANGER, Edgar. Imperial Germany 1850-1918. London: Routledge, 2001; p. XIX.

${ }^{17}$ Houston Stewart Chamberlain, o genro inglês de Richard Wagner e um dos principais responsáveis pela difusão da teoria da superioridade racial nórdica entre o círculo do compositor, descreveria a Primeira
} 
estudiosos da história alemã mantiveram a ideia do Sonderweg, apenas invertendo a polaridade: o "singular" se torna "aberrante" e é responsabilizado pela catástrofe. Passase a apontar as raízes do Terceiro Reich naquela Alemanha imperial-industrial-militar afastada dos ideais iluministas. Nessa reinterpretação do Sonderweg, o período de 193345 foi colocado como culminância lógica da "estranha" história moderna da Alemanha.

Essa geração que negativou a trajetória especial alemã atribuía suas mazelas a uma modernização incompleta. Alguns encontravam na Guerra dos Trinta Anos (1618-1648) o início do desvio de rota: destruída pelo conflito, a sociedade germânica teria perdido nesse momento suas instituições burguesas - que nos vizinhos iriam florescer e debelar o poder feudal ${ }^{18}$. Outros buscavam as raízes do desvio de rota nos séculos XVIII e XIX.

Qualquer que fosse o motivo, os historiadores comprometidos com a ideia do Sonderweg apontavam a incapacidade da burguesia em assumir seu "papel histórico", o de combater as forças do Antigo Regime e inaugurar a nova era. Em muitas análises, essa burguesia alemã teria sido "comprada": seus objetivos econômicos não foram conquistados pela luta, mas "concedidos". Nesse esquema, a burguesia nunca teria antagonizado aquela que, em circunstâncias "normais", seria sua inimiga mortal, a velha aristocracia rural (os Junkers). Ao invés disso, estas classes teriam se unido, num "casamento entre o ferro e o centeio"19. Os interesses dos Junkers teriam sido preservados. Derrotada em suas pretensões liberais em 1848, ultrapassada pelo militarismo de Bismarck no processo de unificação em 1871, a burguesia teria desistido inclusive de desenvolver uma "cultura de classe", preferindo imitar a aristocracia. Investiu na aquisição de propriedades de terra, títulos nobiliárquicos e assimilou os valores marciais típicos da aristocracia, incorrendo no que se chamou de "feudalização da burguesia". Os intérpretes que subscrevem essa teoria considerariam esse processo desastroso, por permitir que a velha aristocracia mantivesse as estruturas de domínio sobre as instituições políticas, o exército, a burocracia do estado e o judiciário. As forças pré-industriais teriam sobrevivido além do que "naturalmente" deveriam: mantiveram o controle mesmo após a revolução de 1918 e durante todo o período do Terceiro Reich. Somente em 1945 tal situação teria se esfacelado, nesse que é considerado o "ano zero" da história alemã, o momento em que ela finalmente se moderniza, aderindo ao Ocidente,

Guerra, em 1917, como uma batalha decisiva entre a desprezível civilização mecânica moderna e a ancestral, eterna e sagrada Kultur das raças superiores; cfe. VIERECK, 2004, p. 9.

18 VIERECK, 2004, p. 50.

${ }^{19}$ BLACKBOURNE et ELEY, 1984, p. 131. 
ao liberalismo, à pluralidade política. Nessa ótica, o pós-Guerra seria o momento em que a Alemanha finalmente se reconcilia com a história e supera o erro por omissão em que incorrera por séculos ${ }^{20}$.

A teoria do Sonderweg chegaria a propostas bastante sofisticadas para explicar as supostas omissões e falhas do processo de modernização alemão, que talvez encontre na obra de Jeffrey Herf sua forma mais bem-acabada. Para Herf, a modernização alemã, em seu caminho peculiar, criara a possibilidade de uma nova conciliação entre elementos antigos e modernos, permitindo combinações desastrosas. O "modernismo reacionário" alemão teria absorvido apenas a metade técnica das inovações, rejeitando, ao mesmo tempo, a contrapartida ideológica. Destituída da herança espiritual iluminista liberalismo, democracia, igualitarismo, estado do pacto social - a sociedade alemã teria se tornado uma máquina eficiente dirigida pelo irracionalismo:

"Essa tradição consistia numa coleção coerente e significativa de metáforas, palavras familiares e expressões emotivas que tinham o efeito de converter a tecnologia, de componente de uma Zivilisation estranha, ocidental, em parte orgânica da Kultur alemã. Combinavam reação política com avanço tecnológico. Onde os conservadores alemães haviam falado de tecnologia ou cultura, os modernistas reacionários ensinaram a direita alemã a falar de tecnologia e cultura"21.

Deve-se levar em conta que a introdução dos conceitos iluministas na Alemanha se fez na esteira de uma derrota. A Revolução Francesa e seu subproduto militar, Napoleão, foram responsáveis por inserir - a ferro e fogo - as novas ideias filosóficas. Se a ocupação francesa até certo ponto moderniza a Alemanha e a livra de resquícios antiquados, ela é ao mesmo tempo percebida como humilhação, como submissão à vontade do estrangeiro vencedor. A vitória francesa, em 1806, tornou-se um catalisador, “[...] transformou o nacionalismo germânico, pela primeira vez, de diletantismo estético em dinamite política"22. O domínio francês foi varrido da Alemanha por uma "guerra de libertação" que seria interpretada, daí por diante, como o momento mais glorioso da

\footnotetext{
${ }^{20}$ BLACKBOURNE et ELEY, 1984, p. 131.

${ }^{21}$ HERF, Jeffrey, O modernismo reacionário. São Paulo: Editora Ensaio, 1993; p. 14. Essa tese já havia sido esboçada por Peter Viereck em 1941. Ele sugeria que, em reação ao árido materialismo da cultura democrática-liberal-burguesa do final do século XIX, uma geração de neorromânticos oferecia alimento emocional e demagógico às massas. Essa "segunda revolução romântica" diferia da primeira em um aspecto fundamental: ela não mais rejeitava o mundo do materialismo-eficiência-industrialismo, mas o devorava. Agora, seus "objetivos fantásticos" não eram perseguidos apenas por meio de ineficientes quimeras literárias, mas "com os mais racionais e científicos meios da técnica moderna, da propaganda moderna, da guerra moderna. Essa deglutição e assimilação dos métodos de seus opositores diretos, das técnicas racionais, que por si só explicam as vitórias da Alemanha hitlerista, é o que faz dessa segunda revolução romântica o 'evento' mais importante dos últimos cem anos" (VIERECK, 2004, p. 147).

22 VIERECK, 2004, p. 58.
} 
trajetória nacional. Essa interpretação, significativamente, foi uma das poucas unanimidades compartilhada pelos três regimes subsequentes - Império, República e Terceiro Reich.

No final, mesmo considerando todas as variantes políticas e metodológicas dos estudiosos, Blackbourne e Elley acham possível encontrar um ponto invariável: todas as interpretações sobre a trajetória da Alemanha compartilham uma "inquietação com padrão da peculiaridade alemã"23.

$$
* \quad * \quad *
$$

Ao longo do século XIX, os territórios germânicos experimentaram transformações profundas em suas realidades objetivas, em movimentos bruscos que lançaram boa parte da população em situações de incerteza e alienação. Os sentimentos e visões de mundo derivados do contato com essas transformações alimentariam a retórica nazista de repúdio a parte da modernidade e de nostalgia por um tempo idílico de pureza rural. Muitos grupos se sentiram prejudicados por estas transformações e passaram a enxergar o advento da modernidade como um fenômeno negativo. Um grande processo de refundamentação identitária iniciou-se ali e, muitas vezes, nutriu-se justamente da imagem de um mundo mais simples, unívoco e lento, livre de intromissões estrangeiras e, sobretudo, localizado no passado.

Fritz Stern denominou esse movimento de "revolução conservadora": tratava-se de "destruir o detestado presente com vistas a recapturar um passado idealizado em um futuro imaginário" ${ }^{24}$. Tal modalidade de pensamento, segundo Stern, ganhou cada vez mais poder político, na proporção em que se tornava intelectualmente menos coerente. Era abraçada, em parte, pelos insatisfeitos, por aqueles que foram deixados de fora da sociedade liberal e industrial. Nessa rejeição à modernidade, deixou-se de lado inclusive os aspectos libertários do iluminismo: dentro dessa ideologia, fazia sentido defender

\footnotetext{
${ }^{23}$ BLACKBOURNE et ELEY, 1984, p. 20. A obra de Blackboune e Eley era dedicada a defender o ponto contrário, sustentando que se abandonasse a ideia de Sonderweg. Faziam isso por dois caminhos: primeiro, procurando demonstrar a inexistência de um padrão de desenvolvimento "normal" pelo qual a trajetória da Alemanha pudesse ser medida; analisando alguns aspectos da história da França e da Inglaterra, justamente os exemplos tomados pelos historiadores como modelares do desenvolvimento moderno "normal", negam ter existido, em qualquer parte, o liberalismo clássico do qual a Alemanha teria se afastado; por outro lado, procuram demonstrar que, ao contrário do que sustentavam os historiadores partidários da teoria do Sonderweg, as instituições "modernas" da Alemanha - a burguesia, o parlamentarismo, o liberalismo, etc. - não estiveram tão inativas quanto se postulava.

${ }^{24}$ STERN, Fritz. The Politics of Cultural Despair: a study in the Rise of the Germanic Ideology. Berkeley: University of California Press, 1974; p. XVI.
} 
"autoridade arbitrária, disciplina, tradição, desprezo pelo espírito de liberdade, afirmação da moralidade da guerra e da escravidão" 25 .

O estado teve papel importante no estabelecimento do capitalismo na Alemanha: ainda na primeira metade do século XIX, promoveu a secularização e removeu privilégios da Igreja (que se constituíam entraves à economia); proporcionou a emancipação dos camponeses e a formação de um mercado interno; cassou os privilégios de guildas, removeu tarifas internas ao comércio. Os estados individuais que viriam a compor a Alemanha investiram em instrução, criando oficinas-modelo, estimulando a criatividade técnica por meio de prêmios para inventos, incutindo novos gostos e padrões por meio da expansão da educação formal. Exposições industriais realizadas em diversas partes divulgavam as possibilidades e as vantagens da "nova economia". Em 1850 e 60 já havia poderosos, ricos e autoconscientes industriais e comerciantes capitalistas, mas em muitas partes, ainda nessa altura, era o estado - via burocracia - quem fomentava o desenvolvimento capitalista. Quando da unificação, o estado beneficiou ainda mais a nova economia, oferecendo vantagens longamente desejadas: “[...] mercado nacional, o Reichsbank [Banco Imperial], os inícios de um sistema de comunicações nacional, condições favoráveis para o estabelecimento de companhias limitadas e uniformização da moeda, dos pesos e medidas, e leis de patentes" ${ }^{26}$. O estado ajudou a remover a resistência decidida das guildas e corporações e os enclaves "atrasados" apegados de maneira intransigente à "economia natural".

"Acima de tudo, através da reforma institucional e de mudanças na organização educacional e de comunicação, o estado ajudou a estabelecer a possibilidade e o desejo por um novo tipo de homo oeconomicus. Ele imprimiu um ar de naturalidade aos desenvolvimentos que, naquela altura, não eram de maneira nenhuma percebidos como naturais" 27 .

O papel das companhias foi crucial: permitiam a mobilização de capitais enormes, para investimentos que exigiam somas gigantescas (ferrovias, linhas de navegação a vapor etc.). O mercado de ações resultante desse sistema permitiu aos investidores terem acesso a uma forma de aplicação nova e potencialmente mais lucrativa que as antigas aplicações típicas da aristocracia, em propriedades imobiliárias e títulos do governo, estimulando assim a circulação dos capitais. Em algumas décadas, esse processo ganhou

\footnotetext{
25 STERN, 1974, p. XV.

${ }^{26}$ Idem.

27 Idem.
} 
velocidade e acabou por mudar o eixo da economia alemã da produção rural para os novos setores industriais e comerciais, que assimilaram a anterior.

Todas essas alterações econômicas provocaram efeitos profundos sobre a sociedade. Alterou-se a composição social da classe média, que passou a abrigar em seu seio uma nova elite industrial cada vez mais rica e influente. Até então, esse segmento era formado por cidadãos ilustrados, a chamada Bildungsbürgertum - classes educadas (professores, clérigos, advogados) que serviam ao estado e se preocupavam pouco com a vida material $^{28}$. A elite industrial penetrou também no Parlamento. A própria natureza da formação cultural mudou: os Gymnasium tradicionais, com sua ênfase na cultura clássica, foram sendo substituídos por sistemas educacionais mais voltados para as ciências naturais e aplicadas. A ênfase no "aprendizado puro" deu lugar a uma abordagem pragmática. "A aquisição de conhecimento subordinou-se ao imperativo da conquista de qualificações úteis para o fomento das futuras carreiras"29.

A vida agrícola também experimentou profundas transformações. Restrições feudais foram abolidas e a atividade rural se tornou mais decididamente orientada para o mercado. Houve um intenso êxodo rural, que superlotou as cidades e ofereceu mão-deobra abundante e barata para as indústrias. O sistema de posse de terras foi modificado: o mercado inseriu-se no acesso à propriedade. Mercantilizadas, as terras passaram a servir como garantia em empréstimos. Muitas vezes, diante de adversidades, passaram às mãos dos bancos, ou trocaram de mãos pela venda ${ }^{30}$. Como na Grã-Bretanha, os burgueses enriquecidos investiram na propriedade de terras, como forma de ascensão social. No sul, os proprietários sublocavam suas terras, cobrando de camponeses sem-terra uma taxa pelo uso; oprimidos pelo sistema, diante de dívidas crescentes e colheitas minguantes, esse grupo foi um dos que desenvolveu mais diretamente o ímpeto revolucionário em 1848.

O proletariado urbano cresceu devagar, somente em 1860 chegando a compor cerca de $15 \%$ da população e, a partir de então, formando uma "consciência de classe" e passando a ter sua voz ouvida politicamente ${ }^{31}$. As classes de artesãos seriam rapidamente atraídas para uma visão reacionária. Desprotegidos contra o mercado pela abolição dos

\footnotetext{
${ }^{28}$ Trata-se do grupo identificado por Norbert Elias, tratado no início desse capítulo.

${ }^{29}$ FEUCHTWANGER, 2001, p. 102.

30 Um dado significativo aponta essa tendência: após 1835, apenas um terço das terras trocou de mãos por meio de sucessão hereditária; os outros $65 \%$ o fizeram por meio de vendas ou desapropriação por dívidas (FEUCHTWANGER, 2001, p. 8).

${ }^{31}$ Como será apontado posteriormente, a entrada do proletariado na vida político-institucional, no final do século XIX, foi um fator de inquietação para as classes dirigentes, moldando uma percepção alarmista do processo social.
} 
dispositivos tradicionais, foram ativos revolucionários em 1848. Nas décadas de 1860 e 1870 tomaram caminhos diversos, alguns ingressando de maneira privilegiada na economia industrial, outros misturando-se ao proletariado como mão-de-obra genérica. De todo modo, Feuchtwanger aponta que, em geral, entretiveram um sentimento de nostalgia que os tornou receptáculos preferenciais para ideologias nacionalistas, antiliberais, anticapitalistas e antissemitas.

Um sentimento que Fritz Stern nomeou de "desespero cultural" formou-se entre as classes que se sentiram prejudicadas pela modernização da Alemanha. Um amplo espectro de concepções circunda esse sentimento: o antissemitismo, o antiliberalismo, o nacionalismo, a idealização do passado - num desejo de voltar a um fantasioso tempo de harmonia social e prosperidade - a procura por um líder carismático e autoritário capaz de resolver os impasses pela força e legitimidade de seu poder. Tais linhas de pensamento originaram-se da sensação de desalento advinda da perda de garantias tradicionais, que acabaram levando a uma corrosão da vida profissional e das perspectivas de futuro. A penetração do mercado na mediação das relações humanas, o liberalismo político e a democracia tomando lugar do regime monárquico absoluto, todas essas coisas foram associadas às perdas reais e ressentimentos causados por elas. Emergiu, em geral, um olhar desconfiado sobre a nova configuração moderna: as forças titânicas desprendidas pelo novo sistema eram reputadas como daninhas e potencialmente desastrosas. Havia uma sensação de crise cultural, de decadência e pessimismo em toda a Alemanha.

$* \quad * \quad *$

Essa sensação se traduziria politicamente em propostas que se contrapunham ao parlamentarismo, à democracia e ao igualitarismo. Formou-se o cenário ideal para a atuação de

"[...] autoproclamados profetas sociais, pintando com brochas largas e cores vivas, fermentando uma mistura quase sempre venenosa de darwinismo social, chauvinismo, racismo e antissemitismo. Dessa cepa eram Paul Lagarde, Julius Langbehn e o genro inglês de Richard Wagner, Houston Stewart Chamberlain. Seus escritos gozavam de uma vasta popularidade. Eles forneceram o caminho para que os alemães bem-educados [...] obtivessem consciência social e encontrassem uma forma de serem anti-governistas a partir de um ponto de vista de extrema direita" ${ }^{32}$.

32 FEUCHTWANGER, 2001, p. 103. 
Fritz Stern, no que chamou de "um estudo da patologia da crítica cultural"33, acompanhou de perto o pensamento de três desses "profetas sociais" que, alimentados por esse estado de coisas, erigiram rapsódias que deram formato literário ao desespero cultural. Suas obras gozaram de imensa aceitação, rendendo seguidas reedições. Atuaram ao longo de três gerações sucessivas, iniciando em 1850 e estendendo-se até a ascensão nazista. Ampliaram o alcance e estruturaram o pensamento antimoderno. Paul de Lagarde (1827-1891), Julius Langbehn (1851-1907) e Moeller von den Bruck (1876-1925) sofriam com o dilema que atacavam, colocavam-se como profetas de tempos melhores, propondo reformas "impiedosas e idealistas, nacionalistas e utópicas", num salto do desespero para a utopia ${ }^{34}$. Moralistas e guardiães do que consideravam tradições sagradas, atacaram o progresso e a modernidade, liberalismo e secularismo. Alertaram contra a civilização industrial, que supostamente instaurava a perda de valores, unidade e fé. Tinham especial aversão ao liberalismo: para eles, o cerne de todos os males modernos, base de tudo o que detestavam: "vida burguesa, manchesterismo, materialismo, parlamento e partidos políticos, a falta de uma liderança política". Desejavam "uma nova fé, uma nova comunidade de crentes, um mundo com padrões fixos e sem dúvidas, uma nova religião nacional que unisse todos os alemães" ${ }^{35}$. O liberalismo era, em sua visão, o que impedia a consecução desses objetivos. A redenção se encontraria, segundo suas doutrinas, no nacionalismo e nas tradições culturais populares. Sentiam que um agente externo conspirava para dissolver sua unidade ancestral, e encontraram na figura do judeu o culpado ideal. Detestavam o estado, mas acreditavam fortemente na planificação política e cultural. Atacaram a imprensa, os partidos políticos, a vida urbana e comercial, e sonharam com a incorrupta (e idealizada) vida rural anterior, e com o tempo dos reis como senhores absolutos.

No final, demandavam uma autoridade nacional maior e uma coesão social mais firme. Eram costumeiramente partidários do imperialismo, e seu desejo por um heroísmo nacionalista os levava a admirar a violência, que justificavam com argumentos darwinistas ou racistas. Este tipo de ideólogo nacionalista, manifestante de uma certa “organização política do ressentimento" ${ }^{36}$, apareceu em todos os países; a ideologia do

\footnotetext{
33 STERN, 1974, p. XI.

${ }^{34}$ Idem, p. XI.

35 Idem, p. XII.

${ }^{36}$ Idem, p. XXI.
} 
desespero cultural e da redenção nacional se tornou rapidamente uma força política, dada a sua capacidade de atrair as massas descontentes ${ }^{37}$.

No cerne, o movimento antimoderno articula-se ao um grande dilema identitário que se apresentava aos povos diante das enormes transformações oriundas da modernidade. Todos foram instados repensar suas identidades, agora que se viam incluídos, muitas vezes contra sua vontade e em posição desfavorável, nesse grande concerto de forças que estendia seus tentáculos pelo mundo todo, reforçando as conexões e interdependências. A obrigatoriedade de apontar elementos que garantissem uma unidade singular e irredutível dentro desse sistema que tendia à homogeneização propeliu esforços de autodeterminação, uma busca pela Cultura essencial, na acepção de Elias. Quase sempre, o outro acaba sendo assimilado negativamente nas narrativas que sustentavam identidades. Sintomaticamente, ocorre um intenso esforço historicista, que busca "descobrir" no passado elementos que lastreiem uma determinada identidade.

No final do século, uma variante muito significativa desse historicismo emerge nas periferias da Europa. Em 1891 inaugura-se em Skansen, Suécia, o primeiro museu ao ar livre que procura preservar e exibir "costumes tradicionais". Peter Burke analisou a disseminação desse tipo de museu, no que chamou de Movimento Skansen, descrevendoo como uma "revolta da periferia cultural da Europa contra o centro; parte de um movimento, entre os intelectuais, em direção à autodeterminação e liberação em termos regionais ou nacionais"; além disso, um movimento que se origina na crença de que a cultura tradicional ou popular está em vias de desaparecer diante das forças irresistíveis da modernidade ${ }^{38}$.

\footnotetext{
${ }^{37}$ Em prefácio à edição de 1974, que aparecia mais de dez anos após a original (1961), Stern comentou o ressurgimento dessa retórica antimoderna, "contra o vazio de uma era materialista, contra a hipocrisia da vida burguesa e o afastamento da natureza, contra o empobrecimento espiritual em meio à abundância, contra todo o 'sistema liberal capitalista'" (p. IX); ressaltava a ironia de que, naquele momento, tal retórica estivesse de posse de setores do espectro político mais à esquerda. No final, afirmava que "devemos aceitar que esse tipo de revolta contra a modernidade permanece latente na sociedade Ocidental e que seu programa confuso e fantasioso, sua retórica irracional e apolítica corporifica aspirações tão genuínas, embora não tão generosas ou tangíveis, quanto as aspirações corporificadas em outros movimentos reformistas mais familiares" (p. XXII). O ressurgimento de parte dos argumentos antimodernos, agora novamente nas mãos de uma orgulhosa "direita ressurgida", parece confirmar as palavras de Stern.

${ }^{38}$ BURKE, Peter. Popular Culture in Norway and Sweden. In: History Workshop, n. 3 (Spring 1977), p. $143-$ 147. Bennett vai afirmar que há algo de bíblico nessa visão idealizada do passado, na qual as relações sociais são "concebidas num molde pré-Edênico" em que predomina a harmonia; nessa perspectiva, a modernidade simboliza o pecado que desagrada ao criador e semeia desgraças (BENNETT, Tony. The Birth of the Museum - history, theory, politics. London/New York: Routledge, 2005; p. 156); ou nas palavras de Wallace, falando sobre Greenville Village de Ford: "Era um Éden pré-capitalista imune aos males modernos, povoado com homens e mulheres de caráter" (WALLACE, Michael. Visiting the Past - History
} 
Adolf Hitler e o movimento encabeçado por ele seriam nutridos por essa tradição antimoderna. Para Joachim Fest, Hitler encontrava-se no ponto focal de uma série de circunstâncias coletivas, muito maiores que ele:

“o 'cinza' particularmente triste da República de Weimar; o rebaixamento da nação pelo
Tratado de Versalhes e o segundo rebaixamento social de largas camadas da população
devido, ao mesmo tempo, à inflação e à crise da economia mundial; a fraqueza da tradição
democrática na Alemanha; os sobressaltos causados pela ameaça de revolução comunista;
a experiência da guerra; os cálculos falhos de um conservantismo que se tornara precário;
e, finalmente, as angústias que se difundiram pela transição de uma ordem conhecida para
outra, nova e ainda incerta. Tudo isso, acrescido ainda do desejo de encontrar a proteção
de um mando autoritário"

Nesta enumeração, nota-se a presença de elementos pontuais e particulares ao caso alemão. Lá a mobilização patriótica e entusiasta da Primeira Guerra, que formou um sentimento de unidade entre os cidadãos, especialmente dentre aqueles que se envolveram diretamente nas ações do front - como o próprio Hitler - foi sucedida de maneira súbita e chocante pela humilhante derrota, agravada pelas pesadas sanções estabelecidas pelos países vencedores. O ressentimento causado por esses eventos daria o tom nas duas décadas seguintes, alimentando o extremismo político e arruinando as chances de sobrevivência do sistema republicano. Para muitos alemães, a adoção da república equivalia à submissão aos modelos políticos dos países vencedores. A regime era visto “como responsável pelas desordens, pela derrota e humilhação nacionais"40.

“[...] a amargura motivada pelas cláusulas do tratado de paz intensificou mais ainda o ressentimento contra a república, porque esta se mostrara incapaz de poupar ao país o rigor e a desonra daquele 'diktat da vergonha'; [...] a própria noção da república tornouse cada vez mais sinônimo de vergonha, de desonra e de incapacidade. E não se apagou jamais o sentimento de que com ela se impusera, pela mentira e pela coação, uma forma de governo essencialmente estranha ao país. Mesmo durante seus poucos anos felizes, a república não conseguiu captar verdadeiramente as simpatias da população [...]"41.

A República só seria tolerada na medida em que significava uma débil barreira ao comunismo, outra força política que atuou durante todo o período Weimar. Não se deve tampouco minimizar o papel da crise econômica, que corroeu a vida cotidiana dos alemães em ondas sucessivas. Em muitos documentos do Arquivo Lasar Segall pode-se

\footnotetext{
Museums in the United States. In: BENSON, Susan Porter; BRIER, Stephen; ROSENZWEIG, Roy (ed.). Presenting the past - Essays on History and the Public. Philadelphia: Temple University Press, 1986, p. 145).

${ }^{39}$ FEST, Joachim. Hitler. Rio de Janeiro: Ediouro, 2010, p. 3.

${ }^{40}$ Idem, p. 61.

${ }^{41}$ Idem, p. 65.
} 
encontrar os vestígios das dificuldades impostas pela hiperinflação, como num curioso debate registrado em cartas entre Segall e os editores do Círculo dos Artistas Gráficos e Colecionadores, a respeito da maneira correta de se atualizarem os valores ajustados por uma contribuição do artista russo para a publicação ${ }^{42}$. Ainda que a crise inflacionária tenha sido debelada em 1924, as taxas de desemprego seguiram elevadas na Alemanha ao longo de todo o período republicano. O golpe final veio com a crise mundial de 1929, que fez com que o apoio ao partido nazista extrapolasse a base original e conquistasse novos segmentos da população.

$\mathrm{Na}$ enumeração citada por Fest devem ser notados também alguns elementos que apontam um mal-estar civilizacional mais antigo e difuso. Ele se refere a "angústias que se difundiram pela transição de uma ordem conhecida para outra, nova e ainda incerta". Esse sentimento encontrava-se vivo também fora da Alemanha, e tinha raízes que remontavam, pelo menos, ao início do século XIX, quando as grandes transformações modernas - políticas, econômicas e sociais - semearam a incerteza quanto às formas do futuro. No geral,

"A velha Europa, cosmopolita, feudal e camponesa, que tinha sobrevivido por singular anacronismo [...] desfazia-se no decorrer de uma revolução silenciosa, e as agitações, os conflitos que a acompanhavam não poupavam ninguém. $\mathrm{O}$ futuro, que fora durante longo tempo o domínio na esperança e da utopia sorridente no plano privado ou social, tornavase agora uma causa de preocupação e ansiedade para grupos cada vez mais numerosos.

Esse clima de inquietação ocasionou, naturalmente, numerosos movimentos, sobretudo de ideologias defensivistas na base do nacionalismo popular e do racismo, que se apresentavam como doutrinas salvadoras de um mundo em perigo. Essa atitude defensivista se manifestou particularmente através do antissemitismo, denominador comum de numerosos partidos e ligas concorrentes"43.

As concepções de mundo de Adolf Hitler misturavam traços mal compreendidos da filosofia de Nietzsche e ecos do darwinismo, tingidos com o antissemitismo conforme

\footnotetext{
42 Segall discordava da fórmula de reajuste proposta pelos editores, devolvia o cheque enviado como pagamento e solicitava outra importância. Os 300 mil marcos que inicialmente deveriam ser pagos a Segall a título de liquidação dos honorários se haviam convertido, entre março e outubro de 1923, em 6.8 bilhões, segundo os cálculos da empresa, ou em 32 bilhões de marcos, segundo pleiteava Segall. Ver documentos ALS 00491 (Carta do editor do Círculo dos artistas gráficos e colecionadores a Lasar Segall, 23/3/1923) e ALS 00545 (Cópia de Carta de Lasar Segall ao Círculo dos artistas gráficos e colecionadores, 12/10/1923). Os reflexos dos problemas econômicos aparecem em diversas obras de arte produzidas por Segall. Temas como a viuvez e a orfandade, a mendicância, a prostituição, a fome e a morte por escassez de recursos são recorrentes em telas e gravuras desse período. Não se deve desprezar o papel que a crise inflacionária alemã exerceu na decisão de Segall em emigrar para o Brasil, decisão tomada no momento mesmo em que ele experimentava grande aceitação e reconhecimento de seu trabalho. Seu descontentamento com a situação aparece em diversas cartas escritas nesse período, e é bastante eloquente o fato de que ele deixa a Alemanha exatamente no ano em que a crise atingiu seu paroxismo. ${ }^{43}$ Idem, p. 21. Neste trecho, Fest refere-se especificamente à situação da Áustria, mas parece ser possível aplicar essas constatações a outras nações da Europa.
} 
o praticavam vários pensadores da época e do passado, dentre eles Wagner, sempre admirado pelo Führer. Para Hitler, a natureza é amoral, e a única lei aceitável na regulação das relações entre os indivíduos deve ser aquela que é ditada por ela. "Um ser bebe o sangue do outro. Enquanto um morre, o outro se alimenta. É preciso não ficar por aí dizendo tolices, falando de humanidade" 44 . Hitler declarava que todas as épocas de decadência do passado se deviam à desobediência a essas supostas "leis divinas de existência", no que acusava o cometimento de uma "infidelidade biológica". Aliada a essa concepção encontrava-se a doutrina racista, segundo a qual uma pequena elite ariana era responsável pela elevação das capacidades humanas até seus patamares máximos. Na narrativa de Hitler, vivia-se justamente o momento em que essa casta superior ameaçava desaparecer, sucumbindo, por um lado, à conspurcação biológica pela mistura com raças inferiores e, por outro, pela supressão de seu direito à supremacia, por meio da ofensiva de movimentos os mais diversos que procuravam instaurar uma igualdade, que considerava artificial, entre os indivíduos. Para Hitler, vivia-se

"[...] uma ofensiva geral, sob os mais diversos disfarces: comunismo, pacifismo, Liga das Nações e todas as instituições e todos os movimentos internacionais mas também a moral judaico-cristã da piedade e as variantes de sua fraseologia cosmopolita, [que] tentavam persuadir o homem de que ele era capaz de dominar a natureza, domesticar seus instintos e construir a paz eterna" ${ }^{45}$.

Para Fest, a força de Hitler provinha exatamente desse poderoso delírio escatológico. "Como que hipnotizado pela ideia de uma grande enfermidade mundial, por toda parte enxergava a existência de vírus, pragas e úlceras afetando a humanidade". Com base nessa constatação pseudocientífica, acreditava cada vez mais, até chegar ao completo desvario, em seu papel missionário, colocando-se - e sendo visto por parte expressiva da população - como um novo redentor, encabeçando a luta pela salvação da humanidade. Grandes decisões tidas como estrategicamente desnecessárias e até mesmo contraproducentes - como a "solução final" para a questão dos judeus e a invasão e guerra de extermínio contra os russos - explicavam-se justamente por essa convicção de que se tratava de uma luta do escolhido em busca de "repelir o Mal para os domínios de Lúcifer" $"$.

A contribuição particular de Hitler, que era também o predicado que o tornou apto a enfeixar a força da sociedade alemã sob si, foi sua capacidade de condensar essa

\footnotetext{
${ }^{44}$ Apud. FEST, 2010, p. 156.

45 FEST, 2010, p. 159.

${ }^{46}$ Idem, p. 153.
} 
doutrina, "a ponto de fazer dela um instrumento demagógico e um sistema que oferecia explicação plausível para todos os descontentamentos, angústias e sintomas de crise do tempo presente" ${ }^{, 4}$.

Era inevitável que a arte fosse cooptada pelas forças em combate. Aos artistas seriam impostos os mesmos dilemas, e todas as tensões culturais deixariam suas marcas no campo da estética. É bem conhecida a proeminência das questões culturais entre os germânicos. A classe ilustrada alemã tratada por Norbert Elias avaliava o culto ao espírito como a atividade mais nobre, superior aos mesquinhos interesses materiais. Era corrente a noção de que a arte teria a capacidade de regenerar a sociedade e a política. Peter Viereck ressaltou a onipresença da reflexão sobre estética entre os membros do partido Nacional Socialista. Uma grande parcela dos líderes do regime era formada por indivíduos que, na primeira juventude, haviam imaginado seguirem caminhos artísticos ou literários ${ }^{48}$. "Estetas com metralhadoras", nas palavras de Viereck, eram capazes de discutir, ao longo de uma mesma reunião, a invasão da França e as medidas a serem adotadas para livrar a arte das mãos do capitalismo judaico ${ }^{49}$.

Uma primeira onda de resistência às propostas de renovação pode ser apontada nos embates entre a arte sancionada pelo Império e a modernidade dos introdutores do impressionismo, realismo e simbolismo na Alemanha. A faceta eufórica e triunfalista do Império em expansão aparece na pintura de Anton von Werner. Diretor da Academia Imperial de Belas Artes de Berlim desde 1875, tornara-se célebre durante a Guerra Franco-Prussiana (1870), quando, comissionado pelo governo, estivera no front e realizara uma série de imagens que se tornaram emblemáticas. Werner era uma espécie de artista oficial da Alemanha guilhermina. Seu prestígio era ainda maior por conta da proximidade com o imperador: o pintor fora professor de artes de Guilherme II e tinha sobre ele grande ascendência.

As opiniões de Guilherme II sobre estética consubstanciavam-se, pela própria proeminência do lugar de onde emanavam, num dos polos de tensão das disputas em torno

\footnotetext{
47 Idem, p. 160.

48 Goebbels tentara a vida como dramaturgo, poeta e romancista; Alfred Rosenberg pensara em ser arquiteto ou filósofo; muitos outros haviam tentado carreiras na música, na literatura ou nas artes visuais. O próprio Hitler, como é sabido, tentou em duas ocasiões ser admitido na Academia de Belas Artes de Viena, sem sucesso. Por muito tempo, sobreviveu da venda de cartões postais e quadros contendo suas pinturas de paisagens; cfe. VIERECK, 2004, p. 157.

${ }^{49}$ Idem, p. 154.
} 
da arte. Uma reunião de suas concepções estéticas pode ser encontrada no famoso Discurso da sarjeta ${ }^{50}$. "A arte deve criar a partir do grandioso manancial da mãe natureza", dizia ele, num processo que, "a despeito de sua tremenda, aparentemente irrestrita e infinita liberdade, deve funcionar de acordo com leis eternas que o próprio Criador impôs, e que nunca podem ser desprezadas ou violadas, sem com isso causar grandes riscos ao progresso mundial". A arte clássica seria feita de acordo com essas leis eternas, divinas, "a lei da beleza e da harmonia".

"A arte que viola as leis e ultrapassa as fronteiras que Eu indiquei não pode mais ser considerada arte. É produção fabril, comercialismo, e nunca arte. É tão frequente que, sob a surrada bandeira da 'liberdade', se desça ao excesso, à licenciosidade, e à audácia. De todo modo, aquele que peca contra a quintessência da arte, que procura soluções para a sua tarefa principal na mera perspectiva técnica, perde o contato com a lei da estética e com todo o sentimento de beleza e harmonia".

A arte, dizia Guilherme II, deveria auxiliar na educação do público, deveria incutir nas pessoas, especialmente entre os membros das classes trabalhadoras, grandes ideais que norteassem suas condutas, através da exposição ao belo e ao harmonioso. "Se a arte, no entanto, retrata nada mais do que a miséria - o que vem ocorrendo com tanta frequência atualmente - e o faz sob uma luz ainda mais terrível do que aquela emanada pela própria miséria, então ela peca contra o povo alemão". A arte só poderá cumprir sua missão de elevar o povo quando ela mesma "deixar de se rebaixar ao nível da sarjeta".

Salientam-se, no "Discurso da Sarjeta", elementos interessantes para compreender as concepções em conflito. Primeiro, a afirmação da existência de leis inflexíveis guiando a criação artística. Os limites ali mencionados não eram biológicos ou naturais - como afirmaria a escola estética "positiva - mas "morais" ou religiosos: Guilherme II atribuía ao próprio Criador a determinação das "leis eternas". Espelhando a narrativa bíblica, ameaça com punição a quem ousasse contrarias estes mandamentos. Neste caso, a danação recairia sobre toda a sociedade, que se veria destituída do direito ao progresso. A arte, no discurso, aparece como recurso pedagógico ou "edificante": ela deveria servir como ideal elevado estimulando a reforma nas condutas das pessoas, especialmente dos membros das classes menos favorecidas. Mas naquele momento, segundo o Kaiser, a arte falhava, distanciando-se do padrão ideal. Isso é indicado no desdobramento do discurso.

50 No original, Rinnsteinrede - forma como ficou conhecida sua proclamação de dezembro de 1901, feita durante a inauguração da Siegesallee, a "Avenida da Vitória" em Berlim A versão do Rinnsteinrede analisada neste trabalho foi obtida junto ao projeto "German History in Documents and Images (GHDI)", um repositório de fontes primárias sobre a história da Alemanha disponibilizado pelo Instituto Histórico Alemão de Washington-DC. Endereço eletrônico: http://germanhistorydocs.ghidc.org/pdf/eng/301 Wilhelm\%20II True Art 50.pdf (acessado em 10/8/2016). 
Na continuação de sua diatribe, Guilherme II se dirige a alvos precisos, voltando-se nitidamente contra certas concepções modernas da arte. Ao endereçar críticas à "arte comercial", aquela que se anunciava em reclames na imprensa na busca por atenção do público, ele parece se referir de maneira pejorativa a todo o sistema independente que se formara no final do século XIX, sistema que diminuía o poder da intermediação estatal, cassando-lhe o estatuto de canal de articulação exclusivo entre o artista e seu público. Ao referir-se a uma arte que preferia retratar as misérias, ele censurava a corrente realista. Segundo Peter Paret, esta vertente incomodava Guilherme II também por seu potencial politicamente subversivo ${ }^{51}$. Joan Weinstein, que também procurou observar os conteúdos implícitos do Discurso da Sarjeta, encontrou nele a intenção de interferir na luta em andamento na Alemanha Imperial "sobre quem iria definir o que era arte" 52 . Permeando o discurso como um todo, despontava um tom defensivo, revelando a desvantagem de seu emissor. Fica claro que Guilherme II perdia o controle ao reconhecer inimigos internos (os que supostamente excitavam a agitação social) e externos (a influência estrangeira emitida pelo ocidente decadente). Traía, além da xenofobia, o medo da politização das classes populares.

Essa variante de ojeriza à modernidade exibida por Guilherme II, que era praticada oficialmente nas instituições sob seu alcance, destinava-se a combater uma "primeira modernidade" alemã, como aquela representada pelos artistas identificados com o impressionismo e com o realismo. Max Liebermann talvez tenha sido o representante máximo desse movimento. Nascido de uma rica família de judeus integrantes da nova elite industrial, ele aliou a prática artística com uma intensa mobilização política (ainda que não admitisse o caráter político de sua ação) voltada para a criação de estruturas que dessem amparo às correntes artísticas não reconhecidas pelo status quo. Encorajou a formação de coleções de arte moderna privadas e públicas, estimulou a realização de exposições regulares e fundou com outros artistas, em 1898, a influente Secessão de

\footnotetext{
51 PARET, Peter. The Tschudi affair. In: The Journal of Modern History; Vol. 53, N. 4 (Dez - 1981). Chicago: The University of Chicago Press, 1981; p 589-618, p. 595. Em 1892 as autoridades censuraram a peça Os Tecelões, de Gerhardt Hauptmann, que tocava, com as ferramentas do realismo literário, na questão da exploração dos trabalhadores. Após prolongada batalha judicial, a interdição foi derrubada. Guilherme II demonstrou sua contrariedade abdicando de seu camarote pessoal no Deutsche Theater de Berlim; cfe. FEUCHTWANGER, 2001, p. 103.

52 WEINSTEIN, Joan. The end of expressionism - art and the November Revolution in Germany, 1918-19. Chicago: The University of Chicago Press, 1990., p. 2
} 
Berlim, que acabaria se tornando um dos principais esteios da arte moderna na Alemanha, criando as condições para o florescimento de uma nova geração de $\operatorname{artistas}^{53}$.

Um outro ponto em que as tensões culturais entre modernos e tradicionais se manifestaram no campo da arte foi na administração das coleções públicas. Por conta de disputas em torno dos critérios de admissão de obras, o diretor da Galeria Nacional de Berlim, Hugo von Tschudi, desentendeu-se com o próprio Kaiser. Tschudi, historiador da arte que fora indicado para o cargo, em 1896, justamente porque se acreditava que teria uma posição conservadora, converteu-se à ideia de que a arte alemã contemporânea só seria compreendida quando observada em conjunto com os mais recentes desenvolvimentos da arte francesa. Contrariando o desejo do governante, e contornando os interditos orçamentários por meio do amparo de uma rede de colecionadores entusiastas do impressionismo, Tschudi preencheu a Galeria Nacional com obras de Manet, Monet, Degas, Rodin, Millet, Pissaro e Sisley, entre outros, "num momento em que mesmo o Louvre apenas começava a adquirir impressionistas franceses" ${ }^{\text {54 }}$. Em 1908 o imperador tentou defenestrar Tschudi de seu cargo, mas foi impedido pela opinião pública.

O próprio Lasar Segall iria experimentar pessoalmente as tensões dessa Alemanha culturalmente cindida. Chegando em Berlim em 1906, em busca de complementar sua formação e se tornar um artista profissional, Segall deparou-se com esse universo cultural em plena ebulição, marcado por tensões pronunciadas entre tendências conflitantes. Em 1907, o artista ingressou como estudante na Academia Imperial de Belas Artes de Berlim, então sob direção de Anton von Werner, local onde se praticavam concepções tradicionais de arte. As descrições deixadas em suas recordações, registradas muitas décadas depois dão indícios do posicionamento de Segall em meio às polêmicas que se desenrolavam:

"Em 1907 entrei na Academia de Belas Artes, que tinha o título pomposo de 'Koenigliche Kaiserliche Akademische Hochshule fuer Bildende Kuenste' [...]. A Academia era um edifício pretensioso, cheio de escadarias em mármores de toda espécie, dos quais emanava um frio glacial que se harmonizava perfeitamente com o espírito prussiano lá reinante, restritivo da menor veleidade de liberdade artística. $\mathrm{O}$ ensino, sobrecarregado de regras acadêmicas, era tão exageradamente pedantesco como a própria aparência dos professores, os quais, ornados de bigodes marciais, que sobrepujavam os queixos rigidamente imprensados em colarinhos de incrível altura, jamais envergavam outro traje

53 DESHMUKH, Marion F. "Politics is an art": the cultural politics of Max Liebermann in Wilhelmine Germany. In: Studies in the History of Art, Vol. 53, Symposium Papers XXXI: Imaging Modern German Culture: 1889-1910, Washington: National Gallery of Art, 1996; p. 173.

54 PARET, 1981, p. 599. Um relato mais circunstanciado sobre o que ficou conhecido como o "Caso Tschudi" pode ser encontrado no citado artigo de Peter Paret. 
a não ser o fraque, cartola e bengala. O Kaiser, que se interessava pelo que ele chamava de arte e que era responsável tanto pela arquitetura pomposa e fria do prédio como pelas diretrizes impostas ao ensino e à disciplina acadêmicas, dignava-se honrar-nos às vezes com sua visita.

Militarmente alinhados, tínhamos então todos de gritar com vozes estentóricas 'Viva o Kaiser' em nossas diversas línguas de origem, para dar caráter mais 'espontâneo' à essas aclamações.

Hoje não entendo como é que pude aturar durante alguns anos essa atmosfera sufocante" $" 55$.

Segall demonstra nesse relato um posicionamento antagônico quanto ao estado de coisas, que coincide em muitos aspectos com a ótica dos secessionistas: a Academia aparece como um lugar onde a rígida disciplina impõe a repetição mecânica de um cânone ultrapassado e pedante, onde se desaconselha veementemente o exercício da experimentação e da liberdade artística $^{56}$.

De todo modo, a análise do contexto demonstra uma maré vazante para as tendências tradicionais na arte. Apesar dos esforços encabeçados por Guilherme II e Anton von Werner, as tendências modernas da arte ganhavam espaço nas coleções públicas e privadas, nos compêndios de história da arte e na imprensa especializada da Alemanha.

O nacionalismo, que poderia obstar a aceitação da arte de cunho impressionista, por associação com o universo estrangeiro, e especialmente francês, era contornado por uma geração de críticos de arte que lançavam mão de um procedimento engenhoso. Tratase, na descrição de Patricia Berman, da "formulação de identidades artísticas por meio de genealogias inventadas" ${ }^{\circ 7}$. Tal estratégia tem como cerne a crença de que a arte genial do passado, e também a arte moderna, eram feitas de acordo com os mesmos valores, que atravessam o tempo e o espaço. Existe no discurso desses críticos uma negociação entre passado e presente, permitindo que se apreenda a tradição no interior da vanguarda. Segundo Berman, Julius Meier-Graefe foi o cultor principal dessa retórica, conciliando a

\footnotetext{
55 SEGALL, Lasar. Minhas Recordações. In: Lasar Segall - Textos, depoimentos, exposições. São Paulo: Museu Lasar Segall, 1993; p. 12.

${ }^{56}$ É possível argumentar que tal relato, escrito muitas décadas depois da experiência berlinense, pode não refletir o posicionamento do jovem Segall naquela altura, mas antes a visão retrospectiva do modernista consagrado e maduro, já estabelecido em seu ateliê na Vila Mariana. De qualquer forma, as escolhas posteriores de Segall demonstram coerência com essas declarações. Em 1910, ele deixaria Berlim e buscaria um ambiente culturalmente mais arejado na Academia de Dresden.

57 BERMAN, Patricia G. The Invention of History: Julius Meier-Graefe, German Modernism, and the Genealogy of Genius. In: Studies in the History of Art, Vol. 53, Symposium Papers XXXI: Imagining Modern German Culture: 1889-1910 (1996), p. 90-105
} 
arte contemporânea internacional com a identidade nacional germânica, colocando-se como mediador entre os agentes da arte oficial do Império - que repudiavam a arte estrangeira, especialmente a francesa - e os elementos ligados à Secessão de Berlim, que abraçaram o pluralismo estético internacional. A estratégia empregada para conciliar esses extremos consistia em reconstituir o conceito romântico de gênio e inseri-lo na narrativa genealógica que leva à Alemanha contemporânea:

"Meier-Graefe construía elaboradas genealogias de gênios, nas quais artistas do passado, como Michelangelo e El Greco, e artistas contemporâneos, como Rodin e Cézanne, eram removidos de seus contextos nacionais e temporais e realocados em terrenos transhistóricos nos quais eles não eram constrangidos pela pertença a qualquer cultura ou categoria normativa" 58 .

Fosse quando escrevia - por exemplo, em seu "História da arte moderna" - fosse organizando exposições, Meier-Graefe recorria ao expediente de semear mestres consagrados em meio aos modernos, apontando as ligações entre eles e, assim, buscando legitimar os novos. Uma exposição de arte impressionista que organizou em 1903, por exemplo, apresentava na sala de entrada quadros de Goya, El Greco, Velázquez e Vermeer ${ }^{59}$. Com isso, "pretendia assegurar ao público que a arte moderna era familiar e que o modernismo era uma força cultural redentora e inevitável"60.

Robert Jensen observou esse fenômeno a partir de outra perspectiva ${ }^{61}$. Para ele, o aparecimento das vanguardas corresponde a movimentos sociais, econômicos e culturais específicos. Em termos sociais, Jensen refere-se ao que chama de "motim no interior da profissão artística" ${ }^{\text {"2 }}$ : um número crescente de pessoas postula a profissão, formando um conjunto que ele chama de "proletariado artístico", instituindo uma competição interna que invalidaria as antigas instâncias de consagração e inviabilizaria os tradicionais canais

\footnotetext{
58 Idem, p. 91.

59 Idem, p. 93.

60 Idem, p. 94. Pensadores devotados a compreender os princípios reguladores dos museus "modernos" - isto é, os que se organizam a partir do século XIX - encontram nessa abordagem genealógica da arte um alinhamento com a ordem do pensamento do tempo: "O desenvolvimento dos museus no século XIX foi dirigido pela perspectiva de que era possível atingir 'uma representação total da realidade humana e da história, por meio da exposição ordenada de uma seleção de artefatos' [...]. Isto é, os museus deviam arranjar suas exibições de artefatos selecionados de maneira a estimular a organização do mundo humano e natural - para além de suas paredes". Nessa ordenação racional que acreditava-se espelhar a ordem real das coisas, os museus de arte tiveram papel especial. Por meio das obras de arte organizadas entre precursoras e sucessoras, numa cadeia de influências ao longo do tempo, atingir-se-ia aquilo "além do visível, a ordem das coisas, a ordem racional descoberta e acessível através das Luzes; os objetos são apenas portas para essas ordens invisíveis"; cfe BENETT, 2005 p. 126 e 164.

61 JENSEN, Robert. The Avant-Gard and the Trade in Art. Art Journal, Vol. 47, No. 4, Revising Cubism (Winter, 1988), p. 360-367.

62 Idem, p. 360.
} 
de distribuição. Economicamente, há uma penetração decisiva das forças de mercado na regulação das relações entre produtores e consumidores de arte, tomando espaço e assimilando funções que antes pertenciam a outros atores. Em termos culturais, Jensen aponta que esse processo ocorre no interior de um arco ideológico marcado pela influência decisiva das ideias evolucionistas - especialmente as de Darwin e Marx. Tal paradigma passa a informar as interpretações sobre a realidade; para "sobreviver", uma obra de arte ou um artista precisavam demonstrar sua legitimidade histórica, isto é, justificar sua existência provando-se resultado natural e inevitável dos desdobramentos de processos oriundos no passado. Artistas e "movimentos" seriam mais geralmente aceitos e consagrados quanto mais claramente conseguissem parecer um télos realizado.

Para Jensen, esse estado de coisas conduz a uma sequência de secessões: os salões de recusados seguidos pelas secessões que os recusam, seguidos pelas vanguardas que os procuram deixar para trás. Cada uma dessas rupturas, para Jensen, representa a tentativa de formação de uma nova elite artística, de um pequeno grupo, saliente no oceano de artistas, por suas propostas divergentes. Ele destaca, nesse processo, o papel central das galerias, que no início do século XX tomam a frente como instituições consagradoras mais importantes, selecionando os artistas que formariam as novas elites e dando-lhes destaque. Nesse processo, lançavam mão de antigas estratégias reconfiguradas: a exposição individual - que no passado, segundo Jensen, eram reservadas aos artistas consagrados, ou já desaparecidos - e, especialmente, o manejo habilidoso das narrativas históricas, que buscavam associar os artistas novos aos movimentos do passado, procurando colocá-los na posição de herdeiros-continuadores.

Como exemplo, Jensen cita a cada vez mais vertiginosa sucessão de novidades inaugurada em 1900. Na Exposição Universal de Paris daquele ano, a geração impressionista foi formalmente apresentada como um movimento estético renovador, herdeiro da tradição da pintura e continuador dela e como matriz para tudo o que vinha se fazendo de relevante em termos artísticos no mundo todo. A partir de 1903, uma nova “onda renovadora” foi apresentada ao público pelos Salóes dos Independentes e Salões dos Autônomos, desbancando os impressionistas, introduzindo uma geração "pósimpressionista”. Já em 1907 as obras de Seurat, van Gogh, Cézanne, Lautrec e Gaugin atingiam valor comercial estável, e seus autores, apesar de "novos", já ocupavam a categoria de "mestres consagrados".

"Eles eram radicalmente renovadores para os padrões de um público (incluindo a vasta maioria dos artistas) que somente então acabavam de aceitar o Impressionismo. Ainda 
assim foram proclamados velhos mestres, herdeiros de uma evolução da arte que começava precisamente em David e continuava numa linha que geralmente incluía Ingres, Delacroix, Corot, Courbet e Manet. Jovens artistas absorveram rapidamente as lições desses novos mestres; alianças eram forjadas da noite para o dia" ${ }^{\prime 63}$.

Daí em diante, inaugurou-se uma busca, entre os marchands mais proeminentes, pela "nova geração", que deveria ser inserida na história da arte em relação aos pósimpressionistas, assim como eles haviam sido inseridos em relação aos impressionistas. A história da arte fragmenta-se, deixando de ser "o avanço unívoco do Impressionismo" para se tornar uma competição entre facções e indivíduos, todos buscando seu lugar "inevitável" na história. Empunhando o estandarte do progresso, a arte de vanguarda se consolidou. Na prática, "tornou-se um termo que acima de tudo definia, para benefício do público consumidor, um grupo de elite entre os artistas". Nesse processo, além dos galeristas e críticos, Jensen aponta a necessidade de colaboração dos artistas; uma das características mais importantes das vanguardas, para o autor, é “a forma voluntária com que os artistas assumem e fomentam seus próprios mitos" ${ }^{64}$.

As forças tradicionalistas, no entanto, não desistiram da luta. Revestidas de nacionalismo, manifestaram-se intermitentemente contra as propostas cosmopolitas dos “modernos". Em 1911, 140 artistas, críticos e outras personalidades do mundo cultural assinaram o manifesto produzido pelo pintor Karl Vinnen, intitulado "Um protesto dos artistas alemães" ${ }^{65}$. Os artistas subscritores reagiam à aquisição de um quadro de Vincent van Gogh pelo diretor do Museu de Bremen, Gustav Pauli. A introdução da arte estrangeira, segundo Vinnen, especialmente quando supervalorizada pela especulação, fazia com que os artistas alemães abandonassem sua inclinação racial e passassem a ser meros imitadores das modas vindas de fora das fronteiras ${ }^{66}$. Além da referência ao caráter racial da arte nacional, o protesto de Vinnen sugeria "uma ligação entre a dominação estrangeira de franceses e judeus sobre as belas artes"67.

\footnotetext{
${ }^{63}$ Idem, p. 361.

${ }^{64}$ Idem.

${ }^{65}$ No original, "Ein Protest deutscher Künstler"; o documento foi assinado, entre outros, Käthe Kollwitz, que depois se diria arrependida por não ter percebido o potencial insidioso da proposta; cfe. DESHMUKH, 1996, p. 176.

${ }^{66}$ VINNEN, apud. LONG, Rose-Carol Washton (Org.). German expressionism: documents from the end of the Wilhelmine Empire to the rise of National Socialism. Berkeley: University of California Press, 1995; $\mathrm{p}$. 7-8.

${ }^{67}$ DESHMUKH, 1996, p. 176.
} 
Outro porta-voz influente dessa teoria que associava arte, pátria e raça era o crítico de arte Henry Thode. A partir de 1905, Thode percorreu a Alemanha ministrando palestras em que defendia haver uma grave ameaça ao caráter nacional embutida no avanço do impressionismo. Ele atacava fervorosamente a Secessão de Berlim, a quem acusava de promover a arte francesa em detrimento da nacional. Declarava-se particularmente alarmado pelo fato de que tais secessionistas haviam encontrado formas de contornar a rejeição oficial, criando seu próprio circuito de publicações, galerias e locais de exposição, e dessa maneira formavam, entre as classes médias alemãs, um público que os enxergava como arautos do "novo". Incapaz de frear esse processo, Thode recorreu à estratégia de rotular seus expoentes como "estrangeiros" e, dessa forma, supostamente nocivos ao caráter alemão ${ }^{68}$.

É importante lembrar que os atritos entre concepções estéticas distintas não ficaram restritos à polarização entre tradicionalistas e modernos: observaram-se contendas no interior do próprio campo daqueles identificados com as correntes renovadoras. Em 1910, Liebermann e outros dirigentes da Secessão de Berlim recusaram a admissão de 89 trabalhos de 27 artistas de vanguarda no Salão do grupo. Liebermann “detestava intensamente o expressionismo, acreditando que o movimento refletia valores incivilizados" $"$. Dessa forma, o experiente pintor impressionista reeditava contra os expressionistas argumentos semelhantes aos que foram usados contra si, afirmando que se tratava de uma arte tosca e preguiçosa. Ainda que no começo do século alguns experimentadores fossem capazes de inserir obras nas mostras da Secessão - Deshmukh cita Otto Modersohn e os artistas de Worpswede - o descontentamento dos “jovens” com a liderança de Liebermann cresceu gradualmente e resultaria em novas secessões.

Liebermann estava em uma posição difícil: por um lado, via-se forçado a defender-se da extrema-direita, dos nacionalistas e racistas, pugnando por uma visão compreensiva da arte e da sociedade, uma em que religião, política e etnia não fossem índices para determinar a qualidade, a pertinência e o valor de uma pessoa ou de sua obra.

68 CLINEFELTER, Joan L. Artists for the Reich - Culture and Race from Weimar to Nazi Germany. Oxford/New York: Berg, 2005. p. 12.

69 DESHMUKH, 1996, p. 177. Liebermann decidiu abandonar a presidência da Secessão após as querelas de 1910. Em seu discurso de despedida, declarou: “[...] Talvez eu não compreenda a linguagem formal da nova arte... e por isso me oponha à sua admissão em nossa exposição. Nesse caso, nenhum dano maior terá sido feito; eles podem gabar-se por uma certa glória que vem do martírio numa exposição livre de júri. Talvez eu tenha sido parcial. Eu nunca fui conscientemente injusto, e nunca suprimi o talento"; apud. DESHMUKH, 1996, p. 178. 
Por outro, encarnava a figura do conservador, ao opor-se às novas correntes estéticas que apareciam após a virada do século. Uma de suas cruzadas era contra aqueles que pleiteavam o afastamento entre pintura e mundo objetivo: "não há nenhuma afirmação mais ridícula do que aquela que agora se lê e ouve quase diariamente, de que o naturalismo está morto. Toda arte fundamenta-se na natureza, e tudo o que é duradouro nela é a natureza"70. Nas palavras do crítico de arte Karl Scheffler, "a arte e a personalidade de Liebermann nunca foram populares. Na verdade, sempre houveram inimigos - primeiro, entre os reacionários, e depois, entre os que se autodeclaravam revolucionários" ${ }^{, 71}$.

Mesmo a crítica de arte inclinada às correntes progressistas recuou diante das propostas formais das vanguardas. A posição do próprio Julius Meier-Graefe sinaliza essa situação. Em 1913, quando era reconhecido como o mais relevante crítico de arte da Alemanha, publicou o artigo "Para onde vamos?", na revista "Neue Rundschau" [Novo Panorama]. O texto polêmico trazia pesadas admoestações contra a arte contemporânea, especialmente a respeito das novidades formais propostas pelos expressionistas alemães dos grupos "A Ponte" e "O Cavaleiro Azul". Graefe "queixa-se de que os jovens expressionistas não se ocupam com a tradição, de que são pouco instruídos"72. Quando reeditou o famoso compêndio com que saudara a arte moderna feita na França, Graefe pontificou: o movimento de renovação chegava ao fim com Picasso. A destruição das formas desencadeada pelo espanhol tornava impossível, na ótica daquele crítico, a continuidade do processo de desenvolvimento da pintura $^{73}$.

Emil Nolde e seu "Pentecostes" tornaram-se símbolos da arte de vanguarda recusada pela Secessão de Berlim. Mais tarde, Nolde desenvolveria um discurso violento de ataque à geração que o precedeu, combinando elementos antissemitas e xenofóbicos em suas invectivas. Por ocasião do protesto de Vinnen, declarou:

"As palavras do pintor Vinnen se direcionam... principalmente contra o trabalho da Secessão de Berlim... Desde que foi fundada ela enfatizou repetida e zelosamente que os franceses são os grandes pintores e que [os alemães] são apenas medianos... A geração que sucede a Secessão... sabe que dela depende a realização de grandes tarefas" 74

\footnotetext{
${ }^{70}$ Apud. DESHMUKH, 1996, p. 178.

${ }^{71}$ Apud. DESHMUKH, 1996, p. 178.

72 ILLIES, Florian. 1913: antes da tempestade. Tradução Silvia Bittencourt. São Paulo: Estação Liberdade, 2016. P. $87-88$

73 Idem, p. P. 86.

${ }^{74}$ Apud DESHMUKH, 1996, p. 177.
} 
$\mathrm{O}$ ataque de Nolde juntava-se ao coro de forças conservadoras e antissemitas que lançavam acusações graves contra Liebermann: “oponentes antissemitas ligavam a pintura de Liebermann com o socialismo, e suas atividades eram associadas à dominação judaica do comércio" 75 .

Mais tarde, Nolde encontraria partidários de sua arte no interior do partido nazista, que tentariam interpretar esses eventos como a luta de um artista racialmente puro contra o sistema das artes dominado pelos judeus, socialistas e partidários da cultura estrangeira. Nolde seria apresentado pelos nazistas entusiastas da arte moderna como um nacionalista avant la lettre, que sofrera por anos combatendo o sistema cultural contaminado e que agora esperava a redenção. Esse acerto narrativo foi deliberada e minuciosamente construído, num esforço coordenado em que Nolde tomou parte ativa, conforme atesta a análise de sua correspondência e de outros documentos efetuada num artigo publicado recentemente ${ }^{76}$. Uma versão burilada da narrativa com que Nolde pretendia se apresentar como o artista modelo do regime nazista aparece numa carta a Joseph Goebbels:

“[...] já antes do início do movimento nacional socialista eu era praticamente o único artista alemão que lutava abertamente contra a infiltração estrangeira na arte alemã, contra o sujo mercado de arte, e contra as extorsões da era Liebermann-Cassirer, uma luta contra forças vastamente superiores que me causou décadas de desvantagens e dificuldades materiais" $" 77$.

As polarizações apresentadas até aqui, devem ser relativizadas. Tais categorias devem servir apenas como balizas iniciais, já que cada artista se posicionará de maneira diferente diante das forças em tensão, e é possível que até o mesmo artista seja encontrado em terrenos opostos, a depender do período de sua vida que venha a ser analisado.

\footnotetext{
75 DESHMUKH, 1996, p. 177.

${ }^{76}$ FULDA, Bernhard; SOIKA, Aya. Emil Nolde and the National Socialist Dictatorship. In: PETERS, Olaf (Ed.) Degenerate Art: the attack on modern art in Nazi Germany, 1937. New York: Neue Galerie New York, 2014. p. 186-195. Nolde, ironicamente, seria um dos artistas modernos mais diretamente prejudicado pela Ação contra a Arte Degenerada, sendo o que mais obras apreendidas teve (1052, segundo FULDA et SOIKA, 2014, p. 186; a Base de Dados "Entartete Kunst" da Universidade Livre de Berlim aponta que foram 1143). Ele perdeu suas honrarias e posições públicas, foi confinado a uma espécie de prisão domiciliar e teve seus instrumentos de trabalho confiscados, vendo-se obrigado a produzir apenas aquarelas e desenhos durante os anos finais do Terceiro Reich. Nolde denominaria essas obras de "ungemalte Bilder" - quadros não-pintados - e os distribuiria a jornalistas que o procuravam, após a queda do regime, como prova material da perseguição sofrida; dessa forma, a desgraça se tornou auspiciosa: o entusiasmo de Nolde para com o regime nazista pôde ser esquecido e sua figura reabilitada (FULDA et SOIKA, 2014, p. 194).

${ }^{77}$ FULDA et SOIKA, 2014, p. 192.
} 
O caso de Lovis Corinth é exemplar disso. Grande nome da arte alemã do início do século XX, ocupava cargos de liderança na Secessão de Berlim. Em suas conferências e textos sobre arte, expressava um amálgama de elementos tratados até aqui como antagônicos.

Para Corinth, o verdadeiro artista era aquele capaz de conjugar o domínio técnico absoluto com a expressão individual. Somente pela conquista plena das técnicas o artista estaria apto a dar às suas inclinações pessoais as condições de florescer. Essa combinação, para ele, protegia o artista contra influências externas, garantindo individualidade absoluta em sua produção. Ao caracterizar o que denominava "influência externa", Cortinth incorria na retórica que, em geral, era exercitada pelos antimodernos. Corinth cunhou o termo Modebilder para se referir pejorativamente a uma pintura feita de acordo com convenções, padrões e modelos adotados racionalmente pelos $\operatorname{artistas}^{78}$. Condenava a condução da arte pelo intelecto: o sentimento deveria predominar. Esse estado de coisas levava a uma pintura em que a visão pessoal era sacrificada em nome do cálculo racional: "agora apenas o intelecto guia a mão do artista, e não seus sentimentos".

Para Corinth, essa situação se devia a fatores políticos. Os artistas alemães não conseguiam escapar da influência cultural francesa, especialmente irresistível numa Alemanha fragmentada em pequenos reinos politicamente desencontrados. Mas o prognóstico de Corinth era otimista. Para ele, a França estagnara, e a força crescente da Alemanha após a unificação tornava-a cada vez mais apta a assumir o papel de novo polo cultural do Ocidente: "após superar esse período, a Alemanha terá desenvolvido sua própria arte nacional, e então nós seremos os modelos seguidos por outros, deixando a condição de seguidores que nós por tanto tempo, e justificadamente, mantivemos"79.

Corinth recorria à sua própria versão da estratégia de criar genealogias entre artistas modernos e os mestres consagrados do passado, com vistas a chancelar as propostas renovadoras de sua geração. Para ele, não havia contraposição entre os novos e os velhos: todos os pintores relevantes, de qualquer época, tinham exercido o direito de produzir arte de acordo com seus ditames pessoais. Nesse aspecto, aproximava-se do discurso de Max Liebermann e de Julius Meier-Graefe, todos eles defensores da ideia de

\footnotetext{
${ }^{78}$ WITH, Christopher B. "Work and Make it Better": Lovis Corinth, German Art, and the Peril from Abroad. In: Studies in the History of Art, Vol. 53, Symposium Papers XXXI: Imaging Modern German Culture: 18891910, Washington: National Gallery of Art, 1996. p. 209-227; p. 210.

79 Apud WITH, 1996, p. 211. Deve-se notar a validade da generalização de Norbert Elias para a compreensão desse caso: o impulso por considerar a "cultura" como valor supremo, oposto à "civilização", entre povos que ainda buscam sua identidade.
} 
que o verdadeiro valor da arte "residia num campo transhistórico e transtemporal onde as criações de todas as eras se juntavam através da ligação comum com a criatividade desimpedida" ${ }^{\prime 80}$. No entanto, Corinth tomava um caminho diferente. Aceitava o caráter "transhistórico" da arte, mas não o "transnacional". "Deve-se lembrar que o sol brilha na Provença em tons diferentes daqueles do Mark Brandenbrug" 81 . Para ele, a arte "sempre será condicionada pelo acidente da nacionalidade" ${ }^{, 82}$.

Corinth aproxima-se, nesse aspecto, da retórica daqueles que viam na arte moderna uma ameaça ao caráter germânico. Valoriza, como eles, a sensibilidade sobre o intelecto, incorrendo numa espécie de pensamento irracional bastante similar ao professado pelos "profetas sociais" analisados por Fritz Stern. No entanto, Corinth evita transgredir uma linha importante. Para ele, o caráter nacional da arte reside na cultura do indivíduo, e não em sua essência biológica. Em outras palavras, Corinth não associava arte e raça, como fariam os responsáveis pelas ideias que levariam à ação contra a arte degenerada.

Essa linha, uma vez cruzada, conduziria a caminhos perigosos: quando se admite que certas tendências estão inscritas na essência do sujeito, por conta de fatores biológicos, aceita-se que certos grupos são portadores de características inevitáveis. Enquadra-se esse grupo na categoria dos incorrigíveis, a serem afastados ou eliminados do convívio com os "puros".

\footnotetext{
${ }^{80}$ WITH, 1996, p. 211.

${ }^{81}$ Apud WITH, 1996, p. 211.

82 WITH, 1996, p. 211.
} 


\section{Capítulo 2 \\ Uma arte que clama por camisa-de-força: arte moderna como sintoma de degeneração}

A decisão dos nazistas de se referirem à produção estética moderna como "arte degenerada" [entartete Kunst] torna obrigatório um olhar sobre a trajetória da própria ideia de degeneração. Tal como o antissemitismo, o conceito de degeneração era um elemento cultural dotado de longa tradição e bastante disseminado na cultura da Europa. A ideia de degeneração era ubíqua e encontrou usuários para muito além das fronteiras germânicas. Os nazistas apenas o coletaram e rearranjaram de maneira a harmonizar-se com seus interesses imediatos.

Em linhas gerais, a ideia de degeneração continha a noção de que pairava sobre a humanidade civilizada o risco permanente de involução, ou seja, de uma inversão de sentido na marcha do progresso. Acreditava-se que essa potencial calamidade acabaria por apagar as características vantajosas gradualmente conquistadas ao longo do tempo, levando o civilizado a se rebaixar evolutivamente aos níveis dos primitivos e, com o aprofundamento da síndrome, ao dos animais. Acreditava-se que a degeneração se disseminava pelo mesmo mecanismo da evolução: a hereditariedade. O processo de transmissão dos atributos de uma geração para a outra, ainda cercado de mistérios, era visto como o lugar de reprodução da síndrome do retrocesso ${ }^{83}$. Com o aumento da influência do cientificismo no final do século XIX, a ideia de degeneração extrapolou o campo médico-científico, passando a servir como instrumento de análise sociológica. A partir dessa ampliação do campo de estudos, formaram-se diferentes "diagnósticos sociais".

Cada um dos teóricos da degeneração desenvolveu e apresentou seus estudos etiológicos, na busca por determinar as causas do mal. Alguns responsabilizaram o consumo excessivo de substâncias como o álcool, o tabaco, o café e outros estupefacientes. Outros indicaram a indolência e a vida licenciosa pelo início do processo

\footnotetext{
${ }^{83}$ É importante notar que, até os anos 1920-1930, o processo de transmissão das características entre as gerações estava eivado de noções científicas que hoje são amplamente reconhecidas como errôneas. Persistia entre os médicos e cientistas um resíduo das ideias do naturalista francês Jean-Baptiste de Lamarck. Ainda se acreditava que características adquiridas ao longo da vida podiam penetrar de alguma forma no ciclo da hereditariedade. Doenças adquiridas pelos pais - e também seus pecados e vícios, ou virtudes e aperfeiçoamentos - eram entendidas como elementos intervenientes nos padrões de hereditariedade; cfe. BORGES, Dain. 'Puffy, Ugly, Slothful and Inert': Degeneration in Brazilian Social Thought, 1880-1940. Journal of Latin American Studies, Vol. 25, No. 2. (May, 1993), p. 235-256; p. 251.
} 
de degradação, que seria então incorporado de alguma maneira ao ciclo hereditário. Outros ainda encontraram nos próprios desdobramentos da modernidade as causas da degeneração: a vida nas grandes cidades, diziam, com a exposição aos seus eflúvios tóxicos, com sua excessiva carga de estímulos - a abundância de jornais e livros, a quantidade crescente de cartas e telegramas recebidos, o acúmulo de viagens de trem etc. - provocava um grande impacto sobre corpos e mentes, desencadeando o processo de degeneração, que se tornaria então hereditário. Essa segunda corrente etiológica alinhava-se com os diagnósticos dos "profetas sociais", conforme os descreveu Fritz Stern, imprimindo, todos eles, um caráter negativo à modernidade.

Havia ainda uma vertente, cada vez mais influente ao se aproximar ofin-de-siècle, que associava a degeneração a determinadas "raças", portadoras de características indesejadas que se transmitiam hereditariamente a todos aqueles que com elas se imiscuíssem. Essa mentalidade levaria a ações de identificação, segregação e, em casos extremos, eliminação física dos grupos considerados "impuros".

Parte dos teóricos entretinha a ideia da visibilidade da degeneração: o portador da síndrome apresentaria marcas físicas reconhecíveis - os estigmas - capazes de denunciar sua condição. A frenologia, campo de estudos dedicado a coletar, classificar e interpretar os estigmas, nasceu por volta do início do século XIX, e se tornaria cada vez mais sofisticada, esmiuçada em tratados escritos sob a égide da ciência. No final do século, teóricos como Cesare Lombroso e Max Nordau postulariam a existência de estigmas psíquicos, sinais indiretos da presença da degeneração, que se manifestariam nas produções intelectuais e nos comportamentos dos seus portadores. A partir dessa constatação, obras artísticas e literárias passaram a ser tomadas como evidências do estado mental do seu produtor, capazes de sustentar diagnósticos. Mesmo que os corpos dos autores acometidos pela moléstia hereditária estivessem inacessíveis, os doutores da degeneração seriam capazes de detectar sua condição insana através do escrutínio dos produtos de suas mentes.

Para compreender adequadamente a ideia de degeneração, é preciso levar-se em conta a profunda alteração que se experimentava, na segunda metade do século XIX, nas concepções sobre o homem. A ascensão do cientificismo, colocando as ciências naturais dentre os gêneros de discurso hegemônicos, significava, conforme notou Schorske, o afastamento dos ideais liberais iluministas. Segundo aquele autor, a "cultura liberal tradicional tinha se concentrado sobre o homem racional, cujo domínio científico sobre a natureza e controle moral sobre si deveriam criar a boa sociedade". Já no fin-de-siècle, 
"[...] o homem racional teve de dar lugar àquela criatura mais rica, mas mais perigosa $\mathrm{e}$ inconstante, que é o homem psicológico. Esse novo homem não é simplesmente um animal racional, mas uma criatura de sentimentos e instintos. Tendemos a fazer dele a medida de todas as coisas em nossa cultura ${ }^{84}$."

Dessa maneira, Schorske ressalta a predominância, daí em diante, das explicações que consideram não mais a vontade e a razão como fonte de sentimentos e pensamentos, decisões e ações dos homens, mas os fatores psico-fisiológicos. E essa concepção, ele ressalta, faz-se onipresente ${ }^{85}$. Mesmo os artistas modernos se declararão "artistas da subjetividade interior" e irão buscar, em suas obras, uma forma plástica para esse novo homem psicológico. Os doutores da degeneração, por sua vez, se concentrarão em pesquisar as perversões orgânicas que dominam os enfermos e dirigem-lhes a vontade.

Em busca por compreender a ideia de degeneração em seu contexto, procurou-se a bibliografia especializada. $\mathrm{O}$ estudo mais completo sobre o tema identificado no âmbito desta pesquisa foi o do historiador britânico Daniel Pick, publicado pela primeira vez em $1989^{86}$. Nele o autor procurou reconstituir a formação da ideia de degeneração, medir sua difusão, descrever as linhas gerais de suas configurações mais importantes e, principalmente, conectá-la às realidades sócio-políticas, apontando as intenções subjacentes do discurso científico que diagnosticava com alarde escatológico o processo de involução.

Na obra, Pick constatava a escassez de estudos recentes sobre a ideia de degeneração, apesar de sua evidente ubiquidade no século XIX. Propôs-se a desvendar, como já fora feito antes com as teorias de Darwin, os medos e preocupações sociais subjacentes ao discurso científico, que se queria objetivo e verdadeiro. Com isso, defendeu que a ideia de degeneração não se restringia ao universo científico, mas traía, sob suas pretensões de objetividade, "o submundo de ansiedade política e social", operando uma inversão significativa no discurso: "Os doutores da degeneração

\footnotetext{
${ }^{84}$ SCHORSKE, Carl E. Viena fin-de-sècle - Política e Cultura. São Paulo: Companhia das Letras, 1988; p. 26

${ }^{85}$ Lúcia Lippi Oliveira denominou de "positivista" essa maneira de conceber o homem, compreendendo o termo de maneira abrangente como "tendência de analisar a conduta humana através de analogias com a ciência natural"; cfe OLIVEIRA, Lúcia Lippi. A questão nacional na Primeira República. São Paulo: Brasiliense; Brasília: CNPq, 1990; p. 67.

86 PICK, Daniel. Faces of Degeneration: a European disorder, c. 1848 - c. 1918. Cambridge: Cambridge University Press, 1989.
} 
assumiram como verdade que seus trabalhos eram impessoais. Nos termos dessa negação ritual, o comentário social foi transformado em "verdade científica""87.

As Revoluções, cujo epicentro localiza-se na França, a partir de 1789 e depois em 1830 e 1848, provocaram uma sensação de ruptura histórica, entendida cada vez mais como instabilidade política, instaurando uma apreensão quanto ao futuro. $\mathrm{O}$ ciclo aparentemente incessante de tremores sociais "parecia mostrar a radical imprevisibilidade da mudança, a irredutibilidade de novos fenômenos sociais a modelos prévios" ${ }^{\text {" } 8}$. Com isso, a confiança no progresso cederia espaço ao medo, que acabaria encontrando na ideia de degeneração uma corporeidade aparentemente científica.

Além disso, novas questões que emergiram nas décadas finais do século XIX acabariam capturadas pelo discurso médico-científico: os enigmas advindos da sociedade de massas, as incertezas colocadas pela vida nas metrópoles e, especialmente, os novos contornos da vida política, que via emergir um contingente novo e potencialmente subversivo de eleitores pobres, fazendo crescer a presença parlamentar de partidos socialistas e congêneres.

Finalmente, Pick aponta uma última função subjacente do discurso médicocientífico que manejava a ideia de degeneração: seu caráter instrumental na luta por enquadramento e dominação do "outro". Pick afirma que, de certo modo, degeneração era um conceito integrante da grande "linguagem oitocentista do imperialismo racista" 89 . Ela garantia a apreensão dos povos de regiões "selvagens", sob o domínio dos europeus, como inferiores em termos técnicos e mentais, o que legitimaria a dominação. Pick defende, no entanto, que se observe também, e mais especialmente, o uso "interno" do conceito de degeneração. O autor percebe no coração da própria "civilização" a existência de segmentos rotulados atrasados, primitivos, ameaçadores, resistentes às melhorias, cujo comportamento indesejado seria cada vez mais frequentemente apontado como sendo reflexo de distúrbios psíquicos e morbidades, muitas vezes compreendidos como adquiridos pela via hereditária. Esse discurso nivelava os "selvagens primitivos" de lugares longínquos e exóticos com as camadas marginais da sociedade ocidental: pobres, camponeses, anarquistas e outros dissidentes políticos e refratários ao estilo de vida

\footnotetext{
87 PICK, 1989, p. 10-11.

88 PICK, 1989, p. 56. Essa inversão na interpretação das revoluções, do otimismo ao desespero, pode ser apreendida nas palavras de Charles de Remusat, em 1860: “O pessimismo [...] fez grandes avanços em tempos recentes. Muitos franceses [...] que trinta ou quarenta anos atrás estavam cheios de esperança e entusiasmo pelos princípios da Revolução chegam agora à conclusão de que a democracia moderna não passa de 'decadência turbulenta'"' (REMUSAT apud PICK, 1989, p. 56-57).

89 PICK, 1989, p. 38.
} 
burguês, loucos, crianças, mulheres, delinquentes, vagabundos, criminosos, alcoólatras etc. Não é coincidência que os mais misteriosos e ameaçadores parisienses, os delinquentes juvenis das periferias da cidade, fossem rotulados justamente Apaches ${ }^{90}$.

Ainda sob a Terceira República, a França estava longe de ser "uma nação". Foi necessário um esforço imenso para promover a "modernização da população rural”, um "traumático e prolongado processo de auto-colonização cultural, educacional, política e econômica"91. Da mesma maneira, Pick demonstra o emprego das teorias de Cesare Lombroso na busca por soluções para os problemas internos da Itália. Após a unificação política, restava às autoridades lidar com uma enorme gama de grupos dissidentes. Todo o campesinato italiano estava fora da esfera de poder dos governantes; somente 8 em cada mil habitantes falava a língua oficial, e $75 \%$ da população era analfabeta ${ }^{92}$. O trabalho de Lombroso estava profundamente comprometido com a perseguição daquilo que Pick chamou de "quimera da unidade nacional" 93 , estabelecendo um padrão "normal" de conduta e existência e enquadrando todos os "inimigos da unidade" em categorias pejorativas, assinaladas pela incursão na patologia ou na criminalidade.

\footnotetext{
${ }^{90}$ Cfe. KALIFA, Dominique. Arqueologia do "Apachismo": Bárbaros e Peles-vermelhas no século XIX. Trad. Suelen Amanda Rodrigues. Revista Projeto História, v. 40, 2010; p. 21-42 e PERROT, Michelle. Na França da Belle Époque, os "Apaches", primeiros bandos de jovens. In: PERROT, Michelle. Os excluídos da história: operários, mulheres e prisioneiros. Trad. Denise Bottmann. Rio de Janeiro: Paz e Terra, 1988. p. 315-332. É também significativo o fato de que, numa das primeiras críticas ao que viria a ser conhecido como impressionismo, o espirituoso opositor Louis Leroy descrevesse o episódio em que um observador, sob o efeito da exposição, perdera o juízo e dançara, em frente ao atônito guarda da sala, a "dança do escalpo"; cfe. LEROY, Louis. "L'Exposition des Impressionnistes". In: ALTSCHULER, Bruce. From Salon to Biennial Exhibitions that made Art History; Vol. I: 1863-1959. London/New York: Phaidon, 2008. p. 42-43 [publicado originalmente no jornal parisiense "Le Charivari" em 25/4/1874].

${ }^{91}$ PICK, 1989, p. 40. Esse processo foi analisado em WEBER, Eugene. Peasants into Frenchmen - The Modernization of Rural France 1870-1914. Stanford: Stanford University Press, 1976. Weber coletou relatos de autoridades civis, eclesiásticas e militares em missões pelo território ainda não servido por estradas e ferrovias, que se mostravam embasbacadas com a "falta de civilização" da população camponesa da França. Esses discursos traduziam a crença de que vastas áreas do país-símbolo da modernidade ainda eram incivilizadas, ou seja, "não integradas, não assimiladas pela civilização francesa: pobres, atrasados, ignorantes, selvagens, bárbaros, incultos, vivendo como animais na companhia de seus animais. A eles deveria se ensinar maneiras, moral, escrita, o conhecimento do francês e da França, o senso de estrutura legal e institucional para além de sua comunidade imediata"; p. 5.

92 PICK, 1989, p. 118. O sul da Itália, dizia-se, era para os habitantes do norte "o início da África", tido como "um outro mundo, racialmente diferente, um espaço a ser explorado, penetrado, contido, colonizado" (PICK, 1989, p. 114). Importante ressaltar que, por outro lado, o discurso pós-unificação tomava como modelo ideal a imagem de uma Itália medieval unificada, sob o regime das comunas, uma sociedade que se queria ver como efetivamente orgânica, onde os elementos aderiam espontaneamente à unidade. Entretinha-se a imagem de que na Idade Média a instituição da família era forte, os lugares sociais eram claros e indisputados, e não havia problemas de crença: um mundo comunal perfeito e ajustado contraposto como contraste ao presente fragmentário e individualista, cfe. PICK, 1989, p. 116. ${ }_{93}$ PICK, 1989, p. 119.
} 
O estudo de Pick procura reconstituir algumas etapas na formação da ideia de degeneração, elegendo o século XIX como período para suas observações. Ainda que em tempos anteriores as ideias de decadência e mesmo a de corrupção da essência humana pela civilização fossem já preocupações detectáveis, o século XIX apresenta-se como objeto privilegiado pelo fato de que neste momento testemunha-se um enorme avanço dos discursos da medicina e das ciências naturais sobre o pensamento social, resultando na transposição de termos como evolução, degeneração, morbidade e perversão para a análise da sociedade ${ }^{94}$. Trata-se de um novo tipo de retórica, amparada na autoridade da ciência. Questões da teologia e da filosofia são capturados pela ciência, passando a serem compreendidos como "fatos médicos, antropológicos ou de antropologia física empiricamente demonstráveis" $" 95$. Nesse sentido Pick identifica na obra de Prosper Lucas uma primeira estação no desenvolvimento da ideia. Lucas publica em 1847 um estudo sobre a "força maravilhosa" da hereditariedade, onde enfatizava "a reprodução de caracteres constantes através das gerações"96, que podia frutificar em vantagens, mas também desvantagens.

Seguindo essa trilha, Bénédict August Morel é tido como cultor da ideia de degeneração biológica, que apareceu em sua obra de 1857, o "Tratado de hereditariedade natural". Morel se concentrava em determinar a dinâmica da modificação negativa, enfatizando a cadeia de patologias transmitidas entre as gerações em direção ao degenerado, acumulador dessa herança nefasta, num processo que parecia pôr em risco toda a civilização ${ }^{97}$. Pick defende que a obra de Morel espelha diretamente as apreensões advindas dos abalos sediciosos de 1848. A ideia de "reprodução patológica" das revoluções teria sido convertida por Morel numa nova concepção de degeneração, compreendido como "processo de diferenciação patológica ao longo das gerações" 98 .

\footnotetext{
${ }^{94}$ SERPA JR. defende que a construção e disseminação do conceito de degeneração, assim como o avanço da medicina mental sobre novos territórios antes pertencentes à filosofia e às ciências sociais, movimento realizado com a assimilação e o manejo da linguagem e dos procedimentos da ciência, eram parte de uma estratégia maior que visava anexar terrenos, expandir domínios e conferir solidez institucional a esse novo campo de conhecimentos. Buscava-se, em suma, elevar a psiquiatria à estatura da medicina; cfe. SERPA JR, Eduardo Domont de. O Degenerado. História, Ciências, Saúde - Manguinhos, Rio de Janeiro, v. 17, supl. 2, dez. 2010, p. 447-473.

95 PICK, 1989, p. 20.

96 LUCAS apud PICK, 1989, p. 49.

${ }^{97}$ Phillipe Buchez, colega de Morel e entusiasta de suas teorias, explicitaria num discurso o impacto renovador das teorias do amigo no campo de estudos sobre a hereditariedade: "[...] ninguém antes afirmara que certas doenças, certas intoxicações, certos hábitos dos progenitores têm o poder de criar nos filhos um estado sucessivo, um estado orgânico especial, indefinidamente transmissível até o ponto da extinção da raça se nada for feito para mudar isso" (BUCHEZ apud PICK, p. 61).

98 PICK, 1989, p. 56.
} 
Dessa maneira, o novo conceito científico de degeneração e hereditariedade patológica seria uma projeção de uma leitura da situação social circundante para o campo da medicina e da teoria científica.

Em termos gerais, Pick encontra duas modificações essenciais nas teorias da degeneração, ao longo do século XIX. Havia inicialmente uma convicção sobre a visibilidade da degeneração - manifestando-se através dos estigmas apontados pelos tratados de fisiognomia ${ }^{99}$. Em paralelo a essa ideia, havia uma corrente de estudos que acreditava que o problema da degeneração estava fadado a desaparecer por conta própria, pela extinção das estirpes degeneradas, tão profundamente afetadas pela redução de suas capacidades que, finalmente, se provariam inviáveis e deixariam de existir. Essas duas concepções traziam algum alívio, pois asseguravam tanto a capacidade de se detectar o degenerado quanto decretavam o fim iminente do mal, que pereceria por suas próprias deficiências estruturais.

Pick aponta uma mudança nesses paradigmas a partir da obra do psiquiatra Valentin Magnan, publicadas principalmente nas décadas de 1870 e 1880. Magnan requalificou o conceito de degeneração, elevando-o a uma noção generalizada e difusa de que as patologias eram um onipresente "fenômeno da época"100. A teoria de Magnan suspendia a possibilidade de localizar com segurança o degenerado e a degeneração, instaurando a crença na existência de uma "essência invisível" permeando as "classes perigosas da cidade"101. As mesmas "classes perigosas" começaram a aparecer com insistência na literatura; o imaginário, por volta de meados do século XIX, povoou-se com os misteriosos personagens oriundos do submundo do crime oculto nos substratos obscuros das grandes cidades. Nesse pensamento, "crime, decadência moral e poluição racial" se emaranhavam como causas intervenientes ${ }^{102}$. Além disso, as teorias de Magnan suspendiam a reconfortante certeza da auto-eliminação do degenerado: para ele, esse mal

\footnotetext{
${ }^{99}$ Paul Broca desenvolveu um sistema de detecção das características morais do indivíduo por meio da análise da forma e do volume do crânio. A frenologia parecia ser um caminho seguro para "encontrar o 'mapa' do criminoso". Joseph Simms, entusiasta vulgarizador da frenologia, afirmou em 1872 que em breve, quando todos os traços fossem reconhecidos e catalogados, os criminosos não poderiam mais sair à rua, pois suas faces seriam um cartaz gritante anunciando suas más intenções; cfe. SIMMS, Joseph. Physiognomy Illustrated; or, Nature's Revelations of Character. A Description of the Mental, Moral and Volitive dispositions of Mankind, as Manifested in the Human Form and Countenance. New York: Murray Hill Publishing Company, 1887; p. 37.

100 PICK, 1989, p. 99.

101 Idem, p. 52.

102 Idem, p. 21.
} 
oculto era resistente e insidioso, e acabaria por penetrar em todos os estratos da sociedade, enfraquecendo e minando as bases da nação.

O pensamento de Cesare Lombroso representou uma etapa importante no processo de associação entre arte e degeneração. Em "O Homem de Gênio", publicado pela primeira vez em 1888, Lombroso criou ou aprofundou conceitos que instrumentalizaram o avanço da ciência sobre as manifestações culturais. As ideias esboçadas pelo médico italiano frutificariam em uma nova vertente da crítica de arte, desenvolvida às últimas consequências em Degeneração de Max Nordau (1892). Com o objetivo de contextualizar o pensamento de Lombroso, recorreu-se novamente ao trabalho de Daniel Pick, que dedicou um capítulo de Faces of Degeneration à análise da produção e recepção das teorias lombrosianas.

Segundo Pick, Lombroso vem sendo tratado como excêntrico, sinistro ou aberrante pela maior parte dos estudiosos. Esquece-se, afirma, que suas teorias hoje aparentemente esdrúxulas eram perfeitamente cabíveis no contexto em que apareceram. Conforme afirmou-se anteriormente, "falavam poderosamente para uma crise particular, e providenciaram uma nova linguagem de representação social" 103.

Titulado médico em 1858, Cesare Lombroso esteve desde cedo comprometido com a ideia de uma medicina ativa e extensiva, com tutela sobre a sociedade. Suas primeiras publicações são marcadas pela ênfase no determinismo dos fatores ambientais e em soluções reformistas radicais. Defendia a fragmentação coercitiva das grandes propriedades e distribuição das terras entre os camponeses. Além disso, insistia em drenagem de pântanos, educação, correção alimentar, higiene, irrigação, atenção na forma das construções, criação de mais hospitais e presídios. Com o tempo, a preocupação com a origem e a trajetória étnica da população, seus padrões e variações, tornou-se obsessiva, destronando todos os outros temas e ocupando lugar central nos seus esforços. Com auxílio de estatísticas, fotografias, modelos de cera e milhares de medições antropométricas, Lombroso acreditava ter encontrado e isolado os traços físicos indicativos de atavismo ${ }^{104}$, que declarava ser a praga mais renitente do país. Suas ideias,

\footnotetext{
103 Idem, p. 111.

104 Do latim atavus, o pai do trisavô, ou em sentido figurado, antepassado.
} 
afinal, acabaram por dirigir-se ao campo do Direito, onde combateu as doutrinas vigentes, baseadas na chamada teoria clássica, derivada da contribuição de Cesare Beccaria.

Segundo relato do próprio Lombroso, a descoberta do atavismo ocorreu em 1870. Observando o crânio do famoso bandoleiro Vilella, Lombroso encontrou uma formação específica que explicava, segundo ele, a tendência criminosa e as características comportamentais desviantes daquele indivíduo. Postulou então que aquela estrutura era típica dos seres humanos primitivos e dos animais ferozes, e que sua posse revelava a degeneração, ou seja, o retorno a uma condição anterior, que ele denominou atavismo. Todo o seu edifício conceitual estava assim, julgava ele, amparado em achados empíricos inquestionáveis. Em suas palavras:

"Não se tratava apenas de uma ideia, mas de uma revelação. À vista daquele crânio, foi como se eu percebesse repentinamente, claro como uma vasta planície sob um céu flamejante, o problema da natureza do criminoso - um ser atávico que reproduz em sua pessoa os instintos ferozes da humanidade primitiva e dos animais inferiores" 105 .

Essa formação específica encontrada no crânio de Vilella recebeu a denominação de "estigma". Nessa concepção, o crime era resultado de uma espécie de anacronismo biológico, e o criminoso um ser perturbado por anomalias hereditárias que o impediam de desenvolver ao máximo o potencial de sua espécie. Embora "natural”, o crime era inaceitável. O trabalho de Lombroso tinha como finalidade dotar a sociedade da capacidade de detectar o criminoso para defender-se dele. Tal sistema de pensamento pôde ser acionado, na Itália e fora dela, como justificativa para políticas de "pena capital, castração, segregação, supervisão estatal da reprodução"106.

Ao longo de sua vida, Lombroso colecionou centenas de exemplares de manuscritos e obras de arte produzidas por delinquentes e internos de manicômios. Pela observação desses produtos oriundos do que considerava mentes degeneradas, Lombroso funda a noção - depois retomada e ampliada por Max Nordau - de que a linguagem do acometido, bem como qualquer outra expressão do seu conteúdo mental, era também

\footnotetext{
105 LOMBROSO apud PICK, 1989, p. 122.

106 PICK, 1989, p. 126. Importante notar que a ideia de que a tendência para o crime esteja inscrita na fisiologia do sujeito, adquirida de maneira hereditária e identificável pela análise de sua morfologia cerebral ainda é defendida no século XXI. Um exemplo notável e influente é o do psicólogo britânico Adrian Raine, que busca reabilitar algumas das ideias centrais das teorias de Lombroso. Um estudo do que denomina neurocriminologia pode ser encontrado em "The Anatomy of Violence", obra que tem como escopo compreender a natureza humana para encontrar maneiras combater o crime. Raine defende a realização de tomografias e análises genéticas preventivas, detectando os indivíduos propensos ao crime, a serem então confinados indefinidamente em áreas segregadas; cfe. RAINE, Adrian. The Anatomy of Violence: the biological roots of crime. New York: Pantheon Books, 2013.
} 
dotada de estigmas, reveladora de suas patologias, atestando a herança aberrante e o atavismo. Os produtos das mentes insanas, segundo Lombroso, tendiam a acumular evidências do estado mental patológico do produtor, que ele listou em sua obra:

“[...] exagero na exatidão dos detalhes, o abuso dos símbolos, inscrições ou acessórios, a preferência por uma cor em particular, uma desenfreada paixão pela mera novidade [...] tendência aos chistes e jogos de palavras, apego excessivo a sistemas, tendência de falar consigo mesmo, e substituir a lógica por epigramas, uma extrema predileção pelo ritmo e assonâncias do verso na escrita em prosa, e mesmo um grau exagerado de originalidade" 107

Em "O homem de gênio", Lombroso procurava comprovar a ideia de que gênio e loucura tinham uma raiz comum, frequentemente entrecruzando-se no mesmo indivíduo. O estudo é feito a partir da comparação entre os traços psíquicos e morais comumente encontrados entre internos de manicômio e criminosos - que o autor colheu em observações empíricas realizadas durante sua atividade profissional - com dados sobre as formas psíquicas e morais dos "gênios", obtidos em uma enorme quantidade de fontes bibliográficas e documentais. Dessa maneira, identifica características compartilhadas entre gênios, criminosos e insanos, sugerindo uma razão fundamental comum, a degeneração ${ }^{108}$ :

[...] apatia, perda do senso moral, tendência à impulsividade ou à dúvida, desigualdades psíquicas devidas ao excesso de alguma faculdade (memória, gosto estético, etc.), ou defeito em outras qualidades (capacidade de cálculo, por exemplo), mutismo exagerado ou verbosidade, vaidade mórbida, originalidade excessiva, e excessiva preocupação consigo mesmo, a tendência a explicar os mais simples fatos com interpretações místicas, o abuso do simbolismo e de palavras especiais que são usadas quase que exclusivamente como modo de expressão"109.

A diferença entre o gênio e o interno de manicômio, segundo Lombroso, residia na utilidade dos resultados da atividade anormal de suas mentes. Das distorções mentais dos insanos nada resultava de aproveitável, ao contrário do gênio, cujo peculiar gênero de insanidade, ao mesmo tempo que o tornava inútil para a vida prática, produzia as mais elevadas realizações humanas.

\footnotetext{
107 LOMBROSO, Cesare. The Man of Genius. Londres: Walter Scott, 1891; p. 359-360.

108 A degeneração descrita por Lombroso em "O Homem de Gênio" origina-se de fatores hereditários e tende ao desaparecimento por sua própria conta. Legada aos filhos por progenitores "ébrios, sifilíticos, insanos, tuberculosos etc., ou por fatores acidentais, tais como lesões na cabeça ou contaminação por mercúrio, que alteram profundamente os tecidos, perpetuam neuroses ou outras doenças no paciente e, o que é pior, agravam-se nos descendentes, até que a marcha da degeneração, avolumando-se de maneira cada vez mais rápida e fatal, só é detida mediante a completa idiotia ou esterilidade", cfe. LOMBROSO, 1891, p. 5.

109 LOMBROSO, 1891, p. 5-6.
} 
A explicação que Lombroso oferece a respeito das opções estéticas dos insanos revela uma concepção evolucionista das artes, a mesma que iria reaparecer nos discursos dos críticos das vanguardas do início do século XX. Vítimas do atavismo, os insanos recuariam às formas estéticas anteriores, típicas dos povos primitivos. Por isso, explica, apresentavam fixação pela poesia e pela expressão rítmica das ideias e sentimentos, já que compreendia o ritmo como manifestação primitiva, típica dos grupos pouco evoluídos. Da mesma forma, ao escreverem, tendiam ao uso de símbolos, demonstrando uma regressão ao estágio de escrita "fonética-ideográfica através da qual os povos primitivos [...] passaram antes da descoberta da escrita alfabética" ${ }^{" 110}$. O emprego de imagens na comunicação, seja pela representação escrita através de símbolos, seja pelo uso frequente que fazem da metáfora, são sinais de primitivismo no emprego da língua, expressões de pobreza do pensamento ${ }^{111}$. O mesmo se pode notar, afirma o autor, em artistas que deixam de assimilar em suas obras as "descobertas" e "aperfeiçoamentos" do ofício. Lombroso ilustra essa afirmação com a descrição do caso de um trabalho em que a capacidade técnica do artista transparece em cada detalhe, exceto na ausência total da perspectiva. Dessa forma, segundo Lombroso, tal pintor insano demonstraria ter regredido aos patamares primitivos, rebaixando-se ao estágio de evolução pictórica dos atuais chineses ou dos antigos egípcios ${ }^{112}$.

$\mathrm{O}$ atavismo artístico se manifestaria de maneira mais evidente na música. Lombroso lembra as lições de Spencer, que postulou ser o ritmo a forma mais básica pela qual a energia se manifesta na natureza. $\mathrm{O}$ homem se abandona à música porque isso é natural, e vai permitir que o impulso rítmico o domine com mais frequência, intensidade e duração quanto mais estiver privado dos controles da razão. Isso explicaria, por um lado, a alta incidência de insanidade entre os poetas da nova geração, e também clarificaria o motivo que torna tribos selvagens inclinadas para a música. $\mathrm{O}$ canto e a dança são tomados por Lombroso como expressões naturais de estímulos orgânicos, reflexos quase mecânicos, que serão mais aparentes, frequentes e espontâneos naqueles em que menor for o controle racional. Crianças, selvagens, povos antigos, camponeses, mulheres e, evidentemente, loucos, terão preferência por essa forma de expressão. A música é a expressão mais etérea de todas, a mais fortemente conectada às emoções e

\footnotetext{
110 Idem, p. 189-190.

111 Idem, p. 190.

112 Idem, p. 199-200.
} 
distante do mundo real; isso explica a quantidade de gênios mórbidos que se destacaram neste campo.

Concluindo, a obra de Lombroso aponta para uma continuidade entre a fisiologia do gênio e a patologia do insano. A inspiração do gênio e o paroxismo epilético têm para ele um parentesco inegável. A aparição súbita e temporária de genialidade em insanos durante suas crises, e a similaridade externa entre os matoides ${ }^{113}$ e os gênios conecta todos estes indivíduos entre si: são todos aparentados em suas raízes etiológicas.

Os apontamentos finais de Lombroso parecem prenunciar "Degeneração", de Max Nordau, que seria publicada pouco mais de 4 anos depois. Lombroso enfatiza a utilidade dos conceitos que acabava de apresentar para a análise de obras de arte e literatura:

"Talvez o estudo dessas peculiaridade da arte no insano, além de nos indicar uma nova fase dessa misteriosa doença, possa ser útil em estética, ou de alguma forma, à crítica de arte, por demonstrar que uma predileção exagerada por símbolos, por minúcias nos detalhes [...], as intrincadas inscrições, a excessiva proeminência dada a alguma cor (e é bem sabido que alguns de nossos mais destacados pintores incorrem neste pecado), a escolha de temas licenciosos, e mesmo um grau exagerado de originalidade sejam pontos que pertençam à patologia da arte" $" 114$.

Apesar de ter se mostrado aberto à contribuição dos gênios-insanos, admitindo que o tempo acabava quase sempre por demonstrar que estavam no caminho certo, encerra seu estudo sobre "O Homem de Gênio" com uma admoestação às jovens gerações, sempre prontas a celebrar os "matoides literários" que proliferavam nos jornais e nas livrarias, destilando insensatez sem conteúdo e convencendo pelo apelo de suas prosas loucas, cheias de imagens, trocadilhos e assonâncias. Alerta também para os riscos políticos do matoidismo, associando dissidência à loucura. Exorta aos políticos que vigiem de perto os reformadores que agem "estimulados e guiados apenas pela doença mental"115. Tais indivíduos, encontrando resistência aos seus objetivos, tenderiam a se tornar violentos, convertendo-se em praticantes de uma loucura ativa: eis aí a origem dos regicídios e das rebeliões ${ }^{116}$.

113 A palavra matoide origina-se do radical italiano matto, que significa louco, estranho, insano, desequilibrado. Lombroso define matoide como sendo um indivíduo limítrofe entre o insano, o gênio e o normal, geralmente descendente de gênios e, quase sempre, fruto das "grandes cidades, fatigadas pela civilização"; cfe LOMBROSO, 1891, p. 209.

114 Idem, p. 208.

115 Idem, p. 360.

${ }^{116} \mathrm{Na}$ conclusão de sua obra, Lombroso fazia uma referência clara aos anarquistas, que nas últimas décadas disseminavam-se pela Itália. Segundo PICK, na década de 1870 os anarquistas italianos adotaram a "propaganda através de atos" (PICK, 1989, p. 130): O anarquismo tornou-se uma ameaça imaginária - e às vezes concreta - constante na Itália. 
Estudos que tratam da perseguição à arte moderna pelo regime nazista costumam adotar a obra Degeneração de Max Nordau como um dos marcos iniciais do fenômeno ${ }^{117}$. A imensa celebridade do livro levou suas ideias centrais muito distante no espaço e no tempo, através de sucessivas traduções e reedições, o que torna seu escrutínio obrigatório para quem deseja compreender a formação do pensamento antimodernista. Degeneração constitui-se num monumento parcialmente esquecido da mentalidade cientificista do final do século XIX. No que tange ao seu alcance e grau de influência, pode ser inscrita no grupo que reúne obras de Gustav Le Bon, Houston Stewart Chamberlain e mesmo Herbert Spencer e Charles Darwin. Neste segmento, procura-se observar as ideias de Nordau em seu contexto ${ }^{118}$.

Nascido em Pest, Hungria, em 29 de julho de 1849, Max Nordau revelou-se desde cedo um prodígio intelectual, passando a colaborar já aos 13 anos com periódicos locais, atividade que trazia renda extra à família. Em 1867, obteve o seu baccalauréat e ingressou na Faculdade de Medicina. Começava ali uma "atividade dupla" que se estenderia até o final da vida. Nordau aliaria a prática médica com a de jornalista/literato, dividindo as horas de seus dias com rigor inexorável.

Em abril de 1873 ele vivenciou sua primeira experiência fora da Hungria: viajou como correspondente do jornal Pester Lloyd à Feira Mundial realizada em Viena. Durante aquele verão, Nordau colheu impressões e fez contatos com pessoas do mundo todo e de todas as classes sociais. Travou relações com soberanos e chefes de estado, com jornalistas de várias línguas e com trabalhadores manuais de toda sorte. As contribuições diárias que enviava para o Pester Lloyd eram republicadas em diversos outros jornais de língua alemã, tornando o nome por trás daquelas crônicas mais conhecido. Com o dinheiro extra obtido com a atividade junto à Feira Mundial, Nordau realizou uma longa viagem pela Europa, durante a maior parte dos dois anos seguintes. A primeira etapa foi na Alemanha, onde circulou por várias cidades, sempre colhendo impressões que

\footnotetext{
117 Ver, por exemplo, BARRON, Stephanie. Modern Art and Politics in Pre War Germany. In: BARRON, Stephanie (Org.). Degenerate art: the fate of the avant-garde in Nazi Germany. Los Angeles: Los Angeles County Museum of Art, 1991 e PETERS, Olaf. From Nordau to Hitler: "Degeneration" and anti-modernism between the fin-de-siècle and the national socialist takeover of power. In: PETERS, Olaf (Ed.) Degenerate Art: the attack on modern art in Nazi Germany, 1937. New York: Neue Galerie New York, 2014. p. 16-35 118 Os dados biográficos apresentados neste segmento foram obtidos em NORDAU, Maxa; NORDAU, Anna. Max Nordau - a biography. New York: Nordau Comitee, 1943. Consultou-se também a edição argentina desta mesma obra: NORDAU, Maxa; NORDAU, Anna. Max Nordau - Centinela de la Civilización. Buenos Aires: Editorial Israel, 1943; todas as citações referem-se à edição em inglês.
} 
registrava por escrito. Era geralmente recebido e abrigado por pessoas que conhecera durante a Feira Mundial, e aproveitava para estender seu círculo de relações entre os jornalistas, literatos, acadêmicos e artistas dos locais por onde passava.

Em 1881, já fixado em Paris, Nordau começou a redigir um estudo que seria publicado em 1883 sob o título As mentiras convencionais da civilização. A obra seria seu maior sucesso editorial, traduzida para diversas línguas, levando seu autor a um novo patamar de celebridade. Apesar da prosperidade trazida pelas enormes vendagens, Nordau manteve sua rotina inalterada, revezando-se entre o consultório e a escrivaninha. O círculo de relações de Nordau ampliou-se nessa época, e ele criou raízes em Paris. Por volta de 1889, segundo suas biógrafas, Nordau passou a sentir a necessidade de empreender um estudo sobre os últimos desenvolvimentos literários da França e de outras partes. Assim começava a se esboçar Degeneração:

"Ele percebia que a crítica científica desses fenômenos se fazia necessária. Os trabalhos de Charcot (de quem Sigmund Freud mais tarde seria estudante) e sobretudo de Cesare Lombroso pareciam-lhe indispensáveis para a compreensão desses movimentos. Os decadentes e simbolistas e egoístas, todos estes místicos, em resumo, pareciam exibir os sintomas de uma doença e de degeneração, e seus trabalhos pareciam um perigo real para o desenvolvimento da literatura saudável. Esta foi a origem de 'Degeneração'.

O livro apareceu em 1893. Causou uma sensação sem paralelo na Alemanha. Inevitavelmente, uma tempestade de indignação se levantou entre os jovens escritores e seus líderes. Conforme a obra era traduzida em uma língua depois da outra, a tempestade varria um país atrás do outro. Nordau se tornou o objeto do ódio e também o alvo de muitos círculos literários e coteries, enquanto que outros o admiravam sinceramente" ${ }^{\text {"119. }}$.

Traduzido para várias línguas, Degeneração inspirou uma enxurrada de livros, panfletos e artigos, em toda a Europa, na América do Norte e do Sul, a favor e contra seus argumentos. Suas biógrafas acreditam que, entre o ano de publicação de Degeneração e a eclosão da Primeira Guerra Mundial, Nordau tenha sido "um dos mais influentes pensadores do tempo" ${ }^{120}$. Degeneração fez com que Nordau passasse a ser reconhecido como uma espécie de guru, fazendo convergir para seu consultório pessoas das mais diversas origens, em busca de orientação e aconselhamento. Segundo as biógrafas, Nordau passou a ser visto como “[...] filósofo, líder, escritor, médico e conselheiro geral para todos os que o procuravam com todos os tipos imagináveis de dilemas humanos"121.

A partir de 1897, Nordau envolveu-se com a propagação e defesa do sionismo, em associação com Theodor Herzl. Nessa atividade, viajou por toda a Europa, tomando

\footnotetext{
${ }^{119}$ NORDAU et NORDAU, 1943, p. 89; ao contrário do que afirmaram as biógrafas neste trecho, o primeiro volume de Degeneração foi publicado em 1892.

120 Idem, p. 90.

121 Idem, p. 108.
} 
parte ativa nos Congressos Sionistas e buscando apoiadores ao projeto de um estado judeu. A Primeira Guerra Mundial forçou-o a abandonar a França. Ele viveria em Madri até 1919. O acirramento do nacionalismo faria com que ele experimentasse a condição de apátrida, que se prolongaria até sua morte, em 1923: “na França ele era considerado um inimigo, na Alemanha, um francófilo e, acima de tudo, um inimigo do pangermanismo" $" 122$. Seus editores alemães rejeitaram um texto que haviam encomendado, em 1916, por considerarem que trazia uma visão muito amistosa sobre a França. O governo da França, por seu lado, sequestrou toda a fortuna que Nordau deixara depositada em um banco francês ${ }^{123}$.

Em Degeneração, Nordau expande as iniciativas de Lombroso, aprofundando a apropriação dos fenômenos culturais pelo discurso médico-científico. Nordau deseja, nominalmente, uma "crítica científica" de arte, filosofia e literatura ${ }^{124}$. Para tanto, insiste na caracterização da "degeneração cultural”, procurando descrever minuciosamente as "lesões invisíveis" do sistema nervoso, expondo "um mundo escuro e secreto de morbidades" 125 .

Nordau ambienta seu estudo numa Europa que, apesar de se manter ainda como centro do mundo civilizado, sofreria de decadência. Descreve-a como acometida por uma crise em que a civilização abandona as antigas tradições (descritas como seguras, saudáveis, confiáveis), adotando no lugar novos padrões (representados como doentios e perniciosos). O fin-de-siècle seria marcado por "um desprezo pelas visões tradicionais de costume e moralidade", uma "emancipação da disciplina tradicional"126, abrindo as portas para a liberação de desejos, tendências e impulsos até então suprimidos. No campo específico da arte, o clima fin-de-siècle significava o ocaso das formas aceitas e da ordem

\footnotetext{
122 NORDAU et NORDAU, 1943, p. 233.

123 Idem, p. 238.

${ }^{124}$ Essa intenção é declarada logo na apresentação da obra, cfe. NORDAU, Max. Degeneration. London: William Heinemann Publisher, 1895, p. VIII.

125 PICK, 1989, p. 136. Nordau aborda a cultura de seu tempo empregando métodos e terminologia médica: os capítulos intitulam-se "Sintomas", "Diagnóstico", "Etiologia", "Prognóstico" e "Terapêutica". Os livros II, III e IV trazem os "estudos de caso", onde Nordau reúne os literatos, artistas e filósofos em conjuntos de acordo com suas patologias dominantes: "Misticismo" (reunidos no livro II, compreendendo os Pré-rafaelitas, Simbolistas, Tolstói e Wagner, entre outros), "Egomania" (livro III, Parnasianos e Diabolistas, Decadentes e Estetas, Ibsen e Nietzsche); o livro IV é dedicado ao Realismo (especialmente à análise de Zola) e ao grupo que Nordau identifica como o dos "Jovens Alemães" (responsável por desenvolver o Realismo na Alemanha).

${ }^{126}$ NORDAU, 1895, p. 5.
} 
estabelecida "que por milênios satisfez a lógica, estorvou a depravação e produziu em todas as artes algo de belo"127. Sem o lastro da tradição, mirava-se o futuro em busca de esperança, desejando que o porvir trouxesse a salvação. Comemoravam o novo, dizia Nordau, sem saber em que direção ele se desenvolveria. "Todas as certezas estão destruídas e qualquer palpite parece plausível" ${ }^{128}$. Nessa situação, a arte ganhava papel proeminente: olhava-se para ela como única linguagem capaz de prever o futuro. "O poeta, o músico, deve anunciar, ou adivinhar - ou ao menos sugerir - em que formas a civilização irá evoluir" ${ }^{129}$.

Esse diagnóstico da situação europeia presente no segmento inicial de Degeneração espelha as impressões que o autor vinha colhendo desde a juventude, em suas peregrinações pelo continente como correspondente da imprensa. Já em suas antigas anotações Nordau desenvolvia uma visão bastante crítica da situação dos homens e mulheres comuns, que considerava explorados pelas altas classes, e registrou com desprezo os hábitos das elites de cada região, que julgava vazias, superficiais e dadas aos excessos. Nesse sentido, em Degeneração Nordau estabelece significativas clivagens sociais na sua apreciação da cultura. Para ele, eram os afortunados - os "10 mil mais ricos" da França, mais a alta burguesia alemã e inglesa - que estariam no estágio fin-de-siècle. Acreditava que a maioria pobre da população não sentia ainda os seus efeitos. "As massas persistem em hábitos adquiridos por mais tempo que os líderes e criadores"130. Apenas a minoria rica, em sua opinião, saudava a modernidade; mas sendo uma minoria influente, criava-se a sensação de que o novo era unanimemente aceito.

Como "sintomas" da degeneração cultural, Nordau aponta manifestações externas de mudanças nos costumes. Concentra-se em comentar minuciosamente a aparência das altas classes, examinando suas indumentárias, seus penteados, os interiores de suas casas e as formas dos objetos culturais preferidos por eles. Considerava haver em curso uma verdadeira "revolta contra a lei orgânica da harmonia" e uma busca pelo "efeito de dissonâncias calculadas", resultando numa profusa "polifonia". Segundo Nordau, o intento era atrair atenção, mantê-la sobre si, criar forte estranhamento nervoso. O objetivo seria "produzir uma sensação a qualquer preço". Fixar-se num único estilo do passado era considerado filisteu, fora de moda, provinciano $^{131}$.

\footnotetext{
127 Idem.

128 Idem, p. 6.

129 Idem.

130 NORDAU, 1895, p. 474.

${ }^{131}$ Idem, p. 10.
} 
A partir da disposição fin-de-siècle presente nas tendências da arte e da literatura contemporâneas, Nordau diagnosticaria a prevalência de duas doenças: degeneração e histeria. Caracteriza degeneração como sendo um desvio mórbido do tipo original, uma condição hereditária, que limita o desenvolvimento mental do seu portador. Quando adquirida, transmite-se aos descendentes, marcando a progênie com uma mácula inescapável: formam "uma nova subespécie”. Em algumas gerações o degenerado se torna estéril e sua linhagem desaparece ${ }^{132}$. Nordau indica o complemento do degenerado: o histérico. São eles que formam as legiões de seguidores e imitadores dos gênios ensandecidos. O histérico é marcado pela emotividade exacerbada, pela susceptibilidade pronunciada; é impressionável, sugestionável e dado a uma intensa mendacidade ${ }^{133}$.

Adotando e aprofundando o conceito de estigma mental desenvolvido por Lombroso, Nordau procura ressaltar os indícios de morbidade na produção intelectual dos acometidos. Além de assimetrias físicas, formas conspícuas das orelhas, crânios, olhos, marcas físicas externas e aparentes - detectáveis, argumenta, entre os responsáveis pelos movimentos artísticos modernos - a degeneração se manifestaria também no terreno mental, obnubilando o funcionamento do cérebro de uma maneira tão peculiar e evidente que permitiria diagnóstico seguro da insanidade. "Não é necessário medir o crânio de um autor, nem observar o lóbulo da orelha de um pintor" para determinar se ele é degenerado: basta observar os produtos de sua mente ${ }^{134}$. Sugere, dessa forma, a existência de uma espécie de "fisiognomia mental"135. Os estigmas mentais, segundo Nordau, manifestamse nas formas de falta de senso moral - a ausência de discernimento entre o certo e o errado - na tendência ao exagero, no desprezo à lei, aos costumes sociais e à modéstia, no egoísmo, na impulsividade. Manifestar-se-iam ainda como desânimo, fraqueza mental, pessimismo, medo, tédio. Nordau afirma detectar todas estas condições acometendo com frequência os homens do fin-de-siècle. O traço final, "marca cardeal" da degeneração, é o misticismo, que se manifesta também como piedade exagerada, ocupação com questões religiosas etc. Toda a argumentação de Nordau em "Degeneração" se desenvolverá a partir desses postulados sobre os estigmas mentais. O que ele faz, ao longo dos minuciosos estudos de caso, é recolher e apontar características nas obras dos escritores, filósofos e pintores que seriam indicativas da degeneração.

\footnotetext{
132 Idem, p. 16.

133 Idem, p. 25.

134 Idem, p. 17.

135 Idem, p. 18.
} 
Após apontar os sintomas e realizar o diagnóstico, Nordau indica as causas da doença do tempo. Os homens do fin-de-siècle, geradores da cultura estigmatizada pela degeneração e histeria, estariam acometidos pelos males da vida moderna, entre eles, e principalmente, a vida em grandes cidades. A vida cotidiana, argumenta Nordau, vinha passando por enormes modificações nas 5 décadas anteriores ao seu estudo. "O habitante das grandes cidades, mesmo o mais rico, cercado por grande luxo, é continuamente exposto a influências desfavoráveis que enfraquecem suas energias vitais muito mais do que ocorreria normalmente"136. Respira um ar contaminado por detritos orgânicos, consome alimentos adulterados, contaminados e fenecidos e é presa constante de uma excitação dos nervos. Viver na cidade grande é tão insalubre, afirma, quanto viver ao lado de uma área pantanosa. A mortalidade na cidade grande é mais alta que em outras partes, e as crianças têm seu desenvolvimento comprometido. O número de degenerados, criminosos e lunáticos se multiplica ${ }^{137}$. Em especial, abundam os alto-degenerados aqueles que, apesar de acometidos pela enfermidade, mantém elevada capacidade intelectual, produzindo a poluição cultural com sua arte contaminada. Há uma grande fadiga, uma endêmica depressão da vitalidade, que atinge os homens urbanos e os conduz à histeria e ao enfraquecimento das faculdades mentais.

"todas as condições da vida [nos últimos cinquenta anos] experimentaram uma revolução sem paralelos na história do mundo. A humanidade não pode apontar outro século em que invenções que penetram profunda e tiranicamente nas vidas de todos os indivíduos se amontoem tão profusamente quanto hoje" ${ }^{138}$.

A geração nascida na década de 1840 (da qual fazia parte o próprio Nordau) testemunhou esta transformação ao longo de sua vida, e por isso ele toma aquele ano como base para estabelecer uma análise quantitativa-comparativa. Reunindo dados de fontes diversas, Nordau procurou demonstrar a disseminação de ferrovias, o aumento significativo no número de cartas escritas e recebidas, a multiplicação de jornais e livros - tanto em número de novos títulos quanto em tiragens - concluindo que toda essa

\footnotetext{
${ }^{136}$ Idem, p. 35.

${ }^{137}$ Em Literatura como Missão, Nicolau Sevcenko, aponta estudos realizados por autoridades que notavam o aumento estratosférico no número de casos de insanidade entre os habitantes do Rio de Janeiro na virada do século XX. Num registro semelhante ao de Nordau, tais autoridades tratavam da loucura, do alcoolismo, da delinquência juvenil e da criminalidade como problemas "morais", a serem aplacados por meio de medidas punitivas e dissuasórias. Não levavam em conta, nos seus diagnósticos sociais, o "circo de horrores" provocado pela confluência de êxodo rural, desigualdade e exploração que formariam aquilo que Sevcenko chamou de "inferno social". Cfe. SEVCENKO, Nicolau. Literatura como missão - tensões sociais e criação cultural na Primeira República. São Paulo: Editora Brasiliense, 1999. p. 62-63.

138 NORDAU, 1895, p. 37.
} 
atividade expandida exigia um sobre-esforço do sistema nervoso de cada indivíduo. Ainda que o corpo humano fosse adaptável, a forma repentina com que essas modificações ocorriam impediam-no de reagir. Tal exaustão condenava os menos vigorosos à queda nas "valas laterais" da "estrada para o progresso" "139, provocando a histeria, adquirida na primeira geração, hereditária nas seguintes. A arte e a cultura modernas seriam, portanto, o resultado dessa grande fadiga histérica.

Esse processo, segundo Nordau, não ocorria de maneira homogênea. Alguns povos, em decorrência de circunstâncias históricas, estariam mais suscetíveis a ele. O povo francês encontrava-se indefeso diante dos efeitos maléficos da modernização, em função do estado debilitado com que chegou ao século XIX, arrasado pelas guerras napoleônicas, pelas revoluções e pelos diversos outros transes por que passou. Essa peculiaridade francesa explicaria, segundo Nordau, não só sua fulminante derrota em 1870, mas o fato de que é na França que aparecem "as mais loucas modas na arte e na literatura" $" 140$.

Em conclusão, afirma

"[...] erra aquele que acredita que as escolas estéticas surgidas nos últimos anos sejam arautos de uma nova era. Elas não nos dirigem para o futuro, mas guiam para um retrocesso aos tempos de um distante e superado passado. Suas palavras não são profecias extáticas, mas o balbucio gaguejante de mentes insanas, e aquilo que os ignorantes tomam por demonstrações efusivas de energia, vigor jovem e impulsos construtivos turbulentos não passa realmente de convulsões e espasmos de exaustão" ${ }^{141}$.

Essencialmente fisiológica, portanto sujeita ao escrutínio da ciência e aberta à compreensão objetiva, a mente é explicada por Nordau no capítulo em que trata do Misticismo. Sua concepção do funcionamento do cérebro, compartilhada pela medicina de seu tempo, era basicamente mecânica: a intelecção consciente ocorria na superfície cinzenta do cérebro, um tecido constituído por incontáveis células-nervosas unidas por fibras nervosas, que formam em conjunto a terminação final de todos os estímulos recebidos pelas diversas partes componentes do organismo e as processam. Cada célula cerebral tem um lugar e uma função específica. Nordau compara a ação de um estímulo sobre o cérebro como a de um objeto lançado numa superfície líquida, formando um grande efeito na área central e irradiando-se daí para as áreas vizinhas. É assim que se

\footnotetext{
139 Idem, p. 40.

140 Idem, p. 43.

${ }^{141}$ Idem, p. 43.
} 
concebia a associação de ideias: a partir de um estímulo, uma determinada área do cérebro era subitamente ativada, e igualmente, mas em menor grau, suas vizinhas, ou suas similares, ou aquelas ligadas àquela experiência específica de alguma maneira, cada qual de forma mais ou menos intensa, e elas irradiariam, de maneira mais vívida ou mais tênue, seu conteúdo. A evocação simultânea de diversos conhecimentos era vista como condição imprescindível para a interpretação do fenômeno que originou o estímulo inicial, mas apenas quando devidamente controlada pela vontade. Caso corresse livre, a associação de ideias iria finalmente ativar todo o conteúdo da mente e o resultado seria o caos.

As figuras de linguagem empregadas por Nordau para explicar o funcionamento considerado normal do cérebro são muito sugestivas: a vontade deve fazer uma "seleção" das ideias evocadas na mente pelo estímulo, suprimindo as "mais fracas"; ocorreria "uma luta pela vida entre as representações", mediada pela vontade, que deveria "combater aquelas que não podem ser forçadas a concordar" ${ }^{\prime 142}$ com a que era mais central. A vontade seria capaz de reconhecer a hierarquia dos conteúdos suscitados pelo fenômeno no cérebro e controlar o desenvolvimento das associações, estrangulando as ideias secundárias e digressões, criando uma atenção maior para as mais importantes à interpretação do fenômeno. A vontade, na metáfora de Nordau, é como um servo atarefado na função de iluminar ou obscurecer pontos específicos do aposento, de acordo com as necessidades de seu senhor.

O degenerado, dotado de um cérebro maculado por más-formações hereditárias, e o histérico, cujo cérebro originalmente normal está exausto, possuem uma vontade muito tênue ou entorpecida, o que impede ou dificulta a atenção. Assim, os cérebros do degenerado e do histérico são caprichosos, funcionando sem objetivo ou razão. As associações ocorrem desabridamente. Há algum tipo de disfunção no processamento dos estímulos: ou eles são mal percebidos, ou atingem de maneira excessivamente aguda os centros nervosos superiores. Em qualquer caso, seu pensamento é absurdo e "incapaz de expressar as verdadeiras relações dos fenômenos"143. Formas incertas e obscuras emergem do inconsciente em reação aos estímulos, mas, no lugar de serem suprimidas ou totalmente esclarecidas pela vontade, como seria o caso num cérebro normal, elas se confundem com as associações legítimas e diretas que o fenômeno suscita, e se amalgamam a elas, dotando o resultado do processo de uma forte dose de confusão e

\footnotetext{
142 NORDAU, 1895, p. 53.

143 Idem, p. 56.
} 
absurdo. Em consequência, degenerados e histéricos tomam por real aquilo que é apenas fruto de associações mentais espúrias. Essa profusa combinação faz com que a experiência que suscitou o pensamento fique recoberta por inúmeros significados, anexos contraditórios e insensatos. O acometido por esta condição esforça-se por compreender, e julga que está de fato compreendendo as coisas, mas na verdade sua mente lhe apresenta apenas os resultados incoerentes do seu próprio funcionamento anormal. É a este fenômeno que Nordau chama Misticismo.

Uma vez explicada a mecânica dessa morbidade, Nordau passa a apresentar os casos específicos de acometidos e suas variantes. Acusa os Pré-rafaelitas de desenvolverem uma "ecolalia do pincel"144, pela insistência em dotar todas as áreas de suas telas com o mesmo grau de nitidez. Um cérebro onde a vontade funcionasse normalmente, ele explica, faria com que o olhar se concentrasse apenas nas imagens centrais, deixando os detalhes em segundo plano. Com base nesse argumento, interpreta a homogeneidade de tratamento das imagens dos pré-rafaelitas como sintoma de incapacidade cerebral de selecionar e hierarquizar os elementos ${ }^{145}$.

Mallarmé, Verlaine e os literatos ligados ao movimento Simbolista são os próximos analisados de Nordau. Eles são místicos porque fogem da noção de "poesia saudável" cunhada pelo médico. É certo, admite, que é parte da natureza da poesia brincar com palavras, sons e ideias, mas a boa poesia deve ter, subjacente, um eixo lógico, que permita que esses jogos evoquem ideias harmônicas e coerentes. Feita dessa forma, ela faculta ao espírito são uma decifração cristalina e unívoca, portando um sentido claro, encrustado nos enigmas, sons e associações entre imagens, sensações e ideias. A poesia dos acometidos de misticismo, pelo contrário, cria um lodaçal de imagens indefinidas e incoerentes entre si, uma "cacofonia de selvagens", uma "pirotecnia extravagante de cérebros vazios" ${ }^{146}$ que sonega um eixo lógico de sentidos. Há um descompasso, ou completo desligamento, entre as palavras e um sentido qualquer inteligível. Busca-se evocar emoções e sensações abertas, uma liberdade para interpretar que, segundo Nordau,

\footnotetext{
144 Idem, p. 84.

${ }^{145}$ As razões para o ataque de Nordau a esse grupo são obscuras. Neste que é o único capítulo em que se trata da pintura em Degeneração, escolhe como alvo um grupo cuja aparição se dera no final da década de 1840 e que, portanto, se encontrava havia 40 anos inativo. Talvez a escolha se deva à influência duradoura dos Pré-rafaelitas no mundo da cultura germânica fin-de-siècle; segundo Schorske, os membros da Secessão de Viena inspiravam-se largamente nas propostas deles (cfe. SCHORSKE, Carl E. Viena fin-de-siècle - política e cultura. Trad. Denise Bottmann. São Paulo: Companhia das Letras, 1988. p. 285).

146 Idem, p. 117.
} 
significa de fato um vazio absoluto. A poesia deles é semelhante ao discurso dos idiotas, "que inserem palavras que não têm absolutamente nenhuma conexão com o objeto de que tratam"147. Da mesma forma, permite-se qualificar Tolstói como portador de um “intelecto sem atenção" ${ }^{148}$, pois ele também é dado, assim como os Pré-rafaelitas, a munir suas obras de "uma abundância de detalhes incrivelmente acurados"149, incursionando em longas digressões sobre filosofia, política, história que denotam a ausência de uma ideiaguia.

Finalmente, dedica um capítulo à análise daquele que, em seu julgamento, é o mais alto degenerado de tipo místico, Richard Wagner. Nordau diagnostica em Wagner

"mania de perseguição, megalomania e misticismo, [...] vaga filantropia, anarquia, desejo de revolta e contradição; em seus escritos, todos os sinais de grafomania, a saber, incoerência, ideação fugitiva, tendência ao trocadilho idiota e, [na música], o característico emocionalismo tingido simultaneamente de entusiasmo erótico e religioso" $" 150$.

A ideia wagneriana de "Obra de arte total" (Gesamtkunstwerk) é especialmente combatida. À afirmação de Wagner de que a evolução das artes significa o abandono da independência das linguagens e a aceitação da condição de partícipe em um amálgama de gêneros a serviço do drama, Nordau contesta com o emprego da teoria da evolução, cuja lei determina que o progresso se dará sempre em direção à diferenciação das funções, do simples e indiviso ao complexo e especializado, e não pelo "retrocesso de seres diferenciados com ricas especializações para o protoplasma sem características" ${ }^{151}$. Interpreta essa insistência de Wagner numa arte sem especializações como sintoma de degeneração: ele seria incapaz de compreender estruturas complexas e independentes. Wagner, como todo degenerado, não pode atingir os píncaros intelectuais de um cérebro sadio, que leva à complexidade das operações especializadas; é por isso que tende a forçar as operações a voltarem para um nível mais simples, para poder lidar com elas; quer arrastar tudo para estágios mais antigos e baixos, para torná-los acessíveis a si, mais fáceis de serem compreendidos por seu cérebro defeituoso. É por isso, afirma, que os simbolistas insistem em audições-coloridas, desejando a proximidade "com o sistema sensorial de uma ostra" ${ }^{152}$. A obra de arte do futuro, conforme a quer Wagner, é para Nordau a obra

\footnotetext{
${ }^{147}$ Idem, p. 93.

148 Idem, p. 146.

149 Idem.

150 Idem, p. 171-172.

151 Idem, p. 175.

152 Idem, p. 142.
} 
de arte de tempos há muito passados: "o que ele toma por evolução é retrocesso, é um retorno a um estágio humano, ou melhor, pré-humano, primitivo" ${ }^{153}$. Os conceitos de Leitmotif e de melodia sem fim são outras características da música de Wagner que Nordau ressalta como sendo indícios de degeneração. O primeiro seria uma confusão mórbida entre as funções da música e da língua: Wagner estaria tentando empregar a música, através dos sinais sonoros convencionados - os Leitmotifs - numa função narrativa que deveria caber à palavra. Já a melodia sem fim sinalizaria a incapacidade de atenção típica dos místicos, impedindo a correta delimitação dos elementos pertinentes a um conjunto, resultando em caos.

$$
* \quad * \quad *
$$

A egomania é descrita como disfunção cerebral que embaralha a percepção do eu e do não-eu: a consciência do eu quando morbidamente exagerada cria o egomaníaco. $\mathrm{O}$ organismo desenvolve gradualmente a consciência de si e do externo a si. Nordau analisa esse desenvolvimento na criança, cuja mente de início encontra-se num estado de confusão, onde apenas reage aos estímulos sem os organizar em categorias. Nesse momento, seus centros superiores do cérebro ainda não se formaram e não há controle sobre os centros inferiores. Com o tempo, a criança passa a distinguir a origem dos estímulos. No início, ocupa-se quase que exclusivamente com os seus próprios processos orgânicos. Embora já tenha a noção de individualidade orgânica, pouco se importa com as coisas externas: "seus próprios estados preenchem mais ou menos completamente a sua consciência"154. Neste estágio, é o "modelo do egoísmo", sendo indiferente às coisas que não estão imediatamente conectadas consigo.

No desenvolvimento normal, essa situação se transforma, e o indivíduo passa a se ocupar mais e mais com os estímulos externos, fazendo com que os internos se dirijam gradualmente para um segundo plano; adquire assim "uma ideia justa de suas relações com os outros homens e com a natureza"155. "O 'eu' se retira decididamente para trás do 'não-eu' e a imagem do mundo preenche grande parte da consciência"156. Comte e Spencer chamam a este estágio "altruísmo", e a chegada a ele é a marca da conquista sobre o ego. Isso significa o interesse pelo outro por curiosidade ou simpatia, e não por

\footnotetext{
153 Idem, p. 176.

154 Idem, p. 252.

155 Idem.

156 Idem.
} 
necessidade de satisfação de desejos. O indivíduo saudável força o ego para um nível inferior de consciência, e ocupa-se majoritariamente com o exterior: é sensível aos pensamentos e sensações das outras pessoas, e é capaz de projetar e antever o efeito de suas ações sobre os outros. É capaz de entender a natureza bem o suficiente para se proteger daquilo que é perigoso, bem como para tirar proveito daquilo que é vantajoso. Isso tudo é resultado de uma série de atividades coordenadas entre as diversas partes do corpo coligadas por um cérebro sadio. O altruísmo é possível apenas aos plenamente desenvolvidos e isentos de enfermidade mentais.

O degenerado possui alguma disfunção química, biomecânica, celular ou molecular (a causa original, admite Nordau, ainda não era plenamente conhecida) que impede o funcionamento normal de seu sistema nervoso; não pode, portanto, alcançar o alto desenvolvimento cerebral que proporciona o altruísmo. Passa a vida como uma eterna criança, mergulhado em si. É ligado apenas aos seus próprios processos: é um egomaníaco. Seus nervos são fracos e não se estimulam normalmente pelos eventos do mundo externo, ou seus nervos são normais, mas é o cérebro que carrega alguma falha em coordenar os estímulos que lhe são enviados pelos nervos. Em qualquer dos casos, ele é obtuso. Lombroso e Sollier, cita Nordau, concluíram através de experimentos que entre idiotas, imbecis e criminosos é comum haver pronunciadas deficiências nos sentidos de paladar, olfato e tato. Lombroso afirmou que "sem acesso à sensação de dor, eles mesmo insensíveis, nunca entendem a dor nos outros"157.

Em suma, deficiências nos sentidos conduzem à condição de egomania. A consciência exacerbada dos processos internos, a primazia do eu sobre o não-eu, é ainda mais profunda, quando a atividade vital de algum órgão é intensificada e modificada de maneira anormal: assim origina-se a hiperestimulação e/ou o emocionalismo, fenômenos dos quais sofrem invariavelmente os degenerados. A atividade dos "nervos, vasos e glândulas" determina o tom dos pensamentos e sua direção. A mente degenerada está prenhe de obsessões e impulsos que, a despeito de seu julgamento - que os atribui a si e à sua exclusiva vontade - têm origem interna, resultantes de seus processos orgânicos anormais. Somado a isso, a fraqueza da vontade impede o degenerado de "suprimir suas obsessões, resistir a seus impulsos, controlar seus humores fundamentais, manter os altos centros na perseguição atenta dos fenômenos objetivos" ${ }^{\text {"158 }}$. O mundo externo inexiste

\footnotetext{
${ }^{157}$ Apud NORDAU, 1895, p. 257.

158 NORDAU, 1895, p. 257.
} 
para ele, ou aparece em cores pálidas e desimportantes, ou ainda, como imagem distorcida e falsificada. Sua consciência é monopolizada pelo eu, que não permite a primeira de se ocupar com nada além "dos dolorosos e tumultuados processos que acontecem nas profundezas de seus órgãos"159.

Há diferenças de grau na egomania, variando de acordo com a extensão dos danos orgânicos apresentados. No grau leve, aparece na forma cômica com que o egomaníaco valoriza a si e aos seus esforços, sensações, inclinações, atividades. É comum pensar, por exemplo, que a atividade profissional que exerce é o pináculo do desenvolvimento humano, apresentando um reconhecimento deformado de seu verdadeiro valor para a sociedade. Os estetas e os parnasianos, segundo Nordau, incorrem nesse erro, e não se omitem em afirmar que a sua atividade - a literatura - é a mais importante das realizações humanas. Em graus mais profundos, manifesta-se a egomania como imoralidade ou loucura moral, em que o indivíduo, em busca de gratificar seus desejos repulsivos, ultrapassa indiferente todas as normas da vida em sociedade, que, afinal, é incapaz de perceber. O portador de aberração moral é atraído por - e se delicia com - atos que enchem o homem são de nojo e horror; tal condição produz o indivíduo que tem prazer com o crime e uma decidida inclinação para o mal.

Os egomaníacos têm um traço característico muito pronunciado, o qual compartilham com os degenerados em geral: a incapacidade de adaptação. Para Nordau, adaptação é também um ato volitivo, nascido da vontade consciente e da ação do sujeito; o degenerado é incapaz de tal ato; primeiro, porque é incapaz de interpretar corretamente o mundo que o circunda, e por isso não pode fazer aquilo que, segundo Nordau, é a própria definição de adaptação: entender as forças naturais e fazer suas leis e tendências coincidirem com seus desejos. Incapaz de entender e se adaptar, o degenerado sofre, por ação dos homens e suas instituições, por ação da natureza, e se revolta contra isso. Vive um estado de constante revolta e sonha destruir tudo o que lhe ofende. Mas é um revolucionário ilógico, que quer destruir, mas nunca reformar nem desestagnar. Trata-se de um inconformismo mórbido, destrutivo, inconsequente e impensado, diferente daquele exercido pelo progressista/reformador. O egomaníaco luta contra inimigos imaginários ou, ainda pior, contra leis que são de fato, benéficas: contra a vacina obrigatória, contra o recenseamento da população ${ }^{160}$.

\footnotetext{
159 Idem.

${ }^{160}$ Idem, p. 264
} 
O egomaníaco é, enfim, um corpo que precisa ser expelido: a sociedade que não os expulsa ou, pior ainda, que os admira, é comparada por Nordau a um corpo em que os rins não funcionam, deixando de eliminar as impurezas, o que leva, inevitavelmente, à morte.

Dentre os egomaníacos considerados nos estudos de caso, Nordau principia avaliando os Parnasianos, Diabolistas, Decadentes e Estetas: Teóphile Gautier, Catulle Mendes, Theodore de Banville, Joris Karl Huysmans e, principalmente, Charles Baudelaire. O que encontra de similar entre eles é a predileção pelo mal, a atração pelas sensações fortes e desagradáveis e a completa cegueira quanto aos padrões morais da sociedade, que transgridem com indiferença enquanto perseguem seus impulsos. Baudelaire associa a essas características a predileção pelo grotesco e repugnante. Nordau afirma serem evidentes os estigmas de degeneração em Baudelaire: além do fato de ter morrido de "paralisia geral" depois de meses de insanidade profunda, foi um místico e um erotômano, "comedor de haxixe e ópio", e era profundamente atraído por outros degenerados, como Poe e Thomas de Quincey ${ }^{161}$. O próprio título que escolheu para sua coletânea de poesias - As Flores do Mal - trai a consciência que tinha de sua própria morbidade. Nordau cita e analisa os poemas de Baudelaire, e encontra neles a recriação em versos dos mundos artificiais de sua mente, o que evidencia a incapacidade de compreender a natureza real; a predileção pelo sombrio e detestável, pela morte e corrupção, pelo que é doente e criminoso, pelo repugnante.

Ibsen, a quem, segundo Nordau, desejava-se entregar o cetro de maior literato da Europa, mereceu também um capítulo à parte em "Degeneração", no interior do segmento dedicado aos egomaníacos. Para Nordau, toda a obra do norueguês revolve-se ao redor de 3 eixos, "genuínas obsessões" de fundo religioso: pecado original, confissão e redenção. A primeira, disfarçada - talvez mesmo para o autor, supõe Nordau - sob o conceito de hereditariedade, assumindo assim um manto de ciência. Ibsen descreve uma hereditariedade sempre daninha, resultando invariavelmente em algum traço infeliz e desfavorável, impeditivo ou malévolo. É na escolha invariável do legado negativo que Ibsen trai a sua religiosidade subterrânea: se assim não fosse, ele respeitaria a "lei da ciência", que demonstra que os traços hereditários benéficos e vantajosos são mais frequentes que os negativos. Mas em Ibsen os personagens "não herdam nada além do

161 Idem, p. 286. 
mal" "162. A confissão reaparece reiteradamente nas peças: em todas elas, a ação se desenvolve até chegar o momento de uma exposição pública de erros de um dos personagens, gerando o alívio da tensão e abrindo caminho para a reparação, ou o perdão. Finalmente, a redenção: a punição de um inocente em voto pelos erros alheios, motivo que Ibsen compartilha com Wagner.

Mas sobretudo, em Ibsen, a degeneração assume a forma de anarquia. Ela se manifesta na constante revolta contra tudo o que existe, e no consequente desejo de destruir tudo, sem que haja, em contrapartida, uma proposta para reconstruir de maneira nova e melhorada. O dilúvio aparece como única revolução possível, e mesmo a arca deve ser destruída ${ }^{163}$. É uma luta que não tem outro objetivo que não seja lutar, e nenhum resultado possível satisfará o anarquista. Em Ibsen, segundo Nordau, família, sociedade, casamento, estado, são elementos condenados à destruição, já que eles aparecem como obstáculos ao livre desdobramento do "eu". É esse o objetivo do homem na doutrina de Ibsen: dar largas ao "eu”, sem preocupações de qualquer espécie. Ele faz ridículas as personagens que encarnam o desejo pela contenção individual em favor do grupo; essa é sua forma de tornar ridícula a própria ideia. Os seus heróis, por sua vez, são justamente aqueles que praticam o desprezo pelas instituições em favor do "eu". Ibsen manifesta, assim, a incapacidade dos degenerados, por falhas estruturais em seus cérebros, de se adaptarem ao mundo existente. Eis a raiz da rebelião (e do crime). Segundo Nordau, apenas "fraquezas dos centros motores" impediam Ibsen de preencher a sina e tornar-se um delinquente real, fazendo-o contentar-se em ser criminoso apenas na imaginação ${ }^{164}$.

À Nietzsche, Nordau dedicou não somente um capítulo especial em Degeneração, mas a eleição para a duvidosa honraria de ser o mais alto degenerado de tipo egomaníaco. O médico considerava seu dever combater frontalmente aquele filósofo, já que, em sua opinião, ele oferecia o "suporte teórico" à "deificação do vício", o "incensamento [...] da licenciosidade, doença e corrupção", a glorificação do eu, da vontade e do ego ${ }^{165}$. O capítulo dedica-se a demonstrar, como nos outros casos, os "processos orgânicos mórbidos" ${ }^{166}$ geradores do pensamento de Nietzsche, procurando subtrair de sua filosofia o valor que lhe era atribuído naquela altura. O caráter assistemático das obras é empregado como evidência de insanidade: "o autor tem o hábito de lançar no papel com

\footnotetext{
162 Idem, p. 358.

163 Idem, p. 396.

164 Idem, p. 399.

165 Idem, p. 415-416.

166 Idem, p. 416.
} 
pressa febril tudo o que lhe passa pela cabeça, e quando já colecionou uma pilha de retalhos, envia ao impressor, e aí tem-se um livro"167. Desse amontoado emergem evidentes contradições que invalidariam a totalidade de sua doutrina, não fosse a desesperada - e inútil - tarefa a que se lançam seus adeptos na tentativa de harmonizar e extrair sentido dos aforismos do mestre.

Para Nordau, a maior perversidade do pensamento de Nietzsche residia em sua doutrina moral, segundo a qual a moralidade comezinha tolhe o pleno desabrochar do homem, sacrificando o possível em nome do seguro. Nietzsche teria sustentado, especialmente em Genealogia da Moral, que ao homem pleno, executor livre da vontade, fora sobreposto um aparelho de controle - consubstanciado no estado, na religião etc. que teria substituído a liberdade original pela contenção claustrofóbica no interior de um esquema supressor ${ }^{168}$. Na contra-argumentação, Nordau afirma que este homem plenamente livre nunca existira, sendo mero fruto de uma visão mistificada do passado, e que os homens sempre se viram obrigados a sacrificar seus impulsos individuais em favor de códigos coletivos que eram, em última análise, benéficos a todos. Argumenta ainda que a imagem nietzschiana das "bestas louras" - os pretensos homens livres de espírito guerreiro e irredutíveis às regras coletivas - era derivada da figura dos invasores bárbaros do final da Antiguidade, e lembra que estudos recentes (cita Gustav Freytag) haviam demonstrado que eles eram em geral camponeses que buscavam terras cultiváveis e que optavam, sempre que possível, pelo acordo e pelo contrato.

No fundo, Nordau conclui, toda a filosofia de Nietzsche não passava da justificação de impulsos sádicos, descrevendo a crueldade como "um poderoso instinto primordial do homem" que não deveria ser reduzida pela moralidade ${ }^{169}$. O fato de o filósofo se encontrar, naquela altura, irreversivelmente confinado num asilo de insanos, era a prova maior de que toda a sua filosofia emanava da morbidade: não se tratava de um cérebro que até então funcionara perfeitamente e que fora subitamente acometido por

\footnotetext{
167 Idem, p. 420.

${ }^{168}$ Notar que Nietzsche desenvolvia sua própria versão da ideia de degeneração: seriam os homens assim tolhidos por uma moralidade coletiva cerceadora que acabariam por tornarem-se artificialmente reduzidos e dolorosamente contorcidos. A humanidade reduzida por esse conceito de moralidade que cria as equivalências bom/não-egoísta e mau/egoísta estaria ameaçando seu próprio futuro: "E se no 'bom' houvesse um sintoma regressivo, como um perigo, uma sedução, um veneno, um narcótico, mediante o qual o presente vivesse como que às expensas do futuro? Talvez de maneira mais cômoda, menos perigosa, mas também num estilo menor, mais baixo?... De modo que precisamente a moral seria culpada de que jamais se alcançasse o supremo brilho e potência do tipo homem? De modo que precisamente a moral seria o perigo entre os perigos?..." (NIETZSCHE, 2009, p. 12)

169 NORDAU, 1895, p. 450.
} 
uma enfermidade, mas de um processo de dominação progressiva da enfermidade sobre um cérebro que sempre a abrigara, e que tingira tudo o que ele produzira com os traços da morbidade. "Ele é obviamente insano desde o nascimento, e seus livros carregam em cada página os sinais da insanidade" ${ }^{170}$. O cérebro extremamente ativo, lançando-se incessantemente em vertiginosas ideações, de que Nietzsche sempre se jactara, sofreria, na interpretação de Nordau, de uma facilitação anormal das conexões entre as representações, levando a um fluxo caótico e incoerente de ideias; trata-se de um exuberante pensamento que dança no ritmo daquilo que, como aponta Nordau, o próprio filósofo chama de "alegre ritmo da insanidade"171. Finalmente, reputa a filosofia de Nietzsche como beneficiária direta da atuação de uma "monstruosa personalidade" que atravessara a história da Alemanha: Bismarck. Nietzsche jamais atingiria tal nível de celebridade em outros tempos, dizia Nordau, senão entre expropriados de seus direitos e de suas liberdades básicas. Os contemporâneos procuravam em Nietzsche a voz que advogava pela liberdade contra o estado opressor. Voltavam-se inutilmente a ele, segundo Nordau, porque a liberdade que ele pregava não era política ou moral, mas sensual.

$$
* \quad * \quad *
$$

Quando passa a se dedicar ao Realismo, concentrando-se especialmente na figura de Emile Zola, Nordau acaba por desenvolver com mais profundidade sua crítica de arte científica, estabelecendo o que pode ser considerado a essência de sua obra: a compreensão do fenômeno artístico como resultado de processos orgânicos. Ele explica que a obra de arte se origina da reação a uma emoção, que por sua vez pode advir de duas fontes: ou é evocada por um processo vital nos órgãos internos do artista, ou emana de uma impressão recebida de algum estímulo exterior ${ }^{172}$. Em ambos os casos, o artista sente a necessidade de expressar essa emoção na forma de obra. No caso de a emoção ter origem interna, o artista irá recorrer às suas memórias e às imagens particulares de sua mente; neste caso, a obra resultante tenderá ao idealismo. No caso de sua emoção ter-se originado

\footnotetext{
170 Idem, p. 453.

171 Idem, p. 468.

172 Notar que esta noção é derivada das ideias de Herbert Spencer: em A origem e função da música, Spencer argumenta que todos os sons produzidos por seres humanos e animais, inclusive aqueles que se organizam musicalmente, são respostas fisiológicas a uma sensação ou emoção. Nordau, dessa forma, aprofunda e expande a noção spenceriana, procurando reafirmar o domínio da ciência sobre as manifestações culturais; cfe. SPENCER, Herbert. Origin and function of music. In SPENCER, Herbert. Progress: its law and cause. New York: J. Fitzgerald Publisher, 1882, p. 258 e ss. A primeira publicação de Origin and function of music ocorreu em 1857.
} 
de um estímulo externo, o artista irá compor a partir de fenômenos do mundo exterior, e o resultado será mais realista ${ }^{173}$.

Para invalidar o realismo, Nordau aprofunda a discussão a respeito da natureza da arte. Para ele, a arte não é nunca

“[...] uma representação objetiva e confiável dos fatos externos [...] mas é sempre uma confissão do autor; ela trai, consciente ou inconscientemente, a sua forma de sentir e pensar; desnuda suas emoções, e mostra quais ideias preenchem sua consciência e estão à disposição da emoção que anseia por expressão. Não é um espelho do mundo, mas um reflexo da alma do artista" ${ }^{\prime 14}$.

Mesmo quando se trata das "artes imitativas", continua Nordau, há um descolamento da realidade: o quadro, a estátua, apresentam seleções, acentuações, supressões. Não há arte imediata, sem a agência do artista. No final, trata-se, para Nordau, não de uma representação "do fenômeno como realmente é, mas como o artista o viu"175. $\mathrm{O}$ artista, conclui, jamais irá produzir algo imparcial como a fotografia ${ }^{176}$.

Sempre buscando invalidar a ideia de Realismo - entendido como "espelho do mundo" - Nordau reflete sobre as diferenças entre a literatura e as artes visuais. Nas letras, os obstáculos entre o mundo e sua representação são ainda mais pronunciados: trata-se de uma tradução para a forma de linguagem de conceitos originados pelos mais altos centros de cognição. As artes visuais, por outro lado, se expressam pelos mesmos sentidos em que o fenômeno representado se expressa: luz e cores, formas e volumes, todos eles processados pelos centros de intelecção mais baixos. O pintor poderia, se quisesse, "reduzir-se à condição de mera câmara escura, transmitir suas impressões visuais da maneira mais mecânica possível para seus órgãos motores, e compelir-se a não pensar nem sentir nada durante o progresso do trabalho" ${ }^{177}$. O resultado de tais operações seria algo mais próximo do realismo. De toda forma, ele argumenta, tais operações são impossíveis na literatura. Ao literato está vedado o registro de meras percepções; tudo o que ele sempre produzirá serão interpretações.

$\mathrm{Na}$ análise psicofisiológica de Zola, Nordau retoma a abordagem médica, pela qual afirma que aquele escritor

"pratica a mais extensiva e intensiva forma de antropomorfismo e simbolismo atávicos, resultantes de raciocínio subdesenvolvido ou embaralhado pelo misticismo, encontradiço

\footnotetext{
173 Idem, p. 476.

174 Idem, p. 476.

175 Idem, p. 477.

176 Idem, p. 478.

177 Idem, p. 477.
} 
entre selvagens em sua forma natural, e entre todas as categorias de degenerados numa forma atávica de atividade mental" ${ }^{178}$.

Com isso, quer dizer que Zola “dispõe os fenômenos arbitrariamente para que eles pareçam expressar uma ideia que os está dominando". Misteriosos poderes se manifestam através das personagens e eventos, e "suas intermináveis descrições não delineiam nada além de seu próprio estado mental" 179 . "As novelas de Zola não provam que as coisas estão desarranjadas neste mundo, mas apenas que o sistema nervoso do autor está fora da ordem" 180 .

Nos dois capítulos finais de "Degeneração", Nordau permite-se um palpite sobre "as ulteriores evoluções do mal", oferecendo assim um prognóstico ${ }^{181}$. Diante de um quadro que descreve como sendo de "severa epidemia mental, espécie de peste negra de degeneração e histeria" ${ }^{182}$, prevê que ainda estava por vir o paroxismo - a culminância da enfermidade. Mas conclui com otimismo: a humanidade irá se recuperar, já que os degenerados tendem a desaparecer por conta própria. Não estão em condições de sobreviver à competição com os homens sadios. Estes, por sua vez, ou se adaptarão às novas condições da vida moderna, ou as rejeitarão inteiramente, voltando a viver como antes. A própria arte, prevê, tende a desaparecer nos séculos seguintes, já que é uma linguagem ligada aos sentimentos e emoções, e que

"a psicologia nos ensina que o desenvolvimento se dá do instinto ao conhecimento, da emoção ao julgamento, da associação aleatória de ideias para um processo regular e ordenado de pensamento. A atenção toma o lugar da ideação livre; a vontade, guiada pela razão, substitui o capricho" ${ }^{\prime 183}$.

Expressa desconfiança quanto à viabilidade das novas propostas estéticas. Nega que as formas tradicionais estejam esgotadas, como dizem os partidários das novidades. "Não são as antigas formas dúcteis e flexíveis o suficiente para permitir a expressão de cada sentimento e de cada pensamento?". Por outro lado, afirma que as “" "espasmódicas buscas por novas formas não são nada mais do que vaidade histérica, aberrações de

\footnotetext{
178 Idem, p. 494.

179 Idem, p. 495.

180 Idem, p. 499.

181 Idem, p. 537.

182 Idem, p. 537.

183 Idem, p. 543.
} 
vagabundos e charlatães" ${ }^{184}$. A arte do futuro, conclui, se desenvolverá nos caminhos da arte do passado, e toda a produção das vanguardas proponentes de novas formas estaria condenada, como uma doença que completa seu ciclo e desaparece.

Desdenha também da arte "socialista": "a arte não pode tomar partido em assuntos de política, nem é sua função encontrar e propor soluções para questões econômicas”. No máximo, concede, deve cooperar, evocando e excitando as ideias, sem nunca operar diretamente ${ }^{185}$.

Pode-se acelerar a cura. Nordau sugere, então uma terapia. Diz ser essa, afinal, a intenção geral da obra. Descarta ser possível convencer os degenerados a abandonarem seus vícios: escravos de suas doenças, estariam definitivamente perdidos. Restava proteger a sociedade da contaminação. Caberia aos homens saudáveis, enfim, desmascarar os degenerados, expor suas chagas em público, alertando a sociedade para os riscos advindos do contato com suas obras. Mas adverte: perseguir e proscrever tais produtos culturais é inútil. Nada é mais eficiente para estimular a curiosidade do público por uma determinada obra do que a perseguição policial e o banimento. Isso se torna, de fato, publicidade: recobre a obra com uma aura de mistério e o artista com a capa do mártir. A solução, enfim, deveria ser pacífica. Nordau sugeria que se formassem sociedades compostas por homens livres de preconceitos e bem-educados que se dedicassem a analisar, com as ferramentas da ciência, as obras de arte, e que por esse expediente concluíssem sobre sua potencial periculosidade para a sociedade. A única punição eficiente, depois disso, segundo Nordau, seria o boicote.

Para Neil Levi, "Degeneração" aparece como uma espécie de resposta de Nordau à ideia, corrente em seu tempo, que ligava o modernismo - lido como decadência cultural - à influência dos judeus. Nordau estaria, desta maneira, tentando desonerar os judeus da acusação de contaminação cultural via modernismo. A tentativa de Nordau, segundo visto, não se fez pela defesa do modernismo, mas pela procura de outros culpados pelo processo; o resultado final seria uma acusação que recaía contra a modernidade como um todo, abarcando todos os povos civilizados e, dentre eles, os grupos mais ricos ${ }^{186}$.

\footnotetext{
184 Idem, p. 544.

185 Idem, p. 546. Como exemplo desse tipo de arte, cita "A Cabana do Pai Tomás", de Harriet Beecher Stowe, que mesmo sem ter deliberadamente se engajado, teria dado visibilidade à escravidão, suscitando um repúdio geral contra ela.

${ }^{186} \mathrm{Na}$ tese de Levi, a atribuição do modernismo à influência dos judeus representava uma nova configuração do sentimento antissemita na Europa e, mais especificamente, da ideia de "judaização", que ele descreve como sendo a crença de que os judeus exercem "influência desproporcional" ao tamanho
} 
Importante notar a forte presença das ideias de Max Nordau no Brasil, já desde antes da publicação de Degeneração. Com o emprego das ferramentas de busca disponíveis no site da Biblioteca Nacional, na seção denominada "Hemeroteca Digital", é possível observar a incidência do termo "Max Nordau" nos jornais brasileiros digitalizados e disponibilizados para consulta. As ocorrências referem-se a reproduções de textos escritos pelo médico e também a aparições de seu nome em textos de outros autores, que o citavam com frequência extraordinária. Reproduções e citações emergem em jornais do Pará, Maranhão, Mato Grosso, Espírito Santo, Rio de Janeiro, Minas Gerais, São Paulo, Santa Catarina, Paraná, Rio Grande no Norte e do Sul e Pernambuco. Elas ocorrem no intervalo entre os anos de 1889 e 1934, predominando especialmente na década de 1890.

Os jornais permitem também que se observe uma expressiva presença de livros de Nordau traduzidos e comercializados no Brasil. Os Editores Laemmert \& Co. tiveram ampla participação nesse processo. Na última década do século XIX, aquela casa publicou muitas traduções de obras do médico húngaro, entre as quais "Paradoxos", "Mentiras convencionais de nossa civilização" e romances como "Comédia do Sentimentalismo". O livro "Degeneração" foi dividido em brochuras e publicado em partes denominadas "Fin-de-Siècle" (1897), "O Mysticismo" (1898) e "O Egotismo" (1899). As obras foram traduzidas a partir do inglês pelo escritor Manuel Coelho da Rocha.

A presença mais regular e duradoura de Max Nordau na imprensa brasileira se deu com a série "Cartas d'Alemanha", publicada pela Gazeta de Notícias do Rio de Janeiro. Iniciada em 15 de fevereiro de 1892, a série apresentava mensalmente textos de Max Nordau, trazendo notícias comentadas de questões políticas, econômicas e culturais da Europa; prolongou-se até 17 de dezembro de 1899, perfazendo um total de 76 aparições. Max Nordau teve bastante espaço também na imprensa judaica produzida no Brasil ${ }^{187}$.

\footnotetext{
de sua população, desvirtuando as estruturas das sociedades que os abrigam. No passado, a ideia de judaização esteve ligada ao campo material, da usura e das finanças; agora, no século XIX, dirigiam-se para o campo cultural. Para Levi, Richard Wagner fora o responsável por disseminar a preocupação com a suposta influência daninha dos judeus sobre a cultura, especialmente através do ensaio Das Judenthum in der Musik [O judaísmo na Música], de 1850; cfe. LEVI, Neil. Modernist Form and the Myth of Jewification. New York: Fordham University Press, 2013. As ideias deste autor citadas nesta página podem ser encontradas nas páginas 23 e 28.

${ }^{187}$ Em 1916, chegou-se a anunciar a vinda de Nordau para a América do Sul, passando pelo Brasil e pela Argentina; o projeto não se realizou; cfe. "Max Nordau virá ao Brazil e à Argentina fazer conferências"; A Notícia (RJ), 25/26/3/1916, p. 2.
} 
No Brasil, "Degeneração" mereceu comentários publicados em diversos jornais. N'O Paiz (RJ) de 16 de abril de 1894, Xavier de Carvalho mencionava na coluna "Carta Parisiense" a sensação causada pelo livro em Paris e adiantava o seu juízo sobre a obra:

"Entre as últimas publicações recebidas das casas editoras parisienses uma das mais interessantes pela audácia da controvérsia, pela originalidade dos pontos de vista, pela clareza dos seus juízos é a última obra de Max Nordau, La Degenerescénce, publicada pela Livraria Felix Alcan, boulevard Saint Germain. [...] Max Nordau é por vezes bastante injusto nas suas apreciações, querendo ver em todo homem de gênio um alienado. De maneira que só os imbecis é que são indivíduos de sério valor. Como todo bom alemão, odeia a França; é por isso que é tão cruel para com os escritores mais distintos da França moderna. É um livro curioso a ler, mas não pode servir para qualquer estudo sério sobre a literatura contemporânea pela sua muito parcialidade e injustiça" 188 .

No Maranhão, A Pacotilha publicou um comentário sobre a obra recém-lançada, que estaria "fazendo neste momento grande impressão na Alemanha, Inglaterra e França". $\mathrm{Na}$ coluna, o redator oferece uma sinopse do livro, demonstrando compreensão e concordância com o argumento central: a degeneração, explica, é "fruto do mal do século [...] produto da excessiva fadiga cerebral contemporânea", e se manifesta de diversas maneiras, entre elas a "volta ao passado, a suas ideias infantis de política e moral", o recurso a formas de arte primitivas - especialmente Wagner e sua insistência na fusão das linguagens artísticas, e a falta de capacidade de atenção ${ }^{189}$.

No jornal A República, do Pará, o redator mostra-se estupefato e um tanto incrédulo com a sentença de Nordau. Afirma que Lombroso recebera um "presente dos mais incômodos" ao ser citado como o homenageado na obra, já que ali se diria que todos os literatos que demonstrassem qualquer traço de crença religiosa enquadrar-se-iam na categoria de místicos, "adivinha-se que quase todos entrem na mesma categoria"; "místicos também são todos os poetas que dão provas de imaginação muito violenta ou sensibilidade muito delicada, o que importa dizer todos eles"190.

O Commercio de São Paulo do dia 2 de setembro de 1893 comenta "Degeneração", que "está causando sensação profunda" na Europa; o jornal dá destaque à lista de diferenças feita por Nordau entre a situação do mundo em 1840 e 1890, buscando ressaltar o aumento de complexidade da vida moderna que estaria na raiz etiológica da degeneração ${ }^{191}$.

\footnotetext{
${ }^{188}$ CARVALHO, Xavier de. "Carta Parisiense". O Paiz (RJ), 16/4/1894, p. 2.

189 "Um Livro notável"; A Pacotilha (MA), 10/3/1894, p. 2-3. Essa mesma nota, repetida palavra por palavra, foi publicada na Gazeta de Petrópolis no dia 2 de maio de 1894, assinada por "La Fresnaye".

190 “Todos Loucos!"; A República (PA), 4/7/1893, p. 2.

191 “A Degenerescência”; O Commercio de São Paulo, 2/9/1893, p. 2.
} 
A repercussão da "crítica de arte científica" de Max Nordau no Brasil foi bastante notável, conforme será destacado no segmento dedicado à crítica brasileira e suas relações com a arte de vanguarda. 


\section{Capítulo 3 \\ Estética Positiva, nacionalismo naturalista: recepções ao modernismo no Brasil}

O pensamento cientificista e a ideia de degeneração tiveram ampla penetração na cultura brasileira no final do século XIX. Para Dain Borges, tais noções foram predominantes nas décadas que seguiram a proclamação da República, configurando-se como "ideologia central, quase oficial, da oligarquia republicana conservadora"192. Para este mesmo autor, tal paradigma só encontraria ocaso a partir dos anos 1930, ainda que tenha permeado também a visão de mundo dos intelectuais identificados como "modernistas"193.

O pensamento cientificista, em sua forma e trajetória no Brasil, foi analisado por Roque Spencer Maciel de Barros ${ }^{194}$. Insinuando-se num terreno dominado pelas disputas entre liberais e católico-conservadores, teria como característica central o entendimento de que todos os fenômenos do universo - inclusive aqueles atinentes aos homens, suas sociedades e culturas - eram regidos e determinados por forças naturais, que poderiam e deveriam ser descobertas pela ciência. Dessas descobertas seriam extraídas as "leis" capazes de explicar e prever os fenômenos:

"Para o cientificista, não há nenhuma irredutibilidade entre as normas e os ideais, de um lado, e o mundo dos fatos, de outro: uma só natureza engloba e explica os dois planos, numa rejeição decidida de dualismos e pluralismos, tenham os nomes que tiverem. $\mathrm{O}$ mundo humano, os valores espirituais, a consciência, são apenas fenômenos mais complicados do que os da pura ordem física - mas não são de outra natureza. $\mathrm{O}$ mesmo determinismo que rege os movimentos dos astros, as combinações químicas dos corpos, etc. rege também os fenômenos sociais e os psíquicos; assim, se há uma marcha 'fatal' no universo físico, deverá ela verificar-se também no universo humano, que é o mesmo mundo físico num nível mais complexo" 195 .

Dentre todas as matrizes do pensamento cientificista, a doutrina de Auguste Comte seria aquela que encontraria maior número de adeptos no Brasil. Os positivistas brasileiros variavam no grau de apego à ortodoxia, indo desde o acatamento ultra ortodoxo dos preceitos comtianos até a adoção seletiva, combinando-os com outras matrizes de pensamento, formando um intrincado mosaico de mentalidades. De todo modo, interessa notar que os positivistas brasileiros ofereceriam um paradigma de

\footnotetext{
192 BORGES, op. cit. p. 240.

${ }^{193}$ Idem, p. 252.

${ }^{194}$ BARROS, Roque Spencer Maciel de. A ilustração Brasileira e a Ideia de Universidade. São Paulo: Editora Convívio/Editora da Universidade de São Paulo, 1986.

${ }^{195}$ BARROS, 1986, p. 107.
} 
interpretação da trajetória do país. A lei dos três estados, com que organizavam a narrativa sobre a nação, oferecia "[...] uma límpida e acessível filosofia da história" que servia “como instrumento de interpretação da realidade do país e como programa para a sua transformação "científica""196. Nesse sentido, insistiriam na ideia de que o desvio do Brasil devia-se somente ao fato de que o país se encontrava em outra fase de desenvolvimento, mas que sua essência era da mesma natureza daquela encontrável entre os povos ditos civilizados.

A chegada do pensamento cientificista ao Brasil, conforme ressalta Borges, acontece em meio a uma profusão de mudanças radicais, "quando o entusiasmo do idealismo romântico era combinado com arrogância científica, fervor abolicionista, fanatismo republicano, a rebelião de uma nova geração e um novo rancor anticlerical"197. No Brasil, eram os cientificistas os portadores das "ideias perigosas". Por isso, ao contrário do que ocorreria em outros contextos, o pensamento degeneracionista no Brasil não enfatizou o passado, já que seu legado "não era o de uma era de ouro, mas uma maldição ou algo de que se envergonhar" ${ }^{198}$. As preocupações se concentrariam na regeneração. O cientificista brasileiro não olha com nostalgia para um passado supostamente não corrompido, como faziam os europeus; de fato, enxergariam nele justamente a origem da degeneração, e assim projetariam as esperanças para o futuro. Incapazes de encontrarem em sua história o momento de glória da raça, os cientificistas brasileiros se insurgem contra ela, e lançam-se a uma busca pela utopia, a se realizar no porvir $^{199}$.

De todo modo, essa configuração específica do contexto brasileiro faz com que o cientificismo assuma um caráter progressista em seu momento inaugural. Isso irá se manifestar na crítica de arte, resultando numa vertente que será aqui denominada estética positiva, tomando de empréstimo o termo cunhado por um de seus cultores ${ }^{200}$. A Academia de Belas Artes e seus cânones são descritos por este grupo como manifestações

\footnotetext{
196 Idem, p. 123.

197 BORGES, 1993, p. 240.

198 BORGES, 1993, p. 240.

199 Essa característica do pensamento cientificista brasileiro deu azo a um amplo programa de intervenções compreendidas como meios de promover o "saneamento". As modificações urbanas no Rio de Janeiro, o arrasamento de cortiços, a instituição da vacinação obrigatória, as tentativas de erradicar mosquitos e ratos, eram atos que faziam parte desse pacote de medidas de regeneração da raça. Acreditava-se na premissa lamarckiana de que a melhoria do ambiente e o subsequente contato da população com a modernização levariam a um progresso racial.

200 O termo foi introduzido na Revista Musical e de Bellas Artes, em 1879, por um redator que se denominava "Fromentin"; ver nota 208.
} 
do passado atreladas ao escravismo, aos subprodutos do jugo colonial e à monarquia; daí o repúdio à tradição e a busca por uma nova linguagem estética, afastada daqueles modelos ditos acadêmicos e mais ajustada ao momento moderno. Essa condenação do tradicional e consequente busca pelo novo se dará de acordo com princípios vistos como "científicos".

Com o fim do Império, expoentes desta vertente encontrariam acesso facilitado a posições institucionais. Nesse mesmo momento de triunfo, emergem detratores de suas proposições, atacando o que consideravam decadência no ensino e na prática artística sob novas diretrizes. Este antagonismo à agora Escola Nacional de Belas Artes se faz, em alguns casos, com o emprego da mesma vertente cientificista que fora instrumento de combate ao tradicional.

A virada do século, trazendo as ousadias formais das vanguardas e, especialmente, as gerações de modernistas que se colocariam em atividade a partir do final da década de 1910 reativariam o discurso cientificista e o levariam a um novo patamar de reacionarismo. Nesse momento, os remanescentes da estética positiva reforçariam a oposição às "novidades". Realinhariam seu discurso, tratando de atacar as propostas introduzidas pelos modernistas com as armas da retórica cientificista, categorizando-as como manifestações de um processo de degeneração. Nesse momento, o discurso dos críticos de arte ligados à estética positiva se apegaria fortemente às tradições do passado.

Neste capítulo, pretende-se demonstrar as linhas gerais desta estética positiva, sua relação inicial com a tradição e com a modernidade e sua conversão, já no período republicano, em defensora do estabelecido. A maior parte da exposição que segue foi organizada a partir de fontes primárias, colhidas especialmente em periódicos da época, uma vez que, ao contrário do caso alemão, encontrou-se escassa bibliografia consolidada sobre esses fenômenos.

No final do século XIX o universo das artes visuais brasileiras amparava-se no "modelo de promoção das artes por parte do Estado, mediante encomendas públicas"201. O sucesso de Pedro Américo, que conseguiu fazer o governo interessar-se por seu " $A$ Batalha do Avẫ', atestava a solidez desse regime. A relação entre artistas e Estado se

\footnotetext{
${ }^{201}$ SCHWARCZ, Lilia Mortiz; STUMPF, Lúcia Klück; LIMA JUNIOR, Carlos. A Batalha do Avaí - a beleza da barbárie: a Guerra do Paraguai pintada por Pedro Américo. Rio de Janeiro: Sextante, 2013. p. 14.
} 
estreitara ao longo do século XIX e a pintura épica de Américo, à qual somava-se a de Victor Meirelles e outros, era auspiciosa para o governo, que buscava a construção de uma "epopeia nacional"202.

Diante desse cenário, organiza-se uma primeira luta pela modernidade no Brasil - nominalmente contra o "academismo". Emerge uma corrente de críticos "renovadores", que formava um programa progressista e se mostrava descontente com a situação das artes no Brasil. No seu discurso, constrói-se uma polarização entre "idealistas" - a quem reputavam apegados à tradição da linguagem e às convenções acadêmicas já ultrapassadas - e "realistas", que viam como renovadores da pintura, mas que lamentavam serem escassos no Brasil. Nessa altura, os "idealistas" eram identificados como pertencentes aos quadros da Academia Imperial de Belas Artes.

Essa escola estética renovadora é bastante influenciada pelo pensamento cientificista, que emerge no Brasil no final da década de 1870. Segundo Tania Regina de Luca, essa década constituiu-se num "ponto de inflexão na vida cultural brasileira"203. A geração que despontou ali buscava renovar o cenário nacional, minando as bases do Segundo Império ao trazer para o debate público temas como a abolição, republicanismo, estado laico e a liberdade religiosa, abrindo caminho para as grandes transformações que se observariam nas décadas seguintes. Autodeclarados modernos, os luminares dessa geração amparavam-se num "bando de ideias novas", enumeradas por Sílvio Romero:

"Positivismo, evolucionismo, darwinismo, crítica religiosa, naturalismo, cientificismo na prosa e no romance, folclore, novos processos de crítica e de história literária, transformação da intuição do direito e da política, tudo se agitou e o brado de alarma partiu da escola do Recife" ${ }^{204}$.

\footnotetext{
202 Idem. Para Migliaccio, a exposição de 1879 representou o ápice desse regime estético e, ao mesmo tempo, o início de seu ocaso. Nesse ano, foram exibidas lado a lado as telas de Meirelles e Américo, instigando um aceso debate sobre as qualidades de cada um deles, e levando aos salões um afluxo inédito de público; ao mesmo tempo, o autor considera que se patenteou ali "o cansaço do público em relação à épica do Estado"; cfe. MIGLIACCIO, Luciano. O Século XIX. In: AGUILAR, Nelson (Org.) Mostra do redescobrimento: Século XIX. São Paulo: Associação Brasil 500 Anos Artes Visuais, 2000; p. 110. Notar que Schwarcz et alii também consideraram a Guerra do Paraguai como o ponto culminante do Segundo Reinado, levando-o ao seu paroxismo e, ao mesmo tempo, permitindo que surgissem as estruturas que seriam responsáveis por sua derrocada em 1889; cfe. SCHWARCZ et alii, op. cit., p. 13.

${ }^{203}$ DE LUCA, Tania Regina. A Revista do Brasil: um diagnóstico para a (N)ação. São Paulo: Fundação Editora UNESP, 1999; p. 20.

${ }^{204}$ ROMERO apud. DE LUCA, 1999, p. 20. O jargão cientificista da época, que parecia aos jovens de 1870 o que havia de mais instrumental para o combate às mazelas nacionais, passa a ser empregado para descrever o país. Nas palavras de Tobias Barreto, os problemas nacionais convertiam-se em "fenômenos patológicos do organismo social brasileiro"; apud DE LUCA, 1999, p. 21.
} 
Um dos fóruns públicos onde se reuniram os partidários da renovação estética, contra o que já chamavam "academismo", foi a Revista Musical e de Bellas Artes, que circulou entre janeiro de 1879 e dezembro de $1880^{205}$. A doutrina da Revista foi codificada numa série de artigos intitulados Estética Positiva, assinada por Fromentin. O redator procurava munir de argumentos sólidos a vertente "moderna", preparando-a para a batalha contra os "acadêmicos-idealistas"206.

Empregando conceitos oriundos do Positivismo, Fromentin afirmava que pretendia alcançar uma "estética estudada à luz da ciência moderna", extraindo-a do "sistema nebuloso e difuso da metafísica". Para ele, os pintores "idealistas" desenvolviam uma versão atualizada das teorias de Platão, buscando eliminar os "acidentes" do mundo real na busca pela beleza ideal, mirando modelos perfeitos que acreditavam existir num plano superior. $\mathrm{O}$ resultado, para Fromentin, era uma pintura que impedia a expressão individual, a paixão e a vida, suprimidas em nome de supostas ideias puras e elevadas ${ }^{207}$. Para ele, a arte idealista deveria ser abandonada em favor de uma estética compreendida em termos orgânicos:

“As sensações artísticas são em grande parte explicadas pela ótica e pela acústica, e se os fenômenos cerebrais, isto é, os efeitos morais da arte não são ainda conhecidos, há ao menos uma coordenação de fatos que forma quase uma parte empírica da ciência.

A última palavra, em todo caso, será dada pela fisiologia, mas nunca pela psicologia" ${ }^{208}$.

Com isso, Fromentin desenvolvia uma visão mecanicista dos fenômenos estéticos muito próxima daquela que Max Nordau cultivaria mais profundamente em "Degeneração", 15 anos mais tarde:

“[...] a sensação do prazer é causada pela excitação dos nervos da sensibilidade e uma estimulação mais ou menos localizada da vida; [...] cada uma das faculdades indicadas pelos psicologistas tem no cérebro o seu órgão particular.

\footnotetext{
${ }^{205}$ A Revista era um empreendimento de Arthur Napoleão e Leopoldo Américo Miguez, ambos músicos e dedicados ao comércio de instrumentos musicais e partituras; cfe. SILVA, Rosângela de Jesus. Crítica de Arte na Imprensa Carioca do Século XIX: Revista Musical e de Bellas Artes. Anais do III Encontro de História da Arte. Campinas, IFCH/UNICAMP, 2007; p. 606. Durante a pesquisa, foram escrutinadas todas as edições desta publicação, na busca por compreender o programa da crítica de arte que pugnava por renovações estéticas no final do século XIX.

${ }^{206}$ Os artigos de Fromentin foram inspirados, segundo o próprio autor, nas ideias do crítico de arte francês Eugène Véron; a análise da obra A Estética, de Véron, demonstra que Fromentin em muitos pontos de sua argumentação na Revista de fato apenas traduziu e transcreveu as palavras do francês; cfe. VÉRON, Eugène. Aesthetics. Trad. W. H. Armstrong. London: Chapman \& Hall, 1879 [a primeira edição em francês, presumivelmente aquela que foi escrutinada por Fromentin, apareceu em 1878].

${ }^{207}$ Revista Musical e de Bellas Artes; "Estética Positiva”, Ano 1, Ed. 19, 10/5/1879, p. 2.

${ }^{208}$ Revista Musical e de Bellas Artes; "Estética Positiva”, Ano 1, Ed. 20, 17/5/1879, p. 2.
} 
[...] A origem do gozo estético existe na excitação particular dos órgãos [...]; quanto mais considerável for o número de fibras que entram em vibração mais viva será a sensação resultante" 209.

Estabelecendo dessa forma ser possível mensurar as sensações e determinar-lhes relações de causalidade, pôde extrair leis de funcionamento: "Ficam assim estabelecidas as três condições fundamentais do gozo estético: intensidade, variedade e concordância das vibrações, isto é, dos elementos constitutivos da sensação" ${ }^{210}$. Para Fromentin, o artista deveria perseguir a emoção que sensibilizava seus nervos e organizá-la na forma de obra de arte, de maneira a estabelecer uma conexão com o público. Partia da premissa de que artistas e público, como contemporâneos, estavam submetidos aos mesmos estímulos e emoções. Isso, segundo ele, era incompatível com os princípios tradicionais, que levavam o artista a buscar a repetição de fórmulas, o cumprimento de certos padrões de execução técnica colocado acima da "verdade interior". Esse procedimento, concluía, resultava em obras estéreis.

A fisiologia da estética de Fromentin é usada como arma contra o estabelecido; é instrumento para defender a ascensão de uma nova ordem artística e seu argumento justificador ${ }^{211}$. No final da década de 1870 essas leis ainda podiam servir aos "libertários": as regras de produção artística extraídas da fisiologia da estética produziriam uma arte "simpática", ou seja, resultaria em obras que estabeleciam uma ressonância entre o artista e o público, ao contrário daquela produzida de acordo com as convenções da academia. A doutrina da Estética Positiva, dessa forma, conduzia à luta institucional; o próprio autor sugeria que as constatações reveladas por ele deveriam resultar num combate aos tradicionalistas:

"Entre nós, onde o estudo das belas-artes é unicamente acadêmico, a marcha por essa senda será quase impossível, se a mocidade que se dedica à arte não reagir com todo o entusiasmo contra as mediocridades que, acasteladas na ignorância e nas teorias metafísicas, querem opor um dique insuperável às doutrinas modernas.

Os homens que representam a escola acadêmica exercem uma influência desastrosa pela autoridade que têm e pela sinceridade de que estão dotados, tentam, dizem eles, elevar o nível da arte, mas como os antigos disseram a última palavra sobre a arte, estão, pois, os

\footnotetext{
${ }^{209}$ Revista Musical e de Bellas Artes; "Estética Positiva", Ano 1, Ed. 21, 24/5/1879, p. 3.

${ }^{210}$ Revista Musical e de Bellas Artes; "Estética Positiva", Ano 1, Ed. 21, 24/5/1879, p. 3

211 Mais tarde, esse mesmo aparato "estético-fisiológico" seria empregado para combater as propostas de renovação, tanto por Max Nordau quanto pelos críticos brasileiros antagonistas das vanguardas do início do século XX. As propostas de Fromentin já deixavam claras as linhas pelas quais se exerceria essa resistência às experimentações estéticas mais ousadas: “A condição, porém, a que não podem fugir as manifestações artísticas é a unidade final de pensamento; assim como num quadro ou numa estátua deve existir uma fusão de cores e de linhas numa harmonia geral, do mesmo modo na poesia deve-se poder reunir em um grupo único as ideias expressas nas diversas partes da obra". Cfe. Revista Musical e de Bellas Artes; "Estética Positiva”, Ano 1, Ed. 22, 31/5/1879, p. 2.
} 
artistas condenados, para alcançar o belo, a copiar e imitar eternamente, não o sentimento e a ideia dos clássicos, mas a expressão desse sentimento e dessa ideia, - a forma, que sem a emoção e a personalidade nada diz ao espírito, não pode ser inspiradora" ${ }^{212}$.

Para ele, os jovens deveriam buscar a "arte por excelência, caracterizada pela personalidade do artista e pela sua emoção" 213 .

Fazia parte da compreensão cientificista da cultura a hierarquização das manifestações artísticas. A teoria da sucessão de estados com que se organizava a história, assim como a visão evolucionista do desenvolvimento do universo natural, resultaram numa narrativa que classificava as manifestações estéticas no interior de uma escala que partia do primitivo (identificado como "popular" ou associado às "raças selvagens") e chegava ao civilizado (que se confundia, neste discurso, com as estruturas e valores do "homem branco ocidental"). A geração de 1870 praticava essa compreensão evolucionista do fenômeno artístico, que seria mais facilmente detectável no discurso a respeito da música.

Neste segmento, serão apresentadas algumas manifestações deste evolucionismo cultural colhidos nos textos da Revista Musical e de Bellas Artes, de autoria dos críticos identificados com os movimentos renovadores. A observação desta variante da crítica cientificista parece se justificar pelo fato de que, mais tarde, ela entraria em choque violento com as concepções modernistas. Ao estabelecerem uma nova articulação com o "outro" primitivo, tomando-o como lastro da identidade nacional e identificando-se a ele, as vanguardas provocariam reações agudas por parte dos cultores da ideia evolucionista.

Em fevereiro de 1879, a Revista apresentou uma apreciação sobre o Zé Pereira, “instrumento popular [...] transportado das aldeias do Norte de Portugal”. O texto era condescendente e atribuía o fascínio exercido pelo instrumento ao poder do ritmo, que apelava ao que havia de mais "primitivo" no homem:

\footnotetext{
${ }^{212}$ Revista Musical e de Bellas Artes; "Estética Positiva", Ano 1, Ed. 20, 17/5/1879, p. 3.

${ }^{213}$ Revista Musical e de Bellas Artes; "Estética Positiva", Ano 1, Ed. 20, 17/5/1879, p. 3. Poucos foram os pintores apontados como adequados pela Revista. Um dos raros que mereceu elogios foi Nicolau Facchinetti. "Com o cavalete, a tela e a caixa de tinta às costas, em guisa de mochila, ei-lo a trepar pelas asperosidades das montanhas de Minas, ou embrenhando-se pelos sertões ínvios de qualquer de nossas províncias para os seus estudos"; a Revista o elogiava por pintar o que via, com as cores e a luminosidade do Brasil; cfe. Revista Musical e de Bellas Artes; "O pintor Facchinetti", Ano 1, Ed. 40, 4/10/1879, p. 5.
} 
"O ritmo tanto pertence ao selvagem quanto ao homem civilizado; a melodia é o efeito musical mais acessível e mais fácil ao ouvido humano, e é por isso que ela impressiona com preferência os povos meridionais, tão propensos a tudo que lhes dê pouco trabalho; a harmonia é a última perfeição da arte, a sua parte mais bela e mais científica e a que indica mais o estado de adiantamento da arte entre qualquer povo.

O ritmo é de todos, a melodia de muitos, a harmonia de alguns.

O povo, fazendo repercutir pelas ruas em dias de carnaval, o sonoro zabumba, conhecido pelo nome de Zé Pereira, ceda à sua inclinação natural e presta um grande serviço aos ouvidos da nossa população; porque ainda assim é o Zé Pereira o instrumento em que as incultas expansões musicais de um povo, se tornam mais toleráveis"214.

O conceito evolucionista das manifestações artísticas se demonstra claramente neste texto. Ele divide a música em estágios de desenvolvimento e os atribui aos povos do mundo, que assim também são enquadrados nessa classificação hierárquica evolutiva. Os povos meridionais são identificados como primitivos, inimigos do trabalho, guiados pelo instinto. Os setentrionais são evoluídos, refinados, civilizados e diligentes.

Uma sistematização mais detalhada dessa concepção evolucionista da música apareceria na série de artigos "Etnografia dos instrumentos de música", que foi publicada entre janeiro e maio de 1880. O texto era uma tradução de artigo original de Johannes Weber $^{215}$. A série trazia dados sobre manifestações musicais em diversas partes do mundo, obtidas de relatos de viajantes e emissários das nações da Europa em países coloniais. O texto categorizava as manifestações que observava, distribuindo-as entre aquelas três etapas evolutivas, atribuindo ritmo ao primitivismo, melodia a um estágio intermediário e harmonia a um estágio superior de civilização. $\mathrm{O}$ primitivo é descrito como intelectualmente inferior, comparável à criança:

"É evidente que nem o instrumento do Congo nem o da Zululândia, nem outros instrumentos africanos do mesmo gênero servem para nele se executarem melodias e só prestam para conseguir dele uma miscelânea de sons, ao acaso, que, apesar de fracos, encantam os habitantes dessas regiões.

Assim é também que se vê entre nós crianças soprando numa gaita, abrindo e fechando os orifícios para produzir uma espécie de barulho que é suficiente para as divertir"216

\footnotetext{
${ }^{214}$ Revista Musical e de Bellas Artes; "O Zé Pereira", Ano 1, Ed. 8, 22/2/1879, p. 1; itálicos no original.

215 Joahnnes Weber era crítico musical, ativo na imprensa francesa entre 1861 e 1895; ele publicava resenhas sobre o tema no Les Temps; cfe. BOMBERGER, E. Douglas. "A tidal wave of encouragement": American composers' concerts in the Gilded Age. Westport/Connecticut: Praeger, 2002, p. 50 e ELLIS, Katharine. Interpreting the Musical Past: Early Music in Nineteenth-Century France. Oxford e New York: Oxford University Press, 2005, p. 98.

${ }^{216}$ Revista Musical e de Bellas Artes, "Etnographia dos instrumentos de música", Ano 2, Ed. 2, 17/1/1880, p. 3. Os povos africanos em geral são alocados na categoria de "primitivos", e o texto permite entrever uma associação muito estreita entre o grau de evolução e as características fenotípicas: “Os negros Gallas que são vizinhos do Nilo são menos grosseiros do que as outras populações do interior da África. O Capitão Speke, que passou dois anos com eles, fala de seus concertos musicais como sendo menos bárbaros do que os dos outros negros. Com efeito, os etnógrafos são de opinião que os Gallas são de raça mista; tem a fisionomia moreno-escura, os cabelos bastante compridos, ora encarapinhados, ora lisos; há tribos com
} 
Cita a opinião de Richard Francis Burton a respeito da música dos habitantes da África oriental:

"Não há nada pior no mundo do que a música que se ouve nesta região. Admiravelmente dotados de um instinto rítmico, os indígenas, destituídos da menor sensibilidade auditiva traem a impotência musical e mostram-se satisfeitos com sons monótonos que eles não procuram nem variar, nem combinar. Entretanto, é impossível deixar de reconhecer o quanto os alegra a música" 217 .

Para Weber, enfim, os povos selvagens são caracterizados musicalmente por manifestações destituídas de complexidade. São culturas “[...] cuja música está no mesmo estado rudimentar que a educação moral e intelectual; em outros termos, daqueles que só se ocupam com a música por instinto, sem terem chegado ao alcance de um sistema de som"218. Indianos e chineses são apresentados como povos que tem esse sistema, "porém, sem conhecerem absolutamente a harmonia" ${ }^{219}$. Estariam, na escala de desenvolvimento musical, no mesmo patamar dos europeus da Idade Média.

Nessa altura, a visão sobre a cultura "primitiva", identificada como a praticada pelos populares e incultos, ainda podia ser recoberta com condescendência e até simpatia pelos intelectuais que pensavam sobre arte. Havia mesmo espaço para uma certa nostalgia do "primitivo", do sujeito livre das amarras da civilização ${ }^{220}$. Ainda assim, apareceram com frequência admoestações ao apego às manifestações "primitivas". Em agosto de 1879, a Revista abriu espaço para que alguém identificado apenas como Mário publicasse uma censura aos fluminenses, pelo pouco apreço à arte musical elevada. Mário reconhecia a existência de um amplo movimento musical entre os seus conterrâneos, mas o considerava de um gênero inferior. O propalado "amor à arte musical" de que tanto se gabavam os fluminenses era de fato inexistente, segundo Mário,

“[...] a não ser que queiram impingir-nos por amor à arte: os milhares de pianos fortes, fracos, cravos e espinhetas que soluçam plangentes desde os arrebóis da madrugada até

sangue mais africano do que outras", cfe. Revista Musical e de Bellas Artes, "Etnographia dos instrumentos de música", Ano 2, Ed. 3, 31/1/1880, p. 3. .

${ }^{217}$ Revista Musical e de Bellas Artes, "Etnographia dos instrumentos de música", Ano 2, Ed. 2, 17/1/1880, p. 3.

${ }^{218}$ Revista Musical e de Bellas Artes, "Etnographia dos instrumentos de música", Ano 2, Ed. 3, 31/1/1880, p. 5.

219 Idem.

220 “Para o povo da Antiga América, bem como para todos os músicos de instinto, seja qual for a latitude em que vivam, a música é a expressão triste ou alegre, mas sempre espontânea de uma alma sensível e pura a que o cálculo científico não vem espiar e que se expande sem peias nem constrangimentos"; cfe. Revista Musical e de Bellas Artes; "A Música na América”, Ano 1, Ed. 9, 1/3/1879, p. 6. 
ao fúnebre soar da meia-noite as mais ternas modinhas; - os centenares de polcas e contradanças que diariamente se publicam na Corte e a aceitação que entre nós tem a banda dos alemães, os realejos das esquinas e o cego da flauta"221.

Para Mário, esse suposto "amor à arte musical" recuava diante das exigências de trabalho e dedicação da música erudita; disso resultava, dizia ele, inexistir entre os fluminenses artistas capazes de compor uma orquestra no Rio de Janeiro. O mesmo Mário voltaria à carga, em novembro, admoestando o público pela indiferença com que recebera o grande violinista J. White, que se apresentara no Rio diante de uma plateia diminuta. Ao mesmo tempo, lamentava, "têm tido enchentes: todos os espetáculos de cavalinhos, todos os prestímanos, todos os saltimbancos, charlatães e especuladores que se têm dignado vir a esta terra ganhar o nosso dinheiro"222.

Havia quem defendesse nas páginas da Revista a criação de estratégias para conformar o gosto popular a padrões mais elevados. Um colaborador identificado apenas como “L." propôs a realização de uma “Ópera Popular”, oferecendo espetáculos com alto padrão artístico e, ao mesmo tempo, a preços mais acessíveis às classes populares. A proposta trazia em si uma crítica à opulência dos espetáculos de então que, para superar o "embotamento" da sensibilidade do público, elevara os gastos com os acessórios, cenários e luxos visuais a patamares inauditos - deixando de lado, nesse movimento, o que realmente importava numa ópera, a inventividade das composições musicais. De qualquer maneira, L. considerava benéfica a criação de espetáculos acessíveis:

"O gosto popular ganhará em cultura, os costumes em suavidade, e com a instituição devem prosperar outras indústrias relativas.

[...]

A ópera popular contribuirá para a solução deste grande problema, a igualdade social mas, como a querem os bons espíritos, nobilitando os plebeus, e não rebaixando aquilo que é distinto, nobre e belo, ao nível das classes incultas" ${ }^{223}$.

A ópera Salvator Rosa de Carlos Gomes, apresentada no Rio de Janeiro em $1880^{224}$, foi entendida, por alguns, como uma concessão ao gosto popular, aproximandoa desse ideal de espetáculo acessível ao público geral. Essa aproximação, no entanto,

\footnotetext{
${ }^{221}$ Revista Musical e de Bellas Artes; "Uma verdade", Ano 1, Ed. 31, 2/8/1879, p. 1.

${ }^{222}$ Revista Musical e de Bellas Artes; "Uma verdade", Ano 1, Ed. 44, 1/11/1879, p. 2.

${ }^{223}$ Revista Musical e de Bellas Artes; "Ópera Popular", Ano 1, Ed. 44, 1/11/1879, p. 2-3.

224 No Rio de Janeiro, encerrou-se a temporada lírica daquele ano com uma apresentação única dessa peça.
} 
parece ter desagradado a alguns, o que levou "A.C.", um colaborador da Revista, a defender o maestro brasileiro ${ }^{225}$ :

"O Salvator Rosa foi composto em circunstâncias especiais e com um fito determinado. Carlos Gomes quis fazer uma partitura eminentemente popular. Se conseguiu ou não o seu fim, que o diga toda a Itália, onde, desde as capitais até a mais pequena aldeia em que há um simulacro de cantores e uns rudimentos de orquestra, ela se tem cantado com triunfo franco e indubitável.

A ópera Salvator Rosa, conquanto tenha páginas de peregrina beleza e de boa fatura musical, é sob o ponto de vista popular que deve ser julgada.

Carlos Gomes escreveu esta ópera para o povo. O povo percebeu e aceitou a dedicatória e aplaude-a em todos os teatros constante e entusiasticamente.

Para quem tem partituras como a Fosca e sobretudo como a Maria Tudor, não é menos brilho haver escrito o Salvator Rosa.

Se a ciência musical tem direito a uma Fosca, o povo tem direito a um Salvator Rosa" 226.

A.C. contestava a visão daqueles que pretendiam ver em Salvator Rosa "um retrocesso" na carreira do maestro. Afirmava que Carlos Gomes havia se desviado do caminho intencionalmente, procurando lisonjear,

"por exceção, uma vez o gosto das massas; mas como artista digno que é, revestiu todas essas belezas fáceis e acessíveis, com uma fatura séria e correta, com o cunho científico e profundo, que tem feito confessar, mesmo aos seus adversários, que Carlos Gomes é homem que sabe de seu ofício" 227.

Em suma, "[i]ncluída na série ascendente da evolução artística que revela a sucessão de suas óperas, o Salvator Rosa acusa uma depressão que não prejudica o crédito do maestro".

Com a proclamação da República, o universo artístico iria experimentar algumas alterações. O movimento político abriu espaço para que as ideias antiacadêmicas, que vinham sendo exercitadas desde pelo menos o final da década de 1870, alcançassem parte de seus objetivos. Isso se deu, no Rio de Janeiro, através de uma sublevação capitaneada por artistas oriundos dos próprios quadros da Academia.

Já proclamada a República, um grupo de jovens artistas, liderados por dois professores da ainda Academia de Belas Artes - Rodolpho Bernardelli e Rodolpho

\footnotetext{
225 Segundo Medeiros, tratava-se do músico e jornalista Alfredo Camarate; cfe. MEDEIROS, Alexandre Raicevich de. A Revista Musical \& de Bellas Artes (1879-1880) e o Panorama Musical do Rio de Janeiro no fim do século XIX. In: Anais do XVI Encontro Regional de História da ANPUH-Rio: Saberes e Práticas Científicas, 2014; p. 7-8

${ }^{226}$ Revista Musical e de Bellas Artes, "O Salvator Rosa". Ano 2, Ed. 21, 14/8/1880, p. 165.

${ }^{227}$ Revista Musical e de Bellas Artes, "Carlos Gomes e o Salvator Rosa". Ano 2, Ed. 22, 21/8/1880, p. 173.
} 
Amoedo - pressionaram pela reforma daquela instituição que, segundo julgavam, ainda mantinha os vícios acumulados durante o longo período imperial ${ }^{228}$. Em junho de 1890, muitos estudantes decidiram afastar-se da instituição e criaram uma espécie de "Atelier Livre" num barracão situado no Largo do Machado, no Rio de Janeiro.

Quando se realizou a primeira reunião, em junho de 1890, os descontentes formavam um só bloco. As discussões realizadas naquele dia, que resultaram numa nota publicada n'O Paiz do dia 17 de junho de 1890, indicavam que os estudantes da Academia duvidavam da pertinência e da utilidade de sua existência, "no estado de desmoralização em que se acha" ${ }^{229}$. Indagavam-se se não seria mais proveitoso que a instituição fosse extinta. Da segunda reunião, em 21 de julho, saiu um documento que continha proposta de reforma da Academia, a ser entregue ao Ministro da Instrução Pública. Neste documento, sepultava-se a ideia de extinguir a instituição. Nessa mesma reunião, Rodolpho Bernardelli foi aclamado "presidente da assembleia".

Entre as propostas mais inovadoras do chamado "Projeto Bernardelli-Amoedo"230 estavam a limitação do tempo de exercício dos professores e do dirigente da Academia: aqueles deveriam exercer no máximo de 10 anos de profissão, e os últimos, seriam substituídos a cada 5 anos, salvo recondução. Previa que os artistas dotados de "conhecimentos excepcionais sobre qualquer parte da teoria, da história ou das técnicas das artes" poderiam abrir cursos livres associados à Academia. O projeto sinalizava também o abandono, já há tanto tempo demandado, das cópias de modelos clássicos, e propunha a adoção de estudos do natural ${ }^{231}$.

228 O episódio foi reconstituído por Ana Maria Tavares Cavalcanti num artigo publicado em 2007. Ela lembra que esse momento da história da arte brasileira ficou esquecido por muito tempo, tendo sido mencionado pouquíssimas vezes no século XX. Além da narrativa romantizada do episódio contida em "Mocidade Morta" (1899), de Gonzaga Duque, houve menção à revolta dos alunos na obra que Frederico Barata publicou sobre Eliseu Visconti, em 1944; cfe. CAVALCANTI, Ana Maria Tavares. Os embates no meio artístico carioca em 1890 - antecedentes da Reforma da Academia das Belas Artes. 19\&20, Rio de Janeiro, v. II, n. 2, abr. 2007. Disponível em: <http://www.dezenovevinte.net/criticas/embate_1890.htm>. (Acessado em 8/3/2017).

${ }^{229}$ Apud. CAVALCANTI, 2007, s.p.

230 O conteúdo do Projeto Bernardelli-Amoedo pode ser observado em "Pardal Mallet: O Projeto "Bernardelli - Amoedo" e Reforma da Academia, publicação de documento original por Camila Dazzi, disponível em http://www.dezenovevinte.net/artigos imprensa/pardalmallet projetoba.htm (Acessado em 8/3/2017).

231 Já em 1879 se criticava o ensino baseado na cópia de "estampas", prática descrita como prejudicial aos artistas em formação: "Ao passo que em todas as academias do mundo a estampa é empregada só nos primeiros dias para o discípulo assentar a mão, passando este ao desenho do gesso; ao passo que na paisagem o estudo do natural é nessas academias adotado logo nos primeiros meses; a nossa Academia de Belas Artes gasta anos embrutecendo o discípulo com o desenho tracejado e faz durante todo o curso de paisagem, apenas paisagistas de gabinete!"; cfe. Revista Musical e de Bellas Artes, "Academia de Bellas Artes"; Ano 1, Ed. 24, 14/6/1879, p. 2.; Cavalcanti lembra que João Zeferino da Costa, professor de pintura 
Parte dos estudantes sublevados divergiu dos rumos que tomava a assembleia e erigiu uma secessão. Cavalcanti recolhe dados sobre isso das recordações de Gonzaga Duque, que publicou uma memória sobre sua participação naqueles eventos em 1907. Gonzaga Duque lembrou que, ao lado dos reformistas liderados por Bernardelli, apareceu "um grupo de artistas simpatizantes dos "princípios da escola comtista", que retomaram a ideia inicial de extinguir a Academia ${ }^{232}$. Esse grupo viria a ser conhecido como o dos Positivistas.

O projeto dos Positivistas aprofundava radicalmente a extensão das reformas institucionais. Foi publicado num libreto editado em $1890^{233}$. O tom republicano aparece já na forma horizontal com que os "cidadãos" Montenegro Cordeiro, Décio Villares e Aurélio de Figueiredo se dirigiam ao também “Cidadão Ministro e Secretário de Estado dos Negócios do Interior", oferecendo a ele um programa para o ensino de artes no Brasil. Nessa proposta, não havia espaço para a existência da Academia, "instituição caduca e retrógrada - só prejudicial à sociedade e aos artistas e fatalmente condenada". Sendo “orgânico o vício de tal instituição, é inútil pretender corrigi-la com reformas ilusórias e superficiais que serão fatalmente efêmeras" ${ }^{\text {"234 }}$.

Os Positivistas consideravam daninha a existência de tal instituição, que impunha, em sua opinião, um monopólio do ensino de artes na Capital da República, no que consideram "um ataque odioso à Liberdade porquanto só os ricos e protegidos das exprovíncias podiam vir dedicar-se aos referidos estudos"235. Propunham que se descentralizasse o ensino da arte, estendendo-o a todas as classes e idades, por meio de sua inserção nas escolas públicas e pela manutenção de museus de arte em todos os estados. Sugeriam que se extinguisse a Academia e que se aproveitassem os artistas como professores nas escolas públicas, num movimento que, em sua opinião, tinha o duplo benefício, por um lado livrando os estudantes "dos corruptores processos do regime

de paisagem da Academia em 1889, lutava já há tempos contra as restrições da instituição, pugnando para realizar suas aulas ao ar livre, "requerendo insistentemente ao governo passes gratuitos nos bondes para levar os alunos aos arredores da cidade"; cfe. CAVALCANTI, 2007, s.p.

232 CAVALCANTI, 2007, s.p.

233 "Projecto de Reforma no Ensino das Artes Plasticas apresentada ao Cidadão Ministro e Secretário de Estado dos Negócios do Interior pelos cidadãos Montenegro Cordeiro, Decio Villares e Aurélio de Figueiredo". Rio de Janeiro, 1890; ver DAZZI, Camila; VALLE, Arthur (org.). "Projeto Montenegro": A reforma do Ensino das Artes Plásticas em 1890. 19\&20, Rio de Janeiro, v. II, n. 3, jul. 2007. Disponível em: http://www.dezenovevinte.net/txt artistas/projeto montenegro.htm. (Acessado em 8/3/2017).

234 "Projecto de Reforma...", p. 6-7.

${ }^{235}$ Idem, p. 6. 
acadêmico" e por outro proporcionando aos artistas um meio de subsistência, a "atividade de um trabalho reconhecidamente útil e honesto"236.

O impasse terminou em dezembro, quando um projeto de reforma - amplamente influenciado pela proposta de Bernardelli e Amoedo, e que acabou contando com a assinatura de um dos líderes dos Positivistas, Décio Villares - foi promulgado pelo governo. A antiga Academia passou a se chamar Escola Nacional de Belas Artes, Rodolpho Bernardelli foi empossado diretor e Amoedo, seu vice ${ }^{237}$.

$* \quad * \quad *$

No Brasil, o emprego da terminologia "científica" com a finalidade de condenar manifestações estéticas consideradas ousadas, incorrendo na retórica da degeneração, foi detectado logo no período posterior à proclamação da República. O descontentamento com o rumo adotado pela Escola Nacional de Belas Artes - descontentamento que mal ocultava uma censura ao próprio regime republicano - tingiu as críticas de Carlos de Laet logo após a reforma que colocou a dupla Bernardelli-Amoedo na direção ${ }^{238}$.

Nas primeiras críticas que dirigiu à ENBA, já em 1890, Laet - sob o pseudônimo Cosme Peixoto ${ }^{239}$ - considerou inferior a qualidade das obras expostas, e responsabilizou a nova gestão por este fenômeno. Referiu-se também ao número reduzido de alunos

\footnotetext{
236 Ibidem, p. 8.

237 Contrariando um dos pontos da proposta que subscreveu, Bernardelli permaneceria no cargo por 25 anos. Notar que, entre as alterações nas instituições culturais realizadas na esteira da proclamação da República, estaria a reformulação do Imperial Conservatório de Música. Além de ter seu nome alterado para o de Instituto Nacional de Música, alguns de seus quadros foram substituídos. Leopoldo Américo Miguez, um dos proprietários da Revista Musical e de Bellas Artes, assumiu a direção em 1890, e permaneceu à frente a instituição até 1902, ano de sua morte. A gestão de Miguez, ao contrário da de Bernardelli, seria elogiada mesmo por aqueles que demonstravam posturas antirrepublicanas, como Cosme Peixoto (Carlos de Laet); cfe. COSME PEIXOTO, O Salão de 1894 III, Jornal do Brasil, 26/11/1894, p. 1.

${ }^{238}$ Antônio J. Chediak, que compilou minuciosamente as numerosas polêmicas sustentadas por Carlos de Laet, identificou dois períodos em sua crítica aos irmãos Bernaredelli e aos "novos" que a eles se associavam. No primeiro, o do Império, apesar de algumas divergências, "foi defensor da pintura bernardelesca". No segundo, o Republicano, voltou-se não apenas contra eles, mas contra "todos aqueles que acompanharam a chamada Escola Nova e, em seu entender, usurparam as cadeiras de Vitor Meireles e Pedro Américo"; cfe. CHEDIAK, Antônio J. Carlos de Laet, o polemista. Rio de Janeiro: Livraria Editora Zelio Valverde, 1943; p. 94-95.

${ }^{239}$ A identificação de Laet com o pseudônimo Cosme de Moraes pode ser encontrada em Pintores Paulistas. Correio Paulistano, 17/10/1895, p. 1; citado por OLIVEIRA, Helder Manuel da Silva. Olhar o mar : um estudo sobre as obras "Marinha com barco" (1895) e "Paisagem com rio e barco ao seco em São Paulo 'Ponte Grande'”' (1895) de Giovanni Castagneto. Dissertação (Mestrado) Universidade Estadual de Campinas. Campinas, SP: 2007; p. 162. Cosme Peixoto, por sua vez, foi o pseudônimo que substituiu Cosme de Moraes, segundo pedido do próprio autor, cfe. Jornal do Brasil de 3/10/1895, p. 1. Fica claro que Carlos de Laet adotava os sobrenomes dos presidentes do Brasil.
} 
matriculados quando comparado aos índices de frequência que se observavam no tempo da Academia Imperial de Belas Artes.

Cosme Peixoto voltaria à carga em 1894, mais uma vez por ocasião do Salão de Belas Artes. Insistiu em apontar o absenteísmo do diretor da ENBA, acusando-o de negligenciar a administração da instituição ao ausentar-se do país prologada e repetidamente. Nesta e em outras ocasiões, Cosme Peixoto (ou de Moraes) apontou sistematicamente o que considerava defeitos nas faturas de desenhos, pinturas a óleo, esculturas e gravuras realizadas por estudantes e professores da ENBA.

Cosme publicou no Jornal do Brasil uma longa apreciação ao Salão de 1895, dividida em vários folhetins ${ }^{240}$. Seu julgamento é negativo, descrevendo uma mostra em que predominavam a falta de qualidade e os indícios de patologia psíquica por parte dos pintores. O crítico recorreu à obra de Max Nordau para classificar os artistas:

"[...] em toda a exposição [...] se me deparou a exemplificação do caso patológico tão magistralmente desenvolvido pelo sr. Max Nordau na sua recente obra Degenerescência. O douto alemão não tratou especialmente da arte, mas de passagem esflorou o assunto, projetando luminosa réstea sobre certas misérias da pintura contemporânea. Para bem compreender e aquilatar o salão de 95 cumpre estudar este livro, máxime nos tópicos em que alude às artes e aos artistas degenerados. Dir-se-ia que, ao escrevê-los, o vigoroso pensador tinha passado por certa exposição!"241

Enumera três degenerados no Salão de 1895: Rodolpho Amoedo, Belmiro de Almeida e Diana Cid.

De Amoedo, “digno vice-diretor da Escola", menciona o escândalo de sua obra $n^{\circ}$ 18, que apresenta duas moças passeando num campo. Cosme de Moraes critica, em primeiro lugar, as cores selecionadas pelo artista. O gramado é de um verde que é antes do "suco de erva do que da erva propriamente dita"; menciona ainda de maneira desairosa as cores inseridas pelo artista no chapeu de sol de uma das figuras (que descreve como "chapeu de sol encarnado") e no cachorro que as acompanha ("extremamente roxo"). Nas suas palavras, uma "bambochata de cores"242. Acusa Amoedo, nesta e em outras obras,

\footnotetext{
${ }^{240}$ COSME DE MORAES. Folhetim - O Salão de 1895 I. Jornal do Brasil, 20/9/1895, p. 1; Folhetim - O Salão de 1895 II. Jornal do Brasil, 23/9/1895, p. 1; Folhetim - O Salão de 1895 III. Jornal do Brasil, 25/9/1895, p. 1

${ }^{241}$ COSME DE MORAES. Folhetim - O Salão de 1895 I. Jornal do Brasil, 20/9/1895, p. 1. Neste mesmo texto, Cosme de Moraes explica o conceito de degenerado: "Que é um degenerado, na tecnologia da moderna psiquiatria? É um morador do 10 andar no prédio da neuropatia. No mesmo pavimento reside a histeria. Embaixo, a simples neurastenia. Lá em cima, a alienação. Morel, que em 1857 já discutia a matéria, define a degenerescência - o desvio doentio de um tipo primitivo".

${ }^{242}$ Bambochata significa literalmente "gênero de pintura que representa festas populares e cenas rústicas ou burlescas"; em sentido figurado, significa "extravagância", "aquilo que ultrapassa os limites do bom senso". De Bamboccio, apelido do pintor holandês Pieter Van Laer, que pintava nesse gênero.
} 
de perseguir "a ideia fixa de violentos efeitos luminosos e cromáticos "pour épater le bourgeois"".

Verdes e vermelhos que o crítico afirma serem dignas apenas de "alguns tabuleiros de alfaces e rabanetes", mas nunca de uma tela de Amoedo. Cosme de Morais encontra qualidades em algumas outras das obras expostas por Amoedo, o que o leva a dizer que há esperança para o artista: "Isso mostra que, quando consegue desprender-se de sua ideia fixa e realmente quer ver o que tem ante si, o sr. Amoedo deixa de ser o degenerado colorista, o orgíaco da palheta e desalmado açulador de cores enraivadas" 243.

Apesar dos meios elogios, declara temer que o artista vá seguir o caminho do excesso, seduzido pelo "histerismo que o aplaude". Incorre então em uma nova carga de explicações científicas, informando que o vermelho tem poder dinamogênico - a capacidade de superexcitar a função do aparelho visual, magnetizando especialmente os acometidos por enfermidades psíquicas. Menciona um experiência conduzida por Alfred Binet, em que se mediu a excitação que as cores causavam em uma "histérica"; os vermelhos, segundo a experiência, levaram-na a picos de excitação. "Se a pobre rapariga olhasse para os delírios cromáticos do sr. Amoedo, certo que o aparelho marcaria o triplo" 244 .

Na segunda parte do folhetim trata dos casos de Belmiro de Almeida e Diana Cid.

De Belmiro, analisa a tela Aurora de 15 de novembro. Nesta, não são as cores que incomodam o crítico, mas a inserção de elementos que desafiam as regras da natureza ${ }^{245}$. Ao lado da figura feminina que porta a bandeira pátria, Cosme de Morais acusa "um leão que, aos pés da aurora republicana repousa sobre uma nuvem”.

"Neste, como em outros pontos, triunfa o realismo da Escola: segundo é notório, nada mais real que um leão sobre um cúmulus nimbus.

Há mesmo organizações artísticas tão infensas ao convencionalismo que, quando veem nuvens sem leão por cima, vociferam contra as abusões acadêmicas" ${ }^{246}$.

\footnotetext{
243 COSME DE MORAES. Folhetim - O Salão de 1895 I. Jornal do Brasil, 20/9/1895, p. 1.

${ }^{244}$ Idem. Cosme de Morais volta a citar Nordau para dar peso a sua argumentação: "Bem é de entender [...] que no vermelho gostosamente se atolem pintores histéricos, e que expectadores histéricos experimentem singular prazer com a vista de quadros que sobre eles agem de modo dinamogênico, despertando agradáveis sensações".

${ }^{245}$ Segundo VIEIRA, o paradeiro da pintura Aurora de 15 de novembro é desconhecido; ele informa ainda que esta obra que foi uma das poucas incursões de Belmiro de Almeida na pintura histórica, e que ela fez polêmica e foi muito comentada por ocasião de sua exibição; cfe. VIEIRA, Samuel Mendes. À Flor da Pele: Amuada de Belmiro de Almeida e a pintura na segunda metade do século XIX. Dissertação (Mestrado) Universidade Federal de Juiz de Fora/MG, 2014; p. 43-44.

246 COSME DE MORAES. Folhetim - O Salão de 1895 II. Jornal do Brasil, 23/9/1895, p. 1. Sobre a degeneração de Belmiro, diz ainda que em seus trabalhos "vê-se que procura o artista vencer a eiva do nervosismo que o faz ver as cousas através de imaginário nevoeiro, em terras onde o sol despenha catadupas de luz. A anestesia de parte mais ou menos considerável da retina perfeitamente nos explana
} 
Finalmente, reserva para Diana Cid as críticas mais devastadoras. Se em Belmiro a moléstia ainda é leve e passageira, e se ainda se pode esperar que a Escola de Belas Artes se livre da condição "meio doentia" em que se encontra, o caso é mais grave no que se refere à pintora argentina. Cosme de Morais considera-a além de qualquer salvação, "tão adiantada se mostra a daninha nevrose da época!"247.

O que incomoda o crítico na obra de Cid é a inserção de imagens fantasiosas. Descreve, por exemplo, a pintura de uma mulher vestida de negro com a cabeça entre as mãos; em frente a esta figura flutua um "medonho esqueleto, envolto em azulada roupagem e com asas cor de rosa tirante a violeta" ${ }^{248}$. Tal esqueleto, supõe o crítico, é uma projeção da imagem mental vista pela mulher de olhos fechados.

Cosme de Moraes não foi voz isolada no ataque às obras de Diana Cid. Oscar Guanabarino também empregaria conceitos degeneracionistas para se referir a ela, por ocasião da Exposição Geral da Escola Nacional de Belas Artes. Criticando-lhe a feição simbolista, Guanabarino recorreu a conceituações nitidamente hauridas da leitura de Max Nordau:

“[...] essa forma indecisa e antipática tem hoje não só grande número de cultores como até apreciadores e defensores - é a maldita escola simbolista, invadindo o cérebro dos artistas, produzindo uma loucura sui generis que ameaçaria arruinar a arte se espíritos esclarecidos não lhe tivessem saído ao encontro para dar-lhe decisiva batalha. O n. 60, Estudo de nu, é mais bem trabalhado do que qualquer dos dois outros, mas ainda assim nota-se não o cunho do acabado, do completo e do definitivo, sente-se que falta ali qualquer coisa, que o corpo humano não tem aquela forma duvidosa e que esses velados são simples pretexto para evitar a dificuldade do desenho rigoroso, emprestando ao quadro um tom de esboço". ${ }^{249}$

Cosme de Morais expõe sua posição: antipatiza com a república, bem como com as diretrizes artísticas que triunfaram e institucionalizaram-se na Escola de Artes oficial, após a destituição da monarquia. Isso se manifesta em diversos momentos de seu texto,

\footnotetext{
a causa de tão curiosa anomalia, na Europa insistentemente acusada em obras de Puvis de Chavannes e de outros pintores de nota."

${ }^{247}$ COSME DE MORAES. Folhetim - O Salão de 1895 II. Jornal do Brasil, 23/9/1895, p. 1

248 Idem.

${ }^{249}$ Apud. GRANGEIA, Fabiana de Araujo Guerra. A crítica de artes em Oscar Guanabarino : artes plásticas no século XIX. Dissertação de mestrado). Campinas: Universidade Estadual de Campinas - Instituto de Filosofia e Ciências Humanas, 2005; p. 161-162. Aparece nessa primeira rusga de Guanabarino com as propostas modernas um elemento que emergiria de maneira recorrente no discurso de oposição às vanguardas: a acusação de escassez técnica. A distância cada vez maior que os vanguardistas tomariam em relação às convenções de representação pictórica seria apontada, pelos seus críticos, como sendo nada mais que escapismo, ocultando a incapacidade de desempenhar adequadamente o ofício. Aqui, na crítica de Guanabarino a Diana Cid, fala-se artifícios que disfarçam "dificuldade do desenho rigoroso".
} 
mas pode-se destacar dois deles: por um lado, nega as "virtudes" da República, sugerindo que sua legitimidade emana da força das espadas. Por outro, faz reparos ao que considera decadência da escola oficial de belas artes em tempos republicanos: acusa a Escola Nacional de Belas Artes de ter perdido a capacidade de formar artífices que consigam realizar bons desenhos

Cosme de Morais encerra sua invectiva admoestando os críticos que, mesmo percebendo nitidamente o absurdo das pinturas dos degenerados, atestados de suas condições mórbidas, recusam-se a alertá-los disso, e os enchem de louvores, fazendo-os crer que todos veem como eles, impedindo-os assim de que se apercebam de sua anomalia e busquem terapia. Encerra o texto dizendo ter deixado de referir-se a um degenerado, "e com certeza o mais que todos", o diretor da Escola Nacional de Belas Artes.

Analisa-se nesse segmento a trajetória e o discurso de Oscar Guanabarino, (Niterói/1851 - Rio de Janeiro/1937), crítico de arte que ficaria mais conhecido como opositor da Semana de Arte Moderna ${ }^{250}$. Essa análise parece justificar-se ao se constatar que a atividade do niteroiense se estendeu por mais de quatro décadas, atravessando o período que se inicia nas lutas da geração de 1870 pela renovação no campo da arte e vai se encerrar, na outra ponta, no momento em que os modernistas se esforçam pela consolidação de suas propostas. Por ter atuado num período marcado por transformações importantes no campo da estética brasileira, Guanabarino constitui-se num padrão com que se pode mensurar os movimentos que lhe rodeiam. Crítico moderno quando jovem, tornou-se retrógrado na senectude graças ao apego continuado aos mesmos valores com que se lançou à atividade. Dessa forma, Guanabarino ilumina, com sua trajetória, as vicissitudes do pensamento típico do final do século XIX e seu choque com as transformações que aparecem nas décadas iniciais do século XX.

No período inicial de sua atividade, Guanabarino engrossava as fileiras dos partidários da modernidade. Inscrevia-se entre aqueles que colaboravam com a Revista

\footnotetext{
${ }^{250}$ Parte da apreciação que segue deve-se à pesquisa de GRANGEIA, 2005. Granjeia concentrou sua análise no período que vai do início da atividade de Guanabarino como crítico de arte, na década de 1880, até a data limite de 1900. Em sua dissertação, ela delineou as feições principais do discurso de Guanabarino no período, que serão apresentados a seguir. A apreciação sobre o período posterior a 1900, e especialmente sobre os atritos com os modernistas, se serviu dos textos do próprio crítico, tanto daqueles publicados na coletânea organizada por Maria Eugênia Boaventura quanto por outros coletados em periódicos da época.
} 
Musical e de Bellas Artes. Pianista formado com os melhores mestres de seu tempo, passou a militar na crítica de arte na década de 1880, fazendo parte de uma nova geração, comprometida com a profissionalização da atividade ${ }^{251}$.

A partir de 1884, Guanabarino ganhou fórum permanente, ocupando a seção Artes e Artistas no jornal republicano $O$ Paiz $^{252}$. Guanabarino alternava-se na coluna com Gonzaga Duque, Coelho Netto, França Júnior e Arthur Azevedo, entre outros ${ }^{253}$. Nessa altura, a crítica de arte de Guanabarino alinhava-se entre as correntes renovadoras. Seu programa dedicava-se a

“[...] atacar uma arte que, naqueles tempos - de 1880 até 1900 - era, para ele, retrógrada. Nesse sentido, lutava por uma espécie de modernidade; lutava por uma arte nova, uma arte que ainda não existia no Brasil, uma arte que pudesse ser chamada de 'nacional'.

Essa arte à qual almejava seria representada pelos caminhos que estavam sendo trilhados, por exemplo, por pintores como Pedro Weingärtner, José Ferraz de Almeida Júnior [...], Modesto Brocos, Henrique Bernardelli e Benjamin Parlagreco.

Era preciso enterrar um passado para construir outro; deixar de lado os temas bíblicos e mitológicos tão explorados pela Academia, deixar de lado as disposições ideais de modelos e objetos à luz do ateliê, deixar de lado o virtuosismo, o acabamento impecável do desenho e o uso artificial do preto ou do betume para representar sombras também artificiais. Esse passado que precisava ser enterrado incluía nomes como o de Victor Meirelles - cujas tão afamadas pinturas poderiam resumir-se na palavra 'artifício' - e o de Pedro Américo, os 'grandes' do Império" 254.

O conceito de modernidade de Guanabarino, na pintura, parecia aproximar-se dos princípios impressionistas. Nesse sentido, moderno era capturar as imagens que cercavam o artista, aquilo que se lhe apresentava diante dos olhos, de maneira fiel à luminosidade natural. Era rejeitar os truques acadêmicos - a luz artificial do estúdio, o modelado obtido com o uso da tinta preta. A pintura ao ar livre tinha imposto outro tratamento às sombras, proscrevendo o uso do preto. Em geral, os críticos modernos da geração de 1880 desprezavam os ensinamentos tradicionais da academia, louvando os artistas que, a exemplo de Manet, iam "aprender com a natureza".

\footnotetext{
${ }^{251}$ Segundo Grangeia, a crítica "passava naquele momento a ser uma função de especialista e não mais uma atividade sem maiores consequências, que pudesse ser exercida por qualquer pessoa com certo estilo literário. E, para ser exercida por especialistas, precisaria calcar-se em critérios de avaliação (fundamentados em teorias estéticas e no estudo histórico das artes e da literatura) e objetivos (ligados à importância do desenvolvimento artístico diante da necessidade de se construir uma identidade nacional) definidos"; cfe. GRANGEIA, 2005, p. 25-26.

${ }^{252}$ Guanabarino escreveria para a coluna até 1919. Em 18 de setembro daquele ano mudou-se para o Jornal do Commercio, onde seria responsável pelo folhetim Pelo mundo das artes, coluna hebdomadária que manteria até 1936. Ao contrário de Artes e Artistas, em que se revezava com outros publicistas, no Jornal do Commercio Guanabarino redigia com exclusividade.

${ }^{253}$ GRANGEIA, 2005, p. 18.

254 Idem, p. 187.
} 
A crítica de Guanabarino articulava cultura e sociedade. Falando de arte, ele se referia a temas políticos e sociais, exercendo pressão por mudanças. Na década de 1880 , estava comprometido com a oposição ao status quo imperial. Ele forjou em seu discurso associações significativas entre a antiga estética oficial com as condições sociais do país e, da mesma forma, apontou articulações entre a estética moderna com o programa republicano e progressista das correntes de oposição. Guanabarino acusava o governo imperial de ser negligente com a gestão da cultura, e censurava as academias e instituições oficiais pelo conservadorismo e pela resistência à renovação. Para os opositores,

“[...] a arte tinha uma função social importante, pois seria um modo de unir um povo em torno de um mesmo ideal. No caso de Guanabarino, esse ideal ligava-se [...] às noções de Pátria, progresso, civilidade. Uma nação independente precisava ser construída e essa nação precisava ter uma história, uma tradição a partir da qual pudesse se desenvolver e na qual pudesse se espelhar" ${ }^{\prime 255}$.

Para o crítico, a situação mantida pelas autoridades no poder impedia o desenvolvimento do país. Ele responsabilizava a escravidão e seus subprodutos, a submissão e a miséria, pelo baixo desenvolvimento das artes no Brasil. Era necessário eliminar essas mazelas e criar um meio onde o gosto se desenvolvesse, para que se tivesse finalmente condições para um florescimento das artes. O governo deveria chamar a si esta tarefa. Guanabarino defendia um programa de reformas urbanas modernizantes, argumentando que somente a cidade embelezada pela arquitetura ofereceria o cenário para a necessária educação estética do povo ${ }^{256}$. Por conta desse compromisso com a ideia de progresso, Guanabarino se preocupava especialmente com o conteúdo das obras ${ }^{257}$.

\footnotetext{
255 GRANGEIA, 2005, p. 189.

${ }^{256}$ A preocupação de Guanabarino com a organização do espaço público na cidade se estenderia pelas décadas seguintes. De início, alinhou-se às correntes progressistas, defendendo o projeto republicano de reformas urbanas. Da década de 1920 em diante, suas observações seriam pontuadas pelo tom lamentoso, seja pelo estado de abandono em que supostamente se encontrava a capital da República, seja pela disseminação das favelas, seja pelo sucesso do estilo neocolonial, abominado pelo niteroiense. Por conta dessa repulsa, Guanabarino exerceria em suas colunas uma perseguição ao arquiteto José Mariano Filho, que dirigiu a Escola Nacional de Belas Artes entre 1926 e 1927. Ver, por exemplo, a associação que faz entre favelas e a "arquitetura primitiva" supostamente cultivada pelos divulgadores do estilo neocolonial, cfe. "Pelo mundo das artes"; Jornal do Commercio, 6 de fevereiro de 1929, p. 2.

257 “A nova arte [...] precisava basear-se na realidade, não na fantasia. A representação figurativa deveria estar ligada ao mundo real e comum a todos. Nada de grandes composições militares ou grandes feitos históricos em grandes telas; mas sim elevar à monumentalidade as cenas mais particulares dos sertões do país. Ou seja, entregar ao que teriam os brasileiros de mais característico e particular um status histórico"; cfe GRANGEIA, 2005, p. 188.
} 
Em resumo, no final do século XIX Guanabarino fazia uma crítica comprometida com renovações estéticas - contra o estabelecido - e a articulava aos ideais progressistas de seu tempo, às causas sociais e políticas à vanguarda de sua época.

A deposição de D. Pedro II e a ascensão republicana modificaram esse quadro, beneficiando uma parte da geração de Oscar Guanabarino. Quintino Bocaiúva, diretor de O Paiz, ocuparia diversos cargos no novo regime. Rodolpho Bernardelli, artista incensado pelos renovadores, seria empossado diretor da Escola Nacional de Belas Artes. Parte das modificações exigidas pela geração de críticos da década de 1880, Guanabarino entre eles, fora alcançada. Se, como afirmou Vera Lins, a consolidação da República alienou a parcela mais idealista do grupo dos renovadores do final do século XIX, um outro segmento parece ter se amoldado com facilidade à nova situação. Alguns dos mais ferrenhos críticos do regime imperial iriam encontrar na república caminho livre para a ascensão. O pensamento brasileiro, nesse momento, aproxima-se decididamente das correntes cientificistas: "[o] naufrágio da república sonhada pelos republicanos românticos mantém, no entanto, em voga, ideologias como o cientificismo evolucionista e o positivismo, que vão formar o pensamento que cimentará o novo Estado republicano" 258 .

Na década de 1920 a posição de Guanabarino em relação à arte tomaria feições decididamente reacionárias. As experimentações formais dos adeptos das vanguardas incitariam a combatividade do crítico, que se dedicaria com afinco a lidar com as manifestações modernistas, especialmente as que se davam no terreno musical. Começam a frequentar as colunas de Pelo Mundo das Artes censuras cada vez mais ácidas às novas tendências da arte em geral, e da música em particular.

Guanabarino reorienta as relações de causalidade. Abandona o ataque ao inimigo vencido - o passado imperial e sua estrutura escravista e latifundiária - e elege novos algozes entre os elementos modernos que apareciam no cenário. No seu discurso recalibrado, seriam eles agora os responsáveis pela degradação. Em crônica de abril de 1921 abre a longa sessão de ataques ao modernismo com as seguintes palavras:

"As belas artes, como o mundo social e político, estão passando por uma crise que pode ser atribuída ao desencadeamento de uma loucura epidêmica; e assim como o bolchevismo da Rússia pretende invadir todos os países ocidentais da Europa, para depois levar a corrupção aos outros continentes, espalhando a vesânia para substituir a ordem, assim também temos o bolchevismo nas artes, com a pretensão de destruir tudo quanto o

258 LINS, 1991, p. 35. 
gênio conquistou durante séculos e impor produções que destroem todas as leis estéticas e que atestam uma revolução desvairada, sem princípios fundamentais e sem orientação alguma, sendo essa a sua única lógica, que é a lógica dos desequilibrados.

A crítica sensata brada contra semelhantes invasores do território do belo, mas luta, apesar disso, contra a onda crescente dos adeptos desses esnobismos e dos seus admiradores ${ }^{259}$ ".

Em outubro de 1921, faria referência aos rumos da música moderna, que considerava absurdos, e apresenta-se como combatente isolado dessas tendências corrosivas. "A tendência atual é para a música moderna verdadeiro contrassenso harmônico, negação constante da técnica musical". Considerava, porém, que isso fosse passageiro: "isso que por aí anda é uma questão de moda, e toda a moda é transitória" 260 . Guanabarino encontraria em Heitor Villa Lobos a corporificação do tipo de músico moderno que repudiava. Comentando um recital de composições do maestro, o crítico expunha sua doutrina a respeito da música moderna e oferecia, ao mesmo tempo, uma visão sobre aquilo que considerava ideal em termos musicais. Em sua opinião, os músicos modernos - a quem denomina "cubistas musicais" - dedicam-se a buscar a originalidade a qualquer preço, e nesse afã extrapolam os limites naturais da linguagem musical. Tornam-se assim "absurdos, repugnantes e depravados"261.

O ano de 1922 trouxe a Semana de Arte Moderna e, com ela, atritos mais ásperos entre Guanabarino e os proponentes de renovações estéticas. Menotti del Picchia saiu em defesa dos modernistas e seguiu-se na imprensa uma prolongada escaramuça entre os dois, que acabaria descendo do terreno da argumentação estética para considerações jocosas na esfera pessoal ${ }^{262}$. A crítica de Guanabarino aos modernistas retorna à fórmula

259 "Pelo Mundo das Artes"; Jornal do Commercio, 24 de maio de 1921, p. 2.

${ }^{260}$ Ambas citações desse parágrafo são de "Pelo Mundo das Artes"; Jornal do Commercio, 12 de outubro de 1921, p. 2.

${ }^{261}$ Guanabarino hauria sua compreensão do que viesse a ser o padrão normal em termos musicais das ideias de Camille Saint-Saëns, velho compositor francês que se destacava pelo combate às tendências modernas. Saint-Saënz, segundo Guanabarino, ensinava que a harmonia era invenção recente, desenvolvida a partir do século XVI, que veio trazer ordem à música. Interpondo-se entre ritmo e melodia, a harmonia representava a lógica musical, e punha fim à era de primitivismo. Tal harmonia se fez sobre leis naturais, descobertas e aperfeiçoadas por gerações sucessivas. Lentamente, no entanto, "acordes proibidos foram admitidos e as dissonâncias mais audaciosas adquiriram foros de cidade"; cfe. "Pelo Mundo da Arte"; Jornal do Commercio, 26 de outubro de 1921. É notável no discurso de Guanabarino sobre a música um claro evolucionismo cultural, nos moldes daquele praticado na Revista Musical e de Bellas Artes, conforme demonstrado anteriormente.

262 Em defesa das propostas da Semana, del Picchia escreveu uma Carta aberta ao Sr. Oscar Guanabarino. O argumento central é que Guanabarino, por mais valor que tivessem suas convicções, era parte de um passado que se despedia. "Somos expoentes de duas gerações diferentes: uma que morre, outra que surge". Aos jovens caberia encontrar uma nova forma de expressão, mais adequada ao século XX. "O passado é um cadáver, [...] está bem onde está e, por estar bem onde está, com seus gênios, com seus heróis, com seus deuses, não é justo que penetremos seus umbrais nevoentos, encarapitados num torpedo século XX para acordar a estouros de motor essa boa gente, perturbando-lhe o sono multissecular 
já tantas vezes acionada: denuncia-os como charlatães que abandonam os princípios que deveriam reger as artes, criando "a escola do absurdo com a pretensão de desbancar a arte que vem sendo aperfeiçoada através dos séculos" ${ }^{\text {263 }}$. Recorre ao artifício de comparar os resultados dessas propostas com as realizações de pacientes psiquiátricos:

"Essa nova arte, que tem por base a ausência de arte, invadiu a música, a pintura e a escultura sob diversas denominações, mas sem nenhuma novidade, nem interesse a não ser para os psiquiatras. É preciso que se saiba que nos manicômios se produzem poemas, partituras, quadros e estátuas, e que essa arte dos doidos tem o mesmo característico da arte dos futuristas e cubistas que andam soltos por aî́" ${ }^{\prime 264}$.

O discurso reacionário de Guanabarino na década de 1920 reveste-se também de um repúdio crescente ao que considera o avanço da cultura popular sobre o gosto do público, roubando a audiência das manifestações tidas como elevadas e edificantes. Seu lamento ganha ares dramáticos quando constata que a disseminação do popular nas manifestações culturais contagiava mesmo as classes mais elevadas e instruídas. Lido como "marcha retroativa das artes" 265 , que teria começado na Europa, com "a aparição doida do futurismo agravada pela grande guerra", o fenômeno ganhou espaço cada vez maior nas censuras de Guanabarino. O crítico iria se concentrar, cada vez mais, no combate à penetração do popular na cultura ${ }^{266}$. O velho crítico acreditava estar testemunhando um processo progressivo de degradação, onde a demanda do público por diversões rasteiras produzia espetáculos cada vez menos edificantes, o que por sua vez

e venerável"; cfe. Carta Aberta ao Sr. Oscar Guanabarino; Correio Paulistano, 23 de fevereiro de 1922, p. 4; apud. BOAVENTURA, 2000., p. 115-119.

263 "Pelo Mundo das Artes"; Jornal do Commercio, 22 de fevereiro de 1922, p. 2; apud. BOAVENTURA, op. cit., p. 255.

264 Idem, p. 256.

265 Todas as citações desse parágrafo são de "Pelo Mundo das Artes"; Jornal do Commercio, 2 de fevereiro de 1927, p. 2.

${ }^{266}$ Na França, dizia, o charleston já tinha trânsito em todas as esferas sociais: "a dança anti-higiênica, e ao mesmo tempo escandalosa, lasciva e de gestos indecentes oficializou-se em Paris - aristocratizou-se como complemento da moda do quase nu em vésperas de tudo nu". No Rio de Janeiro, onde "o chá dançante matou os concertos", a preferência por entretenimentos vulgares esvaziava as casas de respeito, e levava multidões a seguirem artistas considerados inferiores. Enquanto grandes pianistas estrangeiros encaravam plateias vazias em seus recitais, levando uma má impressão da cidade para o mundo todo, músicos populares enchiam as salas de espetáculo. Guanabarino censurava também o triunfo das modinhas, "que todos nós conhecemos há mais de 60 anos, por intermédio de capadócios em esquinas e praias ao luar". Lamentava ainda o fenômeno do cinema, que roubava público ao teatro de valor: "[...] o público deixa o teatro dramático vazio na segunda representação de peças de valor, [mas] frequenta o cinema onde essas mesmas peças são representadas por artistas de merecimento discutível, sobressaindo mais os galãs bonitos e as mulheres formosas"; cfe. "Pelo Mundo das Artes"; Jornal do Commercio, 20 de março de 1929, p. 2. 
contribuía para a queda do nível do gosto geral: "o público perverteu o teatro e o teatro desmoralizou o público"267.

Esse tipo de censura se aplicava também à arte "erudita" que transigia com padrões da cultura popular. Guanabarino considerava absurdas as propostas da arquitetura neocolonial: "com um pouco de exagero, poderíamos chegar à perfeição das palhoças e construir uma belíssima capital com casinhas cobertas de sapê" ${ }^{268}$. Entre todos os artistas que experimentavam com os elementos populares, Villa Lobos mereceu as admoestações mais ásperas e recorrentes. Comentando os sucessos do compositor, que produzia num estilo que denominou "barulhismo", Guanabarino pôde aprofundar sua reflexão sobre a natureza da arte brasileira, pela via negativa, tratando de separar da "nossa cultura" os elementos africanos e lusos, e também aqueles oriundos das classes populares do Brasil e da Europa. Diante da aclamação que recentemente vinha recebendo Villa Lobos, apontava que parte do público o sancionava por conta de suas experiências com as sonoridades populares:

"Em algumas de suas peças para piano existem os arabescos musicais, fórmulas arpejadas que não são novas, mas usadas há mais de um século e muito exploradas por Liszt e Chopin, e milhares de compositores; e ultimamente por quase todos os modernos. Do meio desses desenhos surgem então, os motivos populares, que não são seus e sim do povo, com a sua melodia ingênua, primitiva, elementar; mas alegra porque desperta a saudade, a saudade dos tempos que lá se foram, ou lembram festas populares"269.

"Mas, o Brasil” seguia, "não é a costa d'África, mãe de certos ritmos introduzidos na música que pretendem naturalizar como brasílica; nem tampouco é nacional o ritmo do Zé Pereira, genuinamente português, e no entanto introduzido em uma das composições do músico futurista" ${ }^{270}$. A admissão de elementos populares na composição musical de talhe erudito seria o elemento central da censura de Guanabarino à arte de Villa Lobos. Ao longo dos anos 1920 o crítico sempre se referiria de maneira pejorativa a essa tendência da obra do músico, subindo de tom na medida em que apareciam sinais cada vez mais frequentes do sucesso e da aceitação das propostas do maestro. Tratava-se, no seu julgamento, de uma "[...] arte baixa e capadoçal que os insensatos procuram arrastar das ruas para introduzir nos nossos salões e invadir o teatro, templo em que se cultuam as mais belas manifestações dos artistas"271.

\footnotetext{
267 "Pelo Mundo das Artes"; Jornal do Commercio, 23 de fevereiro de 1927, p. 2.

268 "Pelo Mundo das Artes"; Jornal do Commercio, 9 de março de 1927, p. 2.

269 "Pelo Mundo das Artes"; Jornal do Commercio, 9 de junho de 1926, p. 2.

270 Idem.

271 "Pelo Mundo das Artes"; Jornal do Commercio, 3 de julho de 1929, p. 2.
} 
Num desdobramento destas posturas, o crítico niteroiense lançaria uma campanha contra o violão, "instrumento de capadócio, inda que sirva de passatempo ingênuo na intimidade das famílias ou em saraus familiares" ${ }^{272}$. O culto ao violão e à música popular acabou se tornando, para o crítico, num dos principais alvos de sua censura: consideravao culto da imoralidade e apologia do analfabeto.

As censuras repetidas por Guanabarino ao longo da década de 1920 acabam por se articular em relações de causalidade, formando uma narrativa sobre a trajetória da cultura moderna:

"Há quem esteja fatigado de ouvir as obras primas dos gênios musicais, exigindo sensações novas, processos novos, uma outra instrumentação que não se pareça com a de Wagner nem com a de Verdi, tanto que já foi escrita uma ópera jazz band que já percorreu o mundo com o mesmo êxito alcançado pelas partituras dos mais célebres compositores. Cumpre notar, entretanto, que os grupos de aberrantes crescem em proporções assustadoras. $\mathrm{O}$ álcool tem, forçosamente, que ceder terreno à cocaína e aos derivados do ópio. Quando a população do Rio era de quinhentas mil almas apenas o teatro era um atrativo de primeira ordem, tanto para os intelectuais, que preferiam os espetáculos dramáticos, como para os sensíveis à música, que de preferência iam ouvir óperas ou operetas.

[...]

$\mathrm{Na}$ atualidade, porém, o que se observa na maioria dos rapazes ricos é o prazer em guiar automóveis de alta categoria, frequentar campos de football e pagar a peso de ouro uma grama de cocaína.

A música não está em crise; em crise estão aqueles que não a percebem ou que a desdenham por tola afetação; mas, como existe essa corrente, claro está que nasceram seus exploradores" 273 .

O velho publicista extrapolava o campo da arte, expandindo seus diagnósticos para a vida moderna como um todo. Criava uma visão de mundo marcada pelo repúdio às tendências do presente. Ao fazê-lo, reavivou velhas ideias de Max Nordau: como o médico húngaro, o niteroiense também observa e censura os consumidores, responsabilizando-os pela proliferação dos excessos na arte. Retoma também uma certa tradição oitocentista que atribuía a culpa pela degradação da cultura e da moralidade à vida nas grandes cidades e às modificações trazidas pela modernidade. Em contradição com combativo republicano que fora na década de 1880, acabaria por cultivar a nostalgia dos tempos imperiais. Com frequência, nas últimas crônicas que publica, refere-se às qualidades desaparecidas dos tempos de D. Pedro II: a moralidade, a excelência artística

\footnotetext{
272 "Pelo Mundo das Artes"; Jornal do Commercio, 4 de setembro de 1929, p. 2.

273 "Pelo Mundo das Artes"; Jornal do Commercio, 20 de março de 1929, p. 2.
} 
etc. Guanabarino fecha o ciclo de sua atividade crítica em 1936, alguns meses antes de falecer $^{274}$.

Num estudo sobre as contendas entre "modernistas" e "passadistas"275, Gilda de Mello e Souza classificou os textos de críticos das propostas das vanguardas estéticas em duas categorias. Por um lado, apontou a existência de uma linha

"ocasional, originada por algum acontecimento relevante (exposição, publicação de livro, conferência, inauguração de prédio) e caracterizada tanto pela extrema violência quanto pela escolha de um ou mais bodes expiatórios, sendo feita frequentemente com pseudônimo" 276 .

Por outro, referiu-se à crítica de aparição regular, em colunas de existência estável nos jornais e revistas, "mais ponderada, que podia assumir a forma de estudo e manifestar posições estéticas precisas" 277 .

$\mathrm{Na}$ primeira categoria, Souza alinhou tanto o texto com que Monteiro Lobato fulminou a exposição de Anita Malfatti, em 1917, quanto os pequenos comentários satíricos, sarcásticos e mordazes que apareciam nas ocasiões citadas. A pesquisa reiterou a validade dessa categorização. Parece haver, de fato, uma diferença formal e temática entre os artigos de ocasião - polêmicos, inflamados e provocativos - e os conjuntos formados pelo retorno sistemático à reflexão, num espaço fixo e previsível nos jornais e revistas. O segundo tipo parece oferecer ao crítico a oportunidade de aprimorar e aprofundar suas reflexões. No entanto, a análise detida dos textos categorizados como “ocasionais" evidencia também, no final, um certo programa. Para Souza, a leitura desse material resultava na conclusão de que se tratava de um pensamento estético raso, "variantes mais ou menos tolas e mesquinhas", que em geral

"reflete sobre a arte a opinião do senso comum, corrente na burguesia e baseada num conceito muito estreito de mimese. Opõe-se por isso a qualquer uso artístico da deformação, seja impressionista, cubista ou futurista - acusando sistematicamente os

\footnotetext{
${ }^{274}$ A última aparição de "Pelo Mundo das Artes" encontrada foi publicada no dia 17 de junho de 1936. Não foram encontradas justificativas ou explicações para a interrupção. Sete semanas depois, o Jornal do Commercio deu início a um novo folhetim, que passou a ocupar o espaço de Pelo Mundo das Artes. Guanabarino faleceu 17 de janeiro de 1937; num texto publicado no dia seguinte, dizia-se que morrera "após longa doença, que muitos meses antes de lhe tirar a vida lhe tirou a atividade" (apud GRANGEIA, op. cit., p. 30).

275 SOUZA, Gilda de Mello e. Vanguarda e Nacionalismo na Década de 20. In: SOUZA, Gilda de Mello e. Exercícios de Leitura. São Paulo: Duas Cidade/Editora 34, 2009. p. 304-344

276 Idem, p. 309.

277 Idem.
} 
modernos de incompetentes, ignorantes das regras básicas da arte, plagiários e cabotinos" $^{\prime 278}$ (p. 309).

De fato, a crítica de arte ocasional e ligeira parece refletir o senso comum sobre a arte, isto é, o pensamento estético adquirido indiretamente, no contato com as opiniões dos outros. Formam um conjunto de conceitos desligados das discussões mais avançadas, disponíveis apenas aos especialistas. Justamente por esse motivo, parece relevante observar mais detidamente as críticas de arte rotuladas “ocasionais", já que elas permitem observar o pensamento estético dominante - o senso comum - que, de fato, dirigia a opinião da maioria sobre o que vinha a ser aceitável e desejável em arte. Isso levou a constatar que as propostas das vanguardas foram amplamente repudiadas no Brasil; o repúdio extrapolou o universo da imprensa e se manifestou, em muitas ocasiões, em ataques físicos a obras de arte moderna.

No exercício da observação da crítica “ocasional”, buscou-se identificar algumas recorrências, localizando argumentos que reapareceram e procurando remetê-los a sua origem. Entre todas as influências, salta aos olhos o pensamento de Max Nordau; resquícios da denominada "estética positiva" também são nítidos. A observação dessa crítica "ocasional" é essencial para esta pesquisa, especialmente no que tange ao antimodernismo no Brasil, uma vez que aqui esse tipo de posicionamento se abriga justamente nesses textos ligeiros, esporádicos e reativos, que em geral ocultam o autor por trás de pseudônimos ou simplesmente elidem qualquer referência a nomes.

A busca pela reconstituição das vozes dos "derrotados" parece justificar-se quando se leva em conta o papel decisivo que tiveram no momento em que as disputas ainda estavam acesas. Nelson Schapochnik procurou refletir sobre os apagamentos seletivos realizados pelos modernistas brasileiros, acatados e repetidos por parte da crítica e da academia nas décadas seguintes. Em suas palavras, "o triunfo da sinfonia modernista [...] teve o efeito de abafar, quando não silenciar, as vozes dissonantes que se desgarraram ou não aderiram ao programa das vanguardas". Para ele, o esforço por resgatar os discursos dos "derrotados" se justifica por trazer à tona tensões esquecidas. Seria necessária, portanto, “[...] a reconstrução daquele horizonte crítico-literário na perspectiva do que lhe era simultâneo", pois já "é tempo de examinar a diversidade de

\footnotetext{
278 Idem.
} 
atitudes e opiniões com vistas à compreensão de como essas batalhas e divergências se formalizaram em experimentações estéticas e literárias"279.

Neste segmento, procura-se observar o campo da crítica de arte imediatamente anterior à Semana de Arte Moderna de 1922. O acesso a este contexto, realizado por meio da leitura de bibliografia especializada, aponta a existência de uma corrente renovadora anterior à dos modernistas. Tendo Monteiro Lobato como seu expoente, esta doutrina estética, que Tadeu Chiarelli denominou naturalismo nacionalista, compartilha traços importantes com a vertente renovadora que emergiu no Rio de Janeiro na década de 1880, descrita e analisada no capítulo anterior. Da mesma forma, essa corrente foi responsável pelo choque inicial com as propostas modernistas, servindo-se do discurso degeneracionista.

Ainda neste segmento realiza-se a exposição da análise da crítica de arte ocasional que apareceu ao redor da Semana de Arte Moderna. Procurou-se demonstrar recorrências nos discursos dos críticos e apontar as prováveis leituras realizadas por eles, cujos argumentos incorporaram em seus ataques ao modernismo.

$* \quad * \quad *$

O estudo de Tadeu Chiarelli sobre Monteiro Lobato oferece um panorama da atividade da crítica de arte em São Paulo nas primeiras décadas do século $\mathrm{XX}^{280}$. O cenário descrito por ele não se afasta muito daquele encontrado na análise da situação na Capital Federal, descontada a diferença cronológica. Se no Rio de Janeiro, já desde a década de 1870, despontava uma geração que propunha a ruptura com a tradição, em São Paulo isso ocorreria especialmente a partir de 1916, com o surgimento de uma crítica militante que desnudaria uma situação de desconforto com a arte dita oficial e que pregaria novo projeto $^{281}$. Em São Paulo também, como no Rio, essa crítica militante insistiria na necessidade de uma pintura mais "naturalista", isto é, preocupada com aquilo

\footnotetext{
${ }^{279}$ SCHAPOCHNIK, Nelson. Considerações mamalucas sobre o futurismo paulista. In: GUASTINI, Mário. A Hora Futurista que Passou e outros escritos. São Paulo: Boitempo, 2006, p. 19. No mesmo sentido, Néstor García Canclini convence-se, com Bordieu, da necessidade de se observar as disputas pelo controle do campo cultural entre os grupos envolvidos: "“A investigação sociológica da arte deve examinar como se formou o capital cultural do respectivo campo e como se luta por sua apropriação. Os que detêm o capital e os que aspiram a possuí-lo promovem batalhas que são essenciais para entender a significação do que é produzido; porém, essa competição tem muito de cumplicidade e através dela também se afirma a crença na autonomia do campo", cfe. CANCLINI, Néstor García. Culturas Híbridas: Estratégias para Entrar e Sair da Modernidade. São Paulo: EDUSP, 2008; p. 36.

${ }^{280}$ CHIARELLI, Tadeu. Um Jeca nos Vernissages: Monteiro Lobato e o desejo de uma Arte Nacional no Brasil. São Paulo: Editora da Universidade de São Paulo, 1995.

${ }^{281}$ CHIARELLI, 1995, p. 77.
} 
que está à vista dos olhos, substituindo a cópia de modelos ideais herdados da tradição do ofício. Desprezava-se a arte acadêmica, convencionalista ou "fantasista", e o excesso de técnica, que supostamente toldava o sentimento do artista. Valorizava-se o filtro do temperamento do autor. Exigia-se que no resultado final a verdade aparecesse conforme registrada pela "mão" do artista. Não deveria ser objetivo do artista buscar semelhança a uma "placa fotográfica". A formulação de Zola era ainda o norte: "um pedaço da criação através de um temperamento" 282 .

Chiarelli ressalta a presença do elemento patriótico, descrevendo o que chama de "naturalismo nacionalista", doutrina que se traduz no desejo de que o artista capte a verdade nacional, o tipo brasileiro, a paisagem do país, sua luz e suas cores, desvinculando-se da noção de "belo absoluto" cultivada na academia. Esse tipo de corrente crítica empolgava mesmo intelectuais que, mais tarde, seriam identificados com o "modernismo"283.

O caráter progressista do "naturalismo nacionalista" desaparecia rapidamente quando exposto a obras contendo propostas típicas dos movimentos de vanguarda. Nesse caso, a crítica naturalista tendia a recuar para uma posição mais conservadora, acionando “ditames estéticos acadêmicos - 'eternos', 'atemporais"” para tentar conter as inovações perigosas $^{284}$. Parte deste repúdio às propostas da vanguarda se devia mais ao apego ao nacionalismo que ao naturalismo: para a crítica fundamentada nesta linha, a incursão na linguagem das vanguardas por brasileiros significava "imitação servil", “afrancesamento", afastamento dos índices considerados adequados de nacionalidade. Essa atitude hostil da crítica paulista diante das exposições de arte moderna manifesta-se, primeiro, como "frieza" e, mais tarde, por conta do aumento do número de eventos ligados a essa nova estética, como "negação veemente"285. De todo modo, esse reposicionamento da crítica paulista implica numa aproximação com as concepções tradicionais:

"Frente a essa 'nova arte', que tentava romper com as relações analógicas mais evidentes entre a arte e a realidade, as distinções entre academismo e naturalismo se atenuam. As

\footnotetext{
${ }^{282}$ CHIARELLI, 1995, p. 78. No entanto, Chiarelli detecta nas críticas analisadas algum grau de transgressão das próprias linhas: o pendor pelo naturalismo às vezes se mescla com a apreciação de características "tradicionais": "[...] uma valorização excessiva do desenho como estruturador da composição e, em alguns casos, um fascínio pelos malabarismos técnicos de alguns pintores" (p. 82).

283 Em 1915, num texto publicado n'O Pirralho, intitulado Em prol de uma pintura nacional, Oswald de Andrade demonstrava apego ao "naturalismo nacionalista", ao defender a ideia de que o Pensionato Artístico desnacionalizava o olhar do artista brasileiro, ajustando-o às realidades da Europa. No mesmo texto, elegia Almeida Jr. como o "mais nosso" dos artistas brasileiros, "precursor, encaminhador, modelo" para a arte nacional" apud. CHIARELLI, 1995, p. 96.

${ }^{284}$ CHIARELLI, 1995, p. 76.

285 Idem, p. 83
} 
duas estéticas quase se confundem como estratégia para o fortalecimento de uma cultura artística presa à verossimilhança" ${ }^{" 286}$.

$$
* \quad * \quad *
$$

Para Tadeu Chiarelli, os intelectuais ligados ao movimento Modernista de 1922 transformaram Monteiro Lobato num dos elementos centrais de sua autodefinição. No discurso dos modernistas, o taubateano passara a encarnar o "outro" dialético, o "antimoderno" arquetípico, o "acadêmico" apegado às tradições, uma presença que servia de estímulo à união de todos aqueles que pugnavam pela renovação estética no Brasil ${ }^{287}$. Daí por diante, tornou-se obrigatório citar a oposição de Lobato em praticamente toda análise que faça referência ao Modernismo Brasileiro ${ }^{288}$.

Monteiro Lobato torna-se, dessa forma, protagonista do momento de fundação do Modernismo, e assim é visto pela maioria dos seus comentadores desde então. As gerações que se seguiram à dos Modernistas de 1922 encarregaram-se de dar continuidade a essa interpretação, aprofundando-a. Na opinião de Tadeu Chiarelli, era parte da estratégia desmerecer seu papel de crítico, delineando-o como despeitado pintor fracassado, para que se pudesse omitir a existência de um discurso moderno exterior ao dos membros do movimento Modernista. Mário da Silva Brito, historiador e crítico de arte, entusiasmado epígono do modernismo, não só reiterou, como adicionou novas nuances à imagem vilanesca de Lobato. Para ele, Lobato “[...] antecedeu Hitler ao rotular de teratológica a arte moderna"289.

Quando analisado à luz dos desenvolvimentos anteriores da crítica de arte brasileira, daqueles que se observam no final do século XIX, o discurso de Lobato poderia ser entendido como associado, ao menos em parte, às concepções da estética positiva. Lobato defendia, afinal, a fidelidade à natureza, o que significava o abandono das

\footnotetext{
286 Idem, p. 88.

287 CHIARELLI, 1995, esp. Capítulo "A Fama de Mau Pintor".

288 Mário de Andrade seria um dos principais cultores dessa argumentação, ao apontar o impulso de defender a arte de Malfatti contra o espírito conservador como móvel da primeira atração que reuniu o grupo dos Modernistas: "Eu, pessoalmente, devo a revelação do novo e a convicção da revolta a ela [Malfatti] e à força de seus quadros. [...] Se alguns poucos escritores ponderáveis [...] que iam se tornar os propulsores eficazes do movimento modernista, já nos conhecíamos então, eles podem testemunhar se o primeiro espírito de luta, a primeira consciência coletiva, a primeira necessidade de arregimentação foi despertada ou não pelo que se passava na cidade, com a exposição de Anita Malfatti. Foi ela, foram os seus quadros, que os deram uma primeira consciência de revolta e de coletividade em luta pela modernização das artes brasileiras"; Apud ALMEIDA, Paulo Mendes de. De Anita à Academia. São Paulo: Terceiro Nome, 2014, p. 21.

${ }^{289}$ Apud CHIARELLI, 1995, p. 34. Para Chiarelli, essa comparação seria injusta ao concentrar a acusação sobre um indivíduo por incursão numa ideia que era então corrente, "[...] já que a associação da arte moderna com monstruosidades era comum na Europa desde o século passado" (CHIARELLI, 1995, p. 34).
} 
convenções - que ele, assim como os redatores reunidos na Revista Musical e de Bellas Artes, chamava de idealismo. Por outro lado, a mesma fidelidade à natureza desautorizava o afastamento das formas conforme percebidas pelos sentidos. Lobato, nas palavras de Chiarelli, exercia

"[...] a crítica que busca perceber e valorizar numa obra de arte o grau de capacidade do artista em captar as características do ambiente retratado o mais fielmente possível, sem - por um lado - nenhum tipo de idealização (o que aproximaria a obra das tendências acadêmicas) e - por outro - sem nenhum tipo de deformação expressiva que comprometa a verdade aparente (o que aproximaria a obra das tendências de vanguarda)" ${ }^{290}$.

Annateresa Fabris concluiu algo semelhante ao escrutinar a crítica de arte exercida por Lobato. Para ela, não seria adequado rotular sua concepção estética de "acadêmica", pois ele se posicionava contra as soluções tradicionais (que considerava "idealistas"), e preferia uma arte naturalista:

"Sua concepção de arte (para a qual requer o 'estudo direto, ininterrupto e honestíssimo da natureza') leva-o a atacar o academicismo, por gerar 'a imitação, a coação do livre voo, a emasculação da personalidade'. 'Receituário', 'fase de repouso', o academismo é um dos dois momentos da vida da arte, cabendo ao 'gênio rebelde', que faz 'uma nova consulta à natureza', retomar o caminho da criação" 291 .

Uma faceta talvez mais acentuada em Lobato que nos seus antecessores cariocas era o forte nacionalismo, que o levava a exigir interesse exclusivo pelos temas locais. Mas a busca pelo índice da nacionalidade não era preocupação exclusiva do taubateano. $\mathrm{Na}$ verdade, era uma preocupação já bastante antiga e que, conforme já apontado anteriormente, ligava os modernistas às gerações anteriores, estabelecendo continuidades não reconhecidas pela geração de 22 . Em outro texto ${ }^{292}$ Charelli propõe que se reconheça essa continuidade entre os ideais dos "acadêmicos" e dos "modernos", traduzida numa ideia alegórica dos atributos do Brasil. Em ambos os casos, especialmente na pintura, a temática é a mesma, variando apenas as características superficiais das obras. Os modernistas teriam inovado apenas na medida em que assimilaram os "estilemas oriundos dos movimentos das vanguardas do início do século XX, ainda que atenuados" ${ }^{\text {"9 }}$.

De todo modo, Chiarelli insiste, Lobato representava uma força disruptiva, pela forma marcante pela qual irrompeu na cena cultural brasileira, especialmente pela introdução de uma nova forma linguística, despida da formalidade que até então marcava

\footnotetext{
${ }^{290}$ CHIARELLI, 1995, p. 31, nota 13.

${ }^{291}$ Apud CHIARELLI, 1995, p. 41.

292 CHIARELLI, Tadeu. De Anita à Academia - para repensar a história da arte no Brasil. Revista Novos Estudos - CEBRAP, no 88, Nov/2010.

293 Idem, p. 121.
} 
a imprensa. Para Chiarelli, essa irrupção teria estabelecido "um espaço de dissidência em relação ao status quo", que nos anos 1920 seria ocupado pelos modernistas ${ }^{294}$.

Talvez seja possível argumentar, portanto, que Lobato seja compreendido não enquanto um "acadêmico", mas como partícipe de uma concepção "positiva-nacionalista" idiossincrática do fenômeno estético.

A análise do conteúdo da célebre crítica de Lobato à exposição de Anita Malfatti ${ }^{295}$ demonstra uma proximidade entre sua intepretação da modernidade estética com aquela dos degeneracionistas, especialmente de Max Nordau e Cesare Lombroso, ainda que, como será apontado a seguir, suas conclusões não sejam exatamente as mesmas. Lobato aciona os elementos deste tipo de discurso de uma maneira descompromissada, no seu célebre "estilo seco e vigoroso, usando metáforas campestres e expressões cultas e coloquiais" 296 . Importante notar a existência de outras evidências do contato de Lobato com as ideias de Nordau: na dissertação de mestrado de Camila Spagnoli, que levantou os hábitos de leitura do taubateano, menciona-se a presença da obra "Paradoxos" em sua coleção ${ }^{297}$. Referência às ideias de Nordau aparece também na correspondência de Lobato, numa carta de $1903^{298}$. Ainda que destituído do rigor classificatório típico dos tratados médicos do século XIX, os elementos centrais do discurso degeneracionista são nitidamente visíveis em seu texto.

O degeneracionismo de Lobato aparece com mais força nas considerações iniciais de seu polêmico artigo, antes que ele começasse a tratar especificamente da exposição de Malfatti. Ele considerava haver duas espécies de artistas, os saudáveis, que "[...] veem normalmente as coisas e em consequência disso fazem arte pura, guardando os eternos ritmos da vida, e adotados para a concretização das emoções estéticas, os processos clássicos dos grandes mestres" e uma outra cepa,

\footnotetext{
${ }^{294}$ CHARELLI, 1995, p. 43. O próprio Mário de Andrade reconheceria esse caráter dissidente no discurso de Lobato, colocando-se inclusive como continuador: "Já que Monteiro Lobato não quis continuar a sua atitude inicial que foi um estouro nos arraiais bambos da estética paulista, façamos nós a revolução heroica" (apud CHIARELLI, p. 26).

295 Publicado originalmente como "A propósito da Exposição Malfatti" n'O Estado de São Paulo de 20 de dezembro de 1917, o texto foi reeditado sob o título "Paranoia ou mistificação" em 1919, no livro "Ideias de Jeca Tatu", onde ganhou estabilidade e nova visibilidade.

${ }^{296}$ GONÇALVES, 2012, p. 97.

${ }^{297}$ SPAGNOLI, Camila Russo de Almeida. Monteiro Lobato, o leitor. Dissertação (Mestrado) em Filosofia. São Paulo: Instituto de Estudos Brasileiros-IEB - Universidade de São Paulo, 2014; p. 251.

${ }^{298}$ LOBATO, Monteiro. A Barca de Gleyre - 1o Tomo. São Paulo: Editora Brasiliense, 1961; p. 33.
} 
"[...] formada pelos que veem anormalmente a natureza, e interpretam-na à luz de teorias efêmeras, sob a sugestão estrábica de escolas rebeldes, surgidas cá e lá como furúnculos da cultura excessiva. São produtos de cansaço e do sadismo de todos os períodos de decadência: são frutos de fins de estação, bichados ao nascedouro. Estrelas cadentes, brilham um instante, as mais das vezes com a luz de escândalo, e somem-se logo nas trevas do esquecimento" 299 .

Neste parágrafo, Lobato abrasileira o degeneracionismo, pejando-o de metáforas de coloração local. Em primeiro lugar, ele responsabiliza a "cultura excessiva " pela existência do artista que incorre numa visão anormal da natureza. Como visto, era comum entre os degeneracionistas do século XIX associar a decadência ao acúmulo excessivo de cultura (nesse caso, pela terminologia de Norbert Elias, dir-se-ia excesso de “civilização"). De todo modo, parece ser seguro entender essa afirmação como uma condenação a certos aspectos da modernidade, cujos excessos provocariam o afastamento da "[...] arte pura", dos "[...] eternos ritmos da vida, dos "[...] processos clássicos dos grandes mestres", em suma, do afastamento de uma ideal pureza original. Ao falar do artista que considera anormal como sendo "produto do cansaço", Lobato remete à ideia de exaustão civilizacional, formulada antes do fim da primeira metade do século XIX. Como visto, tal noção era cara a Nordau, que responsabilizava a modernidade por um tal estado de enfraquecimento psíquico que impedia o julgamento, exagerava morbidamente a emoção e a sensibilidade, enfraquecia a vontade e transformava os homens em histéricos, prontos a aceitar passivamente as mais radicais experiências estéticas, as mais desabridas transgressões morais. Finalmente, ao designar tais artistas como "frutos de fim de estação, bichados no nascedouro", Lobato remete à ideia de "fim de raça" (análoga à de fin-de-siècle): indivíduos tão pesadamente carregados com um fardo hereditário mórbido que não podem fugir à sua condição. "Bichados ao nascedouro", estariam condenados a marcar sua produção com os estigmas da degeneração. Produzem uma arte teratológica, ou seja, desenvolvida de maneira anormal desde seus estágios embrionários, congenitamente monstruosa. A ideia da inevitabilidade dá o tom desse segmento.

Em seguida, faz referência a Lombroso

"De há muito já que a estudam os psiquiatras em seus tratados, documentando-se nos inúmeros desenhos que ornam as paredes internas dos manicômios. A única diferença reside em que nos manicômios esta arte é sincera, produto ilógico de cérebros transtornados pelas mais estranhas psicoses; e fora deles, nas exposições públicas, zabumbadas pela imprensa e absorvidas por americanos malucos, não há sinceridade nenhuma, nem nenhuma lógica, sendo mistificação pura".

\footnotetext{
299 A fonte para a análise aqui desenvolvida encontra-se publicada no site do Museu de Arte Contemporânea (MAC-USP), disponível no endereço eletrônico http://www.mac.usp.br/mac/templates/projetos/educativo/paranoia.html (acessado em 20/04/2016).
} 
O psiquiatra italiano coletava e analisava sistematicamente os produtos artísticos e artesanais dos internos de manicômios e presídios, e também registrava pacientemente as inscrições que faziam nas paredes de suas celas. Parte desse material está exposto atualmente no Museu de Antropologia Criminal Cesare Lombroso, em Turim. Como visto, Lombroso defendia a ideia de que os produtos das mentes insanas e criminosas carregavam certas características recorrentes que eram indicativas de morbidade hereditária.

\section{Lobato continua:}

Todas as artes são regidas por princípios imutáveis, leis fundamentais que não dependem do tempo nem da latitude. As medidas de proporção e equilíbrio, na forma ou na cor, decorrem de que chamamos sentir. Quando as sensações do mundo externo transformamse em impressões cerebrais, nós "sentimos"; para que sintamos de maneiras diversas, cúbicas ou futuristas, é forçoso ou que a harmonia do universo sofra completa alteração, ou que o nosso cérebro esteja em "pane" por virtude de alguma grave lesão.

Neste segmento, Lobato se aproxima estreitamente das ideias de Nordau e de Véron. Ao determinar que as artes são regidas por "princípios imutáveis, leis fundamentais que não dependem do tempo nem da latitude", subscreve a ideia de que há um padrão normal para o desenvolvimento da arte, de cujo afastamento resulta a anormalidade a ser detectada e combatida. Ao ressaltar o papel do cérebro como mediador no processo de recepção das sensações e sua expressão na forma de obra, Lobato reedita a ideia da arte como resultado de função fisiológica. Isso permite que ele classifique a arte cubista e futurista como sendo resultado de "pane" cerebral.

Finalmente, Lobato retoma a discussão sobre o papel do crítico de arte. Em "Degeneração", Nordau os acusava, assim como Lobato faria neste texto, de charlatanismo e oportunismo. Seriam indivíduos que, mesmo percebendo o caráter mórbido ou mentiroso da arte moderna, empregavam as ferramentas ao seu dispor para dissimular essa situação com explicações falsas, "[...] teorizam aquilo com grande dispêndio de palavrório técnico" (nas palavras de Lobato) procurando mistificar o público. Para Nordau, os críticos associavam-se aos degenerados para obter notoriedade, e não hesitavam em trocar o objeto das louvações ao primeiro sinal de cansaço por parte do público.

Lobato, no entanto, afasta-se de Nordau nos desdobramentos de sua crítica. Entre paranoia ou mistificação, o taubateano decide-se pela segunda: cubistas e futuristas, apesar das considerações iniciais que os aproximavam da categoria de "degenerados", 
seriam afinal apenas charlatães e trocistas, aproveitando-se da ingenuidade do público para tornar aceitáveis seus excêntricos experimentos. Mistificadores, riam-se do público da mesma forma que os parisienses se riam dos incautos ao apresentarem uma tela pintada por um burro com uma broxa amarrada na cauda.

$* \quad * \quad *$

Embora tenha experimentado uma ascensão repentina no cenário econômico brasileiro, propelido pela prosperidade do café, São Paulo era, no final do século XIX, um Estado desaparelhado. No aspecto cultural-educacional, era bastante diferente do Rio, que desde o final do período colonial desenvolvera instituições públicas voltadas para as artes e ofícios, para a imprensa e literatura etc. No início do período republicano, São Paulo se viu instado a criar essas estruturas. Ao contrário do Rio de Janeiro, a construção das instituições culturais foi feita, em maior parte, por esforços privados.

Miriam Rossi descreveu a formação de um circuito artístico na São Paulo da Belle Époque, enfatizando o papel da "burguesia da República"300. São Paulo experimenta um recrudescimento de contatos com o exterior graças ao incremento na navegação a vapor e, em flagrante paradoxo, um pensamento nacionalista que prega a volta para o interior e o abandono das influências estrangeiras. $\mathrm{O}$ artigo de Rossi tem como meta fundamental rebater a crença arraigada numa suposta apatia cultural "pré-modernismo": ela defendia que, proporcionalmente, se realizavam mais exposições naquelas décadas que no momento em que redigiu seu estudo ${ }^{301}$.

Dentre os eventos considerados em seu artigo, Rossi dedica-se a analisar a Semana de Arte Moderna de 1922 no interior de seu contexto, ou seja, como um acontecimento incrustado no rol de eventos artísticos que ocorriam na Capital, situando-a como "mais uma" entre as exposições coletivas que se desenrolavam. 1922 foi um ano simbólico carregado de mudanças: aparece a oposição dentro do acordo oligárquico da República Velha; emergem as primeiras confrontações sérias entre militares e governantes civis; funda-se o Partido Comunista. E tudo isso num ano carregado do simbolismo atribuído

\footnotetext{
${ }^{300}$ ROSSI, Mirian Silva. Circulação e mediação da obra de arte na Belle Époque paulistana. São Paulo: Anais do Museu Paulista. vol.6-7 no.1 São Paulo, 1999, editado em 2003. p. 83-119.

${ }^{301}$ Entre as diversas fontes empregadas para corroborar esse dado, em grande parte recolhidas em notas sobre arte nos jornais da época, Rossi apresenta um testemunho do próprio Menotti del Picchia, em que este reconhecia a efervescência do campo artístico em São Paulo, em discurso proferido em 1911: "[...] o anseio artístico que agita o país, a preocupação estética e curiosa que atulha as exposições, o clarinar das nossas seções de arte anunciando nomes de pintores e escultores nacionais e estrangeiros, todo esse levedar de cousas de espírito deve dar o que pensar aos nossos sociólogos" (apud. ROSSI, p. 86).
} 
ao centenário da Independência. A Semana estava na lista oficial de eventos comemorativos da efeméride. A opinião de Rossi sobre a Semana:

Patrocinada pelos mais importantes protagonistas da elite dirigente, a Semana de Arte Moderna teve pouco de moderno, e nada na sua realização pode ser entendida como uma reação ao status quo, como as propostas do grupo pretendiam. Esteve longe, ainda, de atingir a "independência mental brasileira através do abandono das sugestões europeias". As obras dos principais participantes da Semana, como Victor Brecheret, Anita Malfatti, John Graz, Zina Aita e Vicente do Rego Monteiro estavam impregnadas das influências estrangeiras, adquiridas durante seus aprendizados na Europa ${ }^{302}$.

Tadeu Chiarelli também procurou desmontar a visão canônica sobre o cenário cultural paulista pré-1922, numa busca que terminava por reenquadrar o significado do evento modernista. Para ele, críticos e historiadores da arte dedicaram um olhar enviesado a esse cenário cultural "pré-moderno": "foram unânimes em considerá-lo 'paupérrimo', 'rarefeito' ou mesmo 'indiferente' às novas propostas artísticas" ${ }^{303}$. Isso se teria dado, segundo o autor, porque se basearam quase exclusivamente nos testemunhos dos artistas e intelectuais modernistas.

Ao contrário deles, Chiarelli sugere que se veja a cidade como palco de um cenário artístico vivo, e que esta mesma vida seja vista como responsável por 1922: a semana deve ser entendida como "um elo" nessa cadeia de exposições que aportavam na cidade, e o modernismo, "a ampliação de um debate artístico já instaurado na cidade nos anos que antecederam a Semana"304. A Semana de 1922 - cuja importância como "marco principal da arte moderna no Brasil" Chiarelli reconhece - teria sido um evento que prolonga a tradição sustentada pela elite local, realizadora de diversas exposições nos anos anteriores. Há, defende, uma clara continuidade entre estes eventos "revolucionários" e aqueles que eles vêm, alegadamente, substituir. Nas palavras do autor,

Esse caráter oficial da Semana de Arte Moderna de 1922 reafirma, portanto (ao invés de inaugurar), o desejo de segmentos da elite paulistana de dinamizar o ambiente artísticocultural da cidade, sem se importar com o teor estético e/ou ideológico do evento patrocinado. Para Paulo Prado e seus amigos, ao que parece, tanto fazia concorrer para a viabilização de uma mostra de arte francesa de caráter eclético, como a de 1919, como para o 'festival modernista' de 1922, tão eclético, aliás, quanto o evento que o precedeu em três anos ${ }^{305}$.

\footnotetext{
302 ROSSI, 1999, p. 96.

${ }^{303}$ CHIARELLI, 1995, p. 64.

${ }^{304}$ CHIARELLI, 1995, p. 64.

305 Idem, p. 54.
} 
De todo modo, a Semana de Arte Moderna provocou uma grande polarização entre os que pensavam e escreviam sobre arte no Brasil. Logo se formaram dois campos antagônicos que travaram memoráveis polêmicas, empregando como veículos as páginas dos periódicos de São Paulo e do Rio de Janeiro. Neste segmento, são analisados os textos produzidos a propósito da Semana de Arte Moderna de 1922 reunidos e organizados na publicação " 22 × 22"306. Procura-se demonstrar alguns padrões argumentativos que foram se solidificando nos textos dos detratores dos modernistas, formando recorrências que, reunidas, se aproximam de uma doutrina antimodernista. Ao longo das semanas que antecederam o evento modernista, nos dias seguintes às sessões no Teatro Municipal e ainda naqueles que as sucederam, apareceram manifestações em que vão se decantando algumas acusações recorrentes. Algumas delas remetem aos argumentos que Max Nordau empregara em sua investida contra a arte moderna, no século XIX.

A primeira característica que salta dos textos, tanto daqueles escritos pelos promotores da Semana quanto de seus algozes, é uma certa indefinição de categorias. Seriam eles futuristas? Seriam apenas "modernos"? A discussão sobre os rótulos a serem empregados, inclusive pelos próprios modernistas, ocupava grande espaço nesse momento inicial, marcado por certa indefinição conceitual ${ }^{307}$. Oscar Guanabarino patenteia essa incerteza quanto ao conteúdo do movimento, afirmando que "não se define, não estabelece princípios, não esclarece qual seja o rumo que essa pretensa arte moderna deve tomar. $\mathrm{O}$ que temos lido até agora é uma reunião de frases sonoras, retumbantes, sem sentido, sem seriedade, sem fé e sem crenças"308.

Os críticos mais bem-informados, como Cândido (Salisbury Galeão Coutinho) tomavam a sério o termo "futurista" com o qual se apodava os modernistas. Cândido começa suas elucubrações sobre a próxima Semana de Arte Moderna explicando didaticamente o movimento de Marinetti e companhia. A primeira medida de Mário de Andrade ao rebater Cândido (os dois protagonizariam uma sucessão de réplicas e tréplicas na coluna "Notas de Arte" da Gazeta) foi de rechaçar a pecha de futurista. O crítico levou ainda algum tempo fazendo referências aos textos de Marinetti, procurando analisar as

\footnotetext{
306 BOAVENTURA, 2000.

307 O relacionamento entre Mário e Oswald de Andrade ficou abalado quando Oswald tachou publicamente Mário de "futurista"; como é bem sabido, Mário se ressentiu a ponto de vir a público renegar a pecha (GONÇALVES, 2012, p. 239-240). Claudia Valladão de Mattos, em “Lasar Segall” (1997, p. 41), demonstra que os críticos que escreveram sobre a exposição paulistana do russo em 1924 não estavam familiarizados com o expressionismo, e diante de uma arte que reconheciam como "moderna", empregavam termos como "futurismo" ou "cubismo".

308 Apud BOAVENTURA, 2000, p. 291.
} 
dissidências dos italianos e a formação de facções futuristas até perceber que os modernistas desejavam fazer um uso apenas metafórico do termo futurismo, uma espécie de contraponto ao igualmente indefinido "passadismo".

Outra acusação recorrente endereçada aos modernistas era de que não traziam nada de realmente novo. Lima Barreto incorreu neste argumento em seu comentário ao movimento dos paulistas. Para ele, assim como para muitos outros algozes da Semana, a atitude de combater o "velho" era, ela mesma, "velha" e, portanto, os jovens paulistas nada de novo propunham. "Uma corrente estética que propõe uma revolução", escrevia o misterioso F. em 10 de fevereiro de 1922, estaria apenas plagiando "atitudes de guerreiros que o antecederam"309. Não se justificaria portanto, para Pauci Vero Electi, que eles carregassem como lema "A originalidade - A independência - A personalidade!"310.

Muitos lamentavam que os modernistas pregassem o abandono das tradições acumuladas. $\mathrm{O}$ ataque aos "maiores nomes da história artística de nosso país"311 instilava o ódio em parte da crítica. A defesa dos velhos heróis é uma constante nos textos dos críticos dos modernistas. O ataque a Carlos Gomes foi o motivo declarado da série de artigos escritos por Oscar Guanabarino. A própria Guiomar Novaes, participante da Semana, manifestou publicamente o desagrado com o tratamento satírico dado a Chopin. Em geral, os críticos condenavam os "apedrejadores atrevidos" ${ }^{312}$, que desrespeitavam a tradição e desejavam fazer tábula rasa da cultura, procurando apagar contribuições consideradas valiosas dos mestres do passado. Num texto publicado n'A Gazeta em 16 de fevereiro de 1922, Clodomiro Santarem lamentava a abolição das regras da estética, o que considerava prejudicial já que elas se provavam proveitosas: sem as "golilhas" e "argolões de ferro", "livre das peias que a tolhiam" ele vaticinava que em breve a arte se esgotaria, tornando-se impotente e inerme. "A arte vive da coerção, movimenta-se na luta, morre de liberdade" ${ }^{313}$. "Acabarão por não querer mais o mármore para a estatutária, as tintas para a pintura, a que darão solene pontapé; como já estão dando, no som, para a música" ${ }^{314}$.

Uma acusação recorrente brandida contra os modernos, que ecoava a admoestação feita por Max Nordau já em 1892, é a de que desejavam roubar para si as funções da

\footnotetext{
${ }^{309}$ Apud BOAVENTURA, 2000, p.204.

${ }^{310}$ Apud BOAVENTURA, 2000, p. 249.

${ }^{311}$ Ataka Perô apud BOAVENTURA, 2000, p. 306.

312 Idem apud BOAVENTURA, 2000, p. 310.

313 Apud BOAVENTURA, 2000, p. 225.

${ }^{314}$ Anônimo apud BOAVENTURA, 2000, p. 240.
} 
crítica e da história da arte. Segundo os algozes dos modernos, caberia à crítica e à história da arte rotular, qualificar, apontar características dominantes e recorrentes de um determinado momento cultural, e tais atividades deveriam ser realizadas a posteriori. Os antimodernos demonstravam desconforto com o fato de os próprios artistas criarem narrativas para si e para suas manifestações, voltando as costas para as antigas instâncias de consagração. É o que se lê, por exemplo, em texto de P.B.C. publicado n'A Cigarra de 15 de julho de 1922. O autor solicita ao artista que tenha a humildade e a paciência de aguardar a consagração em silêncio, a ser concedida pela "crítica sensata", pela "justiça da posteridade" 315 . Juntava-se a essa acusação a argumentação - também anteriormente já acionada por Nordau - de que verdadeiros espíritos criadores jamais aceitariam o jugo da escola: o autêntico artista não transige com limitações impostas por uma doutrina.

A essas considerações sobre o modus operandi dos modernos, que os seus algozes consideravam parte de um esquema autocelebratório, uniam-se acusações repetidas de "cabotinismo" - termo bastante empregado para qualificar a Semana de Arte Moderna. Acusava-se os modernistas de desejarem a celebridade a qualquer preço; qualificava-se sua atuação de "cabotinismo impenitente"316, de "cavação". Seriam "ruidistas", para F. ${ }^{317}$, ou ainda, uma “[...] horda que escalava aos berros o caminho estrelado do Olimpo", nas palavras de Pauci Vero Electi ${ }^{318}$.

Os críticos insistiam na acusação de insuficiência técnica: seriam pseudo$\operatorname{artistas}^{319}$. Pauci Vero Electi afirma que Anita Malfatti não dominava os elementos básicos da pintura ("harmonia, cor e perspectiva" 320 ). O rótulo de "moderna" que assumiu, afirma o crítico, seria um subterfúgio para continuar pintando sem a posse das competências básicas exigidas de um artista tradicional. Adicionam a essa constatação a acusação de que os modernos têm consciência de sua incapacidade mas, cometendo "um verdadeiro estelionato" ${ }^{321}$, tentam iludir o público com suas farsas. Acusam-nos ainda de incorrer em "piratagem artística" ${ }^{322}$, plagiando os mestres do passado. O próprio evento que promoveram teria sido uma "imitação grotesca do Salon des refusées" de $1863^{323}$.

\footnotetext{
315 Apud BOAVENTURA, 2000, p. 320.

316 Pauci Vero Electi apud BOAVENTURA, 2000, p. 250.

317 Apud BOAVENTURA, 2000, p. 235.

318 Apud BOAVENTURA, 2000, p. 270.

${ }^{319}$ Apud BOAVENTURA, 2000, p. 250.

${ }^{320}$ Apud BOAVENTURA, 2000, p. 252.

${ }^{321}$ Pauci Vero Electi apud BOAVENTURA, 2000, p. 250.

322 Idem apud BOAVENTURA, 2000, p. 269.

323 Orpheus apud BOAVENTURA, 2000, p. 281.
} 
A Semana, por sua vez, foi interpretada pelos críticos antagonistas como algo sem seriedade, um chiste, uma "grossa pagodeira"324, uma "molequeira"325, uma "blague"326 a que se dispuseram inclusive "cavalheiros de nossa nata social, transformando o palco do Municipal "numa descompassada feira livre"327. Parece tê-los irritado a ausência da solenidade que se exigia no trato com a alta cultura. Além disso, muitos afirmaram se tratar de um projeto mambembe, frouxamente articulado, reunindo numa estranha coleção eclética elementos díspares e desencontrados.

Associa-se com frequência as tendências modernas à imoralidade. $\mathrm{O}$ editorial do Estado de São Paulo em que se comentava a Semana dizia que "[n]ão lhes falece propriamente a razão; o que neles míngua e em muitos de há muito abriu o chambre - é o pudor" 328 .

Um elemento discursivo de presença destacada nas críticas à Semana de Arte Moderna de 1922 e aos seus promotores é o recurso à associação entre arte moderna e loucura. Em contundentes palavras publicadas n'A Gazeta do dia 22 de fevereiro de 1922, Pauci Vero Electi descreve o futurismo como o "extravasar" de um "abcesso" "que ameaça empestar a cidade" ${ }^{329}$. Só se curará a epidemia “com o extermínio de certos cabeças" ${ }^{330}$, tarefa a que se propõe o crítico. Em geral, é recorrente a acusação de que os futuristas ou modernistas eram loucos. Oliveira Castro cunhou interessantes neologismos para rotulá-los, como o advérbio "francodarochamente", usado para qualificar o modo de suas ações, ou nas acusações de que incorreriam em "artritismo mental" ou em "juquerismo" "331. O termo "teratologia" aparece de maneira intermitente. Enfim, acusa-se a presença de uma "peste artística"332, um "delírio coletivo" empolgando os modernistas $^{333}$, uma geração "positivamente atacada de hipotrofia mental e despida de autocefalia" 334 . Mais uma vez, como no caso de Lobato contra a exposição de Malfatti, fica a impressão de que o emprego dessa retórica psiquiátrica parece meramente metafórico, servindo mais como recurso de oratória que como parte de uma doutrina

\footnotetext{
324 Anônimo apud BOAVENTURA, 2000, p. 267.

325 Idem apud BOAVENTURA, 2000, p. 266.

${ }^{326}$ Ataka Perô apud BOAVENTURA, 2000, p. 305.

327 Anônimo apud BOAVENTURA, 2000, p. 266.

${ }^{328}$ Apud BOAVENTURA, 2000, p. 259.

${ }^{329}$ Apud BOAVENTURA, 2000, p. 249.

${ }^{330}$ Apud BOAVENTURA, 2000, p. 249.

${ }^{331}$ Apud BOAVENTURA, 2000, p. 232.

332 Apud BOAVENTURA, 2000, p. 249.

${ }^{333}$ Ataka Perô apud BOAVENTURA, 2000, p. 305.

${ }^{334}$ Idem apud BOAVENTURA, 2000, p. 307.
} 
lógica e consequente. De todo modo, o contato com as ideias de Max Nordau transparece no texto dos críticos da Semana de Arte Moderna.

Toda essa crítica, que seria inscrita no lado do derrotado, no julgamento posterior da história, revelou-se paradoxalmente benéfica ao movimento modernista. Os opositores da Semana erraram na interpretação da vaia (da qual eles mesmos fizeram parte). Acreditavam que ela sinalizava o fracasso do empreendimento. Comemoravam o fato de que a sociedade de São Paulo reagira com ruidosas pateadas diante da suposta tentativa de achincalhar a cultura promovida pelos modernistas: “[...] a vaia era necessária como uma tumultuosa cerimônia de desagravo", "a vaia monumental que desagravou a verdadeira arte" 335 .

A vaia, conforme suspeitavam os redatores do Estado de São Paulo, foi propositalmente estimulada pelos próprios modernistas. Depois de uma segunda-feira inicial morna, cuja única queixa se devera à sua excessiva duração, os modernistas teriam plantado uma claque entre os espectadores para que puxassem o coro de vaias ${ }^{336}$. Foi justamente a ausência de manifestações violentas de contrariedade, na Exposição de 1913 de Lasar Segall no Brasil, que fez com que ela passasse em brancas nuvens. A falta de vaia fez com que, na opinião de historiadores do modernismo ${ }^{337}$, ela não pudesse ser considerada a primeira exposição de arte moderna do Brasil, título que ficou com a de 1917 de Malfatti, descomposta por Monteiro Lobato.

As críticas à Semana recolhidas por Boaventura, exceto por alguns casos, são reativas, e não propositivas, desejam enxotar as propostas consideradas esdrúxulas,

\footnotetext{
335 Oscar Guanabarino apud BOAVENTURA, 2000, p. 294-295.

${ }^{336}$ Na seção "Artes e Artistas" do dia 16 de fevereiro de 1922, o redator declara-se na dúvida se a vaia fora "[e]spontânea manifestação da galeria ou claque de novo gênero" (apud. BOAVENTURA, p. 445); Menotti del Picchia, em seu relato biográfico, confirmou a claque e registrou inclusive os nomes dos membros desse grupo infiltrado pelos próprios organizadores para garantir aquilo que eles sabiam ser necessário para o coroamento do evento: "uma violenta reação do público" (apud GONÇALVES, 2012, p. 316); carta de Mário de Andrade a Menotti publicada no mesmo volume de memórias, demonstrava a total consciência dos organizadores da Semana sobre o papel da vaia no processo de consagração: "Vaiaram-nos, mas o público já está acostumado com descomposturas: não leva a sério. O que fica é o nome e um sentimento de simpatia que não se apagam mais da memória do leitor. Estamos célebres! Enfim! Nossos livros serão lidíssimos! Insultadíssimos, celebérrimos. Teremos nossos nomes eternizados nos jornais e na História da Arte Brasileira" (apud GONÇALVES, 2012, p. 342).

${ }^{337}$ Nas palavras de Paulo Mendes de Almeida: "O certo é que a exposição de Segall, em 1913, não produziu aquele impacto, que as inovações subversivas soem provocar. A própria crítica indígena, conservadora como era, e reconhecendo, embora, o que havia de diferente em sua pintura, foi-lhe tolerante, compreensiva" (ALMEIDA, 2014, p. 21). Já a exposição de Anita, segundo o mesmo Almeida, graças aos ataques que sofrera, "determinou a tomada de consciência nacional de um problema que, até então, não fora sequer equacionado entre nós" (idem, p. 23), congregando em torno da causa do modernismo pessoas que estavam ainda dispersas em suas buscas individuais.
} 
ofensivas, imorais, ridículas etc., atendo-se a um vago apego à “tradição", nem ela mesma bem definida nos textos.

Tânia de Luca apontou o caráter renovador de duas gerações brasileiras, as de 1870 e de 1922. Cada uma a seu tempo, afirma, atuou em meio a cenários de crise e ruptura, em que as convicções são colocadas sob escrutínio, abrindo espaço para a busca de uma redefinição dos parâmetros da sociedade:

"Na historiografia brasileira a geração de 1870, assim como os integrantes de 1922, estão particularmente associados às ideias de transformação, ruptura e modernidade: Abolição, República e Escola do Recife de um lado; tenentismo, comunismo, revolução estética de outro. Esses eventos emblemáticos, que condensam múltiplos significados e sentidos, acabaram por se tornar marcos periodizadores da nossa história"338.

A análise da crítica negativa à Semana de Arte Moderna de 1922, assim como a consideração ponderada das trajetórias de seus emissores, reforça a suposição de que se tratava ali, justamente, de um embate entre estes dois paradigmas. Os ideais estéticos caros à geração de 1870 se chocam com as propostas dos modernistas de 1922.

${ }^{338}$ DE LUCA, 1999, p. 19. 


\section{Capítulo 4 \\ Rotas alteradas: trajetórias das obras de Lasar Segall confiscadas na "Ação contra a Arte Degenerada"}

A International Foundation for Art Research - IFAR descreve a provenance de uma obra de arte como um registro cronológico de sua sucessão possessória ${ }^{339}$. Observada de outras maneiras, no entanto, a provenance pode revelar

“[...]outras variações importantes: mudança de gostos artísticos e de princípios organizativos de coleções, registro de alianças políticas e sociais e um indicador das condições econômicas e de mercado que influenciam a venda ou a transferência da obra de arte" 340 .

Vista dessa maneira mais compreensiva, a provenance oferece índices para a observação de todo um conjunto de circunstâncias que cerca a obra de arte. A partir desta abordagem, procurou-se erigir uma análise das variações nos padrões de recepção ao modernismo no período alemão de Lasar Segall. O acompanhamento das provenances de suas obras participantes da Ação contra a Arte Degenerada empreendida pelos nazistas revelou-se auspicioso para compreender os acontecimentos que atravessaram a história alemã, especialmente no intervalo que vai da ascensão da república de Weimar (1918) até o fim da Segunda Guerra Mundial (1945). A perspectiva microscópica oferecida pelo caso Segall ilumina uma série de fenômenos macroscópicos nos campos da política, da economia, da cultura, da sociedade. Neste segmento, pretende-se expor o resultado da análise das provenances das obras de Segall, articulando-as, dentro dos limites mais amplos possíveis, à constelação de fenômenos que as cercam.

As informações necessárias a esse exercício foram coligidas em 3 repositórios. A Base de Dados elaborada pela Freie Universität Berlin [Universidade Livre de Berlim -

\footnotetext{
339“ $U m$ histórico ideal de provenance oferece um registro documentado dos nomes dos proprietários, períodos em que detiveram a posse da obra e formas pelas quais a possessão foi transferida, por exemplo, por herança, pela venda através de um marchand ou leilão, e locais onde a obra foi mantida, desde o momento em que foi criada pelo artista até o momento atual. Infelizmente, registros completos e intactos como esse são raros, e a maior parte das obras de arte contém lacunas em sua provenance"; cfe. texto disponível no site da IFAR: https://www.ifar.org/provenance guide.php (acessado em 31/10/2016). ${ }^{340}$ Idem.
} 
$\mathrm{ULB}]^{341}$ foi um deles; nesta fonte, foram encontrados registros referentes a 58 obras de Lasar Segall, presentes em 8 coleções públicas, em 7 cidades diferentes ${ }^{342}$.

A "Lista Fischer" foi outra fonte importante de informações. Trata-se de dois volumes completos do inventário realizado pelos nazistas por volta de 1942, arrolando as obras confiscadas na Ação contra a Arte Degenerada. Esse material foi doado à Biblioteca do Victoria and Albert Museum em 1996 por Elfriede Fischer, viúva do colecionador Heinrich Robert "Harry" Fischer ${ }^{343}$. O documento é de grande importância para a reconstituição das provenances porque indica uma série de dados complementares, consignando os nomes dos autores e das obras, a técnica de cada uma e, o que é mais importante para o caso em questão, apontando os museus de origem dos objetos e o destino dado a cada uma das obras confiscadas ${ }^{344}$.

Para complementar os dados oferecidos pela Base de Dados da ULB e pela "Lista Fischer", recorreu-se à própria documentação do Arquivo Lasar Segall (ALS), custodiado junto ao Museu Lasar Segall, repositório que permitiu, em muitos casos, elucidar a data de aquisição das obras e determinar os responsáveis por conduzir as negociações, circunstanciando o processo ao atribuir a admissão das obras a indivíduos específicos. Um dos documentos mais importantes para este trabalho é o caderno de registro de vendas de obras, mantido por Lasar Segall desde os anos iniciais de sua atividade profissional ${ }^{345}$. Nele encontram-se dados sobre os nomes das obras comercializadas, suas técnicas, valores e os nomes dos compradores. Ao confrontar as informações desses diferentes repositórios, patentearam-se pequenas discrepâncias. Por esse motivo, pareceu

\footnotetext{
${ }^{341}$ A Base de Dados é uma iniciativa que emprega modernas ferramentas eletrônicas de gestão de informações na organização de um repositório bastante compreensivo de dados a respeito da Ação Contra a Arte Degenerada. Os pesquisadores da ULB reuniram todas as contribuições conhecidas sobre o tema, desde os primeiros relatos escritos ainda na década de 1940 até as descobertas mais recentes. A narrativa completa sobre a elaboração da Base de Dados pode ser encontrada em http://www.geschkult.fu-berlin.de/en/e/db entart kunst/geschichte/forschungsgeschichte/index.html (acessado em 14/2/2017).

${ }^{342}$ Nas seguintes instituições: Schlesisches Museum der Bildenden Künste de Breslau; Kunsthütte de Chemnitz; Staatliches Kupferstichkabinett de Dresden; Stadtmuseum em Dresden; Museen der Stadt (Museum für Kunst und Heimatgeschichte) em Erfurt; Städtische Sammlungen em Freiburg im Breisgau; Städtische Galerie em Nürnberg; Museum Folkwang em Essen.

$343 \mathrm{O}$ Victoria and Albert Museum disponibiliza versões digitais deste documento em seu endereço eletrônico http://www.vam.ac.uk/content/articles/e/entartete-kunst/ (acessado pela última vez em 14/2/2017).

${ }^{344}$ Os funcionários responsáveis pela elaboração da lista criaram uma codificação alfabética para indicar os destinos dados a cada um dos itens; dessa maneira, é possível saber as exposições das quais a obra eventualmente tomou parte, e também é possível determinar se ela foi vendida, trocada ou destruída. $345 \mathrm{O}$ caderno possui o número de tombo ALS 00021-A, com o qual será referido daqui por diante.
} 
importante apresentar todos os dados obtidos durante a pesquisa, evidenciando as diferentes contabilizações.

Após essa checagem inicial de fatos, procurou-se compreender, pelo acesso à bibliografia especializada, um pouco mais sobre os princípios e convicções que norteavam as decisões dos administradores de coleções públicas e sobre o cenário cultural e político em que eles atuaram. Como se verá, trata-se em muitos casos de militantes das correntes de vanguarda, que mais tarde seriam afastados de suas funções pelos nazistas. Suas decisões como gestores das coleções seriam questionadas e apontadas como sinais da suposta degradação da cultura sob o regime republicano, sob influência dos judeus, dos estrangeiros ou dos bolcheviques.

A observação da provenance dessas obras proporcionou dados que parecem relevantes para a compreensão do cenário cultural em questão. Ficou evidente a relação entre a República de Weimar e as vanguardas estéticas. A partir de 1918 as coleções de arte se abrem para as obras dos expressionistas. Aparece com destaque o papel de indivíduos e associações de cidadãos entusiastas da arte moderna, responsáveis por editar revistas, organizar exposições e adquirir obras com recursos próprios ou coletivos e doálas a coleções públicas. Ficou evidente também a ênfase gráfica desse momento artístico. Tanto no caso específico de Lasar Segall quanto do quadro mais geral, percebe-se um predomínio de obras sobre papel, especialmente gravuras (litografias, xilogravuras e gravuras em metal).

Essas tendências colhidas a partir do contato com as fontes determinaram a forma como foi organizada a exposição dos resultados nesse segmento do trabalho. Decidiu-se demonstrar, até onde fosse possível, a trajetória das obras de Lasar Segall que participaram da Ação contra a Arte Degenerada, desde seu ingresso nas coleções até seu destino final. Nessa exposição, reuniram-se os dados a respeito dos mediadores que participaram da trajetória das obras, bem como das instituições que as acolheram até o confisco de 1937.

Como visto, as tendências de vanguarda na Alemanha tiveram que enfrentar resistências por parte dos próprios representantes do "primeiro modernismo", como no caso dos embates entre os líderes da Secessão de Berlim e os "expressionistas" encabeçados por Emil Nolde, rejeitados no Salão de 1910.

A análise da provenance das obras de Segall demonstra que sua admissão nos museus públicos foi relativamente tardia, coincidindo, significativamente, com o período 
republicano da Alemanha. Não seria antes de 1919 que seus trabalhos passariam a fazer parte das coleções, e essa assimilação prolonga-se até 1932, às vésperas da ascensão dos nazistas. Segundo a bibliografia analisada, o caso de Segall não era desviante. Ele sinaliza um movimento geral, uma clara alteração nos padrões do universo da arte na Alemanha a partir do final do império guilhermino. Ainda que alguns artistas e grupos tenham iniciado suas atividades em um período anterior - como "A Ponte", de Dresden, em ação desde 1905 - a arte de vanguarda não teria trânsito entre o público antes dos anos finais da Primeira Guerra Mundial ${ }^{346}$. O impulso mais decidido, que levaria a arte expressionista a se firmar como a corrente principal, se daria a partir da Revolução de Novembro de 1918. Joan Weinstein dedicou um prolongado estudo à investigação das relações entre expressionismo e revolução; na obra, ela assinala a tendência entre os artistas alemães especialmente os que já vinham exercitando experimentações mais progressistas em suas obras - de se associarem à retórica da revolução.

John Willett entende a associação entre a arte de vanguarda e as revoluções políticas que emergiram nos países derrotados na Primeira Guerra como resultado de uma convergência de visões de mundo ${ }^{347}$. Modernismo e revolução política compartilhavam a crença na possibilidade de transformações positivas, rápidas e profundas. Diante dessa perspectiva, muitos dos responsáveis pelo trabalho criador assumiram a função de descobrir e apontar o caminho para essas transformações. Além disso, as revoluções proporcionaram grandes alterações no aparato cultural, liberalizando o acesso a academias, orquestras, galerias e teatros, tornando mais permeável o sistema de ensino, ampliando a concessão de subvenções a artistas. Dessa maneira, o número de produtores de objetos culturais ampliou-se, bem como diversificou-se a sua origem social. A consequente expansão na disponibilidade de produtos culturais gerou uma expansão também no público, que em breve formaria uma grande massa de consumidores. Por fim, nesse período ocorrem alterações técnicas (surgimento do cinema, do rádio, das gravações musicais) e sociais (urbanização, proletarização) que promovem uma aproximação entre a arte modernista e a cultura "popular".

\footnotetext{
346 LÖFFLER, Fritz; BERTONATI, Emilio Bertonati; von WALDEGG, Joachim Heusinger. Dresdner Sezession, 1919-1923. Munique: Galleria del Levante, 1977; s.p. FROMMHOLD também descreveu um cenário de relativa indiferença quanto às vanguardas na cidade de Dresden antes de 1918: FROMMHOLD, Erhard. Lasar Segall and Dresden Expressionism. Milano: Galeria del Levante, 1976.

347 WILLETT, John. Arte e Revolução. In HOBSBAWM, Eric J. (Org.) História do Marxismo - vol. 9. Rio de Janeiro: Paz e Terra, 1987.
} 
A partir de 1918, na Alemanha, o entusiasmo associativista entre os artistas se acirrou, e os novos grupos assumiram formas próximas à de "milícias", "modeladas diretamente naquelas de trabalhadores, revolucionários e soldados"348. Para muitos artistas, a revolução política pareceu ocasião propícia para pôr termo também à velha ordem estética. Em 1918 e 1919 os expressionistas perceberam a similaridade de interesses entre as suas propostas artísticas e os desejos dos revolucionários: "controle dos trabalhadores sobre o próprio trabalho, liberdade para gerir os seus negócios, para escolher seus próprios juris e autoridades, para obter voz decisiva nos assuntos de arte" 349 . Alguns grupos iriam além, extrapolando o mundo da arte e procurando atuar politicamente na sociedade.

Esses meses de intensa mobilização não passaram desapercebidos ao jovem Segall. A Guerra, conforme notou Cláudia Valladão de Mattos, já o expusera a novas situações existenciais que o instigaram a buscar uma nova linguagem ${ }^{350}$. Em 1916, inspirado pelas traumáticas experiências dos judeus orientais ${ }^{351}$, Segall produziria algumas gravuras que se afastavam de suas antigas maneiras pictóricas, que expôs no Salão de Outono da Associação de Artistas de Dresden ${ }^{352}$.

Mas a incursão definitiva de Segall na "nova arte" se daria a partir de seu ingresso, em dois momentos distintos, em associações comprometidas com a mudança. Primeiro, em 1917, ainda antes da Revolução, quando Segall se juntou ao Novo Círculo (Der neue Kreis), ao mesmo tempo em que, segundo Mattos, se mudava para a casa de Victor Rubin,

\footnotetext{
348 WEINSTEIN, 1990, p. 1.

349 Idem, p. 6.

${ }^{350}$ MATTOS, Cláudia Valladão de. Lasar Segall. São Paulo: Editora da Universidade de São Paulo, 1997.

${ }^{351} \mathrm{Em}$ suas memórias, Segall diria que a necessidade de dar forma visual à violência contra os judeus o forçou a abandonar a fidelidade à natureza, permitindo que a emoção ditasse as formas, distorcendo-as: "Senti que as formas da natureza nada me diziam, que apenas as formas do meu universo importavam. Veio-me o anseio de produzir uma composição, 'Pogrom'. Enquanto trabalhava, veio-me de repente um impulso de figurar as casas chorando. Senti que as casas, assim como os homens, eram testemunhas do Pogrom. Desenhei uma rua com casas tortas, e um homem que era tão alto quanto as casas de três andares. Renunciei a todas as proporções e perspectivas. Tudo isso era supérfluo. Minha experiência era muito forte, e eu necessitava me afastar de todas as regras e criar livremente" (Fragmento de texto autobiográfico escrito por Lasar Segall - ALS 05654).

352 LÖFFLER; BERTONATI; v. WALDEGG, 1977, s.p.; referências documentais a essa exposição e os títulos das gravuras aparecem num texto sem indicação de autoria intitulado "Dresdner Brief" (Correspondência de Dresden) publicado no periódico Kunstchronik Kunstmarkt - Wochenschrift für Kenner und Sammler (nr. 2, 1916/1917) - de Leipzig, 6 de outubro de 1916, à página 108. As gravuras exibidas eram “Nach dem Pogrom" (Depois do Pogrom), "An den frischen Gräbern" (Frente às sepulturas recentes) e "Die unschuldigen Opfer" (As vítimas inocentes). Para Erhard Frommhold, a seleção dessas obras pelos jurados da exposição tinha uma finalidade estratégica: seria parte dos esforços de guerra, numa "tentativa deliberada de incitar a população judaica a se rebelar contra a dominação czarista"; cfe. FROMMHOLD, 1976, s.p.
} 
"um negociante judeu, interessado por arte moderna, que possuía um círculo relativamente grande de amigos também preocupados em promover as novas tendências estéticas" ${ }^{353}$. Depois, quando em 1919 assinou o manifesto da Dresdner Sezession Gruppe 1919, tornando-se um de seus membros-fundadores.

Documentos do Arquivo Lasar Segall permitem compreender um pouco melhor a natureza do Novo Círculo. Já desde a primeira reunião ${ }^{354}$, realizada no Hotel Bristol de Dresden em 28 de abril de 1917, os potenciais associados dividiram-se em duas linhas de opinião: por um lado, aqueles que acreditavam ser necessário priorizar atividades de suporte material e fomento à nova sensibilidade (organizar exposições, levantar recursos, criar um público por meio da publicação de um periódico próprio ${ }^{355}$ ); por outro, partidários de uma associação menos pragmática, preocupados em investigar a fundo essa nova sensibilidade e desenvolver suas formas. Todos concordavam em alguns pontos: em primeiro lugar, admitiam unanimemente sentirem uma mudança nas sensibilidades. Conforme o diagnóstico de Heinrich Stadelmann, que fez a exposição inicial, "mesmo nos difíceis três últimos anos" despontavam germes de novas correntes culturais. Todos estavam também de acordo com a forma de ação da associação, evocando a metáfora dos círculos concêntricos: a proposta era que se formasse um pequeno círculo inicial, e que este desenvolvesse a nova sensibilidade e comunicasse mais tarde aos círculos mais externos. Felix Zimmermann sumarizaria a discussão, propondo a formação de uma Associação que se ocupasse do trato dessa nova sensibilidade a partir de três linhas: a Absorção (Aufnahme), por meio de exposições de arte, conferências, encenações de peças, leituras públicas de obras, proporcionando aos integrantes do círculo o contato com as novas sensibilidades; o Julgamento (Urteil), submetendo as ideias novas a uma cerrada barragem de questionamentos que purificassem-nas e as conduzissem à sua realização e o Fomento (Förderung), concentrando esforços em criar um público para a nova arte, assegurando desta forma um amparo material para sua realização. O objetivo final, em suas palavras, era constituir em Dresden "um centro de renovação intelectual”.

Em nenhum momento, nem nas discussões iniciais, nem no Programa da Neue Kreis, é consignado termo "Expressionismo". Fala-se, vagamente, em novas bases da vida intelectual, nova diretriz, nova cultura, novo espírito do tempo. Segundo Cláudia

\footnotetext{
${ }^{353}$ MATTOS, 1997, p. 122. Ver figuras 1, 2 e 3, aspectos da residência de Victor Rubin.

${ }^{354} \mathrm{~A}$ ata da reunião encontra-se no Arquivo Lasar Segall, registrada sob o número de tombo ALS 05660.

355 Hugo Zehder foi um dos que defenderam a ênfase nos aspectos financeiros do empreendimento, insistindo na necessidade da obtenção de apoiadores para essa arte nova; ele afirmaria que não interessava criar um "Clube de Debates" (ALS 05660).
} 
Valladão de Mattos, o grupo realizaria uma primeira exposição em março de 1918; Segall apresentou uma série de gravuras inspiradas em Die Sanfte ("Uma doce criatura", novela de Dostoievski) e "pela primeira vez, alcança o reconhecimento da crítica" "356.

Mas se, até então, o novo espírito de que falavam os membros do Novo Círculo tomava apenas timidamente os espaços no universo cultural alemão, acontecimentos políticos precipitariam uma grande transformação, que no final inverteria as relações de força. Em 9 de novembro de 1918 milhares de trabalhadores acorreram em massa e pacificamente ao centro de Berlim, ocupando prédios públicos e derrubando sem resistência o governo de Guilherme II. Era a Revolução. O poder cai nas mãos da esquerda alemã, que logo se fragmenta. Em dezembro, o velho SPD $^{357}$ passa a pugnar pelo estabelecimento de uma democracia parlamentar, comprometido em combater o bolchevismo e preservar a propriedade privada. A dissidência do SPD, o USPD ${ }^{358}$, rachou ao meio. Parte dele apoiava o SPD, parte o combatia. Finalmente, os Espartaquistas se consolidaram como extrema esquerda, almejando aprofundar a revolução, em busca de instaurar uma ditadura do proletariado nos moldes da Rússia. Faltava-lhes, no entanto, o necessário respaldo popular. Os Espartaquistas converteram-se oficialmente num partido em dezembro de 1918, sob a sigla KPD (Kommunistische Partei Deutschlands, ou Partido Comunista da Alemanha).

Em janeiro a fratura agravou-se, por conta da radicalização absoluta dos extremos: os Espartaquistas lançaram-se em ações revolucionárias de guerrilha urbana, tomando prédios e procurando forçar a deposição do SPD. Este lança mão de forças paramilitares

\footnotetext{
356 MATTOS, 1997, p. 123. O interesse do público por esta série se patenteia também no caderno de registro de vendas de obras (ALS 00021-A), onde Segall registra em diversas ocasiões vendas de suas tiragens para colecionadores particulares e para museus.

357 O SPD (sigla para Sozialdemokratische Partei Deutschlands, ou Partido Social-Democrata da Alemanha) aparecera, em versões preliminares, na década de 1860. Seus desenvolvimentos foram acompanhados com interesse por Karl Marx e Friedrich Engels. llegal até 1890, ingressou daí em diante na vida parlamentar alemã, e acabaria se tornando, no final do século e nas primeiras décadas do século XX, no maior e mais poderoso partido socialista da Europa. A força desse agrupamento parecia tão irresistível que o próprio Engels, em 1895, passou a acreditar que, graças a ele, não haveria mais a necessidade de revolução: "[n]ós, os 'revolucionários', os 'subversivos', prosperamos muito melhor com os meios legais que com os ilegais e a subversão. Os partidos da ordem [...] afundam-se com a legalidade que eles próprios criaram" (ENGELS apud FERRAZ, João Grinspum. Ordem e Revolução na República de Weimar. Dissertação de Mestrado em Ciência Política. Universidade de São Paulo, 2009; p. 38).

358 O USPD (Unabhängige Sozialdemokratische Partei Deutschlands, ou Partido Social-Democrata Independente da Alemanha) havia se formado em 1917, composto pela ala mais à esquerda do SPD, que se descontentou com a decisão do partido em apoiar a concessão de extensões orçamentárias para a Guerra solicitada por Guilherme II (FERRAZ, 2009, p. 39).
} 
de extrema direita, amparando-se nos Freikorps ${ }^{359}$. A luta é real e bruta. Os líderes revolucionários Rosa Luxemburgo e Karl Liebknecht são capturados e executados pelos Freikorps ainda em janeiro. A refrega segue áspera até maio, pontuada por barricadas e metralhadoras. Somente em meados de 1919 o cenário se estabilizaria, com a derrota do levante comunista e a consolidação parlamentarista do SPD, com o apoio decisivo dos industriais.

A agitação revolucionária ressoou no universo da arte. Em Dresden, os artistas organizaram-se em comitês e grupos de pressão e procuraram propor mudanças na forma como os assuntos artísticos eram conduzidos. Em janeiro de 1919, na esteira dos acontecimentos revolucionários, um grupo de intelectuais e artistas funda um novo grupo, o Dresdner Sezession Gruppe $1919^{360}$. Lasar Segall era um de seus membros originais. O objetivo da nova associação era a promoção da arte expressionista ${ }^{361}$. O Grupo estava ligado à galeria Emil Richter, com quem assinara um acordo para a exposição e venda de obras, e com a publicação "Neue Blätter für Kunst und Dichtung" (Nova Folha de Arte e Literatura), editada por Hugo Zehder. Segall integraria este grupo até sua dissolução, em 1922, permanecendo ativo mesmo depois que muitos de seus membros originais já haviam renunciado à participação ${ }^{362}$. A participação nesse grupo projetou o nome de Segall. Parte expressiva das obras que passaram a integrar as coleções dos museus públicos alemães chegou a eles no período entre 1919 e 1922, e muitas delas por intermédio da galeria Richter.

\footnotetext{
${ }^{359}$ Formados às pressas por "ex-oficiais, desempregados à deriva e jovens aventureiros ansiosos por matar" (GAY apud FERRAZ, p. 58), os Freikorps eram os mais destacados de um sem número de grupos paramilitares de direita, nacionalistas, defensores de um estado forte e centralizado, violentos e intolerantes. Os Freikorps estiveram ativos durante todo o período republicano, agindo com apoio do governo; esse grupo foi responsável por sufocar as dissidências revolucionárias e desempenhou assassinatos políticos; as SS e a SA de Hitler seriam fundadas nos moldes dos Freikorps, incorporando inclusive seus líderes, Ernst Röhm e Heinrich Himmler. Cfe. FERRAZ, 2009.

360 Um relato circunstanciado da trajetória desse grupo pode ser encontrado em WEINSTEIN, 1990, especialmente entre as páginas 107 e 160 . Weinstein encontra um significativo paralelo entre os acontecimentos políticos e culturais de Dresden e as transformações nas posturas e propostas do Grupo Secessão 1919 de Dresden: conciliador a princípio, preferindo a reforma à revolução, o grupo torna-se mais radical a partir de abril de 1919, quando o governo federal endurece o regime e cassa algumas das liberdades com que acenara aos artistas de Dresden. Entre abril e agosto, o grupo passa a manifestar uma postura mais decididamente política, assumindo uma retórica revolucionária.

${ }^{361}$ Conrad Felimüller, um de seus mais destacados membros, procurou garantir espaço para a "nova arte" no cenário cultural de Dresden, integrando-se ao Conselho de Artistas e obtendo um número maior de assentos para os representantes das vanguardas; cfe. WEINSTEIN, 1990, p. 119.

${ }^{362}$ WEINSTEIN, 1990, p. 159.
} 


\section{Obras de Lasar Segall nos museus alemães}

Neste segmento, procura-se apresentar os resultados da pesquisa sobre o momento de ingresso das obras de Lasar Segall nas coleções públicas da Alemanha. Para deixar mais clara a exposição, estruturou-se a narrativa em torno das cidades e museus em que se encontravam obras do artista.

\section{Dresden}

Lasar Segall viveu em Dresden - sem contar algumas longas ausências - entre 1910 e 1922, complementando sua formação na Academia de Belas Artes e forjando amizades com intelectuais e artistas locais (Fig. 4). Foi a partir de suas articulações com grupos de Dresden que Segall foi capaz de projetar seu nome no mundo da arte, fazendo com que suas obras chegassem a coleções públicas de outras cidades.

Em Dresden, Segall teve obras confiscadas de duas instituições públicas: do Gabinete de Gravuras (Kupferstichkabinett) e da Galeria Municipal de Dresden. Desta, a Base de Dados aponta o confisco de 21 obras, entre elas a pintura a óleo "Eternos Caminhantes" (Fig. 5). Esse montante, que equivale a quase metade de todas as obras de Segall confiscadas pelos nazistas, indica a importância da Galeria Municipal para sua carreira.

A aceitação de obras de arte ligadas às tendências de vanguarda nos museus públicos de Dresden resultou, segundo Joan Weinstein, da pressão exercida por artistas ligados a essa vertente, através de discussões realizadas em fóruns públicos, especialmente nos meses que sucederam a Revolução de Novembro. Conrad Felixmüller e Otto Lange, membros do Dresdner Sezession Gruppe 1919, lançaram uma campanha pela imprensa contra a administração da Galeria de Pinturas de Dresden (Gemäldegalerie), em julho de 1919, alegando que havia uma interdição tácita aos expressionistas, visto que até aquele momento ela não havia adquirido sequer uma única obra dessa tendência ${ }^{363}$.

Além das desvantagens pecuniárias, havia um outro problema advindo dessa interdição: a dificuldade em inserir obras nas coleções dos museus impedia o contato com o público. Segundo Weinstein, a Dresdner Sezession Gruppe 1919 tentou romper a falta de publicidade criando uma subdivisão chamada "Associação de arte dos trabalhadores de Dresden", cujas diretrizes teriam sido escritas por Lasar Segall. O objetivo seria

\footnotetext{
363 WEINSTEIN, 1990, p. 139.
} 
promover uma aproximação entre a arte do grupo e os trabalhadores, contornando o boicote dos museus públicos ${ }^{364}$.

Felixmüller e Lange chegaram a oferecer uma lista com quatro nomes para ocupar a direção da Galeria de Dresden. A resposta a esse ato foi violenta. O historiador da arte Wilhelm Junius afirmou, em texto publicado nos jornais da cidade, que o povo não desejava que seus museus se tornassem "um parque de diversões para experimentações artísticas e extravagâncias". "O povo [...] certamente emitiria julgamentos negativos [...] a respeito dos abusos patológicos e sintomas infantis de regressão da arte mais moderna e revolucionária" 365 .

A indicação de Paul Ferdinand-Schmidt para a direção do Museu Municipal de Dresden foi auspiciosa para os expressionistas, mas a falta de recursos dos museus da Saxônia, ainda mais aguda que no restante do país, reduzia sua capacidade de aquisição ${ }^{366}$. Ainda assim, a admissão de obras de Segall no Museu Municipal de Dresden se deve, em maior parte, à figura de Paul Ferdinand-Schmidt ${ }^{367}$.

\section{Dresden] \\ Staatliches Kupferstichkabinett de Dresden [Gabinete de Gravuras Estatal de \\ O Staatliches Kupferstichkabinett de Dresden é um dos repositórios de gravuras} mais importantes da Europa. Os primórdios dessa coleção remontam ao século XVII, quando os governantes da Saxônia iniciaram esforços para reunir e preservar documentos e obras de arte impressas sobre papel, acumulando-as numa instituição criada para este fim. A fundação oficial ocorre em 1720. Durante o período nazista, a coleção foi expurgada de suas recentes aquisições modernas. O que restou do confisco permaneceu

\footnotetext{
364 WEINSTEIN, 1990 p. 139; Lasar Segall chegaria a comentar, alguns anos mais tarde, suas impressões sobre esse empreendimento, em carta ao irmão Oscar: "Tu me perguntas se existem partidários da arte moderna, especialmente entre os operários, por quem demonstras forte interesse. A arte moderna tem muitos partidários; não encontrarás na Alemanha uma galeria de arte que não possua sua seção de arte moderna, e isso já é muita coisa. A temática "Arte para operários", "Arte para o povo" me ocupou fortemente por algum tempo. Isso foi há cerca de dois anos. Naquele tempo participei da fundação de uma escola " Associação de arte dos trabalhadores", mas me afastei depois de pouco tempo, não dos operários, mas da ideia de arte voltada para uma classe específica. A arte deve ser para todos! Arte não é política, arte política é uma narrativa, é agitação, é tendência, é apenas um meio para um objetivo. Arte reside na concepção, e não na narrativa" (Carta de Lasar Segall a seu irmão Oscar, 19 de fevereiro de 1923 - ALS 00486).

${ }^{365}$ Apud WEINSTEIN, 1990, p. 140.

${ }^{366}$ Idem.

${ }^{367}$ Num relatório publicado em 1921, Schmidt prestava contas de suas aquisições para as coleções sob sua responsabilidade. Além de obras de "antigos artistas de Dresden" e de impressionistas, destacava-se a formação de uma ampla seção moderna, contando com obras de Karl Schmidt-Rottluff, Paula Mondersohn-Becker, Lasar Segall, Erich Heckel, Otto Dix e outros; cfe. Jahresbericht der Städtischen Sammlungen zu Dresden vom 1 September 1920 bis 31 August 1921; ALS 05710
} 
em Dresden até 1940. Neste ano, temendo os ataques aéreos dos aliados, a coleção foi evacuada para o castelo Weesenstein, cerca de $25 \mathrm{~km}$ ao sudeste da cidade. Dessa forma, o acervo centenário escapou da "tempestade de fogo" que destruiu Dresden em 13 de fevereiro de 1945. Ao fim da guerra, o Exército Vermelho levou $90 \%$ da coleção para a União Soviética $^{368}$. Em 1958 a maior parte foi devolvida. Ainda assim, cerca de 50 mil folhas, incluindo $5 \mathrm{mil}$ desenhos, continuam desaparecidos em função das movimentações do período da Guerra ${ }^{369}$. A administração do Kupferstichkabinett manteve uma ativa política de aquisições de arte moderna, resultando num total de $537^{370}$ obras confiscadas pelos nazistas na ação contra a Arte Degenerada.

Há dados desencontrados quanto ao número de obras de Segall presentes na coleção do Kupferstichkabinett, bem como às suas datas de entrada. A Base de Dados informa serem duas as obras de Segall oriundas dessa coleção: as gravuras Zwei Schemen (Mann und Weib) (Duas silhuetas - homem e mulher-Fig. 6) - litografia e Porträt des Schriftstellers Gorelik (Retrato do escritor Gorelik - Fig. 7) - gravura em metal. A mesma Base de Dados informa que teriam sido adquiridas em 1920. A "Lista Fischer" é ainda mais econômica nas informações: aponta que de Segall foi confiscada apenas uma obra, "Porträt des Schriftstell. Corslick" (sic); informa ainda que a obra teria sido destinada ao depósito do Ministério de Propaganda e Esclarecimento do Povo ${ }^{371}$. Os registros feitos por Lasar Segall no caderno de vendas de obras, no entanto, apontam que a aquisição foi realizada em fevereiro de 1921; além disso, consigna um total de 4 obras vendidas nessa transação: as gravuras citadas na Base de Dados - Mann und Weib (litografia) e Porträt des Schriftstellers Gorelik (gravura em metal) -, e mais os desenhos "Kopf N." (carvão sobre papel) e "Drei Männer vor der Sinagoge" (bico de pena, Figuras 29 e 30) 372. Além dessa anotação, o Arquivo Lasar Segall não possui outros registros das negociações entre Segall e o Kupferstichkabinett. Durante a pesquisa, consultou-se os responsáveis pelo registro das provenances das obras do Kupferstichkabinnett, que confirmaram a presença das quatro obras mencionadas no caderno de registro de vendas. Andreas Pischel, gestor

\footnotetext{
${ }^{368}$ Numa carta do Arquivo Lasar Segall, datada de 1954, um antigo morador de Dresden informava a Segall que "todas as preciosidades da Antiken-Sammlung (Coleção Antiga) estão em Moscou, em caixas no porão, provavelmente apodrecendo" (ALS 04622, tradução de Juliana Paes).

369 Os dados históricos sobre o Kupferstichkabinett foram obtidos no site da instituição: http://www.skd.museum/de/museen-institutionen/residenzschloss/kupferstichkabinett/sammlungsgeschichte/index.html (acessado em 20/10/2016).

370 Há uma discrepância entre os números oferecidos pela Base de Dados da ULB (537) e aqueles do próprio Kupferstichkabinett (381).

${ }^{371}$ Lista Fischer, vol. 1, p. 109.

${ }^{372}$ ALS 00021-A - Caderno de registro de venda de obras, p. 25.
} 
das coleções daquela instituição, informou que as obras "Drei Männer" e "Kopf N." nunca deixaram a coleção; informou também que casos semelhantes ocorreram com outros artistas, o que revela, segundo ele, que o processo de confisco foi às vezes realizado de maneira contraditória ${ }^{373}$.

Na época em que as obras de Segall entraram na coleção do Gabinete de Gravuras, Max Lehrs dirigia a instituição. Especialista em gravuras, administrava aquela coleção desde 1883, e neste cargo permaneceu, exceto por um interregno entre 1904 e 1908, até sua aposentadoria, em 1924. Apesar de ter se doutorado com uma tese sobre a gravura do século XV na França, Alemanha e Países Baixos, Lehrs privilegiou durante sua gestão a aquisição de obras de arte de seu tempo. A seção moderna da coleção admitiu obras de Emil Orlik, Max Klinger, Karl Stauffer-Bern e Hans Thoma ${ }^{374}$. Não há, entre os itens do Arquivo Lasar Segall, cartas trocadas entre Segall e Lehrs; existe, no entanto, um registro da proximidade entre o artista e aquele diretor. Em 1920, Segall e Lehrs, além de Käthe Kollwitz, Otto Gußmann e Paul-Ferdinand Schmidt, assinaram uma convocação aos artistas, intelectuais e mecenas de Dresden, para que formassem uma liga de amparo aos artistas em má situação financeira, em meio aos tempos de crise ${ }^{375}$.

\section{Stadtmuseum Dresden [Museu Municipal de Dresden]}

No Stadtmuseum Dresden Lasar Segall possuía 21 obras, número que demonstra, como já foi dito, a importância dessa instituição em sua carreira. O Stadtmuseum acabou por se configurar numa espécie de bastião das vanguardas em Dresden. A ação contra a Arte Degenerada iria confiscar 484 obras dessa coleção, contra apenas 50 da Staatliche Gemäldegalerie Dresden ${ }^{376}$ (Galeria de Pinturas Estatal de Dresden).

A presença de Paul Ferdinand-Schmidt à frente do Museu Municipal foi certamente fundamental para a ampla aceitação de obras expressionistas. No curto período em que esteve à frente daquela instituição, entre 1919 e 1924, Schmidt priorizou aquisições de

\footnotetext{
373 Dados obtidos mediante consulta pelo portal do Kupferstichkabinnett (https://kupferstichkabinett.skd.museum/), realizada no dia 5 de dezembro de 2017.

374 Cfe. SCHWINGENSTEIN, Christoph, Lehrs, Max in: Neue Deutsche Biographie 14 (1985), p. 114 [Onlinefassung]; URL: https://www.deutsche-biographie.de/gnd116876638.html\#ndbcontent (acessado em 20/10/2016).

${ }^{375}$ Texto/circular, ALS 05713, c. 1920.

376 O baixo número de obras de arte moderna confiscadas da Galeria de Pinturas Estatal de Dresden parece comprovar a validade das acusações de Felixmüller e Lange de que seus administradores demonstravam pouco apreço pela a arte nova.
} 
obras dos artistas do Dresdner Sezession Gruppe 1919 e de outras associações expressionistas, muitas delas engajadas com as causas sociais e políticas do tempo.

Segundo Meike Steinkamp ${ }^{377}$, seu apego excessivo à arte de vanguarda desagradou as autoridades de Dresden, e ele acabou sendo afastado de suas funções, mesmo antes da ascensão dos nazistas. Seu substituto, Karl Grossmann, reuniu todas as aquisições expressionistas realizadas por Schmidt em um espaço separado na exposição, e mais tarde

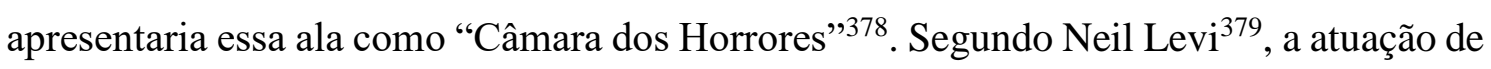
Paul Ferdinand-Schmidt à frente da coleção Municipal de Dresden seria tomada como exemplo negativo pelos nazistas, na sua ação contra a Arte Degenerada.

Muito espaço no piso térreo na exposição de Arte Degenerada [...] foi reservado para atacar o antigo diretor do Museu Municipal de Dresden, Paul Ferdinand-Schmidt. O dispositivo mais impressionante era um arranjo de pinturas confiscadas daquele museu: os quadros literalmente cercavam um texto que atribuía a Schmidt a decisão de adquirilos. As obras servem, em outras palavras, como uma ilustração de sua política de aquisições: a 'atribuição' dessas obras não a quaisquer artistas individualmente, mas ao já há muito demitido diretor do museu era um corolário à ideia de [Alfred] Rosenberg de que os artistas em si eram 'inocentes' vítimas das maquinações do mundo da arte dominado pelos judeus" ${ }^{\prime 380}$.

As primeiras aquisições das obras de Segall foram mediadas pela galeria Emil Richter. Numa carta de 19 de setembro de 1919, a Galeria informava a Segall que Schmidt havia decidido adquirir "Eternos Caminhantes" pelo valor de 4000 marcos, restando apenas aguardar a deliberação do Comitê decisório para concluir a negociação ${ }^{381}$. Em 30 de outubro, o próprio Schmidt escreveu a Segall para noticiar a decisão favorável do Comitê. Nesse documento, ele parabeniza Segall por ser o primeiro entre os adeptos da "Nova

377 STEINKAMP, Maike. Das unerwünschte Erbe. Die Rezeption "entarteter" Kunst in Kunstkritik, Ausstellungen und Museen der Sowjetischen Besatzungszone und der frühen DDR, Schriftenreihe der Forschungsstelle „Entartete Kunst", Band 2. Berlim: Akademie Verlag, 2008.

378 STEINKAMP, 2008, p. 29; Otto Dix informaria a Lasar Segall, em carta de 1927, sobre o ocaso de suas obras na coleção do Museu Municipal de Dresden: "Na Alemanha, no momento, compra-se poucas obras de arte. As pessoas ricas compram automóveis. Os nossos quadros que P. F. Schmidt comprou uns anos atrás, encontram-se no Museu Municipal num depósito. Espero que eles um dia possam festejar uma ressurreição" (Carta de Otto Dix a Lasar Segall, 6 de junho de 1927, ALS 00871; tradução de Wolfgang Pfeiffer).

379 LEVI, 2013.

${ }^{380}$ LEVI, 2013, p. 62-63. O texto sobre P. F. Schmidt presente na Exposição de Arte Degenerada de 1937 citava trecho de uma nota publicada na revista "Ararat" em 1920: "Obras da coleção do Museu Municipal de Dresden, Dr. P. F. Schmidt. Esse astuto diretor de museu com um olhar certeiro para novas aquisições elevou em pouco tempo a um alto patamar a coleção municipal de arte de Dresden"; cfe. ALTSHULER, 2008, p. 264; os organizadores da exposição esperavam certamente um efeito irônico com essa frase, que falava em seu tino colecionador justamente diante das "monstruosidades" adquiridas em sua gestão.

${ }^{381}$ ALS 00264 
Arte" a ter suas obras admitidas na coleção municipal ${ }^{382}$. Além do óleo, o museu adquiriu também, na mesma transação, três desenhos e sete gravuras de Segall. Como agradecimento, Segall presenteou Schmidt com as litografias "Homem e mulher" (Fig. 8) e "No leito de morte" 383 (Fig. 9). Segundo a Base de Dados, novos conjuntos de obras de Lasar Segall ingressaram na coleção da Galeria Municipal em 1921 e 1930.

No caso do Museu Municipal de Dresden, há certa harmonia entre as 3 fontes de informação: todas elas apresentam a mesma quantidade de obras, 21.

\section{Chemnitz}

A Kunsthütte de Chemnitz foi fundada em 1860, com a finalidade de abrigar obras de arte, sediar exposições e conferências e amparar a atividade artística da região de Chemnitz. Entre as 284 obras confiscadas pelos nazistas em 1937, 8 eram de Segall.

A entrada das obras de Segall na Kunsthütte está bem documentada, conforme pode ser visto num conjunto de itens do Arquivo Lasar Segall. As negociações, que ocorreram na mesma época daquelas realizadas com o Museu Municipal de Dresden, foram sempre conduzidas por Friedrich Schreiber-Weigand ${ }^{384}$. Elas se intensificaram entre outubro de 1919 e março de 1920, período no qual houve frequente comunicação entre o pintor e o diretor do Museu de Chemnitz. Numa carta de 29 de outubro de 1919 o diretor manifestava o desejo de adquirir obras de Segall para a coleção da Kunsthütte. Nessa altura, pelo que se apreende nos documentos, havia obras de Segall expostas naquele museu. $\mathrm{O}$ diretor comentou que a exposição atraía "um interesse extraordinariamente vívido e uma visitação grande. No domingo estiveram presentes

\footnotetext{
382 ALS 00285; tradução de Wolfgang Pfeiffer.

${ }^{383}$ ALS 00285. A relação entre Segall e Schmidt renderia outros frutos artísticos: Segall produziu o desenho "Retrato de P.F. Schmidt" (Fig. 10) e uma pintura a óleo, em 1921, em que o diretor aparece à frente do quadro "Eternos Caminhantes". Essa última obra desapareceu durante o período nazista, restando apenas reproduções fotográficas em preto e branco (Fig. 11).

384 Friedrich Schreiber-Weigand (1879-1953), filho de um dos fundadores da Kunsthütte, atuou nos museus de Chemnitz entre 1911 e 1933, quando foi afastado do cargo pelos nazistas; voltaria à chefia da instituição após a Segunda Guerra. A partir de 1922 foi diretor das Coleções de Arte Municipais de Chemnitz [Städischen Kunstsammlungen], e nesta posição erigiu uma coleção de arte repleta de obras de expressionistas. Sob sua administração, o Museu de Chemnitz se tornou uma das instituições mais fortemente comprometidas com a arte da vanguarda alemã; cfe. DUDEK, Gudrun. Friedrich Wilhelm Schreiber-Weigand - Sächsische Biografie. Chemnitz, Institut für Sächsische Geschichte und Volkskunde e.V., 2012. Disponível em http://saebi.isgv.de/biografie-druck/Friedrich Schreiber-Weigand (18791953) (acessado em 20/10/2016). Segundo Steinkamp, Schreiber-Weigand demonstrou preferência pelos artistas do grupo $A$ Ponte e privilegiou especialmente a obra de Paul Schmidt-Rottluff, nascido em Chemnitz. Schreiber-Weigand teria reservado oito salas, no andar superior do museu, para abrigar e expor obras de arte de vanguarda; cfe. STEIMKAMP, 2008, p. 30. Em retribuição aos esforços do diretor, Lasar Segall o presenteou com uma cópia da gravura "Für die Sanfte", (Uma doce criatura), cfe. Caderno de Registro de Vendas ALS 00021-A, p. 23v.
} 
cerca de 950 pessoas" ${ }^{385}$. A ocasião parece ter sido aproveitada pelo diretor como oportunidade para intermediar vendas de obras de Segall entre os colecionadores de Chemnitz, como no caso de Leopold Eger ${ }^{386}$. Schreiber-Weigand tratou também de negociar com os administradores do Museu a aquisição de obras de Segall:

O senhor Eger gostaria de adquirir a gravura "Umarmung” (“Abraço” Fig. 12), e deixou claro que não o desagrada a ideia de presentear a nossa coleção com ela. Ele não está disposto, no entanto, a pagar a soma total pedida, e especialmente, não deseja pagar a comissão de Richter. Peço ao senhor que o informe de que maneira tenciona proceder nessa negociação. Tenho muito interesse, naturalmente, em receber a gravura em nossa coleção. O Comitê de Exposição sugeriu ontem por unanimidade que as duas gravuras indicadas - "Bettler" ("Mendigo" Fig. 13) e "Am Totenbett" ("No leito de morte") - sejam adquiridas para nossa coleção. Estou seguro de que a diretoria irá concordar com essa indicação ${ }^{387}$.

Nas cartas seguintes, Schreiber-Weigand e Segall fazem referências a compradores particulares que adquiriram obras por ocasião da exposição. Na carta de 12 de novembro de 1919, o diretor da Kunsthütte de Chemnitz informa sobre diversas aquisições:

Foi finalmente decidido que aceitaremos a doação da pintura "Im Atelier" ("No ateliê", Fig. 14), feita por um admirador das artes que preferiu ficar anônimo. Além disso, a Kunsthütte irá adquirir "Am Totenbett" e "Die Bettler". Foram vendidas para colecionadores privados "Mann und Weib" e duas cópias de "Am Totenbett". A gravura "Umarmung" foi vendida para o senhor Eger, sem cobrança de comissão, e peço ao senhor que me envie uma cópia pessoalmente" 388 .

Outras duas gravuras de Segall entraram para a coleção do Museu de Chemnitz em 1922, através de uma doação feita pelo próprio artista ${ }^{389}$. A Lista Fischer apresenta 8 obras de Segall presentes na coleção da Kunsthütte, assim como a Base de Dados. Segall, por sua vez, registrou em seu caderno a venda de apenas uma delas, o óleo "Im Atelier"390.

\footnotetext{
${ }^{385}$ ALS 00290, 29 de outubro de 1919.

${ }^{386}$ Leopold Eger, negociante judeu, teria um papel importante na difusão da obra de Segall em Chemnitz. Além de colecionar suas obras, ajudou a torná-las conhecidas entre o círculo dos colecionadores locais. Como membro do conselho da Kunsthütte, organizou a exposição de obras de colecionadores privados, da qual a pintura Apachentaz, de Segall, fez parte (cfe. NITSCHE, Jürgen. Lebenswege Chemnitzer Juden Familie Leopold Eger. Manuscrito ainda não publicado cedido pelo pesquisador, 2016).

${ }^{387}$ ALS 00290.

388 ALS 00297.

389 “Acabamos de receber suas gravuras, com as quais tão generosamente nos presenteou. Eu as teria buscado pessoalmente, não fosse o clima ter tornado impossível uma visita a Dresden. Agradeço de coração o presente. Fico feliz que tenhamos recebido essas duas gravuras, que melhor comporão a modesta coleção que temos de suas obras" (ALS 00422, 27 de março de 1922); dada a presença de uma de suas cópias na coleção de Chemnitz, atestada pela Base de Dados da ULB, supõe-se que uma dessas obras doadas seja a gravura Viúva e filho, figura 22.

${ }^{390}$ ALS 00021-A, p. 23.
} 


\section{Breslau}

A cidade de Breslau, fundada no século $X$, passou pelas mãos de diversos dominadores; entre 1871 e 1945 fez parte da Alemanha. Hoje encontra-se sob o governo da Polônia.

Durante a pesquisa, ao confrontar as informações das fontes, apareceram discrepâncias nos dados que indicam haver diversos erros no registro das obras de Segall presentes neste Museu. Na Lista Fischer, percebe-se que os nazistas confundiram os nomes de Lasar Segall e Richard Seewald no momento de realizar o inventário, atribuindo a Seewald obras que são de Segall. Neste caso, o exame do caderno de registro de obras é de pouca ajuda, uma vez que se percebe que Lasar Segall não anotou as obras que vendeu ao Museu de Breslau 391

A Base de Dados desfez os equívocos, retirando do conjunto atribuído a Seewald e passando para Segall 19 obras: Im Bordell (Zwei Frauen)[No Bordel - Duas Mulheres]; Drei Negerfrauen [Três Mulheres Negras]; Zwei Frauen auf der Straße [Duas mulheres na rua]; Mappendeckel der Mappe "Erinnerung an Wilna" von Segall [Capa do álbum ,Lembranças de Vilna' de Segall]; Bübü und das Liebespaar [Bubu e o par enamorado]; Liegende [Deitada]; Drei Köpfe [Três Cabeças]; Kopf eines Matrosen und Schornsteine [Cabeça de Marinheiro com Chaminé]; Sitzende Frau mit Kaktus [Mulher sentada com cacto]; Schiff und Möwen [Navio e Gaivotas], Emigranten auf dem Oberdeck [Emigrantes no convés] e as 8 gravuras que compõe a série $B u b u^{392}$.

Há vários documentos do Arquivo Lasar Sergall que complementam as informações colhidas nas outras fontes, permitindo mapear o ingresso das gravuras de

\footnotetext{
391 De fato, o último registro do caderno é justamente "Besitz Museum Breslau" [Propriedade do Museu de Breslau, ALS 00021-A, p. 31]; o restante das folhas está em branco, o que sugere abandono da tarefa de registro exatamente neste ponto.

${ }^{392}$ No início da pesquisa, percebeu-se que a Base de Dados reiterava parte das inconsistências detectadas na Lista Fischer, atribuindo a Seewald as 8 gravuras da série Bubu. Após a análise do Catalogue Raisonné de Seewald (JENTSCH, Ralph. Richard Seewald: Das graphische Werk : Radierungen, Holzschnitte, Lithographien, Plakate, Linolschnitte. Esslingen: Kunstgalerie Esslingen, 1973) ficou constatado que este artista não havia produzido tais gravuras. Em 11 de outubro de 2016 essas informações foram submetidas aos administradores da Base de Dados ULB, em conjunto com uma solicitação de revisão nas informações. Por volta de agosto de 2018, após uma troca de mensagens, os administradores da Base de Dados retificaram as informações, atribuindo a Segall as gravuras da série Bubu.
} 
Segall que mais tarde seriam confiscadas. Esse conjunto é formado por cartas escritas por Erich Wiese $^{393}$ e seus assistentes ${ }^{394}$.

A mais antiga delas, datada de 10 de outubro de 1930, tem o seguinte teor:

"Estou de novo em casa, carregado de incontáveis impressões, e agradeço novamente ao senhor e a vossa amável esposa pelas horas agradáveis que pude passar em vossa casa. Dificuldades econômicas e técnicas suspendem por ora nossos planos de exposição. Decidiu-se por um adiamento até a primavera de 1931. Lamento por isso, especialmente por conta da impossibilidade de exibir os seus quadros, os quais me agradam sobremaneira. Em todo caso, informarei ao senhor em tempo hábil, e peço que o senhor já me envie as gravuras ${ }^{395}$ que adquiri. Para onde devo transferir a soma de 300 Marcos? Eu poderia também, em algum dos meses seguintes, expor vossas gravuras e aquarelas, caso isso não venha a coincidir com alguma de suas exposições planejadas. Seria ótimo se o senhor me enviasse as aquarelas que selecionei, assim como mais algumas gravuras e xilogravuras à sua escolha" ${ }^{396}$.

O documento mostra que Wiese esteve em Paris, onde negociou diretamente com

Segall a aquisição de gravuras e aquarelas ${ }^{397}$. Wiese não volta a falar nas aquarelas, o que leva a concluir que esta ideia não foi levada adiante. Outra carta, datada de $22 \mathrm{de}$ dezembro de 1930, também tratava da aquisição de obras:

"Por favor, não demore muito a enviar as gravuras, pois não sei por quanto tempo ainda terei os recursos com que pagá-las. Mande mais algumas outras gravuras, além daquelas combinadas, para que eu possa substituí-las de tempos em tempos. Não há nenhum mal, aliás, que tenhamos aqui uma grande seleção de seus trabalhos.

Aqui também piora a situação dia a dia, quase hora a hora. Tão quietas estão as coisas que quase não se pode mais falar em comércio de arte" ${ }^{398}$.

${ }^{393}$ Erich Wiese (1895-1972) era filho de um foguista de locomotiva. Doutorou-se na Universidade Friedrich Wilhelm da Silésia em 1920, com tese sobre os escultores de Breslau. Foi contratado como Historiador da Arte do Museu de Belas Artes da Silésia em 1925, assumindo a função de curador. Em 1929 tornou-se diretor daquela instituição. Durante sua gestão, incorporou preferencialmente obras de arte moderna à coleção do Museu, especialmente com a aquisição de trabalhos gráficos de artistas expressionistas como George Grosz e Otto Dix. Com a ascensão dos nazistas, foi afastado do cargo, em 23 de junho de 1933. Seu sucessor foi Cornelius Müller-Hofstede. Wiese mudou-se para Hirschberg im Riesengebirge. Após a Guerra, voltou a ocupar cargos em instituições públicas: em 1950 tornou-se diretor do Museu Regional de Hesse em Darmstadt, e lecionou, a partir de 1952, na Escola Técnica Superior de Darmstadt. Fonte: http://kulturportal-west-ost.eu/biographien/wiese-erich-2 (acessado em 7/10/2016). Segundo dados da Base de Dados, 943 obras foram confiscadas do museu dirigido por Wiese.

${ }^{394}$ Ver exemplares em Anexo 1.

${ }^{395}$ Wiese emprega o termo Radierung para se referir às obras adquiridas; trata-se de uma palavra que indica genericamente gravuras feitas sobre metal, sem especificar mais detalhadamente as técnicas empregadas; o Museu Lasar Segall prefere identificar mais pormenorizadamente as gravuras realizadas sobre metal, identificando-as como "água-forte", "ponta-seca" ou uma combinação das duas técnicas, como era comum nas obras de Segall.

${ }^{396}$ ALS 01300.

397 Lasar Segall viveu em Paris entre 1928 e 1932. O relacionamento de Segall com Wiese não se resumiu à aquisição de obras. Wiese intercedeu por Segall junto ao marchand Léonce Rosenberg, proprietário da galeria L'Effort Moderne que representava, naquela altura, Pablo Picasso, Juan Gris e Georges Braque, entre outros; cfe. documento ALS 01325, carta de Erich Wiese para Léonce Rosenberg, 24 de novembro de 1930.

${ }^{398}$ ALS 01338. 
A carta que segue a essa oferece dados precisos sobre a aquisição. Datada de 15 de janeiro de 1931 e assinada pelo diretor em exercício, diz o seguinte: "Confirmamos o recebimento em boa ordem das 15 gravuras que nos foram enviadas. $\mathrm{O}$ senhor diretor Wiese, que viajou há cerca de 14 dias, manifestar-se-á sobre vossa remessa quando retornar" 399 . Essa carta permite inferir que entre 22 de dezembro de 1930 e 15 de janeiro de 1931 Segall enviou de Paris a Breslau um pacote contendo 15 gravuras. Nem todas ingressaram na coleção do Museu, pois Wiese recusou algumas delas e pediu a Segall que enviasse aquelas que haviam sido selecionadas quando de sua visita ao ateliê do artista em Paris ${ }^{400}$.

Em 1932 Segall parece ter tentado fazer Wiese se interessar pela aquisição de outras de suas gravuras. A resposta de Wiese oferece uma visão dos destinos das obras de Segall em Breslau:

\begin{abstract}
"Muito obrigado pela carta do dia 11 do mês corrente, que me interessou especialmente pela descrição imparcial da atual atmosfera artística de Paris. Aqui a situação está, evidentemente, uns $1000 \%$ mais grave, e ainda que eu venha tentando energicamente há meses adquirir mais algumas de suas gravuras, não tenho tido sucesso, infelizmente, ainda mais porque atualmente é praticamente impossível fazer pagamentos a países estrangeiros. Resta a felicidade de ter adquirido em tempo hábil aquela bela série. Elas já foram expostas em duas ocasiões e despertaram grande interesse. Há pouco tive também a oportunidade de me referir a vosso trabalho numa conferência" ${ }^{" 401}$.
\end{abstract}

Esses documentos, portanto, complementam as informações colhidas na Base de Dados, que deixava em aberto a data de aquisição das obras pelo Museu da Silésia. Resta notar, a respeito das aquisições de obras de Segall pelo Museu de Breslau, que elas se deram bastante tardiamente. Ainda às vésperas da ascensão dos nazistas, Wiese aparece à frente do Museu, dando prosseguimento à tarefa de complementar a coleção de arte moderna daquela instituição. Em função disso, Segall pôde fazer chegar ao Museu sua produção mais recente, já bastante marcada, na forma, pela estética da Nova Objetividade e refletindo, em seus temas, suas experiências no Brasil ${ }^{402}$.

\title{
Erfurt
}

\footnotetext{
${ }^{399}$ ALS 01377.

${ }^{400}$ ALS 01324 (Carta de Erich Wiese a Lasar Segall, 24 de novembro de 1930).

${ }^{401}$ ALS 04442 (Carta de Erich Wiese a Lasar Segall, 26 de janeiro de 1932).

402 Em nenhum dos documentos aparecem referências aos títulos das gravuras ou descrições de seus conteúdos. Através dos dados da Base de Dados, no entanto, é possível identificar algumas delas (Figs. 15 a 19).
} 
Fundado no final do século XIX, o Museu de Erfurt (Museen der Stadt - Museum für Kunst und Heimatgeschichte) se converteu em pouco tempo num dos mais destacados repositórios de arte moderna da Alemanha. Atesta essa afirmação a impressionante soma de 1100 obras confiscadas de seu acervo na ação dos nazistas contra a Arte Degenerada. Entre elas, havia quatro gravuras de Segall. Essa imponente coleção, no entanto, não se formou pacificamente. Durante a década de 1920 ocorre o momento em que, segundo Steffen Rassloff, o Museu deixa de ser um espaço dominado pelas classes altas e se abre ao modernismo, num processo marcado por intensas disputas ${ }^{403}$.

A coleção do Museu de Erfurt teve início com a herança legada pelo pintor Friedrich Nerly, da escola romântica. Logo aumentou-se o acervo com paisagens, retratos e naturezas mortas de artistas como S. Beck, Joseph Anton Koch, Caspar David Friedrich, Paul Baum, Christian Rohlfs entre outros. Um primeiro esforço por renovação foi empreendido por Edwin Redslobs, que dirigiu o Museu entre 1912 e 1919. Historiador da arte de formação, tentou abrir o museu às novas correntes estéticas, tendo conseguido fazer chegar obras dos artistas do grupo "A Ponte" à coleção; no entanto, como assevera Rassloff, o predomínio de famílias tradicionais no Conselho do Museu impediu transformações mais profundas na política de aquisições. Somente após a Revolução o Museu tendeu definitivamente na direção expressionista, gerando forte reação. No final de 1919, o Jornal "Mitteldeutschen Zeitung" publicou um texto que acusava o museu de estar se tornando "um baluarte da anticultura e da aniquilação da arte de natureza semitamoscovita" ${ }^{\natural 04}$. O sucessor de Redslobs, Walter Kaesbach, recebeu um apoio crucial para dar continuidade à política de aquisição voltada para a arte de vanguarda: o industrial judeu Alfred Hess tomou para si o papel de incentivador desse movimento, fazendo generosas doações que permitiram a aquisição de obras de Lyonel Feininger, Emil Nolde, Ernst Barlach, Gerhard Marcks e Max Pechstein. O próprio Hess manteve em sua casa uma grande coleção de obras de arte moderna. O Museu tornou-se dessa maneira uma presa notável para a ação contra a arte moderna empreendida pelos nazistas.

As obras de Segall entraram na coleção do Museu de Erfurt de maneira indireta, sem a necessidade do contato entre o artista e os administradores da coleção. A provenance das gravuras oferecida pela Base de Dados da Universidade Livre de Berlim

\footnotetext{
${ }^{403}$ Todas as informações sobre o Museu de Erfurt são oriundas de RASSLOFF, Steffen. Die Erfurter Museen. Kulturgeschichte im Spannungsfeld von Gesellschaft und Politik. In: Stadt und Geschichte. Zeitschrift für Erfurt 18 (2003). p. 24. Disponível em http://www.erfurt-web.de/Geschichte Erfurter Museen (Acessado em 4/11/2016) ${ }^{404}$ RASSLOFF, 2003, p. 24.
} 
registra que as obras passaram à coleção do Museu em fevereiro de 1921 através de uma “oferta para membros" (Mitgliedsgabe) feita pela associação Kunstbund Hamburg.

A Kunstbund foi formada por pessoas interessadas em divulgar as novas tendências estéticas. Seus objetivos foram apresentados num "Chamado" (Aufruf) datado de $1921^{405}$ :

"Nós reconhecemos na arte nova, na forma como ela manifesta uma profunda transformação nos conceitos da literatura e das criações visuais, na forma como expõe uma nova atitude da alma e da obra, um importante conteúdo espiritual de nosso tempo, que deflagra e estimula um renascimento da essência alemã. Desejamos servir a esse movimento, para que ele se enraíze em nossa comunidade" ${ }^{406}$.

Reconhecendo as dificuldades materiais agudas por que passava o país, os autores do manifesto exortavam os amantes das artes a insuflarem ânimo no cenário artístico, impedindo que a nova sensibilidade definhasse diante da penúria. É importante notar a atuação de um grupo de não-artistas preocupados em promover a arte de vanguarda. A Kunstbund Hamburg era composta por críticos de arte, historiadores da arte, gestores de órgãos culturais, colecionadores e intelectuais. Reuniam-se para a realização de conferências (como a de Wilhelm Niemeyer intitulada "O tempo presente e a arte", ou a de Karl Georg Heise, historiador da arte e diretor do Museu de Arte e História da Arte de Lübeck, ou ainda uma ministrada por Victor Dirken intitulada "Formas expressionistas na arte do passado"), exposições de arte (xilogravuras dos artistas Karl Opfermann, von Ruckteschell, Stegemann; pinturas e gravuras de Walter Gramatté, Otto Müller, Franz Radziwill e Lasar Segall, ocasião em que os visitantes seriam guiados por Niemeyer e Rosa Schapire); saraus literários conduzidos por August Stramm e Karl Lorenz e espetáculos de teatro. Suas atividades eram realizadas na sala de leitura ou "no pequeno auditório da Escola Estatal de Artes Decorativas ${ }^{407}$. Assinavam o manifesto os diretores da Kunstbund Hamburg: Victor Dirksen, assistente da Kunsthalle de Hamburgo, Wilhelm Niemeyer, professor de História da Arte na Escola Estatal de Artes Decorativas, e Rosa Schapire.

A Kunstbund Hamburg declarava, no mesmo manifesto, a publicação de um periódico, intitulado "Kündung, eine Zeitschrift für Kunst" ${ }^{408}$. Todo associado receberia

\footnotetext{
${ }^{405}$ ALS 05718, Manifesto do Kunstbund Hamburg, c. 1921; reproduzido em Anexo 2.

${ }^{406}$ ALS 05718.

407 ALS 05718.

408 O manifesto informava que o jornal era impresso na própria oficina tipográfica da Escola de Artes Decorativas, sob direção de Johannes Schultz, e que somente esse expediente permitia a publicação em tempos de tão difíceis circunstâncias econômicas.
} 
uma cópia da publicação e, junto com cada cópia, 4 gravuras. O texto do manifesto diz que, pelas dimensões privilegiadas das folhas e pelo esmero com que cada obra era impressa, elas se constituíam em "gravuras plenamente válidas". Dessa forma, portanto, entraram as gravuras de Segall ao Museu de Erfurt (Figs. 20-23) ${ }^{409}$.

Entre os dirigentes da Kunstbund Hamburg encontrava-se Rosa Schapire, uma personagem importante para a trajetória da Arte Moderna na Alemanha e para a carreira de Lasar Segall na Alemanha. Foi através dela que Segall estabeleceu relações com a Kunstbund Hamburg, tornando-se um dos artistas contemplados pelos empreendimentos do grupo.

Nascida em 1874 na cidade de Brody, na Galícia, então sob domínio do império austríaco, Rosa Schapire descendia de uma abastada família judia. Em 1893 emigrou para Hamburgo, onde se tornou uma das primeiras mulheres a perseguir uma carreira no campo da história da arte, num momento em que a própria disciplina dava seus primeiros passos. Ao mesmo tempo, engajou-se em movimentos de emancipação feminina. Integrou também as fileiras socialistas. Graduou-se em 1902, pela Universidade de Berna, e em 1904 obteve seu doutorado, sob orientação de Henry Thode ${ }^{410}$, dedicando sua tese ao estudo de Johann Morgenstern, um paisagista do século XVIII. Após concluir os estudos, estabeleceu-se em Hamburgo, onde se tornou ativa incentivadora da arte moderna alemã. Foi uma das maiores apoiadoras das atividades do grupo "A Ponte", e desenvolveu uma relação especialmente intensa com o artista Karl Schmidt-Rottluff, de quem publicaria o Catalogue Raisoneé dos trabalhos gráficos em 1924. Em 1916, juntamente com Ida Dehmel, Schapire fundou a Frauenbund zur Förderung deutscher bildenden Kunst (Federação das Mulheres pelo fomento das Belas Artes Alemãs). O objetivo principal desse grupo era oferecer suporte material para a continuidade da produção artística num momento de extrema crise, provocada pela Guerra. A Federação concentrava seus recursos na realização de exposições e na aquisição e doação de obras de arte contemporânea para coleções públicas. Após a Revolução de 1918, com a expansão do movimento expressionista, Schapire editou duas publicações dedicadas à "nova arte", os jornais Die Rote Erde (A terra vermelha) e Kündung (Anunciação). Em 1933, quando sua produção reunida já atingia quase 200 itens (entre livros de história da

\footnotetext{
${ }^{409}$ Segundo os dados da Base de Dados, apenas as 4 gravuras de Segall entraram na coleção do Museu de Erfurt por esse caminho.

${ }^{410}$ Ironicamente, o mesmo Thode que manifestava um profundo desprezo pelas tendências modernas na arte.
} 
arte, traduções, artigos e resenhas na imprensa), sua carreira foi interrompida de modo abrupto pela ascensão dos nazistas. Ela fugiria para a Inglaterra em agosto de 1939, apenas dois meses antes do início da Segunda Guerra. Schapire faleceu em Londres em $1954^{411}$.

À frente da Federação das Mulheres, Schapire adquiriria ainda uma outra obra de Segall - o quadro a óleo Liebende (Fig. 24) - que seria doado ao Museu Folkwang de Essen $^{412}$. Schapire iria também escrever um texto sobre a arte de Segall, publicado na Kündung.

\section{Freiburg e Nürnberg}

Duas impressões da mesma gravura faziam parte das coleções da Städtische Galerie Nürnberg e da Coleção Municipal de Freiburg im Bresgau. A xilogravura "Irrende Frauen" (Fig. 25) (“Mulheres errantes”) chegou às coleções pela mesma via indireta das descritas no segmento anterior: foram parte da $4^{\mathrm{a}}$ edição anual do "Círculo dos Artistas Gráficos e Colecionadores” (“Kreis graphischer Künstler und Sammler”). O registro do contato entre Segall e esse Círculo está no documento ALS 00491, datado de 23 de março de 1923. Assinado por um preposto do grupo, o documento tem o seguinte teor:

"Caríssimo senhor Segall!

Para minha grande alegria fiquei sabendo através de [Will] Grohmann que o senhor deseja contribuir com vossa xilogravura ${ }^{413}$ "Irrende Frauen" (Mulheres errantes) para nossa próxima edição anual. Agora que Archipenko já está representado, quero conseguir também alguma coisa de Chagall, e ficaria bastante agradecido se o senhor o convencesse. A tiragem será de 295 cópias, das quais 175 deverão ser assinadas. Propomos no total o honorário de 300.000 marcos. No dia 26 estarei em Berlim e o procurarei, para que possamos combinar mais alguns detalhes" ${ }^{414}$.

\footnotetext{
${ }^{411}$ Todas as informações biográficas apresentadas neste parágrafo foram obtidas em BEHR, Shulamith. Anatomy of the woman as collector and dealer in the Weimar period: Rosa Schapire and Johanna Ey. In: MESKIMMON, Marsha; WEST, Shearer. Visions of the "neue Frau": Women and the Visual Arts in Weimar Germany. Brookfield/EUA: Scolar Press, 1995. p. 96-107.

${ }^{412}$ No documento do Arquivo Lasar Segall registrado sob o código ALS 00363 (6 de julho de 1920), Schapire informa a Segall sobre a aquisição e doação da obra. Schapire esteve pessoalmente na grande exposição individual de Segall na cidade de Hagen, onde tomou a decisão de adquirir o quadro e doá-lo. O título original dessa pintura era "Liebende" (Amantes); atualmente é conhecida nos registros do Museu Lasar Segall sob o título "Dois Seres", código de catalogação RLS 1503; a Base de Dados identificou equivocadamente a pintura "Liebende" com outra, intitulada "Zwei Schwestern" (Duas Irmãs; ver apontamentos sobre isso no caderno de imagens, Figura 24).

$413 \mathrm{O}$ autor emprega o termo "Holzstock", que se refere à matriz de madeira entalhada que gera as gravuras.

${ }^{414}$ A soma repleta de zeros oferecida pela contribuição de Segall demonstra a profundidade da crise econômica e da espiral inflacionária que assolava a Alemanha naquela altura; para fins de comparação, basta mencionar que a pintura a óleo "Eternos Caminhantes" fora vendida ao Museu Municipal de Dresden por 4000 marcos, em 1919. Como será apontado à frente, os nazistas empregariam o recurso de expor essas quantias exorbitantes, junto com as obras de arte moderna, nas exposições de "Arte
} 
A observação dos caminhos de ingresso das obras de Segall nos Museu de Erfurt, Freiburg e Nürnberg leva a uma significativa constatação. Fica aparente a característica intrínseca do expressionismo alemão que Starr Figura chamou de “ímpeto gráfico”. Por conta de uma confluência de fatores políticos, sociais, econômicos e artísticos, a arte de vanguarda da Alemanha promoveu "uma verdadeira renascença das artes gráficas" 415 . Prova veemente disso reside no fato de que cerca de dois terços das obras confiscadas pelos nazistas na ação contra a Arte Degenerada era composto por gravuras ${ }^{416}$. O caso de Segall reflete isso em escala reduzida: das 58 obras confiscadas, 49 eram gravuras.

A gravura fora a marca registrada do Renascimento alemão. No norte da Europa o crescente descontentamento com o poder da Igreja romana reorientou a produção de imagens, manifestando-se num novo gênero pictórico. No lugar dos óleos, afrescos e esculturas com os quais os peninsulares se expressavam, os europeus do norte fomentaram uma intensa produção gráfica. Artistas como Hans Holbein e Lucas Cranach, entre outros, produziram grande volume de material gráfico, carregado de ideais antiromanos. Nas palavras do historiador da arte francês André Chastel, o antagonismo entre católicos e protestantes se aprofundou de tal maneira que

se consubstanciou em duas formas de discurso pictórico completamente opostas: de um lado a tradição da monumental pintura mediterrânea em sua forma mais elevada; de outro, a popular e facilmente replicável arte da gravura setentrional, que pela primeira vez se tornava uma força importante na vida cultural e religiosa" ${ }^{417}$.

Ao longo do tempo, no entanto, a gravura havia se tornado uma linguagem marginal. No final do século XIX era vista como prática secundária, empregada para reprodução em série por parte de "artistas retrógrados" 418 . Os membros do grupo A Ponte estariam entre os primeiros a retomar seriamente a gravura, elevando-a novamente aos patamares de respeitabilidade do passado. Era um meio que servia aos desígnios artísticos daquela geração, pois tal linguagem

Degenerada", nos anos 1930 e 1940, como forma de suscitar a indignação diante de gastos aparentemente exagerados com "arte degenerada".

415 FIGURA, Star. German Expressionism: the graphic impulse. In: FIGURA, Star (Org.). German Expressionism: the graphic impulse. New York: The Museum of Modern Art, 2011; p. 10.

${ }^{416}$ Segundo dados da Base de Dados, foram confiscadas 11033 obras classificadas na categoria genérica "gravura" (Druckgraphik), contra 1990 pinturas (Gemälde), 1188 desenhos (Zeichnung), 1547 aquarelas (Aquarell), 256 esculturas e números menores de outras linguagens (fotografias, mosaicos, têxteis, livros etc).

${ }^{417}$ CHASTEL apud HAY, Denys. Review: The Sack of Rome, 1527. by André Chastel. In: Renaissance Quarterly, vol. 37, no 2. University of Chicago, 1984. p. 247-250, 1984, p. 248

${ }^{418}$ FIGURA, 2011, p. 13. 
“[...] engendra um senso de liberdade experimental. Para os pobres artistas jovens, era um meio menos dispendioso de produzir e desenvolver suas habilidades em comparação com a pintura e, como o desenho, oferecia um imediatismo e uma intimidade que a pintura não alcançava" ${ }^{419}$.

O potencial propagandístico da gravura, explorado durante o século XVI pelos agentes da Reforma Protestante, também serviu aos expressionistas alemães. Com estes, a gravura reencontrava sua vocação e voltou a servir como uma linguagem da luta contra um estado de coisas. Os artistas d'A Ponte foram os primeiros a adotar a prática de enviar cópias de suas gravuras aos "membros passivos", forma como se referiam aos apoiadores. A gravura é uma arte dotada de poder volante: foi assim que as obras de Segall, sem a intervenção do artista ou dos negociantes ligados a ele, chegaram aos museus de Erfurt, Freiburg e Nürnberg ${ }^{420}$.

O "ímpeto gráfico" da vanguarda alemã ocorre em paralelo ao fenômeno da massificação e mercantilização da cultura, do qual a produção e venda de gravuras a um círculo mais amplo de admiradores das artes fazia parte. Christine Haug, em estudo sobre o papel das grandes lojas de departamento na mediação entre arte e público ${ }^{421}$, aponta a atuação de grandes grupos comerciais, como o Wertheim, no ramo editorial, colocando no mercado uma grande quantidade de livros a preços baixos e, mais tarde, estabelecendo seções de arte onde se comercializa preferencialmente obras gráficas acessíveis a um grupo maior de clientes ${ }^{422}$. Essa expansão do mercado de gravuras promove a confluência

\footnotetext{
${ }^{419}$ FIGURA, 2011, p. 12.

${ }^{420}$ Cabe notar que o caráter volante das gravuras expressionistas fez com que sua disseminação se expandisse pelo mundo. Mário de Andrade, na São Paulo dos anos 1920, era colecionador de publicações de arte alemãs. Dizia já conhecer a obra de Segall desde antes de se encontrar pessoalmente com ele, através dessas publicações. A propósito da exposição de Segall realizada em 1924, Mário escreveu que "[...] há muito que eu seguia nas revistas e jornais esse interessantíssimo artista que é Lasar Segall"; ANDRADE, Mário de. Pintura - Lasar Segall. In: MILLER, Álvaro et alii. Lasar Segall; antologia de textos nacionais sobre a obra e o artista. Rio de Janeiro: Funarte/Instituto Nacional de Artes Plásticas, 1982. p. 19. Notar que Mário de Andrade possuía uma cópia da gravura "Mulheres Errantes" em sua coleção de arte, bem como de outras gravuras de Segall publicadas originalmente em álbuns ("Die Sanfte" e "Erinnerung an Wilna"). O contato de Andrade com publicações alemãs sobre arte - muitas delas tratando da trajetória de Lasar Segall - foi minuciosamente analisado na pesquisa de PAULA, Rosângela Asche de. O Expressionismo na biblioteca Mário de Andrade: da leitura à criação. Tese (Doutorado) em Literatura Brasileira, USP/FFLCH, 2007. No Arquivo Lasar Segall encontram-se outros indícios da chegada de publicações de arte alemãs às mãos de intelectuais brasileiros. Em carta de 26 de outubro de 1927, Manuel Bandeira comentava que já conhecia algumas obras de Segall, "o seu autorretrato, da Galeria do Sr. Siegfried Meyer, e reproduções estampadas na revista "Kunst und Dekoration" (ALS 00900).

421 HAUG, Christine. "Die Illusion der Einmaligkeit einer Ware". Warenhäuser als kulturelle Erfahrungsräume und Vermittler populärer Kultur um 1900. In: HAUG, Christine; MAYER, Franziska; PODEWSKI, Madleen (Org.). Populäres Judentum - Mediem, Debatten, Lesestoffe. Tübingen: Max Niemeyer Verlag, 2009. p. 85-102.
}

${ }^{422}$ HAUG, 2009, p. 98. 
dos interesses das associações de artistas - que jamais ocultaram suas motivações pragmáticas - com os grupos comerciais. Após 1918, aparecem diversas publicações dedicadas a oferecer itens gráficos colecionáveis a preços acessíveis. Marca esses empreendimentos, além dos interesses comerciais, um certo senso de dever pedagógico para com o desenvolvimento estético do público. É nesse cruzamento de arte, comércio e pedagogia que se funda, em 1921, o Círculo dos Artistas Gráficos e Colecionadores, ligado à editora de Arndt Beyer, sediada em Leipzig ${ }^{423}$. Esse Círculo, como visto, fez circular gravuras de Segall que chegaram a coleções de museus públicos e que seriam, mais tarde, confiscadas pelos nazistas.

\section{Essen}

Do Museu Folkwang em Essen, duas pinturas a óleo de Segall seriam confiscadas: a já citada "Liebende" e o quadro "Witwe"424 (Viúva - Fig. 26).

Fundado em 1902 na cidade industrial de Hagen, o museu já nasceu com a intenção de abrigar a "arte nova", e por isso se tornou um dos mais importantes centros modernistas da Alemanha. Fundado por Karl Ernst Osthaus, que empregou capital oriundo de uma herança, o museu foi pioneiro na Alemanha na exibição pública de obras de Cézanne, Gauguin, van Gogh e Matisse. Após a morte do fundador, entusiastas da arte da cidade vizinha de Essen, reunidos numa associação, adquiriram o conjunto de obras reunidas por Osthaus e o fundiram com a coleção de arte da cidade de Essen, que se iniciara em 1906. Tanto Osthaus quanto Ernst Gosebruch, diretor da coleção de arte de Essen e, depois da morte do primeiro, também do Museu Folkwang, acreditavam na necessidade de fomentar a vanguarda artística da Alemanha como forma de dar vazão a um novo domínio estético, algo que acreditavam se harmonizar com o espírito modernizador da Westfália também no terreno da economia ${ }^{425}$. Essa orientação modernizante do Museu o tornou presa preferencial da ação contra a Arte Degenerada. Segundo dados oferecidos pelo próprio Museu, cerca de 1400 obras foram confiscadas de sua coleção ${ }^{426}$. Grande parte delas se perdeu definitivamente, mediante a política de

\footnotetext{
${ }^{423}$ HAUG, 2009, p. 100

${ }^{424}$ A pintura a óleo "Viúva" é citada, na Base de Dados, como tendo entrado na coleção do Museu Folkwang em 1928; há documentos do Arquivo Lasar Segall que invalidam esse dado. Em especial, uma anotação realizada pelo próprio artista no caderno de registro de vendas (ALS 00021-A). Na página 25, aparece a entrada "Foram vendidas na exposição de Hagen as seguintes obras"; entre outras, encontrase "Witwe' Gemälde [pintura], 1920 - Folkwang Museum Hagen"; Segall anota que a pintura "Liebende" fora comprada pela "Federação das Mulheres pelo fomento das Belas Artes Alemãs" (p. 24v).

${ }^{425}$ A Westfália abriga, desde o século XIX, o maior parque industrial alemão.

${ }^{426}$ A Base de Dados da ULB registra o confisco de 1293 obras do Museu Folkwang.
} 
vendas instituída pelos nazistas ${ }^{427}$. O prédio que sediava o Museu foi destruído em bombardeios durante a Segunda Guerra. Após o fim do conflito, sucessivas gestões tentaram reconstituir a coleção, através de uma nova política de aquisições. Somente na década de 1970 a coleção atingiria patamares similares ao volume anterior ${ }^{428}$.

Indícios da relação entre Lasar Segall e os prepostos dos museus que se fundiriam no Museu Folkwang podem ser encontrados no Arquivo Lasar Segall. Em 1919, Karl Ernst Osthaus contatou Segall em duas ocasiões, tratando de organizar uma exposição de seus trabalhos em Hagen. Em 12 de julho, Osthaus o convidava formalmente, e em 30 de agosto agradecia o aceite do artista. Essa exposição individual no Museu Folkwang acabaria se configurando como um evento importante para a consolidação de Segall no cenário da arte moderna da Alemanha, e dela resultariam as aquisições dos dois quadros a óleo que mais tarde seriam confiscados na ação contra a arte degenerada ${ }^{429}$.

O período republicano, como visto, foi momento em que a arte de vanguarda alemã deixou a marginalidade e se tornou hegemônica. Mas, ao lado desse fenômeno, fermentava uma reação que se organizava e exercia pressão, e que acabou obtendo vitórias - ainda que fugazes - na disputa por espaço no cenário cultural. Desde o final do século XIX até a ascensão dos nazistas, mesmo que o modernismo estético obtivesse cada vez mais espaço nos museus, galerias e coleções particulares, exercitava-se uma retórica antimoderna que, com a deposição da República, gozaria de um curto predomínio.

As argumentações antimodernas de Guilherme II e Henry Thode, como visto, amparavam-se fortemente na xenofobia. Em sua retórica, as correntes estéticas modernas eram tidas por inconvenientes porque ameaçariam contaminar a cultura nacional. A noção que lia a modernidade como fruto de desvios psíquicos, tendendo assim a

\footnotetext{
${ }^{427}$ Sobre a venda de obras de arte moderna expurgadas dos museus públicos alemães pelos nazistas, ver PETROPOULOS, Jonathan. From Lucerne to Washington D.C. - "Degenerate art" and the question of restitution. In: PETERS, Olaf (Ed.) Degenerate Art: the attack on modern art in Nazi Germany, 1937. New York: Neue Galerie New York, 2014. p. 282-301.

428 Informações obtidas no site da instituição: https://www.museum-folkwang.de/de/ueberuns/geschichtearchitektur/geschichte.html (acessado em 21/11/2016).

${ }^{429}$ As pinturas foram adquiridas separadamente pelos museus de Hagen e de Essen, mas depois, com a unificação das coleções, ambas se tornaram propriedade do Museu Folkwang. O próprio Segall registraria em suas memórias o significado daquela exposição: “Um marco importante para mim foi a realização de uma exposição bastante ampla de meus trabalhos no Folkwang-Museum em Hagen, no ano de 1920. [...] Inaugurada com uma conferência de Will Grohmann, revestiu-se, tanto do ponto de vista artístico como moral, de grande significação para mim e foi até certo ponto um acontecimento na vida artística da Alemanha" (SEGALL, 1993, p. 21).
} 
compreendê-la como enfermidade, e a acusação de que algumas raças traziam uma propensão maior para a incursão nesses distúrbios seria mais desenvolvida pelas gerações posteriores de antimodernistas. Ligados à ancestral tradição reacionária, eles colocariam sobre a arte o peso de ser o meio de regenerar - ou de pôr a perder de vez - a Alemanha.

Uma figura central no desenvolvimento do discurso antimoderno embasado na concepção racial de arte foi Bettina Feistel-Rohmeder. Filha de um ativista reacionário e antissemita, Bettina fundaria em 1920 a Deutsche Kunstgesellschaft (DK - Sociedade de Arte Alemã), na mesma cidade de Dresden em que Segall e seus colegas expressionistas esforçavam-se por fazer as formas da vanguarda aceitas nos museus, galerias, coleções e compêndios de história da arte. Bettina dizia-se inspirada pelas conferências de Henry Thode. A doutrina da Sociedade era a de que a arte de um povo está integralmente ligada à raça, de forma biológica e inescapável, e que a arte moderna é antigermânica, representando uma contaminação estrangeira capaz de aniquilar a cultura nacional. Aliava a isso um violento antissemitismo e uma intransigente ojeriza à democracia. Feistel-Rohmeder afirmava a existência de uma conspiração, conduzida pelos agentes judeus infiltrados no comércio de arte e na imprensa, com finalidade de destruir o caráter nacional por meio da penetração da cultura estrangeira. Para eles, o monopólio judeu sobre os canais de distribuição e divulgação da arte forçava os artistas a se adaptarem aos seus desígnios. A Sociedade desejava criar estruturas que permitissem a aglutinação de artistas, público e críticos ligado à verdadeira essência germânica, configurando uma "arma na batalha pela alma da Alemanha" 430 .

As ideias raciais estavam em voga naquela altura e Bettina construiu o ideário da Sociedade a partir de obras de Hans F. K. Günther, Ludwig Ferdinand Clauss e Friedrich Wilhelm Prinz zur Lippe. A partir dessas leituras, concluiu que o povo nórdico representava o píncaro da evolução humana, constituindo-se nos mais avançados e civilizados humanos. Ao mesmo tempo, seriam os mais frágeis, sob a constante ameaça de conspurcação pelo contato deletério com influências exógenas. Com base nesse ideário, ela formulou que "as criações artísticas eram manifestações físicas da raça e de seu universo mental" ${ }^{431}$. Um indivíduo racialmente íntegro produziria obras que traduziriam em formas as características raciais e valores germânicos. Da mesma forma, “artistas degenerados estariam biologicamente predispostos a produzir pinturas que

\footnotetext{
430 CLIENEFLTER, 2005, p. 13. Esta obra traz uma análise bastante aprofundada das ações e ideias da DK. ${ }^{431}$ Idem, p. 19.
} 
refletissem seu aviltamento racial" ${ }^{\prime 32}$. Bettina Feistel-Rohmeder acabou produzindo uma teoria estética bastante peculiar. No lugar da reflexão, sugeria que a verdadeira conexão entre público e arte acontecia no plano da emoção, desde que houvesse uma identificação racial entre o artista e o público. Para ela, "sempre que uma obra de arte suscitava uma ressonância emocional no público, era a correspondência entre a autoconsciência racial

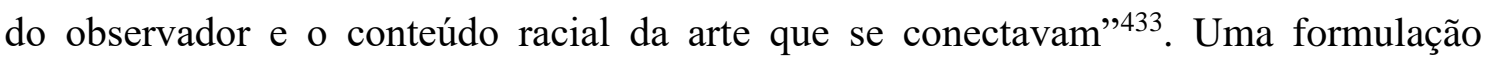
exemplar dessa ideia foi publicada em 1927:

"Como saber se uma obra de arte é alemã? Essa não é nem a primeira questão a ser tratada aqui. Ao invés disso, a questão é: você é alemão? Quer dizer, você tem a clara percepção de que tudo aquilo que nossos imortais nos legaram corre como uma torrente viva, de maneira que sua essência nada pode fazer exceto pulsar e fluir com esse rio primal? Se você for alemão dessa maneira, então você não precisa perguntar: mesmo que você se encontre diante de uma obra de arte inédita, você já saberá!" ${ }^{334}$.

Uma outra nuance da doutrina de Bettina Feistel-Rohmeder: ela defendia que as mulheres seriam biologicamente mais sensíveis que os homens, dotadas de um olhar melhor aparelhado para captar o conteúdo subjetivo de uma obra de arte. Dessa forma, estariam em melhor situação para compreender as indicações raciais presentes numa obra de arte: "A ciência e os homens investigam as teorias raciais e as organizam num sistema ordenado. Mas [...] a percepção feminina, como a percepção artística, é capaz de ver além das meras aparências e captar a verdade essencial”435.

Além de Bettina, um outro membro da DK ofereceria uma base doutrinária para a perseguição ao modernismo: o doutor Paul Schultze-Naumburg. Pintor, escritor e arquiteto, Schultze-Naumburg iniciara sua trajetória associado às Secessões de Berlim e Munique, fora um dos signatários do Manifesto dos artistas encabeçados por Paul Vinnen, em 1911, e tornou-se, após a Primeira Guerra, um cada vez mais extremado chauvinista reacionário. Publicou, em 1928, o influente "Kunst und Rasse" (Arte e Raça), feito que o levou a se tornar um dos mais requisitados conferencistas das associações de direita da Alemanha e que o conduziu às páginas do Völkische Beobachter, o principal jornal do partido nazista.

Em "Kunst und Rasse”, Schultze-Naumburg adota o jargão médico-biológico para analisar o funcionamento da arte:

\footnotetext{
432 Idem.

433 Idem, p. 20.

${ }^{434}$ Apud. CLINEFELTER, 2005, p. 20; grifos no original.

435 Idem, p. 21.
} 
"Em nenhum lugar se pode captar tão bem a cultura de um povo, num dado momento, quanto nas suas obras de arte. Nelas se manifestam as formas do meio, do vestuário, as ferramentas, ocupações, e todos os outros fenômenos, e sobretudo a corporeidade dos membros do grupo. [...] Os ideais do tempo e seus símbolos ganham ali suas formas mais claras"

[...]

É chocante que na arte alemã de hoje a representação do homem nórdico seja encontrada apenas em raras exceções, e mesmo assim, predominantemente, em versões inferiores. Características estrangeiras exóticas dominam as representações de seres humanos. Entre esses tipos, de todo modo, uma forte tendência é notada, qual seja, a de que não se procura representar os traços nobres desses tipos mas, indisfarçavelmente, aqueles do homem primitivo, assemelhando-se, com suas caras distorcidas, ao habitante animalesco das cavernas. Além disso, vemos em toda parte a preferência por uma ênfase nas manifestações da degeneração. Mesmo os eventos que se escolhe representar apontam quase sempre para um nadir físico e mental. É um verdadeiro inferno de subumanidade que se desenrola perante nossos olhos, e respira-se aliviado quando se abandona essa atmosfera e se penetra no ar puro de outras culturas, especialmente aquelas da Antiguidade e da Renascença, nas quais raças nobres lutam em suas artes para representar o que de mais elevado possuem" ${ }^{\text {436. }}$.

Diante desse quadro, Schultze-Naumburg questiona-se sobre os destinos do povo germânico. Estariam os degenerados tão profusamente disseminados entre a população que nada pudesse ser feito para impedir a contaminação? Estaria o tipo nórdico de fato num processo recessivo destinado à extinção? Para ele, em conclusão, o universo artístico que se apresentava naquela altura era reflexo dos desejos dos subumanos, e se fosse dada a "eles" a liberdade de construir o futuro, "a aparência [desse futuro] seria a mesma daquela que se apresenta em suas pinturas" ${ }^{\$ 37}$.

A contundência do texto era amplificada pela inserção de chocantes imagens de pessoas acometidas por enfermidades físicas e mentais e reproduções de obras de arte moderna, organizadas graficamente de maneira a sugerir uma conexão imediata entre arte moderna e doença (Fig.27).

A DK foi fundada na esteira da Revolução de 1918, momento em que os autoproclamados defensores dos valores tradicionais alarmaram-se com a ascensão da arte de vanguarda. Para eles, os bárbaros que por tanto tempo vinham rondando os portões, e contra os quais eles tanto vinham alertando, haviam penetrado os "jardins sagrados da cultura alemã" ${ }^{438}$. Associando-se a outros grupos com concepções similares, a DK foi capaz de realizar algumas exposições - onde apresentava exemplares daquilo

\footnotetext{
${ }^{436}$ SCHULTZE-NAUMBURG apud. LONG, 1995, p. 300.

437 Idem, p. 301.

438 CLINEFELTER, 2005, p. 25.
} 
que considerava arte racialmente pura - e pôde manter uma publicação onde defendia suas doutrinas e atacava os adversários. A influência das ideias da DK fez-se sentir durante todo o período republicano.

Quando os nazistas subiram ao poder, no entanto, os membros da Sociedade experimentaram certa frustração, porque viram que não havia interesse por parte do novo regime em adotar integralmente suas concepções a respeito da arte:

"Alguns artistas modernistas estavam inclinados a cooperar com o Terceiro Reich e havia nacional-socialistas que acreditavam que havia algo de singularmente germânico na arte daqueles modernistas que eram racial e politicamente confiáveis. O debate entre aqueles que buscavam incorporar o modernismo estético ao Terceiro Reich por meio da sua interpretação como ‘alemão' e os firmes defensores da pureza cultural atravessou o verão de $1933^{\prime 439}$.

A polarização entre os membros do alto escalão nazista quanto à política cultural se mostrou de maneira mais clara nas disputas entre Alfred Rosenberg e Joseph Goebbels. Rosenberg fora editor do Völkischer Beobachter durante a era Weimar, e liderara o braço cultural do partido, a Liga de Combate pela Cultura Germânica. Esperava reconhecimento quando da ascensão de Hitler, e ficou desapontado quando Goebbels foi nomeado para os cargos máximos da cultura do Terceiro Reich, os de Ministro da Propaganda e presidente da Câmara de Cultura do Reich. Todo artista que desejasse manter-se em atividade precisava submeter solicitação à Câmara de Cultura, o que dava a Goebbels imensos poderes sobre o cotidiano das práticas artísticas alemãs. Não bastasse ser preterido, Rosenberg era ainda obrigado a ver empossado um indivíduo que não partilhava de sua visão sobre arte: Goebbels era um dos que "acreditava que a arte moderna produzida por arianos emprestaria ao Reich prestígio e grande aceitação" ${ }^{440}$. Dessa forma, ele permitia que se mantivessem em atividade os modernistas, desde que provassem pureza racial e simpatia pelo regime. Da mesma forma, apoiava iniciativas como a da Liga Alemã Estudantil Nacional-Socialista, entidade que defendia com entusiasmo a ideia de que o Expressionismo Nórdico era a estética mais adequada ao novo regime.

O próprio Führer emitia sinais dúbios quanto a suas convicções estéticas. Apesar de condenar nominalmente dadaísmo e cubismo, reputando-os como "produtos doentios de loucos ou degenerados", típicos de estados infiltrados pelo bolchevismo, não apontava, até 1937, uma ruptura definitiva com a arte moderna in totum. O único traço recorrente

\footnotetext{
${ }^{439}$ CLINEFELTER, 2005, p. 70.

440 Idem, p. 72. Como visto, Goebbels preparava Emil Nolde para o papel de artista símbolo do Expressionismo Nórdico, que ele desejava fosse adotado como arte oficial do regime.
} 
nas ideias de Hitler a respeito da doutrina estética adequada, de acordo com as ideias expostas em Mein Kampf, residia na condenação intransigente a qualquer elemento estrangeiro $^{441}$. Num discurso do partido em 1934, proferiu a opinião de que "toda essa arte balbuciante de cubistas, futuristas, dadaístas etc. não é nem racialmente fundamentada, nem nacionalmente adequada"442. Mas no final, como notou Joan Clinefelter, a postura de Hitler até 1937 era vaga o suficiente para permitir interpretações diametralmente opostas. No discurso no Congresso do Partido em 1933, declarou que o regime não toleraria, na arte, "representantes da decadência". Tanto os defensores do Expressionismo Nórdico quanto seus algozes partidários de uma arte mais harmonizada com os antigos cânones se apropriariam dessa mesma frase para acusar o lado oposto ${ }^{443}$.

Bettina Feistel-Rohmeder, Paul Schultze-Naumburg e a DK, por seu lado, nunca tiveram dificuldades em determinar o sentido ideal da arte nacional. Em suas doutrinas, não havia nenhum espaço para tendências modernas. Desde o início, eles combatiam os partidários das vanguardas e sentiram-se bastante insatisfeitos quando notaram a indecisão do partido. Após janeiro de 1933, continuaram insistindo em suas ideias e passaram a forcejar para que o estado os assimilasse como seus agentes culturais. Bettina Feistel-Rohmeder expressou da seguinte maneira essa posição, num artigo publicado em 1933, intitulado "O que os artistas alemães esperam do novo governo":

“[...] na arte também, haverá de agora em diante apenas uma diretriz para ação, uma filosofia oriunda de uma apaixonada consciência nacional e de estado ancorada nas realidades do sangue e da história! A arte deve servir ao crescimento e ao fortalecimento dessa comunidade nacional...

Eles [os artistas] esperam não apenas que se persiga, criminalize e erradique o materialismo, marxismo e comunismo, mas que também a batalha espiritual, que os artistas nacionais sustiveram por mais de uma década sem nenhuma ajuda do estado, seja agora incorporada pelo povo como um todo e que a não-arte e não-cultura bolchevique

\footnotetext{
${ }^{441}$ Dessa forma, criticou a tendência abstracionista, que reputou como algo típico dos povos negros; empregou as onipresentes acusações contra bolcheviques e judeus, mais uma vez apontados como disseminadores de elementos dissolventes, desejando a ruína da cultura racialmente pura, e chegou a admoestar os elementos latinos ou românicos empregados para ornamentar o Reichsrat de Viena. Isso aponta que, no interior dessa lógica, era possível imaginar o modernismo "racialmente puro" ocupando o posto de arte oficial do regime.

${ }^{442}$ Apud. LORENZEN, Heidrun; STUTH, Steffen. Verfemte Moderne: Kunstwerk aus der Aktion "Entartete Kunst" der Nationalsozialisten im Kulturhistorischen Museum Rostock. Rostock: Schriften des Kulturhistorischen Museums Rostock, Neue Folge 5, 2011; p. 16.

443 CLINEFELTER, 2005, p. 72. Para Joachim Fest, a manutenção de correntes de opinião antagônicas e mutuamente excludentes no seio do partido era parte fundamental da estratégia de dominação de Hitler. Esse permanente estado de guerra entre tendências opostas servia para que o Führer pudesse suspender indefinidamente decisões concretas - o que mascarava a ausência de programas - e devolvia a ele, no final, o poder de arbitrar as disputas e, dessa maneira, manter-se acima de todos os outros elementos do regime; cfe. FEST, 2010, p. 349.
} 
sejam condenadas à destruição - de maneira que é um ponto de honra para o estado colocar os soldados já conhecidos dessa batalha cultural nas primeiras fileiras!"

Segundo Clinefelter, partiu de Bettina Feistel-Rohmeder a ideia original das exposições de arte degenerada. Neste mesmo artigo de 1933, ela expôs uma metodologia para o tratamento da arte moderna que faria escola. As etapas da ação foram detalhadamente descritas. Primeiro, os diretores de museus deviam separar e remover toda arte moderna das coleções sob sua supervisão. Deviam então exibir tais obras de maneira difamatória, com fins pedagógicos, para apontar a profundidade da degradação cultural sob o regime republicano. Ela sugeria que os nomes das autoridades responsáveis por adquirir os quadros e os valores pagos por eles fossem informados ao público. Sugeria que, após empregadas nessa propaganda, as obras fossem queimadas: "apenas uma função resta para essas obras de não-arte: a saber, como aparas para ignição do aquecimento de prédios públicos" ${ }^{\text {445 }}$. Recomendava que se demitisse os diretores de museus que haviam "pecado contra uma nação empobrecida... pelo desavergonhado desperdício de dinheiro público" ${ }^{446}$. Defendia que os nomes dos artistas ligados ao bolchevismo fossem interditados definitivamente, nunca mais aparecendo em publicações. Numa passagem nitidamente dirigida à Bauhaus, prescrevia que a arquitetura moderna fosse demolida: "blocos de apartamentos e igrejas que se parecem com estufas dotadas de chaminés ou caixas de vidro com pernas de pau" deveriam ser eliminados da paisagem nacional ${ }^{447}$. $\mathrm{O}$ mesmo fim aconselhava fosse dado às esculturas modernas. Muitas dessas diretrizes seriam fielmente seguidas nas exposições difamatórias, inclusive naquelas promovidas, mais tarde, pelo regime nazista.

Apesar da indiferença da cúpula nazista para com esse manifesto, os capítulos locais das entidades de extrema-direita adotaram as suas prescrições, dando início a um ciclo regional de exposições de arte degenerada. E, mais importante, a doutrina de Bettina Feistel-Rohmeder penetrou indiretamente nas instituições culturais, por conta de uma lei promulgada em abril de 1933. A Lei de Restauração do Serviço Público expurgou dos órgãos governamentais todos os "não-arianos" (judeus) e "politicamente suspeitos" (comunistas e socialistas). O vácuo deixado por esse êxodo foi preenchido por quadros profundamente impregnados pelas doutrinas de Bettina Feistel-Rohmeder. Membros da

\footnotetext{
${ }^{444}$ Apud CLINEFELTER, 2005, p. 65; itálicos no original.

445 Idem, p. 65.

446 Idem.

${ }^{447}$ Idem, p. 66.
} 
DK galgaram postos na administração da cultura. Mesmo sem uma política central claramente antimoderna, puderam pôr em prática suas doutrinas.

As exposições de arte degenerada organizadas por elementos locais espalharamse por toda a Alemanha: entre 1933 e julho de 1937 (quando o governo abriu a exposição oficial de arte degenerada) 22 edições ocorreram ${ }^{448}$. Embora apresentassem como "arte degenerada" elementos muitos diversos entre si - do impressionismo à nova objetividade - todas seguiam as diretrizes descritas no manifesto de Bettina Feistel-Rohmeder de abril de 1933. Os quadros e esculturas apareciam não como obras de arte, mas como documentos comprobatórios da decadência, vestígios da cultura de Weimar. Descritas em termos melodramáticos - "Schandausstellungen” [exposições da vergonha], "Schreckenskammern" [câmaras dos horrores] - já promoviam associações cheias de censura entre a arte moderna e o bolchevismo, o judaísmo e a degeneração cultural do Ocidente, formando um amálgama cultural descrito como insalubre e nocivo à "alma" germânica. Desde os títulos as exposições deixavam claras suas intenções: “Arte do Governo 1919-1933” (Karlsruhe); “O Espírito de Novembro: arte a serviço da decadência" (Stuttgart); “Arte de Dois Mundos" (Hagen); “Arte que não veio de nossa alma" (Chemnitz).

"Essas exibições acusavam os artistas de crimes contra o povo alemão e aproximavam a
arte ao comunismo, à 'conspiração judaica' e ao governo parlamentarista. As exposições
de arte degenerada ilustravam visualmente a completa ruptura com a República de
Weimar. Elas também desejavam simular a devolução da cultura germânica ao povo e a
restauração dos valores nacionais e tradicionais" ${ }^{4}$.

Como judeu, estrangeiro e expressionista, Segall não tinha nenhuma chance de ser poupado da ação contra a arte degenerada. Ele manifestou-se contra a perseguição à arte de vanguarda, publicando um texto intitulado "A arte da pintura na Alemanha" no periódico "Gegenwart”, em 12 de março de $1935^{450}$. No texto, Segall reflete sobre o papel dos pintores alemães, desde o século XVI, apontando que, em sua opinião, apenas em dois momentos eles chegaram a atingir níveis elevados em suas realizações: no próprio século XVI e "nos últimos 25 anos" (ou seja, desde 1910). Para Segall, o maior problema dos artistas alemães era que permitiam que "a forma e a linguagem da pintura" ficassem abaixo do "assunto principal", ou seja, permitiam que o "teor" - o tema - excedesse a

\footnotetext{
448 CLINEFELTER, 2005, p. 68.

449 Idem.

${ }^{450}$ O recorte do jornal encontra-se no Arquivo Lasar Segall, catalogado sob o número de tombo ALS 06252; uma tradução dele para o português, feita nessa mesma época, provavelmente por Jenny Klabin Segall, tem o número de tombo ALS 06257.
} 
pintura "cousa que a pintura em seu mais alto grau de aperfeiçoamento não admite". Apesar de serem exímios técnicos, não eram artistas, mas prosadores: descuidavam da arte em favor da narrativa.

Para Segall, os artistas da Alemanha dos últimos 25 anos conseguiram "livrar-se dos seus vícios" justamente porque estiveram dispostos a reconhecer "tudo quanto havia de original e valioso além das fronteiras". Isso, segundo Segall, não os ameaçava com a perda de personalidade, mas ao contrário, enriquecia suas realizações: "A linguagem das artes plásticas, bem como a da música, é universal. [...] Toda a arte prende-se ao solo em que nasce. Mas se ela é realmente grande e poderosa, então desconhece as fronteiras, tendo por campo de ação o universo" ${ }^{451}$. A arte alemã reorientada dessa maneira, avalia Segall, estava prestes a elevar-se a novos patamares de realizações quando, "para o seu infortúnio, surgiu o Terceiro Reich!"”.

“O artista alemão está desarraigado. Ele é obrigado a transmitir ao seu trabalho a vertigem nacional-socialista, apoiado em uma doutrina ilusória.

E a que obrigam-no a desistir? Ele deve abster-se da verdade e de toda a autenticidade artística. A fim de criar a 'arte alemã', forçam-no a menosprezar as leis da arte e a linguagem da pintura que por todos em todo o mundo é compreendida. Isto significa que o artista alemão não mais pode aprender dos outros e a eles em sua obra não mais se pode dirigir. Forçoso é assim que ele retroceda a um provincialismo prosaico e estúpido com efeitos simbólicos alheios à vida" ${ }^{452}$.

Segall já se encontrava bem longe da Alemanha no momento da ascensão dos nazistas, e estava, portanto, fisicamente fora do alcance deles. Mas sua arte não teve a mesma sorte. Todas as 58 obras que compunham coleções públicas na Alemanha foram confiscadas, entre julho e outubro de 1937. Esse é o período oficial de confisco, registrado nas provenances oferecidas pela Base de Dados da ULB. Mas algumas delas, ilustrando a dubiedade da política cultural sob os nazistas, participaram de exposições difamatórias antes daquela oficialmente empreendida, em $1937^{453}$.

De todas as suas obras confiscadas, o quadro "Eternos Caminhantes" foi aquele que mais vezes foi exibido nas exposições difamatórias. Em 9 ocasiões diferentes, a partir de setembro de 1933, a pintura foi colocada entre outras obras de arte moderna como documento comprobatório da degeneração dos tempos republicanos, vestígio da infiltração dos judeus e estrangeiros no universo das artes.

\footnotetext{
${ }^{451}$ ALS 06257, p. 3.

452 Idem, p. 3.

453 Ver em Anexo 7 a lista de exposições difamatórias do modernismo realizadas na Alemanha entre 1933 e 1941.
} 
Ela figurou numa das primeiras exposições difamatórias realizadas na Alemanha após a ascensão dos nazistas, em Dresden, no átrio do prédio da Prefeitura, que ficou em cartaz entre 23 de setembro a 18 de outubro de $1933^{454}$. Uma crítica a essa exposição foi publicada na imprensa de Dresden, um documento sem indicação de autoria que merece ser reproduzido na íntegra por trazer uma perspectiva singular sobre os dilemas da política cultural após a ascensão dos nazistas ${ }^{455}$ :

“ 'Arte Degenerada' Uma exposição em Dresden

A 'Exposição de Arte Degenerada', no átrio da nova prefeitura, vem gozando de um número incomumente alto de visitas. Na maioria das vezes, os visitantes dão a impressão de estarem vendo pela primeira vez uma exposição de arte, e é extraordinariamente instrutivo ouvir os julgamentos espontâneos dessas pessoas. Os organizadores provavelmente sabiam desde o início que as obras expostas - as quais em sua maioria foram criadas após 1918, sendo apenas algumas de antes da Guerra (Nolde, Heckel, Schmidt-Rottluff) - encontrariam resistência por parte do público mais amplo. Se o objetivo foi alcançado - instruir para que se possa diferenciar o valioso do sem valor parece incerto, quando se vê que muitos quadros totalmente inofensivos foram também assim com frequência reprovados drasticamente, por exemplo, um taciturno desenho de Paula Mondersohn-Becker, natural de Worpsweder. Fica-se tentado a supor que esses visitantes ingênuos condenariam mesmo as obras apreciadas e reconhecidas pelos organizadores, pois o ponto de vista de onde emitem seus julgamentos é o do senso comum sobre beleza e naturalidade.

Depois de 1918 em toda parte foram produzidas pinturas impertinentes, e como a municipalidade de Dresden adquiriu predominantemente obras de pintores locais, acabou incorporando algum material desviante às suas coleções. Muitas dentre elas são obras de então jovens artistas Felix Müller, W. Jakob, Chr. Voll, E. Hoffmann. Dentre estes há amostras de Otto Lange, W. Heckrott, B. Kretzschmar, P. Cassel, Mitschke-Collande, Skade, Grundig, Griebel. Alguns artistas que hoje se alinham às concepções dos organizadores certamente ficarão descontentes em ver suas obras antigas incluídas nesta exposição de arte degenerada: W. Rudolph, O. Schubert, o escultor Maskos. Fica-se tentado a pensar que, em muitos casos, a degeneração seja mera consequência da puberdade, ou produto de um tempo caótico. Este ponto deveria ser melhor esclarecido. Muitos não vão gostar de ver Walter-Kurau incluído entre os degenerados, o mesmo Walter-Kurau que mereceu a defesa por parte de um pintor reconhecidamente germânico como o Professor Lührig, que recomendou uma exposição em sua memória. Já a postura do público contra os quadros de O. Dix ("Trincheira", "Mutilados de guerra") e G. Grosz

\footnotetext{
454 Segundo dados da Base de Dados, essa exposição tornou-se itinerante, em 1935, e percorreu 13 cidades da Alemanha até 1937. "Eternos Caminhantes" foi exibida, ainda segundo dados da Base de Dados, em cinco dessas etapas (Dresden, Hagen, Dortmund, Frankfurt am Main e Nürnberg). O governo da Saxônia produziu um pequeno filme de propaganda, com duração de 6 minutos; "Eternos Caminhantes", bem como outras obras de Segall, pode ser vista nas filmagens (Zeitdokumente: Ausstellung: Entartete Kunst im Lichthof des Dresdener Rathauses).

$455 \mathrm{O}$ texto é uma tradução de documento disponível em http://sammlungonline.berlinischegalerie.de/eMuseumPlus?service=Externallnterface \& module=collection \&objectld=210 473\&viewType=detailView; o site pertence à Berlinische Galerie - Museum für Moderne Kunst [Galeria de Berlim - Museu de Arte Moderna]; o autor é desconhecido; o recorte é datado de 9-10/out/1933 e intitulado pelo site como "Entartete Kunst", [o. O.] Rezension der Ausstellung "Entartete Kunst" in Dresden, 23. September bis 18. Oktober 1933. O recorte foi coletado por Hannah Höch (artista alemã ligada ao dadaísmo), cujos arquivos foram adquiridos pela Berlinische Galerie em 1979; a maior parte dos itens da coleção foi digitalizada e está disponível para consulta on-line. A versão original deste texto foi disponibilizada em “Anexo 3" desta dissertação.
} 
é compreensível e justificada. É também justa a desaprovação a toda Abstração que se aproxima de trabalhos como os de Paul Klee ("Ao redor do peixe"), Feininger ("Gelmeroda"), Kandinsky e o suíço O. Lüthy ("Madonna"). É correta também a postura antagônica contra Nolde e "A Ponte", neste caso, por motivos estéticos. A exposição toca, neste ponto, numa questão crucial não apenas para Dresden. Serão degenerados artistas como Nolde, Kirchner, Heckel, O. Müller, Schmidt-Rottluff? Em outras partes da Alemanha elementos nacional-socialistas defendem convictamente esses pintores. $\mathrm{Na}$ exposição promovida em Berlin pela Liga dos Estudantes Nacional-socialistas foram exibidas com honras as obras de Nolde, Heckel, Schmidt-Rottluff, O. Müller. Muitos nacional-socialistas aficionados por arte veem em Nolde o heroi da arte alemã, o profeta da genuína mística nórdica. Do ponto de vista destes aficionados, seria louvável a seleção de obras do círculo d'A Ponte apresentada em Dresden: "O homem sentado" de Heckel (1913), o "Retrato de Mulher" de Schmidt-Rottluff (1913), "Os Banhistas" de O. Müller, "O Jardim" de Emil Nolde, a "Cena de Rua" de E. L. Kirchner (1926), assim como as diversas aquarelas e gravuras desses pintores. Mesmo Gerhard Marcks é hoje reconhecido em toda parte como um escultor alemão. Sobre Kokoschka ("Os pagãos") e Hoffer não há, de forma alguma, consenso. Ainda não se chegou a um acordo sobre esses casos; torna-se cada vez mais necessário que as instâncias decisórias cheguem logo a um esclarecimento. Um particularismo duradouro nas concepções de arte seria prejudicial. Surpreendentemente, apenas um artista judeu foi incluído entre os selecionados, Lasar Segall de Vilna, que morou em Dresden por dez anos. Todos os quadros trazem os preços pelos quais foram adquiridos, e em muitos casos trata-se dos valores dos tempos da inflação. O mais correto seria convertê-los aos valores correntes.

À saída dessa exposição, pergunta-se instintivamente onde se pode encontrar a arte sancionada. Talvez na seção de arte moderna da Galeria de Pinturas Municipal? Ela passou recentemente por uma reformulação. Então visita-se a tal Galeria. Foram removidos: E. Munch („Menina doente“, „A vida“) todas as obras de Nolde, Kirchner, Schmidt-Rottluff, Heckel, Kokoschka (seis pinturas e também "Crianças brincando" de 1910), de Hofer e Beckmann, exceto por uma pintura antiga; as pinturas da Associação de Patronos: Franz Marc, P. Klee, Kandinsky, Feininger, Schlemmer; também muitos dos jovens de Dresden. Foram substituídos por impressionistas alemães do século XIX, e muitos dos velhos artistas de Dresden voltaram a ser exibidos, Sascha Schneider, Zwintscher, Bantzer, e depois Richard Müller, Gußmann Rößler, Dreher, Dorsch, Feldbauer, Lührig, Unger, L. v. Hofmann, Hettner. Dos mais jovens de Dresden apenas uns poucos permaneceram. Por isso emergiram dos depósitos alguns quadros quase esquecidos, de Schindler ("Sob luzes artificiais"), v. Zügel ("A caminho de casa"). Mas fica a sensação de que algo parece errado, o conjunto da exposição mostra-se arbitrário e empoeirado. Não há sinal do espírito jovem e revolucionário dos movimentos recentes. Isso também não é bom. Para onde vamos? Muitos esperam, pelo benefício da Arte, por um esclarecimento e esperam que ele venha logo.

J.L."

Essa crítica documenta os dilemas com que se deparavam as autoridades responsáveis pela arte e a indefinição que dominava o juízo nesses primeiros tempos nazistas. Ao descrever o afluxo de um público ingênuo, inexperiente e espontâneo, o autor demonstra que a iniciativa de expor a arte moderna sob o signo do opróbrio atraiu para uma exposição de arte pessoas que geralmente não frequentava esses lugares; por isso, sugere o autor que seus julgamentos são duros demais, e que nem mesmo as obras consideradas legítimas pelos organizadores seriam aprovadas por esse público. O próprio autor é mais brando que organizadores e público em seu julgamento, e demonstra 
discordar da presença de alguns artistas entre os apontados como degenerados. Questiona inclusive o próprio conceito de degeneração, sugerindo que ele seja compreendido como tolice juvenil ou reflexo das circunstâncias do tempo, e não algo intrínseco e irremovível do artista, ou de uma "escola". Ainda assim, percebe-se no discurso do crítico a concordância com a doutrina nazista antimoderna, seja quando confirma o caráter decadente da República, seja quando insiste na necessidade de uma arte genuinamente germânica.

O texto demonstra sobretudo a incerteza sobre a linha de política cultural a ser seguida. Evidencia a existência de dissonâncias entre os próprios nacional-socialistas, aludindo ao fato de que havia grupos que louvavam os "expressionistas nórdicos". Questiona a decisão de anotar os valores exorbitantes das pinturas nas legendas, artifício que procurava enfurecer o público, inclusive pela inserção de frases como "adquirido com o dinheiro dos impostos pagos pelos trabalhadores alemães" acompanhando esses valores. Finalmente, seu relato sobre a visita ao museu de arte moderna expurgado das obras dos considerados degenerados toca na questão ainda não resolvida sobre qual seria, então, a arte sancionada. Pede, por isso, que as autoridades ofereçam clareza no julgamento da arte: acusa-as, dessa forma, de omissão. Considera essa incerteza nociva para a arte, e espera uma orientação clara vinda de cima.

Além de "Eternos Caminhantes", outras obras de Segall participaram dessas exposições de difamação realizadas antes da decisão oficial do regime em proscrever a arte moderna. Esses dados podem ser obtidos na Base de Dados. Naquela mesma mostra de Dresden, de 1933, foi exibida a gravura "Für die Sanfte" (uma das que Segall faz para ilustrar a obra de Dostoievski). O óleo "Im Atelier", que fora doado por um mecenas anônimo à Kunsthütte Chemnitz, participou da exposição "Arte que não veio de nossa alma”, no Museu Municipal de Chemnitz, entre maio e junho de 1933.

Na primeira exposição "Entartete Kunst” organizada pelo regime nazista, que se inaugurou em 19 de julho de 1937 em Munique, onze obras de Segall foram exibidas: as pinturas "Eternos Caminhantes", "Amantes" e "Viúva" (este exibido com o título "Purimfest", "Festa do Purim"), e as gravuras "Mann und Weib", "Zwei Schemen" e um álbum não identificado contendo 6 páginas. As obras de Lasar Segall foram reunidas num segmento expositivo intitulado "Revelação da alma racial judaica", em conjunto com outras obras de Jankel Adler, Marc Chagall e Hans Feibusch ${ }^{456}$.

${ }^{456}$ Cfe. GRIMM, Dagmar; GUENTHER, Peter; KORT, Pamela. The works of art in „Entartete Kunst“, Munich, 1937. In: BARRON, Stephanie (Org.). Degenerate art: the fate of the avant-garde in Nazi 
Em julho de 1937, o núcleo do poder nazista finalmente convenceu-se da "necessidade" de dar combate ao modernismo. Algumas fontes citam a leitura de "Purificação dos Templos da Arte", de Wolfgang Willrich, como motivo dessa decisão ${ }^{457}$. Outras indicam que o alto comando nazista decidiu colocar fim à indefinição como forma de reconquistar o controle sobre a política cultural, que se pulverizara em iniciativas desencontradas durante os quatro anos de omissão do governo central. Seja como for, a perseguição ao modernismo oficializou-se, traduzida sob a denominação de "ação contra a arte degenerada" 458 . Para Clinefelter, essa escolha foi pragmática: "Eles estavam menos preocupados com a estética do que com o emprego da arte como um instrumento de suporte para seu regime e sua ideologia" 459 .

Ainda em julho, Goebbels delegou ao presidente da Academia de Belas Artes, Adolf Ziegler, os poderes necessários para confiscar de instituições públicas alemãs obras de arte moderna, que iriam abastecer a exposição oficial contra a arte degenerada. Ziegler organizou uma comissão que na primeira metade de julho de 1937 percorreu 30 museus e reuniu cerca de 1100 obras, que foram enviadas para Munique. Lá, a partir de 19 de julho, apenas três semanas após a ordem de Hitler, uma seleção de cerca de 600 dessas obras foram exibidas na exposição "Entartete Kunst"460.

Germany. Los Angeles: Los Angeles County Museum of Art, 1991. p. 350-351. Segundo ALTSHULER, 2008, p. 257, apenas 6 dos cerca de 112 artistas exibidos eram judeus. Ainda segundo esta mesma fonte, o segmento reunia obras de artistas judeus e as relacionava com um impulso primitivo, que se satisfazia em copiar a estética dos negros; essa concepção transparece na frase que ornava a parede da sala: "O impulso dos judeus pelo que há de selvagem se revela - na Alemanha, o negro se torna o ideal racial de uma arte degenerada".

${ }^{457}$ Säuberung des Kunsttempels. Eine kunstpolitische Kampfschrift zur Gesundung deutscher Kunst im Geiste nordischer Art (Purificação dos Templos da Arte - Uma polêmica arte-política pela recuperação da arte germânica no espírito do estilo nórdico); a obra trilhava os mesmos caminhos de outras dedicadas ao tema: procurava associar arte moderna com bolchevismo e anarquismo, indicando seu potencial deletério e, por outro lado, reafirmava a ligação entre raça e arte e enfatizava a necessidade de reencontrar a essência germânica na expressão artística. Trazia no apêndice uma "Lista dos parceiros do sistema de arte bolchevique" (cfe. MEINEL, Sabine. Karl Völker - Leben und Werk. Tese de Doutorado defendida na Universidade Martin Luther de Halle-Wittenberg, 2008, p. 179). Notar que o autor acabaria participando da organização da exposição oficial de Arte Degenerada, cfe. ALTSHULER, 2008, p. 258.

${ }^{458}$ A decisão do regime agradou apenas parcialmente aos membros da DK, já que, junto com a proscrição da arte moderna, os nazistas afirmaram que "uma nova arte" emergiria; os sócios daquela entidade mostraram-se céticos diante dessa afirmativa, uma vez que, para eles, a arte era reflexo da biologia da raça e, portanto, o surgimento de uma nova arte a partir de uma mesma raça parecia improvável; cfe. CLINEFELTER, 2005, p. 77.

${ }^{459}$ CLINEFELTER, 2005, p. 77.

${ }^{460}$ Segundo Neil Levi, a "Exposição de Arte Degenerada" acabaria sendo a exposição de arte moderna mais visitada de todos os tempos; LEVI, 2013, p. 2. Segundo dados coletados por ALTSHULER, 2008, p. 256, 3,2 milhões de pessoas estiveram na mostra, sendo que 2 milhões somente na primeira etapa, em Munique. Em Munique, a entrada era gratuita, fato que se anunciava na própria fachada do local de exposição; em Berlim, edição que foi visitada por mais de 500 mil pessoas, a entrada passou a ser cobrada. A mostra passou por 12 lugares, e 65 cidades a requisitaram (ALTSHULER, 2008, p. 266). 
A exposição oficial mantinha fidelidade aos métodos propostos por Bettina Feistel-Rohmeder em seu citado artigo de 1933. No guia à Exposição, as obras são tratadas como "documentos originais" que permitem perceber "o pavoroso capítulo final da decadência cultural das últimas décadas, antes da grande transformação" ${ }^{461}$. Os valores pagos pelas obras apareciam nas etiquetas que as acompanhavam. Como se tratava, em muitos casos, de obras adquiridas durante o período de hiperinflação, os valores pareciam absurdamente altos $^{462}$. Os nomes dos diretores responsáveis pelas aquisições apareciam em destaque, apresentados como inimigos do povo ${ }^{463}$. Da mesma forma, havia espaço na exposição para a exibição dos nomes dos críticos de arte que haviam promovido as vanguardas nas décadas anteriores (Fig. 28).

Em 27 de julho, Hitler assinou um decreto que autorizava o confisco de todas as obras da "era da decadência". Isso desencadeou uma segunda investida de Ziegler sobre as coleções públicas da Alemanha, iniciada em agosto de 1937. Dessa vez, 100 instituições foram visitadas, numa ação que resultou no confisco de quase 21 mil obras de mais de $1400 \operatorname{artistas}^{464}$.

Como visto, Bettina sugerira que as obras fossem queimadas após esgotada suas funções de propaganda. O governo nazista de fato queimou parte das obras confiscadas mas, reconhecendo o valor de mercado de muitas delas, preferiu negociá-las. No geral, as 21 mil obras seguiram 3 destinos: um terço “desapareceu de maneira inexplicável”, um terço foi destruído na Estação de Bombeiros Central de Berlim no dia 20 de março de

${ }^{461}$ Entartete Kunst Ausstellungsführer [Guia da Exposição de Arte Degenerada], 1937, p. 2.

462 Um exemplo dessa distorção pode ser encontrado no Arquivo Lasar Segall: em outubro de 1923, Segall recebeu dos editores da Revista do Círculo dos Artistas Gráficos e Colecionadores a importância de 6,8 bilhões de marcos, a título de pagamento de direitos para reprodução da xilogravura "Mulheres erradias" (ALS 00536).

${ }^{463}$ Uma minuciosa e exaustiva reconstituição da Exposição de Arte Degenerada oficial de 1937 foi apresentada em BARRON, Stephanie (Org.). Degenerate art: the fate of the avant-garde in Nazi Germany. Los Angeles: Los Angeles County Museum of Art, 1991.

${ }^{464}$ A estimativa é de PETROPOULOS, 2014. p. 283; outros estudos apontam entre 14 mil e 20 mil o número de itens confiscados. 
$1939^{465}$, e um terço, finalmente, foi dispersado através de vendas e negociações com vários museus e coleções privadas ${ }^{466}$.

Para um terço das obras confiscadas pelos nazistas, como visto, essa etapa de sua provenance foi também o capítulo final. Para aquelas que sobreviveram, no entanto, o futuro ainda traria muitas circunvoluções inesperadas. A etapa seguinte da provenance das obras confiscadas pelos nazistas que sobreviveram à fogueira é aquela que, talvez, seja a mais significativa. O destino dessas obras após a derrota alemã demonstra as questionáveis políticas adotadas pelos vencedores, por colecionadores e agentes do mercado e pelas autoridades culturais.

O destino das obras confiscadas dos museus públicos alemães foi decidido no verão de 1938. Os altos escalões formaram uma comissão dedicada a discutir e implementar o aproveitamento dos produtos resultantes da ação contra Arte Degenerada. Alojada sob o Ministério da Propaganda do Reich de Joseph Goebbels, a comissão reunia burocratas ligados aos órgãos culturais do regime. Contava com apenas dois civis: o negociante de arte Karl Haberstock e o antiquário Max Taeuber. Rolf Hetsch, também um burocrata nazista, realizou um inventário do material confiscado. A primeira tarefa da comissão consistiu em dividir o material confiscado em duas categorias: aproveitável ou inaproveitável para fins de comércio com o exterior. Os itens considerados aproveitáveis - 780 pinturas e esculturas, 3500 gravuras - foram reunidos num depósito no Palácio Schönhausen em Berlim ${ }^{467}$. A comissão acabaria selecionando 4 negociantes de arte a

465 No aniversário de 75 anos desse evento, no entanto, algumas suspeitas foram levantadas a respeito da efetiva destruição dessas cerca de 5000 obras. A cerimônia, ao contrário da queima de livros de 1933, foi conduzida a portas fechadas, e nenhum registro fotográfico foi realizado. Meike Hoffman responsável pelo centro de pesquisas da Universidade Livre de Berlim sobre a Arte Degenerada, acredita que a destruição aconteceu de fato, ainda que algumas obras possam ter sido "resgatadas". Cfe. SPÄTH, Daniela. Conspiracies swirl in 1939 Nazi art burning. http://www.dw.com/en/conspiracies-swirl-in-1939-nazi-art-burning/a-17510022; publicado em 20/3/2014 (acessado em 7/10/2016). Mais recentemente, os responsáveis pela administração da Base de Dados Entartete Kunst da Universidade Livre de Berlim deixaram de atestar a destruição das obras, substituindo o termo "destruída" pela frase "listada como destruída no inventário nazista" (acesso em 28/9/2018).

466 PETROPOULOS, 2014, p. 283.

467 Segundo Petropoulos, foi o marchand Karl Haberstock quem teria convencido Hitler sobre o valor de mercado de muitas das obras confiscadas, sugerindo a realização de leilões internacionais. Tal empreendimento teria a dupla vantagem de afastar tais obras da Alemanha e, ao mesmo tempo, trazer algum dinheiro em troca (PETROPOULOS, 2014, p. 285). Haberstock sugeriu também que o montante obtido nessas transações fosse empregado na aquisição de obras de "mestres europeus", visando a futura criação de um Führermuseum. 0 negociante solicitou que o Estado proporcionasse alguma base legal para essas transações, de maneira a tranquilizar os futuros compradores e dotar 
quem caberia o papel de intermediadores dessas transações: Ferdinand Möller e Karl Buchholz de Berlim, Hildebrand Gurlitt de Hamburgo e Bernard A. Böhmer de Güstrow. Eles tinham experiência na negociação de arte moderna e contatos com os colecionadores $^{468}$.

Em 30 de junho de 1939 ocorreu o leilão "Pinturas e Esculturas de mestres modernos oriundas de Museus alemães", na Galeria de Theodor Fischer, em Luzern; 125 obras foram colocadas à venda ${ }^{469}$. Iniciativas semelhantes foram empreendidas também em caráter local. Em 1936, Klaus Graf von Baudissin, diretor do Museu Folkwang de Essen desde 1934, vendeu "Improvisação 28" de Wassily Kandinsky. Essas ações abriram precedentes que foram explorados nos anos que se seguiram. Até 30 junho de 1941, quando a política de aproveitamento das obras "degeneradas" via vendas ou trocas cessou oficialmente, mais de 8000 delas haviam mudado de mãos ${ }^{470}$. Em muitos casos os negociantes de arte lidavam diretamente com os diretores dos museus, fazendo a ligação entre as obras de arte moderna incômodas ao novo regime e colecionadores estrangeiros ávidos por adquiri-las para seus acervos. O que não foi dessa maneira aproveitado acabou destruído.

O destino das obras de Segall é variado e ilustra os possíveis caminhos tomados pelas obras de arte que participaram da ação nazista contra a arte moderna ${ }^{471}$.

Nenhuma das 11 gravuras extraídas do Museu de Breslau voltou para seu lugar de origem: 5 foram destruídas, 1 tem paradeiro desconhecido, 3 foram para o Gabinete de Gravuras de Berlim e 2 para o Museu de Rostock. Das 8 obras extraídas da Kunsthütte de Chemnitz, 6 foram destruídas e 2 - a pintura a óleo Im Atelier e a gravura Witwe und Kind, têm destino desconhecido. As duas gravuras confiscadas do Gabinete de Gravuras de Dresden voltaram ao lugar de origem. As 21 obras confiscadas do Museu Municipal de Dresden tiveram os seguintes destinos: 10 tem paradeiro desconhecido, 10 estão atualmente no Stadtische Galerie Dresden ${ }^{472}$ e 1 - o óleo “Eternos Caminhantes", está

as vendas de uma aura de legitimidade jurídica. Com anuência de Hitler, Haberstock redigiu uma minuta, que foi encaminhada para a análise de Goebbels e seus assessores no Ministério da Propaganda, e depois sancionada por meio de um decreto assinado pelo Führer em 31/5/1938.

${ }^{468}$ LORENZEN et STUTH, 2011, p. 19.

469 PETROPOULOS, no artigo citado, apresenta detalhes sobre esse leilão.

470 LORENZEN et STUTH, 2011, p. 19.

471 Ver em "Anexo 5" a tabela contendo os dados a respeito de cada uma das obras de Segall

confiscadas na ação contra a arte degenerada.

472 Não se pode dizer, portanto, que as 10 obras que voltaram a Dresden retornaram ao seu lugar de origem: elas foram confiscadas do Stadtmuseum Dresden, um museu municipal, mas foram devolvidas à Städtische Galerie Dresden, que é descrita como "museu de arte da capital da unidade federativa (no caso, a Saxônia; cfe. http://www.galerie-dresden.de/index.php?node=99\& (acessado em 15/2/2017). 
em São Paulo, no Museu Lasar Segall. Das 4 gravuras confiscadas de Erfurt, 3 foram destruídas e 1 está desaparecida. A gravura extraída do museu de Freiburg está no Museu de Rostock. Uma outra cópia da mesma gravura confiscada do museu de Nürnberg tem paradeiro desconhecido. Do museu Folkwang de Essen, dois óleos foram confiscados; "Witwe" é dado como destruído e Liebende pertence atualmente a uma coleção particular no Brasil. Fechando a aritmética: do total de 58 obras confiscadas de museus públicos alemães pela ação dos nazistas, 23 foram destruídas, 15 estão desaparecidas, 17 voltaram a museus públicos diferentes daqueles de onde haviam confiscadas (uma delas fora da Alemanha), 1 está em coleção particular e apenas 2 conseguiram retornar para a mesma coleção de onde foram extraídas.

O caso de Segall demonstra que a ação dos nazistas teve efeito duradouro, sobrevivendo aos seus próprios perpetradores. As coleções de arte moderna da Alemanha foram definitivamente desfiguradas. Isso se deve às decisões tomadas após a guerra, pelos países vencedores. Em termos gerais, na Alemanha sob o domínio dos soviéticos houve certa preocupação com a restituição das obras, mas ela foi realizada segundo critérios políticos que impediram uma solução perfeita; dificuldades técnicas - como a alegada impossibilidade de determinar adequadamente a origem da obra - também foram obstáculos ${ }^{473}$. A postura dos soviéticos quanto às ações dos nazistas em relação às obras de arte foi clarificada na Instrução $n^{\circ}$ 124, vinda do Alto Comando da Administração Militar Soviética da Alemanha, promulgada em 30 de abril de 1945:

"A seção alemã da Administração para Instrução do Povo [Verwaltung für Volksbildung - AIP] da zona de ocupação militar soviética [...] autoriza a realização de todas as diligências necessárias para a investigação e a devolução de obras de arte que anteriormente estivessem em propriedade de instituições públicas ou de particulares e que tenham sido alienadas por ação dos fascistas entre o dia 1 de janeiro de 1938 e a capitulação. A AIP está autorizada a investigar objetos de arte desse tipo, especialmente aqueles que foram confiscados no âmbito da chamada ação contra a 'Arte Degenerada', e tomar as decisões que considerar necessárias para que se proceda a devolução"474

\footnotetext{
473 Numa exposição recente (Viena, dezembro de 2008 a fevereiro de 2009), intitulada „Recollecting: Looted Art and Restitution", curada por Alexandra Reininghaus, denunciou-se a deliberada atitude de protelar, dificultar ou evitar as restituições, adotada sistematicamente pelo governo austríaco, desde 1945. A exibição apresentava objetos diversos, entre eles muitas obras de arte, destacando a presença de elementos que permitiam facilmente a identificação de seus proprietários - como etiquetas e selos fixados diretamente nos versos das obras, nas molduras, ou em ex-libris afixados às páginas de livros, desmontando a afirmação das autoridades austríacas, que frequentemente alegavam ser impossível restituir o material confiscado por falta de informações sobre seus antigos proprietários. Informações detalhadas sobre essa exibição podem ser obtidas no catálogo da exposição: REININGHAUS, Alexandra (Org.). Recollecting - Raub und Restitution. Wien: Passagen-Verlag, 2009.

${ }^{474}$ Apud LORENZEN et STUTH, p. 22.
} 
Era prioridade lidar com obras que estivessem sob risco e cuja propriedade estivesse indefinida. Kurt Reutti foi encarregado de fazer cumprir essas determinações ${ }^{475}$. As obras amealhadas por Reutti foram confiadas à guarda do Museu Municipal de Rostock (Museum der Stadt Rostock). A devolução aos proprietários originais foi parcial e seletiva. Foi realizada em momentos distintos: em julho de 1949 procedeu-se a devolução de obras originais da Galeria Nacional de Berlim e algumas de Stettin, Breslau e Königsberg; em 1951, obras foram encaminhadas para Dresden. Em 1957, museus localizados no interior da DDR (Alemanha Oriental) receberam de volta as obras confiscadas pelos nazistas: Altenburg, Chemnitz, Dessau, Erfurt, Jena, Leipzig, Magdeburg, Weimar e Zwickau. Por motivos políticos, ficaram em poder do Museu de Rostock obras de museus da Alemanha Ocidental e aquelas advindas de museus da antiga Prússia Oriental, região que, após a Segunda Guerra, caiu sob domínio de outras nações (Stettin e Breslau). No final do processo, restavam 613 obras em poder do Museu de Rostock. Em 2009 essas obras foram oficialmente incorporadas ao acervo daquele museu $^{476}$.

O caso de Aloysius Böhmer ilustra o destino das obras confiscadas pelos nazistas que caíram em poder dos soviéticos. Bernhard Aloysius Böhmer foi um dos 4 marchands que trabalhou com os nazistas. Beneficiou-se de sua boa relação com Rolf Hetsch ${ }^{477}$, obtendo grandes vantagens. Lorenzen e Stuth relatam que ele conseguiu, por exemplo, obter 35 pinturas e 13 esculturas modernas em troca de um único quadro do romântico Carl Gustav Carus ${ }^{478}$.

Böhmer teve uma trajetória dúbia: apesar de ser um dos operadores da política cultural antimoderna dos nazistas, era ele mesmo um escultor que, nos anos 1920 associou-se ao expressionista Ernst Barlach (que depois seria demonizado pela política cultural nazista). Böhmer trabalhou primeiro como assistente de Barlach e, após a morte de Paul Cassirer, assumiu a função de representante do artista, organizando suas exposições e negociando suas obras. Nessa posição, estabeleceu contatos com o círculo de colecionadores e políticos e criou assim as relações que mais tarde o tornariam um dos escolhidos para negociar a "arte degenerada".

\footnotetext{
475 Reutti aparece com frequência nas provenances das obras de Segall, conforme pode ser visto na citada tabela em Anexo 5.

${ }^{476}$ LORENZEN et STUTH, 2011, p. 22-23.

477 Hetsch, como dito anteriormente, era um burocrata nazista responsável por inventariar as obras confiscadas; seu nome também aparece com frequência nas provenances das obras de Segall.

478 LORENZEN et STUTH, 2011, p. 20.
} 
Lorenzen e Stuth lembram que, se por um lado se pode censurar Böhmer pelo fato de ter lucrado com o comércio de obras confiscadas, por outro se deve considerar como uma contrapartida dessa atuação o resgate de muitas obras que, sem sua intervenção, poderiam ter sido destruídas ${ }^{479}$. Em algum momento entre 1942 e 1943, Rolf Hetsch decretou que as obras confiscadas que haviam restado após vendas e destruições fossem transportadas de Berlim para a propriedade de Böhmer na cidade de Güstrow, a título de "evacuação" para prevenir destruição por bombardeios. Essa transferência, segundo Lorenzen e Stuth, realizou-se de maneira não-oficial. As obras ficaram em poder de Böhmer até 3 de maio de 1945, quando ele e a esposa se suicidaram, enquanto as tropas do Exército Vermelho marchavam sobre Güstrow. Wilma Zelck, cunhada de Böhmer, tornou-se curadora dos bens de Peter Böhmer, filho do negociante, que tinha então 12 anos. Wilma desfez-se de uma quantidade ainda não averiguada de obras, em parte para cobrir dívidas deixadas no legado, em parte para seu próprio lucro ${ }^{480}$. Kurt Reutti, interviu, confiscando em julho de 1947 o que restava do espólio de Böhmer: 34 óleos, 9 esculturas e cerca de 1000 gravuras.

De todo modo, a arte moderna sob poder dos soviéticos voltaria a cair no ostracismo. A partir do final da década de 1940, a arte moderna perseguida por Hitler voltaria a ser condenada, agora por ser inadequada aos cânones estéticos soviéticos. Stuth e Lorenzen demonstram que as políticas culturais da Alemanha Oriental se alinharam gradualmente às determinações do realismo socialista, fazendo sombra, mais uma vez, às obras dos mestres modernos da Alemanha ${ }^{481}$. Somente na década de 1970 uma parte das obras oriundas do espólio de Böhmer voltaria a ser exposta, numa lenta abertura que se completaria na década de $1980^{482}$.

No outro lado da "cortina de ferro", adotou-se uma política que acabou por legitimar os confiscos e as vendas realizadas pelos nazistas. Petropoulos aponta que o destino das obras confiscadas era questão de pouco interesse para as autoridades norteamericanas, que delegaram a oficiais de baixa patente o poder de decidir sobre ela. $\mathrm{O}$ documento que norteou a posição dos americanos quanto à questão foi um relatório escrito por Benjamin Habberton, consultor jurídico do Office of Military Government, United States (OMGUS, o órgão criado para administrar a Alemanha Ocidental após o

\footnotetext{
${ }^{479}$ LORENZEN et STUTH, 2011, p. 20.

${ }^{480}$ LORENZEN et STUTH, 2011, p. 21.

${ }^{481}$ LORENZEN et STUTH, 2011, p. 25.

482 LORENZEN et STUTH, 2011, p. 26.
} 
fim da Segunda Guerra). Habberton demonstrou concordar parcialmente com a visão negativa dos nazistas sobre a arte moderna, já que afirmava, no documento oficial, a conveniência de manter vigente o banimento à arte de vanguarda, entre outros motivos, para "preservar e proteger a moralidade pública" do contato com "arte indecente ou obscena" ${ }^{483}$. Havia ainda motivos comerciais para a manutenção da situação: muitos colecionadores e galerias norte-americanas, assim como de outros países, já vinham adquirindo obras de arte moderna confiscada pelos nazistas desde antes da Guerra, e seus interesses foram considerados quando o conflito se encerrou. Os alemães haviam usado a embaixada dos EUA em Berlim para contatar potenciais colecionadores. O ânimo antigermânico também pode explicar a indiferença dos americanos quanto à restituição: não havia o desejo de se devolver bens aos alemães ${ }^{484}$.

O caso de Ferdinand Möller ilustra o destino das obras confiscadas pelos nazistas que caíram em poder dos americanos. Möller - um dos quatro marchands que havia servido aos nazistas - tinha em seu poder, após o fim da guerra, muitas obras valiosas. Seu acervo estava em Zermützel, no leste da Alemanha, região sob domínio soviético. Möller foi visitado por Kurt Reutti, que determinou que não movimentasse as obras até que se esclarecesse quais eram propriedade legítima e quais lhe haviam caído nas mãos por conta da ação nazista. Estas últimas, declarou Reutti, seriam restituídas. Em setembro de 1949 - também por conta da crescente hostilidade do governo oriental para com a arte moderna - Möller fugiu para o lado ocidental. Reestabelecido em Colônia, não encontrou empecilhos para negociar as obras confiscadas. Segundo Petropoulos, Möller obteve grandes lucros negociando essas obras, muitas vezes em transações em que as vendia de volta aos próprios museus de onde haviam sido extraídas pela ação dos nazistas ${ }^{485}$.

O caso de Hildebrand Gurlitt também é emblemático. Seu nome voltou à baila em 2012, quando mais de 1500 obras foram encontradas em compartimentos ocultos nos imóveis de seu filho, Cornelius Gurlitt. Suspeita-se que parte desse conjunto tenha se formado em transações oportunistas ligadas à política cultural nazista, ou a partir de confiscos realizados durante o regime do Terceiro Reich. O governo alemão e a

\footnotetext{
483 Apud. PETROPOULOS, p. 290.

${ }^{484}$ PETROPOULOS, p. 289.

485 PETROPOULOS, p. 288-289. A Fundação Ferdinand Möller, entre 2002 e 2016, forneceria parte do apoio financeiro para a criação e manutenção da Base de Dados da Universidade Livre de Berlim.
} 
organização Lost Art estabeleceram uma força-tarefa que tem objetivo de determinar a origem desse acervo e, se possível, efetuar a restituição ${ }^{486}$.

A trajetória de Gurlitt é supreendente. Entusiasta da arte de vanguarda desde que servira na seção de Imprensa Militar durante a Primeira Guerra Mundial, ele orientou sua carreira de maneira a assumir cargos decisivos em instituições culturais e, dessa forma, influenciar a política de aquisições dos museus. Gurlitt acreditava no poder revolucionário da arte e, em duas ocasiões, pôde pôr em prática suas concepções. Em 1925, tornou-se diretor do pequeno Museu Rei Alberto, em Zwickau, onde em poucos anos consolidou uma expressiva coleção de obras de arte moderna. Priorizou a aquisição de artistas ligados ao Expressionismo e à Bauhaus. Ele seria afastado dessa posição justamente por suas preferências estéticas, que desagradaram a parcela mais conservadora da sociedade local. Em seguida, em 1931, assumiu o cargo de direção da Associação de Arte de Hamburgo, onde deu continuidade à política de estímulo às correntes de vanguarda. Em 1937, diante da ação nazista contra a arte degenerada, Gurlitt decidiu tomar parte nas negociações dos espólios confiscados dos museus. Dentre os 4 marchands que serviram aos nazistas, Hildebrand foi o mais ativo e o que negociou o maior número de obras ${ }^{487}$.

A análise dos livros contábeis de Gurlitt disponibilizados no endereço eletrônico da organização Lost Art oferece dados significativos sobre o modus operandi do marchand. Os registros iniciam-se em 1935 e seguem até 1944. Circulam pelas listas obras de artistas estrangeiros e alemães. Gurlitt intermedia a troca de mãos de obras de Manet, Redon, Sisley, Corot, Ingres, Delacroix, Rodin, Courbet, Renoir e Monet. Negocia quadros de Max Liebermann, Lovis Corinth e Max Slevoght, e também de artistas ligados às vanguardas, como Emil Nolde, Ernst Barlach, Paul Klee e Wassily Kandisky. A observação das negociações envolvendo obras deste último patenteia as relações entre o mercado internacional e o governo nazista, ligados pela ação de Gurlitt. Em 20 de fevereiro de 1939, Gurlitt adquiriu do Ministério da Propaganda do Reich 5 pinturas a

\footnotetext{
${ }^{486}$ No endereço eletrônico do "Lost Art" há cópias eletrônicas dos livros de registro de compra e venda de obras de Hildebrand Gurlitt; http://www.lostart.de/Webs/EN/Datenbank/KunstfundMuenchen.html (acessado em 17/02/2016).

${ }^{487}$ Em números absolutos, Hildebrand Gurlitt obteve 3879 obras dentre as que foram extraídas dos museus públicos pelos nazistas; seus colegas ficaram com 1187 (Bernhard Böhmer), 848 (Ferdinand Möller) e 883 (Karl Buchholz); cfe. HOFFMANN, Meike. Die langen Schatten der Vergangenheit - eine Kritische Betrachtung von Hildebrand Gurlitts Lebensweg. In: Kunst- und Ausstellungshalle der Bundesrepublik Deutschland/Kunstmuseum Bern. Bestandsaufnahme Gurlitt. München: Hirmer Verlag, 2017. As informações biográficas sobre Gurlitt apresentadas neste parágrafo se devem também ao artigo de Hoffmann.
} 
óleo de Wassily Kandisnky. Cruzando esses dados com aqueles disponíveis na Base de Dados, descobre-se que pelo menos 4 desses quadros foram exportados e hoje fazem parte da coleção do Museu Guggenheim, em Nova Iorque ${ }^{488}$. Em outras transações, pode-se notar a negociação direta entre Museus públicos da Alemanha com o marchand $^{489}$.

A trajetória da obra "Eternos Caminhantes", de Lasar Segall, também é ilustrativa das decisões dos aliados em relação à ação contra a arte degenerada dos nazistas. Como visto, o óleo foi a primeira obra de arte moderna adquirida pelo Museu Municipal de Dresden, em 1919. Após 1933, passou pela via crucis das exposições difamatórias, mostrando-se particularmente interessante aos seus promotores que, como visto, a inseriram em 9 edições desses eventos. Em algum momento nos anos finais da Segunda Guerra a pintura desapareceu. Segall considerava-a destruída, até que, em 1954, recebeu uma carta de Emerich Hahn, um negociante de artes húngaro radicado em Paris. Seu conteúdo era o seguinte:

"Paris, 28 de março de 1954

Monsieur

Prof. Lasar Segall

Academia de artes visuais

São Paulo

Muito estimado Sr. Professor!

Creio que vos agradará a notícia de que vosso trabalho "Os eternos caminhantes" escapou como que por milagre da bárbara destruição. Quis o acaso que coubesse a mim, também uma vítima daqueles bárbaros, a satisfação de salvar essa insubstituível obra de arte.

O quadro foi removido do Museu de Dresden depois de 1933, rotulado de "Judeu" (no verso do quadro lê-se em grandes letras: Jude). Após a Guerra ele foi encontrado no porão de uma alta autoridade nazista. Desta forma, as forças de ocupação francesas encontraram a pintura, confiscaram-na e a trouxeram a Paris. Aqui ela foi oficialmente leiloada, num escritório de vendas estatal, em nome das reparações de guerra alemãs, onde eu a adquiri. Apesar de todos os transtornos dos tempos de guerra, com todos os seus perigos, o quadro não sofreu danos. Acredito que algum dos nazistas recuou ante a destruição dessa obraprima e concedeu clemência, tendo reconhecido seu grande valor artístico e comercial. Tomo a liberdade de encaminhar duas fotos e ofereço ao senhor, no verso, uma cópia da data de sua execução e de vossa assinatura para confirmação.

Espero, muito estimado Professor, que o senhor se encontre com boa saúde e que ainda continue produzindo com toda energia.

Agradeço antecipadamente por vossa amável resposta, com as mais respeitosas saudações Seu mui devotado

\footnotetext{
488 Os registros da venda das obras do Ministério da Propaganda para Gurlitt podem ser vistos nas páginas 26 e 27 do livro de "Compras e Vendas" de Hildebrand Gurlitt, disponível em http://www.lostart.de/Content/041 KunstfundMuenchen/Buecher/Buch2/13 S.2627 1939GS.jpg? blob=poster\&v=6 (acessado em 18/2/2017).

489 Nas páginas 48 e 49 do livro de "Compras e Vendas", por exemplo, encontram-se registros de vendas de obras de Max Liebermann e Oskar Kokoschka diretamente do Kunsthalle de Hamburg; cfe. http://www.lostart.de/Content/041 KunstfundMuenchen/Buecher/Buch2/24_S.48491941 gs.jpg? blob=poster\&v=6 (acessado em 18/2/2017).
} 
E. Hahn"490

O mais interessante, no documento, é o que ele revela sobre a ação do Estado francês, que considerou legítimo comercializar uma obra duas vezes confiscada - pelos nazistas e pelas tropas francesas. A declaração de Hahn procurava assegurar a Segall que, por esse caminho, não havia como questionar a legitimidade da posse. Nos anos que se seguiram a essa carta, as negociações foram conduzidas, primeiro por Segall e, após sua morte, por sua viúva Jenny Klabin Segall, que acabaria arrematando o quadro. Por esse tortuoso caminho, Eternos Caminhantes pertence hoje, oficialmente, ao rol de bens da República Federativa do Brasil.

Foi possível, pela observação do momento de entrada dessas obras nas coleções, detectar uma mudança no gosto e nas políticas de aquisição. No intervalo entre dois acontecimentos capitais na história da Alemanha contemporânea, entre a revolução que destronou Guilherme II (novembro de 1918) e a ascensão de Adolf Hitler (janeiro de 1933) as experimentações da vanguarda romperam as resistências e se tornaram desejáveis, ingressando nas coleções públicas e privadas, passando a figurar nas paredes dos salões nobres dos museus, galerias e salas dos colecionadores. As pessoas que operaram essas transformações - artistas, diretores de museus, historiadores e críticos de arte - apareceram nos interstícios dos documentos, deixando à mostra suas concepções e interesses, desejos e ideias. As vanguardas da Alemanha, como também fora dela, se serviram de um novo campo de consagração, formada por associações civis e galerias privadas. As instituições estatais, em muitos casos, foram apenas a estação final de um processo de consagração que se originara fora delas. A cisão social fica evidente na ascensão da nova estética. O papel da burguesia é central nesse processo, uma vez que, na maior parte dos casos, são indivíduos oriundos destes estratos os maiores entusiastas da arte moderna. Por outro lado, indivíduos ligados às antigas estruturas sociais exercem resistência ao reconhecimento da nova estética. Essa resistência se revestiu, em muitos casos, de discursos xenofóbicos e antissemitas, que associavam arte moderna a patologias e morbidades. A alteração no regime estético parece ser a parte visível no mundo das artes de alterações que se desenvolveram também em outras áreas daquela sociedade. Todo o

${ }^{490}$ ALS 04648; uma cópia dessa carta foi inserida no Anexo 4. 
Zeitgeist que atravessa e sustenta a Alemanha imperial desmorona em 1918, e a derrota na Guerra parece ser a materialização do esfacelamento da doutrina guilhermina.

Da mesma maneira, tudo o que acontece com as obras entre 1933 e 1937 aponta para a indefinição que o Terceiro Reich alimentou no campo da arte. Fica evidente a existência de uma dissensão no seio do próprio partido: pequenos potentados, apropriando-se do discurso e dos métodos de Bettina Feistel-Rohmeder e da DK, encarregam-se por conta própria de realizar as "Exposições da Vergonha", denunciando a arte moderna como daninha ao espírito e à raça dos arianos. $\mathrm{O}$ anônimo autor da crítica à pioneira exposição de Arte Degenerada realizada em Dresden em 1933, da qual tomou parte "Os Eternos Caminhantes" de Segall, deixou claro ali todos os dilemas que ainda aguardavam solução quanto ao novo regime estético. Da mesma forma, os acontecimentos pós-1937 apontam para a solução encontrada pelo regime e demonstram suas lacunas e limitações. Ficou claro que a decisão de perseguir a arte moderna não foi tomada com base em uma doutrina ou princípio, mas resultou de cálculos estratégicos e, em última instância, espelhando a forma como tudo se resolvia naquele regime, foi oriunda da vontade do condutor, uma vontade embasada em concepções tacanhas e eivadas de preconceitos e provincianismos.

O tortuoso destino das provenances após 1945 talvez seja o segmento mais significativo do exercício. Primeiro, destaque-se a atitude vingativa do vencedor, que permitiu saques punitivos - caso de "Eternos Caminhantes", que incorporou oficialmente à sua provenance a etapa francesa, em que foi conduzida como "compensação" de guerra a Paris. Caso das dezenas de milhares de gravuras levadas de Dresden para algum ponto no território soviético. Depois do caos, vêm as decisões frias tomadas pelos novos ocupantes da Alemanha. Nesse momento, temos por um lado um vencedor que decide acatar as decisões dos nazistas - sancionando os confiscos de maneira velada, ao recusarse sequer a considerar a restituição. Por outro lado, temos um vencedor nominalmente comprometido com as restituições, desde que isso não significasse passar o tesouro para as mãos do inimigo. Em outras palavras, se os norte-americanos decidiram manter as coisas como estavam, temendo contrariar os interesses do mercado, os soviéticos realizaram uma restituição seletiva, provocando estranhos desvios de rota que ficaram inscritos nas provenances.

Até recentemente, afirma-se no citado site do IFAR, a provenance de uma obra de arte ou objeto cultural era preocupação quase que exclusiva de especialistas entretidos com questões de autenticidade e atribuições de autoria, e talvez, complemente-se, também 
daqueles encarregados pela documentação de obras no âmbito dos museus e coleções públicas. No entanto, a escala inédita e sistemática dos confiscos praticados pelos nazistas ao longo de partes das décadas de 1930 e 1940 universalizou a preocupação com relação à provenance das obras de arte. Nenhum colecionador, público ou privado, pode olhar sua coleção com os mesmos olhos. Certas lacunas tornam-se extremamente suspeitas. 


\section{Capítulo 5 \\ $O$ russo naturalizado brasileiro: Lasar Segall \\ e o antimodernismo no Brasil}

Como visto, as propostas das vanguardas estéticas, que após um período de indefinição terminológica, receberam no Brasil o rótulo de "modernistas", encontraram de imediato uma barragem hostil de invectivas que se nutriam, em muitos casos, das mesmas fontes empregadas na construção da retórica nazista. O caso de Lasar Segall permite que se observe as formas de resistência às propostas modernistas no Brasil.

A primeira passagem do artista russo pelo Brasil se deu em 1913. Nesse ano, Segall realizou duas exposições, em São Paulo e Campinas. Nessas ocasiões, apresentou um conjunto de obras em cuja feição ainda não se detectavam os traços expressionistas que mais tarde caracterizariam seus quadros. Mesmo assim, a análise das impressões produzidas pelo contato com suas propostas revela um certo grau de desconforto por parte da crítica de arte brasileira.

Segall contava com um cenário favorável em São Paulo, cultivado graças às boas relações de sua irmã Luba, que havia desposado um membro da família Klabin e vivia na cidade já há algum tempo. Em Campinas, residia um outro irmão de Segall, Oscar Siegel, que era comerciante. Por conta dessa rede privilegiada de relações, o artista foi bem recebido, estimulado e protegido. Freitas Valle, patrono das artes e senador, foi um dos que acolheu o jovem pintor, o que colocou o "Correio Paulistano" a serviço do artista. Além disso, Segall foi amparado por Nestor Rangel Pestana, respeitado crítico ligado ao jornal Estado de São Paulo, que frequentou o ateliê improvisado do artista e prestigiou a exposição, atraindo simpatias e compradores ${ }^{491}$.

Apesar de toda a atmosfera favorável, as obras de Segall provocaram certo estranhamento entre os especialistas e admiradores das artes de São Paulo. Este ruído aparece de maneira sutil nas notas da imprensa. Nestas críticas, as "ousadias" ou "exageros" de Segall foram creditados à sua juventude; os especialistas em arte expressavam a crença de que se tratava de obras de um artista imaturo, ainda em processo de formação:

"[...] não é o sr. Segall um pintor cuja personalidade se tenha afirmado de um modo definitivo, mas é incontestavelmente um talento vigoroso que revela uma verdadeira alma de artista. Todos os seus trabalhos, de uma técnica moderna e às vezes ousada, têm uma

\footnotetext{
${ }^{491}$ cfe. BECCARI, Vera d'Horta. Lasar Segall e o modernismo paulista. São Paulo: Brasiliense, 1984, p. 49.
} 
nota de sinceridade que impressiona muito favoravelmente e que os torna dignos de atenção do público"492.

Opinião semelhante foi expressada por J.C., que caracterizou Segall como um "impressionista violento":

"Lasar Segall é um temperamento esquisito, impetuoso, que se revela em concepções verdadeiramente bizarras. Cultiva, de preferência, o impressionismo, gênero dificílimo, em que só se podem tornar notáveis individualidades privilegiadas, dispondo de faculdades especiais. Lasar Segall não é, com certeza, um artista que assombre. Nem podia sê-lo. Muito moço ainda, ele ressente-se, naturalmente, de vários defeitos, que o tempo se encarregará de apontar-lhe"

Segall encontraria críticas mais incisivas a partir de seu segundo contato com o Brasil. Radicado no país em fins de 1923, não demoraria a se deparar com versões brasileiras dos refratários à modernidade. Já em 1924, quando realiza algumas exposições de sua produção mais recente ${ }^{494}$, Segall vê estampadas nos jornais da capital paulista as mesmas acusações que recebiam os expressionistas do outro lado do Atlântico.

O autor destas primeiras invectivas era Alfredo Mário Guastini (1884-1949). Formado em direito, Guastini dedicou-se à imprensa. Atuou em cargos de direção no Jornal do Commercio e no Estado de São Paulo e publicou crônicas e críticas culturais nos interstícios de suas atividades, material que foi reunindo em volumes ao longo da vida. A série que dedicou ao combate às novas correntes estéticas dos anos 1920, escritas sob o pseudônimo Stiunirio Gama, foram coligidas num volume editado em 1926, intitulado "A Hora Futurista que passou" 495. Guastini comentou com frequência as façanhas dos proponentes de reformas estéticas nas décadas de 1920 e 1930. Insistiu em rotulá-los "futuristas", e em descrevê-los como seguidores de Marinetti, mesmo depois que os modernistas explicaram o sentido em que tomavam o termo "futurista" $"$. A

\footnotetext{
492 Apud. BECCARI, 1984, p. 54.

${ }^{493}$ Apud. BECCARI, 1984, p. 56.

494 Em 1924 Segall expôs suas obras em duas ocasiões e lugares diferentes. Em 8 de fevereiro, inaugurou uma mostra em seu ateliê, à rua Oscar Porto número 31. Tratava-se de "uma pequena festa de arte", segundo o redator "M." (nota no Correio Paulistano, 8/2/1924, p. 2) Em 22 de março, Segall inaugurou uma segunda exposição, à Rua Álvares Penteado número 24 (Correio Paulistano, 23/3/1924, p. 3). Dessa vez, tratava-se de um evento de maior porte, aberto a público geral e contando com catálogo.

495 Em 2006 o volume ganhou uma nova edição, organizada e prefaciada por Nelson Schapochnik; cfe. GUASTINI, Mário. A Hora Futurista que Passou e outros escritos. São Paulo: Boitempo, 2006.

${ }^{496}$ Sérgio Buarque de Holanda, em artigo publicado ainda em 1921 na Revista "A Cigarra", esclarecia o entendimento lato sensu com que os jovens renovadores definiam o termo: "O futurismo quer simplesmente livrar os poetas de certos preconceitos tradicionais. Ele encoraja todas as tentativas, todas as pesquisas, ele incita todas as afoutezas, e todas as liberdades. Sua divisa é antes de tudo originalidade" (apud. SCHAPOCHNIK, 2006, p. 20).
} 
Semana de Arte Moderna foi repetidamente desdenhada por Guastini, sendo referida em seus textos como "semana de humorismo literário e pictórico" e também, em registro menos gracioso, "semana teratológica".

A alternativa ao "futurismo" é escassamente explicitada por Guastini. Um tênue programa se esboça em meio à pesada artilharia contra os "futuristas". No prefácio que escreveu em 1926 para "A Hora futurista que passou”, Guastini procurou justificar sua repugnância ao futurismo, descrevendo seus adversários como inimigos da tradição, indivíduos que desprezavam na literatura a sintaxe arduamente aperfeiçoada por sucessivas gerações e, na pintura, desconhecendo "desenho, anatomia, beleza, sentimentos e harmonia de cores", perpetrando "verdadeiros aleijões"497. Pugna pela reverência à tradição,

"[...] defendendo aquilo que o passado nos deixou de bom, sem querer, está visto, que dele se copiassem servilmente coisas definitivamente sepultadas pelo tempo. [...] entendo que nas lições do passado se deve buscar estímulo para o futuro, procurando chegar a realizações brilhantes sem deturpar o belo" ${ }^{498}$.

Conclama os contemporâneos para a luta contra os modernistas:

"Não se deixe levar pelo canto traiçoeiro das sereias em busca de reclame: arregimentese para, corajosamente, meter o chanfalho nos depravadores da arte, incensadores contumazes de paranoicos nacionais e estrangeiros - dignos apenas de assistência médica..."499.

No calor das polêmicas, vão surgindo alguns outros traços do programa de Guastini. Ele sanciona algum grau de mudanças e renovações, aceita e estimula o abandono de certas fórmulas antigas, mas exige a manutenção de uma estrutura mínima nas obras. Nas críticas a Pathé Baby, de Antônio Alcântara Machado, na apreciação do estilo da prosa de Paulo Prado ou René Thiollier na revista Terra Roxa, Guastini vai delineando a noção de que existe um tipo louvável de modernismo, "modernismo são, da velha escola", caracterizado por uma "prosa empolgante, límpida, sem arabescos", por "bom senso e horror à pieguice e à pirotecnia"500. Procurando cassar os trunfos dos "futuristas", tenta demarcar outra periodização, afirmando que esse "modernismo são" teria já mais de 20 anos, ou seja, seria anterior à produção dos “futuristas". Fica claro que a censura de Guastini se dirige aos experimentos formais mais ousados da geração

\footnotetext{
497 GUASTINI, 2006, p. 28.

498 Idem, p. 29.

499 Idem, p. 48.

500 Idem, p. 113-114.
} 
modernista: na comparação com a literatura "cristalina" dos "modernistas sãos", Mário de Andrade, Oswald de Andrade e Menotti del Picchia escreveriam "despachos telegráficos de difícil decifração" 501 .

Numa mirada geral, a crítica de Guastini abusa do recurso retórico elaborado por Monteiro Lobato. Como o taubateano, Guastini em muitas ocasiões finge indecisão entre classificar as manifestações modernistas como "paranoia ou mistificação". Sua descrição de Oswald de Andrade demonstra esse traço. O literato, "pai da criança degenerada que é o futurismo" teria decidido "burlar o público - apresentando-se com a camisola mental do doido varrido" ${ }^{\circ 02}$. No final, interessaria apenas fazer reclame de si mesmo e divertirse às custas da massa ignara.

Na violenta crítica que dirigiu a Segall em 1924, Guastini recorreu a esse repisado esquema. Intitulada Alucinação visual, sua crônica de início simula a convicção de se tratar de um caso patológico. Segundo ele, diante da arte do russo, o espectador

“[...] sente estar na presença de um mórbido... Na pintura de Segall nada há de humano. A proporção não existe, a anatomia nunca existiu, a cor, nas suas variegadas combinações, está ainda por ser criada. A arte para ele está na aproximação berrante do amarelo com o vermelho e do preto com o violeta... Apenas o contraste violento. $\mathrm{O}$ resto consiste numa cabeça de um metro de circunferência, bueiros à guisa de olhos, taturanas feitas cabelo, tronco de dez centímetros, pernas de cinco, pés de cinquenta, braços de metro e meio... Estes: um, estrepado no ombro ou coisa que o valha; outro, na cintura de fantoches..." ${ }^{" 503}$.

Depois de simular dúvida quanto à sanidade do autor, perguntando-se se não seria ele um sujeito que enxerga as coisas assim, "um paranoico com alucinações visuais" 504 , o crítico vai concluir que tudo não passa de troça: "[...] Segall sorri ante a estupidez daqueles que perdem tempo a examinar os seus atentados; sorri dos habitantes desta terra retrógrada" ${ }^{\prime 505}$.

Adiciona alguns elementos novos, que não declinara quando se referira ao "futurismo". Adiciona a política, acusando Segall de fazer arte bolchevique e maximalista:

"Não podendo ser Lenin em sua terra, não podendo arregimentar seus patrícios para a demolição da antiga Rússia do Czares, o sr. Lasar Segall faz maximalismo na sua pintura, transformando-se em Comissário do Povo para a Arte de Pintar Abortos..." ${ }^{506}$.

\footnotetext{
501 Idem, p. 112.

502 Idem, p. 33.

503 Idem, p. 46.

504 Idem.

505 Idem, p. 47.

506 Idem, p. 46
} 
Lasar Segall procurou se defender das acusações de Guastini, aproveitando a ocasião que oferecia o senador Freitas Valle, que o convidara para ministrar uma conferência na Vila Kyrial em junho de 1924. Antes da leitura de "Sobre Arte" "507, foi proferido um pequeno preâmbulo, onde se teciam comentários à má recepção das propostas estéticas de Lasar Segall por parte do público e da crítica ${ }^{508}$. Apesar de reconhecer que alguns haviam "compreendido em silêncio", afirmou que "a maioria fez uma ideia falsa" sobre os trabalhos:

“[...] alguém escreveu num jornal que, ao ver meus quadros, recordou-se da visita que fizera ao estabelecimento de Juqueri. Enquanto os hóspedes daquela casa pareceram-lhe gente normal, os meus quadros fizeram-lhe a impressão de trabalhos de louco. Ele mediu estes quadros com um metro padrão universalmente adotado e acredita ter diagnosticado a doença como bom psicólogo" ${ }^{509}$.

Outros, continuou o preâmbulo, tomaram o pintor por um trocista, ou pior, por charlatão. Para Segall, enfim, havia incompreensão por parte do público em relação às propostas da arte moderna, o que levava as pessoas a considerarem as novas tendências como "sintomas de degeneração ou doença nervosa, a não ser que os artistas zombem do público"510. A constatação de Segall faz ver que, no geral, pairava ainda sobre a arte de vanguarda, em São Paulo, a mesma interpretação feita por Lobato, em 1917, por ocasião da exposição de Anita Malfatti: seria fruto da loucura, resultado de um gracejo inconsequente ou puro charlatanismo.

Entre 20 de dezembro de 1927 e 19 de janeiro de 1928 Segall manteve nova exposição em São Paulo. Apesar de muito elogiada por Mário de Andrade, numa série de artigos publicados no Diário Nacional, a mostra foi palco de algumas manifestações de desagrado. No dia 17 de janeiro, "um tolo inconfessável foi à exposição do pintor Lasar Segall e, aproveitando um momento de ausência do guarda da exposição, estragou uma das obras expostas, o 'Auto-Retrato n. 2', furando-lhe os olhos”511. O Jornal Il Moscone,

${ }^{507}$ A conferência foi redigida em russo, e traduzida ao francês e depois ao português. Segall, que devia ter pouco traquejo com a língua portuguesa, entregou a Mário de Andrade o texto a ser lido perante a audiência. As impressões sobre o evento foram registradas pela primeira esposa de Segall, Margarete, numa carta escrita em 20 de junho de 1924 (ALS 08932). 0 texto lido na conferência foi posteriormente publicado na "Revista do Brasil" v.25 n.102 em junho de 1924.

508 Esse discurso introdutório foi registrado no documento ALS 05760.

${ }^{509}$ ALS 05760, f. 1.

510 Idem.

511 Diário Nacional, “Vandalismo mórbido?”, 18/1/1928, p. 3. Em carta a Victor Rubin, Segall mencionaria este episódio como algo positivo: "Minha exposição aqui (de 19/12/1927 - 19/1?/28), que estava realmente interessante, foi uma grande realização artística, algo que eu não antecipava. 0 sucesso se deu principalmente entre aqueles que são mais europeus do que brasileiros e que têm uma relação mais estreita com a arte. Nos jornais e revistas do Rio de Janeiro e São Paulo escreveuse muito sobre a exposição, e muitas reproduções foram publicadas. Antes do encerramento da 
semanário ítalo-paulistano humorístico e ilustrado, vergastou a exposição com uma série de violentos vitupérios. Para o redator, incomodava sobremaneira que Segall, ao pretender pintar o Brasil, o fizesse representando figuras de negros, quando, segundo disse, poderia ter escolhido qualquer um dos 38 milhões de habitantes brancos ${ }^{512}$. No Rio de Janeiro, essa mesma exposição volta a sofrer críticas pela imprensa, como a de Victor Néstor, que concentrou sua carga sobre a pintura Mulata com criança. Para ele, o olhar estrangeiro de Segall destoava, mostrando-se "de um africanismo repugnante ao nosso gosto" $" 513$.

Diante da incompreensão, Segall decidiu publicar uma série de artigos intitulados “Arte e Público" nas páginas do Diário Nacional, a partir de 29 de maio de 1928. No texto, tentava justificar o abandono das convenções da pintura, defendendo a arte moderna. Dirigindo-se aos amantes da arte que ainda se mostravam apegados aos cânones do passado, e que buscavam nos quadros a satisfação do "assunto bonito, sem formas, sem força de criação", instava para que se abrissem à arte do tempo presente, desligandose da exigência de fidelidade às velhas regras de anatomia e perspectiva ${ }^{514}$. O texto de Segall tinha um tom pessimista, traindo a crença na impossibilidade de alterar o gosto do público. Lamenta que esse público não tenha pela arte a mesma atitude que demonstra pelas renovações tecnológicas, que aceita sempre sem pestanejar. Lamenta que não se dê o devido valor aos esforços de artistas comprometidos com a pesquisa, com a busca de novas soluções expressivas, mais adequadas ao seu tempo. Lamenta que o público lance sobre a arte moderna acusações de ser “'selvagem', 'infantil', 'psicopática', 'reclame', 'brincadeira de mau gosto', etc.”515. Reitera o argumento - bastante empregado pelos defensores da estética de vanguarda - de que a arte deve se ancorar nas visões interiores do artista, desobrigada das amarras da tradição ou da fórmula. Apela aos críticos, afirmando que é sempre necessário que as novas propostas estéticas se façam acompanhar de palavras explicativas e orientações, sobretudo naquela altura, em que se notava uma

minha exposição, alguém (não se sabe quem) danificou meu Autorretrato com um corte, e isso também foi um sucesso. Eu preciso dizer que me tornei bastante popular no Brasil, graças às minhas duas exposições - a de 1924 e a atual, algo que não se deve subestimar. 0 número de visitantes de minha exposição atual supera a marca de 4.500, isto é o que torna um artista popular." (ALS 00932 Carta de Lasar Segall a Victor Rubin, 10/2/1928).

512 Il Moscone. Le porcherie di Lasar Segall, ano IV, nr. 39, p. 11.

513 Victor Néstor, “A exposição Lasar Segall," O Globo, 30/7/1928, apud. WOLFE, Edith Angelica Gibson. Melancholy Encounter: Lasar Segall and Brazilian Modernism, 1924-1933. Tese de Doutorado. Austin: University of Texas, 2005, p. 339.

514 Diário Nacional, “Arte e público", 29/5/1928, p. 2.

515 Diário Nacional, "Arte e público", 16/10/1928, p. 7. 
inédita incompreensão por parte do público. Insta os críticos a se absterem do uso em profusão dos "ismos"; isso seria mais um fator de estranhamento e, além disso, "todos eles nasceram na mesma atmosfera espiritual e pertencem à mesma grande tendência moderna", são "formas de expressão que surgem, de um modo necessário, do espírito do tempo" ${ }^{, 516}$. No final, Segall deixa nas mãos do público a decisão:

"O principal é que sejamos verdadeiros para conosco, que a nossa arte seja a verdadeira expressão de nosso tempo, de nossa história, do nosso destino. O principal é que nossa arte aja sobre 'nós', que 'nós' estejamos em contato com ela, já que ela nasce em nós e nos manifesta. Queremos nós nos envergonhar do nosso próprio Eu? Não seria isso uma vergonha e sinal de pobreza nossa se nossa arte devesse levar o selo de uma época passada, um selo falsificado? O público mesmo que decida".

De todo modo, a incompreensão do público brasileiro parece ter pesado na decisão de Segall, que no final de 1928 empreendeu uma nova migração, fixando-se em Paris, onde residiria até $1932^{517}$.

Após seu retorno ao Brasil, Lasar Segall envolveu-se com a ideia de criar uma instância de divulgação da arte moderna no país. A iniciativa, que seria encampada por parte da elite de São Paulo, resultaria na fundação da Sociedade Pró-Arte Moderna, a SPAM. De maneira geral, a configuração da SPAM aproximava-se bastante daquela das associações civis alemãs dedicadas ao amparo e disseminação das correntes estéticas de vanguarda, com as quais Segall teve contato em seus anos expressionistas, como a Kunstbund Hamburg de Rosa Schapire.

Um relato detalhado da trajetória da SPAM pode ser encontrado na obra de Vera d'Horta ${ }^{518}$. Para ela, a SPAM aparecia num momento em que as esperanças e entusiasmos da década de 1920 se esvaziavam, diante de promessas desfeitas e, especialmente, por conta da frustração das expectativas quanto à Revolução de 1930. A SPAM, assim como o Clube dos Artistas Modernos (CAM) e, mais tarde, a Família Artística Paulista e os Salões de Maio, seriam sociedades dedicadas a "ampliar os círculos de interessados pela

\footnotetext{
516 Idem.

517 Numa série de cartas do amigo alemão Friedrich Maron, ele também artista e emigrado ao Brasil em 1924, aparece o lamento mútuo pela tímida recepção do público brasileiro quanto às propostas de artistas ligados às correntes de vanguarda. Nos documentos ALS 00589, ALS 00637, ALS 00739, entre outros, Maron informa sobre os maus resultados de suas exposições em Curitiba e São Paulo; na carta registrada sob o número ALS 00957, Maron refere-se ao fracasso brasileiro como estímulo para a nova migração do amigo: "A Europa vai certamente ser recompensadora para você. Desejo a você, de qualquer forma, mais sucesso em Paris do que aqui".

518 BECCARI, 1984. O capítulo dedicado à SPAM encontra-se entre as páginas 83 e 105.
} 
arte moderna, tirando-a de recintos mais ou menos exclusivos como eram a casa de Freitas Valle, depois o Pavilhão Moderno de dona Olívia, o ateliê de Tarsila e a casa de Mário de Andrade" 519 .

No final de 1932, a SPAM é oficialmente fundada. Numa entrevista concedida naquela ocasião, Segall reafirmava a finalidade pedagógica da associação: "O interesse que se procurará incutir tem um fim altamente educativo e de esclarecimento amplo das questões contemporâneas da arte" ${ }^{, 520}$. De volta ao Brasil, o artista voltava a lidar com a incompreensão do público; dessa vez, no entanto, decidiu tentar um novo caminho para romper as resistências à arte moderna.

Para atingir suas finalidades, a SPAM encetou, nos anos de 1933 e 1934, uma série de eventos. A primeira grande realização foi um baile carnavalesco, que teve o ritmo de um espetáculo, com cenografia dirigida por Lasar Segall. Sob o tema "Carnaval na cidade de SPAM", desenrolou-se uma festa que atravessou a noite de 16 de fevereiro de 1933. O sucesso da festa proporcionou fundos para a Associação, que pôde então mudarse para uma sede própria, na Praça da República. Inicia-se uma série de eventos culturais que buscavam preencher as finalidades da SPAM: exposições de arte, concertos e conferências, que se sucederam ao longo de 1933. A SPAM oferecia também o acesso a uma biblioteca dotada com periódicos artísticos mais recentes e um ateliê que realizava sessões de desenho com modelo vivo ${ }^{521}$.

Já no final do ano de 1933 despontaram os primeiros problemas. A própria SPAM se dividiu internamente. Segundo depoimentos colhidos por Vera d'Horta, formou-se um subgrupo no interior da associação que abriu uma "guerra surda" contra os "judeus", procurando desalojar as pessoas assim identificadas das posições de comando da SPAM $^{522}$.

Em 6 de fevereiro de 1934 a SPAM realizou outro grande baile de Carnaval, cuja cenografia ficou novamente a cargo de Lasar Segall. Desta vez, o tema era "Uma expedição às selvas da Spamolândia". Uma luxuriante floresta artificial foi criada no Rink São Paulo, um rinque de patinação desativado próximo ao atual viaduto Martinho Prado.

\footnotetext{
519 Idem, p. 84. Na dissertação de mestrado de Graciela Naclério Forte encontram-se também informações relevantes sobre a trajetória da SPAM, cfe. FORTE, Gabriela Naclério. CAM e SPAM: Arte, Política e Sociabilidade na São Paulo Moderna, do início dos anos 1930. Dissertação (Mestrado) em História Social - Universidade de São Paulo, 2008.

${ }^{520}$ Apud BECCARI, 1984, p. 86.

521 BECCARI, 1984, p. 95.

522 BECCARI, 1984, p. 103.
} 
Com o baile a SPAM volta a arrecadar um expressivo capital, que permitiria a continuidade das suas atividades.

Alguns dias mais tarde, o Diário Popular publicou, na Seção Livre, um inflamado ataque contra a SPAM. Assinado por José Bonifácio de Souza Amaral, o texto a acusava de ser algo mais do que uma simples associação cultural:

"Os fins secretos da Spamolândia

Faço minhas as palavras do 'Diário da Noite' qualificando a SPAM de 'antro de dissolução dos costumes'.

Seus principais fundadores quem são? E a sua crônica? Uns são estrangeiros de nacionalidade um pouco incerta, outros são neo-brasileiros, desafetos de nossas tradições, e outros, embora pertencentes ao tronco racial mais antigo, a consciência popular os julgue com melhor espírito de justiça.

A SPAM é a ampliação de um velho programa dissolvente que se executava, primeiro, em certas casas particulares a pretexto de educação artística. Pessoas educadas nos boulevards de Paris, fazendo praça da civilização 'moderna', ali recebida, como se Gomorra e Sodoma não tivessem existido, e querendo impingi-la à sociedade brasileira para criar entre nós um ambiente como aquele de que essas pessoas morrem de saudade, atraíam para suas casas algumas famílias ingênuas e vaidosas de nouveaux riches ou de caipiras 'envernizados', prometendo-lhes boa música e a honrosa camaradagem dos circunstantes, além de outras consequências lógicas não prometidas mas de ocorrência certa. Ali apareciam também pessoas que punham o dinheiro e os prazeres acima da dignidade. E a vida corria-lhes como um tumor destinado a arrebentar.

Inconformados com a obscuridade dessa 'modernização', tiveram os seus promotores a ideia de dar-lhe proporções mais amplas e larga publicidade que os elevasse no conceito dos ignorantes e dos ingênuos. Eis a SPAM!

Agora, leitor amigo, eu - brasileiro e paulista - vos pergunto: Pode-se chamar a esse conglomerado internacional, de que fazem parte muitos indivíduos que têm a sua ancestralidade ponteada de corrupções, das quais são herdeiros atávicos, pode-se-lhes chamar representantes da alta sociedade paulista? Eu protesto contra a impropriedade e injustiça da qualificação. Da obscuridade do meu reduto de jornalista, ergo um brado reacionário e intimorato porque ainda creio em Deus, creio na Pátria, creio na Família e creio na suprema força da Moral Cristã. Chame-se a essa classe de iconoclastas dos bons sentimentos 'plutocracia', 'aristocracia argentária', 'satanocracia', o que quiserem, mas não passem daí.

A família paulistana que se preza, que tem realmente tradições pelos quatro costados, ou que procede de troncos raciais dignos, não se mistura, não se barateia; brinca no carnaval com decência, comedimento e espírito, vai a bailes familiares, mas não troca a sua dignidade, a sua compostura, a sua respeitabilidade por uns prazeres triviais e efêmeros que, nas proporções descompassadas vistas na SPAM, só deleitam os ignorantes e os degenerados mentais.

Se a diretoria da SPAM, como ela própria declarou, 'sente-se na obrigação de explicar à sociedade paulistana que fatos perfeitamente deploráveis se verificaram contra a sua vontade etc., ela está ainda ludibriando o público e se arrogando moralidades que não possui e desejos que nunca teve. Para ela, quanto mais escandaloso um fato, mais interessante. Quanto mais dissolvente, mais gozado. A desculpa de um dos organizadores do baile, publicada no 'Diário da Noite' de 10, declarando 'não contestar' que diversas pessoas se apresentaram de forma indecorosa na sala das selvas da SPAMOLANDIA, além de ser uma desculpa esfarrapada, é uma desculpa cínica. Não se podia esperar outra coisa quando o título da festa já era um convite para isso. Todos sabem que uma das finalidades da SPAM é combater os preconceitos sociais. O que nem todos sabem é que, entre eles, se incluem as regras da mais pura e santa moral. Assim, ela congrega nos seus 
salões, sob promessa de instrução artística, inocentes e pecadores, anjos e demônios, visando torná-los iguais na corrupção. Em vez de melhorar os maus, quer piorar os bons. Os homens que lá frequentam, pelo menos $90 \%$ levam na alma as piores intenções. Nós, homens... conhecemos a 'escrita'.

No meu entender, a polícia de São Paulo devia fechar a SPAM com mais razões do que teve para fechar o Teatro da Experiência. Expulsam-se do território nacional os estrangeiros exploradores do lenocínio. Qual a finalidade dessa expulsão? Punir a exploração, a forma indecente de ganhar a vida, ou preservar a sociedade de suas consequências dissolventes? Claro que é preservar a sociedade, pois a ignomínia do lenocínio resulta de suas consequências. Logo, expulsem-se os caftens, mas feche-se também a SPAM.

(Excerto de uma carta particular de 11-2-934, adaptado à publicação jornalística).

José Bonifácio de Souza Amaral

Responsabilizo-me pela publicação supra, São Paulo, 19-2-934

J.B.S. de Amaral" ${ }^{\prime 23}$

O discurso de Amaral contra a SPAM reunia em si elementos retóricos que seriam encontrados também nas diatribes nazistas. A xenofobia aparece na condenação às ações dos "estrangeiros de nacionalidade um pouco incerta", dos "neo-brasileiros", do "conglomerado internacional" que ameaça a ordem e a moral nacionais. Essas afirmações mal disfarçam o antissemitismo, fazendo ressoar as antigas acusações, já presentes desde a publicação dos "Protocolos dos Sábios de Sião" (1897) que falavam em complôs judaicos secretos visando a destruição da "cultura cristã". Ecoa, além disso, argumentos oriundos da teoria degeneracionista do século XIX. Os elementos estrangeiros propagadores da imoralidade são descritos em termos lombroseanos, como "indivíduos que têm a sua ancestralidade ponteada de corrupções, das quais são herdeiros atávicos”. Reitera sua associação com o pensamento degeneracionista ao acusar de "degenerados mentais" aqueles que se deleitavam com os supostos prazeres ignóbeis oferecidos pela SPAM. O texto de Amaral atinge o âmago da associação, ao interpretar o impulso de divulgar a cultura modernista, fundamento da SPAM, como tentativa de fazer transbordar os maus costumes do ambiente privado de algumas casas para a sociedade como um todo.

Em meados de 1934, uma reorganização interna da SPAM removeu dos cargos de direção todos aqueles identificados como judeus. Segundo d'Horta, a direção da SPAM fora tomada de assalto pela "tropa de choque que era o movimento integralista". Segundo a autora, "em defesa de uma tradição atacava-se o estrangeiro com medo de que ele tomasse conta de uma cultura que devia ser 'brasileira', no sentido mais reacionário da palavra" 524 .

\footnotetext{
${ }^{523}$ Diário Popular, 20 de fevereiro de 1934, p. 3; grifos no original.

${ }^{524}$ BECCARI, 1984, p. 103.
} 
Segall, que já se afastara da comissão executiva desde novembro de $1933^{525}$, abandonaria definitivamente a SPAM em 1934. Neste mesmo ano, em dezembro, a sociedade encerrou suas atividades. Mais uma vez, Segall via fracassar uma tentativa de aproximar a arte moderna do público brasileiro. Na interpretação de d'Horta, esse episódio provocou o recolhimento definitivo de Segall, que não voltaria mais a se envolver em projetos culturais coletivos no Brasil.

\begin{abstract}
"Quem examina hoje os meios escolares e universitários, os quadros da literatura e mesmo os do jornalismo e até das artes plásticas, verifica imediatamente que a palavra 'moderno' é uma espécie de tabu, é a etiqueta de uma obra de achincalhe dos pensamentos nobres, da beleza pura, dos princípios construtores. 'Escola moderna' é sinônimo de afastamento da criança da ideia de pátria, do culto aos heróis, do respeito à liberdade na sua acepção legítima dentro do direito humano. Nos cursos primários e nas cátedras das universidades substitui-se ostensivamente a educação cívica e as lições científicas pela prédica de doutrinas subversivas. Ensina-se a traição nas aulas de moral, aconselha-se o embuste como arma de triunfo. E em todos os setores se colocaram as sentinelas avançadas do comunismo em ação daninha e devastadora. Estrangeiros aliaram-se a patrícios nossos para a exploração da indústria livresca. Abrem-se por todo o país casas de mercância de livros corrosivos que deformam a mentalidade dos leitores incautos. Fazse a propaganda de volumes pornográficos como se fossem manuais de virtude" 526 .
\end{abstract}

Poucos dias depois dos levantes que ficariam conhecidos como "Intentona Comunista", em dezembro de 1935, Carlos Maul retomava seus argumentos e subia o tom dos ataques à cultura moderna. Maul, que escrevia regularmente nos periódicos cariocas desde a primeira década do século XX, e que mantinha uma coluna semanal no Correio da Manhã, vinha promovendo já há algum tempo a ideia de que a estética modernista representava a faceta cultural do projeto de dominação comunista. Manifestava um nacionalismo xenofóbico contra o que rotulava "cosmopolitismo bolchevique". A sublevação de dezembro de 1935 pareceu a Maul uma oportunidade para enfatizar essa constatação.

"Com semelhantes exemplos cotidianos quebra-se o ritmo clássico da nossa cultura verdadeira, viola-se a harmonia do que erguemos em quase um século com o fruto das mais preclaras inteligências, e prepara-se a atmosfera propícia à irrupção de intentonas como essa que acaba de roubar ao país algumas vidas preciosíssimas [...]"527.

\footnotetext{
525 Em carta circular encaminhada aos sócios da SPAM, Segall renunciava à sua posição na comissão executiva, alegando-se vítima de perseguições e intrigas; ALS 08946, carta circular de 25/11/1933. ${ }^{526}$ MAUL, Carlos. Palavras aos intelectuais brasileiros. Correio da Manhã (RJ), 5/12/1935, p. 4. 527 Idem.
} 
A associação entre modernismo e comunismo, como visto, fizera escola na doutrina nazista. As exposições de Arte Degenerada buscaram explorar ao máximo essa suposta conexão, unindo em sua retórica arte moderna, cosmopolitismo - visto como influência exógena daninha - judaísmo e bolchevismo.

No Brasil, ainda que se tenham observado exemplares esparsos dessas associações no discurso de alguns dos críticos reacionários, tal argumentação se tornaria mais frequente apenas nas décadas de 1930 e 1940. Rafael Cardoso procurou demonstrar o recrudescimento dessa modalidade discursiva, apontando motivos extra-ideológicos para sua adoção ${ }^{528}$. Naquela altura, o modernismo começava a avançar em sua institucionalização. Alguns de seus entusiastas já ocupavam posições docentes na Escola Nacional de Belas Artes. Havia pouco, Lucio Costa exercera por alguns meses a direção do Museu Nacional de Belas Artes, promovendo aquele que ficou conhecido como "Salão Revolucionário". O ódio dos reacionários fora recentemente renovado, com a seleção do mesmo Lucio Costa no concurso para construção do prédio do Ministério da Educação e Saúde ${ }^{529}$.

O reforço na politização dos debates estéticos pode ser creditado também a mudanças internas no próprio movimento modernista. À fase inicial, marcada pelo que Elizabeth Travassos denominou "atitude combativa, demolidora, que se compraz com a rejeição da crítica e do público", seguiu-se um momento de preocupação com a realidade brasileira: "[j]á não se trata apenas de derrubar o velho com a iconoclastia característica do ethos vanguardista, mas de encontrar as bases para a edificação da arte apropriada aos novos tempos" $" 530$.

João Luís Lafetá distinguiu, da mesma forma, duas facetas sucessivas no Modernismo brasileiro: o projeto estético, que ele descreve como sendo "renovação dos meios, ruptura da linguagem tradicional" e o projeto ideológico, que envolve pensar em “consciência do país, desejo e busca de uma expressão artística nacional, caráter de classe de suas atitudes e produções"531. Para o autor, os projetos estético e ideológico convergiram: à ruptura estética proposta pelo modernismo - abandono da mimese, autonomia da obra de arte - teria correspondido uma ruptura também ideológica, marcada

\footnotetext{
${ }^{528}$ CARDOSO, Rafael. Modernismo e contexto político: a recepção da arte moderna no Correio da Manhã (1924-1937). São Paulo/Universidade de São Paulo - Revista de História, núm. 172, janeiro-junho 2015, p. 335-365.

529 Idem, p. 359.

530 TRAVASSOS, Elizabeth. Modernismo e música brasileira. Rio de Janeiro: Jorge Zahar Editor, $2000 .$, p. 21.

531 LAFETÁ, João Luiz. 1930: A Crítica e o Modernismo. São Paulo: Editora 34, 2000., p. 21.
} 
pelo abandono da mentalidade da antiga "oligarquia rural instalada no poder". O projeto ideológico, segundo Lafetá, ganharia ênfase na década de 1930, sobrepujando as preocupações estéticas. Volta-se para a reflexão sobre "a função da literatura, o papel do

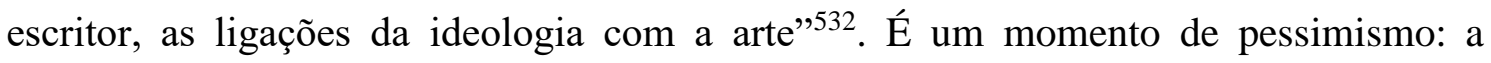
"consciência do atraso", que na década de 1920 era vista com a tranquilidade de quem acreditava na capacidade de recuperação rápida, bastando um "acerto do passo", passa a ser sentida como subdesenvolvimento intolerável e, em muitas análises, estrutural. $\mathrm{O}$ humor anárquico que ditava as produções do modernismo da década de 1920 abre espaço para sóbrias análises sociológicas e históricas, para a literatura engajada com as causas sociais. Neste contexto, a ousadia formal, "lição estética essencial do Modernismo" mostra-se pouco instrumental, o que proporciona um retorno estilístico a um modelo mais convencional. Lafetá aponta que o "ajuste", o mero "acertar o passo" com o exterior, não serve mais: busca-se agora a revolução, seja em direção ao novo seja em direção ao passado $^{533}$.

A politização do debate estético nos anos 1930 e 1940 espelha, ao mesmo tempo, o recrudescimento das rivalidades entre os regimes da Europa. A ascensão fulminante do nazismo gerou êmulos ao redor do mundo, e sua política cultural inspirou seguidores também no Brasil. Por outro lado, o regime comunista da URSS conquistou entusiastas em toda parte. Essa polarização seria aprofundada com a eclosão da guerra, em 1939, que cindiu definitivamente o cenário mundial entre "democratas" e "fascistas". A arte acabaria capturada neste imenso jogo de forças.

No Brasil, a politização do debate estético atraiu a atenção do Estado. Setores do regime de Getúlio Vargas procuraram desenvolver ferramentas de monitoração e controle dessas forças. Um dos braços estatais imiscuídos nessa seara foi representado pela polícia política, que manteve, em partes das décadas de 1930 e 1940, uma estreita vigilância sobre os intelectuais e artistas ligados às "ideias avançadas”. Segundo Maria Luiza Tucci Carneiro, a "lógica da desconfiança" regia a atuação desse órgão. Considerava-se que "os intelectuais e artistas identificados com as ideias de vanguarda [eram] a priori, 'suspeitos da prática de sedição""534. A perseguição visava "aqueles que atentavam contra a

\footnotetext{
532 Idem, p. 28.

533 Idem, p. 30-31.

${ }^{534}$ CARNEIRO, Maria Luiza Tucci. A Arte de Lasar Segall. In: CARNEIRO, Maria Luiza Tucci; LAFER, Celso. Judeus e Judaísmo na Arte de Lasar Segall. Cotia, SP: Ateliê Editorial, 2004; p. 51. Outras condições, como a de judeu e estrangeiro, agravavam a desconfiança, o que fez com que Lasar Segall se tornasse um alvo quase obrigatório dessa vigilância, especialmente quando se considerava sua nacionalidade russa.
} 
estabilidade das elites dominantes"; buscava "bloquear a heterogeneidade de pensamento procurando silenciar aqueles que eram "potencialmente perigosos" "535. A aparição das massas proletárias e, em especial, sua politização e participação cada vez mais informada no jogo político-eleitoral, atemorizava as elites. No início do século XX, orientações políticas indesejadas pelas elites começaram a se fazer notar entre os proletários: grupos comunistas e anarquistas ampliavam sua esfera de influência entre a população pobre e imigrante da cidade.

Para Florindo, esse fenômeno pôs às claras "os limites da nossa República liberal" 536 . Diante da recusa das classes subalternas em assumir o papel de "figurantes das intrigas políticas" que lhe destinava a elite, restava decretar como "desagregadora" a politização popular, criminalizá-la e persegui-la implacavelmente. Daí a necessidade da instauração de uma polícia política e social. Essa nova força a serviço do estado funcionou sob novos princípios e novo sistema de trabalho. Muda a estratégia dos aparelhos policiais, que se tornam mais sofisticados; a intimidação exercida abertamente pelos membros das forças policiais é substituída pelo trabalho discreto da investigação, visando instruir inquéritos que seriam fundamentais para os processos jurídicos deflagrados em etapa posterior. A polícia política e social empregou, nesse esforço, duas novas formas de atuação: "a utilização de agentes duplos não pertencentes aos quadros oficiais de funcionários do Estado e a tortura" ${ }^{537}$.

Policiais do DEOPS acompanharam de perto as atividades de pintores, escultores, críticos de arte e intelectuais ligados ao movimento modernista brasileiro. Seu interesse

\footnotetext{
${ }^{535}$ CARNEIRO, Maria Luiza Tucci. Coleção Histórias da Repressão e da Resistência. In: ANDREUCCI, Álvaro Gonçalves Antunes. O Risco da Ideias: intelectuais e a polícia política (1930-1945). São Paulo: Humanitas/Fapesp, 2006; p. 14.

${ }^{536}$ FLORINDO, Marcos Tarcísio. O Serviço reservado da Delegacia de Ordem Política e Social de São Paulo na era Vargas. Dissertação (mestrado) - Universidade Estadual Paulista, Faculdade de História, Direito e Serviço Social, 2000; p. 3.

${ }^{537}$ FLORINDO, 2000, p. 8. "Agentes duplos" eram os delatores que se infiltravam em diversos meios, obtendo pontos de observação privilegiados sobre segmentos da sociedade considerados perigosos pelas autoridades. Florindo demonstrou que eram variadas as motivações que os levavam a assumir tal papel. Encontrou "agentes reservados" movidos pela ideologia. "Russos brancos", refugiados da Revolução de 1917 no Brasil, colaboravam espontaneamente, assim como brasileiros simpatizantes dos movimentos fascistas - como o Integralismo - todos desejando juntar forças no combate ao comunismo. Havia também aqueles para quem a atividade era vista como uma fonte de rendas; integravam "a indústria da delação", que tinha tornado ricos, da noite para o dia, indivíduos que até então viviam de pequenos trabalhos e, quase sempre, de bolsos vazios. Muitos, finalmente, eram recrutados entre os próprios militantes de esquerda, quando, sob custódia do estado, fragilizados pela situação desfavorável, submetiam-se ao aliciamento.
} 
se concentrava nas atividades políticas dos artistas. As conferências, exposições e peças de teatro realizadas no Clube dos Artistas Modernos foram alvo de investigações por parte de agentes do DEOPS ${ }^{538}$. Local onde se reuniam, nas palavras dos "reservados", "intelectuais de ideias avançadas", o CAM aparecia nos relatórios como um dissimulado ponto de doutrinação comunista. Em 18 de julho de 1933, por exemplo, o agente Guarany ${ }^{539}$ relata: “Houve ontem, no 'Salão dos Artistas Modernos' Rua Pedro Lessa 2, a mais moderna das propagandas comunistas. Os meios empregados pelos artistas são silenciosos, sutis, não inspiram curiosidades, mas quem entra lá sai pensativo".

A exposição de cartazes russos promovida por Tarsila do Amaral motivou muitas elucubrações por parte do agente, que viu no evento uma clara promoção do estilo de vida soviético. A audiência dos eventos também levantava suspeitas. Na conferência de Tarsila do Amaral intitulada "Arte Proletária", em 29 de julho de 1933, o aspecto dos ouvintes foi ressaltado pelo reservado: "Também tinha significado o traje da assistência, indivíduos sem colarinho, mostrando serem operários, outros traziam gravatas vermelhas", todos, dizia, "com aspectos de terroristos (sic) e indesejáveis na maioria composta pelos estrangeiros".

Para os agentes do DEOPS, o CAM era "o mais disfarçado núcleo de comunismo militante em São Paulo". Guarany aponta as ligações de Oswald de Andrade e Pagu, Tarsila do Amaral e Flávio de Carvalho, entre outros, com as doutrinas comunistas. No prontuário do CAM existem relatos sobre conferências ali realizadas por Caio Prado Júnior (que reuniu mais de 500 pessoas e provocou a obstrução do trânsito na Rua Pedro Lessa), Jaime Adour Câmara, Orestes Ristori, Osório César, Pedro Catalo e outros. O formato dos relatos era padronizado, segundo Florindo, devendo obrigatoriamente cobrir uma espécie de pauta: “citar o local da reunião, o horário de início e término dos trabalhos, o número aproximado de presentes na plateia, os ânimos dos participantes, as principais falas, os apartes e as discordâncias entre os oradores" 540 .

\footnotetext{
538 Prontuário referente ao Clube dos Artistas Modernos (CAM), no 2241. Arquivo Público do Estado de São Paulo.

539 Segundo FLORINDO, Guarany atuou no DEOPS entre 1933 e 1935; "Guarany percorria habitualmente os locais de reunião dos vigiados. Atuou em assembleias sindicais, reuniões para a propagação do ideário comunista, conferências e palestras organizadas por anarquistas e socialistas. Participou de associações formadas pelos militantes dos diversos credos considerados extremistas". Tinha um impressionante trânsito entre os intelectuais daquele período, com acesso direto e facilitado a Caio Prado Junior, Tarsila do Amaral, Osório Cesar, entre muitos outros. Guarany converteria essa facilidade de circular em fichas e prontuários que esmiuçavam a vida e as atividades de seus observados, material que orientaria a ação dos órgãos de repressão nos anos seguintes; cfe. FLORINDO, 2000, p. 128.

540 FLORINDO, 2000, p. 120.
} 
No prontuário do Clube dos Artistas Modernos fica evidente uma certa confusão, feita pela polícia política, entre aquela agremiação e a "Sociedade Pró-Arte Moderna", a SPAM. Em 4 de agosto de 1933, por exemplo, Guarany relata ter recebido de Osório Cesar a sugestão de filiar-se ao "S.A.M (Clube ou Sociedade dos Artistas Modernos)". No mesmo prontuário, patenteando a confusão, está anexado um recorte de jornal que se refere a atividades da SPAM, atribuídas pelos investigadores à outra associação ("Inauguração da sede da Sociedade Pró Arte Moderna", Correio de São Paulo de 24 de julho de 1933). Na pesquisa, não foram encontrados registros de investigações do DEOPS sobre a SPAM.

Também Tarsila do Amaral foi perseguida e vigiada, pelos mesmos motivos: agentes do DEOPS a descreviam como uma das mais destacadas agentes do comunismo em atividade. $\mathrm{O}$ agente Guarany se expressou sobre ela da seguinte maneira:

"Incontestavelmente, a Sra. Tarsila do Amaral é a maior e mais arrojada comunista dentre todas as comunistas nacionais. É a maior porque impressiona e quase converte todos que ouvem. É também a mais arrojada, porquanto os seus parceiros procuram sempre arrabaldes e lugares ocultos para pregarem o comunismo, ao tempo que ela serve de salões nobres, onde sem rodeios, ensina teórica e praticamente a doutrina vermelha" ${ }^{541}$.

As atividades de Patrícia Galvão foram minuciosamente monitoradas e registradas em documentos que agora compõe o Prontuário 1053. Pagu foi presa em 23 de janeiro de 1936, acusada de "atividade contra a estrutura do atual regime". Ela escaparia em outubro de 1937, seria recapturada em abril de 1938, e cumpriria o restante da pena em reclusão. Em 1950, voltaria a ser detida sob a acusação de realizar "agitação comunista".

O monitoramento de Osório Cesar, tido pelo DEOPS como uma das maiores lideranças soviéticas no Brasil, produziu uma quantidade copiosa de documentos. O médico foi preso e detido algumas vezes, e sua extensa coleção de livros foi minuciosamente inventariada pelos agentes da polícia.

Lasar Segall, como judeu russo e artista moderno, foi alvo de investigações do DEOPS. Os agentes daquela repartição, no entanto, produziram documentos que trazem informações desencontradas ${ }^{542}$. Algumas fichas apontam Segall como comunista: "O fichado é pintor e costuma usar da arte, para fins de propaganda do credo vermelho". Outros documentos, no entanto, ressaltam supostas qualidades pacíficas e democráticas de Segall:

\footnotetext{
541 "Informe reservado"- Guarany, 30/07/33- Prontuário DEOPS/SP no 1.680 de Tarsila do Amaral. Doc.4. 542 Lasar Segall - prontuário 51749. Todos os documentos que constam no prontuário de Lasar Segall foram reproduzidos em CARNEIRO, 2004, p. 67-73.
} 
"Lasar Segall é, de fato, pintor e proprietário nesta Capital. Não é, no entanto, COMUNISTA. Sempre foi contrário à política reacionária, pelo que se tornou antipático aos totalitários.

A sua índole política é democrática.

Pintor que é, fazia caricaturas em que eram focalizados os políticos reacionários internacionais que pretendem implantar no mundo a NOVA ORDEM.

Daí o haverem taxado de comunista.

[...]

Os seus trabalhos de pintura têm sido elogiados pela imprensa do País. É muito relacionado nos meios culturais, contando o ministro Gustavo Capanema no rol dos seus amigos".

Para corroborar a convicção de que Segall era politicamente inócuo, os agentes do DEOPS aventaram a possibilidade de que houvesse um homônimo do pintor. O encarregado do Arquivo Geral, Frederico Halfeld de Andrade, expediu uma declaração em que dizia não poder afirmar se o Lasar Segall registrado como comunista era o mesmo Lasar Segall pintor, requerente do atestado, já que, na ficha do arquivo, não constava a filiação, informação indispensável para determinar a identidade do fichado. Um documento manuscrito, sem data, inserido no prontuário do pintor, menciona um "primo" de Segall, "Siegell Segall”, que seria diretor do Laboratório de Análises e Pesquisas da Escola Politécnica de São Paulo. Siegell é descrito como "judeu comunista" 543 . No final, as autoridades decidem expedir o atestado solicitado pelo pintor, afirmando nada constar contra ele naquela repartição ${ }^{544}$.

Dos prontuários emerge um interessante documento, o único entre todos os encontrados nos arquivos do DEOPS que tece considerações a respeito das propostas estéticas do modernismo. Trata-se de uma peça intitulada "Propaganda Comunista pela Arte", que não apresenta dados de autoria nem data de produção ${ }^{545}$. Sua versão original

\footnotetext{
${ }^{543}$ Houve não um "Siegel Segall", mas um Miguel Siegel vinculado ao Instituto de Pesquisas Técnicas da Escola Politécnica da USP; engenheiro civil, Siegel contribuiu para o desenvolvimento da indústria siderúrgica no Brasil, cfe. MOTTA, Antônio Carlos Casulari da. COBRASMA - Trajetória de uma empresa brasileira. Tese (Doutorado). Programa de pós-graduação em História Econômica - Universidade de São Paulo, 2006; p. 42. Miguel Siegel era sobrinho de Lasar Segall, e recebeu do tio amparo financeiro durante seus anos de formação, no final da década de 1920 e início dos anos 1930, conforme atestam cartas enviadas pelo estudante, hoje no Arquivo Lasar Segall (documentos ALS 01166, ALS 01232, ALS 01317, ALS 01342 e ALS 04443). Os documentos encontrados, assim como a tese de Motta, não apontam nenhuma ligação de Siegel com movimentos de esquerda.

544 Internamente, Segall ainda seria descrito como comunista. Quatro anos mais tarde, o DEOPS produziu uma ficha do pintor, onde se anotam dados que o identificam sem sombra de dúvida - com os nomes de seus pais e seu endereço - e que declara ser o mesmo comunista (cfe anexo 6).

${ }^{545}$ CARNEIRO, 2004, p. 67 sugere que ele tenha sido produzido por volta de 1939.
} 
pode ser encontrada no prontuário de Patrícia Galvão, e cópias dele estão arquivadas nas fichas de todos os que foram mencionados no texto, inclusive no de Lasar Segall ${ }^{546}$. O texto demonstra o alinhamento, por parte de funcionários do governo, à política cultural nazista. Pelo conteúdo significativo, merece ser integralmente transcrito:

"Propaganda Comunista pela Arte: o presidente da Comissão Organizadora do $3^{\circ}$ Salão Paulista de Belas Artes, no seu discurso inaugural, salientou o papel preponderante da arte na educação dos povos e sua influência notável como agente calmante ou excitante das massas e disse: A arte é sempre social como expressão da vida. Uma vez concretizada influi sobre a sociedade, principalmente nos períodos instáveis. E reconhecendo esse seu grande valor é que levou Hitler a determinar na Alemanha a volta da arte nacional e tradicional germânica, dando combate aos avanguardistas da pintura e aos modernistas da arquitetura que desnacionalizando a arte visavam implantar a desordem na sociedade. Verificou-se aí que as questões políticas se associavam às artísticas para combater a desordem a anarquia a revolução cega o incógnito e o empirismo. Na Itália, Mussolini tem especial atenção para as artes em geral protegendo-as amparando-as e disseminandoas por toda a Itália. E no Japão recentemente está havendo o retorno às antigas tradições abandonando os japoneses as vantagens da técnica ocidental. E que agora como nunca a arte está sendo reclamada para cumprir sua missão evangélica e purificadora no meio árido em que atravessa o mundo de hoje. Estas palavras esclarecem bem... Daí a necessidade dos governos manterem vigilância no setor intelectual-artístico auxiliando também a arte equilibrada e sã com que alimentará espiritualmente as multidões sofredoras e fáceis de serem empolgadas pelas promessas falazes dos extremistas. $\mathrm{O}$ cultivo do espírito o convívio com as belas artes (é óbvio afirmar) enobrecem e nutrem as multidões ensinam a moral propagam o civismo elevam o nível da humanidade e confortam e amenizam a existência. Sublinhadas essas premissas temos a notar que o grande escritor e crítico de arte Camille Mauclair ${ }^{547}$ (entre outros) em vários de seus artigos e livros revela o plano oculto dos judeus-comunistas de pretenderem destruir uma das colunas mais sólidas e nobres da nossa civilização ocidental-cristã que é a arte tradicional latina. Dois são seus principais objetivos: $1^{\circ}$ ) Um mais próximo e material o rebaixamento do valor dos quadros clássicos devido ao cabotino enaltecimento das bambochadas modernas verdadeiros bluffs reduzindo assim ao extermínio os valores colossais das coleções ocidentais de arte clássica e sã. $2^{\circ}$ ) a desorganização o aviltamento e o embrutecimento social produzido pela arte por eles preconizada afim de preparar o terreno para uma ação mais segura, num meio inculto insensível e depravado. Haja vista o cunho geralmente imoral e pornográfico e depravado das manifestações artísticas as vezes as mais insinuantes e não raro em que se revelam veladamente a tal ponto que casos há em que só um artista experto poderia sentir a nuance reveladora de tais tendências e fatos como que ocultos ou latentes numa pseudo obra de arte moderna avançada. Caracterizam geralmente na crítica ou literatura tais manifestações o despudor o cinismo a ousadia e principalmente o desrespeito a tudo que manifesta tradição ataque aos velhos com passado de trabalho e mérito as instituições escolas etc. que se [...] regem no princípio de disciplina respeito ordem e autoridade constituída. Em relação à influência do meio artístico como campo propício para a propagação extremista notem-se as palavras de LUIZ CARLOS PRESTES nas suas últimas declarações quando se refere a

\footnotetext{
546 O prontuário de Gregori Warchavchik, de no 80.388, é composto unicamente de cópia desse documento

547 Escritor polígrafo, Mauclair (1875-1945) seria um ferrenho opositor das vanguardas artísticas, e colaborador do regime de Vichy; cfe. GOLAN, Romy. From Fin de Siècle to Vichy: The Cultural Hygienics of Camille (Faust) Mauclair. In: NOCHLIN, Linda; GARB, Tamar. The Jew in the Text: Modernity and the Construction of Identity. London: Thames and Hudson, 1995.
} 
última esperança que lhe resta baseada essa no trabalho de propaganda dos intelectuais. Como entregues a essa atividade dissolvente devem ser observados pela Polícia as seguintes pessoas: PAGU pintora -TARCILA pintora - FLAVIO DE CARVALHO engenheiro e pintor (amigo íntimo de Geraldo Ferraz) - PAULO ROSSI pintor desenhista da Secretaria da Viação - ARNALDO BARBOSA - pintor e funcionário da Secretaria da Fazenda - GASTÃO WORMS pintor acha-se em viagem ao sul - QUIRINO pintor reside no Rio e em São Paulo - NENE JOSÉ OSWALDO DE ANDRADE FILHO pintor - CARLOS PRADO discípulo de Gastão Worms - DI CAVALCANTI pintor e caricaturista - CÂNDIDO PORTINARI pintor, professor da Universidade Municipal do Rio e com ligações com certas legações de países nórdicos da Europa - LIVIO ABRAMO desenhista trabalha no Diário da Noite íntimoamigo de Geraldo Ferraz - LAZAR SEGALL pintor judeu russo e WARCHAVSCHIG arquiteto judeu russo genros do milionário judeu Klabin - OSWALDO DE ANDRADE advogado e escritor - DR. OZORIO CESAR médico - GERALDO FERRAZ jornalista trabalha nos Diários Associados - GUSMÃO jornalista nordestino amigo de Flavio e Geraldo - GALEÃO COUTINHO jornalista.

O texto, reconhecendo a arte como meio capaz de influenciar a opinião das pessoas, enfatiza a necessidade de monitoramento e controle. Louva os esforços dos chefes dos países do Eixo - Japão, Itália e Alemanha - que teriam tomado o controle sobre a produção e o consumo cultural, impedindo a disseminação do que chama de "desordem" na sociedade. Reitera a associação entre arte moderna e comunismo, acusando a primeira de tentar solapar as bases da civilização cristã para facilitar a propagação do credo vermelho. Ressalta que as estratégias para se atingir essa finalidade são a destruição da tradição estética ocidental-cristã e a corrosão da moral, pela disseminação de conteúdo licencioso. Não falta ao texto a referência a outro argumento caro aos nazistas, o da existência de um complô judaico supostamente operando tais iniciativas insidiosas.

É importante notar que, segundo o texto apócrifo acima reproduzido, o brado de alerta contra a infiltração comunista pela arte moderna e as palavras elogiosas às políticas culturais do eixo teriam sido veiculadas no discurso inaugural do $3^{\circ}$ Salão Paulista de Belas Artes. O texto produzido pelo DEOPS indica, indiretamente, o autor do discurso: o presidente da Comissão Organizadora do referido Salão. Notícias recolhidas na imprensa da época permitem identificar o suposto professante. Segundo nota em O Jornal (RJ), "fez o discurso inaugural o sr. Carlos Alberto Gomes Cardim Filho, presidente da Comissão organizadora do III Salão" ${ }^{, 48}$. O Correio de Paulistano confirma a identidade do autor do discurso, emitindo também um juízo sobre o conteúdo de sua fala: "No ato inaugural, o dr. Gomes Cardim Filho, ativo membro da Comissão organizadora, proferiu

548 O Jornal, 15 de dezembro de 1935, página 8. 
belíssimo discurso que, pelos seus elevados conceitos, merece divulgação" ${ }^{\text {"549 }}$. Gomes Cardim Filho era engenheiro civil e arquiteto formado pela Escola Politécnica de São Paulo. Sua família havia fundado a Escola de Belas Artes em 1925, e nela Gomes Cardim Filho exercia diversas funções, entre outras as de professor catedrático e diretor tesoureiro. Na altura do $3^{\circ}$ Salão, era membro do Conselho de Orientação Artística.

O regime de Getúlio Vargas manteve uma política dúbia com o universo cultural brasileiro. De um lado, como visto, exerceu a repressão, a espionagem, a prisão e a censura, procurando eliminar as narrativas daqueles que perturbavam a imagem oficial que se tentava construir. De outro, fez concessões e alianças com alguns dos intelectuais mais destacados da cena brasileira. A criminalização das manifestações políticas proletárias era o lado coercitivo de uma estratégia maior do governo, que compreendia também uma faceta propositiva, que se traduzia no fomento a uma série de manifestações culturais consideradas adequadas. Em conjunto, formavam parte de um interesse ambicioso, de reelaborar a identidade nacional.

A aproximação entre intelectuais e o Estado gerou uma grande quantidade de estudos interessados em analisar a natureza dessas articulações. Sérgio Miceli, segundo Daniel Pécaut, defende que o posicionamento literário-estético e político dos intelectuais daquele período poderia ser compreendido se se considerasse o fato de que muitos deles vinham de famílias oligárquicas em decadência, que por isso se encontravam ameaçados de perda de status e que, além disso, também se viam acossados pela inflação de profissionais rivais oriundos das recém-fundadas universidades livres ${ }^{550}$. As consequências dessas circunstâncias se fazem presentes na produção desses escritores, que "sucumbem" à "sedução dos empregos públicos" e se tornam defensores de um estado forte. Nas palavras de Miceli,

"Eram, na verdade, herdeiros que puderam tirar partido de uma correlação de forças extremamente favorável à produção de obras cujos reclamos reformistas coincidiam com os interesses de autopreservação da fração de classe a que pertenciam" ${ }^{551}$.

\footnotetext{
${ }^{549}$ Correio Paulistano, 15 de dezembro de 1935, p. 15. Apesar dos elogios, o jornal não reproduziu o discurso; não foi possível localizar, durante a pesquisa, a íntegra daquele discurso inaugural. 550 PÉCAUT, Daniel. A geração dos anos 1920-40. In: PÉCAUT, Daniel. Os intelectuais e a política no Brasil - entre o povo e a nação. Trad. Maria Júlia Goldwasser. São Paulo: Editora Ática, 1998; p. 20.

551 MICELI apud PÉCAUT, 1998, p. 20.
} 
Pécaut procura adicionar outras considerações na explicação sobre a atuação dos intelectuais das décadas de 1920 a 1940. Para ele, a finalidade das ações destes intelectuais estava além dos desejos do estado; buscariam dialogar com demandas mais gerais da sociedade. A missão política de que se imbuíram, crê Pécaut, não era mero reflexo de sua posição como classe defenestrada, mas oriunda de uma desilusão com a República; em outras palavras, não defendiam apenas interesses próprios, mas programas mais amplos e gerais. Pécaut solicita que suas atuações sejam vistas como maiores do que defesa de interesses pessoais ou de classe, propondo que se veja a atuação específica daquele grupo como parte de uma luta por influenciar os destinos de uma "recriação institucional" em andamento. Para Pécaut, estava em curso uma profunda revisão nas instituições, em cujos destinos os intelectuais forcejavam por influenciar ${ }^{552}$.

Helena Bomeny destacou o espaço institucional criado por Gustavo Capanema no Ministério da Educação e Saúde como ponto de contato privilegiado entre os intelectuais progressistas da geração modernista e o regime Vargas, compondo aquilo que denominou “Constelação Capanema". Para Bomeny, essa associação foi possível graças à compreensão, por parte dos intelectuais progressistas em atividade naquela altura, de que a Revolução de 30 significava a possibilidade de renovação do país, pondo fim ao sistema oligárquico em vigência e, principalmente, aparelhando o Estado para a atuação em terrenos em que até então se omitira, como a Educação e a Cultura ${ }^{553}$.

Ainda que tenha sido um dos artistas monitorados pela polícia política do regime, Lasar Segall seria também um dentre estes intelectuais progressistas a estabelecer articulações amistosas com setores do governo Vargas, em ocasiões diversas. Ele se aproximou do Ministério de Gustavo Capanema, tendo quase sempre como interlocutor o chefe de gabinete Carlos Drummond de Andrade. Dessas relações permanecem vestígios no Arquivo Lasar Segall ${ }^{554}$. Sobressai, dentre todos os empreendimentos

\footnotetext{
552 PÉCAUT, 1998, p. 20-23.

553 BOMENY, Helena (Org.). Constelação Capanema: intelectuais e políticas. Rio de Janeiro: Ed. Fundação Getúlio Vargas; Bragança Paulista: Ed. Universidade de São Francisco, 2001; p. 16-17.

554 Em 1935, Segall recorreu ao órgão para obter a liberação de obras que iriam participar de uma exposição nos EUA, mas que ficaram retidas na Alfândega (documento ALS 01777). Em 1937, Segall foi designado pelo Ministério representante do Brasil no Congresso de Arte Independente (ALS 01839). Em 1939, Drummond solicitou a Segall fotos de suas obras e texto biográfico, a serem remetidos para um professor norte-americano envolvido com a redação de um compêndio sobre pintura brasileira (ALS 01983).
} 
conjuntos entre Segall e o Ministério, a grande exposição de obras realizada entre maio e junho de 1943.

Documentos do Arquivo Lasar Segall indicam que partiu do próprio artista a iniciativa de realizar uma exposição sob os auspícios do Ministério de Gustavo Capanema $^{555}$. No final do ano de 1941, Segall escreveu a Carlos Drummond de Andrade propondo uma exibição de seus trabalhos no Rio de Janeiro. A resposta de Carlos Drummond de Andrade tardou, sendo redigida somente em 7 de março de 1942. Informava que a exposição pretendida já estava acertada, e que deveria ocorrer ainda em maio de $1942^{556}$.

Entre a proposta de Segall, em fins de 1941, e a resposta oficial do Ministério, aceitando acolher a exposição, fatos decisivos tinham se desenrolado, tornando insustentável a neutralidade tensa que o governo Vargas mantivera quanto ao conflito em andamento no mundo. Desde o final de 1941, quando os EUA declararam guerra ao Eixo, acordos comerciais e militares faziam o Brasil pender para o campo dos aliados. Em janeiro de 1942, após o rompimento das relações diplomáticas com os países do Eixo, navios brasileiros foram torpedeados na costa do Atlântico, em ataques que foram atribuídos a submarinos alemães. O episódio provocou uma intensa mobilização da opinião pública, que levaria definitivamente à adesão do Brasil ao bloco dos Aliados e à declaração de guerra ao Eixo, em agosto de 1942. Ainda que os indícios apresentados não permitam articular indiscutivelmente o acolhimento da exposição de Segall a essa nova situação geopolítica, a aproximação entre o artista e o governo era bastante significativa em meio a estes acontecimentos. A exposição de Segall seria seguida por uma de Cândido Portinari, no mesmo Museu Nacional de Belas Artes, também patrocinada pelo Ministério de Gustavo Capanema. Tais eventos, novos sinais da aproximação oficial do Governo com a estética modernista, tinham um significado político muito claro naquele momento; diversas outras exposições viriam a ocorrer nesse contexto de mobilização antifascista,

\footnotetext{
555 O Jornal "A Manhã" de 29 de abril de 1942 afirmava que o convite para a exposição viera do próprio ministro Gustavo Capanema; os documentos do ALS, no entanto, sugerem o contrário; ver ALS 02394.

${ }^{556}$ ALS 02407. O Ministério tinha a intenção de realizar a exposição ainda em 1942; em duas ocasiões, Segall foi instado a definir a data, e chegou a declarar publicamente que estrearia em setembro de 1942 (o jornal "A Manhã" de 29 de abril de 1942 anunciou a exposição para esta data). No final, acabou decidindo que a exposição seria realizada em maio de 1943. Comunicado sobre a decisão, Drummond reitera a intenção de acolhimento do Ministério, afirmando que a exposição seria "recebida e estudada com toda a atenção que merece"; cfe. ALS 02450.
} 
até 1945. A arte moderna tinha neles um papel de destaque, simbolizando as correntes progressistas e antifascistas 557 .

“(...) Os puristas das linhas, os chamados clássicos, não eram nem clássicos, nem estavam se importando com o desenho, a cor, os volumes. (...) Saudosistas do tronco aproveitaram o pintor para uma demonstração de força. Segall pintava com as cores sombrias, logo Segall era um doente, um mórbido. Segall pintava com cores vivas, logo Segall era um elemento de rebeldia, que tramava contra a ordem, que pretendia acabar com Deus, com a pátria, com a família. (...) Mais uma vez, fingindo servir ao Brasil, esta gente serve às suas paixões políticas" ${ }^{558}$.

Nestes termos, José Lins do Rego procurou demonstrar o caráter político, mal disfarçado em crítica de arte, dos ataques desferidos contra Segall por ocasião de sua grande exposição de 1943, no Museu Nacional de Belas Artes. Para Rego, não se tratava de verdadeiro purismo ou apego à tradição, mas de um pretexto para exercitar a paixão política. A Exposição de 1943 marcaria um paroxismo na retórica antimodernista, e talvez tenha sido o momento da trajetória do artista no Brasil em que seu nome foi mais fortemente associado à prática de uma arte degenerada.

Para Cláudia Valladão de Mattos (1997), o efeito destas críticas foi contrário ao que desejavam seus autores. Em sua análise da trajetória da crítica brasileira sobre Lasar Segall, a exposição de 1943 representaria um divisor de águas na carreira do artista. Os violentos ataques que recebeu incitaram uma reação por parte expressiva da intelectualidade brasileira, que se uniu para defendê-lo, projetando seu nome e sua obra entre círculos ainda não atingidos ${ }^{559}$. Segundo Mattos, a imagem pública de Segall ascende definitivamente à posição de herói, identificada com o engajamento em prol dos marginalizados. Jorge Amado, em sua defesa de Segall, ressaltaria que ele era um paladino da "liberdade e da reivindicação social" "560. Ao mesmo tempo, respondendo

\footnotetext{
${ }^{557}$ Sobre o processo de identificação da arte moderna com a democracia e o contexto das exposições antifascistas no Brasil e na Europa, ver COSTA, Helouise. Lasar Segall e a arte degenerada: a exposição como campo de disputa política nas décadas de 1930 e 1940. In: SCHWARTZ, Jorge; MONZANI, Marcelo (Orgs.). A "Arte Degenerada" de Lasar Segall: perseguição à arte moderna em tempos de guerra. São Paulo: Museu Lasar Segall/Museu de Arte Contemporânea, 2018.

558 José Lins do Rego, "Arte e Política”, apud FABRIS, 2000, p. 203.

559 MATTOS, Cláudia Valladão de. Lasar Segall. São Paulo: Editora da Universidade de São Paulo, 1997. É importante notar que em 1943 e 1944 há uma forte presença de Segall na imprensa, não só pela polêmica em torno da exposição, mas também pelo lançamento do álbum "Mangue" e pela publicação do número da Revista Acadêmica em homenagem ao artista, eventos que tiveram amplo destaque nos jornais do período.

${ }^{560}$ Apud. MATTOS, 1997, p. 67.
} 
diretamente aos ataques que o colocavam como "estrangeiro", ampliam-se os esforços por “integrar” Segall, ressaltando-se sua naturalização e seu apego ao país. Para Mattos, trata-se de um "[...] ato simbólico de solidarização com os judeus expatriados e recusados em toda parte" ${ }^{, 561}$. A questão da nacionalidade, para Mattos, foi o principal ponto disputado em torno da exposição de 1943: seria Segall brasileiro ou não?

Maria Luiza Tucci Carneiro encontra nos discursos dos algozes da exposição de 1943 ecos da ideologia nazista, e ressalta nessa retórica a associação entre modernismo e comunismo. Ela destaca que a posição do governo era dúbia: enquanto patrocinava a exposição, ação necessária e vantajosa, porque permitia ao regime "configurar o perfil democrático e humanitário do nosso país", mantinha uma política subterrânea contra esses mesmos valores, promulgando as "circulares secretas" que vedavam a entrada de refugiados judeus no Brasil ${ }^{562}$.$$
* \quad * \quad *
$$

"[...] bendita essa quinta-coluna da ordem e da moralidade que se levanta contra as manobras equívocas do cavalo de Troia..."
}

Carlos Maul, Pintura Arte e Pintura Política

O primeiro ataque a Segall aparece em 13 de maio, dois dias antes da inauguração. Em texto intitulado $O$ russo naturalizado está com sorte..., um redator anônimo elucubra sobre o que denomina "consideração excessiva" dispensada a Segall ${ }^{563}$. Na forma de denúncia, aponta que os salões do Museu Nacional de Belas Artes haviam sofrido uma extensa reforma para acolher as obras do "russo", enquanto que "a fina flor" da arte brasileira sofria com o descaso, tendo que expor suas obras em ambientes notadamente degradados. Segundo o redator, apesar dos repetidos e insistentes ofícios do "competente" diretor, Oswaldo Teixeira, o governo não se dignara a arcar com as necessárias obras nas salas do Museu Nacional, a não ser quando o solicitante foi o próprio Segall. Para ele, "[s]empre se disse, e é fato comprovado, que aquilo que os brasileiros não obtêm no Brasil, é obtido pelos estrangeiros". Faz questão de voltar a ressaltar aquilo que considera a nacionalidade incerta de Segall, e lança suspeitas sobre uma suposta filiação ao comunismo. Descreve-o como "um russo, naturalizado brasileiro, é verdade, mas nascido lá pelos orientes em que surge o sol vermelho pelas brumas da manhã”. Em contrapartida,

\footnotetext{
561 Idem, p. 68.

562 CARNEIRO, op. cit, p. 62-65.

563 "O russo naturalizado está com sorte...", A Notícia, Rio de Janeiro, 13 de maio de 1943.
} 
cita como exemplos de nacionalidade inquestionável os pintores Pedro Américo e Victor Meirelles, apontando que suas telas estavam acondicionadas em salas repletas de goteiras, ocasionando danos irreparáveis. O redator encerra seu texto tecendo considerações sobre o caráter estrangeiro do modernismo, e critica sua pretensão em declarar que o antigo estava superado:

"Por que não fazer essas exposições em outros locais? Já se projeta outra, naquele mesmo local, o que faz temer pela integridade de outras obras-primas.

Talvez haja quem pense que é melhor queimar tudo, pois os modernistas farão coisa muito superior, muito mais digna do apreço, muito mais "russa" do que os nossos "antiquados" mestres, sem brilho em comparação com os gênios que surgem na atualidade mais prolificamente que os cogumelos" ${ }^{\$ 64}$.

Cinco dias depois, Tristão Ribas publicou Foi assim que a França apodreceu ${ }^{565}$. O texto inicia-se com uma paráfrase do "opúsculo" do juiz Raul Machado, "A insidia comunista nas letas e nas artes do Brasil". Ribas destaca a "descoberta" anunciada pelo juiz em seu livreto, de que a arte moderna é a parte visível no terreno da estética de um amplo complô comunista, que teria a finalidade de corromper a civilização Ocidental, solapando insidiosamente cada um de seus pilares de sustentação. Para Ribas, este tão alto ensinamento havia sido esquecido, uma vez que se deparava com a exposição de Segall, patrocinada pelo estado, ocupando um dos templos sagrados da arte no Brasil. Ribas incorre numa retórica bastante similar à dos nazistas, quando se põe a descrever a exposição de Segall:

"Será arte aquilo? Será arte a procura do hediondo, a caça ao monstruoso, ao teratológico, a fixação do que há de repulsivo, de feio, de torto, de sujo, na humanidade? Será arte o transformar os aspectos formosos da natureza em composições quase abjetas no fundo e na forma? Uma crítica séria e austera, que não esteja disposta a achincalhar os leitores desprevenidos das gazetas, não poderá aceitar, sem protesto, a declaração do prefácio do catálogo de que o sr. Lasar Segall é o maior dos pintores brasileiros, aquele que penetrou mais o espírito do nosso povo e o sentido da nossa paisagem. Quem examinar o trabalho do expositor guiado pelas palavras delirantes da apresentação tem a impressão de que está sendo vítima de um fenômeno alucinatório ou de uma pilhéria de mau gosto, e além disso, de uma pilhéria muito cara... ${ }^{566}$

Demonstra irritação com a série Mangue, onde "sr. Segall gravou cenas grosseiras de um bairro de meretrício, algumas delas tão ao vivo que não seria possível nem razoável reproduzi-las sem ofensa ao pundonor do público". Na sequência de sua arenga, Ribas refere-se de maneira pejorativa ao fascismo, ao nazismo e ao comunismo, doutrinas que,

\footnotetext{
564 Idem.

565 RIBAS, Tristão. "Foi assim que a França apodreceu”. A Notícia, Rio de Janeiro, 18 de maio de 1943.

566 Idem.
} 
segundo ele, desejavam "matar os símbolos dos sentimentos bons, [...] queimar os primores da arte clássica, em suma, [...] apagar os vestígios do passado, para o começo de uma "nova humanidade", todos, continua, "empenhados a dar ao universo a fisionomia de um campo raso de baixezas e onde o cérebro seja submetido ao domínio das tripas".

No dia seguinte ao do texto de Tristão Ribas, A Notícia publica A decepcionante exposição de Lazar Segall, no Museu Nacional de Belas Artes, creditada a "A.B.C." 567. O autor julga que Segall era receptáculo de uma proteção indevida por parte do Ministério da Educação, tanto porque não precisava de estímulos oficiais, visto ser "riquíssimo", quanto porque, em comparação com outros artistas nacionais, mesmo modernistas como Guignard e Portinari, "nem sequer talento possui, a não ser o da propaganda". A.B.C. declara-se decepcionado com a baixa qualidade a exposição, e conclama o público a combater esses charlatães estrangeiros que faziam sombra aos esforçados conterrâneos:

"O que seria preciso era uma reunião, uma arregimentação dos verdadeiros artistas e pintores, para fazerem, com os medíocres aproveitadores, que vivem a ludibriar a boa-fé dos incautos e dos que nada entendem de arte, enchendo a boca e arreganhando os olhos, apregoando que quem não está com eles é porque 'nada compreende', porque 'não recebe mensagens', fazer com eles o que fizeram os pavões àquela grou que, revestida das penas de um pavão morto, penetrara em seu bando ${ }^{568}$.

Dois dias depois, as colunas de A Notícia voltam à carga. Dessa vez, o autor se identifica como Valério Camaragibe ${ }^{569}$. Numa carta aberta a Tristão Ribas, Camaragibe reitera o coro dos descontentes, novamente referindo-se à imoralidade das cenas do mangue, lugar "deprimente" que "o Chefe de Polícia limpou para bem da higiene e da moralidade dos nossos costumes":

"Eu duvido que algum dos homens importantes que andam enchendo as folhas de elogio ao sr. Segall, numa língua que felizmente ainda não tem dicionário, tenha a coragem de colocar em sua casa, à vista das visitas, qualquer daqueles episódios da vida triste do baixo meretrício. No entanto, eles cá estão nas paredes do Museu que é a menina dos olhos do professor Oswaldo Teixeira, para serem vistos por meninas inocentes que frequentam a nossa pinacoteca pública. As nossas autoridades tão severas no ataque aos maus costumes urbanos precisam voltar as suas vistas para o setor das artes plásticas. Porque não se compreende que o 'bas-fond', nos seus aspectos mais repulsivos possa ser transformando em elemento de cultura artística, de 'saúde' do povo, e de elevação espiritual" ${ }^{\prime 570}$.

\footnotetext{
${ }^{567}$ A.B.C. A decepcionante exposição de Lazar Segall, no Museu Nacional de Belas Artes, A Notícia, Rio de Janeiro, 19 de maio de 1943.

568 Idem.

569 CAMARAGIBE, Valério. Os "vira-lata" da pintura, A Notícia, Rio de Janeiro, 21 de maio de 1943. Notar a aproximação entre a censuras de Camaragibe com a retórica nazista: no Guia à exposição de Arte Degenerada, os artistas de vanguarda eram acusados de "tornar a prostituta um ideal de moralidade" [Die Dirne wird zum sittliche Ideal erhoben!]; ver Entartete Kunst Ausstellungsführer [Guia da Exposição de Arte Degenerada], 1937, p. 17.

570 Idem.
} 
A exposição, descrita como "podridão com rótulo de coisa estética", é criticada também por ser empreendimento de um estrangeiro:

"[...]parece um desaforo vir um estrangeiro da sua terra - não importa que esteja aqui há muitos anos - e a pretexto de fazer arte, invadir o Museu Nacional de Belas-Artes, com uma obra que nada tem de interessante, que é malfeita, primitiva, sem desenho, sem cor, sem alma, e que nos assuntos prima pela 'procura' (é o termo da gíria dos modernistas) da porcaria, como autêntico 'vira-lata'..."

Em 2 de junho, Camaragibe voltaria ao tema, publicando n'A Notícia o texto Arte Burra e Arte Inteligente ${ }^{572}$. Ele comenta uma entrevista recém-publicada, em que um professor de desenho da Escola Nacional de Belas Artes, Quirino Campofiorito, teria criticado a inclinação conservantista daquela academia e felicitado seus alunos pela insistência em renovar o ambiente estético. Para Camaragibe, configurava-se absurda a condenação aos clássicos - Campofiorito, segundo ele, a dissera "arte burra":

"É pois, natural que ele considere a arte clássica a 'arte burra', a arte desses irracionais que se chamam Miguel Ângelo, Leonardo, Botticelli, David, Murillo, Rembrandt, Holbein, Pedro Américo, Parreiras, Batista 'et caterva', e que encheram os museus do mundo de telas burríssimas..." 573 .

Camaragibe considerava igualmente absurda a pretensão dos alunos em imporem suas concepções: "Na opinião do professor Campofiorito, não são os mestres que sabem o que devem ensinar, mas os alunos ignorantes é que estão em condições de distinguir o que está certo e o que está errado em matéria artística”. Finalmente, dava como prova do pensamento incongruente de Campofiorito o fato de ter levado seus estudantes revolucionários para a exposição de Segall, "e lá se demorou a explicar-lhes a significação e a transcendência daquelas monstruosidades sem pés nem cabeça".

No dia 4 de maio, Carlos Maul publicou Pintura arte e pintura política ${ }^{574}$. Divide sua argumentação em duas frentes: estética e política. Em termos de estética, procura comprovar que, ao contrário do que se dizia, os modernistas incorreriam em fórmulas, recaindo na "monotonia", "homogeneidade" e "vulgaridade" tanto quanto seus inimigos declarados. É assim que sustenta haver semelhanças formais, oriundas de uma "receita"

\footnotetext{
571 Idem.

572 CAMARAGIBE, Valério. "Arte burra e arte inteligente". A Notícia, Rio de Janeiro, 2 de junho de 1943.

573 Idem.

${ }^{574}$ MAUL, Carlos. Pintura arte e pintura política. A Notícia, Rio de Janeiro, 4 de junho de 1943.
} 
modernista, atravessando as obras de artistas de vanguarda em toda parte. Para Maul, o ponto comum, além das soluções técnicas, era a temática "monstruosa":

"Quem quer que examine a obra do modernismo verificará imediatamente a uniformidade da técnica e a predileção pelo monstruoso. Entre os 'clássicos' o 'homem era a medida de todas as coisas', isto é, o 'homem helênico', perfeito de corpo, modelo de equilíbrio de linhas, ou seja o símbolo o paradigma da beleza. Entre os 'modernos' o 'homem torto é a medida de todas as coisas' porque eles se deleitam em fixar na tela as deformidades da natureza, os abortos, o feio e o corrompido, o desagradável aos olhos. Não me digam, ainda que com as palavras mais bonitas do mundo, que um nanico sem pescoço, caolho, maneta ou perneta, é belo, é modelar, é digno de ser imitado em pintura para enfeite de paredes. Quando muito, a contemplação de um aleijado inspira piedade, nunca porém nela teremos motivo de exaltação de espírito"s75.

Por outro lado, Maul repisa o argumento de que haveria uma intenção política insidiosa por trás das propostas modernistas, ligada a um plano de dominação comunista. Finalmente, Maul refere-se ao caráter inoportuno da exposição de Segall, que traria uma pregação antibelicista indesejável naquele momento em que o Brasil se mobilizava contra o Eixo:

"O Brasil está envolvido em uma guerra de vida e morte, convocando a unanimidade das suas energias físicas e morais para enfrentar um inimigo sem entranhas que não mede obstáculos para ganhar a última batalha e impor aos vencidos o seu domínio. E um dos capítulos fundamentais do programa do governo, particularmente das nossas autoridades militares, é o que concerne à criação de uma mentalidade de guerra, ou melhor, de uma consciência da situação presente, orientada no sentido de congregar todos os elementos necessários à luta armada. Isso quer dizer que em todos os setores nada se deve fazer que possa afrouxar os ânimos ou debilitar o moral dos indivíduos. Empenhado como está o Estado Nacional em manter a coesão brasileira, em impedir que os corrosivos espirituais destruam a sua força, como é possível admitir que se exponha uma tela como 'Guerra' do Sr. Segall? Esse quadro é o que se pode chamar de pintura antimilitarista. Nele o tema é de desestímulo, de desencorajamento, de fonte de pavor. O seu efeito é semelhante ao de uma propaganda pacifista que se viesse a desenvolver numa frente de combate na hora em que as legiões adversárias estivessem no auge da ferocidade, despejando contra ela todo o ferro das suas bocas de fogo" ${ }^{\text {576 }}$.

Em 11 de junho, A Notícia publicou uma entrevista com o juiz Raul Machado, reavivando a polêmica ${ }^{577}$. Segall é denominado "um artista da deformação". Antes de incursionar pelas considerações do sentido político da arte moderna, Machado aventurouse a filosofar sobre a essência da arte:

"A criação artística surge do impulso de se dar forma a alguma coisa no anseio de expressar emoções. A forma artística é em sua essência, uma imitação da realidade; ela coloca um espelho em frente da Natureza. Todavia, o intuito da arte não é representar, servilmente, o aspecto externo das coisas, mas a sua íntima significação, pois, esta é que constitui a verdadeira realidade.

\footnotetext{
575 Idem.

576 Idem.

${ }^{577}$ Em torno das exposições de arte moderna, A Notícia, Rio de Janeiro, 11 de junho de 1943.
} 
Se o fim da arte fosse reproduzir unicamente o aspecto externo das coisas, a rainha das artes seria, sem dúvida, a fotografia colorida...

Por isso mesmo, toda obra de arte, consoante Aristóteles, deve aspirar à forma, como 'instrumento de compreensão' mas deve exprimir um estado íntimo, como um 'significado emotivo', que o artista deseja fixar e transmitir.

Não raro, diante de uma pintura ou de uma estátua, tecnicamente perfeitas, arguimos, à guisa de restrição aos seus méritos, que lhes falta 'vida'...

Que significa isso? Que o artista não soube transmitir à obra o sentido íntimo da emoção de que se achava porventura possuído"578.

A leitura do trecho aponta uma proximidade entre as ideias estéticas do Juiz e aquelas de Véron e dos estetas e críticos do final do século XIX. Se por um lado reafirmase a necessidade de apego às formas da natureza, por outro preconiza-se a necessidade de ser fiel a uma sensibilidade individual que, às vezes, deve levar à ruptura das tradições canônicas, em nome da expressão. Mas nada que se aproxime das ousadias tomadas pelos modernistas. Estes, em seu afã por dar as costas à técnica e a um certo conjunto de princípios tradicionais do fazer artístico, estariam incorrendo no primitivismo, na puerilidade, na incapacidade e, em última instância, na loucura ou na subversão. E para lidar com estes desvios, Machado afirma haverem apenas dois caminhos: a terapia psiquiátrica ou o braço violento da polícia.

Finalmente, encerra o ciclo de ataques a Segall o texto de "Antônio Conselheiro", intitulado Arte e Doenças Tropicais ${ }^{579}$. Nesta coluna, Conselheiro faz uma profunda articulação entre arte moderna e enfermidades. A descrição que faz de suas impressões diante das obras do "russo naturalizado" faz lembrar uma versão escrita das páginas de Arte e Raça, de Paul Schultze-Naumburg:

“Trouxe do 'lazareto' a mais triste das impressões. Não vou repisar o que já disseram, melhor do que eu, homens abalizados, autoridades no assunto. Quando lá entrei, tive a impressão de estar numa das salas da nossa Santa Casa de Misericórdia, onde se trata de elefantíase, de mal de Hansen e enfermidades glandulares! Porque, os rabiscos, as garatujas que um meu netinho de oito anos se envergonharia de fazer, não podem ser outra coisa senão casos patológicos, dignos de um museu médico e não de uma escola de belas artes!" 580 .

\section{Insídia comunista nas letras e nas artes do Brasil}

Raul Campelo Machado da Silva, conhecido publicamente como Raul Machado, era juiz do Tribunal de Segurança. Em suas funções oficiais, lidava com os casos dos "agitadores" políticos que ameaçavam a estabilidade do regime. Extrapolando suas

\footnotetext{
578 Idem.

${ }^{579}$ CONSELHEIRO, Antonio. Arte e doenças tropicais, A Notícia, Rio de Janeiro, 11 de junho de 1943.

580 Idem.
} 
atribuições, Machado desenvolvia a crítica de arte, que associava à luta anticomunista. Sua obra mais célebre, Insídia comunista nas letras e nas artes do Brasil ${ }^{581}$, seria mencionada em alguns dos ataques a Segall, por ocasião da exposição no Museu Nacional de Belas Artes, em 1943. Editado em 1941, o folheto de 20 páginas era composto por um conjunto de textos curtos publicados originalmente em jornais. Em geral, traziam ataques dirigidos às formas estéticas "modernistas", que eram compreendidas como parte de um plano de dominação comunista.

A trajetória da retórica de Raul Machado aponta um significativo elo entre as ideias antimodernistas e os altos comandantes das forças militares brasileiras. O conteúdo dos textos de Machado agradou a várias autoridades Exército, que determinaram que fosse editado nas oficinas da Imprensa Militar do Rio de Janeiro, de onde saíram 25 mil exemplares da obra. Daí em diante, em efeito cascata, o livro foi adotado por outras autoridades de diversas regiões. Em Vitória (ES), Moacir Ubirajara, Secretário de Educação e Saúde Pública, mandou imprimir o folheto e distribuiu-o entre os professores da rede estadual ${ }^{582}$. Em Sergipe, foi publicado no Diário Oficial e divulgado na rádio pública. No próprio Rio de Janeiro foi lido em sessão da Academia Brasileira de Letras e irradiado por diversas estações radiofônicas.

No folheto, Machado reedita a maioria das ideias que a crítica antimodernista vinha cultivando desde os anos 1920. Desta vez, no entanto, as acusações contra o modernismo se articulam em torno da ideia de penetração comunista. A adoção do coloquial e do popular, a incursão na "imoralidade", as ousadias formais na arte e literatura do Brasil seriam, na ótica de Machado, partes de uma estratégia de dissolução das estruturas cristãs ocidentais, preparando terreno para a instauração da "doutrina vermelha".

Diz acreditar existir um enorme séquito oculto de comunistas, agindo de acordo com "as linhas programáticas de uma inteligência organizadora, a serviço de um plano de atividade diabólica" $" 583$. As estratégias desse ataque se baseariam na "proletarização da literatura e da arte", que significa selecionar temas sociais para os romances modernos, ocasião para a introdução das doutrinas insidiosas. Além disso, tratariam de conspurcar a

\footnotetext{
581 MACHADO DA SILVA, Raul Campelo. Insídia comunista nas letras e nas artes do Brasil. Rio de Janeiro: Imprensa Militar, 1941.

582 Idem, p. 18.

583 Idem, p. 5.
} 
forma, mediante o ataque às regras elementares da gramática, corrompendo a linguagem, “nivelando, quanto possível, às das classes proletárias e incultas, corroendo-se, assim, um dos elementos orgânicos da unidade de um povo"584. Para Machado, a adoção do coloquial na literatura, o uso literário da língua como falada cotidianamente, significa não uma decisão estética, mas político-doutrinária. "E isto se faz, disfarçadamente, sob o pretexto de se estar construindo "língua brasileira"”.

Acusa a arte moderna de recorrer à obscenidade como "ataque premeditado à moral burguesa, que precisa ser destruída" 585 ; fazem prosa "insulsa e desconexa" com a finalidade de desvalorizar o patrimônio.

“A música se transforma em violência de ruídos, visando também uma finalidade única: a negação da melodia, porque esta leva naturalmente a um estado de exaltação espiritual, incompatível com as tendências da doutrina materialista"586. Faz-se "apologia do samba, porque os seus temas são dissolventes da moral, a sua letra é do 'homem do povo' e a sua técnica, se existe, refoge a qualquer preceito artístico de criação burguesa" ${ }^{587}$. Finalmente, “[...] a pintura fica reduzida a verdadeiras criações teratológicas, porque é preciso irmos nos acostumando, desde já, à glorificação do "monstruoso" "588.

A argumentação de Machado serve-se de conceitos muito similares aos encontrados na obra de Véron, e de fato, o juiz chega a citar o crítico francês, apontandoo como lastro para a defesa da existência de processos necessários, elementares e indispensáveis, presentes em todos os outros momentos da arte (que o autor enumera: classicismo, romantismo, naturalismo), e que os modernistas teriam abandonado, incorrendo na "[...] repulsa aos processos clássicos, a falência do estilo e da forma, o desprezo impatriótico da língua, o repúdio da lógica, a negação da beleza e do sentimento... A inconformação com a realidade, pela deformação de tudo" ${ }^{\text {"589. Para }}$ Machado, a arte modernista é inerte, porque não comunica nada, não estabelece empatia, não transmite a sensação imediata que os "processos clássicos" asseguravam. Para ele, essas distorções na arte serviam ao fim oculto de preparar o terreno para o bolchevismo. Traduziam a alegria vândala de destruir, como bárbaros a sitiar a "cidadela da literatura e da arte" $" 590$. Descreve-os ainda como trocistas, a fazer piada do público ingênuo.

\footnotetext{
584 Idem, p. 4.

585 Idem.

586 Idem.

587 Idem.

588 Idem, p. 5.

589 Idem, p. 7.

590 Idem, p. 9.
} 
Finalmente, recorre à acusação de serem técnicos incapazes, ocultando a escassez sob o manto do primitivismo das formas.

O opúsculo destina-se a ser, declaradamente, um "brado de alerta", para que seja reforçada a vigilância. Defende que se adote, por um lado, a censura e a interdição de obras suspeitas, e de outro, que se exerça uma "contrapropaganda", promovendo a moral e a tradição. O juiz Machado ressalta o caráter nacional da arte, natural e necessário, e o interesse bolchevique de dissolver o sentimento pátrio, por ser este um empecilho a sua consecução:

"Os comunistas, porém, se insurgem contra o nacionalismo, porque sabem que no sentimento que o anima reside a principal força viva de defesa das pátrias, visadas pela sua propaganda política.

Imaginaram, assim, de acordo com as tendências de uma ideologia que pretende ser 'universal', uma arte também 'universalista'" 591.

Além disso, visa as classes populares, grupo maior que o pode ajudar a triunfar; daí o primarismo da arte moderna, "porque visa o espírito das massas, destituídas, em modo geral, de apurado gosto estético"592, decretando a "falência do sentimento artístico nas classes intelectualmente elevadas"; "repele a beleza e os anseios de perfeição como coisas fúteis", regride à infância da arte, ou à sua pré-história.

A análise do conteúdo de Insídia comunista... demonstra uma flexão singular do discurso refratário à modernidade, apresentando combinações novas dessa corrente de pensamento. Em alguns pontos, o autor se aproxima do discurso de Oscar Guanabarino ao criticar a penetração do popular na arte, fenômeno que Machado chama de "proletarização"; ambos, o crítico de arte e o juiz, denunciam essa aproximação como daninha à cultura nacional. Machado, como muitos dos refratários às vanguardas, recorre às ideias de Véron, tentando provar a existência de padrões estéticos "naturais" e necessários, que não deveriam ser abandonados. Além disso, o discurso de Machado se aproxima da retórica de Bettina Feistel-Rohmeder e os partidários da $D K$, bem como dos ideólogos da política cultural nazista, ao defender a necessidade de barrar o "universal" em favor da preservação do genuinamente nacional na cultura. $\mathrm{O}$ que singulariza $\mathrm{o}$ discurso de Machado - e o aproxima da retórica nazista - é a finalidade com que ele é construído: trata-se de uma luta anticomunista. Machado garante que todas as “distorções" introduzidas pelos "modernistas" - o abandono das formas tradicionais, a

\footnotetext{
591 Idem, p. 11.

592 Idem, p. 12.
} 
"proletarização"- são estratégias de um plano cuidadosamente orquestrado, gerido nas sombras por mentes diabólicas, em nome da implantação do comunismo. Nisso Machado revela a "lógica da desconfiança" de que trata Carneiro, natural num burocrata encarregado justamente da gestão dos “crimes políticos". A arte moderna, enfim, é para o juiz Machado não apenas "primitiva e grosseira", mas "venenosa e suspeita"593.

A proximidade entre elementos antimodernistas e o poder militar não se resumiria à figura de Raul Machado. Carlos Maul, outro dos que se engajaram na campanha contra a exposição de Lasar Segall, também demonstraria esse traço, e chegaria, de fato, a associar sua pena ao braço "intelectual” do exército, ao ocupar, nos anos 1930 e 1940, posição de comando na Biblioteca do Exército ${ }^{594}$.

Intelectual ativo desde a primeira década do século XX, Maul se associou ao movimento nacionalista que fermentava no Rio de Janeiro no perído da Primeira República. O conceito de "nacionalismo" variava bastante naquela altura, configurando conjuntos bastante heterogêneos de noções entre cada um de seus autodeclarados cultores. Para Carlos Maul, o caráter nacional brasileiro estava ainda em vias de se concretizar, sendo necessário, para isto, que o país sofresse um processo de expurgo dos elementos alienígenas. No manifesto Do Titanismo, como base de uma estética nacionalista (1917), Maul amaldiçoava o "parisismo" dos autores brasileiros, que voltavam as costas ao esplendor natural do Brasil e se nutriam da "paisagem raquítica e amaneirada de países gastos" "595. Por outro lado, condenava a presença de "abusões africanas que os escravos negros trouxeram"

O nacionalismo de Maul o levaria a tomar parte em uma grande quantidade de associações e movimentos, que tinham em comum o ardor nacionalista e a combatividade. Participou de campanhas contra a presença lusitana na imprensa e no comércio do Brasil, contra a reforma ortográfica acertada entre a Academia Brasileira de Letras e sua congênere portuguesa e até mesmo contra o suposto "monopólio" dos poveiros pescadores de origem portuguesa - na atividade da pesca no Brasil. Reinterpretou a história do Brasil em dezenas de artigos e livros, sempre em chave nacionalista, e

\footnotetext{
593 Idem, p. 13.

${ }^{594}$ Para uma análise mais extensa da crítica de arte e da atividade política de Carlos Maul, ver CAIRES, Daniel Rincon. A crítica de arte nacionalista de Carlos Maul. Anais do XXIV Encontro Regional de História da ANPUH, 2018

595 MAUL, Carlos. Do Titanismo, como base de uma esthetica nacionalista. In: Revista Americana, ano VII, no 1 , Outubro/1917; p. 106-119.

${ }^{596}$ Idem, p. 113.
} 
procurou influir nas políticas educacionais, insistindo na necessidade de um currículo unificado em todo o país, que enfatizasse a educação cívica e afastasse as influências estrangeiras que contaminavam a alma nacional.

A partir dos anos 1930, Maul deixaria de lado suas antigas prevenções antilusitanas para concentrar-se num outro inimigo da nacionalidade: o bolchevismo cosmopolita. Assim como Raul Machado, Maul apontaria o campo da produção cultural - especialmente nas letras e nas artes brasileiras - como cenário preferencial para a batalha pela defesa da alma nacional. Convocou os intelectuais brasileiros à guerra, logo após o movimento que ficou conhecido como Intentona Comunista ${ }^{597}$. Atacou reiteradamente os artistas modernos brasileiros, empregando com frequência a retórica da degeneração ${ }^{598}$.

Na maré vazante das tendências estéticas tradicionais, Carlos Maul encastelou-se na Biblioteca Militar. Incorporado à Comissão Diretora, pôde exercitar ali suas facetas de historiador nacionalista, ferrenho anticomunista e pedagogo cívico. Editou obras de sua autoria, participou da seleção de outros tantos compêndios patrióticos, representou a instituição como palestrante em diversas efemérides, fomentou a criação de uma série de livros infantis dedicados ao cultivo do amor pela nação. A atividade de Carlos Maul junto à Biblioteca Militar aconteceu num momento em que a instituição se reestruturava, num processo que, segundo Clarice Berkowicz, fazia parte de um grande movimento de transformação do papel das forças armadas no Brasil, "de invenção do Exército como aparelho de Estado"599.

Maul encontrava-se ainda atuante no momento em que aquilo que chamou de "milagre de uma Revolução" 600 - o golpe militar de 1964 - supostamente varreu do mapa a onda modernista. Em suas memórias, editadas em 1968, Carlos Maul pôde jactar-se do fato de que, após tantas décadas de vitórias e avanços, os "vândalos que Graça Aranha havia arregimentado em $1922 " 601$ haviam sido finalmente batidos.

\footnotetext{
597 Palavras aos intellectuaes brasileiros. Correio da Manhã, 5/12/1935, p. 4; cfe. CARDOSO, 2015.

598 Por exemplo, em O espirito subversivo do modernismo. Correio da Manhã, 25/6/1936, p. 4; Fócos de infecção. Correio da Manhã, 10/3/1935, p. 2 e Falso conceito de cultura. Correio da Manhã, 10/10/1935, p. 4.

599 BERKOWICZ, Clarice B. Araújo. Da Biblioteca do Exército à Biblioteca Militar: o lugar ocupado pela instituição no Estado Novo. Anais do XXVI Simpósio Nacional de História - ANPUH - São Paulo, julho 2011. ${ }^{600}$ MAUL, Carlos. Grandezas e misérias da vida jornalística - Memórias. Rio de Janeiro: Livraria São José Editora, 1968, p. 93.

${ }^{601}$ Idem, p. 88.
} 


\section{Considerações finais}

Em seu estudo sobre as transformações na esfera pública, Habermas demonstrou que, num primeiro estágio, o debate público se ocupou preferencialmente da crítica cultural, julgando a arte e a literatura do tempo a partir de uma argumentação tida como racional $^{602}$. Mais do que qualquer outra linguagem, a pintura tornou-se campo preferencial de discussões públicas. Livres da dependência das guildas, das instituições religiosas e dos círculos nobres, que até então os amparavam e dirigiam, os pintores viram suas obras penetrarem o campo do mercado e tornarem-se bens de consumo que, como tal, estavam à expostos ao escrutínio geral ${ }^{603}$. Nas palavras de um contemporâneo, “"[u]ma pintura em exibição é o mesmo que um livro impresso vendo a luz do dia, uma peça representada sobre um palco - qualquer um tem o direito de julgá-la"604. A discussão estética cria um fórum público onde irão circular também temas políticos, sociais e econômicos, convertendo-se numa plataforma de apoio a um grupo social em ascensão e ainda sem expressão na política institucional.

O presente trabalho procurou expor resultados de uma pesquisa dedicada a compreender as formas do pensamento estético antimoderno. A observação detalhada das polêmicas em torno do modernismo parece ter demonstrado que esse debate manifesta claramente posições políticas, ligadas aos interesses de grupos sociais também bastante discerníveis. Na Alemanha do final do século XIX, o antigo status quo imperial aferravase à estética tradicional, enquanto era assediado - política, econômica, social e esteticamente - por uma burguesia industrial-comercial de caráter cosmopolita interessada na arte impressionista francesa, e em busca de espaço institucional, seja em parlamentos, seja nos museus públicos. Esse mesmo grupo irá chocar-se com um proletariado urbano cada vez mais politizado e com ondas iconoclastas no início do século XX, envolvidos na busca de soluções existenciais - políticas e estéticas - para além das fronteiras da mentalidade burguesa.

Como parte do mesmo movimento, os reacionários se agregam em torno de uma nostalgia falsificada, em nome de um passado imaginário que tratam de instituir a ferro e fogo. Nota-se, por parte dos reacionários, um profundo descontentamento com as novas

\footnotetext{
${ }^{602}$ HABERMAS, Jürgen. The Structural Transformation of the Public Sphere - an inquiry into a category of bourgeois society. Trad. Thomas Burger. Cambridge: The MIT Press, 1991, p. 29.

603 Idem, p. 40.

604 LA FONT apud. HABERMAS, p. 40.
} 
estruturas da vanguarda que se apresentavam em caráter ainda embrionário no fin-desiecle e que se desenvolveriam em sólidas instituições nas décadas seguintes. Irritavamse com a criação de um circuito alternativo de produção e consumo da arte - todo o novo cenário formado por galerias, ateliês, secessões, periódicos de arte etc. Nesse sentido, é interessante notar a desautorização feita pelos reacionários, que negavam aos artistas o direito de identificação, de indicação e descrição de suas "escolas" e de sua posição no interior da narrativa da história da arte.

No Brasil, a primeira geração que fala em nome do modernismo - a dos "positivistas estéticos" - exercia política ao fazer corresponderem os cânones estéticos tradicionais às condenadas estruturas - escravismo, latifúndio e monarquia - e ao fundir como partes de um mesmo fenômeno a "arte moderna" e o pensamento republicano.

Trata-se, enfim, de uma disputa em torno do conteúdo simbólico da arte moderna ${ }^{605}$. Esta última, como visto, foi em diferentes momentos, por diferentes grupos, entendida como contaminação estrangeira, evolução necessária, veículo de energias recalcadas pelo excesso de civilização, fachada cultural de um plano insidioso de conquista, veículo de ideias progressistas e libertárias. A cada uma dessas interpretações do modernismo corresponde um posicionamento no interior das disputas sociais, políticas e econômicas em andamento.

Não se pode negar a disparidade entre os discursos dos críticos analisados. Há claras idiossincrasias pontuando seus pensamentos. A Nordau, conforme argumentou-se anteriormente, interessava absolver os judeus da acusação de serem os corruptores da cultura ocidental, bem como defender o pensamento científico das investidas de filosofias dissolventes, como a de Nietzsche, ou de tentativas de açambarcamento por parte de correntes estéticas "concorrentes", como o naturalismo de Zola ou o "Ibsenismo". A Guanabarino, interessava inicialmente derrotar o status quo imperial e, depois de proclamada a República, zelar pela manutenção do novo estabelecimento, que seria em breve desafiado pelos "futuristas".

Todos, no entanto, se uniam pelo apreço a elementos centrais da estética positiva. Entretinham uma compreensão fisiológica do fenômeno artístico, e disso derivavam a crença em leis de composição regendo a criação. Além disso, mantinham uma visão

\footnotetext{
${ }^{605}$ Sobre os processos sociais de criação de sentido simbólico em objetos e coleções, ver POMIAN, Krzysztof. Coleção. In: Enciclopédia Einaudi vol 1. Memória-História. Imprensa Nacional/Casa da Moeda, 1984.
} 
evolucionista dos fenômenos culturais, compreendidos na ótica darwinista de desenvolvimento gradual, o que lhes permitia estabelecer uma hierarquização das manifestações, dividindo-as entre primitivas ou civilizadas, de acordo com a proximidade ou distância que apresentavam em relação ao ideal. É evidente que, nesse pensamento, os elementos culturais europeus eram tidos como os mais elevados, evoluídos e civilizados, oferecendo-se como padrão pelo qual se media tudo o que se produzia na música, nas artes visuais e na literatura.

Diante de propostas que desdenham de certas determinações fisiológicocientíficas, a Estética Positiva encontra seus limites: ela passa à posição de defensora do estabelecido, contrapondo-se ao "novo". E o faz acusando-o de ser “degenerado", ou seja, de perverter as leis naturais. Passa a apontar as novas propostas como resultado de morbidades psíquicas, e muitas vezes explica essas morbidades como efeitos do contato com as forças supostamente deletérias da "vida moderna". Nesse ponto, a estética positiva associa-se com a longa tradição "pastoral", romântica, que demonizava os efeitos da modernidade e cultivava plangente nostalgia pela vida "simples", "íntegra", "pura" e "autêntica" de um passado idealizado.

Um outro limite da estética positiva se torna evidente quando, ao longo das primeiras décadas do século XX, a cultura dita "popular" começa a penetrar cada vez mais amplamente nos espaços até então reservados à "erudita". Combate-se o popular avaliando-o como "primitivo", acusado-o de imoral e de não-nacional.

Em resumo, o que se propõe, quando se observa os resultados colhidos ao longo da pesquisa, é que a ideia "antimoderna" que combateu as propostas de vanguarda nas primeiras décadas do século XX, e que encontrou, durante o período nazista, ocasião para se tornar política cultural oficial, não nasce com Max Nordau, na década de 1890. Tampouco era de sua natureza essencial ser "antimoderna", uma vez que, em sua primeira aparição, alinhava-se ela mesma às forças modernizantes. O que parece ficar claro quando se tem diante dos olhos o resultado da observação da trajetória e dos usos dessa ideia, é que ela surge na década de 1870 e vai reaparecer intermitentemente nas décadas seguintes. Nas décadas de 1920 e 1930 atingiu o ápice de sua força e disseminação, combatendo as vanguardas estéticas e a cultura "popular" que se infiltrava nos antigos espaços das musas clássicas. 


\section{BIBLIOGRAFIA E FONTES}

\section{Recursos eletrônicos}

http://www.geschkult.fu-berlin.de/en/e/db_entart_kunst/index.html (Database "Entartete Kunst” da Universidade Livre de Berlim)

http://mls.gov.br/acervo/index.php/busca (“Acervos integrados” do Museu Lasar Segall, ferramenta que permite pesquisar simultaneamente em três repositórios distintos sob guarda do Museu: obras, fotografias e documentos)

https://www.ifar.org/provenance guide.php (endereço eletrônico da "International Foundation for Art Research", de onde se extraíram definições sobre "provenance”).

http://www.skd.museum/de/museen-institutionen/residenzschloss/kupferstichkabinett/sammlungsgeschichte/index.html (dados históricos sobre o Kupferstichkabinett de Dresden).

http://kulturportal-west-ost.eu/biographien/wiese-erich-2 (biografia de Erich Wiese).

https://www.museum-folkwang.de/de/ueber-uns/geschichtearchitektur/geschichte.html (histórico do Museu Folkwang, de Essen).

http://www.dw.com/en/conspiracies-swirl-in-1939-nazi-art-burning/a-17510022 (reportagem sobre o aniversário de 75 anos da destruição das obras de arte moderna confiscadas pelos nazistas).

http://www.galerie-dresden.de/index.php?node=99\& (informações sobre a Städtische Galerie Dresden).

http://www.lostart.de/Webs/EN/Datenbank/KunstfundMuenchen.html (informações sobre a coleção de arte de Cornelius Gurlitt, filho do marchand dos nazistas Hildebrand Gurlitt)

http://memoria.bn.br/hdb/periodico.aspx (Hemeroteca Digital Brasileira - Fundação Biblioteca Nacional) Repositório de versões digitais de periódicos brasileiros). 


\section{Bibliografia}

ALAMBERT JUNIOR, Francisco Cabral. A reinvenção da semana (1932-1942). In: Revista USP, São Paulo, n. 94, p. 107-118, jun./jul./ago. 2012.

; CANHÊTE, Polyana. As Bienais de São Paulo: da era do Museu à era dos curadores (1951-2001). São Paulo: Boitempo, 2004.

ALMEIDA, Paulo Mendes de. De Anita ao Museu: O Modernismo, da primeira exposição de Anita Malfatti à primeira Bienal. São Paulo: Terceiro Nome, 2014.

ALTSCHULER, Bruce. From Salon to Biennial - Exhibitions that made Art History; Vol. I: 1863-1959. London/New York: Phaidon, 2008.

BARRON, Stephanie (Org.). Degenerate art: the fate of the avant-garde in Nazi Germany. Los Angeles: Los Angeles County Museum of Art, 1991.

. Modern Art and Politics in Pre War Germany. In: BARRON, Stephanie (Org.). Degenerate art: the fate of the avant-garde in Nazi Germany. Los Angeles: Los Angeles County Museum of Art, 1991.

BARROS, Roque Spencer Maciel de. A ilustração Brasileira e a Ideia de Universidade. São Paulo: Editora Convívio/Editora da Universidade de São Paulo, 1986.

BAUDELAIRE, Charles. Salão de 1846. In: BAUDELAIRE, Charles. Poesia e prosa: volume único. Edição organizada por Ivo Barroso. Rio de Janeiro: Nova Aguilar, 1995.

BECCARI, Vera d'Horta. Lasar Segall e o modernismo paulista. São Paulo: Brasiliense, 1984.

BEHR, Shulamith. Anatomy of the woman as collector and dealer in the Weimar period: Rosa Schapire and Johanna Ey. In: MESKIMMON, Marsha; WEST, Shearer. Visions of the "neue Frau": Women and the Visual Arts in Weimar Germany. Brookfield/EUA: Scolar Press, 1995. p. 96-107.

BENNETT, Tony. The Birth of the Museum - history, theory, politics. London/New York: Routledge, 2005.

BERKOWICZ, Clarice B. Araújo. Da Biblioteca do Exército à Biblioteca Militar: o lugar ocupado pela instituição no Estado Novo. Anais do XXVI Simpósio Nacional de História - ANPUH - São Paulo, julho 2011.

BERMAN, Patricia G. The Invention of History: Julius Meier-Graefe, German Modernism, and the Genealogy of Genius. In: Studies in the History of Art, Vol. 53, Symposium Papers XXXI: Imagining Modern German Culture: 1889-1910 (1996), p. 90105.

BLACKBOURN, David; ELEY, Geoff. The Peculiarities of German History - Bourgeois Society and Politics in Nineteenth-Century Germany. Oxford: Oxford University Press, 1984. 
BOAVENTURA, Maria Eugênia (Org.). 22 por 22: A Semana de Arte Moderna Vista pelos Seus Contemporâneos. São Paulo: Editora da Universidade de São Paulo, 2000.

BOMBERGER, E. Douglas. "A tidal wave of encouragement": American composers' concerts in the Gilded Age. Westport/Connecticut: Praeger, 2002.

BOMENY, Helena (Org.). Constelação Capanema: intelectuais e políticas. Rio de Janeiro: Ed. Fundação Getúlio Vargas; Bragança Paulista: Ed. Universidade de São Francisco, 2001.

BORGES, Dain. 'Puffy, Ugly, Slothful and Inert': Degeneration in Brazilian Social Thought, 1880-1940. Journal of Latin American Studies, Vol. 25, No. 2. (May, 1993), p. 235-256.

BUKOWSKI, Charles. The Roominghouse Madrigals - Early Selected Poems - 19461966. Los Angeles: Black Sparrow Press, 1988.

BURKE, Peter. Popular Culture in Norway and Sweden. In: History Workshop, n. 3 (Spring 1977), p. 143-147.

CAIRES, Daniel Rincon. A crítica de arte nacionalista de Carlos Maul. Anais do XXIV Encontro Regional de História da ANPUH, 2018.

. Oscar Guanabarino: de moderno a "passadista". Revista Eletrônica 19\&20, Rio de Janeiro, v. XII, n. 1, jan./jun. 2017.

Arte Degenerada - A crítica de arte científica de Max Nordau. Anais do XXIII Encontro Regional de História da ANPUH, 2016.

CANCLINI, Néstor García. Culturas Híbridas: Estratégias para Entrar e Sair da Modernidade. São Paulo: EDUSP, 2008.

CARDOSO, Rafael. A Arte Brasileira em 25 quadros [1790-1930]. Rio de Janeiro: Record, 2008.

- Modernismo e contexto político: a recepção da arte moderna no Correio da Manhã (1924-1937). São Paulo/Universidade de São Paulo - Revista de História, núm. 172, janeiro-junho 2015, p. 335-365.

CARNEIRO, Maria Luiza Tucci. A Arte de Lasar Segall. In: CARNEIRO, Maria Luiza Tucci; LAFER, Celso. Judeus e Judaísmo na Arte de Lasar Segall. Cotia, SP: Ateliê Editorial, 2004.

. Coleção Histórias da Repressão e da Resistência. In:

ANDREUCCI, Álvaro Gonçalves Antunes. O Risco da Ideias: intelectuais e a polícia política (1930-1945). São Paulo: Humanitas/Fapesp, 2006.

CAVALCANTI, Ana Maria Tavares. Os embates no meio artístico carioca em 1890 antecedentes da Reforma da Academia das Belas Artes. 19\&20, Rio de Janeiro, v. II, n. 2, abr. 2007. 
CHEDIAK, Antônio J. Carlos de Laet, o polemista. Rio de Janeiro: Livraria Editora Zelio Valverde, 1943.

CHIARELLI, Tadeu. Um Jeca nos Vernissages: Monteiro Lobato e o desejo de uma Arte Nacional no Brasil. São Paulo: Editora da Universidade de São Paulo, 1995.

De Anita à Academia - para repensar a história da arte no Brasil.

Revista Novos Estudos - CEBRAP, nº 88, Nov/2010.

CLINEFELTER, Joan L. Artists for the Reich - Culture and Race from Weimar to Nazi Germany. Oxford/New York: Berg, 2005.

COSTA, Helouise. Lasar Segall e a arte degenerada: a exposição como campo de disputa política nas décadas de 1930 e 1940. In: SCHWARTZ, Jorge; MONZANI, Marcelo (Orgs.). A “Arte Degenerada” de Lasar Segall: perseguição à arte moderna em tempos de guerra. São Paulo: Museu Lasar Segall/Museu de Arte Contemporânea, 2018.

DAZZI, Camila; VALLE, Arthur (org.). "Projeto Montenegro": A reforma do Ensino das Artes Plásticas em 1890. 19\&20, Rio de Janeiro, v. II, n. 3, jul. 2007.

DE LUCA, Tania Regina. A Revista do Brasil: um diagnóstico para a (N)ação. São Paulo: Fundação Editora UNESP, 1999.

DESHMUKH, Marion F. "Politics is an art": the cultural politics of Max Liebermann in Wilhelmine Germany. In: Studies in the History of Art, Vol. 53, Symposium Papers XXXI: Imaging Modern German Culture: 1889-1910, Washington: National Gallery of Art, 1996.

DUDEK, Gudrun. Friedrich Wilhelm Schreiber-Weigand - Sächsische Biografie. Chemnitz, Institut für Sächsische Geschichte und Volkskunde e.V., 2012.

DUQUE, Gonzaga. Mocidade Morta. Rio de Janeiro: Fundação Casa de Rui Barbosa, 1995.

ELIAS, Norbert. O Processo Civilizador - Vol. I - Uma História dos Costumes. Rio de Janeiro: Jorge Zahar Editor, 1994.

ELLIS, Katharine. Interpreting the Musical Past: Early Music in Nineteenth-Century France. Oxford e New York: Oxford University Press, 2005.

FABRIS, Annateresa. Arte Moderna e Identidade Nacional: O Caso Segall. In: KERN, Arno Alvarez (Org.). Sociedades Ibero-Americanas - Reflexões e Pesquisas Recentes. Porto Alegre: EDIPUCRS, 2000, p. 193-210.

FERRAZ, João Grinspum. Ordem e Revolução na República de Weimar. Dissertação de Mestrado em Ciência Política. Universidade de São Paulo, 2009.

FERREIRA, Felix. Belas Artes - estudos e apreciações. Porto Alegre: Zouk, 2012. 
FEST, Joachim. Hitler. Rio de Janeiro: Ediouro, 2010.

FEUCHTWANGER, Edgar. Imperial Germany 1850-1918. London: Routledge, 2001.

FIGURA, Star. German Expressionism: the graphic impulse. In: FIGURA, Star (Org.). German Expressionism: the graphic impulse. New York: The Museum of Modern Art, 2011.

FLORINDO, Marcos Tarcísio. O Serviço reservado da Delegacia de Ordem Política e Social de São Paulo na era Vargas. Dissertação (mestrado) - Universidade Estadual Paulista, Faculdade de História, Direito e Serviço Social, 2000.

FORSTER-HAHN, Françoise. Introduction: Modernity and the Building of Nation. In: Studies in the History of Art, vol. 53, Symposium Papers XXXI: Imaging Modern German Culture: 1889-1910. Washington: National Gallery of Art, 1996. p. 8-16.

FORTE, Gabriela Naclério. CAM e SPAM: Arte, Política e Sociabilidade na São Paulo Moderna, do início dos anos 1930. Dissertação (Mestrado) em História Social Universidade de São Paulo, 2008.

FROMMHOLD, Erhard. Lasar Segall and Dresden Expressionism. Milano: Galeria del Levante, 1976.

FULDA, Bernhard; SOIKA, Aya. Emil Nolde and the National Socialist Dictatorship. In: PETERS, Olaf (Ed.) Degenerate Art: the attack on modern art in Nazi Germany, 1937. New York: Neue Galerie New York, 2014. p. 186-195.

GOLAN, Romy. From Fin de Siècle to Vichy: The Cultural Hygienics of Camille (Faust) Mauclair. In: NOCHLIN, Linda; GARB, Tamar. The Jew in the Text: Modernity and the Construction of Identity. London: Thames and Hudson, 1995.

GONÇALVES, Marcos Augusto. 1922 - A semana que não terminou. São Paulo: Companhia das Letras, 2012.

GRANGEIA, Fabiana de Araujo Guerra. A crítica de artes em Oscar Guanabarino : artes plásticas no século XIX. Dissertação (mestrado - Orientador: Jorge Sidney Coli Jr.). Campinas: Universidade Estadual de Campinas - Instituto de Filosofia e Ciências Humanas, 2005.

GRIMM, Dagmar; GUENTHER, Peter; KORT, Pamela. The works of art in „Entartete Kunst", Munich, 1937. In: BARRON, Stephanie (Org.). Degenerate art: the fate of the avant-garde in Nazi Germany. Los Angeles: Los Angeles County Museum of Art, 1991.

GUASTINI, Mário. A Hora Futurista que Passou e outros escritos. São Paulo: Boitempo, 2006.

HABERMAS, Jürgen. The Structural Transformation of the Public Sphere - an inquiry into a category of bourgeois society. Trad. Thomas Burger. Cambridge: The MIT Press, 1991. 
HAKE, Alfred Egmont. Regeneration: A Reply to Max Nordau. Westminster: Archibald Constable \& Co., 1895.

HERF, Jeffrey, O modernismo reacionário. São Paulo: Editora Ensaio, 1993.

HAUG, Christine. "Die Illusion der Einmaligkeit einer Ware”. Warenhäuser als kulturelle Erfahrungsräume und Vermittler populärer Kultur um 1900. In: HAUG, Christine; MAYER, Franziska; PODEWSKI, Madleen (Org.). Populäres Judentum - Mediem, Debatten, Lesestoffe. Tübingen: Max Niemeyer Verlag, 2009. p. 85-102.

HAY, Denys. Review: The Sack of Rome, 1527. by André Chastel. In: Renaissance Quarterly, vol. 37, $n^{\circ}$ 2. University of Chicago, 1984.

HITLER, Adolf. Minha Luta - Edição Histórica. Trad. Klaus von Punchen. São Paulo: Centauro, 2016.

HOFFMANN, Meike. Die langen Schatten der Vergangenheit - eine kritische Betrachtung von Hildebrand Gurlitt Lebensweg. In: Kunstmuseum Bern. Bestandaufnahme Gurlitt - "Entartete Kunst - Beschlagnahmt und verkauft. BERN: Hirmer, 2017. p. 16-27.

ILLIES, Florian. 1913: antes da tempestade. Tradução Silvia Bittencourt. São Paulo: Estação Liberdade, 2016.

JENSEN, Robert. The Avant-Gard and the Trade in Art. Art Journal, Vol. 47, No. 4, Revising Cubism (Winter, 1988).

JENTSCH, Ralph. Richard Seewald: Das graphische Werk : Radierungen, Holzschnitte, Lithographien, Plakate, Linolschnitte. Esslingen: Kunstgalerie Esslingen, 1973.

KALIFA, Dominique. Arqueologia do "Apachismo": Bárbaros e Peles-vermelhas no século XIX. Trad. Suelen Amanda Rodrigues. Revista Projeto História, v. 40, 2010.

KERN, Daniela Pinheiro Machado. Hanna Levy e a Exposição de Arte Condenada pelo III Reich (1945). Anais do $25^{\circ}$ encontro da ANPAP - Porto Alegre, 2016. p. 813-826.

LAFETÁ, João Luiz. 1930: A Crítica e o Modernismo. São Paulo: Editora 34, 2000.

LEVI, Neil. Modernist Form and the Myth of Jewification. New York: Fordham University Press, 2013.

LINS, Vera. Gonzaga Duque: a estratégia do franco-atirador. Rio de Janeiro: Tempo Brasileiro, 1991.

LOBATO, Monteiro. A Barca de Gleyre - $1^{\circ}$ Tomo. São Paulo: Editora Brasiliense, 1961.

LÖFFLER, Fritz; BERTONATI, Emilio Bertonati; von WALDEGG, Joachim Heusinger. Dresdner Sezession, 1919-1923. Munique: Galleria del Levante, 1977. 
LOMBROSO, Cesare. The Man of Genius. Londres: Walter Scott, 1891.

LORENZEN, Heidrun; STUTH, Steffen. Verfemte Moderne: Kunstwerk aus der Aktion "Entartete Kunst" der Nationalsozialisten im Kulturhistorischen Museum Rostock. Rostock: Schriften des Kulturhistorischen Museums Rostock, Neue Folge 5, 2011.

LONG, Rose-Carol Washton (Org.). German expressionism: documents from the end of the Wilhelmine Empire to the rise of National Socialism. Berkeley: University of California Press, 1995.

LÜTTICHAU, Mario-Andreas von. "Crazy at any price - the pathologizing of modernism in the run-up to the "Entartete Kunst" exhibition in Munich in 1937. In: PETERS, Olaf (ed.). Degenerate Art - the attack on modern art in Nazi Germany 1937. New York: Neue Galerie, 2014.

MACHADO DA SILVA, Raul Campelo. Insídia comunista nas letras e nas artes do Brasil. Rio de Janeiro: Imprensa Militar, 1941.

MATTOS, Cláudia Valladão de. Lasar Segall. São Paulo: Editora da Universidade de São Paulo, 1997.

Lasar Segall: expressionismo e judaísmo: o período alemão de Lasar Segall (1906-1923). São Paulo: Perspectiva/FAPESP, 2000.

MAUL, Carlos. Grandezas e misérias da vida jornalística - Memórias. Rio de Janeiro: Livraria São José Editora, 1968.

MEDEIROS, Alexandre Raicevich de. A Revista Musical \& de Bellas Artes (1879-1880) e o Panorama Musical do Rio de Janeiro no fim do século XIX. In: Anais do XVI Encontro Regional de História da ANPUH-Rio: Saberes e Práticas Científicas, 2014.

MIGLIACCIO, Luciano. O Século XIX. In: AGUILAR, Nelson (Org.) Mostra do redescobrimento: Século XIX. São Paulo: Associação Brasil 500 Anos Artes Visuais, 2000 .

MEINEL, Sabine. Karl Völker - Leben und Werk. Tese de Doutorado defendida na Universidade Martin Luther de Halle-Wittenberg, 2008.

MILLER, Álvaro et alii. Lasar Segall; antologia de textos nacionais sobre a obra e o artista. Rio de Janeiro: Funarte/Instituto Nacional de Artes Plásticas, 1982.

MOSSE, George L. Introduction. In: NORDAU, Max. Degeneration. Lincoln: University of Nebraska Press, 1993

MOTTA, Antônio Carlos Casulari da. COBRASMA - Trajetória de uma empresa brasileira. Tese (Doutorado). Programa de pós-graduação em História Econômica Universidade de São Paulo, 2006.

NIETZSCHE, Friedrich. Genealogia da moral: uma polêmica. Trad. Paulo César de Souza. - São Paulo: Companhia das Letras, 2009. 
NITSCHE, Jürgen. Lebenswege Chemnitzer Juden - Familie Leopold Eger. Manuscrito ainda não publicado, 2016

Lebenswege Chemnitzer Juden - Familie Georg Mecklenburg. Manuscrito não publicado, Cheminitz, 2015.

NORDAU, Max. Degeneration. London: William Heinemann Publisher, 1895. Biologie der Ethik. Leipzig: Verlag von B. Elischer Nachfolger, 1916.

NORDAU, Maxa; NORDAU, Anna. Max Nordau - a biography. New York: Nordau Comitee, 1943.

Buenos Aires: Editorial Israel, 1943. Max Nordau - Centinela de la Civilización.

OLIVEIRA, Helder Manuel da Silva. Olhar o mar : um estudo sobre as obras "Marinha com barco" (1895) e "Paisagem com rio e barco ao seco em São Paulo 'Ponte Grande", (1895) de Giovanni Castagneto. Dissertação (Mestrado) Universidade Estadual de Campinas. Campinas, SP: 2007.

OLIVEIRA, Lúcia Lippi. A questão nacional na Primeira República. São Paulo: Brasiliense; Brasília: CNPq, 1990.

PARET, Peter. The Tschudi affair. In: The Journal of Modern History; Vol. 53, N. 4 (Dez - 1981). Chicago: The University of Chicago Press, 1981.

PAULA, Rosângela Asche de. O Expressionismo na biblioteca Mário de Andrade: da leitura à criação. Tese (Doutorado) em Literatura Brasileira, USP/FFLCH, 2007.

PÉCAUT, Daniel. A geração dos anos 1920-40. In: PÉCAUT, Daniel. Os intelectuais e a política no Brasil - entre o povo e a nação. Trad. Maria Júlia Goldwasser. São Paulo: Editora Ática, 1998.

PEDROSA, Mário. Acadêmicos e Modernos - Vol. 3; organizado por Otília Arantes. São Paulo: Editora da Universidade de São Paulo, 1998

PEREIRA, Sônia Gomes. Revisão historiográfica da arte brasileira do século XIX. Revista do Instituto de Estudos Brasileiros, número 54, 2012, p. 87-106.

PEREIRA, Mário Eduardo Costa. Krafft-Ebing, a Psychopathia Sexualis e a criação da noção médica de sadismo. Revista Latino-americana de Psicopatologia Fundamental, v. 12, n. 2. São Paulo: 2009. p. 379-386.

PERROT, Michelle. Na França da Belle Époque, os “Apaches”, primeiros bandos de jovens. In: PERROT, Michelle. Os excluídos da história: operários, mulheres e prisioneiros. Trad. Denise Bottmann. Rio de Janeiro: Paz e Terra, 1988 
PETERS, Olaf. From Nordau to Hitler: "Degeneration" and anti-modernism between the fin-de-siècle and the national socialist takeover of power. In: PETERS, Olaf (Ed.) Degenerate Art: the attack on modern art in Nazi Germany, 1937. New York: Neue Galerie New York, 2014. p. 16-35.

PETROPOULOS, Jonathan. From Lucerne to Washington D.C. - „Degenerate art” and the question of restitution. In: PETERS, Olaf (Ed.) Degenerate Art: the attack on modern art in Nazi Germany, 1937. New York: Neue Galerie New York, 2014. p. 282-301.

PICK, Daniel. Faces of Degeneration: a European disorder, c. 1848 - c. 1918. Cambridge: Cambridge University Press, 1989.

POMIAN, Krzysztof. Coleção. In: Enciclopédia Einaudi vol 1. Memória-História. Imprensa Nacional/Casa da Moeda, 1984.

PRESNER, Todd Samuel. Muscular Judaism: The Jewish Body and the Politics of Regeneration. New York: Routledge, 2007.

RAINE, Adrian. The Anatomy of Violence: the biological roots of crime. New York: Pantheon Books, 2013.

RASSLOFF, Steffen. Die Erfurter Museen. Kulturgeschichte im Spannungsfeld von Gesellschaft und Politik. In: Stadt und Geschichte. Zeitschrift für Erfurt 18, 2003.

REININGHAUS, Alexandra (Org.). Recollecting - Raub und Restitution. Wien: Passagen-Verlag, 2009.

RIBEIRO, Flexa. A Estética do Cubismo. In: RIBEIRO, Flexa. O Imaginário (Pretextos de Arte). São Paulo: Nova Era - Empresa Editora, 1924.

ROSSI, Mirian Silva. Circulação e mediação da obra de arte na Belle Époque paulistana. São Paulo: Anais do Museu Paulista. vol.6-7 no.1 São Paulo, 1999, editado em 2003. p. 83-119.

RUAS JÚNIOR, José Jarbas Pinheiro. O violão feminino na Primeira República: Um viés através da Revista O Violão. In: Anais do IV Simpósio Internacional de Musicologia, 2014, Pirenópolis. IV Simpósio Internacional de Musicologia, 2014. v. 1. p. 275-280.

SCHAPOCHNIK, Nelson. Considerações mamalucas sobre o futurismo paulista. In: GUASTINI, Mário. A Hora Futurista que Passou e outros escritos. São Paulo: Boitempo, 2006.

SCHORSKE, Carl E. Viena fin-de-sècle - Política e Cultura. São Paulo: Companhia das Letras, 1988.

SCHWARCZ, Lilia Mortiz; STUMPF, Lúcia Klück; LIMA JUNIOR, Carlos. A Batalha do Avaí - a beleza da barbárie: a Guerra do Paraguai pintada por Pedro Américo. Rio de Janeiro: Sextante, 2013.

SCHWARTZ, Jorge. O Fervor das Vanguardas - Arte e Literatura na América Latina. São Paulo: Companhia das Letras, 2012. 
SCHWINGENSTEIN, Christoph, Lehrs, Max in: Neue Deutsche Biographie 14. Onlinefassung, 1985.

SEGALL, Lasar. Textos, depoimentos, exposições. São Paulo: Museu Lasar Segall, 1993.

SERPA JR, Eduardo Domont de. O Degenerado. História, Ciências, Saúde Manguinhos, Rio de Janeiro, v. 17, supl. 2, dez. 2010, p. 447-473.

SEVCENKO, Nicolau. Literatura como missão - tensões sociais e criação cultural na Primeira República. São Paulo: Editora Brasiliense, 1999.

SHAW, Bernard. The Sanity of Art. New York: Benj. R. Tucker Publisher, 1908.

SHEON, Aaron. Van Gogh's Understanding of Theories of Neurosis, Neurasthenia and Degeneration in the 1880s. In: MASHECK, Joseph D. (org.). Van Gogh 100. Westport: Hofstra University, 1996. p. 173-191.

SILVA, Rosângela de Jesus. Crítica de Arte na Imprensa Carioca do Século XIX: Revista Musical e de Bellas Artes. Anais do III Encontro de História da Arte. Campinas, IFCH/UNICAMP, 2007; p. 606.

SIMMS, Joseph. Physiognomy Illustrated; or, Nature's Revelations of Character. A Description of the Mental, Moral and Volitive dispositions of Mankind, as Manifested in the Human Form and Countenance. New York: Murray Hill Publishing Company, 1887.

SOUZA, Gilda de Mello e. Vanguarda e Nacionalismo na Década de 20. In: SOUZA, Gilda de Mello e. Exercícios de Leitura. São Paulo: Duas Cidade/Editora 34, 2009.

SPAGNOLI, Camila Russo de Almeida. Monteiro Lobato, o leitor. Dissertação (Mestrado) em Filosofia. São Paulo: Instituto de Estudos Brasileiros-IEB - Universidade de São Paulo, 2014.

SPENCER, Herbert. Origin and function of music. In SPENCER, Herbert. Progress: its law and cause. New York: J. Fitzgerald Publisher, 1882.

STEINKAMP, Maike. Das unerwünschte Erbe. Die Rezeption „entarteter “ Kunst in Kunstkritik, Ausstellungen und Museen der Sowjetischen Besatzungszone und der frühen DDR, Schriftenreihe der Forschungsstelle ,Entartete Kunst“", Band 2. Berlim: Akademie Verlag, 2008.

STERN, Fritz. The Politics of Cultural Despair: a study in the Rise of the Germanic Ideology. Berkeley: University of California Press, 1974.

TRAVASSOS, Elizabeth. Modernismo e música brasileira. Rio de Janeiro: Jorge Zahar Editor, 2000.

VÉRON, Eugène. Aesthetics. Trad. W. H. Armstrong. London: Chapman \& Hall, 1879. 
VIERECK, Peter. Metapolitics: from Wagner and the German Romantics to Hitler. New Jersey: Transaction Publishers, 2004.

WALLACE, Michael. Visiting the Past - History Museums in the United States. In: BENSON, Susan Porter; BRIER, Stephen; ROSENZWEIG, Roy (ed.). Presenting the past-Essays on History and the Public. Philadelphia: Temple University Press, 1986.

WEBER, Eugene. Peasants into Frenchmen - The Modernization of Rural France 18701914. Stanford: Stanford University Press, 1976.

. França fin-de-siècle. São Paulo: Companhia das Letras, 1988.

WEINSTEIN, Joan. The end of expressionism - art and the November Revolution in Germany, 1918-19. Chicago: The University of Chicago Press, 1990.

WILLETT, John. Arte e Revolução. In HOBSBAWM, Eric J. (Org.) História do Marxismo - vol. 9. Rio de Janeiro: Paz e Terra, 1987.

WITH, Christopher B. "Work and Make it Better": Lovis Corinth, German Art, and the Peril from Abroad. In: Studies in the History of Art, Vol. 53, Symposium Papers XXXI: Imaging Modern German Culture: 1889-1910, Washington: National Gallery of Art, 1996. p. 209-227.

WOLFE, Edith Angelica Gibson. Melancholy Encounter: Lasar Segall and Brazilian Modernism, 1924-1933. Tese de Doutorado. Austin: University of Texas, 2005.

. "Exiled from the World": German Expressionism,

Brazilian Modernism, and the Interstitial Primitivism of Lasar Segall. In: FINGER, Anke; KATHÖFER, Gabi; LARKOSH, Christopher (Orgs.). KulturConfusão - On GermanBrazilian Interculturalities. Berlim: De Gruyter, 2015. p. 267-299.

\section{Documentos $^{606}$}

\section{Arquivo Lasar Segall}

ALS 00021-A - Caderno de registro de vendas de obras c. 1917-1930, alemão.

ALS 00192 - Carta de Leopold Eger para Lasar Segall, 26/4/1918, alemão, tradução de Rosângela Dorazio.

ALS 00252 - Carta de Karl Ernst Osthaus para Lasar Segall,12/7/1919, alemão.

ALS 00264 - Carta da Galeria Emil Richter para Lasar Segall, 19/9/1919, alemão.

ALS 00285 - Carta do Museu Municipal de Dresden para Lasar Segall, 30/10/1919, alemão, tradução de Wolfgang Pfeiffer.

${ }^{606}$ As traduções foram feitas pelo autor da dissertação, exceto quando indicado. 
ALS 00290 - Carta de Friedrich Schreiber-Weigand para Lasar Segall, 29/10/1919, alemão.

ALS 00297 - Carta de Friedrich Schreiber-Weigand para Lasar Segall, 12/11/1919, alemão.

ALS 00363 - Carta de Rosa Schapire, em nome da Federação das Mulheres pelo fomento das Belas Artes Alemãs, para Lasar Segall, 6/7/1920, alemão, tradução de Wolfgang Pfeiffer.

ALS 00422 - Carta de Friedrich Schreiber-Weigand para Lasar Segall, 27/3/1922, alemão.

ALS 00486 - Cópia de carta de Lasar Segall para Oscar Siegel, 19/2/1923, alemão.

ALS 00491 - Carta da Editora do Círculo dos Artistas Gráficos para Lasar Segall, 23/3/1923, alemão.

ALS 00545 - Cópia de Carta de Lasar Segall ao Círculo dos artistas gráficos e colecionadores, 12/10/1923, alemão.

ALS 00589 - Carta de Friedrich Maron para Lasar Segall, 6/11/1924, alemão.

ALS 00637 - Carta de Friedrich Maron para Lasar Segall, 18/7/1925, alemão.

ALS 00739 - Carta de Friedrich Maron para Lasar Segall, 11/5/1926, alemão.

ALS 00871 - Carta de Otto Dix para Lasar Segall, 8/6/1927, alemão, tradução de Wolfgang Pfeiffer.

ALS 00900 - Carta de Manuel Bandeira para Lasar Segall, 26/10/1927, português.

ALS 00957 - Carta de Friedrich Maron para Lasar Segall, 17/10/1928, alemão.

ALS 00932 - Carta de Lasar Segall a Victor Rubin, 10/2/1928, alemão.

ALS 01166 - Carta de Miguel Siegel para Lasar Segall, 14/1/1930, português.

ALS 01232 - Carta de Miguel Siegel para Lasar e Jenny Segall, 29/5/1939, português.

ALS 01300 - Carta de Erich Wiese para Lasar Segall, 10/10/1930, alemão.

ALS 01317 - Carta de Miguel Siegel para Lasar Segall, 12/11/1930, português.

ALS 01324 - Carta de Erich Wiese a Lasar Segall, 24/11/1930, alemão.

ALS 01325 - Carta de Erich Wiese para Léonce Rosenberg, 24/11/1930, alemão.

ALS 01338 - Carta de Erich Wiese para Lasar Segall ,22/12/1930, alemão. 
ALS 01342 - Carta de Miguel Siegel para Lasar Segall, 28/12/1930, português.

ALS 01377 - Carta de “Abramowitz" (Museu da Silésia) para Lasar Segall, 15/1/1931, alemão.

ALS 01613 - Carta de Erich Wiese para Lasar Segall, 1/3/1932, alemão.

ALS 01777 - Carta de Carlos Drummond de Andrade para Lasar Segall, 31/7/1935, português.

ALS 01839 - Carta de Carlos Drummond de Andrade para Lasar Segall, 29/7/1937, português.

ALS 01983 - Carta de Carlos Drummond de Andrade para Lasar Segall, 7/6/1939, português.

ALS 02394 - Carta de Murilo Miranda para Lasar Segall, c. 12/1941, português.

ALS 02407 - Carta de Carlos Drummond de Andrade para Lasar Segall, 7/3/1942, português.

ALS 02450 - Carta do Ministério da Educação e Saúde para Lasar Segall, 7/1/1943, português.

ALS 04442 - Carta de Erich Wiese para Lasar Segall, 26/1/1932, alemão.

ALS 04443 - Carta de Miguel Siegel para Lasar Segall, 29/1/1932, português.

ALS 04447 - Carta de Erich Wiese para Lasar Segall, 21/3/1932, alemão.

ALS 04622 - Carta de Hildebrand Gurlitt para Lasar Segall, 1/2/1954, alemão, tradução de Juliana Paes.

ALS 04648 - Carta de Emerich Hahn para Lasar Segall, 28/3/1954, alemão.

ALS 05654 - Fragmento de texto autobiográfico escrito por Lasar Segall, c. 1920, alemão $^{607}$.

ALS 05660 - Felix Zimmermann, Ata da Reunião do Neue Kreis (Novo Círculo), 28/4/1917, alemão.

ALS 05710 - Relatório da administração das Coleções Municipais de Dresden Jahresbericht der Städtischen Sammlungen zu Dresden vom 1 September 1920 bis 31 August 1921, alemão.

${ }^{607}$ Segall datou esse texto como sendo de 10 de agosto de 1911; Cláudia Valladão de Mattos afirma que essa data foi inserida a posteriori, e que foi "erroneamente datado de 1911" já que "o endereço que Segall fornece no final do texto corresponde ao de sua residência apenas após 1919"; ela sugere que a confecção tenha se dado entre 1920 e 1922. Cfe. MATTOS, 1997, p. 168, nota 1). 
ALS 05713 - Texto de Otto Guszmann, Käthe Kollwitz, Max Lehrs, Paul Ferdinand Schmidt e Lasar Segall, c. 1920, alemão.

ALS 05718 - Manifesto da Kunstbund Hamburg, 1921, alemão.

ALS 05760 - Lasar Segall, texto de introdução à conferência na Vila Kyrial, 1924, português.

ALS 06252 - Texto "A arte da pintura na Alemanha”, de Lasar Segall, c. maio/1935 português.

ALS 08932 - Cópia de carta de Margarete Suhr para Mina Klabin Warchavchick, 20/6/1924, alemão.

ALS 08946 - Cópia de carta circular de Lasar Segall para Mina Klabin Warchavchick, 25/11/1933, português.

\section{Documentos de outros repositórios}

Entartete Kunst Ausstellungsführer [Guia da Exposição de Arte Degenerada]. London: World Propaganda Classics, 2008 [1937].

"Informe reservado"- Guarany, 30/07/33- Prontuário DEOPS/SP n 1.680 de Tarsila do Amaral. Doc.4. Arquivo Público do Estado de São Paulo.

"Projecto de Reforma no Ensino das Artes Plasticas apresentada ao Cidadão Ministro e Secretário de Estado dos Negócios do Interior pelos cidadãos Montenegro Cordeiro, Decio Villares e Aurélio de Figueiredo". Rio de Janeiro, 1890. (disponível para consulta em http://www.dezenovevinte.net/txt_artistas/projeto_montenegro.htm)

Prontuário DEOPS/SP n ${ }^{\circ}$ 2241, Clube dos Artistas Modernos (CAM). Arquivo Público do Estado de São Paulo.

Prontuário DEOPS/SP nº 51749, Lasar Segall. Arquivo Público do Estado de São Paulo.

Prontuário DEOPS/SP nº 80388, Gregori Warchavchik. Arquivo Público do Estado de São Paulo.

\section{Imprensa}

A Degenerescência; O Commercio de São Paulo, 2/9/1893, p. 2.

A inauguração do III Salão Paulista de Bellas Artes - O acto inaugural. O Jornal, 15 de dezembro de 1935, página 8.

A Música na América. Revista Musical e de Bellas Artes, Ano 1, Ed. 9, 1/3/1879, p. 6. 
A.B.C. A decepcionante exposição de Lazar Segall, no Museu Nacional de Belas Artes, A Notícia, Rio de Janeiro, 19 de maio de 1943.

A.C. O Salvator Rosa. Revista Musical e de Bellas Artes. Ano 2, Ed. 21, 14/8/1880, p. 165 .

Academia de Bellas Artes. Revista Musical e de Bellas Artes, Ano 1, Ed. 12, 22/3/1879, p. 1-2.

AMARAL, José Bonifácio de Souza. Os fins secretos da Spamolandia. Diário Popular, 20 de fevereiro de 1934, p. 3;

Artes e Artistas; O Paiz; 14 de setembro de 1909, p. 4.

CAMARAGIBE, Valério. "Arte burra e arte inteligente". A Notícia, Rio de Janeiro, 2 de junho de 1943.

maio de 1943.

Os "vira-lata" da pintura, A Notícia, Rio de Janeiro, 21 de

Carlos Gomes e o Salvator Rosa. Revista Musical e de Bellas Artes, Ano 2, Ed. 22, 21/8/1880, p. 173.

CARVALHO, Xavier de. “Carta Parisiense”. O Paiz (RJ), 16/4/1894, p. 2.

COLLOR, Lindolfo. "O Teatro Nacional - enquete - Opinião do Sr. Oscar Guanabarino"; O Paiz, 20 de abril de 1912.

CONSELHEIRO, Antonio. Arte e doenças tropicais, A Notícia, Rio de Janeiro, 11 de junho de 1943.

Dresdner Brief, Kunstchronik Kunstmarkt - Wochenschrift für Kenner und Sammler (nr. 2, 1916/1917) - de Leipzig, 6/10/1916, p. 108.

DUQUE, Gonzaga. O Aranheiro da Escola. Revista Kosmos, Ano 4, Número 8, agosto de 1907, p. 50-53.

Em torno das exposições de arte moderna, A Notícia, Rio de Janeiro, 11 de junho de 1943.

Entartete Kunst, [о. O.] Rezension der Ausstellung "Entartete Kunst" in Dresden, 23. September bis 18. Oktober 1933.

Etnographia dos instrumentos de música. Revista Musical e de Bellas Artes, Ano 2, Ed. 2, 17/1/1880, p. 10.

FROMENTIN. Estética Positiva. Revista Musical e de Bellas Artes, Ano 1, Ed. 19, $10 / 5 / 1879$, p. 2 

17/5/1879, p. 2.

Estética Positiva. Revista Musical e de Bellas Artes, Ano 1, Ed. 20, Estética Positiva. Revista Musical e de Bellas Artes, Ano 1, Ed. 21, 24/5/1879, p. 3 .

Estética Positiva. Revista Musical e de Bellas Artes, Ano 1, Ed. 22, $31 / 5 / 1879$, p. 2

GUANABARINO, Oscar. Pelo Mundo da Arte; Jornal do Commercio, 26 de outubro de 1921.

. Pelo Mundo das Artes; Jornal do Commercio, 12 de outubro de

1921, p. 2.

1927, p. 2

.Pelo Mundo das Artes; Jornal do Commercio, 2 de fevereiro de 1927, p. 2.

.Pelo Mundo das Artes; Jornal do Commercio, 2 de fevereiro de .Pelo Mundo das Artes; Jornal do Commercio, 20 de março de 1929, p. 2. 1929, p. 2.

Pelo Mundo das Artes; Jornal do Commercio, 20 de março de 1929, p. 2. Pelo Mundo das Artes; Jornal do Commercio, 21 de agosto de .Pelo Mundo das Artes; Jornal do Commercio, 23 de fevereiro de 1927, p. 2.

.Pelo Mundo das Artes; Jornal do Commercio, 24 de abril de 1929, p. 2; 1929, p. 2. Pelo Mundo das Artes; Jornal do Commercio, 24 de abril de 1921, p. 2. .Pelo Mundo das Artes; Jornal do Commercio, 24 de maio de .Pelo Mundo das Artes; Jornal do Commercio, 3 de julho de 1929, p. 2. 1929, p. 2. .Pelo Mundo das Artes; Jornal do Commercio, 3 de julho de 1929, p. 2. .Pelo Mundo das Artes; Jornal do Commercio, 4 de setembro de 
.Pelo mundo das Artes; Jornal do Commercio, 6 de fevereiro de 1929, p. 2.

1926, p. 2.

Pelo Mundo das Artes; Jornal do Commercio, 9 de junho de 1927, p.

.Pelo Mundo das Artes; Jornal do Commercio, 9 de março de .Pelo Mundo das Artes; Jornal do Commercio, 9 de outubro de 1929, p. 2.

L. A Ópera Popular. Revista Musical e de Bellas Artes, Ano 1, Ed. 44, 1/11/1879, p. 2 3 .

Le porcherie di Lasar Segall, Il Moscone ano IV, 1924, nr. 39, p. 11.

LOBATO, Monteiro. “A propósito da Exposição Malfatti”. O Estado de São Paulo, 20 de novembro de 1917.

M. Uma verdade. Revista Musical e de Bellas Artes, Ano 1, Ed. 44, 1/11/1879, p. 1-2.

MAUL, Carlos. Palavras aos intelectuais brasileiros. Correio da Manhã (RJ), 5/12/1935, p. 4. 1943. Pintura arte e pintura política. A Notícia, Rio de Janeiro, 4 de junho de Do Titanismo, como base de uma esthetica nacionalista. In: Revista Americana, ano VII, $\mathrm{n}^{\circ}$ 1, Outubro/1917; p. 106-119.

O espirito subversivo do modernismo. Correio da Manhã, 25/6/1936, p. 4. . Fócos de infecção. Correio da Manhã, 10/3/1935, p. 2. Falso conceito de cultura. Correio da Manhã, 10/10/1935, p. 4.

Max Nordau virá ao Brazil e à Argentina fazer conferências; A Notícia (RJ), 25/26/3/1916, p. 2.

O “Zé Pereira”. Revista Musical e de Bellas Artes, Ano 1, Ed. 8, 22/2/1879, p. 1

O pintor Facchinetti. Revista Musical e de Bellas Artes, Ano 1, Ed. 40, 4/10/1879, p. 5.

O Prêmio de Roma. Revista Musical e de Bellas Artes, Ano 1, Ed. 6, 8/2/1879, p. 1.

O russo naturalizado está com sorte..., A Notícia, Rio de Janeiro, 13 de maio de 1943.

Pintores Paulistas. Correio Paulistano, 17/10/1895, p. 1. 
Registo de Arte - Lasar Segall. Correio Paulistano, 23/3/1924, p. 3

Registo de Arte - Lasar Segall. Correio Paulistano, 8/2/1924, p. 2.

RIBAS, Tristão. "Foi assim que a França apodreceu”. A Notícia, Rio de Janeiro, 18 de maio de 1943.

SEGALL, Lasar. “Arte e público”, Diário Nacional 29/5/1928, p. 2.

SEGALL, Lasar. “Arte e público”, Diário Nacional, 16/10/1928, p. 7

Sociedade Brasileira de Autores Teatrais"; O Paiz, 7 de outubro de 1917, p. 2.

SPÄTH, Daniela. Conspiracies swirl in 1939 Nazi art burning. http://www.dw.com/en/conspiracies-swirl-in-1939-nazi-art-burning/a-17510022;

publicado em 20/3/2014

Terceiro Salão Paulista de Bellas Artes. Correio Paulistano, 15 de dezembro de 1935, p. 15.

Todos Loucos!. A República (PA), 4/7/1893, p. 2.

Um dos mais notáveis pintores modernos numa exposição retrospectiva promovida pelo Ministério da Educação. A Manhã de 29 de abril de 1942

Um Livro notável. A Pacotilha (MA), 10/3/1894, p. 2-3.

Vandalismo mórbido?, Diário Nacional, 18/1/1928, p. 3.

\section{Filmes}

Zeitdokumente: Ausstellung: Entartete Kunst im Lichthof des Dresdener Rathauses. 1933, 6 min. PB, Filmarchiv Koblenz.

BRYAN, Julien. Nazi exhibition of degenerate art Munich 1937, 1937, 4 min. PB. 


\section{ANEXOS}

Anexo 1 - Cartas de Erich Wiese para Lasar Segall

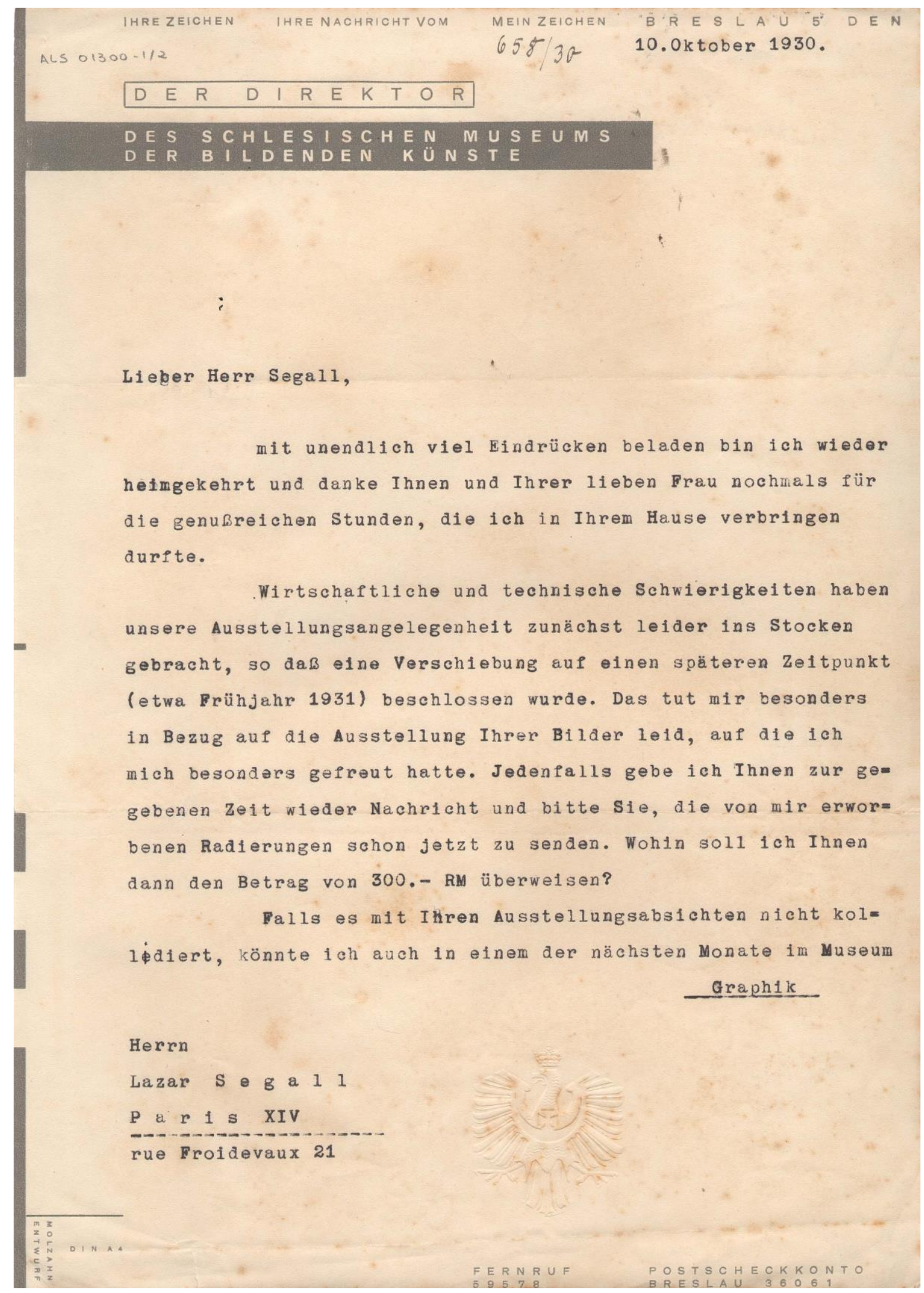




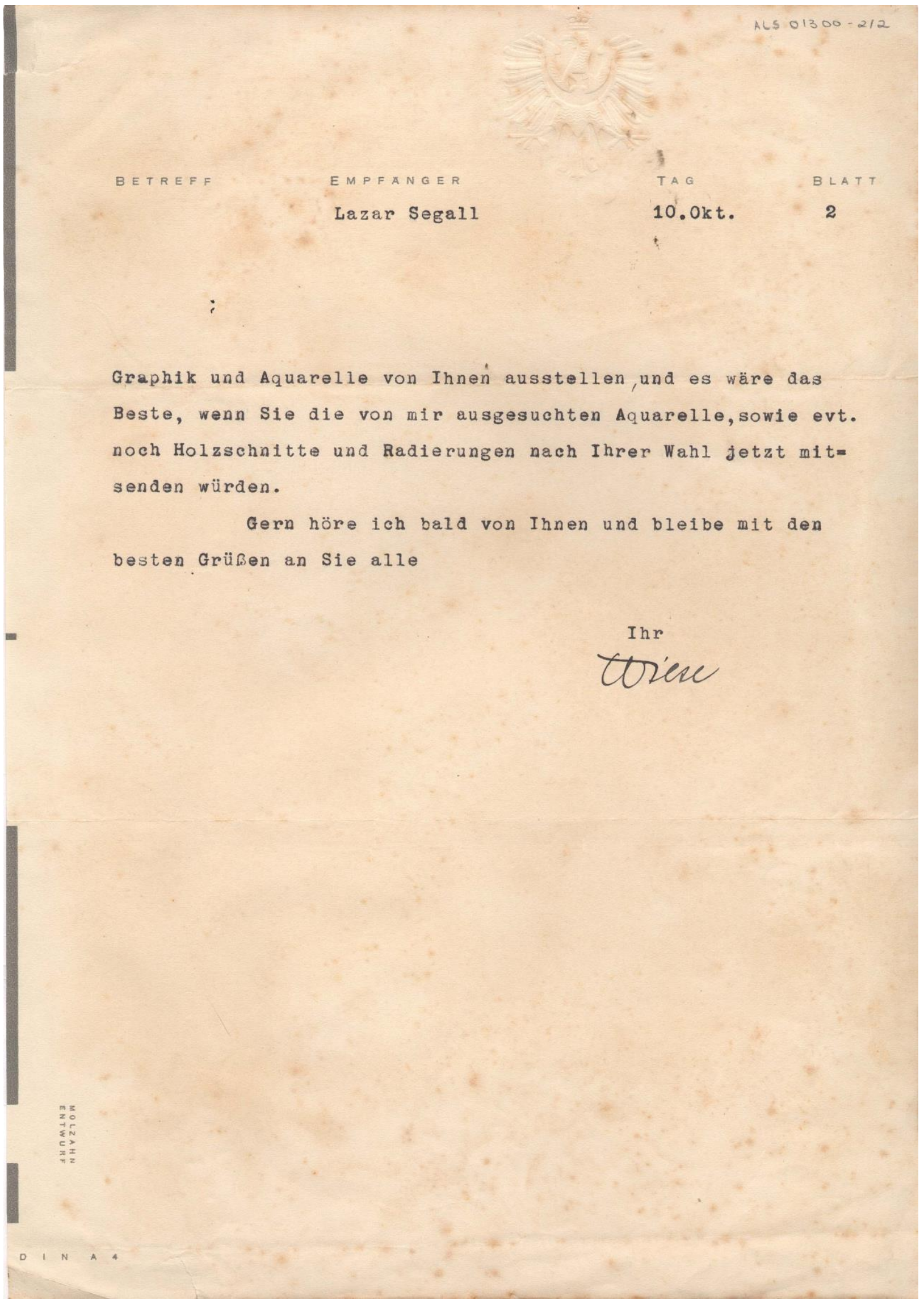

ALS 01300 - Carta de Erich Wiese a Lasar Segall, 10 de outubro de 1930. 


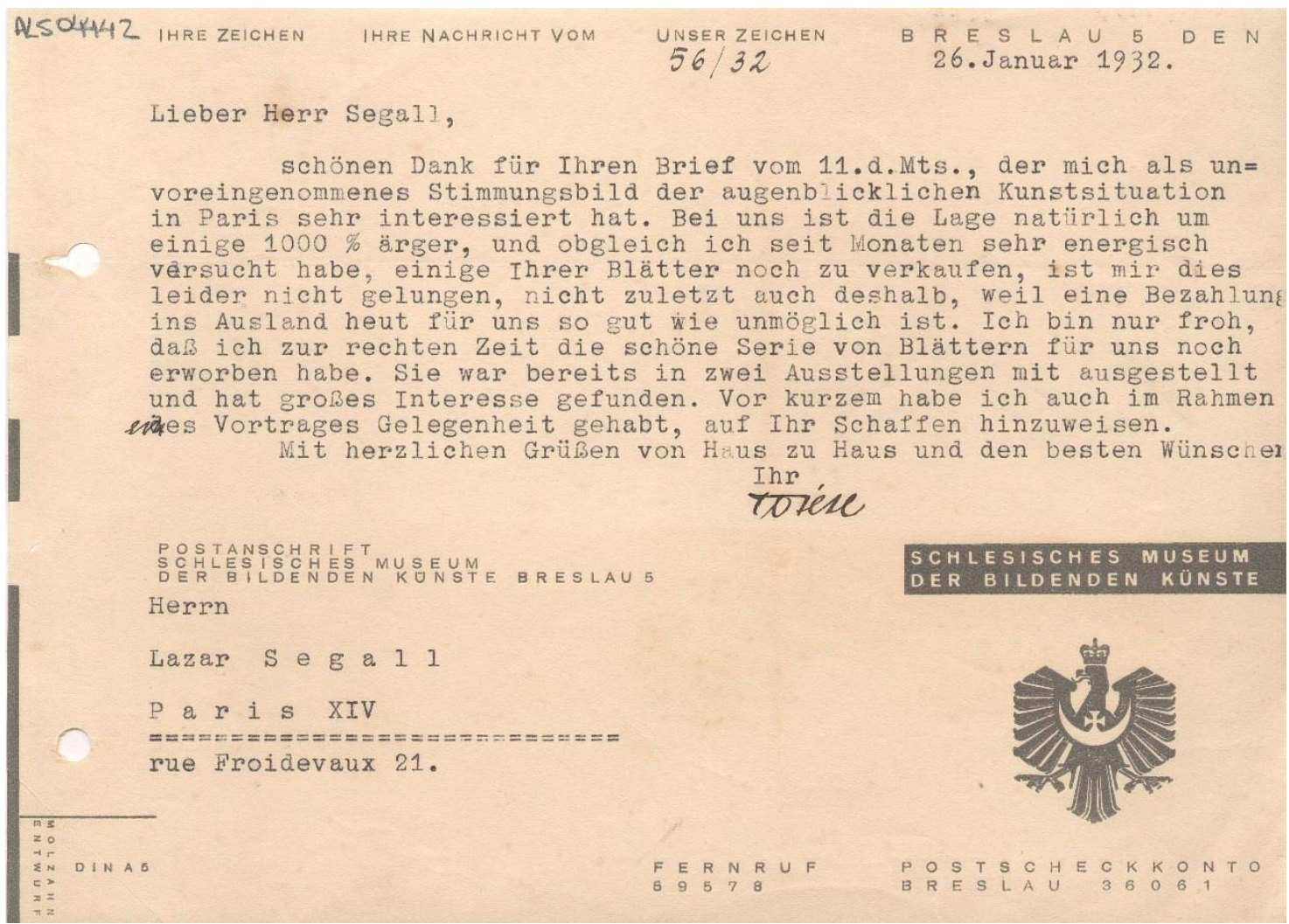

ALS 04442 - Carta de Erich Wiese para Lasar Segall, 26 de janeiro de 1932.

\title{
Sahlesisches MUSEUM dER BILdENDEN KÜNSTE
}

Herrn

Lazar $S$ e g a 1

$$
\text { P a } r \text { i s }
$$

übersenden wir anbei f̈̈r die erhaltenen 10 Blatt Graphik a 30..-RM (dreihundert Reichsmark".

\author{
Ka8so des Schles. Museums \\ der bildenden Kenste \\ remnies \\ acringuteru.
}




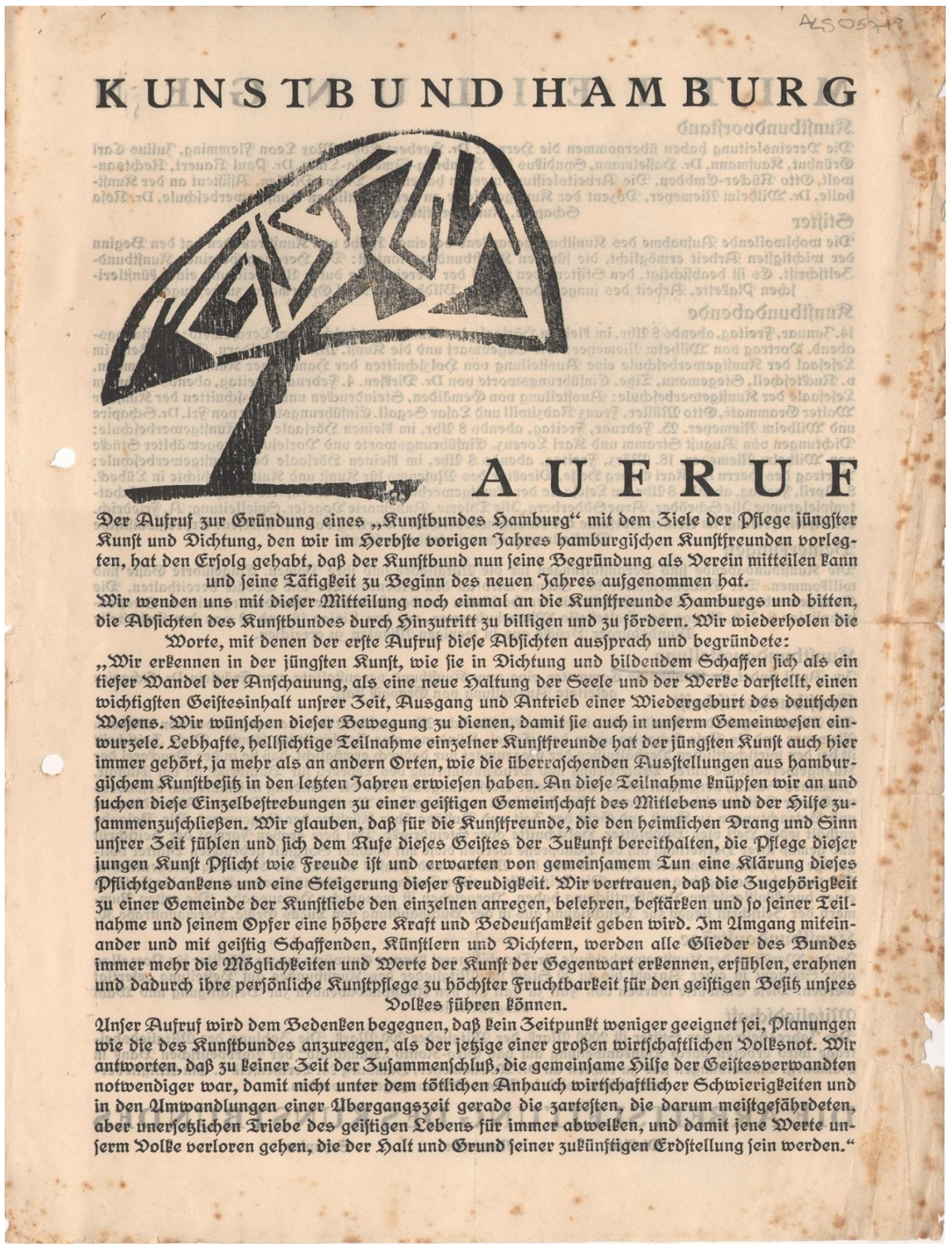




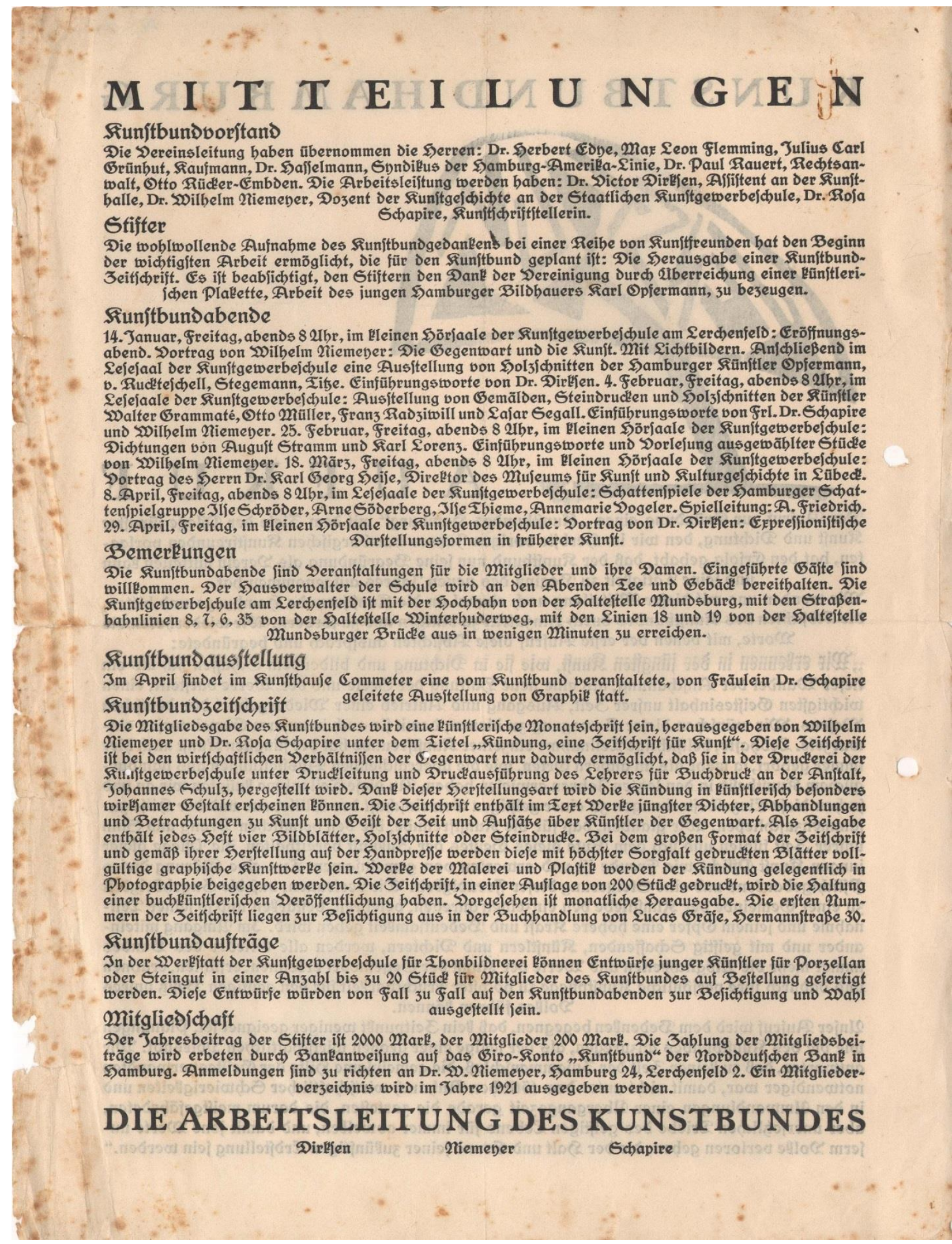

ALS 05718 - Manifesto da Kunstbund Hamburg, 1921. 
Anexo 3 - Resenha sobre a Exposição de Arte Degenerada realizada no átrio da Nova Prefeitura de Dresden

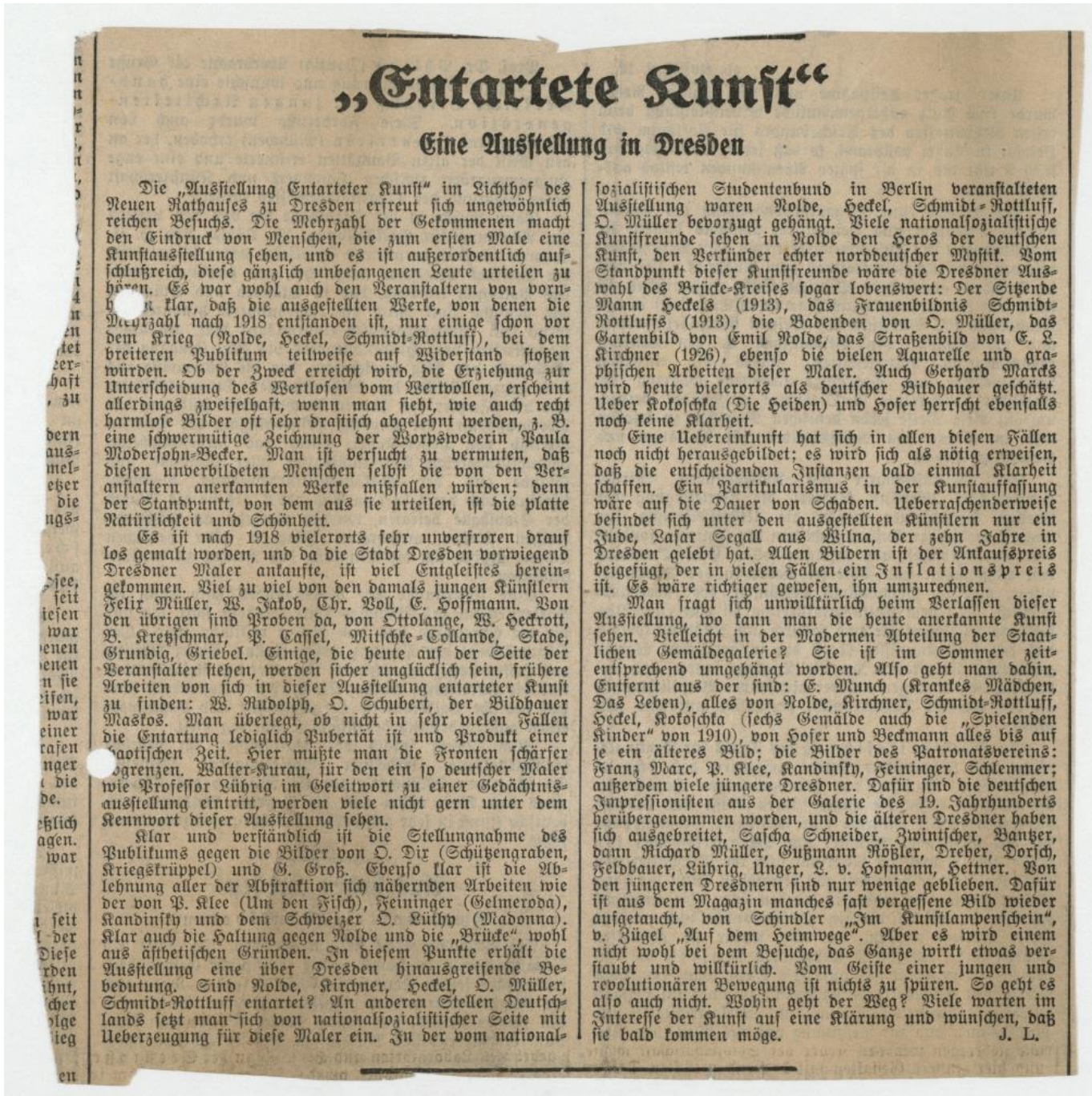

Fonte: Berlinische Galerie - Museum für Moderne Kunst - "Entartete Kunst", [o. O.] Rezension der Ausstellung "Entartete Kunst" in Dresden, 23. September bis 18. Oktober 1933.

Transcrição:

"Entartete Kunst", [o. O.]

Rezension der Ausstellung "Entartete Kunst" in Dresden, 23. September bis 18. Oktober 1933

"«Entartete Kunst»

Eine Ausstellung in Dresden

Die «Ausstellung Entarteter Kunst» im Lichthof des Neuen Rathauses zu Dresden erfreut sich ungewöhnlich reichen Besuchs. Die Mehrzahl der Gekommenen macht den Eindruck von Menschen, die zum ersten Male eine Kunstausstellung sehen, und es ist außerordentlich aufschlußreich, diese gänzlich unbefangenen Leute urteilen zu hören. Es war wohl auch den Veranstaltern von vornherein klar, daß die ausgestellten Werke, von denen die Mehrzahl nach 1918 entstanden ist, nur einige schon vor dem Krieg (Nolde, Heckel, Schmidt-Rottluff), bei dem breiteren Publikum teilweise auf Widerstand stoßen würden. Ob der Zweck erreicht wird, die Erziehung zur Unterscheidung des Wertlosen vom Wertvollen, erscheint allerdings zweifelhaft, wenn man sieht, wie auch recht harmlose Bilder oft sehr drastisch abgelehnt werden, z. B. eine schwermütige Zeichnung der Worpswederin Paula Modersohn-Becker. Man ist versucht zu vermuten, daß diesen unverbildeten Menschen selbst die von den Veranstaltern anerkannten Werke mißfallen würden; denn der Standpunkt, von dem aus sie urteilen, ist die platte Natürlichkeit und Schönheit. Es ist nach 1918 vielerorts sehr unverfroren drauf los gemalt worden, und da die Stadt Dresden vorwiegend Dresdner Maler ankaufte, ist viel Entgleistes hereingekommen. Viel zu viel von den damals jungen 
Künstlern Felix Müller, W. Jakob, Chr. Voll, E. Hoffmann. Von den übrigen sind Proben da, von Ottolange, W. Heckrott, B. Kretzschmar, P. Cassel, Mitschke-Collande, Skade, Grundig, Griebel. Einige, die heute auf der Seite der Veranstalter stehen, werden sicher unglücklich sein, frühere Arbeiten von sich in dieser Ausstellung entarteter Kunst zu finden: W. Rudolph, O. Schubert, der Bildhauer Maskos. Man überlegt, ob nicht in sehr vielen Fällen die Entartung lediglich Pubertät ist und Produkt einer chaotischen Zeit. Hier müßte man die Fronten schärfer abgrenzen. Walter-Kurau, für den ein so deutscher Maler wie Professor Lührig im Geleitwort zu einer Gedächtnisausstellung eintritt, werden viele nicht gern unter dem Kennwort dieser Ausstellung sehen.

Klar und verständlich ist die Stellungnahme des Publikums gegen die Bilder von O. Dix (Schützengraben, Kriegskrüppel) und G. Groß. Ebenso klar ist die Ablehnung aller der Abstraktion sich nähernden Arbeiten wie der von P. Klee (Um den Fisch), Feininger (Gelmeroda), Kandinsky und den Schweizer O. Lüthy (Madonna). Klar auch die Haltung gegen Nolde und die «Brücke», wohl aus ästhetischen Gründen. In diesem Punkte erhält die Ausstellung eine über Dresden hinausgreifende Bedeutung. Sind Nolde, Kirchner, Heckel, O. Müller, Schmidt-Rottluff entartet? An anderen Stellen Deutschlands setzt man sich von nationalsozialistischer Seite mit Ueberzeugung für diese Maler ein. In der vom nationalsozialistischen Studentenbund in Berlin veranstalteten Ausstellung waren Nolde, Heckel, Schmidt-Rottluff, O. Müller bevorzugt gehängt. Viele nationalsozialistische Kunstfreunde sehen in Nolde den Heros der deutschen Kunst, den Verkünder echter norddeutscher Mystik. Vom Standpunkt dieser Kunstfreunde wäre die Dresdner Auswahl des Brücke-Kreises sogar lobenswert: Der Sitzende Mann Heckels (1913), das Frauenbildnis Schmidt-Rottluffs (1913), die Badenden von O. Müller, das Gartenbild von Emil Nolde, das Straßenbild von E. L. Kirchner (1926), ebenso die vielen Aquarelle und graphischen Arbeiten dieser Maler. Auch Gerhard Marcks wird heute vielerorts als deutscher Bildhauer geschätzt. Ueber Kokoschka (Die Heiden) und Hofer herrscht ebenfalls noch keine Klarheit.

Eine Uebereinkunft hat sich in allen diesen Fällen noch nicht herausgebildet; es wird sich als nötig erweisen, daß die entscheidenden Instanzen bald einmal Klarheit schaffen. Ein Partikularismus in der Kunstauffassung wäre auf die Dauer von Schaden. Ueberraschenderweise befindet sich unter den ausgestellten Künstlern nur ein Jude, Lasar Segall aus Wilna, der zehn Jahre in Dresden gelebt hat. Allen Bildern ist der Ankaufspreis beigefügt, der in vielen Fällen ein Inflationspreis ist. Es wäre richtiger gewesen, ihn umzurechnen.

Man fragt sich unwillkürlich beim Verlassen dieser Ausstellung, wo kann man die heute anerkannte Kunst sehen. Vielleicht in der Modernen Abteilung der Staatlichen Gemäldegalerie? Sie ist im Sommer zeitentsprechend umgehängt worden. Also geht man dahin. Entfernt aus der sind: E. Munch (Krankes Mädchen, Das Leben), alles von Nolde, Kirchner, Schmidt-Rottluff, Heckel, Kokoschka (sechs Gemälde auch die «Spielenden Kinder» von 1910), von Hofer und Beckmann alles bis auf je ein älteres Bild; die Bilder des Patronatsvereins: Franz Marc, P. Klee, Kandinsky, Feininger, Schlemmer; außerdem viele jüngere Dresdner. Dafür sind die deutschen Impressionisten aus der Galerie des 19. Jahrhunderts herübergenommen worden, und die älteren Dresdner haben sich ausgebreitet, Sascha Schneider, Zwintscher, Bantzer, dann Richard Müller, Gußmann Rößler, Dreher, Dorsch, Feldbauer, Lührig, Unger, L. v. Hofmann, Hettner. Von den jüngeren Dresdnern sind nur wenige geblieben. Dafür ist aus dem Magazin manches fast vergessene Bild wieder aufgetaucht, von Schindler «Im Kunstlampenschein», v. Zügel «Auf dem Heimwege». Aber es wird einem nicht wohl bei dem Besuche, das Ganze wirkt etwas verstaubt und willkürlich. Vom Geiste einer jungen und revolutionären Bewegung ist nichts zu spüren. So geht es also auch nicht. Wohin geht der Weg? Viele warten im Interesse der Kunst auf eine Klärung und wünschen, daß sie bald kommen möge.

J. L." 


\section{Anexo 4 - Carta de Emerich Hahn noticiando o reaparecimento de Eternos Caminhantes}

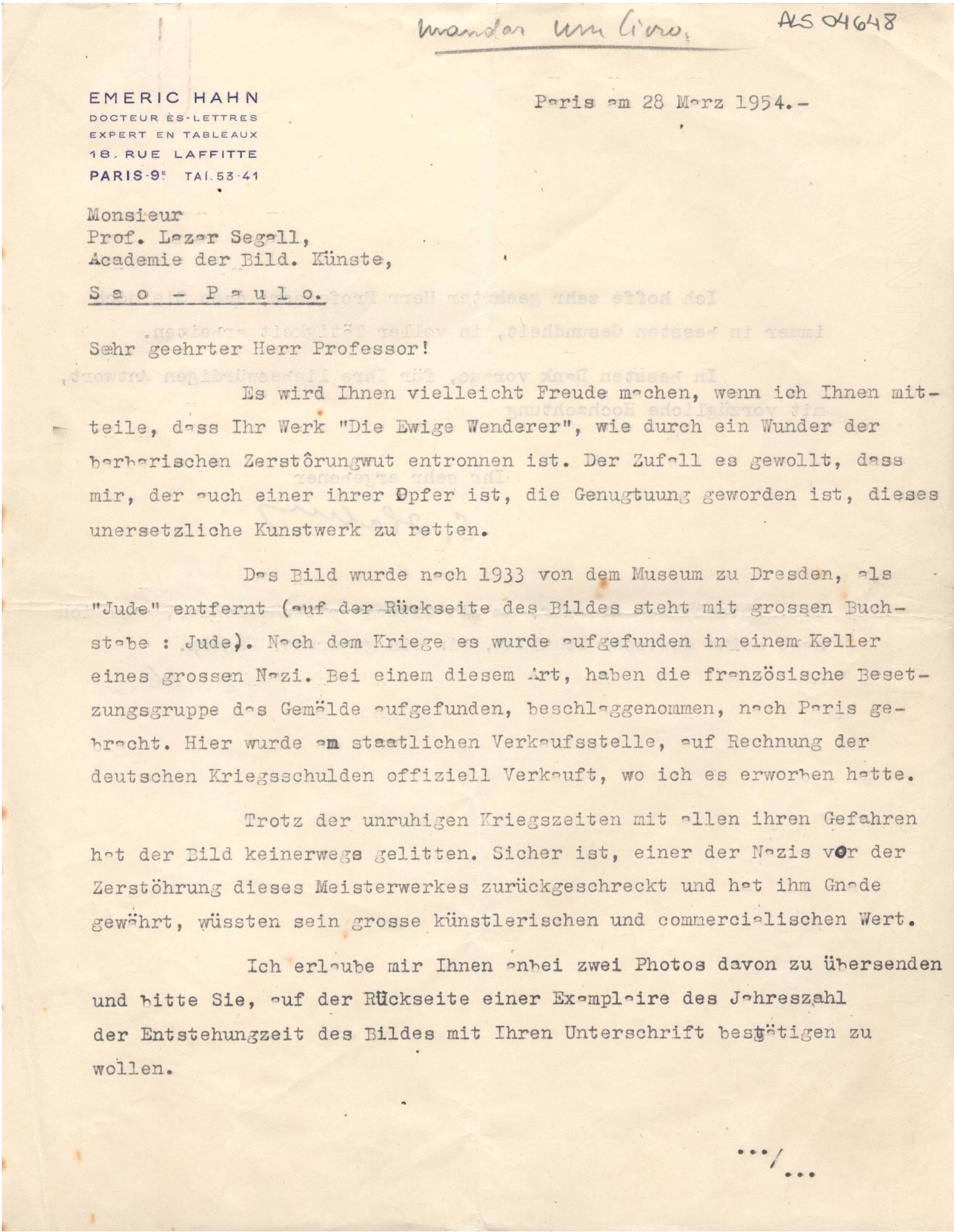




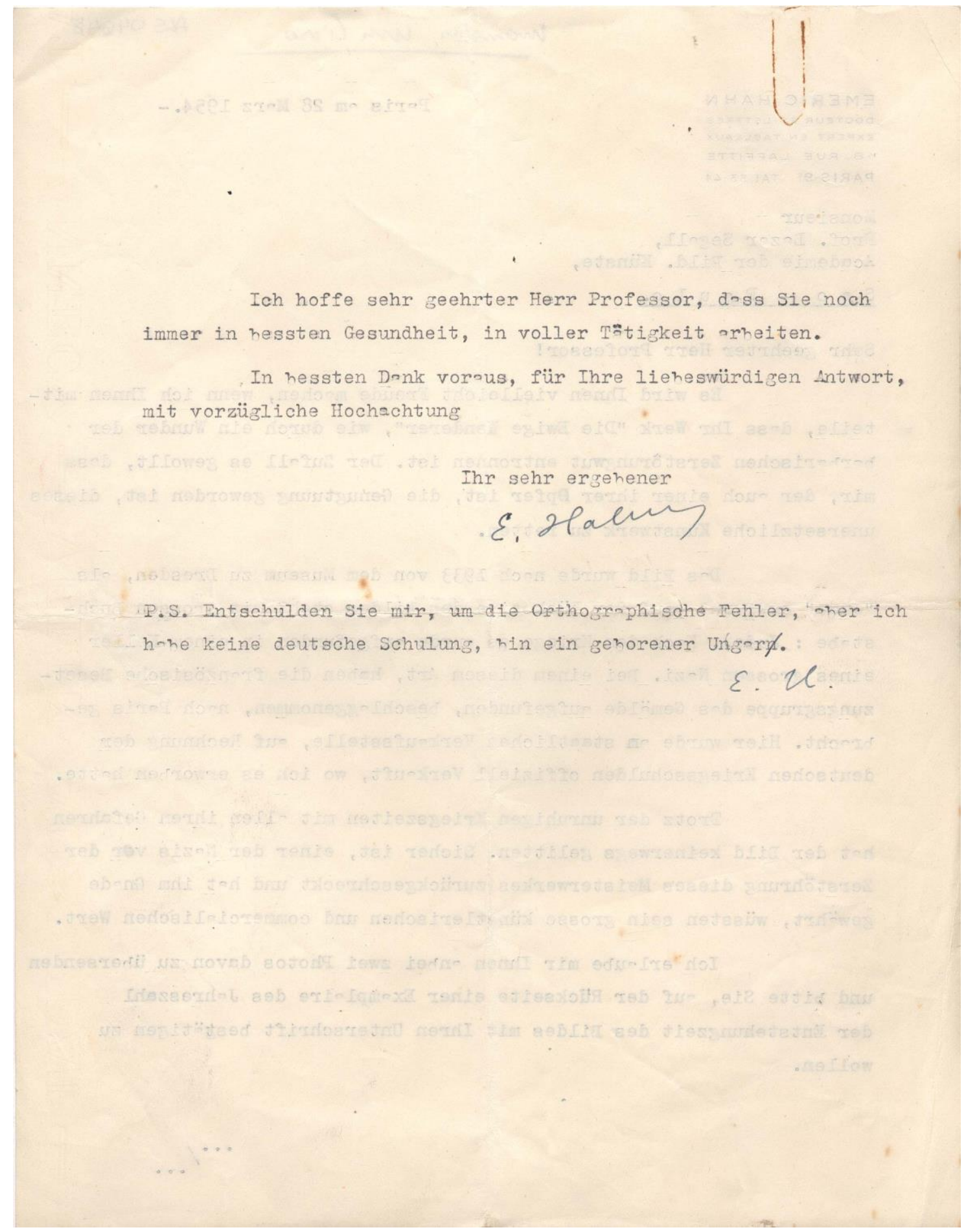

ALS 04648 - Carta de Emerich Hahn a Lasar Segall, 28 de março de 1954. 
Anexo 5 - Fichas das obras de Lasar Segall confiscadas dos Museus públicos alemães na "Ação contra a Arte Degenerada"

Algumas explicações sobre as fichas

Apresenta-se abaixo informações sobre as obras de Lasar Segall presentes em Museu Públicos da Alemanha em 1937 e que acabaram sendo confiscadas pelos nazistas. A lista foi elaborada a partir das informações disponibilizadas pela Base de Dados da Universidade Livre de Berlim; diante de informações adquiridas em outras fontes, alguns dados obtidos na Base de Dados foram retificados; outros foram suprimidos, e muitas informações foram adicionadas. Um exemplo é a introdução da informação sobre a entrada das obras nas coleções, dado que não constava na Base de Dados, ou que apresentava discrepância em relação às informações obtidas em outras fontes, conforme foi apresentado no texto da dissertação. Com o intuito de demarcar claramente a origem das informações, os dados novos, inseridos a partir desta pesquisa, foram sublinhados. Foi inserido o título da obra conforme adotado atualmente pelo sistema de informações do Museu Lasar Segall, bem como o número do tombo atribuído pelo setor de documentação museológica.

Decidiu-se contabilizar individualmente as gravuras que originalmente faziam parte de álbuns, seguindo o critério adotado na Base de Dados da Universidade Livre de Berlim. Do álbum Erinnerung an Wilna, por exemplo, faziam parte 5 gravuras.

Finalmente, procuramos determinar com a maior acuidade possível as obras a que se referiam os inventários elaborados pelos agentes do governo nazista. Isso se mostra particularmente difícil em relação às gravuras, já que as listas não trazem, muitas vezes, a especificação sobre o tipo de linguagem (xilogravura, gravura em metal ou litografia), empregando a palavra genérica "Druckgraphik". Além disso, quando não encontravam o título da obra escrito sobre ela, os responsáveis pelo inventário atribuíram títulos aleatórios, muitas vezes descritivos (por exemplo, "Im Bordell (Zwei Frauen)" [No bordel, (duas mulheres)]. Nestes casos, procuramos determinar a identidade da gravura através do cruzamento de informações obtidas junto à Base de Dados (especialmente a linguagem específica de gravura e as dimensões da obra) com os dados do sistema de informações do Museu Lasar Segall. Com a colaboração da museóloga Pierina Camargo, foi possível atribuir diversas identidades. Nestes casos, fica assinalado abaixo da imagem da obra na lista a informação "Atribuída pela pesquisa". 


\begin{tabular}{|c|c|}
\hline (Atribuída pela pesquisa) & $\begin{array}{l}\text { Im Bordell (Zwei Frauen) [No bordel, duas mulheres]; ponta-seca; } 1929 \\
\text { Museu de Origem: Breslau, Schlesisches Museum der Bildenden Künste [Museu de Belas- } \\
\text { Artes da Silésia] } \\
\text { Localização atual: Berlim, Kupferstichkabinett [Gabinete de Gravuras] } \\
\text { Dimensões: 30,6 x 20,8 cm } \\
\text { Catalogação MLS: MLS 0368 (Mulheres do mangue com baralho) } \\
\text { EK }{ }^{608} \text { - Im Bordell } \\
\text { EK-Ident. Nr.:14335 } \\
\text { Provenance: } \\
\text { - } \quad \text { 12.1930/1.1931 - 08.07.1937: Breslau, Museu de Belas-Artes da Silésia; aquisição por } \\
\text { Erich Wiese (diretor) } \\
\text { - } 08.07 .1937 \text { - 1943/44: Reich Alemão/Ministério da Propaganda do Reich, Berlim, } \\
\text { Confisco; } \\
\text { - 1938 - 1943/44: Berlim, Fundo especial do Ministério da Propaganda; } \\
\text { 1943/44 - 03.05.1945: Cidade de Güstrow, Negociante de obras de arte Bernhard A. } \\
\text { Böhmer, evacuação em função da guerra, retirada de Berlim e levada para a cidade de } \\
\text { Güstrow por Rolf Hetsch; } \\
\text { - 03.05.1945: Cidade de Güstrow, transmitida pelo espólio de Böhmer; } \\
\text { - } 21.05 .1945 \text { - 21.03.1947: Rostock/Berlim/Hamburg, Wilma Zelck, herdeira; } \\
\text { - } \text { guarda de Kurt Reutti; } \\
\text { 21.03.1947 - 07.1949: Rostock, Museu Municipal, Entreposto de armazenagem para } \\
\text { retorno ao museu de origem; } \\
\text { 07.1949: Berlim, Ehem. Museu Estatal de Berlim, Galeria Nacional; entregue por Kurt } \\
\text { Reutti. }\end{array}$ \\
\hline 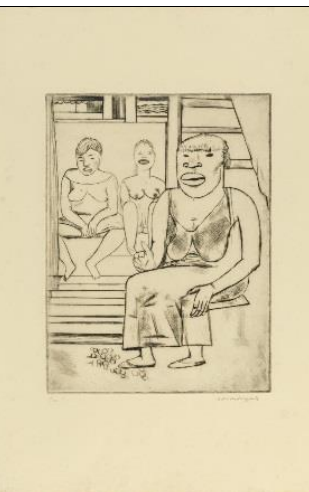 & $\begin{array}{l}\text { Drei Negerfrauen [Três mulheres negras]; ponta-seca; } \mathbf{1 9 2 9} \text {. } \\
\text { Museu de Origem: Breslau, Schlesisches Museum der Bildenden Künste [Museu de Belas- } \\
\text { Artes da Silésia] } \\
\text { Localização atual: Berlim, Kupferstichkabinett [Gabinete de Gravuras] } \\
\text { Dimensões: } 32,8 \text { x } 24,8 \mathrm{~cm} \\
\text { Catalogação MLS: MLS } 0363 \text { (Mulheres do mangue na escada) } \\
\text { EK- Zwei Frauen } \\
\text { EK-Ident. Nr.: } 14336 \\
\text { Provenance: } \\
\text { - } \quad \text { 12.1930/1.1931 - 08.07.1937: Breslau, Museu de Belas-Artes da Silésia; aquisição por } \\
\quad \text { Erich Wiese (diretor) }\end{array}$ \\
\hline (Atribuída pela pesquis: & $\begin{array}{l}\text { - } 08.07 .1937 \text { - 1943/44: Reich Alemão/Ministério da Propaganda do Reich, Berlim, } \\
\text { Confisco; } \\
\text { - } 1938 \text { - 1943/44: Berlim, Fundo especial do Ministério da Propaganda; } \\
\text { - } 1943 / 44 \text { - 03.05.1945: Cidade de Güstrow, Negociante de obras de arte Bernhard A. } \\
\text { Böhmer, evacuação em função da guerra, retirada de Berlim e levada para a cidade de } \\
\text { Güstrow por Rolf Hetsch; } \\
\text { - } 03.05 .1945: \text { Cidade de Güstrow, Böhmer - transmitida pelo espólio de Böhmer; } \\
\text { - } 03.05 .1945 \text { - 21.03.1947: Rostock/Berlim/Hamburg, Wilma Zelck, herdeira; } \\
\text { - } 21.03 .1947: \text { Berlim, SBZ / Administração Central Alemã para a Educação do Povo, sob } \\
\text { guarda de Kurt Reutti; } \\
\text { - } 21.03 .1947 \text { - 07.1949: Rostock, Museu Municipal, Entreposto de armazenagem para } \\
\text { retorno ao museu de origem; } \\
\text { 07.1949: Berlim, Ehem. Museu Estatal de Berlim, Galeria Nacional, entregue por Kurt } \\
\text { Reutti. }\end{array}$ \\
\hline
\end{tabular}

608 "Os códigos EK apresentados em cada ficha são aqueles criados pelos burocratas nazistas para registrar as obras confiscadas em suas planilhas. Eles vão de 1 a 16558; alguns números não foram localizados, e existem casos de duplicidade. Em muitas obras, esses números ainda podem ser encontrados. Em pinturas 


\begin{tabular}{|c|c|}
\hline & $\begin{array}{l}\text { Zwei Frauen auf der Straße [Duas mulheres na rua], litografia, } 1921 \\
\text { Museu de Origem: Breslau, Schlesisches Museum der Bildenden Künste [Museu de Belas- } \\
\text { Artes da Silésia] } \\
\text { Localização atual: destruída } \\
\text { Dimensões: } 44,5 \times 26,5 \mathrm{~cm} \\
\text { Catalogação MLS: MLS0212 (Duas mulheres na rua - do álbum Bubu) } \\
\text { EK- Zwei Frauen } \\
\text { EK-Ident. Nr.: } 14348 \\
\text { Provenance } \\
\text { - } \frac{12.1930 / 1.1931 \text { - 08.07.1937: Breslau, Museu de Belas-Artes da Silésia; aquisição por }}{\text { Erich Wiese (diretor) }} \\
\text { - Reich Alemão/Ministério da Propaganda do Reich, Berlim, Confisco. }\end{array}$ \\
\hline & $\begin{array}{l}\text { Mappendeckel der Mappe „Erinnerung an Wilna“ von Segall [Capa do Álbum - } \\
\text { Lembrança de Vilna]; litografia; s.d. } \\
\text { Museu de Origem: Breslau, Schlesisches Museum der Bildenden Künste [Museu de Belas- } \\
\text { Artes da Silésia] } \\
\text { Localização atual: destruída } \\
\text { Catalogação MLS: ? } \\
\text { EK- Mappe (ohne Inhalt) } \\
\text { EK-Ident. Nr.: } 14584 \\
\text { Provenance } \\
\text { - } \quad \frac{12.1930 / 1.1931 \text { - 08.07.1937: Breslau, Museu de Belas-Artes da Silésia; aquisição por }}{\text { Erich Wiese (diretor) }} \\
\text { - } \quad 08.07 .1937 \text { - xx: Reich Alemão/Ministério da Propaganda do Reich. Berlim. Confísco. }\end{array}$ \\
\hline & $\begin{array}{l}\text { Bübü und das Liebespaar [Bubu e o casal de namorados], litografia, 1921 } \\
\text { Museu de Origem: Breslau, Schlesisches Museum der Bildenden Künste [Museu de Belas- } \\
\text { Artes da Silésia] } \\
\text { Localização atual: destruída } \\
\text { Catalogação MLS: MLS0213 (Homem e casal - do álbum Bubu) } \\
\text { EK-Drei Menschen } \\
\text { EK-Ident. Nr.:15816 } \\
\text { Provenance } \\
\text { - 12.1930/1.1931 - 08.07.1937: Breslau, Museu de Belas-Artes da Silésia; aquisição por } \\
\text { - } \quad \text { Erich Wiese (diretor) } \\
\text { - } 31.07 .1937 \text { - xx: Reich Alemão/Ministério da Propaganda do Reich, Berlim, Confisco. } \\
\end{array}$ \\
\hline & $\begin{array}{l}\text { Liegende [Deitada], litografia, } 1921 \\
\text { Museu de Origem: Breslau, Schlesisches Museum der Bildenden Künste [Museu de Belas- } \\
\text { Artes da Silésia] } \\
\text { Localização atual: destruída } \\
\text { Dimenões: } 26 \text { x } 30 \mathrm{~cm} \\
\text { Catalogação MLS: MLS0210 (Mulher deitada - do álbum Bubu) } \\
\text { EK-Frau auf Diwan } \\
\text { EK-Ident. Nr.:15817 }\end{array}$ \\
\hline
\end{tabular}

eles se encontram geralmente escritos em negrito num pedaço de papel branco colado na moldura. Em outros casos, eles são escritos diretamente sobre a moldura; em obras sobre papel eles foram anotados com lápis azul ou grafite nos antigos passe-partout ou na parte de trás da folha" cfe.

http://www.geschkult.fu-Berlim.de/en/e/db entart kunst/datenbank/ek nummern/index.html.

Segundo Heidrun Lorenz e Steffen Stuth, os burocratas nazistas orientaram explicitamente aos comerciantes de arte responsáveis pela negociação das obras de "arte degenerada" que fizessem desaparecer todos os sinais colocados nas obras pelos proprietários anteriores, um cuidado que achavam desnecessário tomar quando as obras estavam destinadas à destruição; cfe. LORENZ et STUTH, 2011, p. 23. 


\begin{tabular}{|c|c|}
\hline & $\begin{array}{l}\text { Provenance: } \\
\text { - } \frac{12.1930 / 1.1931 \text { - 08.07.1937: Breslau, Museu de Belas-Artes da Silésia; aquisição por }}{\text { Erich Wiese (diretor) }} \\
\text { - } \quad \text { 08.07.1937 - xx: Reich Alemão/Ministério da Propaganda do Reich, Berlim, Confisco. }\end{array}$ \\
\hline \multirow{4}{*}{ (Atribuída pela pesquisa) } & $\begin{array}{l}\text { Drei Köpfe [Três Cabeças], xilogravura, } 1929 \\
\text { Museu de Origem: Breslau, Schlesisches Museum der Bildenden Künste [Museu de Belas- } \\
\text { Artes da Silésia] } \\
\text { Localização atual: destruída } \\
\text { Catalogação MLS: MLS 0325 (Três cabeças de negros) } \\
\text { EK- Drei Köpfe } \\
\text { EK-Ident. Nr.: } 15818 \\
\text { Provenance: } \\
\text { - } \quad \text { 12.1930/1.1931 - 08.07.1937: Breslau, Museu de Belas-Artes da Silésia; aquisiçãa por } \\
\text { Erich Wiese (diretor) } \\
\text { • }\end{array}$ \\
\hline & $\begin{array}{l}\text { Blatt } 1 \text { der Mappe "Bübü" von Segall [Folha } 1 \text { do álbum „Bubu“ de Segall] litografia, } \\
\mathbf{1 9 2 1} \\
\text { Museu de Origem: Breslau, Schlesisches Museum der Bildenden Künste [Museu de Belas- } \\
\text { Artes da Silésia] } \\
\text { Localização atual: destruída } \\
\text { Catalogação MLS: } \\
\text { EK- Mappe } \\
\text { EK-Ident. Nr.: } 16437-01 \\
\text { Provenance: } \\
\text { - } \quad \text { 12.1930/1.1931 - 08.07.1937: Breslau, Museu de Belas-Artes da Silésia; aquisição por } \\
\quad \text { Erich Wiese (diretor) } \\
\text { Exposições: } \\
\text { - Entartete Kunst (2.1), München, Hofgarten-Arkaden, } 19.07 .1937 \text { - 30.11.1937 }\end{array}$ \\
\hline & $\begin{array}{l}\text { Blatt } 2 \text { der Mappe "Bübü" von Segall [Folha } 2 \text { do álbum „Bubu“ de Segall], litografia, } \\
\text { 1921 } \\
\text { Museu de Origem: Breslau, Schlesisches Museum der Bildenden Künste [Museu de Belas- } \\
\text { Artes da Silésia] } \\
\text { Localização atual: destruída } \\
\text { Catalogação MLS: } \\
\text { EK- Mappe } \\
\text { EK-Ident. Nr.: } 16437-02 \\
\text { Provenance: } \\
\text { - } \quad \text { 12.1930/1.1931 - 27.09.1937: Breslau, Museu de Belas-Artes da Silésia; aquisição por } \\
\quad \text { Erich Wiese (diretor) } \\
\text { Exposições: } \\
\text { - Entartete Kunst (2.1), München, Hofgarten-Arkaden, } 19.07 .1937 \text { - 30.11.1937 }\end{array}$ \\
\hline & $\begin{array}{l}\text { Blatt } 3 \text { der Mappe "Bübü" von Segall [Folha } 3 \text { do álbum „Bubu“ de Segall], litografia, } \\
\text { 1921 } \\
\text { Museu de Origem: Breslau, Schlesisches Museum der Bildenden Künste [Museu de Belas- } \\
\text { Artes da Silésia] } \\
\text { Localização atual: destruída } \\
\text { Catalogação MLS: } \\
\text { EK- Mappe } \\
\text { EK-Ident. Nr.: } 16437-03 \\
\text { Provenance: }\end{array}$ \\
\hline
\end{tabular}


- $\quad$ 12.1930/1.1931 - 27.09.1937: Breslau, Museu de Belas-Artes da Silésia; aquisição por Erich Wiese (diretor)

Exposições:

- $\quad$ Entartete Kunst (2.1), München, Hofgarten-Arkaden, 19.07.1937 - 30.11.1937

Blatt 4 der Mappe "Bübü" von Segall [Folha 4 do álbum „Bubu“ de Segall], litografia, $\underline{1921}$

Museu de Origem: Breslau, Schlesisches Museum der Bildenden Künste [Museu de BelasArtes da Silésia]

Localização atual: destruída

Catalogação MLS:

EK- Mappe

EK-Ident. Nr.: 16437-04

Provenance:

- 12.1930/1.1931 - 27.09.1937: Breslau, Museu de Belas-Artes da Silésia; aquisição por Erich Wiese (diretor)

\section{Exposições:}

- Entartete Kunst (2.1), München, Hofgarten-Arkaden, 19.07.1937 - 30.11.1937

Blatt 5 der Mappe "Bübü" von Segall [Folha 5 do álbum „Bubu“ de Segall], litografia, $\underline{1921}$

Museu de Origem: Breslau, Schlesisches Museum der Bildenden Künste [Museu de BelasArtes da Silésia]

Localização atual: destruída

Catalogação MLS:

EK- Mappe

EK-Ident. Nr.: 16437-05

Provenance:

- $\quad$ 12.1930/1.1931 - 27.09.1937: Breslau, Museu de Belas-Artes da Silésia; aquisição por Erich Wiese (diretor)

\section{Exposições:}

- $\quad$ Entartete Kunst (2.1), München, Hofgarten-Arkaden, 19.07.1937 - 30.11.1937

Blatt 6 der Mappe "Bübü" von Segall [Folha 6 do álbum „Bubu“ de Segall], litografia, $\underline{1921}$

Museu de Origem: Breslau, Schlesisches Museum der Bildenden Künste [Museu de BelasArtes da Silésia]

Localização atual: destruída

Catalogação MLS:

EK- Mappe

EK-Ident. Nr.: 16437-06

Provenance:

- $\quad$ 12.1930/1.1931 - 27.09.1937: Breslau, Museu de Belas-Artes da Silésia; aquisição por Erich Wiese (diretor)

Exposições:

- $\quad$ Entartete Kunst (2.1), München, Hofgarten-Arkaden, 19.07.1937 - 30.11.1937

Blatt 7 der Mappe "Bübü" von Segall [Folha 7 do álbum „Bubu“ de Segall], litografia, 1921 


\begin{tabular}{|c|c|}
\hline & $\begin{array}{l}\text { Museu de Origem: Breslau, Schlesisches Museum der Bildenden Künste [Museu de Belas- } \\
\text { Artes da Silésia] } \\
\text { Localização atual: destruída } \\
\text { Catalogação MLS: } \\
\text { EK- Mappe } \\
\text { EK-Ident. Nr.: } 16437-07 \\
\text { Provenance: } \\
\text { - } \frac{12.1930 / 1.1931-27.09 .1937: \text { Breslau, Museu de Belas-Artes da Silésia; aquisição por }}{\text { Erich Wiese (diretor) }} \\
\text { Exposições: } \\
\text { - Entartete Kunst (2.1), München, Hofgarten-Arkaden, } 19.07 .1937 \text { - 30.11.1937 }\end{array}$ \\
\hline & $\begin{array}{l}\text { Blatt } 8 \text { der Mappe "Bübü" von Segall [Folha } 8 \text { do álbum „Bubu“ de Segall], litografia, } \\
\text { 1921 } \\
\text { Museu de Origem: Breslau, Schlesisches Museum der Bildenden Künste [Museu de Belas- } \\
\text { Artes da Silésia] } \\
\text { Localização atual: destruída } \\
\text { Catalogação MLS: } \\
\text { EK- Mappe } \\
\text { EK-Ident. Nr.: } 16437-08 \\
\text { Provenance: } \\
\text { - } \quad \frac{12.1930 / 1.1931-27.09 .1937: \text { Breslau, Museu de Belas-Artes da Silésia; aquisição por }}{\text { Erich Wiese (diretor) }} \\
\text { Exposições: } \\
\text { - Entartete Kunst (2.1), München, Hofgarten-Arkaden, 19.07.1937 - 30.11.1937 }\end{array}$ \\
\hline & $\begin{array}{l}\text { Kopf eines Matrosen und Schornsteine [Cabeça de marinheiro e chaminés], ponta-seca, } \\
\text { 1930 } \\
\text { Museu de Origem: Breslau, Schlesisches Museum der Bildenden Künste [Museu de Belas- } \\
\text { Artes da Silésia] } \\
\text { Localização atual: Rostock, Kulturhistorisches Museum [Museu Histórico-cultural de } \\
\text { Rostock] } \\
\text { Dimensões: } 21,7 \text { x } 27 \mathrm{~cm} \\
\text { Catalogação MLS: MLS0401 (Cabeça de marinheiro e chaminé) } \\
\text { EK- Auf dem Schiff } \\
\text { EK-Ident. Nr.: 8282 } \\
\text { Provenance: } \\
\text { - } 12.1930 / 1.1931-27.09 .1937 \text { : Breslau, Museu de Belas-Artes da Silésia; aquisição por } \\
\text { - } \text { Erich Wiese (diretor) } \\
\text { 27.09.1937 - 1943/44: Reich Alemão/Ministério da Propaganda do Reich, Berlim, } \\
\text { Confisco; } \\
\text { - 1938 - 1943/44: Berlim, Fundo especial do Ministério da Propaganda; } \\
\text { 1943/44 - 03.05.1945: Cidade de Güstrow, Negociante de obras de arte Bernhard A. } \\
\text { Böhmer, evacuação em função da guerra, retirada de Berlim e levada para a cidade de } \\
\text { Güstrow por Rolf Hetsch; } \\
\text { - 03.05.1945: Cidade de Güstrow, Böhmer - transmitida pelo espólio de Böhmer; } \\
\text { 03.05.1945 - 21.03.1947: Rostock/Berlim/Hamburg, Wilma Zelck, herdeira; } \\
\text { 21.03.1947: Berlim, SBZ / Administração Central Alemã para a Educação do Povo, sob } \\
\text { guarda de Kurt Reutti; } \\
\text { 21.03.1947: Rostock, Museu Municipal, Entreposto de armazenagem para retorno ao } \\
\text { museu de origem; } \\
\text { 2009: Incorporada ao patrimônio do Museu Municipal de Rostock. }\end{array}$ \\
\hline
\end{tabular}




\begin{tabular}{|c|c|}
\hline (Atribuída p & $\begin{array}{l}\text { Sitzende Frau mit Kaktus [Mulher sentada com cacto], ponta-seca, } 1928 . \\
\text { Museu de Origem: Breslau, Schlesisches Museum der Bildenden Künste [Museu de Belas- } \\
\text { Artes da Silésia] } \\
\text { Localização atual: Berlim, Kupferstichkabinett [Gabinete de Gravuras] } \\
\text { Dimensões: 23,8 x 17,7 cm } \\
\text { Catalogação MLS: MLS 0265 (Mulher do mangue com cactos) } \\
\text { EK-Sitzende Frau mit Kaktus } \\
\text { EK-Ident. Nr.:8283 } \\
\text { Provenance } \\
\text { - } \quad \text { 12.1930/1.1931 - 27.09.1937: Breslau, Museu de Belas-Artes da Silésia; aquisição por } \\
\text { Erich Wiese (diretor) } \\
\text { - 27.09.1937 - 1943/44: Reich Alemão/Ministério da Propaganda do Reich, Berlim, } \\
\text { - Confisco; } \\
\text { - 1938 - 1943/44: Berlim, Fundo especial do Ministério da Propaganda; } \\
\text { 1943/44 - 03.05.1945: Cidade de Güstrow, Negociante de obras de arte Bernhard A. } \\
\text { Böhmer, evacuação em função da guerra, retirada de Berlim e levada para a cidade de } \\
\text { - Güstrow por Rolf Hetsch; } \\
\text { - 03.05.1945: Cidade de Güstrow, Böhmer - Transmitida pelo espólio de Böhmer; } \\
\text { - } 03.05 .1945 \text { - 21.03.1947: Rostock/Berlim/Hamburg, Wilma Zelck, herdeira; } \\
\text { 21.03.1947: Berlim, SBZ/ Administração Central Alemã para a Educação do Povo, sob } \\
\text { guarda de Kurt Reutti; } \\
\text { 21.03.1947 - 07.1949: Rostock, Museum der Stadt, Entreposto de armazenagem para } \\
\text { retorno ao museu de origem; } \\
\text { 07.1949: Berlim, Ehem. Museu Estatal de Berlim, Galeria Nacional, Entregue por Kurt } \\
\text { Reutti. }\end{array}$ \\
\hline (Atribu & $\begin{array}{l}\text { Schiff und Möwen [Navio e Gaivotas], ponta-seca, } \underline{1928} \\
\text { Museu de Origem: Breslau, Schlesisches Museum der Bildenden Künste [Museu de Belas- } \\
\text { Artes da Silésia] } \\
\text { Localização atual: desconhecida } \\
\text { Catalogação MLS: MLS } 0317 \text { (Três gaivotas e respiradouros) } \\
\text { EK-Schiff und Möwen } \\
\text { EK-Ident. Nr.:8284 } \\
\text { Provenance: } \\
\text { - } 12.1930 / 1.1931-27.09 .1937 \text { : Breslau, Museu de Belas-Artes da Silésia; aquisição por } \\
\text { Erich Wiese (diretor); } \\
\text { - } 27.09 .1937 \text { - 1943/44: Reich Alemão/Ministério da Propaganda do Reich, Berlim, } \\
\text { Confisco; } \\
\text { - } 1938 \text { - xx: Berlim, Fundo especial do Ministério da Propaganda. }\end{array}$ \\
\hline & $\begin{array}{l}\text { Emigranten auf dem Oberdeck [Imigrantes no tombadilho], água-forte, 1929 } \\
\text { Museu de Origem: Breslau, Schlesisches Museum der Bildenden Künste [Museu de Belas- } \\
\text { Artes da Silésia] } \\
\text { Localização atual: Rostock, Kulturhistorisches Museum [Museu Histórico-cultural de } \\
\text { Rostock] } \\
\text { Dimensões: } 29,5 \text { x } 35 \mathrm{~cm} \\
\text { Catálogo MLS: MLS0366 (Emigrantes no tombadilho) } \\
\text { EK-Schiffsschornsteine } \\
\text { EK-Ident. Nr.:8285 } \\
\text { Provenance: } \\
\text { - } \quad \text { 12.1930/1.1931 -27.09.1937: Breslau, Museu de Belas-Artes da Silésia; aquisição por } \\
\text { Erich Wiese (diretor); } \\
\text { - } 27.09 .1937 \text { - 1943/44: Reich Alemão/Ministério da Propaganda do Reich, Berlim, } \\
\text { - Confisco; } \\
\text { 1938 - 1943/44: Berlim, Fundo especial do Ministério da Propaganda; }\end{array}$ \\
\hline
\end{tabular}




\begin{tabular}{|c|c|}
\hline & $\begin{array}{l}\text { - 1943/44 - 03.05.1945: Cidade de Güstrow, Negociante de obras de arte Bernhard A. } \\
\text { Böhmer, evacuação em função da guerra, retirada de Berlim e levada para a cidade de } \\
\text { Güstrow por Rolf Hetsch; } \\
\text { - } \\
\text { - } \\
\text { - } \\
\text { 03.05.1945: Cidade de Güstrow, Böhmer - Transmitida pelo espólio de Böhmer; } \\
\text { 21.03.1947: Berlim, SBZ / Administração Central Alemã para a Educação do Povo, sob } \\
\text { - 21.03.1947: Rostock, Museum der Stadt, Entreposto de armazenagem para retorno ao } \\
\text { museu de origem; } \\
\text { - } 2009 \text { : Incorporada ao patrimônio do Museu Municipal de Rostock. }\end{array}$ \\
\hline & $\begin{array}{l}\text { Am Totenbett, zu Fjodor Dostojewski "Die Sanfte" [No leito de morte; para 'Uma dócil } \\
\text { criatura', de Fiodor Dostoievski], litografia, } 1917 \\
\text { Museu de Origem: Chemnitz, Kunsthütte } \\
\text { Localização atual: destruída } \\
\text { Dimensões: } 34,5 \times 37,5 \mathrm{~cm} \\
\text { Catalogação MLS: MLS0130 (Leito de morte, do álbum "Uma doce criatura") } \\
\text { EK-Am Totenbett } \\
\text { EK-Ident. Nr.: } 10021 \\
\text { Provenance } \\
\text { • } \quad \text { 12.11.1919 - 19.08.1937: Chemnitz, Kunsthütte; aquisição por Friedrich Schreiber- } \\
\text { - } \quad \text { 19.0igand (diretor); } \\
\text { - 31.5.1937 - xx: Reich Alemão / Ministério da Propaganda do Reich, Berlim, Confisco; } \\
\end{array}$ \\
\hline (Atribuída pela pesquisa) & $\begin{array}{l}\text { Umarmung [Abraço]; litografia, } 1917 \\
\text { Museu de Origem: Chemnitz, Kunsthütte } \\
\text { Localização atual: destruída } \\
\text { Catalogação MLS: MLS } 0111 \text { (Abraço) } \\
\text { EK-Umarmung } \\
\text { EK-Ident. Nr.:10022 } \\
\text { Provenance } \\
\text { - } \frac{12.11 .1919-19.08 .1937: \text { Chemnitz, Kunsthütte; doação de Leopold Eger (colecionador }}{\text { privado); }} \\
\text { - } 19.08 .1937 \text { - xx: Deutsches Reich / Ministério da Propaganda do Reich, Berlim, } \\
\quad \text { Confisco }\end{array}$ \\
\hline & $\begin{array}{l}\text { Die Beleidigten [Os ofendidos]; gravura, s.d. } \\
\text { Museu de Origem: Chemnitz, Kunsthütte } \\
\text { Localização atual: destruída } \\
\text { Catalogação MLS: ? } \\
\text { EK-Die Beleidigten } \\
\text { EK-Ident. Nr.:10023 } \\
\text { Provenance } \\
\text { - xx - 19.08.1937: Chemnitz, Kunsthütte } \\
\text { - } \quad 19.08 .1937 \text { - xx: Deutsches Reich / Ministério da Propaganda do Reich, Berlim, } \\
\quad \text { Confisco }\end{array}$ \\
\hline & $\begin{array}{l}\text { Bildnis [Retrato], gravura, s.d. } \\
\text { Museu de Origem: Chemnitz, Kunsthütte } \\
\text { Localização atual: destruída } \\
\text { Catalogação MLS: ? } \\
\text { EK-Bildnis } \\
\text { EK-Ident. Nr.:10024 } \\
\text { Provenance } \\
\text { - xx - 19.08.1937: Chemnitz, Kunsthütte } \\
\text { - } \quad 19.08 .1937 \text { - xx: Deutsches Reich / Ministério da Propaganda do Reich, Berlim, } \\
\quad \text { Confisco; }\end{array}$ \\
\hline
\end{tabular}




\begin{tabular}{|c|c|}
\hline & $\begin{array}{l}\text { - 31.05.1938: Apreensão em benefício do Reich Alemão } \\
\text { Witwe und Kind [Viúva e filho], xilogravura, } 1920 \\
\text { Museu de Origem: Chemnitz, Kunsthutte } \\
\text { Localização atual: desconhecida } \\
\text { Dimensões: } 23,7 \text { x } 17,9 \mathrm{~cm} \\
\text { Catalogação MLS: MLS0139 (Viúva e filho) } \\
\text { EK-Witwe } \\
\text { EK-Ident. Nr. } 10025 \\
\text { Provenance: } \\
\text { - } \quad \text { 3.1922: Doação do artista - 19.08.1937: Chemnitz, Kunsthütte } \\
\text { - 19.08.1937 - desconhecido: Deutsches Reich / Reichsministerium für } \\
\text { Volksaufklärung und Propaganda, Berlin } \\
\text { - 1938 - 1941: Velten/Mark, Depósito para Exposições de Propaganda; armazém de itens } \\
\text { para a exposição itinerante "Entartete Kunst". }\end{array}$ \\
\hline (Atribuída pela pesquisa) & $\begin{array}{l}\text { Bettler [Mendigo], litografia sobre papel, } 1917 \\
\text { Museu de Origem: Chemnitz, Kunsthütte } \\
\text { Localização atual: destruída } \\
\text { Dimensões: } 44 \text { x } 37,5 \mathrm{~cm} \\
\text { Catalogação MLS: MLS0112 (Mendigos III versão) } \\
\text { EK-Bettler } \\
\text { EK-Ident. Nr.:10184 } \\
\text { Provenance } \\
\text { - } \\
\quad \text { Weigand (diretor); } \\
\text { - } 19.08 .1937 \text { - xx: Deutsches Reich / Ministério da Propaganda do Reich } \\
\text { [Reichsministerium für Volksaufklärung und Propaganda], Berlim, Confisco; } \\
\text { - 31.05.1938: Apreensão em benefício do Reich Alemão }\end{array}$ \\
\hline & 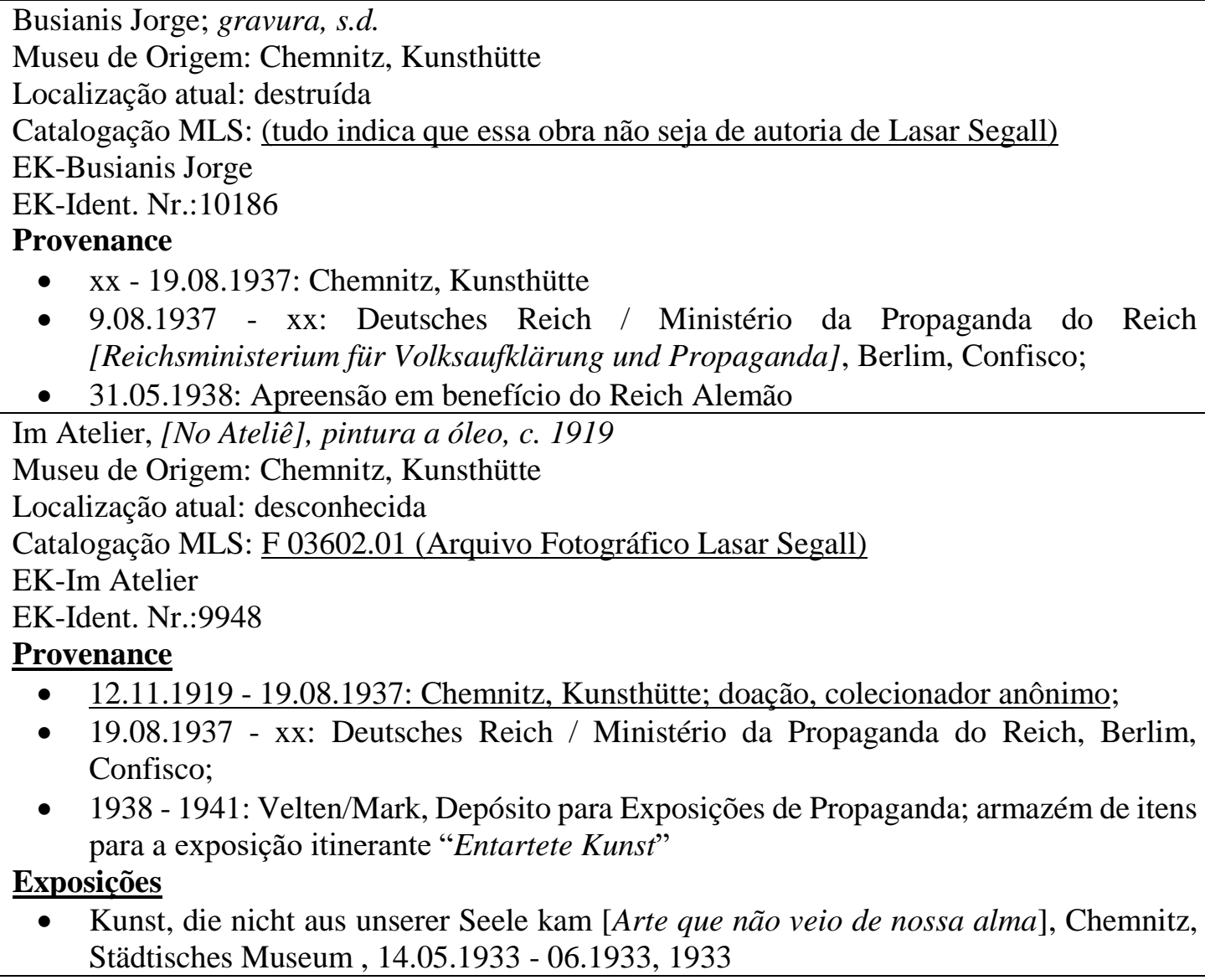 \\
\hline
\end{tabular}




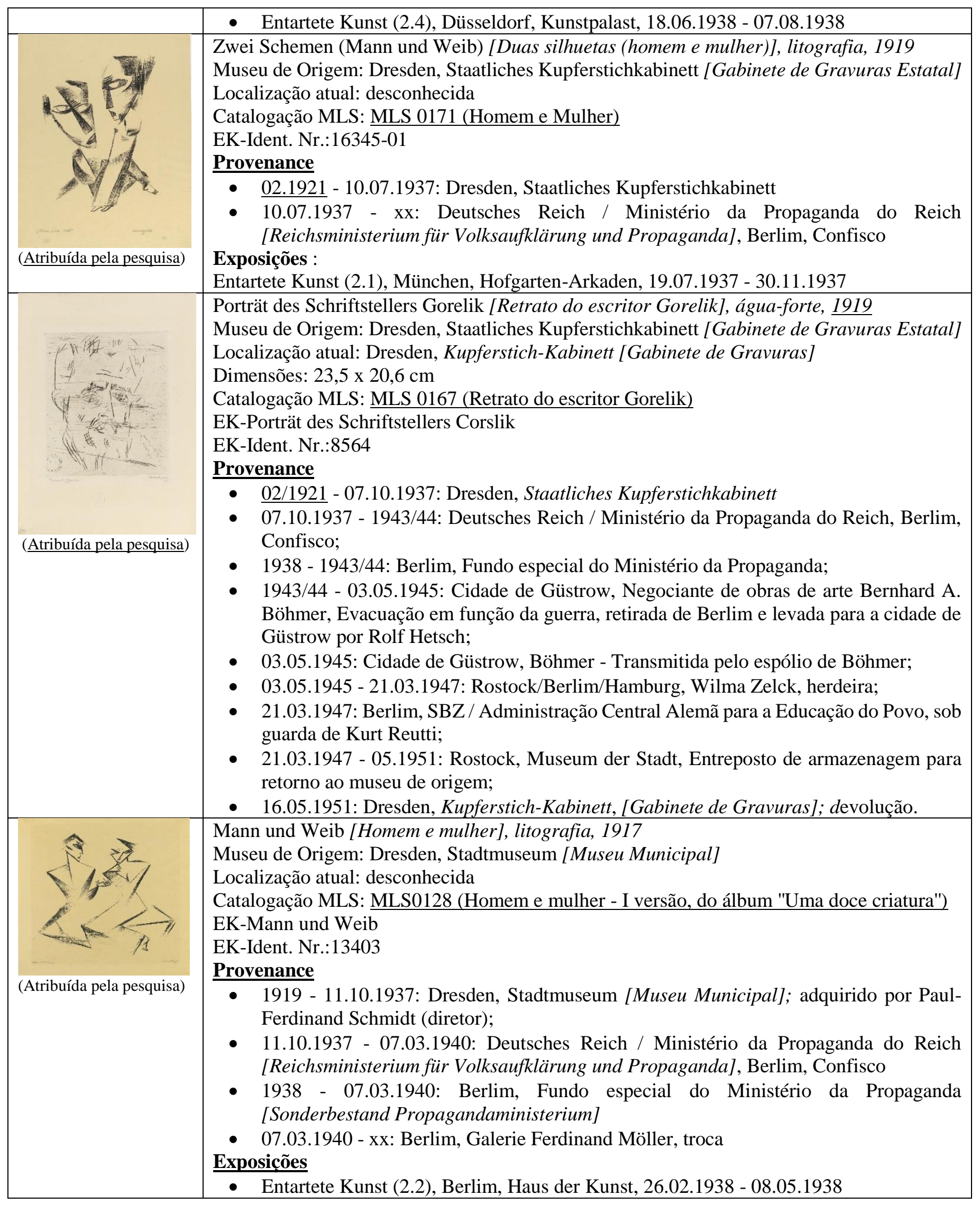




\begin{tabular}{|c|c|}
\hline W & $\begin{array}{l}\text { Zu Dostojewski "Die Sanfte" [Para 'Uma Dócil Criatura' de Dostoievski], litografia, } 1917 \\
\text { Museu de Origem: Dresden, Stadtmuseum [Museu Municipal] } \\
\text { Localização atual: desconhecida } \\
\text { Catalogação MLS: MLS 0127 (Duas cabeças, do álbum "Uma doce criatura") } \\
\text { EK-Die Sanfte } \\
\text { EK-Ident. Nr.:13459 } \\
\text { Provenance } \\
\text { - } 1919 \text { - 11.10.1937: Dresden, Stadtmuseum [Museu Municipal]; adquirido por Paul- } \\
\text { Ferdinand Schmidt (diretor); } \\
\text { - } 11.10 .1937 \text { - xx: Deutsches Reich / Ministério da Propaganda do Reich, Berlim, } \\
\text { Confisco; } \\
\text { - } 1938 \text { - xx: Berlim, Fundo especial do Ministério da Propaganda. }\end{array}$ \\
\hline & $\begin{array}{l}\text { Für die Sanfte [Para 'Uma Dócil Criatura'], litografia, 1917 } \\
\text { Museu de Origem: Dresden, Stadtmuseum [Museu Municipal] } \\
\text { Localização atual: Dresden, Städtische Galerie [Galeria Municipal] } \\
\text { Dimensões: } 42 \text { x } 37 \text { cm } \\
\text { Catalogação MLS: MLS 0127 (Duas cabeças, do álbum "Uma doce criatura") } \\
\text { EK-Die Sanfte } \\
\text { EK-Ident. Nr.:13461 } \\
\text { Provenance } \\
\text { - } 1919 \text { - 11.10.1937: Dresden, Stadtmuseum [Museu Municipal]; adquirido por Paul- } \\
\text { Ferdinand Schmidt (diretor); } \\
\text { - } 11.10 .1937 \text { - 1943/44: Reich Alemão/Ministério da Propaganda do Reich, Berlim, } \\
\text { Confisco; } \\
\text { - } 1938 \text { - 1943/44: Berlim, Fundo especial do Ministério da Propaganda; } \\
\text { 1943/44 - 03.05.1945: Cidade de Güstrow, Negociante de obras de arte Bernhard A. } \\
\text { Böhmer, Evacuação em função da guerra, retirada de Berlim e levada para a cidade de } \\
\text { Güstrow por Rolf Hetsch; } \\
\text { 03.05.1945: Cidade de Güstrow, Böhmer - Transmitida pelo espólio de Böhmer; } \\
\text { 03.05.1945 - 21.03.1947: Rostock/Berlim/Hamburg, Wilma Zelck, herdeira; } \\
\text { 21.03.1947: Berlim, SBZ / Administração Central Alemã para a Educação do Povo, sob } \\
\text { guarda de Kurt Reutti; } \\
\text { 21.03.1947 - 1951: Rostock, Museum der Stadt, Entreposto de armazenagem para } \\
\text { retorno ao museu de origem; } \\
\text { 1951: Dresden, Städtische Galerie, Devolução } \\
\text { Exposicões } \\
\text { Entartete Kunst (1.1), Dresden, Neues Rathaus, Lichthof [átrio da nova prefeitura], } \\
\text { 23.09.1933 - 18.10.1933 }\end{array}$ \\
\hline & $\begin{array}{l}\text { Am Totenbett, zu Fjodor Dostojewski "Die Sanfte" [No leito de morte, para „Uma dócil } \\
\text { criatura” de Fiodor Dostoievski], litografia, } 1917 . \\
\text { Museu de Origem: Dresden, Stadtmuseum, [Museu Municipal] } \\
\text { Localização atual: desconhecida } \\
\text { Dimensões: } 34,5 \text { x } 37,5 \mathrm{~cm} \\
\text { Catalogação MLS: MLS0130 (Leito de morte, do álbum "Uma doce criatura") } \\
\text { EK-Am Totenbett } \\
\text { EK-Ident. Nr.:13462 } \\
\text { Inventário de Origem: } 1919 / 10 \\
\text { Forma de perda: Confisco } \\
\text { Provenance } \\
\text { • } 1919 \text { - 11.10.1937: Dresden, Stadtmuseum [Museu Municipal]; adquirido por Paul- } \\
\quad \text { Ferdinand Schmidt (diretor); } \\
\text { - } 11.10 .1937 \text { - xx: Reich Alemão/ Ministério da Propaganda do Reich, Berlim, Confisco; } \\
\text { • } 1938 \text { - xx: Berlim, Fundo especial do Ministério da Propaganda. } \\
\text { Exposicões }\end{array}$ \\
\hline
\end{tabular}




\begin{tabular}{|c|c|}
\hline & $\begin{array}{l}\text { - Entartete Kunst (2.14), Halle, Landesanstalt für Volkheitskunde, } 05.04 .1941 \text { - } \\
\text { 20.04.1941 }\end{array}$ \\
\hline & $\begin{array}{l}\text { Porträt M. Q. [Retrato de M.Q.], água-forte, } 1917 \\
\text { Museu de Origem: Dresden, Stadtmuseum, [Museu Municipal] } \\
\text { Localização atual: Dresden, Städtische Galerie [Galeria Municipal] } \\
\text { Dimensos: 17,6 x 13,6 cm } \\
\text { Catalogação MLS: MLS0200 (Margarete; datado 1919-1921) } \\
\text { EK-Porträt } \\
\text { EK-Ident. Nr.:13623 } \\
\text { Provenance } \\
\text { - } 1919 \text { - 11.10.1937: Dresden, Stadtmuseum [Museu Municipal]; adquirido por Paul- } \\
\text { Ferdinand Schmidt (diretor); } \\
\text { - } 11.10 .1937 \text { - 1943/44: Reich Alemão/Ministério da Propaganda do Reich, Berlim, } \\
\text { Confisco; } \\
\text { - } 1938 \text { - 1943/44: Berlim, Fundo especial do Ministério da Propaganda; } \\
\text { 1943/44 - 03.05.1945: Cidade de Güstrow, Negociante de obras de arte Bernhard A. } \\
\text { Böhmer, Evacuação em função da guerra, retirada de Berlim e levada para a cidade de } \\
\text { Güstrow por Rolf Hetsch; } \\
\text { - } 03.05 .1945: \text { Cidade de Güstrow, Böhmer - Transmitida pelo espólio de Böhmer; } \\
\text { - } 03.05 .1945 \text { - 21.03.1947: Rostock/Berlim/Hamburg, Wilma Zelck, herdeira; } \\
\text { 21.03.1947: Berlim, SBZ / Administração Central Alemã para a Educação do Povo, sob } \\
\text { guarda de Kurt Reutti; } \\
\text { 21.03.1947 - 05.1951: Rostock, Museum der Stadt, Entreposto de armazenagem para } \\
\text { - } \text { 05torno ao museu de origem; } \\
\text { 05.1951: Dresden, Städtische Galerie /Galeria Municipal], Devolucão. }\end{array}$ \\
\hline & $\begin{array}{l}\text { Knabe [Rapaz], água-forte, } 1916 \\
\text { Museu de Origem: Dresden, Stadtmuseum, [Museu Municipal] } \\
\text { Localização atual: Dresden, Städtische Galerie [Galeria Municipal] } \\
\text { Dimensões: 19,5 x 14,4 cm } \\
\text { Catalogação MLS: MLS0104 (Jovem de Vilna, datado 1915) } \\
\text { EK-Betender Knabe } \\
\text { EK-Ident. Nr.:13624 } \\
\text { Inventário de Origem: 1919/6 } \\
\text { Forma de perda: Confisco } \\
\text { Provenance } \\
\text { - } \quad \text { 1919 - 11.10.1937: Dresden, Stadtmuseum [Museu Municipal]; adquirido por Paul- } \\
\text { Ferdinand Schmidt (diretor); } \\
\text { - } 11.10 .1937 \text { - 1943/44: Reich Alemão/Ministério da Propaganda do Reich, Berlim, } \\
\text { Confisco } \\
\text { - 1938 - 1943/44: Berlim, Fundo especial do Ministério da Propaganda; } \\
\text { 1943/44 - 03.05.1945: Cidade de Güstrow, Negociante de obras de arte Bernhard A. } \\
\text { Böhmer, Evacuação em função da guerra, retirada de Berlim e levada para a cidade de } \\
\text { Güstrow por Rolf Hetsch; } \\
\text { - } 03.05 .1945: \text { Cidade de Güstrow, Böhmer - Transmitida pelo espólio de Böhmer; } \\
\text { 03.05.1945 - 21.03.1947: Rostock/Berlim/Hamburg, Wilma Zelck, herdeira; } \\
\text { - 21.03.1947: Berlim, SBZ / Administração Central Alemã para a Educação do Povo } \\
\text { [Deutsche Zentralverwaltung für Volksbildung], sob guarda de Kurt Reutti; } \\
\text { 21.03.1947 - 1951: Rostock, Museum der Stadt, Entreposto de armazenagem para } \\
\text { retorno ao museu de origem; } \\
\text { 1951: Dresden, Stadtmuseum [Museu Municipal], Devolução. }\end{array}$ \\
\hline
\end{tabular}




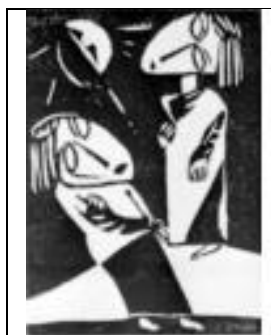

Die irrenden Frauen [As mulheres errantes], xilogravura, 1919

Museu de Origem: Dresden, Stadtmuseum, [Museu Municipal]

Localização atual: Dresden, Städtische Galerie [Galeria Municipal]

Dimensões: 15,9 x $11,7 \mathrm{~cm}$

Catalogação MLS: MLS0155 (Mulheres errantes)

EK-Irrende Frauen

EK-Ident. Nr.:13625

\section{Provenance}

- 1919 - 11.10.1937: Dresden, Stadtmuseum [Museu Municipal]; adquirido por PaulFerdinand Schmidt (diretor);

- 11.10.1937 - 1943/44: Deutsches Reich / Ministério da Propaganda do Reich, Berlim, Confisco

- 1938 - 1943/44: Berlim, Fundo especial do Ministério da Propaganda;

- 1943/44 - 03.05.1945: Cidade de Güstrow, Negociante de obras de arte Bernhard A. Böhmer, Evacuação em função da guerra, retirada de Berlim e levada para a cidade de Güstrow por Rolf Hetsch

- 03.05.1945: Cidade de Güstrow, Böhmer - Transmitida pelo espólio de Böhmer;

- 03.05.1945 - 21.03.1947: Rostock/Berlim/Hamburg, Wilma Zelck, herdeira;

- 21.03.1947: Berlim, SBZ / Administração Central Alemã para a Educação do Povo, sob guarda de Kurt Reutti;

- 21.03.1947 - 1951: Rostock, Museum der Stadt, Entreposto de armazenagem para retorno ao museu de origem;

- 1951: Dresden, Dresden, Städtische Galerie [Galeria Municipal], Devolução.

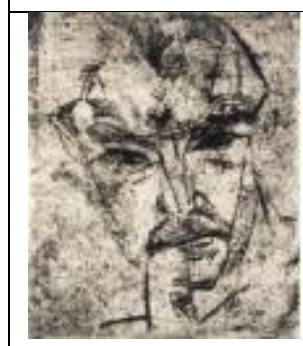

Porträt Prof. Schwangard [Retrato do Professor Schwangart]; ponta-seca sobre papel, 1921

Museu de Origem: Dresden, Stadtmuseum [Museu Municipal]

Localização atual: Dresden, Städtische Galerie [Galeria Municipal]

Dimensões: 23,7 x $19,5 \mathrm{~cm}$

Catalogação MLS: MLS0203 (Professor Schwangart)

EK-Porträt

EK-Ident. Nr.:13626

\section{Provenance}

- 1921 - 11.10.1937: Dresden, Stadtmuseum [Museu Municipal]

- 11.10.1937 - 1943/44: Deutsches Reich / Ministério da Propaganda do Reich, Berlim, Confisco;

- 1938 - 1943/44: Berlim, Fundo especial do Ministério da Propaganda;

- 1943/44 - 03.05.1945: Cidade de Güstrow, Negociante de obras de arte Bernhard A. Böhmer, Evacuação em função da guerra, retirada de Berlim e levada para a cidade de Güstrow por Rolf Hetsch

- 03.05.1945: Cidade de Güstrow, Böhmer - Transmitida pelo espólio de Böhmer;

- 03.05.1945 - 21.03.1947: Rostock/Berlim/Hamburg, Wilma Zelck, herdeira;

- 21.03.1947: Berlim, SBZ / Administração Central Alemã para a Educação do Povo, sob guarda de Kurt Reutti;

- 21.03.1947 - 05.1951: Rostock, Museum der Stadt, Entreposto de armazenagem para retorno ao museu de origem;

- 05.1951: Dresden, Städtische Galerie [Galeria Municipal], Devolução.

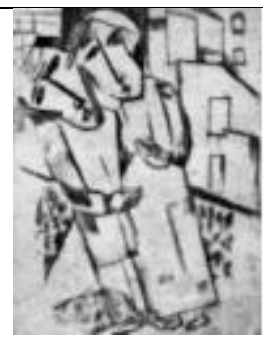

Erinnerung an Wilna 1917 [Recordações de Vilna 1917] água-forte, 1921

Museu de Origem: Dresden, Stadtmuseum [Museu Municipal]

Localização atual: Dresden, Städtische Galerie [Galeria Municipal]

Dimensões: 27,5 x 21,3 cm

Catalogação MLS: MLS0122 (Casal - do álbum "Recordações de Vilna em 1917")

EK-Erinnerung

EK-Ident. Nr.:13627

Provenance

- 1921 - 11.10.1937: Dresden, Stadtmuseum [Museu Municipal]; 


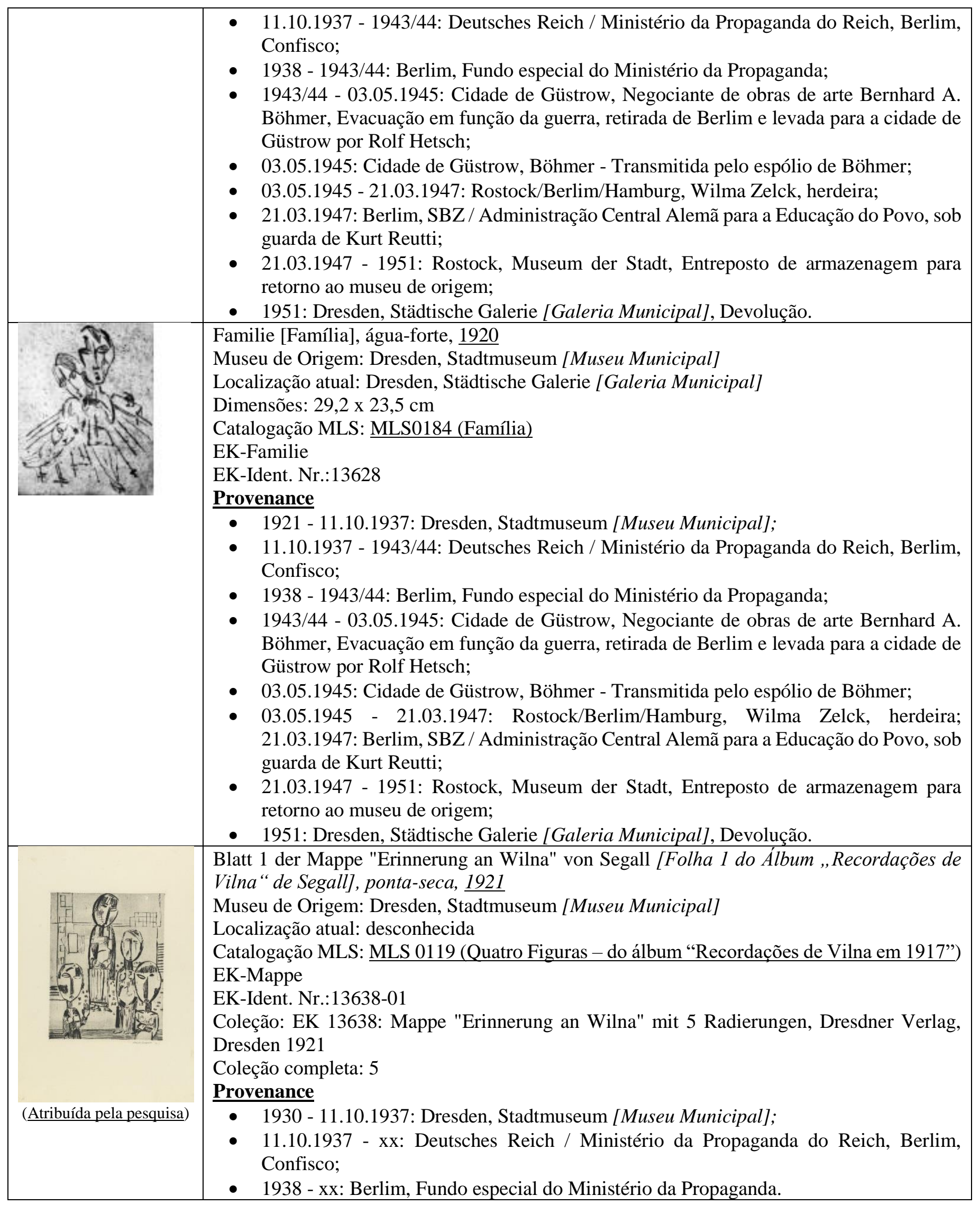




\begin{tabular}{|c|c|}
\hline & $\begin{array}{l}\text { Blatt } 2 \text { der Mappe "Erinnerung an Wilna" von Segall, [Folha } 2 \text { do Álbum „Recordações de } \\
\text { Vilna" de Segall], ponta-seca, } \underline{1921} \\
\text { Museu de Origem: Dresden, Stadtmuseum [Museu Municipal] } \\
\text { Localização atual: desconhecida } \\
\text { Catalogação MLS: MLS0120 (Três figuras - do álbum “Recordações de Vilna em 1917”) } \\
\text { EK-Mappe } \\
\text { EK-Ident. Nr.:13638-02 } \\
\text { Coleção: EK 13638: Mappe "Erinnerung an Wilna" mit } 5 \text { Radierungen, Dresdner Verlag, } \\
\text { Dresden } 1921 \\
\text { Coleção completa: } 5 \\
\text { Inventário de Origem: 1930/114 } \\
\text { Forma de perda: Confisco } \\
\text { Provenance } \\
\text { • } \quad 1930 \text { - 11.10.1937: Dresden, Stadtmuseum [Museu Municipal]; } \\
\text { - } \quad 11.10 .1937 \text { - xx: Deutsches Reich / Ministério da Propaganda do Reich, Berlim, } \\
\quad \text { Confisco; } \\
\text { • } 1938 \text { - xx: Berlim, Fundo especial do Ministério da Propaganda. }\end{array}$ \\
\hline & $\begin{array}{l}\text { Blatt } 3 \text { der Mappe "Erinnerung an Wilna" von Segall, [Folha } 3 \text { do Álbum „Recordações de } \\
\text { Vilna“ de Segall], ponta-seca, } 1921 \\
\text { Museu de Origem: Dresden, Stadtmuseum [Museu Municipal] } \\
\text { Localização atual: desconhecida } \\
\text { Dimensões: } 27,5 \text { x } 21,3 \text { cm } \\
\text { Catalogação MLS: MLS0117 (Casal - do álbum “Recordações de Vilna em 1917”; no álbum, } \\
\text { esta gravura refere-se à página 4) } \\
\text { EK-Mappe } \\
\text { EK-Ident. Nr.:13638-03 } \\
\text { Coleção: EK 13638: Mappe "Erinnerung an Wilna" mit } 5 \text { Radierungen, Dresdner Verlag, } \\
\text { Dresden } 1921 \\
\text { Coleção completa: } 5 \\
\text { Provenance } \\
\text { - } 1930 \text { - 11.10.1937: Dresden, Stadtmuseum [Museu Municipal]; } \\
\text { • } 11.10 .1937 \text { - xx: Deutsches Reich / Ministério da Propaganda do Reich, Berlim, } \\
\text { Confisco; } \\
\text { - } 1938 \text { - xx: Berlim, Fundo especial do Ministério da Propaganda. }\end{array}$ \\
\hline (Atribuída pela pesquis & $\begin{array}{l}\text { Blatt } 4 \text { der Mappe "Erinnerung an Wilna" von Segall, [Folha } 4 \text { do Álbum „Recordações de } \\
\text { Vilna “ de Segall], ponta-seca, } 1921 \\
\text { Museu de Origem: Dresden, Stadtmuseum [Museu Municipal] } \\
\text { Localização atual: desconhecida } \\
\text { Catalogação MLS: MLS 0121 (Cinco figuras - do álbum "Recordações de Vilna em 1917”; } \\
\text { no álbum, esta gravura refere-se à página 3) } \\
\text { EK-Mappe } \\
\text { EK-Ident. Nr.:13638-04 } \\
\text { Coleção: EK 13638: Mappe "Erinnerung an Wilna" mit } 5 \text { Radierungen, Dresdner Verlag, } \\
\text { Dresden } 1921 \\
\text { Coleção completa: } 5 \\
\text { Provenance } \\
\text { • } 1930 \text { - 11.10.1937: Dresden, Stadtmuseum [Museu Municipal]; } \\
\text { - } 11.10 .1937 \text { - xx: Deutsches Reich / Ministério da Propaganda do Reich, Berlim, } \\
\quad \text { Confisco; } \\
\text { • } 1938 \text { - xx: Berlim, Fundo especial do Ministério da Propaganda. }\end{array}$ \\
\hline
\end{tabular}




\begin{tabular}{|c|c|}
\hline (Atribuída pela pesquisa) & $\begin{array}{l}\text { Blatt } 5 \text { der Mappe "Erinnerung an Wilna" von Segall, [Folha } 5 \text { do Álbum „Recordações de } \\
\text { Vilna“ de Segall], ponta-seca, } 1921 \\
\text { Museu de Origem: Dresden, Stadtmuseum [Museu Municipal] } \\
\text { Localização atual: desconhecida } \\
\text { Catalogação MLS: MLS 0118 (Casal com filho - do álbum "Recordações de Vilna em 1917”) } \\
\text { EK-Mappe } \\
\text { EK-Ident. Nr.:13638-05 } \\
\text { Coleção: EK 13638: Mappe "Erinnerung an Wilna" mit } 5 \text { Radierungen, Dresdner Verlag, } \\
\text { Dresden } 1921 \\
\text { Coleção completa: } 5 \\
\text { Museu de Origem: Dresden, Stadtmuseum } \\
\text { Inventário de Origem: } 1930 / 114 \\
\text { Forma de perda: Confisco } \\
\text { Provenance } \\
\text { • } 1930 \text { - 11.10.1937: Dresden, Stadtmuseum [Museu Municipal]; } \\
\text { • } 11.10 .1937 \text { - xx: Deutsches Reich / Ministério da Propaganda do Reich, Berlim, } \\
\quad \text { Confisco; } \\
\text { • } 1938 \text { - xx: Berlim, Fundo especial do Ministério da Propaganda. }\end{array}$ \\
\hline 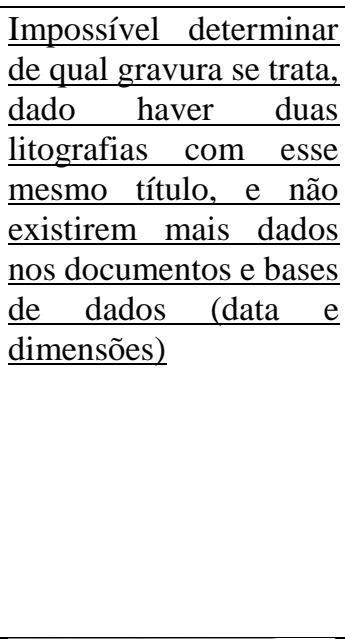 & $\begin{array}{l}\text { Mann und Weib [Homem e mulher] } \\
\text { Museu de Origem: Dresden, Stadtmuseum [Museu Municipal] } \\
\text { Localização atual: desconhecida } \\
\text { Catalogação MLS: ? } \\
\text { EK-Mann und Weib } \\
\text { EK-Ident. Nr.:16362 } \\
\text { Provenance } \\
\text { - xx - xx.1937: Dresden, Stadtmuseum [Museu Municipal]; } \\
\text { - xx.1937 - xx: Reich Alemão/Ministério da Propaganda do, Berlim, Confisco; } \\
\text { - } 1938 \text { - 1941: Velten/Mark, Depósito para Exposições de Propaganda; armazém de itens } \\
\text { Exposica a exposição itinerante "Entartete Kunst”. } \\
\text { - Entartete Kunst (2.1), München, Hofgarten-Arkaden, } 19.07 .1937 \text { - } 30.11 .1937 \\
\text { - Entartete Kunst (2.2), Berlim, Haus der Kunst, 26.02.1938 - 08.05.1938 }\end{array}$ \\
\hline & $\begin{array}{l}\text { Mädchenkopf [Cabeça de garota] } \\
\text { Museu de Origem: Dresden, Stadtmuseum [Museu Municipal] } \\
\text { Localização atual: desconhecida } \\
\text { Catalogação MLS: não há (a imagem apresentada na Base de Dados da FUB, reproduzida ao } \\
\text { lado, origina-se de still de filme "Zeitdokumente", 1933.) } \\
\text { EK-Mädchenkopf } \\
\text { EK-Ident. Nr.:13458 } \\
\text { Provenance } \\
\text { • } 1921 \text { - } 11.10 .1937: \text { Dresden, Stadtmuseum [Museu Municipal]; } \\
\text { - } 11.10 .1937 \text { - xx: Reich Alemão/Ministério da Propaganda do Reich, Berlim, Confisco; } \\
\text { - } 1938 \text { - xx: Berlim, Fundo especial do Ministério da Propaganda [Sonderbestand } \\
\quad \text { Propagandaministerium]. }\end{array}$ \\
\hline & $\begin{array}{l}\text { Mädchenkopf [Cabeça de garota] } \\
\text { Museu de Origem: Dresden, Stadtmuseum [Museu Municipal] } \\
\text { Localização atual: desconhecida } \\
\text { Catalogação MLS: não há (a imagem apresentada na Base de Dados da FUB, reproduzida ao } \\
\text { lado, origina-se de still de filme "Zeitdokumente", 1933.) } \\
\text { EK-Mädchenkopf } \\
\text { EK-Ident. Nr.:13460 } \\
\text { Inventário de Origem: } 1921 / 60 \\
\text { Forma de perda: Confisco } \\
\text { Provenance }\end{array}$ \\
\hline
\end{tabular}




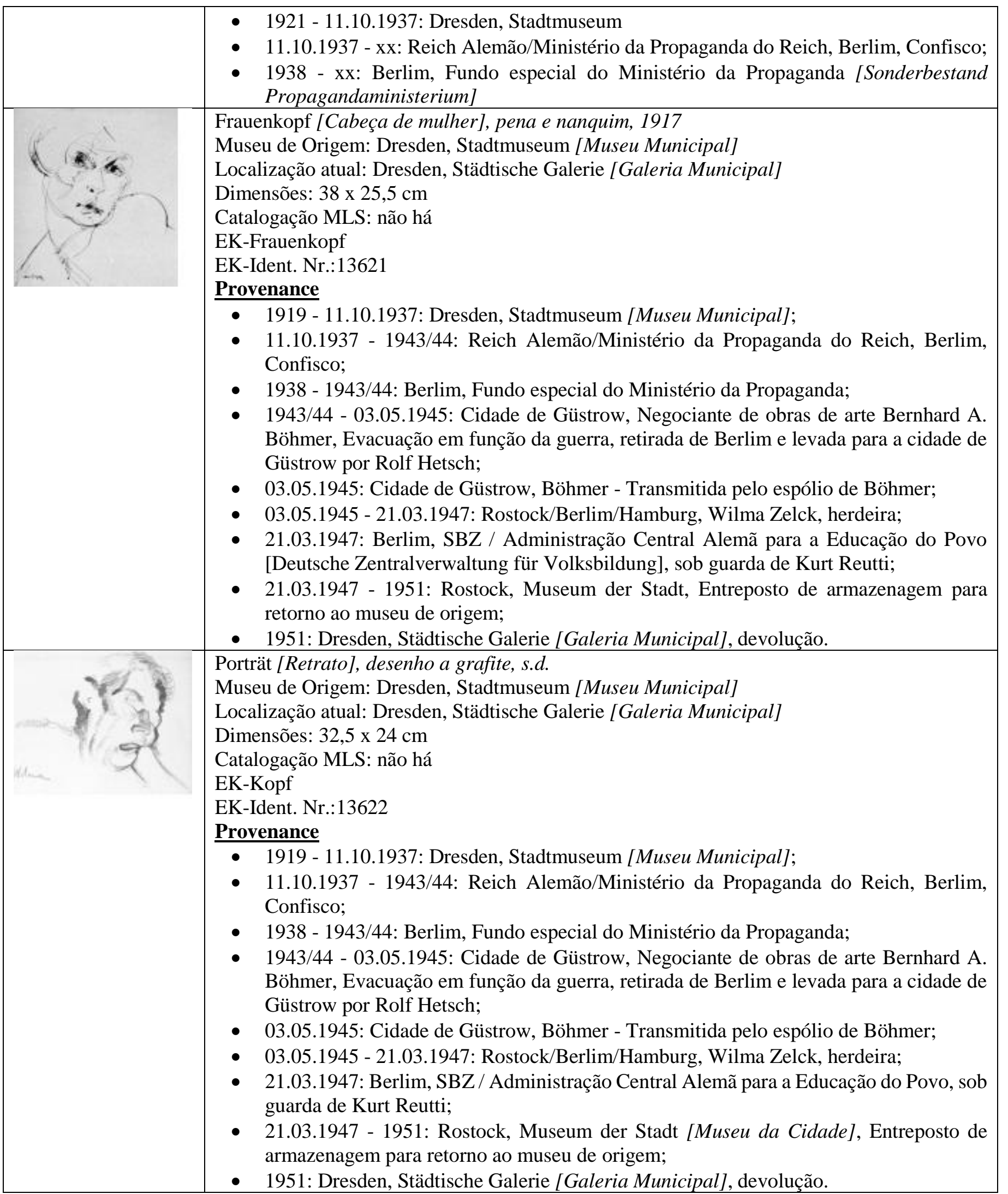




\begin{tabular}{|c|c|}
\hline & $\begin{array}{l}\text { Die ewigen Wanderer [Eternos Caminhantes], óleo sobre tela, } 1919 \\
\text { Museu de Origem: Dresden, Stadtmuseum [Museu Municipal] } \\
\text { Localização atual: São Paulo, Museu Lasar Segall } \\
\text { Dimensões: } 138 \text { x } 184 \mathrm{~cm} \\
\text { Catalogação MLS: MLS0004 (Eternos caminhantes) } \\
\text { EK-Die ewigen Wanderer } \\
\text { EK-Ident. Nr.:15954 } \\
\text { Provenance } \\
\text { - } 1919 \text { - xx.07.1937: Dresden, Stadtmuseum [Museu Municipal]; adquirido por Paul- } \\
\text { - Ferdinand Schmidt (diretor); } \\
\text { - } \quad \text { xx.07.1937 - xx: Reich Alemão/Ministério da Propaganda do Reich, Berlim, Confisco; } \\
\text { - para - xx: Velten/Mark, Depósito para Exposições de Propaganda; armazém de itens } \\
\text { - } \quad \text { xx - após 1954: Paris, Emeric Hahn; } \\
\text { Exposicões } \\
\text { - Entartete Kunst (1.1), Dresden, Neues Rathaus, Lichthof, } 23.09 .1933 \text { - } 18.10 .1933 \\
\text { - Entartete Kunst (1.2), Hagen, Beginn: 11.02.1934 } \\
\text { - Entartete Kunst (1.3), Nürnberg, Städtische Galerie, 07.09.1935 - 21.09.1935 } \\
\text { - Entartete Kunst (1.4), Dortmund, Haus der Kunst, 11.11.1935 - 08.12.1935 } \\
\text { - Entartete Kunst (1.9), Frankfurt am Main, Volksbildungsheim, } 01.09 .1936 \text { - } 30.09 .1936 \\
\text { - Entartete Kunst (2.1), München, Hofgarten-Arkaden, 19.07.1937 - } 30.11 .1937 \\
\text { - Entartete Kunst (2.2), Berlim, Haus der Kunst, 26.02.1938 - 08.05.1938 } \\
\text { - Entartete Kunst (2.3), Leipzig, Grassi-Museum, 13.05.1938 - 06.06.1938 } \\
\text { - Entartete Kunst (2.4), Düsseldorf, Kunstpalast, 18.06.1938 - 07.08.1938 }\end{array}$ \\
\hline & $\begin{array}{l}\text { Betender Knabe, Blatt aus der Zeitschrift "Kündung", I. Folge, 2. Heft [Rapaz em oração, } \\
\text { folha da Revista "Kündung", Série 1, Edição 2.], xilogravura, } 1920 \\
\text { Museu de Origem: Erfurt, Museen der Stadt (Museum für Kunst und Heimatgeschichte) } \\
\text { [Museu da Cidade (Museu de Arte e História Pátria)] } \\
\text { Localização atual: destruída } \\
\text { Dimensões: } 25,1 \text { x } 19,7 \mathrm{~cm} \\
\text { Catalogação MLS: MLS0179 (Jovem orando) } \\
\text { EK-Knabe } \\
\text { EK-Ident. Nr.:1458 } \\
\text { Coleção: } 1938 \text { u. a. "Kündung. Eine Zeitschrift für Kunst" I. Folge, Heft 2, (Februar 1921) } \\
\text { Provenance } \\
\text { - } \quad \text { O2.1921 - 27.08.1937: Erfurt, Museen der Stadt (Museum für Kunst und } \\
\quad \text { Heimatgeschichte) [Museu da Cidade (Museu de Arte e História Pátria)], Oferta para } \\
\text { membros da Kunstbund Hamburg [Associação de Artes de Hamburgo]; } \\
\text { • 27.08.1937 - xx: Reich Alemão/Ministério da Propaganda do Reich, Berlim, Confisco; } \\
\text { - 31.05.1938: Apreensão em benefício do Reich Alemão. }\end{array}$ \\
\hline & $\begin{array}{l}\text { Junge Bettlerin, Blatt aus der Zeitschrift "Kündung", I. Folge, 2. Heft [Jovem mendiga, folha } \\
\text { da Revista "Kündung", Série 1, Edição 2.], litografia, } 1920 \\
\text { Museu de Origem: Erfurt, Museen der Stadt (Museum für Kunst und Heimatgeschichte) } \\
\text { [Museu da Cidade (Museu de Arte e História Pátria)] } \\
\text { Localização atual: destruída } \\
\text { Dimensôes: } 33,3 \text { x } 14,5 \mathrm{~cm} \\
\text { Catalogação MLS: MLS0193 (Jovem mendiga) } \\
\text { EK-Bettler } \\
\text { EK-Ident. Nr.:1459 } \\
\text { Coleção: } 1938 \text { u. a. "Kündung. Eine Zeitschrift für Kunst" I. Folge, Heft 2, (Februar 1921) } \\
\text { Coleção completa: } 13 \\
\text { Provenance }\end{array}$ \\
\hline
\end{tabular}




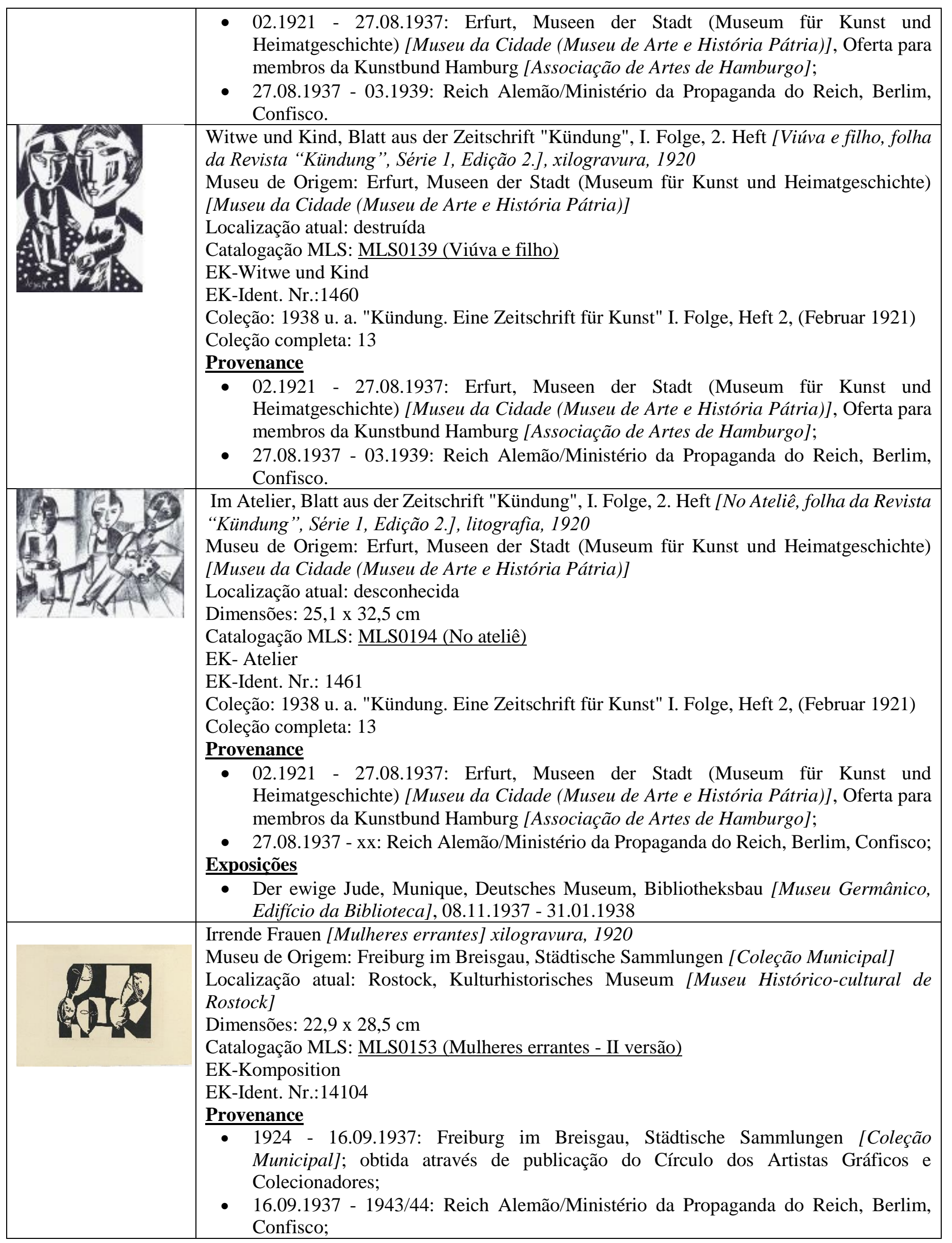




\begin{tabular}{|c|c|}
\hline & $\begin{array}{l}\text { - } 1938 \text { - 1943/44: Berlim, Fundo especial do Ministério da Propaganda; } \\
\text { - } 1943 / 44 \text { - 03.05.1945: Cidade de Güstrow, Negociante de obras de arte Bernhard A. } \\
\text { Böhmer, Evacuação em função da guerra, retirada de Berlim e levada para a cidade de } \\
\text { Güstrow por Rolf Hetsch; } \\
\text { - } \\
\text { 03.05.1945: Cidade de Güstrow, Böhmer - Transmitida pelo espólio de Böhmer; } \\
\text { - } 21.05 .1945 \text { - 21.03.1947: Rostock/Berlim/Hamburg, Wilma Zelck, herdeira; } \\
\text { guarda de Kurt Reutti; } \\
\text { 21.03.1947: Rostock, Museum der Stadt, Entreposto de armazenagem para retorno ao } \\
\text { museu de origem; } \\
\text { 2009: incorporada ao patrimônio do Museu de Rostock. }\end{array}$ \\
\hline & $\begin{array}{l}\text { Irrende Frauen II, Blatt } 5 \text { der Mappe "4. Jahresgabe des Kreises graphischer Künstler und } \\
\text { Sammler" [Mulheres errantes II, folha } 5 \text { do álbum „, } 4^{\circ} \text { Edição anual do Círculo dos Artistas } \\
\text { Gráficos e Colecionadores]; xilogravura, } 1920 \\
\text { Museu de Origem: Nürnberg, Städtische Galerie [Galeria Municipal] } \\
\text { Localização atual: desconhecida } \\
\text { Dimensões: } 23 \text { x 28,6 cm } \\
\text { Catalogação MLS: MLS0153 (Mulheres errantes - II versão) } \\
\text { EK-Verschiedene Mappen } \\
\text { EK-Ident. Nr::7343-05 } \\
\text { Coleção: EK 7343: Mappe "4. Jahresgabe des Kreises graphischer Künstler und Sammler" } \\
\text { mit } 8 \text { Druckgraphiken, Verlag Arndt Beyer, Leipzig } 1924 \\
\text { Coleção completa: } 8 \\
\text { Provenance } \\
\text { - 1926 - 23.08.1937: Nürnberg, Städtische Galerie; obtida através de publicação do } \\
\text { - Círculo dos Artistas Gráficos e Colecionadores; } \\
\text { - 23.08.1937 - xx: Reich Alemão/Ministério da Propaganda do Reich, Berlim, Confisco; } \\
\quad 1938 \text { - xx: Berlim, Fundo especial do Ministério da Propaganda. }\end{array}$ \\
\hline & 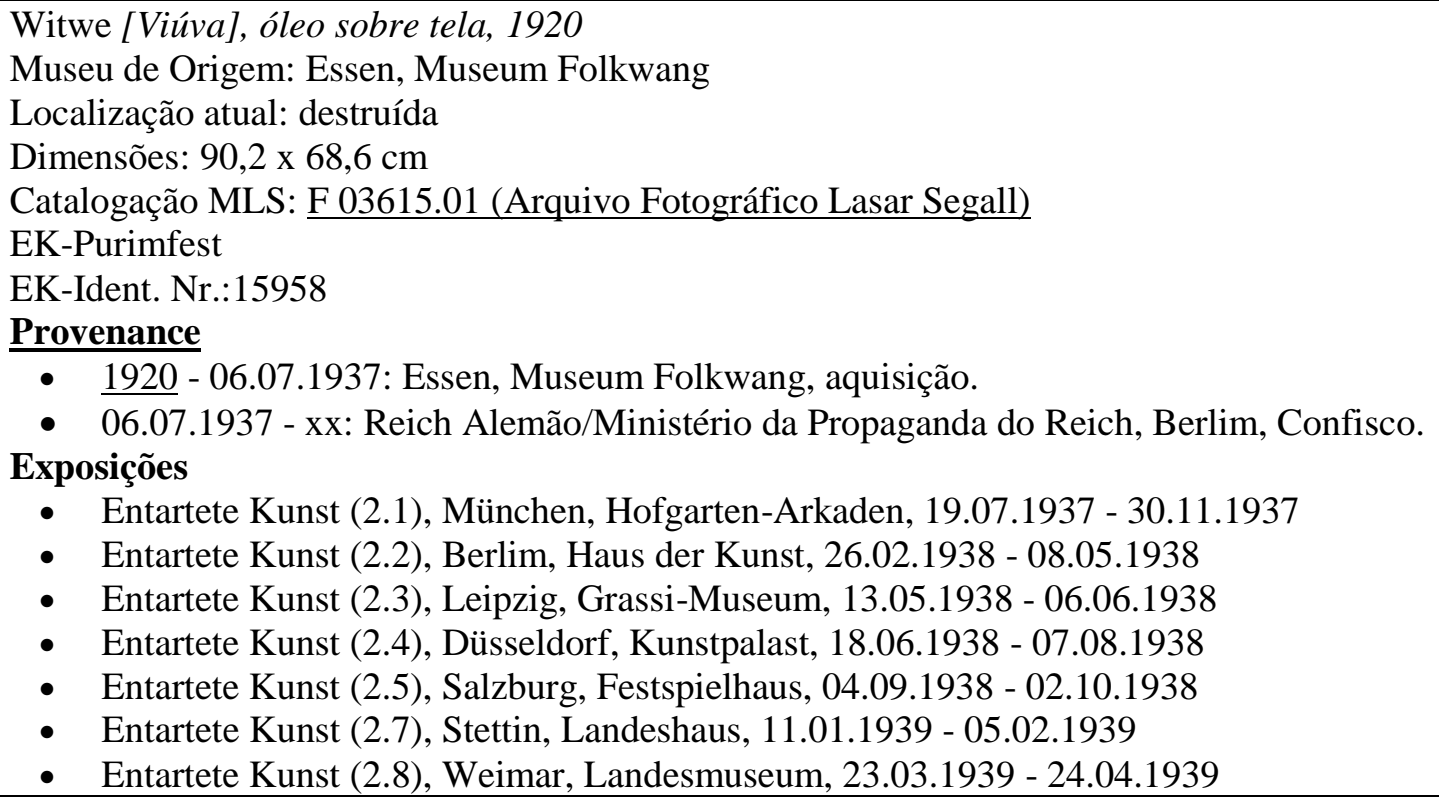 \\
\hline & $\begin{array}{l}\text { Liebende [Amantes], óleo sobre tela, 1919* } \\
\text { Museu de Origem: Essen, Museum Folkwang } \\
\text { Localização atual: Coleção particular } \\
\text { Dimensões: } 95 \text { x } 76,3 \mathrm{~cm} \\
\text { Catalogação MLS: RLS } 1503 \text { (Dois seres) } \\
\text { EK- Liebende } \\
\text { EK-Ident. Nr.: } 15960 \\
\text { Forma de perda: Confisco } \\
\text { Provenance }\end{array}$ \\
\hline
\end{tabular}


- $\quad 07.1920$ - 1922: Hagen, Museum Folkwang; adquirido por Rosa Schapire, em nome da "Federação das Mulheres pelo fomento das Belas Artes Alemãs", e doado ao Museu de Hagen;

- 1922 - 06.07.1937: Essen, Museum Folkwang, adquirida junto com as outras obras da Coleção Osthaus;

- 06.07.1937 - xx: Reich Alemão/Ministério da Propaganda do Reich, Berlim, Confisco;

- 1938 - xx: Velten/Mark, Depósito para Exposições de Propaganda; armazém de itens para a exposição itinerante "Entartete Kunst".

\section{Exposicões}

- $\quad$ Entartete Kunst (2.1), München, Hofgarten-Arkaden, 19.07.1937 - 30.11 .1937

*Ver nota em caderno de imagens, figura 21

Anexo 6. Ficha de Lasar Segall no DEOPS

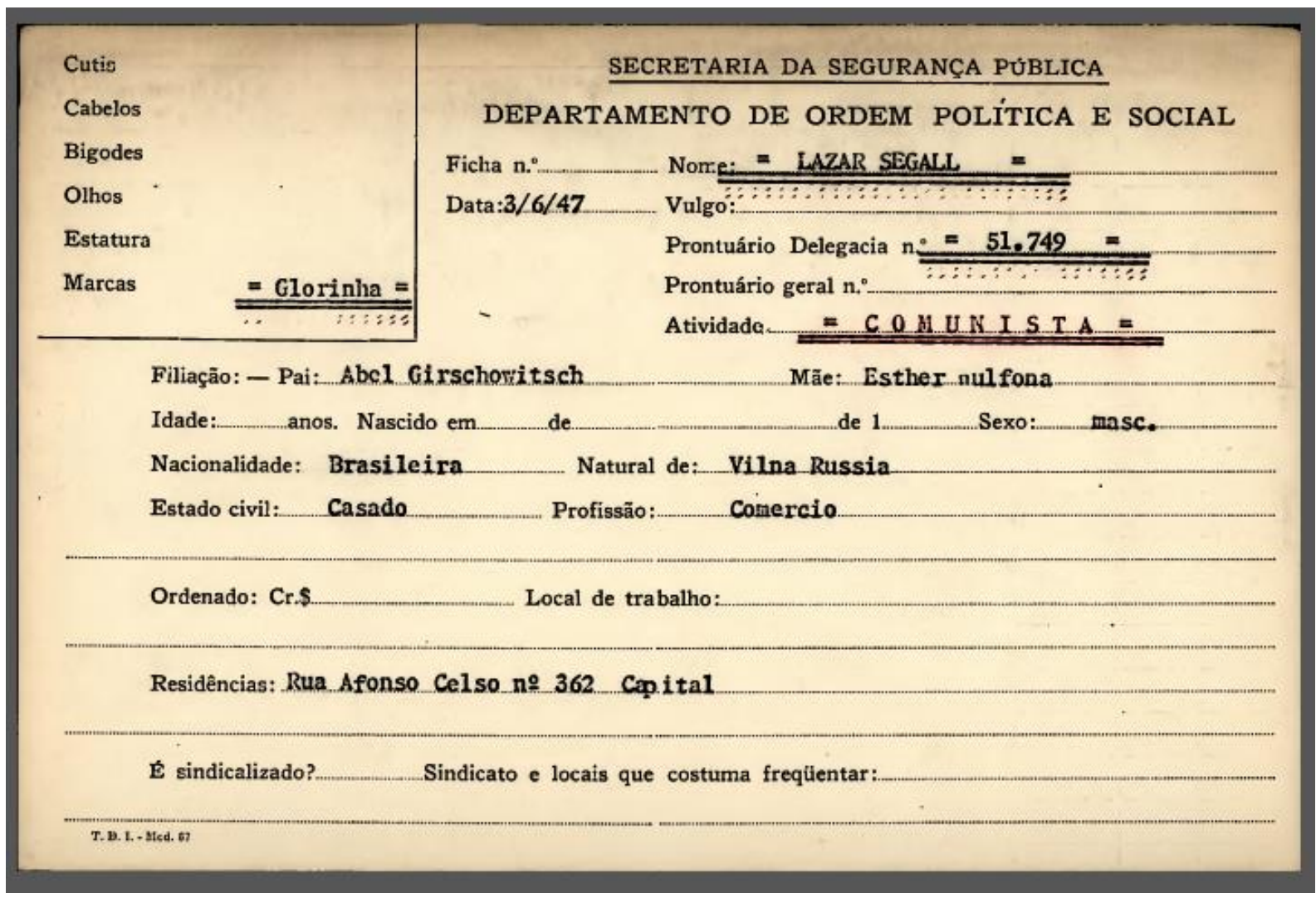

Fonte: Prontuário DEOPS/SP n 51749, Lasar Segall. Arquivo Público do Estado de São Paulo. 
Anexo 7 - Exposições difamatórias - 1933-1941 (sublinhadas as que tiveram obras de Lasar Segall) ${ }^{609}$

1933, Entartete Kunst (1.1), Dresden, Neues Rathaus, Lichthof.

1934, Entartete Kunst (1.2), Hagen, 1934.

1935, Entartete Kunst (1.3), Nürnberg, Städtlische Galerie.

1935, Entartete Kunst (1.4), Dortmund, Haus der Kunst.

1936, Entartete Kunst (1.6), München, Alte Polizeidirektion.

1936, Entartete Kunst (1.8), Darmstadt, Kunstverein, Kunsthalle.

1936, Entartete Kunst (1.9), Frankfurt am Main, Volksbildungsheim.

1936, Der Bolschewismus - große antibolschewistische Schau, München, Deutsches Museum.

1937, Entartete Kunst (1.11), Koblenz, NS-Kulturgemeinde.

1937, Entartete Kunst (1.13), Wiesbaden, Nassauisches Landesmuseum.

1933, Kunst der Geistesrichtung 1918-1933, Breslau, Schlesisches Museum der bildenden Künste.

1933, Regierungskunst 1918-1933, Karlsruhe, Badische Kunsthalle.

1933, Kulturbolschewistische Bilder, Mannheim, Städtische Kunsthalle.

1933, Kunst, die nicht aus unserer Seele kam, Chemnitz, Städtisches Museum.

1933, Mannheimer Galerienkäufe, München, Kunstverein.

1933, Mannheimer Schreckenskammer, Erlagen, Kunstverein, Orangerie.

1933, Novembergeist - Kunst im Dienste der Zersetzung, Stuttgart, Kronprinzepalais.

1933, Schreckenskammer, Nürnberg, Städische Galerie.

1933, Zehn Jahre Ulmer Kunstpolitik, Ulm, Städtisches Museum.

1933, Novembergeist- Kunst im Dienste der Zersetzung 2, Bielefeld, Städtisches Museum.

1933, Schaufenster (März 1933), Dessau, Der Mitteldeutsche, Anhaltische Tageszeitung.

${ }^{609}$ Segundo a Database da Universidade Livre de Berlim, "foram listadas apenas as exposições 'Entartete Kunst' realizadas entre 1933 e 1945, bem como exposições com fim de Propaganda desse período, nas quais as obras foram usadas com fins didáticos. Os números que seguem os títulos das exposições referem-se à sequência das exposições difamatórias: 'Entartete Kunst' (1.1) refere-se também à primeira exposição itinerante 'Entartete Kunst' com ponto de partida em Dresden, 1933; 'Entartete Kunst' (2.1) refere-se à segunda exposição itinerante 'Entartete Kunst', com ponto de partida em Munique, 1937" cfe. http://www.geschkult.fu-berlin.de/e/db entart_kunst/datenbank/ausstellungen/index.html (acessado em 27/06/2016) 
1934, Braune Messe, Mannheim, Rhein-Neckar-Hallen.

1935, Schreckenskammer/Sonderraum Entartete Kunst, Halle, Städtisches Museum für Kunst und Kunstgewerbe.

1937, Entartete Kunst (3), Dessau, Anhaltische Gemäldegalerie.

1937, Bolschewismus ohne Maske, Berlin, Reichstagsgebäude.

1937, Der ewige Jude, München, Deutsches Museum, Bibliothekesbau.

1937, Große Antibolschewistische Ausstellung/Bolschewismus ohne Maske, Nürberg.

1938, Europas Schicksalskampf im Osten, Nürberg, Noris.Halle.

1937, Entartete Kunst (2.1), München, Hofgarten-Arkaden.

1938, Entartete Kunst (2.2), Berlin, Haus der Kunst.

1938, Entartete Kunst (2.3), Leipzig, Grassi-Museum.

1938, Entartete Kunst (2.4), Düsseldorf, Kunstpalast.

1938, Entartete Kunst (2.5), Salzburg, Festspielhaus.

1938, Entartete Kunst (2.6), Hamburg, Schulausstellungsgebäude.

1939, Entartete Kunst (2.7), Stettin, Landeshaus.

1939, Entartete Kunst (2.8), Weimar, Landesmuseum.

1939, Entartete Kunst (2.9), Wien, Künstlerhaus.

1939, Entartete Kunst (2.10), Frankfurt am Main, Kunstausstellungshaus.

1939, Entartete Kunst (2.11), Chemnitz, Kauffmännisches Vereinshaus.

1941, Entartete Kunst (2.12), Waldenburg, Kreisleitung der NSDAP, 1941.

1941, Entartete Kunst (2.14), Halle, Landesanstalt für Volkheitskunde. 


\section{Caderno de Imagens}

Figuras 1, 2 e 3: aspectos da residência de Victor Rubin em Dresden, onde Segall residiu por alguns anos no final da década de 1910.
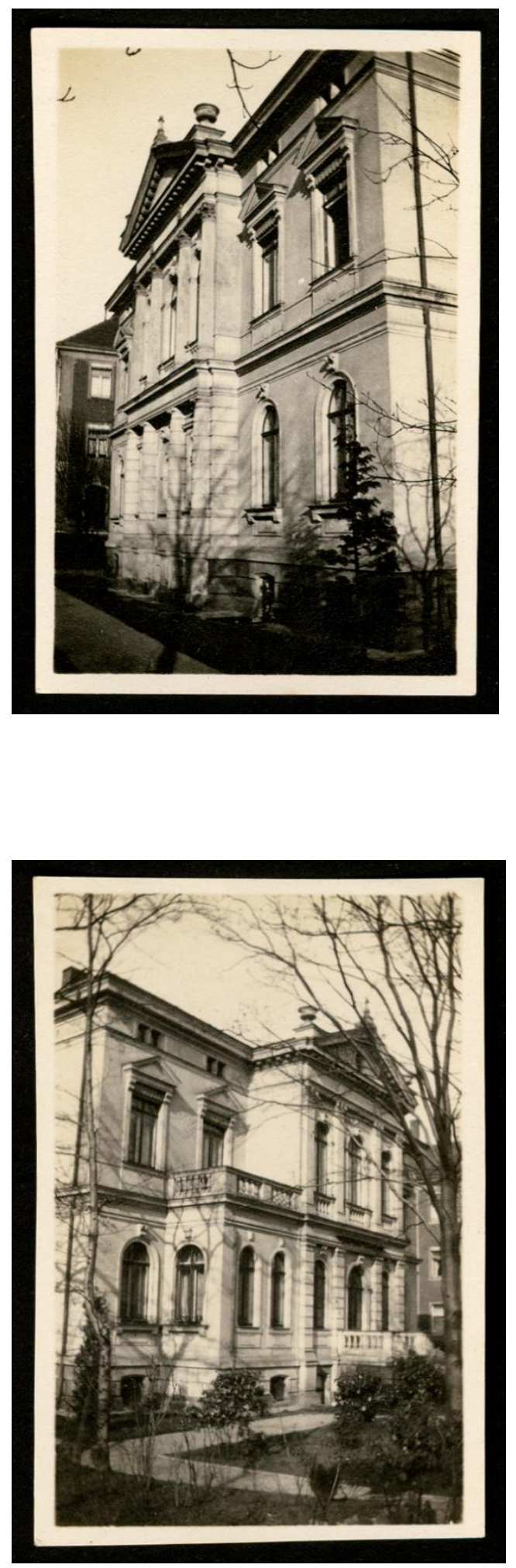

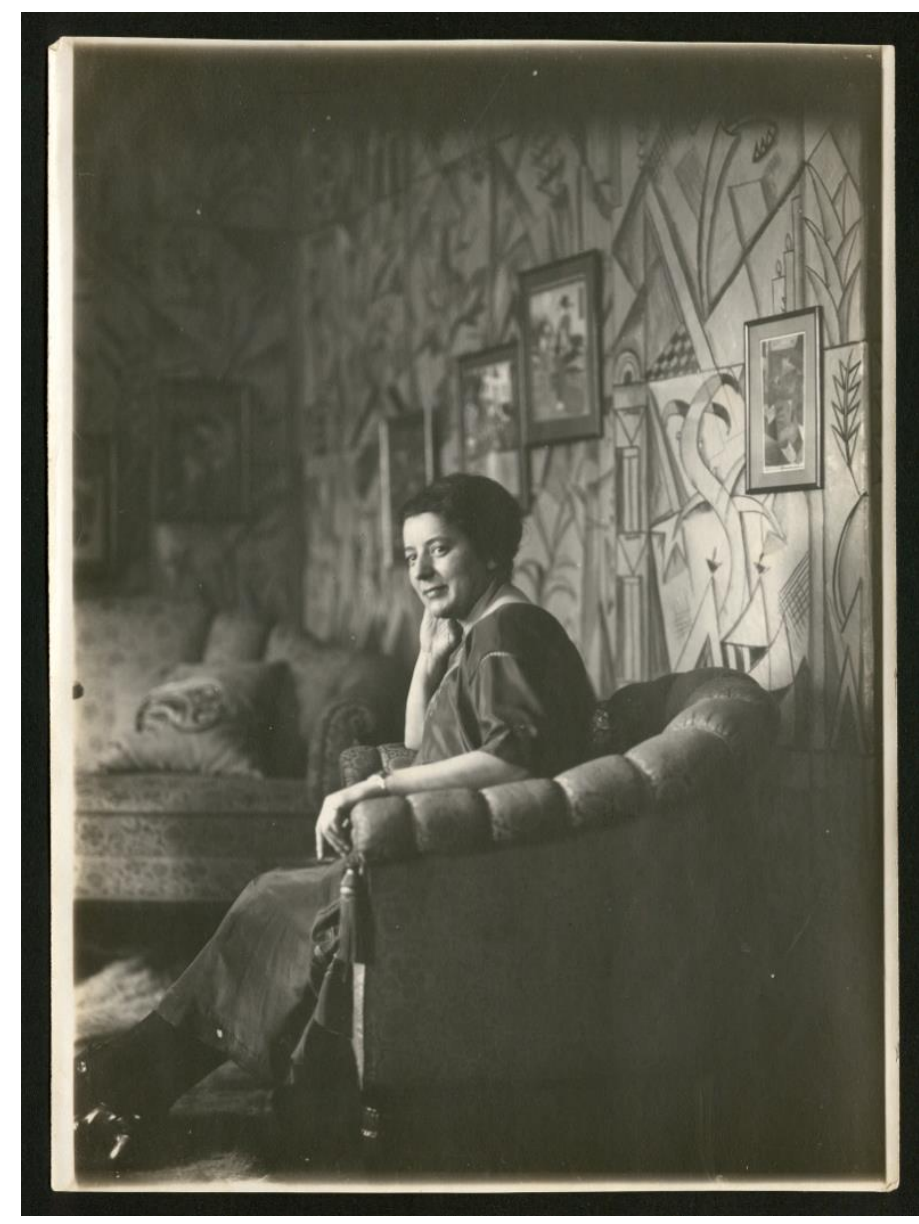

Srta. Rustenbach na casa de Victor Rubin, s.d. Arquivo Fotográfico Lasar Segall (F.02016.00)

Aspectos da fachada da casa de Victor Rubin na Hohestrasse, s.d. Arquivo Fotográfico Lasar Segall (F.02020.00 e F.02025.00) 


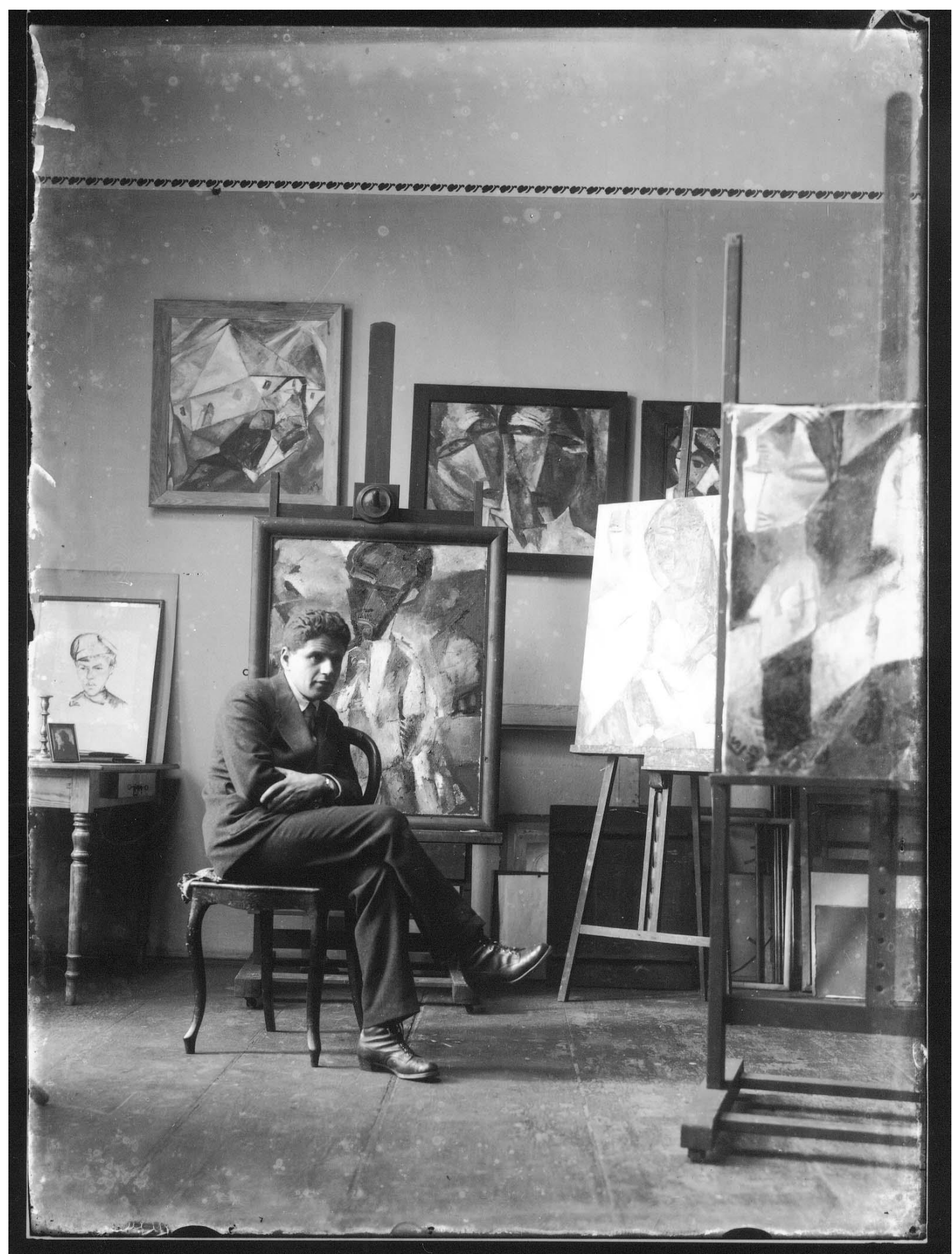

Figura 4. Lasar Segall em seu ateliê em Dresden, c. 1919. fotógrafo não identificado. Arquivo Fotográfico Lasar Segall, F.00087.02 positivo sobre papel, $17,2 \times 13,0 \mathrm{~cm}$ 


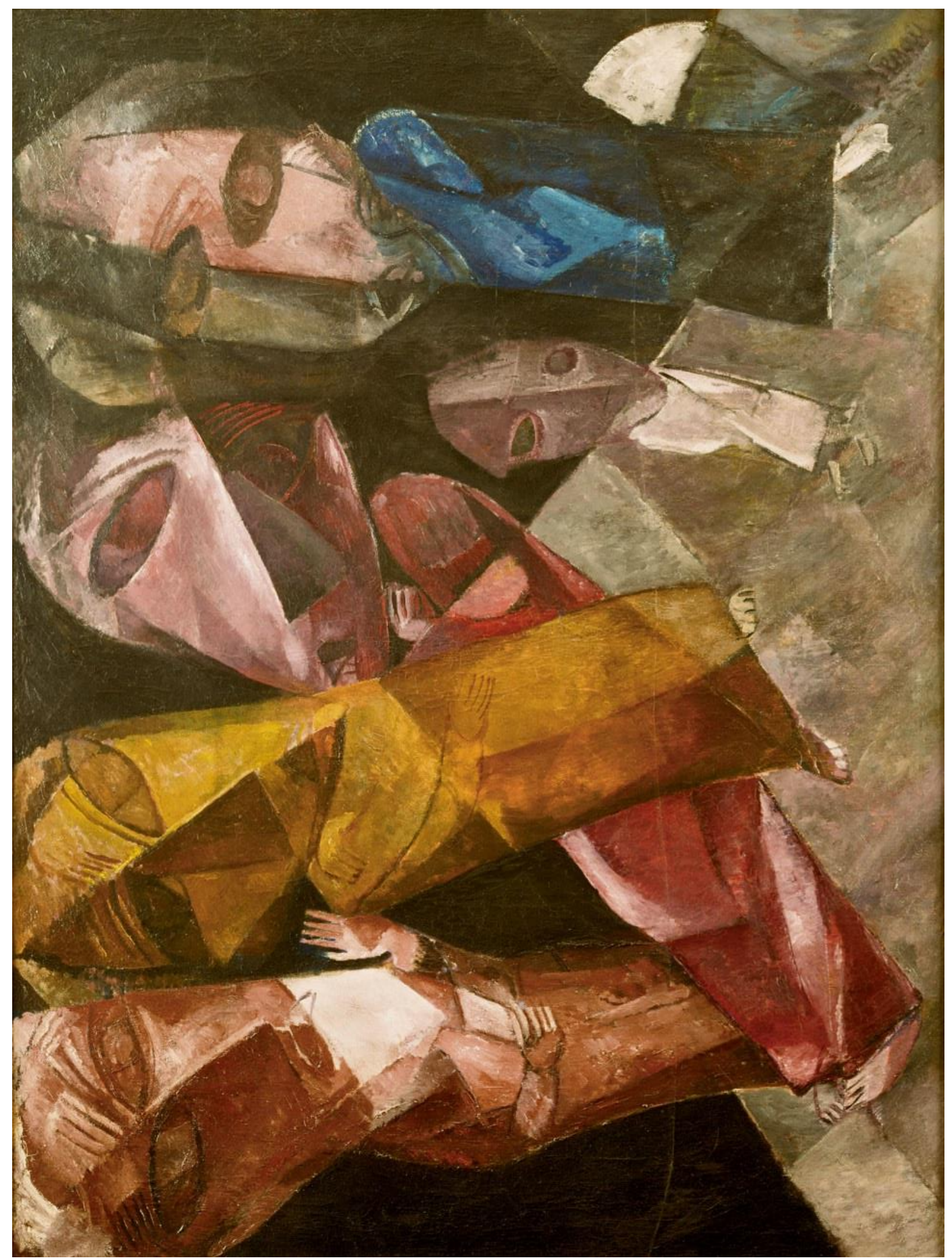

Figura 5 - Die ewigen Wanderer (Eternos Caminhantes, 1919) MLS0004 óleo sobre tela, $138 \times 184 \mathrm{~cm}$ 


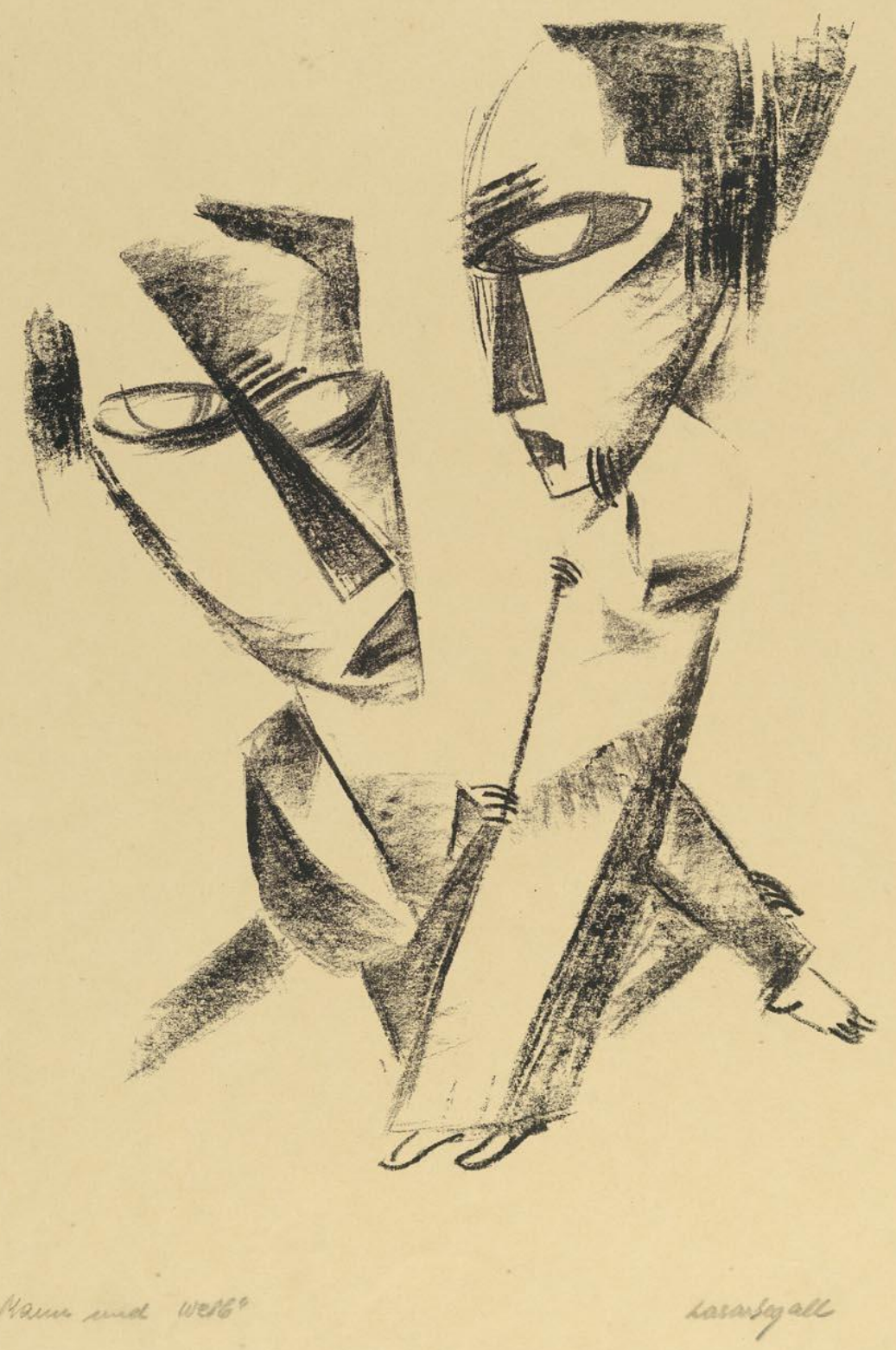

Figura 6 - Zwei Schemen - Mann und Weib (Homem e mulher, 1919) MLS0171 litografia sobre papel, $37 \times 28 \mathrm{~cm}$ 


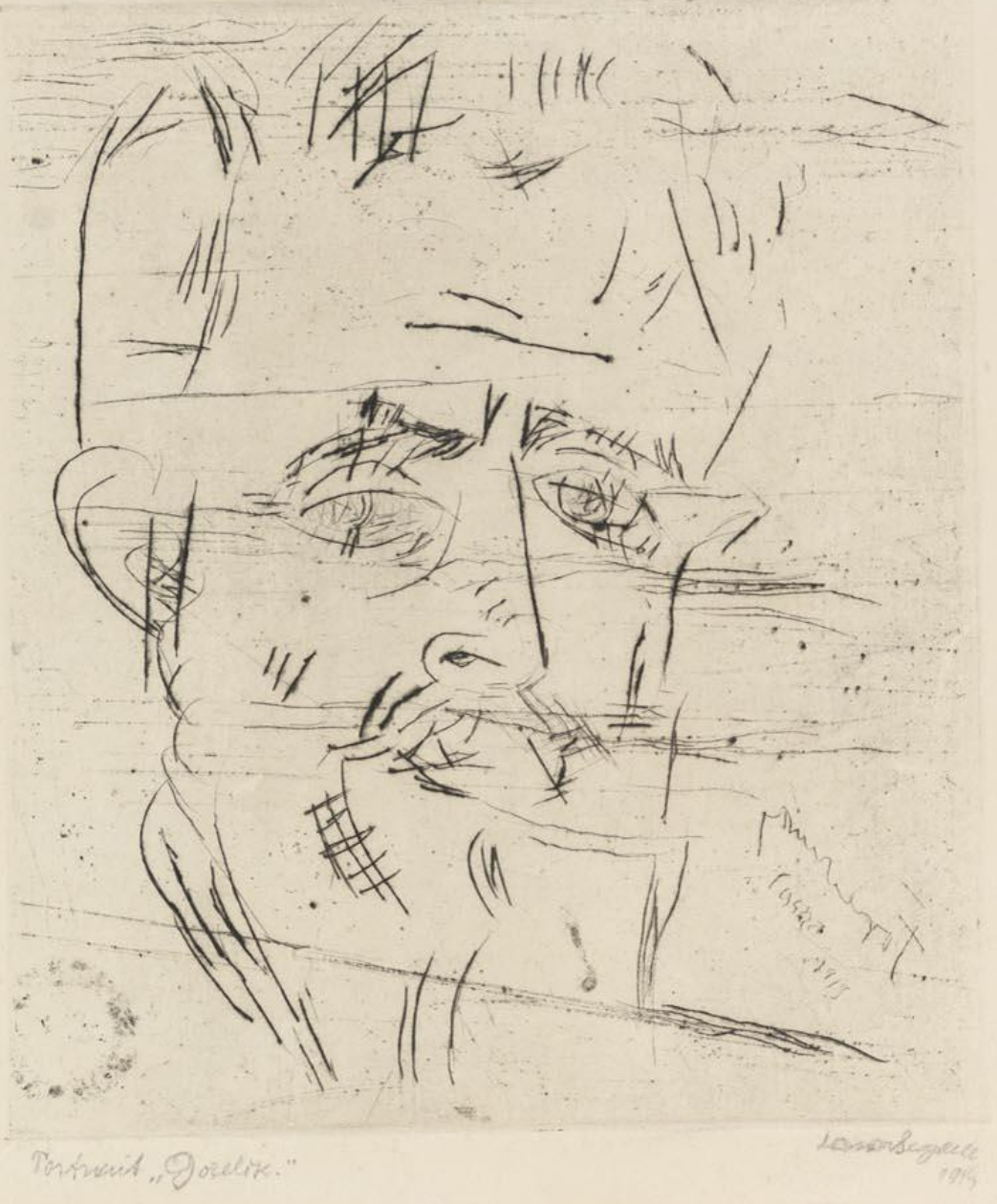

Figura 7 - Porträt des Schriftstellers Gorelick (Retrato do escritor Gorelick, 1919) MLS0167; ponta-seca sobre papel, $24 \times 20,5 \mathrm{~cm}$ 


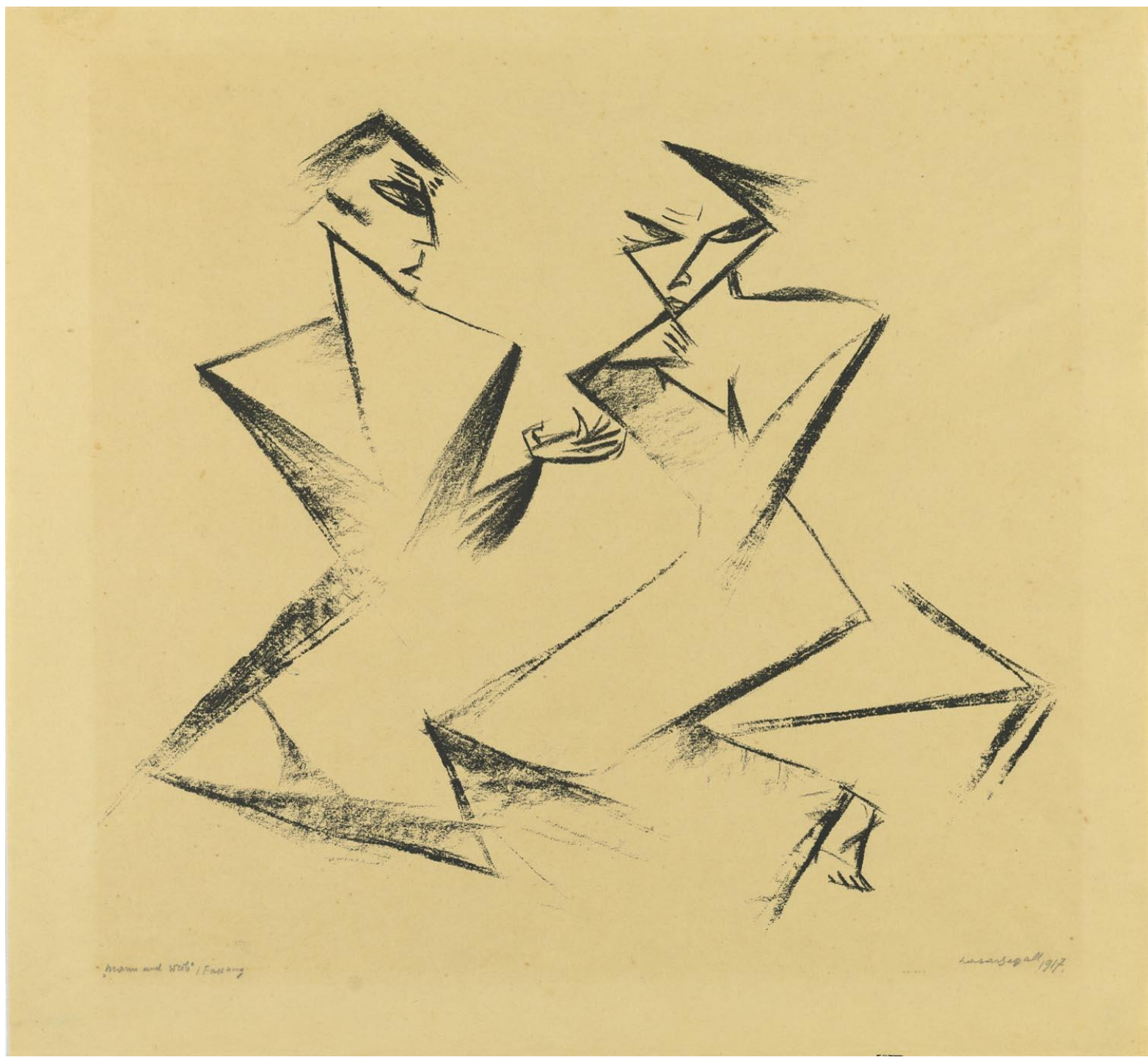

Figura 8 - Mann und Weib (Homem e mulher I versão, do álbum "Uma doce criatura" 1917) MLS0128, litografia sobre papel, $33 \times 39 \mathrm{~cm}$ 


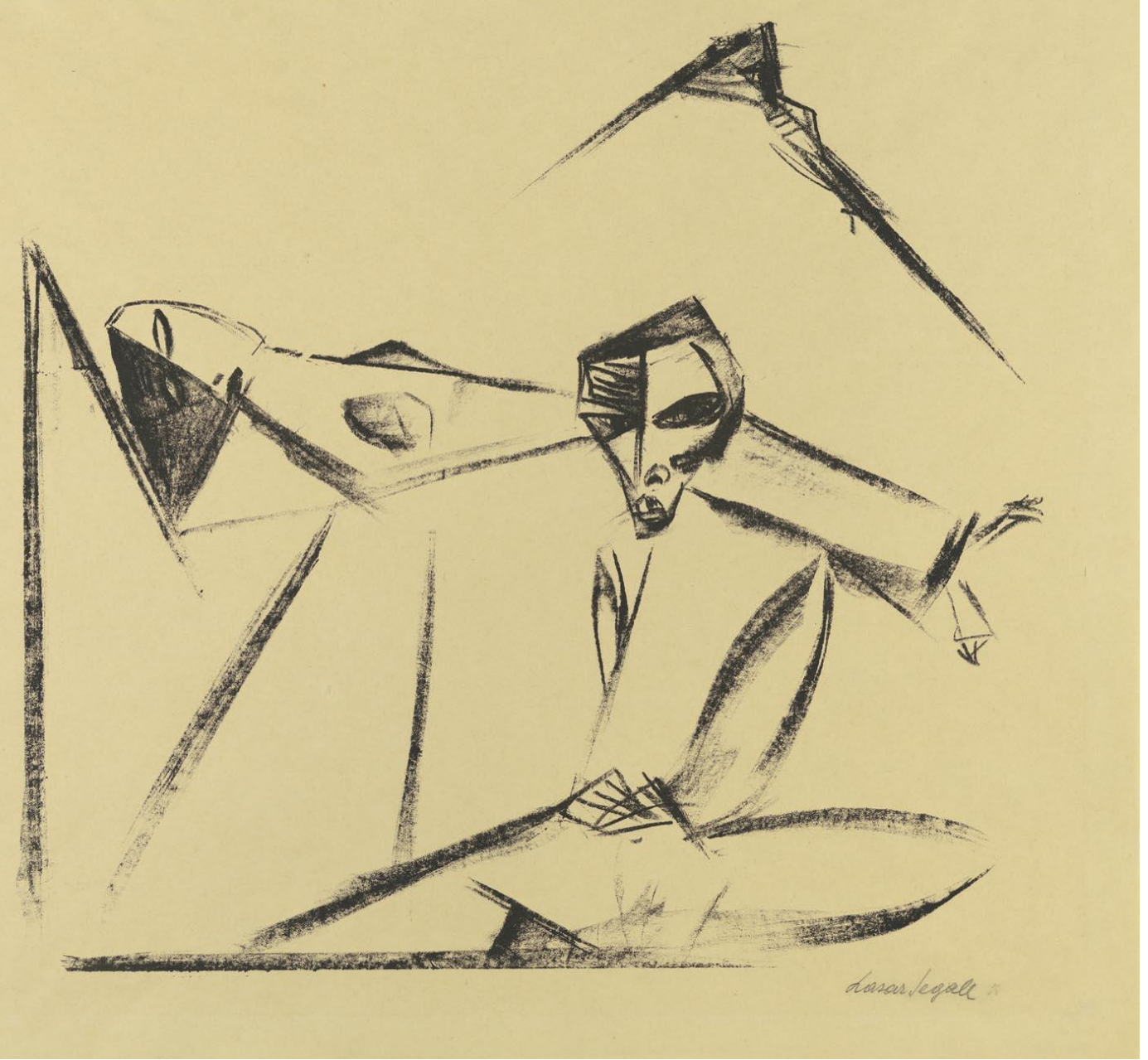

Figura 9. Am Totenbett (Leito de morte, do álbum "Uma doce criatura" 1917), MLS0130 litografia sobre papel, $35 \times 37,5 \mathrm{~cm}$ 


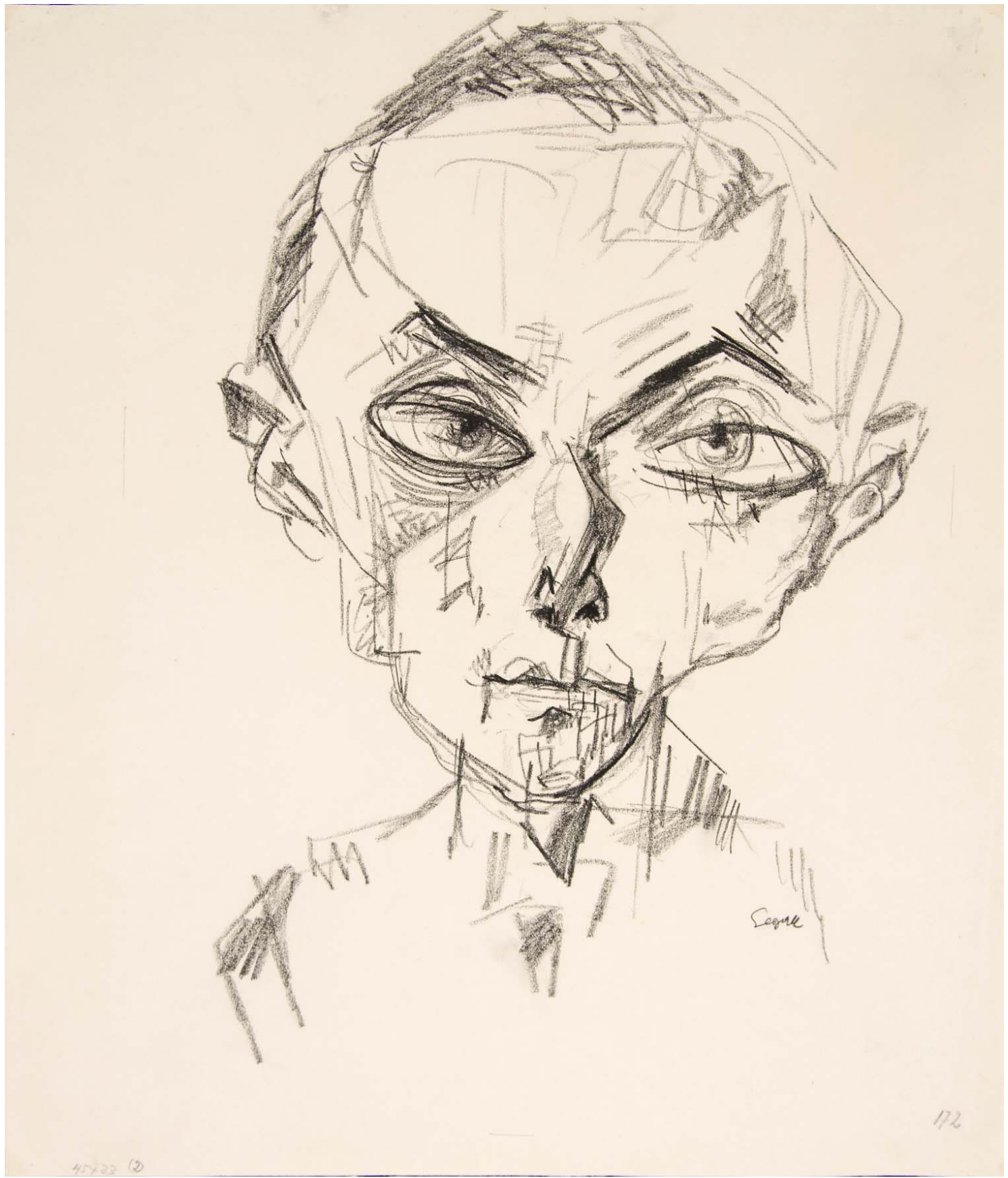

Figura 10 - Retrato de P. F. Schmidt, 1919. MLS0456

grafite sobre papel, $47 \times 41,3 \mathrm{~cm}$ 


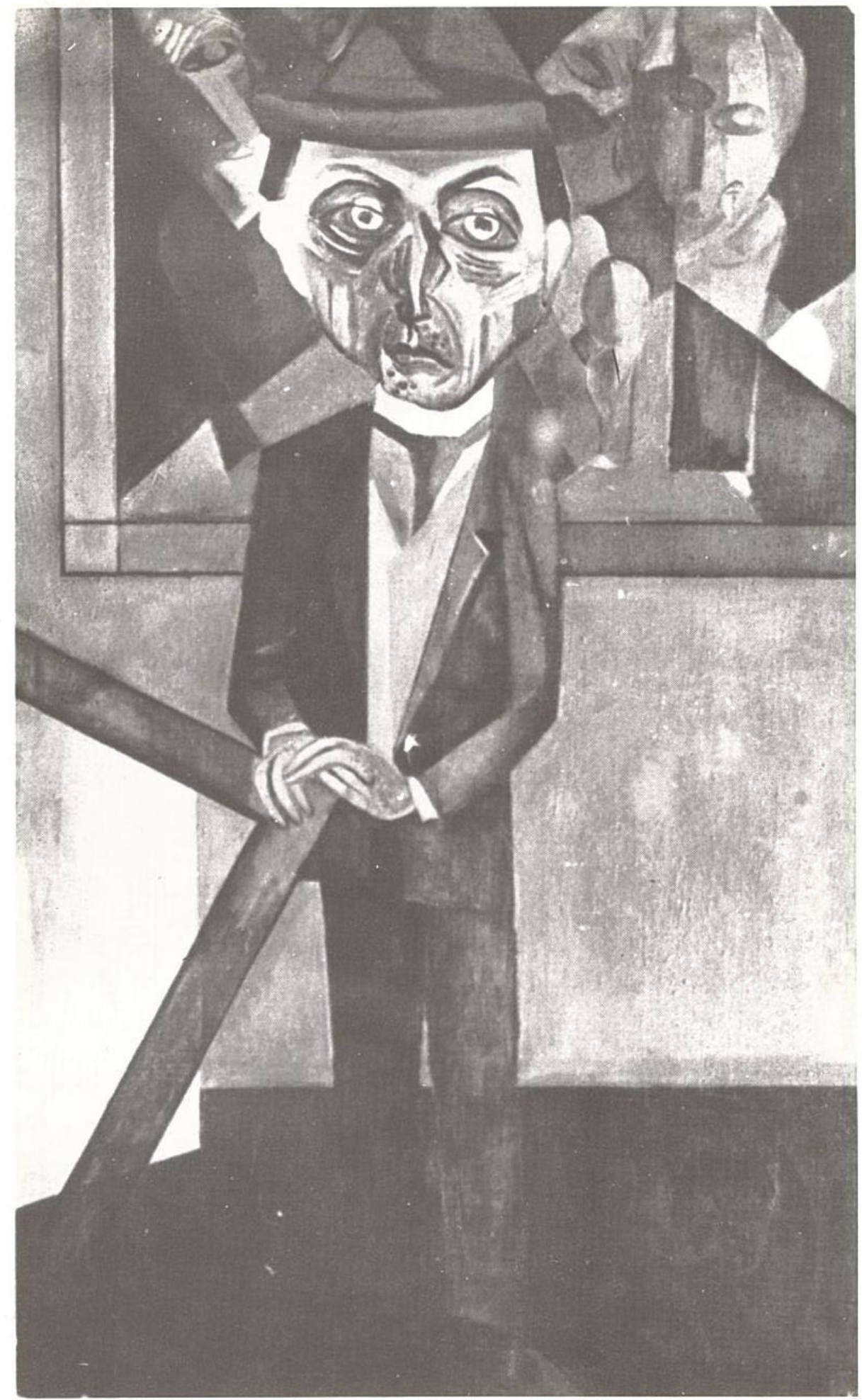

Figura 11 - Dr P. F. Schmidt, 1921; óleo sobre tela, $70 \times 115 \mathrm{~cm}$, desaparecido. Imagem obtida no catálogo "Dresdner Sezession 1919-1923", (Löffler; Bertonati; von Waldegg, s.p.) 


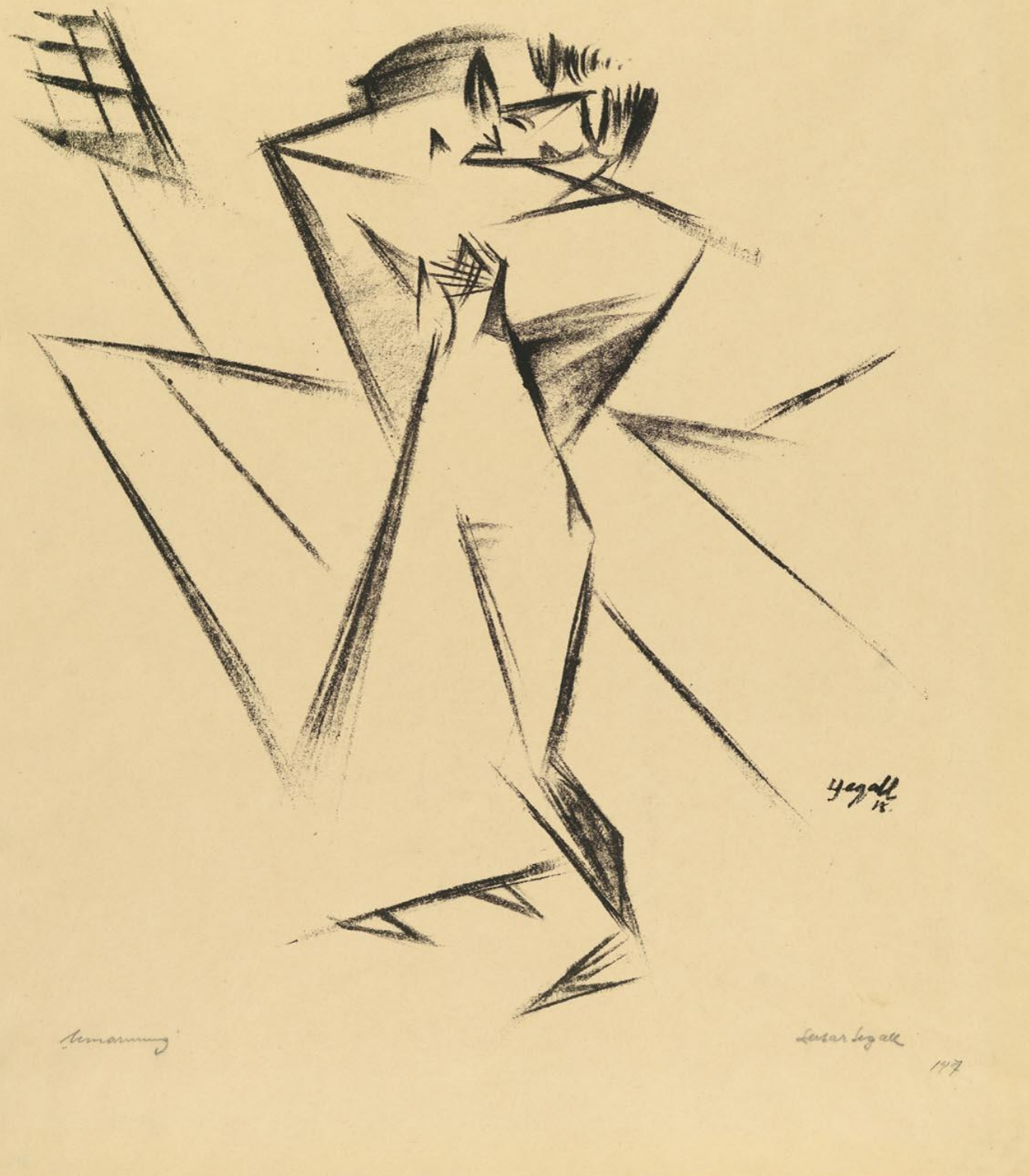

Figura 12. Umarmung (Abraço, 1917) MLS0111

litografia sobre papel, $41,5 \times 37 \mathrm{~cm}$ 


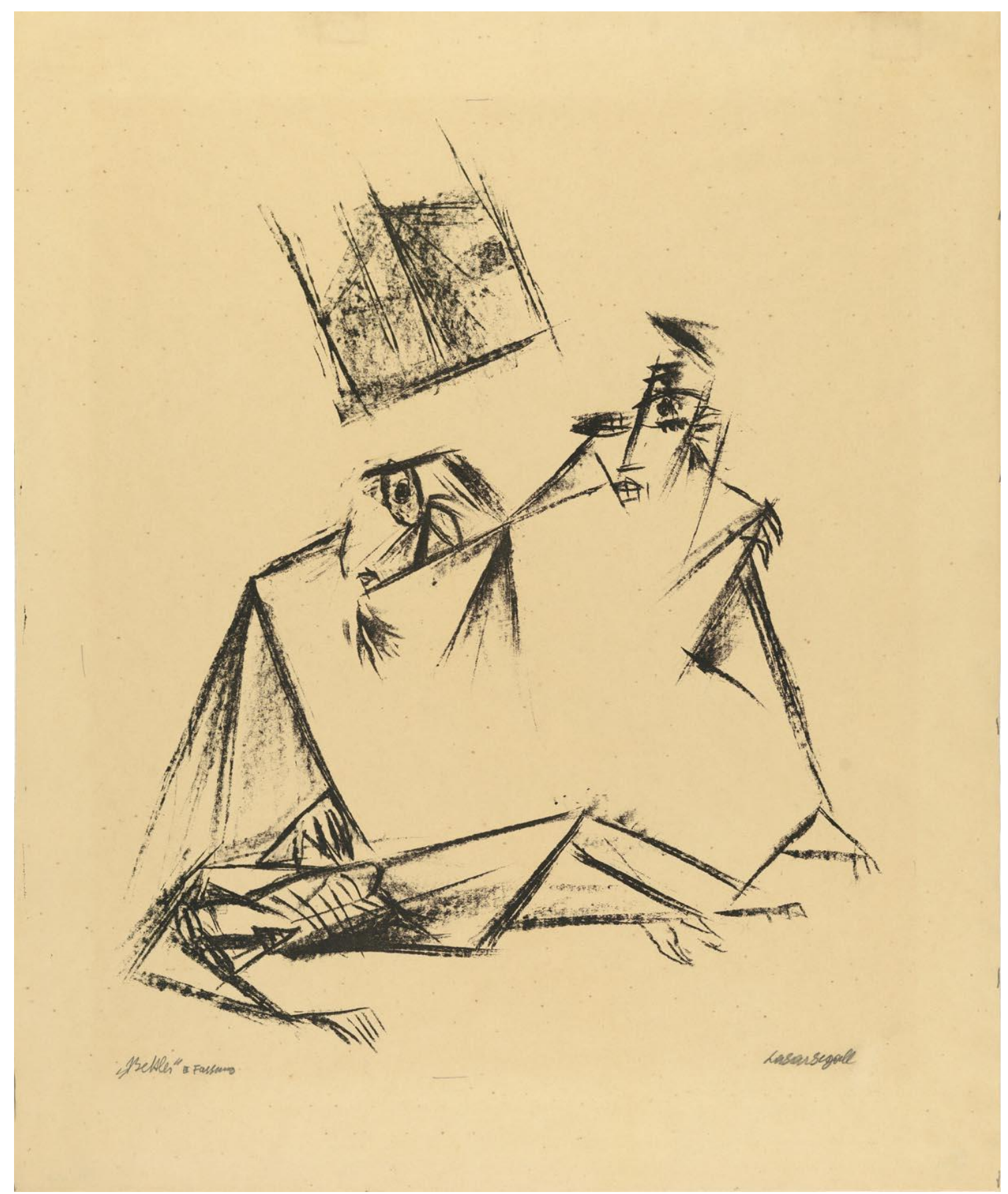

Figura 13. Bettler (Mendigos III versão, 1917) MLS0112 litografia sobre papel, $44 \times 37,5 \mathrm{~cm}$ 


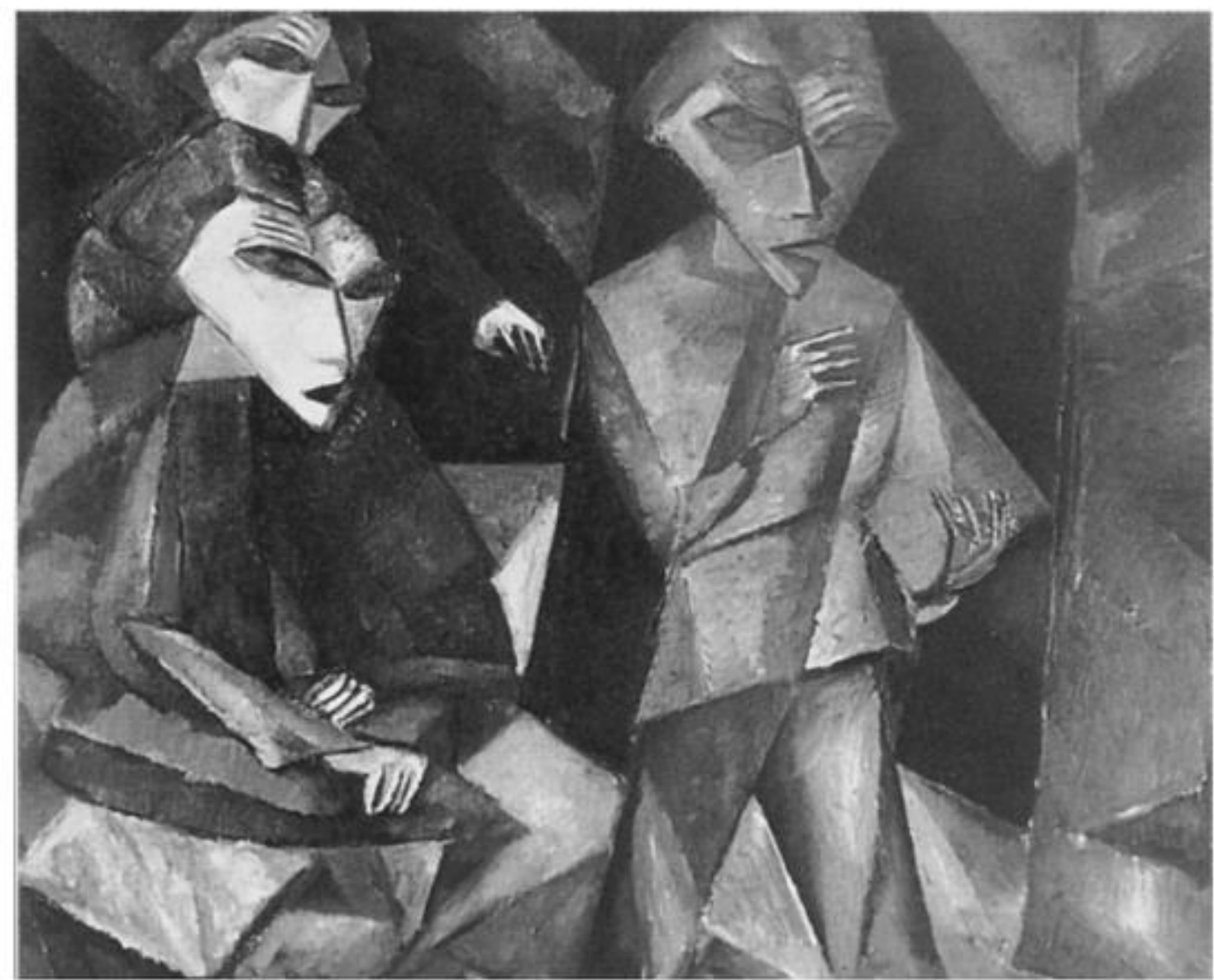

Figura 14. Im Atelier (No ateliê, 1919) óleo sobre tela; 82 x $100 \mathrm{~cm}$; essa obra, doada para o Museu de Chemnitz em 1919 por um colecionador anônimo, está desaparecida desde 1941. Imagem e dimensões obtidas em BARDI, 2000, p. 88. 


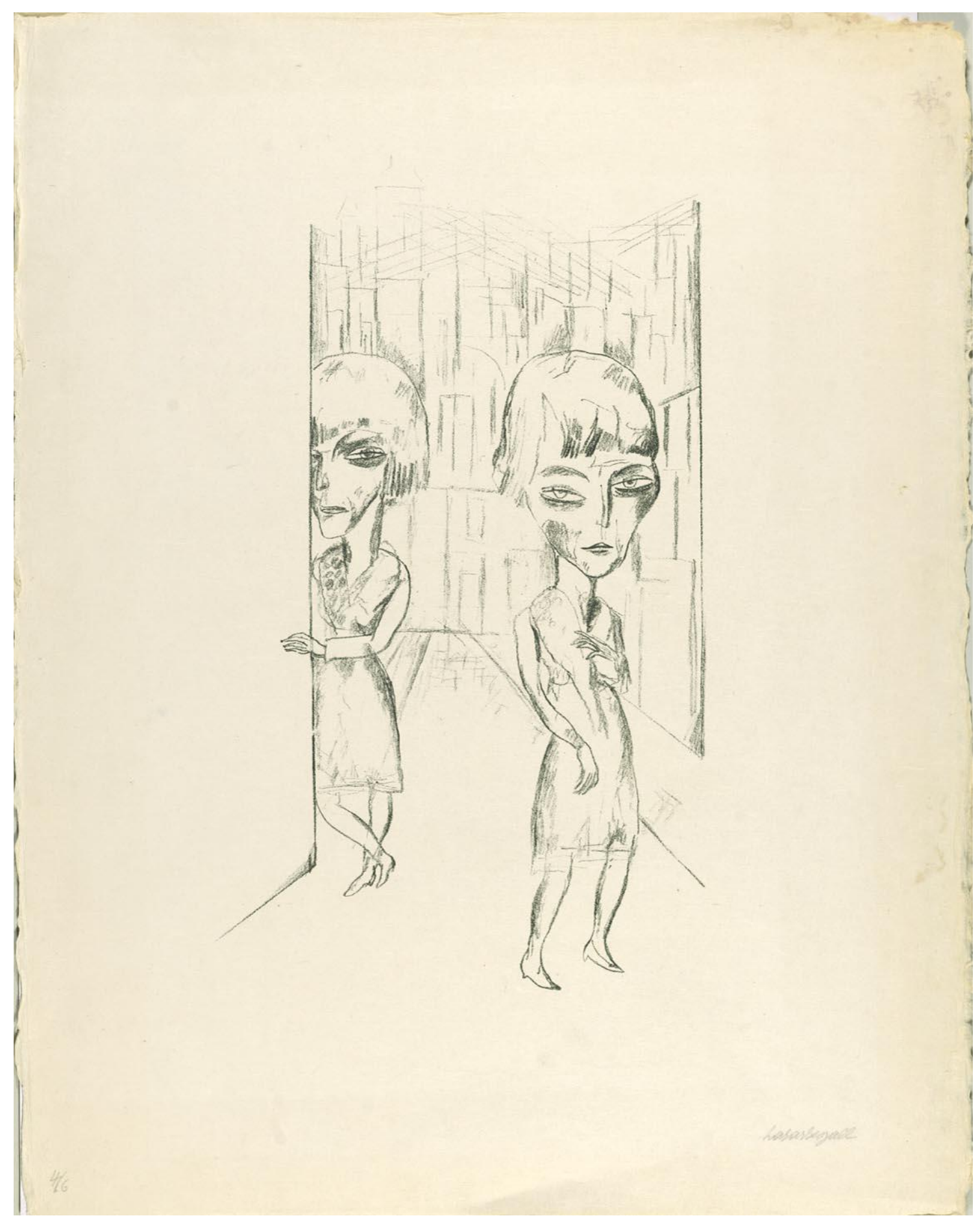

Figura 15. Zwei Frauen auf der Straße (Duas mulheres na rua, 1921) MLS0212 litografia sobre papel, $45 \times 27 \mathrm{~cm}$ 


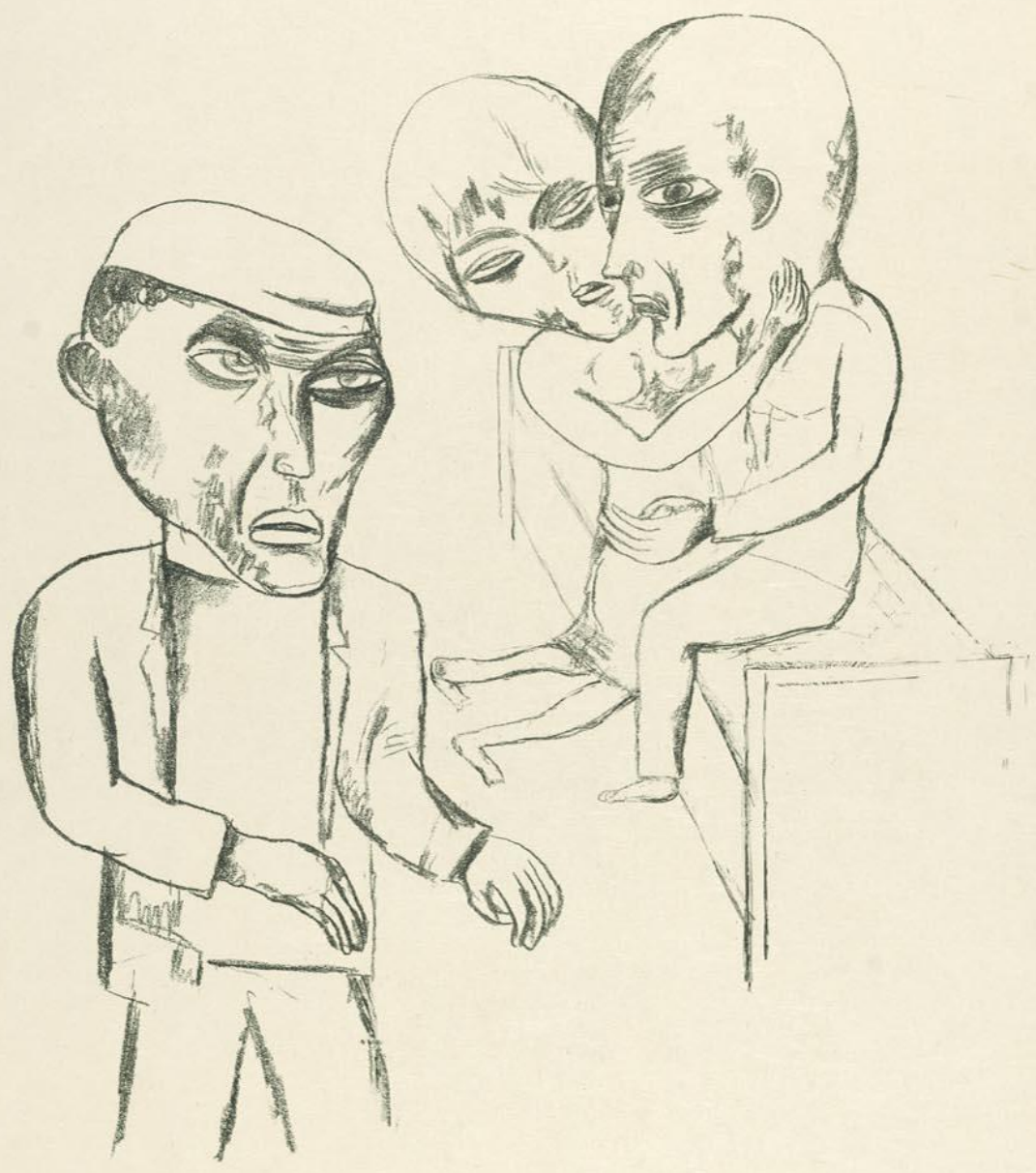

Figura 16. Bübü und das Liebespaar (Homem em casal, 1921) MLS0213 litografia sobre papel, $43 \times 35 \mathrm{~cm}$ 


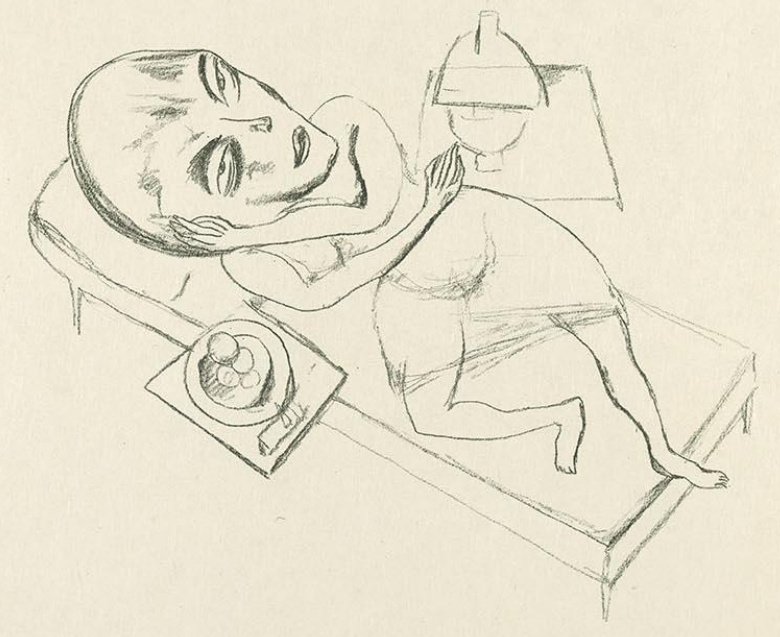

Figura 17. Liegende (Mulher deitada, 1921) MLS0210

litografia sobre papel, $27 \times 32 \mathrm{~cm}$ 


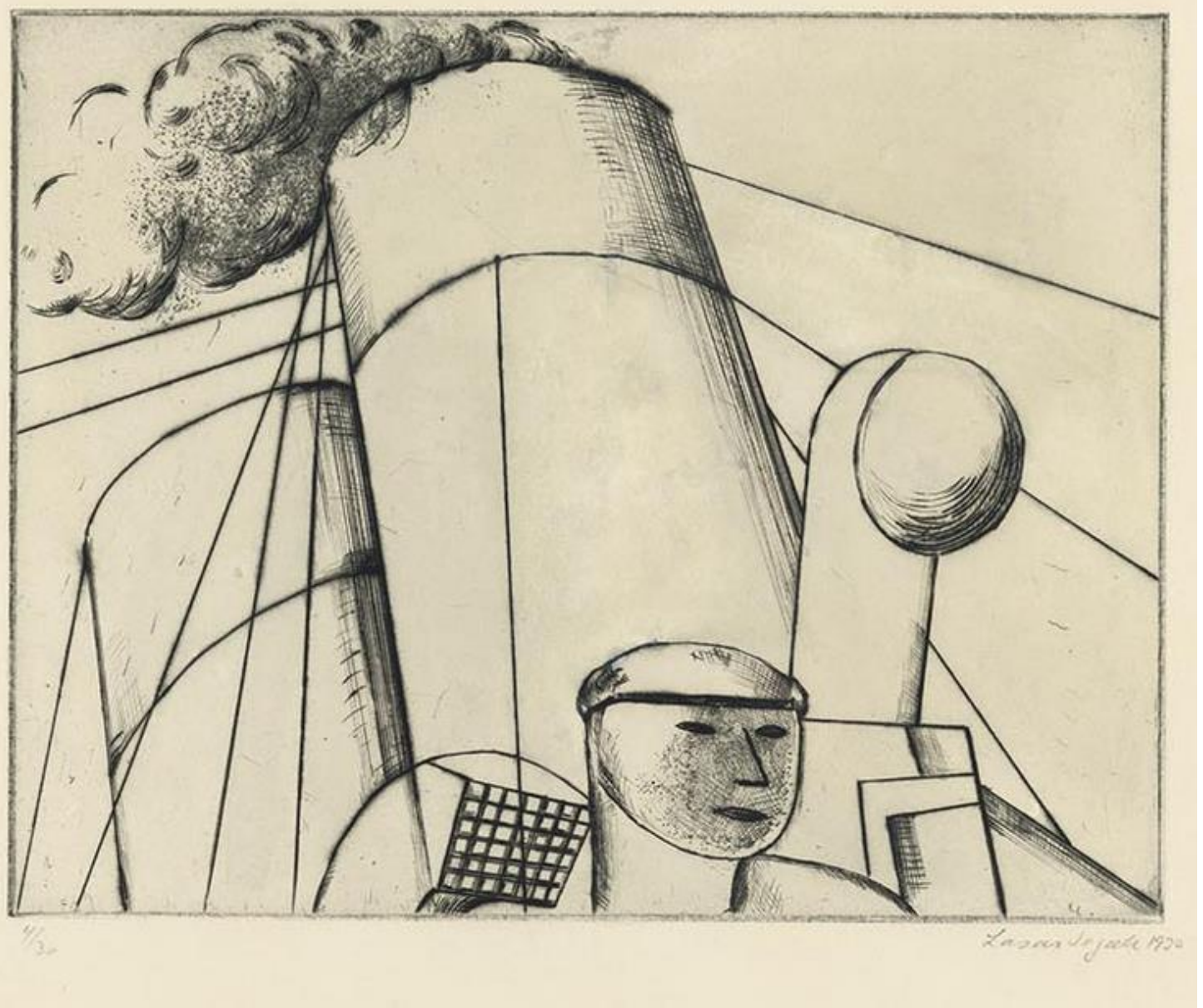

Figura 18. Kopf eines Matrosen und Schornsteine (Cabeça de marinheiro e chaminé, 1930), MLS 0402 ponta-seca, 1930, 22 × $28 \mathrm{~cm}$ 


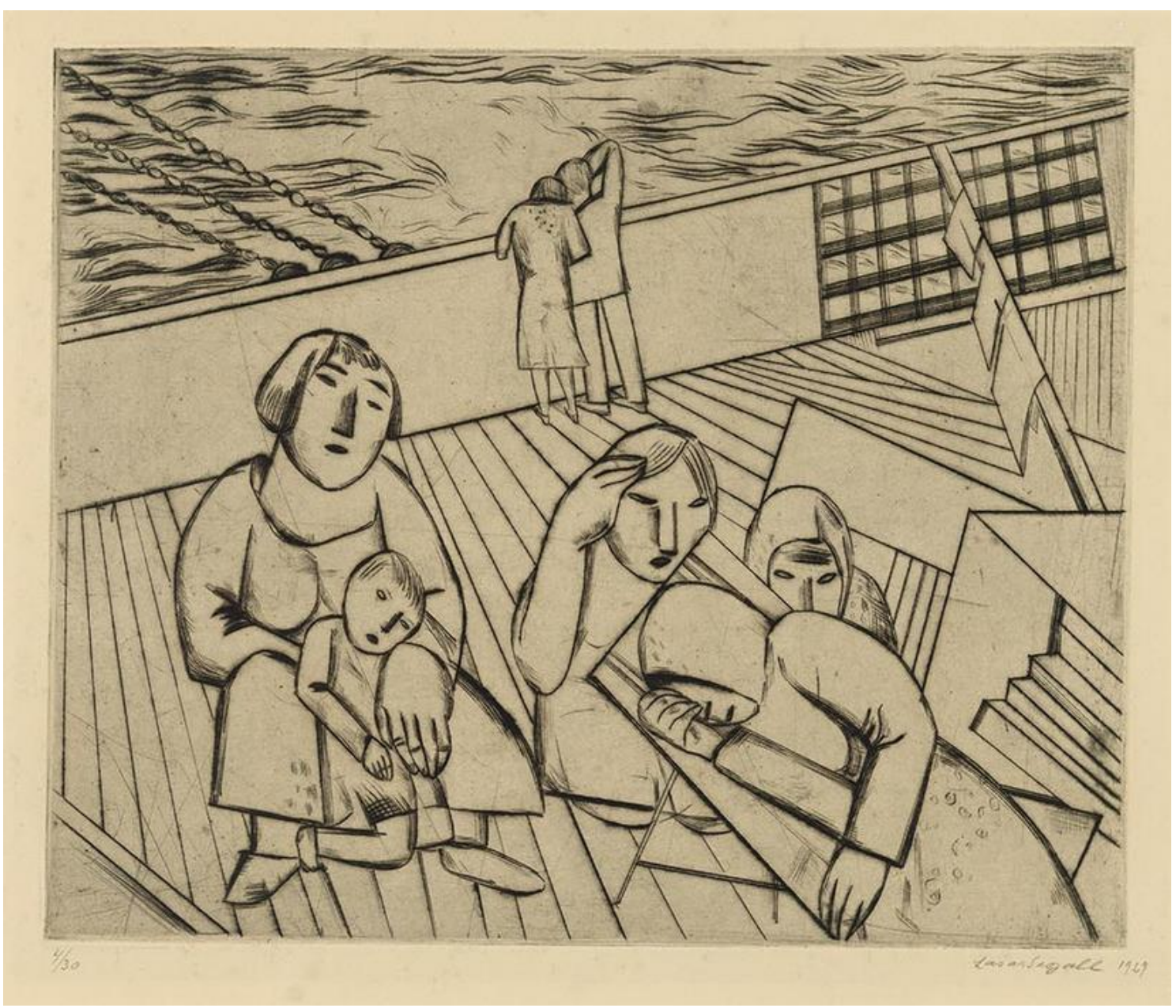

Figura 19. Emigranten auf dem Oberdeck (Emigrantes no tombadilho, 1929) MLS0366, ponta-seca sobre papel, 27,5 × $33 \mathrm{~cm}$ 


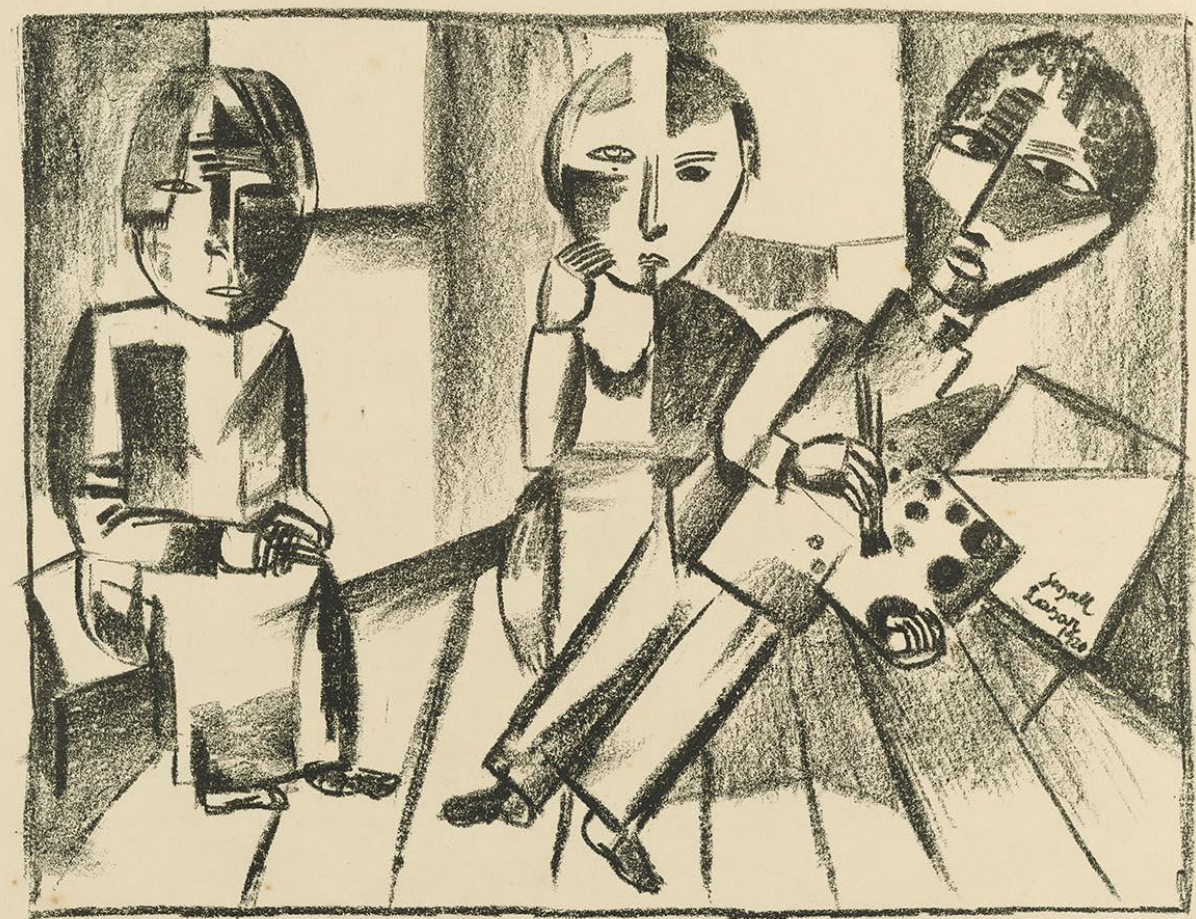

Imagem 20. Im Atelier (No ateliê, 1920) MLS0194

litografia sobre papel, $25 \times 23,5 \mathrm{~cm}$ 


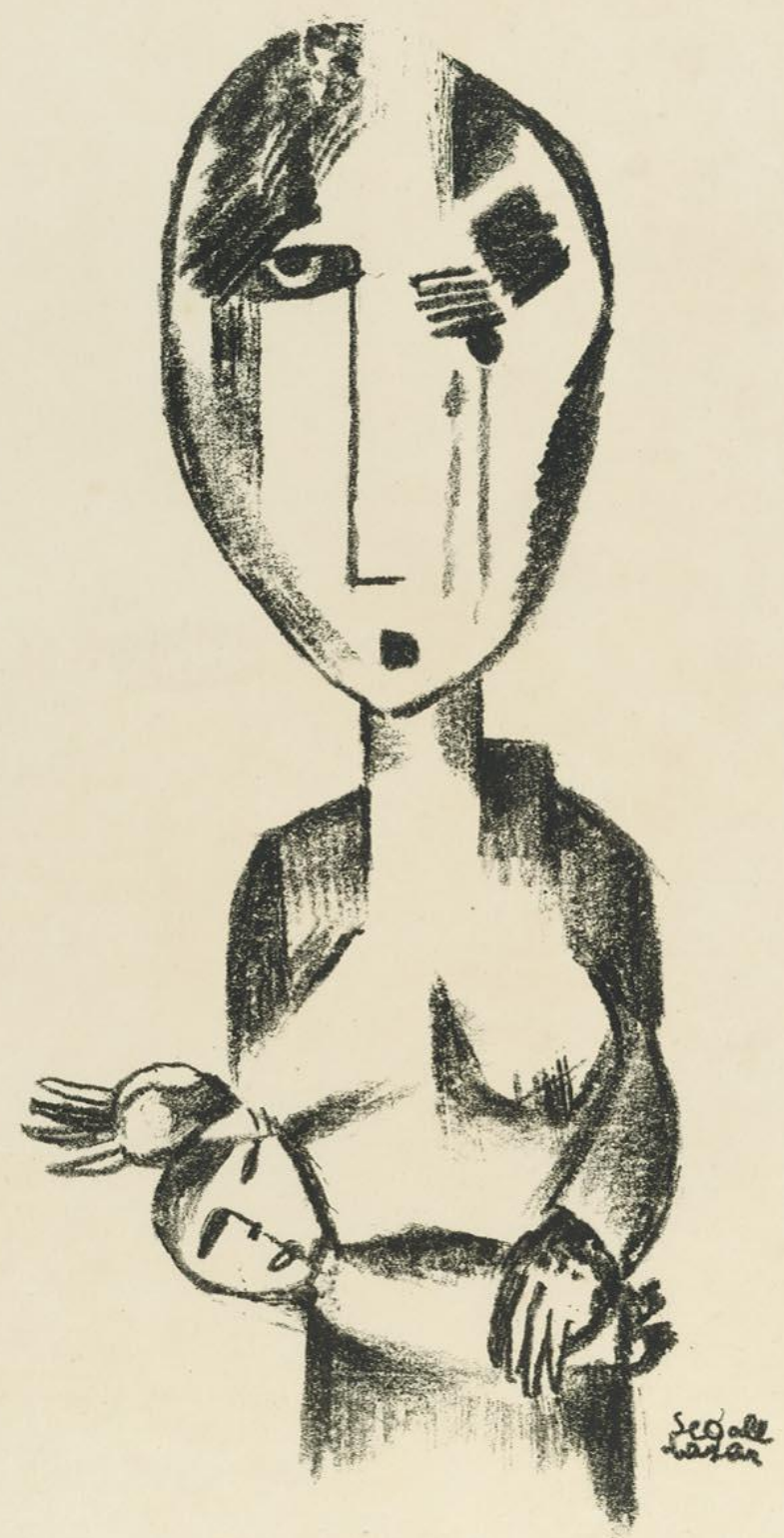

Figura 21. Junge Bettlerin (Jovem mendiga, 1920) MLS0193, litografia sobre papel, $34 \times 17,5 \mathrm{~cm}$ 


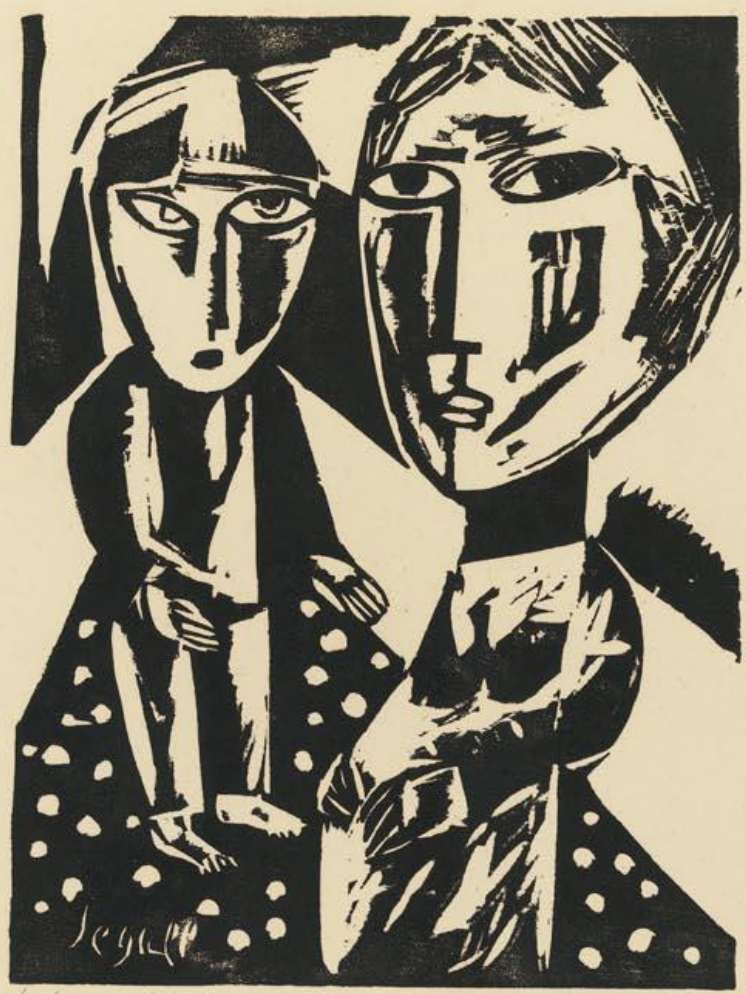

Figura 22. Witwe und Kind (Viúva e filho, 1920) MLS0139 xilogravura sobre papel, 24 x $18 \mathrm{~cm}$ 


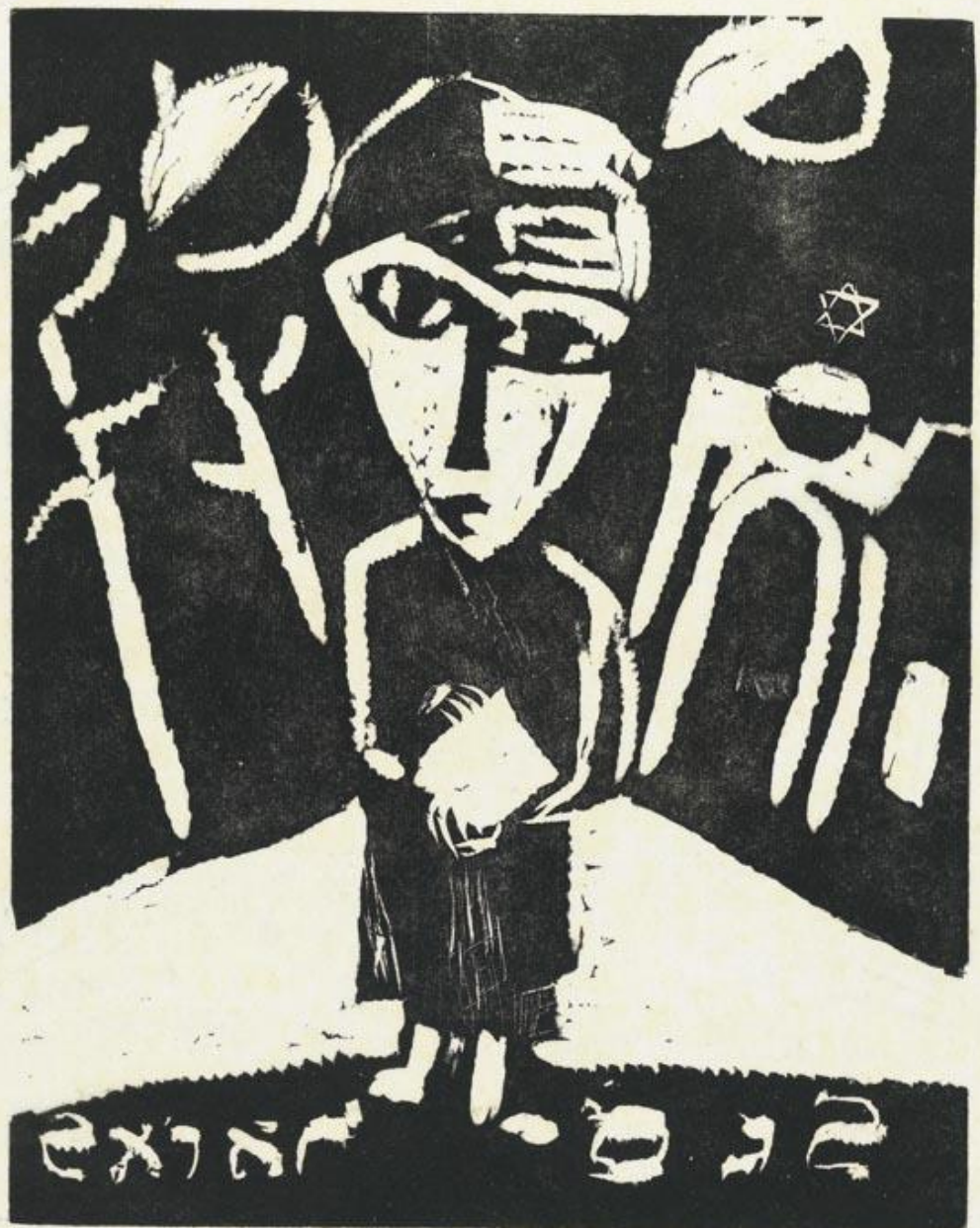

Figura 23. Betender Knabe (Jovem orando, 1920) MLS0179 xilogravura sobre papel, $25 \times 20 \mathrm{~cm}$ 


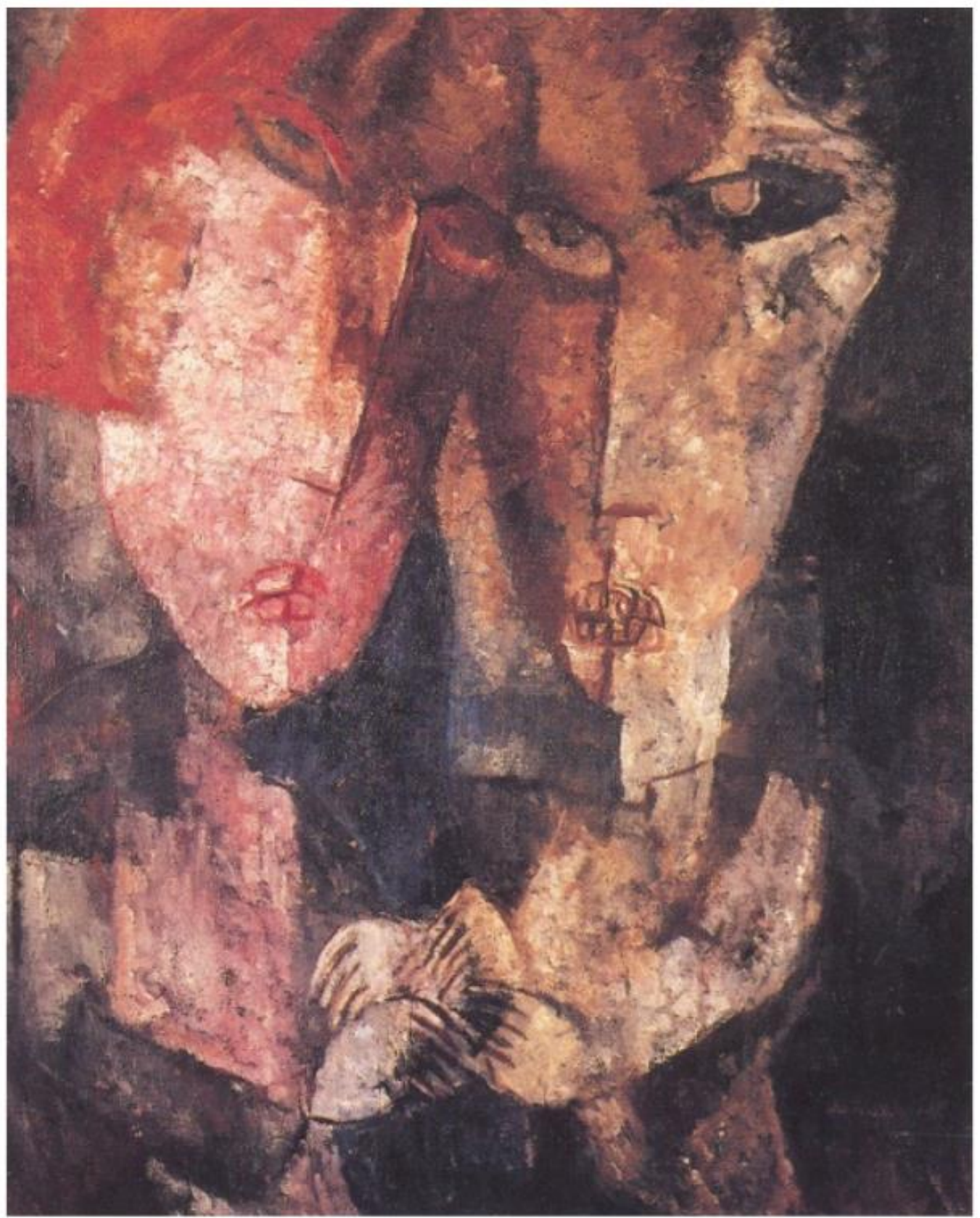

Figura 24. Liebende (Dois seres, 1919) RLS 1503 (coleção particular) óleo sobre tela, $95 \times 76,3 \mathrm{~cm}^{610}$

${ }^{610}$ Há erro na indicação do título dessa obra, por parte da Database; nela, atribui-se o título "Zwei Schwestern" [Duas irmãs], e cita-se como fonte da informação para esse título na obra de Pietro Maria Bardi sobre Segall; na obra de Bardi, edição de 2000, p. 107, há a reprodução de uma pintura intitulada "Duas Irmãs" que tem semelhança estrutural com "Liebende", mas evidentemente não se trata da mesma. No quadro reproduzido em Bardi, as duas figuras são femininas, enquanto em Liebende fica claro tratar-se de um casal. De todo modo, segundo Bardi, "Duas Irmãs", de 1919, também desapareceu.

Fonte da imagem reproduzida nessa página: http://emuseum.campus.fuberlin.de/eMuseumPlus?service=direct/1/ResultDetailView/result.t1.collection detail.\$TspImage.l ink\&sp=10\&sp=Scollection $\& s p=S$ fieldValue $\& \mathrm{sp}=0 \& \mathrm{sp}=1 \& \mathrm{sp}=3 \& \mathrm{sp}=$ SdetailView $\& \mathrm{sp}=44 \& \mathrm{sp}=$ Sdetai $1 \& \mathrm{sp}=3 \& \mathrm{sp}=\mathrm{F}$ (acessado em 16/2/2017). 


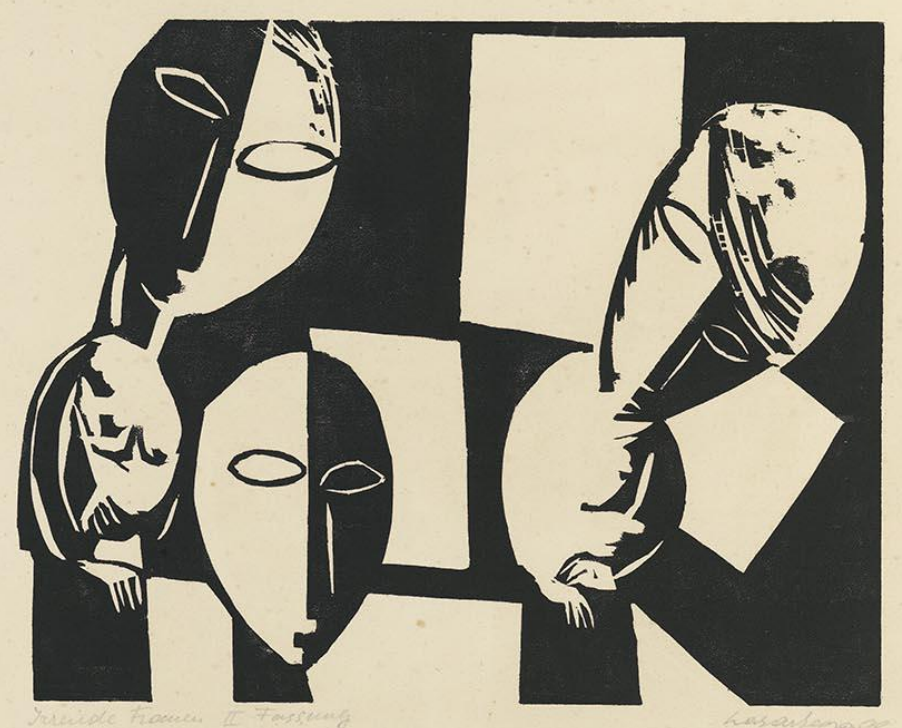

Figura 25 - Irrende Frauen (Mulheres errantes - II versão, 1920) MLS0153 xilogravura sobre papel, $23 \times 29 \mathrm{~cm}$ 


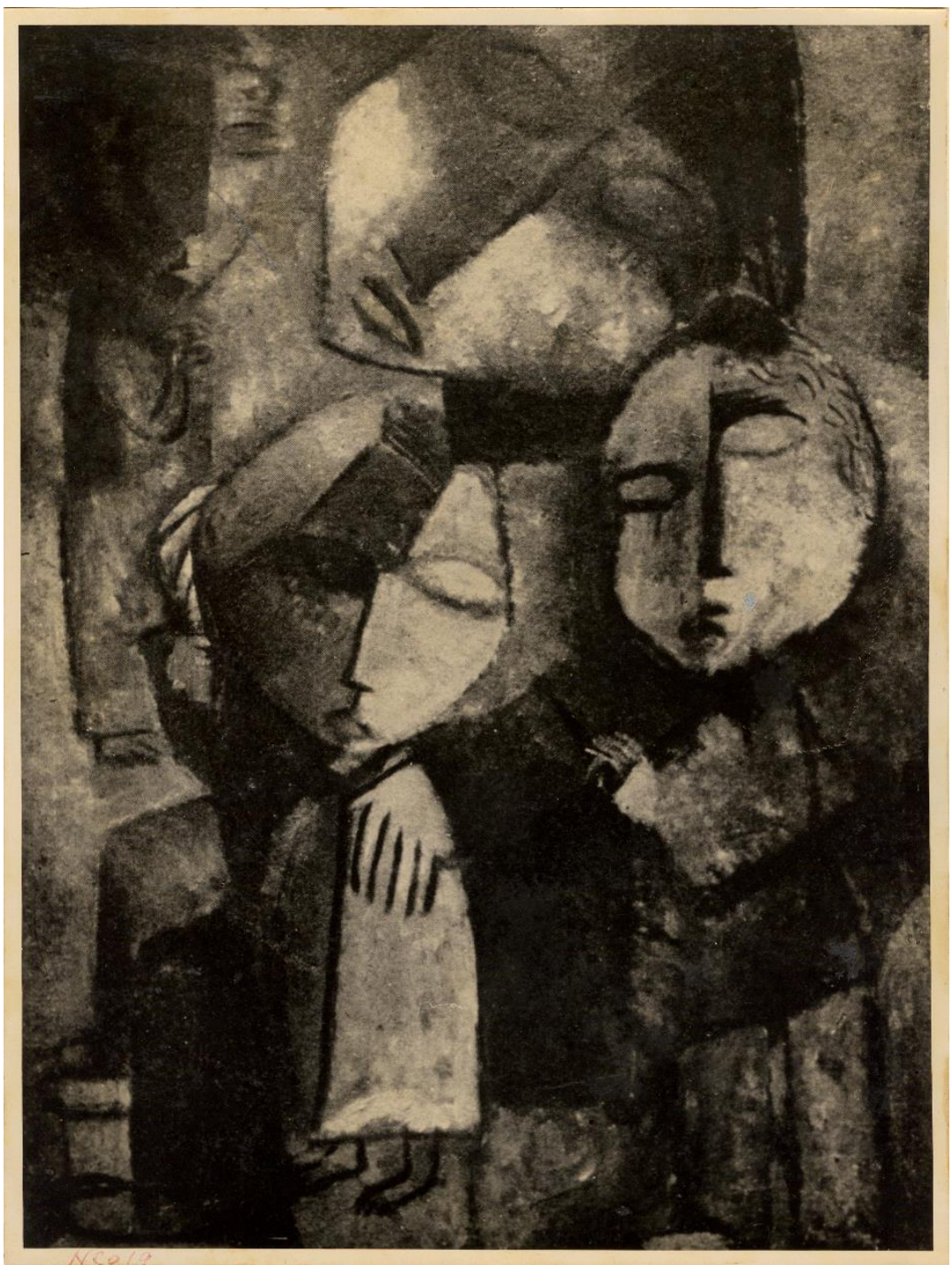

Figura 26. Witwe (Viúva, 1920) óleo sobre tela, 90,2 x 68,6 cm Arquivo Fotográfico Lasar Segall F. 03615.00 
Figura 27. Excertos do Livro "Kunst und Rasse" (Arte e Raça, 1928), de Paul-Schultze Naumburg
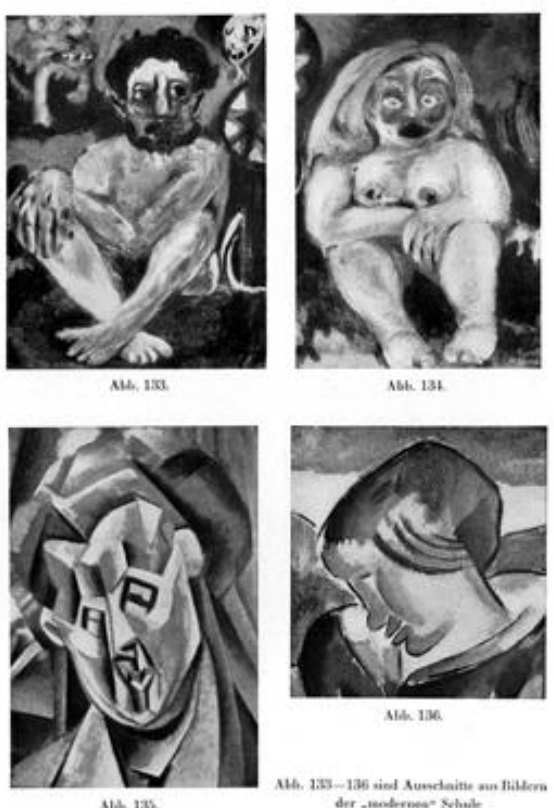

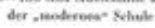
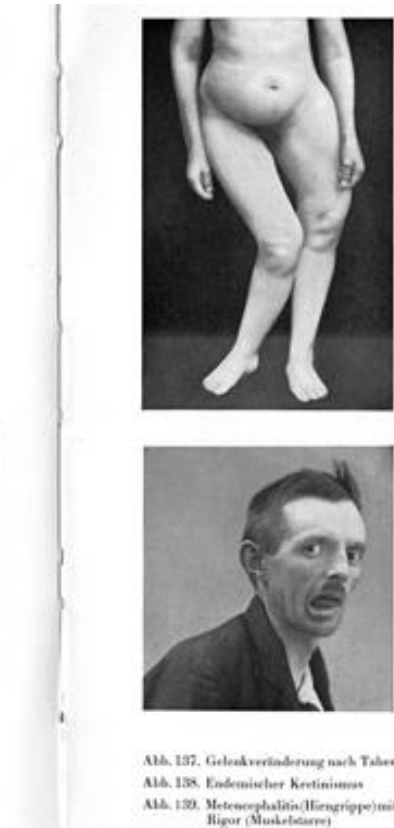

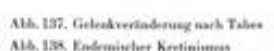

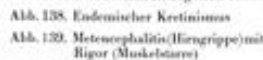

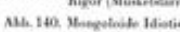

$\rightarrow$
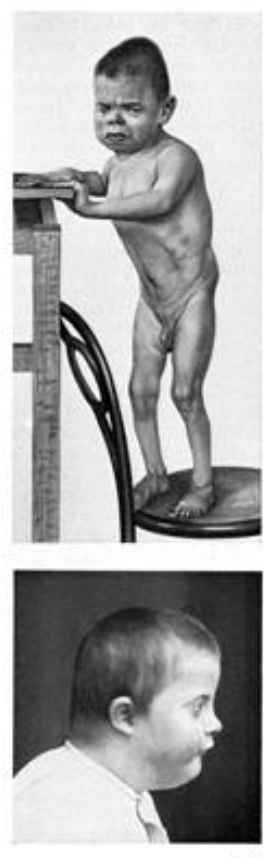

96
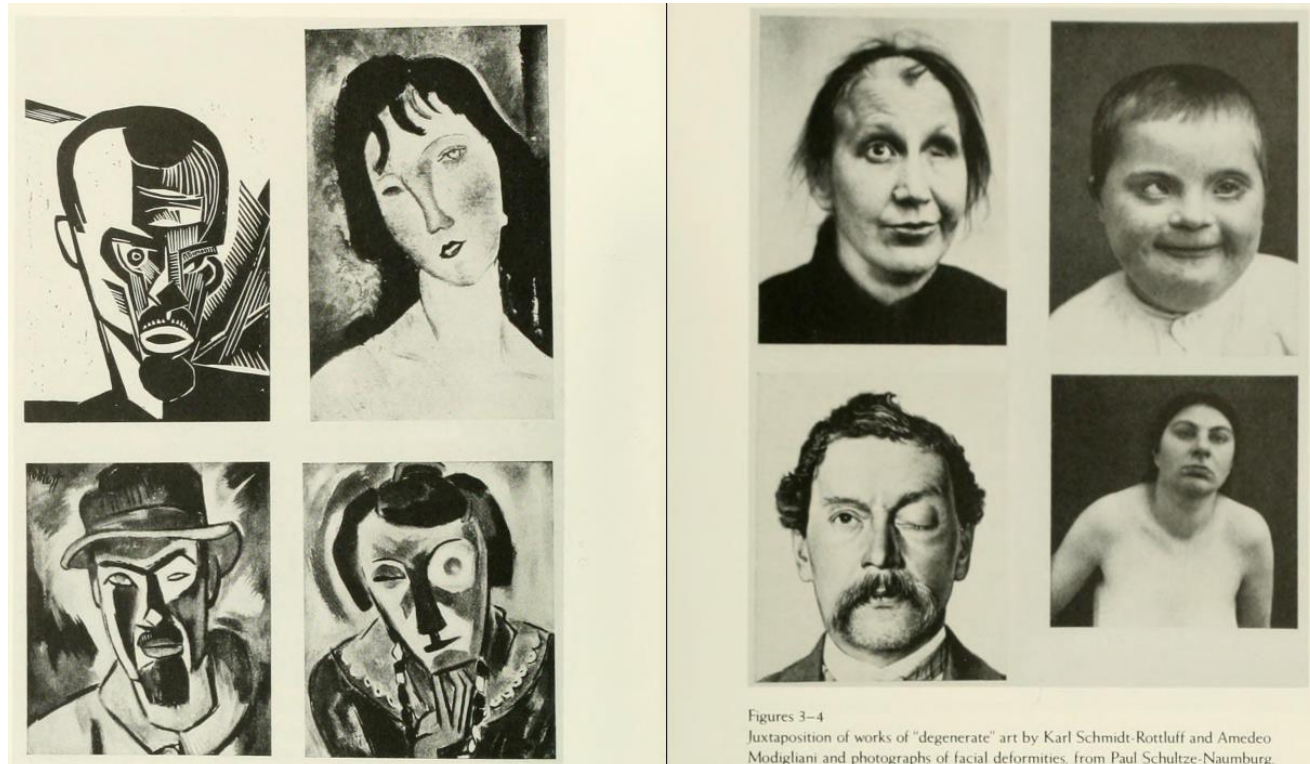

Publicado em 1928, a obra foi influente e disseminou a ideia de que a arte moderna era feita por indivíduos enfermos, os "degenerados", que imprimiam em suas obras os estigmas de suas morbidades. A organização gráfica sugeria a comparação entre obras de arte moderna e figuras de pessoas acometidas por enfermidades. 
Figura 28 - Lista de nomes de "Críticos do Sistema da Época" na Exposição de Arte Degenerada, 1937; entre outros, aparecem os nomes de Rosa Schapire, Paul-Ferdinand Schmidt, Will Grohmann e Meier-Graefe.

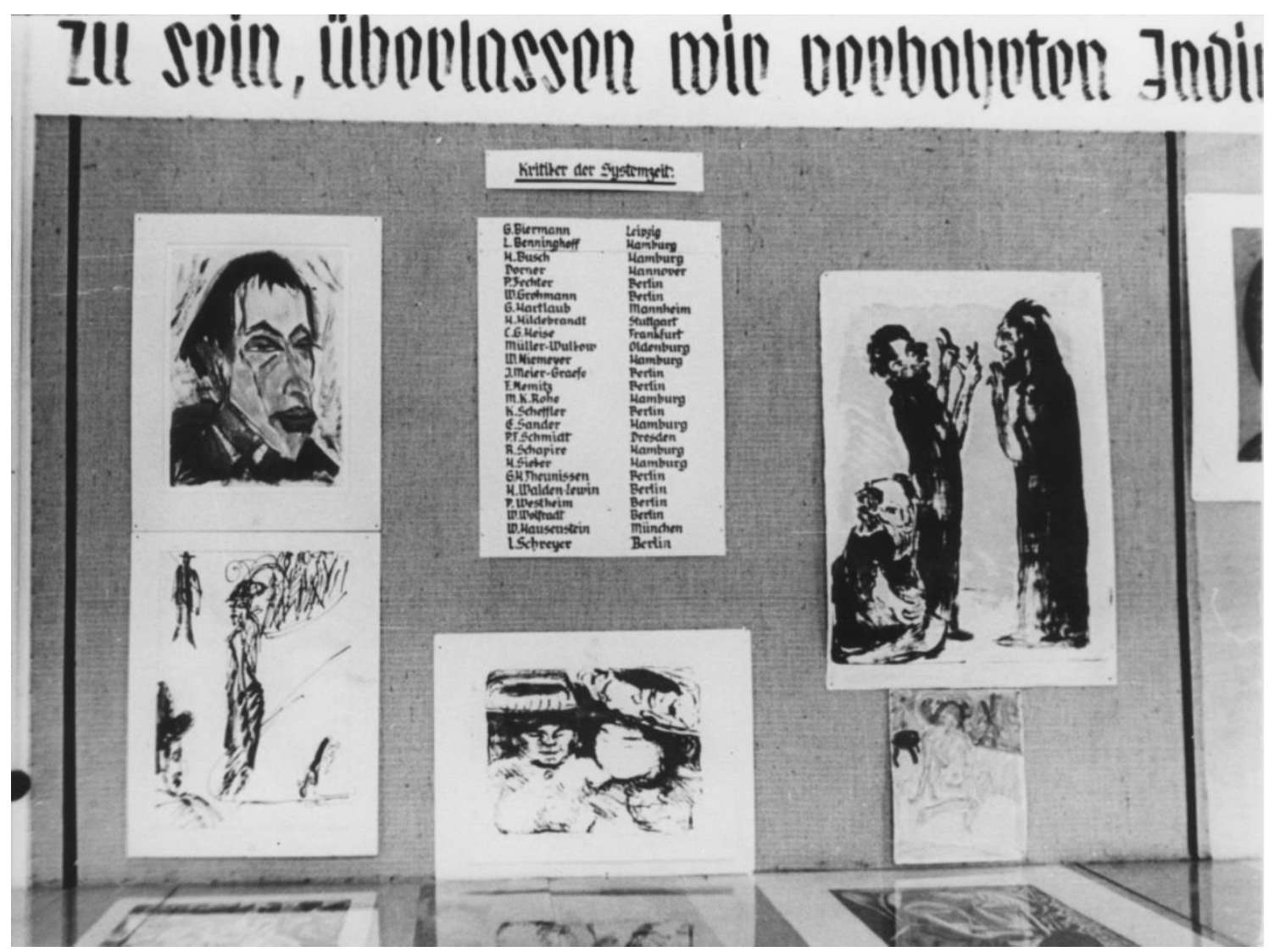

Fonte da imagem: Stadtarchiv München, DE-1992-FS-NS-01099. 


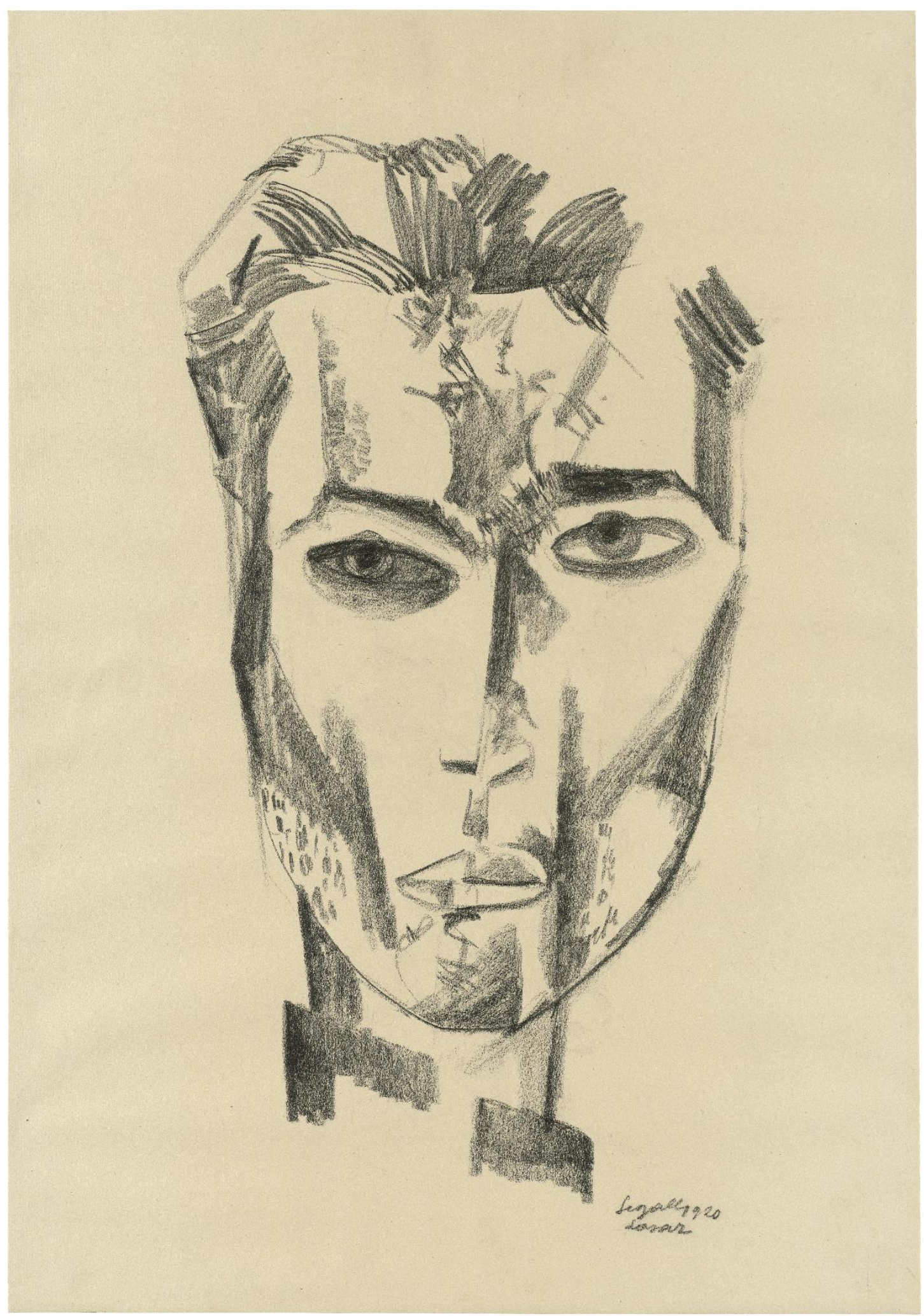

Figura 29. Kopf N. (Cabeça de N.) desenho a carvão sobre papel, 48,7 c $34 \mathrm{~cm}$ Coleção do Kupferstichkabinnett Dresden. 


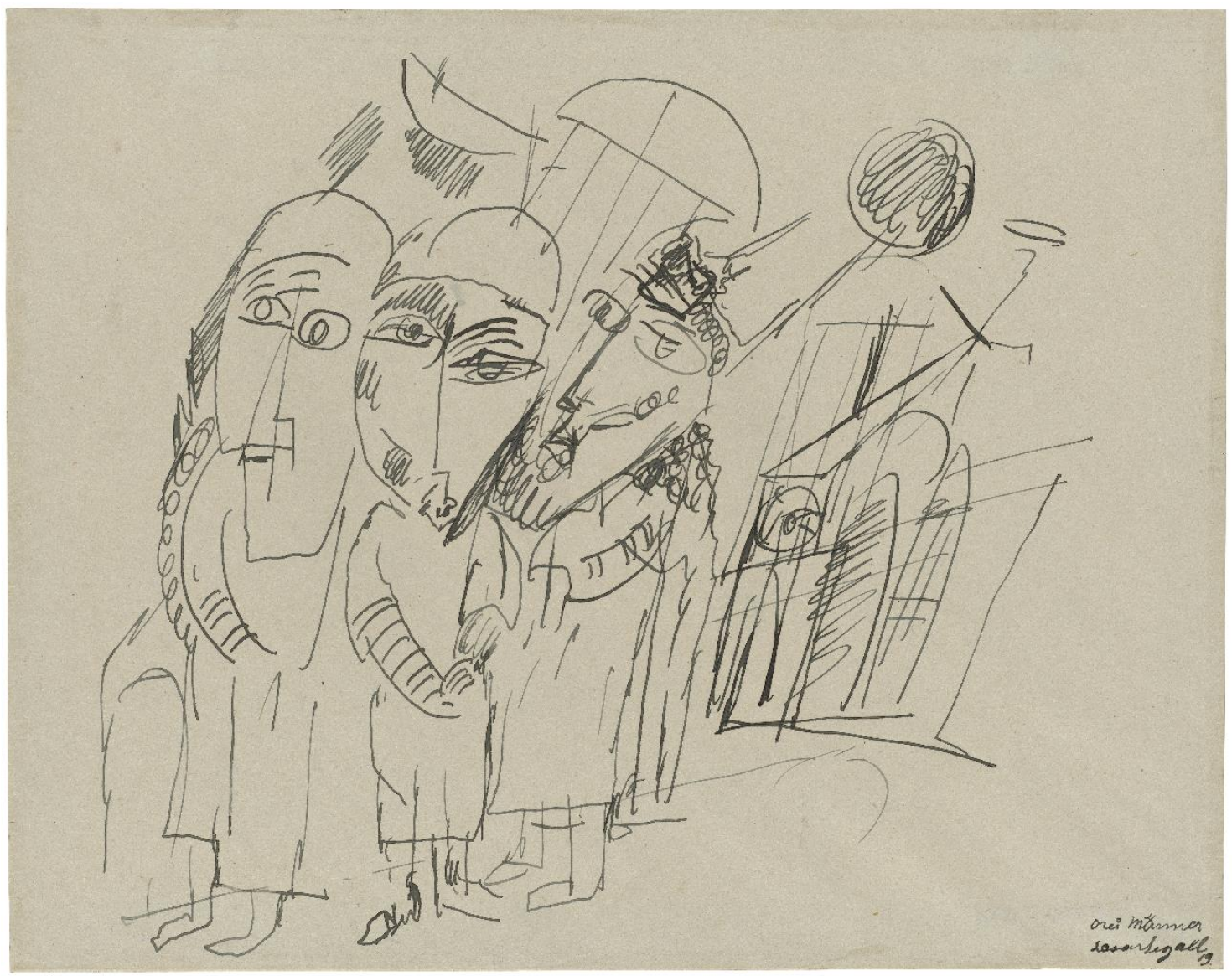

Figura 30. Lasar Segall, Drei Männer (Três homens), bico de pena, $22,2 \times 28 \mathrm{~cm}$. Coleção do Kupferstichkabinnett Dresden. 


\section{$\checkmark$}

Tebuar 1921.

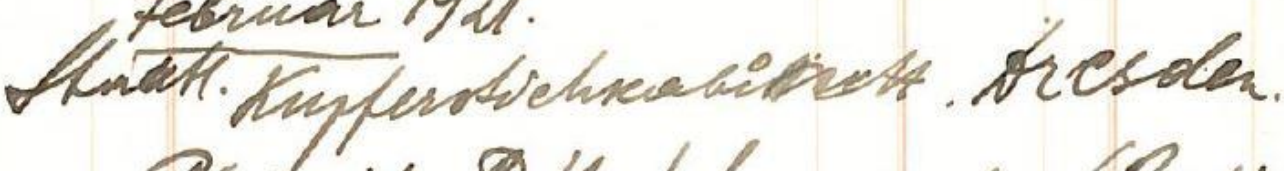

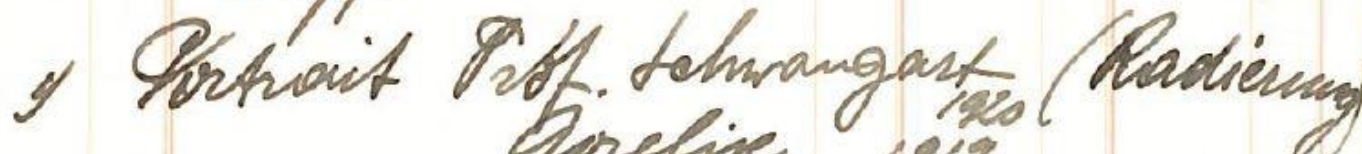

2. 4 - Corelire 1919

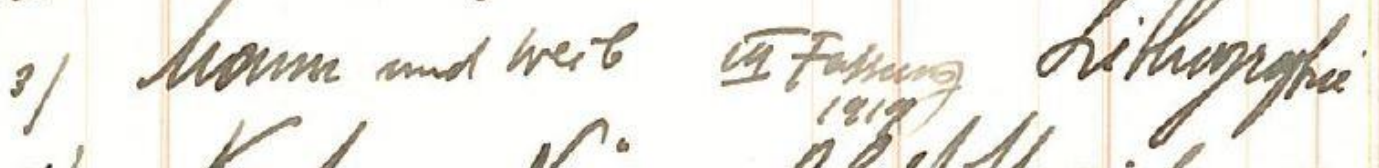
4) Lopt "N. Mlestiftzeichming s) Iedorg chunno whei Macioner on iges.an tymogers"

Figura 31. Caderno de Registro de Vendas (ALS 00021-A), página 7. 